\title{
WEST VALLEY DEMONSTRATION PROJECT ANNUAL SITE ENVIRONMENTAL REPORT CALENDAR YEAR 2006
}

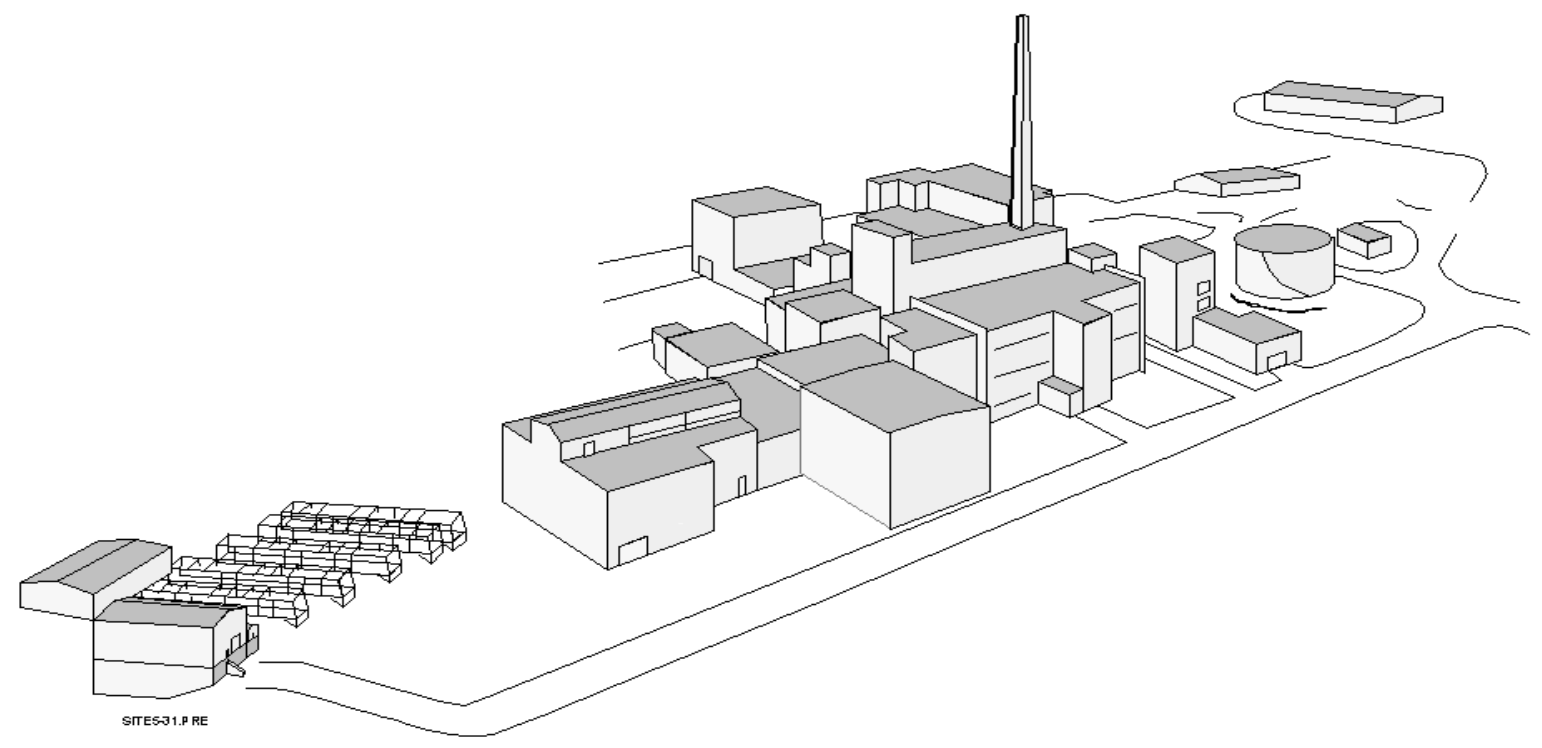

\section{WEST VALLEY NUCLEAR SERVICES COMPANY \\ AND \\ URS GROUP, INC.}
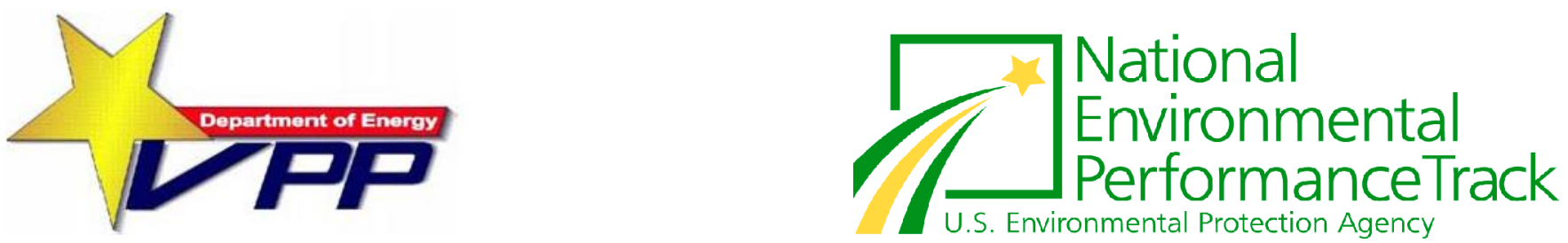

Prepared by: West Valley Nuclear Services Co. and URS Group, Inc.

Prepared for: U.S. Department of Energy

DOE-WVDP

September 2007

10282 Rock Springs Road

Under: Contract DE-AC24-81NE44139

West Valley, New York 14171-9799 



\section{Department of Energy \\ West Valley Demonstration Project \\ 10282 Rock Springs Road \\ West Valley, NY 14171-9799}

To the Reader:

This report, prepared by the U.S. Department of Energy (DOE) West Valley Demonstration Project (WVDP), summarizes the environmental protection program at the WVDP for calendar year 2006.

Monitoring and surveillance of the WVDP facilities are conducted to verify that public health and safety and the environment are protected. The quality assurance requirements applied to the environmental monitoring program by the DOE ensure the validity and accuracy of the monitoring data.

At the WVDP, radiological air emissions are controlled and permitted by the U.S. Environmental Protection Agency (EPA) under National Emission Standards for Hazardous Air Pollutants, Subpart H, regulations. Nonradiological liquid effluent discharges are controlled and permitted through the New York State Pollutant Discharge Elimination System.

Air, surface water, groundwater, storm water, drinking water, soil, sediment, and biological samples are collected and analyzed for radiological and nonradiological constituents. The resulting data are evaluated to assess effects of activities at the WVDP on the nearby public and the environment. Radiological monitoring of treated water effluents and facility ventilation system emissions verified that the dose received by off-site residents continues to be minimal.

The calculated dose to the hypothetical maximally exposed off-site individual from airborne radiological emissions in 2006 was much less than one-tenth of one percent of the EPA limit. The dose from combined airborne and waterborne radiological releases in 2006 to the same individual was less than one-tenth of one percent of the DOE limit.

The Project's continuing commitment to safety was reaffirmed in 2006 when it was recertified as a DOEVoluntary Protection Program (VPP) STAR site and continued its membership in the EPA's National Environmental Performance Track. The WVDP is one of the few DOE sites to be awarded both the VPP STAR and National Environmental Performance Track membership. By the close of 2006, WVDP employees achieved 4.5 million safe work hours over four years without a lost time work accident.

On June 29, 2007, the DOE awarded a four year contract for management and operation of the WVDP to West Valley Environmental Services Company, LLC, a team led by Washington Group International. The new team is focusing on transition activities to ensure the continuation of safely managed environmental cleanup and waste management activities.

If you have any questions or comments about the information in this report, please contact the WVNSCO Communications Department at (716) 942-2152 or complete and return the enclosed survey.

Sincerely,

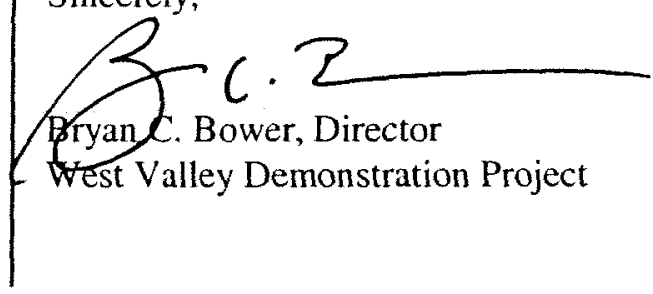





\section{SUMMARY OF CHANGES TO THE 2006 WVDP ANNUAL SITE ENVIRONMENTAL REPORT FROM THE 2005 ANNUAL SITE ENVIRONMENTAL REPORT}

This report, prepared by the U.S. Department of Energy West Valley Demonstration Project office (DOEWVDP), summarizes the environmental protection program at the WVDP for calendar year (CY) 2006. Monitoring and surveillance of the facilities used by the DOE for the WVDP are conducted to verify protection of public health and safety and the environment. The quality assurance protocols applied to the environmental monitoring program by the DOE ensure the validity and accuracy of the monitoring data.

Changes in content for the 2006 Annual Site Environmental Report (ASER) are summarized below.

\section{REVISIONS}

- $\quad$ The Environmental Compliance Summary was updated for CY 2006 to describe continued implementation of the WVDP environmental management system.

- $\quad$ Environmental permits effective during CY 2006 were updated. A modified State Pollution Discharge Elimination System (SPDES) permit was issued by NYSDEC in September 2006. Modifications to the permit are discussed in the Environmental Compliance Summary, Chapters 1 and 3, and in Appendix B.

- $\quad$ Data and text were updated throughout to reflect results from the CY 2006 environmental monitoring program. Tables, graphs, maps, supplemental information sections, and references were updated. Modifications to the environmental monitoring program are summarized in Appendix B.

- New dose-based concentration screening values for common radionuclides in soils, from guidance on decontamination and decommissioning published in 2006 by the Nuclear Regulatory Commission, were added to the table of soils screening levels in Appendix G-1.

- $\quad$ Meteorological wind roses, which had been removed from the ASER in 2005, were returned to Appendix I. (These figures may be useful references during incident response.)

- $\quad$ A list of acknowledgments was added.

- $\quad$ The listing of environmental laws, regulations, standards, and orders, in Table K-2 of the 2005 ASER, was deleted because the information is redundant with that in Table ECS-1 and in the "References and Bibliography" section.

- $\quad$ The table of derived concentration guides (DCGs; in former Table K-1) was moved to the "Useful Information" section to follow the discussion of DCGs.

\section{SPECIAL ISSUES IN CY 2006}

- $\quad$ By the close of CY 2006, the employees at the WVDP achieved more than four years and 4.58 million cumulative work hours without a lost-time work accident.

- An Environmental Assessment (EA) evaluating the proposed decontamination, demolition, and removal of 36 unneeded facilities at the WVDP was issued in 2006. The DOE issued a finding of no significant impact (FONSI), thereby determining that the proposed action did not constitute a major federal action significantly affecting the quality of the environment. Once the EA and FONSI were in place, work began, and several facilities were demolished and removed in 2006. 
- $\quad$ The decommissioning, decontamination, dismantlement, and demolition (D4) project was a primary activity at the WVDP in 2006. Obsolete systems and components in the main plant and throughout the site were taken apart, packaged, and shipped off site for disposition.

- $\quad$ About 400,000 cubic feet (11,300 cubic meters) of radioactive and nonradioactive waste were shipped off site for disposal in 2006.

- $\quad$ The remote-handled waste facility, although down for repairs much of the year, processed four boxes of mixed waste in 2006.

- In 2006, the on-site laboratories were reorganized and the former Analytical and Process Chemistry Laboratory placed under the cognizance of the WVDP Environmental Laboratory (ELAB). New York State Department of Health certification was transferred to the ELAB, and radiological analyses of environmental samples were added to the certification.

- $\quad$ The live-fire range was investigated as a potential storm water monitoring point.

- $\quad$ Revisions to the draft corrective measures studies (CMSs) work plan for several solid waste management units at the WVDP were submitted to the New York State Department of Environmental Conservation (NYSDEC) in 2006. NYSDEC conditionally approved the plan in October 2006, and the work plan is being revised to address NYSDEC's conditions.

- $\quad$ Proposed federal legislation clarifying long-term responsibility for the WVDP had been introduced into the House of Representatives, and a companion bill introduced into the Senate in 2005. These bills remained in committee throughout 2006, and were re-introduced into both houses in 2007 


\title{
West Valley Demonstration Project Annual Site Environmental Report \\ for
}

\section{Calendar Year 2006}

Prepared for the U.S. Department of Energy

West Valley Demonstration Project Office

under contract DE-AC24-81NE44139

\author{
September 2007 \\ West Valley Nuclear Services Company and URS Group, Inc. \\ 10282 Rock Springs Road \\ West Valley, New York 14171-9799
}


This page intentionally left blank 


\section{Preface}

Environmental monitoring at the West Valley Demonstration Project (WVDP) is conducted by the West Valley Nuclear Services Company, under contract to the U.S. Department of Energy. The data collected provide a historical record of radionuclide and radiation levels and chemical data from natural and man-made sources in the survey area. The data also document the chemical and radiological quality of the groundwater on and around the WVDP and of the air and water released by the WVDP. Meteorological data are also presented.

It is the policy at the WVDP to conduct all activities, including design, construction, testing, start-up, commissioning, operation, maintenance, and decontamination and decommissioning, in a manner that is appropriate to the nature, scale, and environmental effects of these activities. The WVDP management is committed to full compliance with applicable federal, New York State, and local laws and regulations for the protection of the environment, to continual improvement, to the prevention and/or minimization of pollution, and to public outreach, including stakeholder involvement.

This report represents a single, comprehensive source of on-site and off-site data collected during 2006. The environmental monitoring program and results are discussed in the body of this report. Additional monitoring information is presented in the appendices. Appendix A contains maps of onsite and off-site sampling locations. Appendices $B$ through $K$ can be found in electronic format on the

compact disk (as indicated by the $\mathbf{6}$ icon) located inside the back cover. Appendix $B$ is a summary of the site environmental monitoring schedule. Appendices $C$ through $J$ contain summaries of data obtained during 2006 and are intended for those readers interested in more detail than is provided in the main body of the report. Appendix K contains a copy of the West Valley Demonstration Project Act.

Requests for additional copies of the 2006 Annual Site Environmental Report and questions regarding the report should be referred to the WVDP Communications Department, 10282 Rock Springs Road, West Valley, New York 14171 (telephone: 716-942-2152). Additional Project information, including WVDP site environmental reports, is available on the internet at http://www.wv.doe.gov. 
This page intentionally left blank

$i v$ 


\section{Table of Contents}

PREFACE

iii

EXECUTIVE SUMMARY

EXE-1

Purpose of This Report

EXE-1

Major Site Programs

EXE-1

The Decommissioning, Decontamination, Dismantlement, and Demolition Project

EXE-1

Environmental Assessment

EXE-1

Waste Management and Shipping

EXE-2

The Remote-Handled Waste Facility

EXE-2

Key Initiatives

EXE-2

Environmental Performance Indicators

EXE-2

Pollution Prevention/Waste Minimization

EXE-2

Environmental Management System

EXE-2

Recognition and Awards

EXE-2

Compliance

EXE-3

Environmental Monitoring

EXE-3

Groundwater Monitoring and North Plateau Characterization

EXE-4

Quality Assurance

EXE-4

Conclusion

EXE-4

INTRODUCTION

INT-1

Site Location

INT-1

General Environmental Setting

INT-1

Site Mission

INT-1

Primary Operations and Activities

INT-3

Relevant Demographics

INT-4 


\section{Table of Contents}

ENVIRONMENTAL COMPLIANCE SUMMARY ECS-1

Compliance Program ECS-1

Compliance Status ECS-1

Environmental Protection Program (DOE Order 450.1) ECS-8

Radiation Protection of the Public and the Environment (DOE Order 5400.5) ECS-9

Radioactive Waste Management (DOE Order 435.1) ECS-9

National Environmental Policy Act ECS-10

Resource Conservation and Recovery Act ECS-12

Clean Air Act ECS-17

Emergency Planning and Community Right-to-Know Act ECS-18

Clean Water Act ECS-19

Safe Drinking Water Act ECS-24

Toxic Substances Control Act ECS-24

Federal Insecticide, Fungicide, and Rodenticide Act ECS-25

Environmental Conservation Law - Structures Impounding Waters and Structures in Waters ECS-25

Current Achievements and Program Highlights ECS-25

The Decommissioning, Decontamination, Dismantlement, and Demolition Project ECS-25

Environmental Assessment ECS-26

Waste Management Activities ECS-26

DOE-VPP STAR Status ECS-26

EPA National Environmental Performance Track ECS-26

Environmental Issues ECS-27

Unplanned Releases ECS-27

Coalition Files Suit Over WVDP EIS Process ECS-27

Proposed Legislation ECS-27

NYSERDA Files Suit to Determine Federal Responsibilities at the West Valley Site ECS-27 Environmental Actions ECS-28

Construction and Demolition Debris Landfill ECS-28

NRC-Licensed Disposal Area ECS-28

Project Assessment Activities in 2006 ECS-28 


\section{Table of Contents}

CHAPTER 1. ENVIRONMENTAL MANAGEMENT SYSTEM

Introduction $1-1$

Completion of Vitrification ___ 1-1

Environmental Management System ______ 1-1

Integrated Safety Management System Implementation ___

Occupational Safety and Environmental Training ___ 1-2

Safety-Trained Supervisor Program ___ 1-5

10 Code of Federal Regulations 851, "Worker Safety and Health Program" ___ 1-5

Self-Assessments ___ _ 1-5

National Environmental Performance Track ___ 1-5

Voluntary Protection Program STAR Status

Environmental Monitoring Program Overview ___ 1-6

Environmental Management of Aqueous Radioactive Waste ___ 1-7

North Plateau Groundwater Recovery System ___ 1-8

Nuclear Regulatory Commission-Licensed Disposal Area Interceptor Trench and

Pretreatment System ___ 1-8

Environmental Management of Airborne Radioactive Emissions ___ 1-8

Environmental Management of Radiation Exposure __ 1-9

Changes in the 2006 Environmental Monitoring Program ___ 1-9

2006 Activities at the WVDP ___ 1-9

The Decommissioning, Decontamination, Dismantlement, and Demolition Project ___ 1-9

Environmental Assessment________ 1-9

Waste Management and Shipping Activities ___ 1-10

Performance Measures ___ 1-10

Radiation Doses to the Maximally Exposed Off-Site Individual____ 1-10

Improvements in Wastewater Treatment at the Low-Level Treatment Waste Facility __ 1-10

SPDES Permit Limit Exceptions ___ 1-10

Waste Minimization and Pollution Prevention

Spills and Releases ___ 1-12 


\section{Table of Contents}

\section{CHAPTER 2. ENVIRONMENTAL RADIOLOGICAL PROTECTION PROGRAM AND}

DOSE ASSESSMENT

RADIATION IN THE ENVIRONMENT __ $2-1$

Sources of Radiation ___ _ _ 2-1

Exposure Pathways ___ 2-1

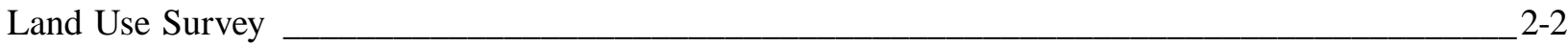

Dose to the Public ____ 2-2

ROUTINE MONITORING PROGRAM ___ 2-4

Radiological Sampling Program Overview ___ 2-4

Water Effluent and Ambient Surface Water Monitoring___ 2-6

Low-Level Waste Treatment Facility Effluent ____ 2-6

Northeast Swamp and North Swamp Drainage____ 2-7

Other North Plateau Surface Waters and Water Effluent ___ 2-7

South Plateau Surface Water and Nuclear Regulatory Commission-Licensed Disposal Area Interceptor Trench ___ 2-8

Off-Site Surface Water ___ $2-8$

Drinking Water Monitoring ___ 2 2-9

On-Site Tap Water ___ 2-9

Off-Site Drinking Water Wells ___

Sediment Monitoring ___ 2-10

On-Site Sediments __ 2-10

Off-Site Sediments ___ 2-10

Air Emission and Ambient Air Monitoring ___ 2-11

Ventilation and Emission Systems ___ 2-12

Perimeter and Remote Ambient Air Monitoring ____ 2-13

Atmospheric Deposition and Soil Monitoring ___ 2-13

Fallout Pots ___ 2-13

Off-Site Surface Soil ___ 2-14

Food Chain Monitoring _____ 2-14

Direct Environmental Radiation Monitoring ____ 2-14

On-Site Radiation Monitoring ____ 2-14

Perimeter and Off-Site Radiation Monitoring____ 2-14

Confirmation of Results ___ 2-14

Meteorological Monitoring ___ 2-15

Special Monitoring ___ 2-16

WVDP Annual Site Environmental Report Calendar Year 2006 


\section{Table of Contents}

Chapter 2 (concluded)

RADIOLOGICAL EFFLUENTS AND DOSE__ 2-17

Dose Assessment Methodology ____ 2-17

Measurement of Radionuclide Concentrations in Liquid and Air Releases ___ 2-17

Measurement of Radionuclide Concentrations in Food ___ 2-17

Predicted Dose From Airborne Emissions ___ 2-19

Maximum Dose to an Off-Site Individual____ 2-19

Collective Population Dose ___ 2-19

Iodine Emissions From the Main Stack ___ 2-19

Predicted Dose From Waterborne Releases ___ 2-21

Maximum Dose to an Off-Site Individual___ 2-23

Collective Dose to the Population___ 2-24

Calculated Dose From Local Foodstuff Tests ___ 2-24

Predicted Dose From All Pathways ___ 2-24

Risk Assessment ___ 2-25

Release of Materials Containing Residual Radioactivity ___ 2-26

Dose to Biota: Aquatic and Terrestrial Wildlife___ 2-26

Summary ___ 2-28

CHAPTER 3. ENVIRONMENTAL NONRADIOLOGICAL PROGRAM INFORMATION___ 3-1

Overview of New York State Water Classifications, Water Quality Standards, and Water Effluent Limits ___ 3-1

Surface Water, Subsurface Drainage Water, and Water Effluent Monitoring ___ $3-2$

SPDES Permit-Required Monitoring ___ 3-2

Mercury Analytical Method Study _____ 3-2

Storm Water Discharge Monitoring ____ 3-4

South Plateau Surface and Subsurface Water Monitoring ____ 3-5

Other On-Site and Off-Site Surface Water Monitoring _________ 3-5

Drinking Water Monitoring ___ 3-6

Soil and Sediment Monitoring ___ 3-6

Air Emission Monitoring ___ 3-7

Special Monitoring ___ _ _ 3-7

$i x$ 


\section{Table of Contents}

CHAPTER 4. GROUNDWATER PROTECTION PROGRAM 4-1

Groundwater Monitoring Program Overview 4-1

Surface Water Hydrology 4-1

Geology 4-2

Hydrogeology 4-2

Routine Groundwater Monitoring Program 4-2

Groundwater Monitoring Program Highlights 1982 Through 2006 4-2

Monitoring Well Network 4-6

Groundwater Elevation Monitoring 4-6

Analytical Trigger Level Evaluation 4-6

Results of Routine Groundwater Monitoring 4-6

Monitoring the Sand and Gravel Unit on the North Plateau 4-8

Plume on the North Plateau 4-8

Results for Volatile and Semivolatile Organic Compounds 4-10

North Plateau Groundwater Recovery System 4-12

Permeable Treatment Wall 4-12

Northeast Swamp Drainage Monitoring 4-12

North Plateau Characterization 4-12

Evaluation of Near-Term and Long-Term Plume Management Activities 4-13

Monitoring on the South Plateau: Weathered Lavery Till and the NDA 4-13

WNNDATR and Well 909 4-13

Additional Monitoring and Investigations 4-14

Results of Radioisotopic Sampling 4-14

North Plateau Groundwater Quality Early Warning Monitoring 4-14

Investigation of Chromium and Nickel in the Sand and Gravel Unit and Evaluation of Corrosion in Groundwater Monitoring Wells 4-14

Fuel Receiving and Storage Pool Water Infiltration 4-15

Off-Site Groundwater Monitoring 4-15

CHAPTER 5. QUALITY ASSURANCE

Quality Assurance Program

Responsibility

Planning

Training

Control of Design, Procedures, Items, and Documents

Corrective Action 


\section{Table of Contents}

Chapter 5 (concluded)

Documentation 5-2

Audits and Assessments

Quality Control

Field QC

Laboratory QC

Independent Comparisons and Crosschecks

Data Management

Data Verification and Validation

Data Assessment and Reporting ___ 5-5

Audits and Assessments __ 5 _ 5 _ _ _ _ _ _ _ _ _ _

External ___ 5-5

Internal ___

Summary ___ 5-6

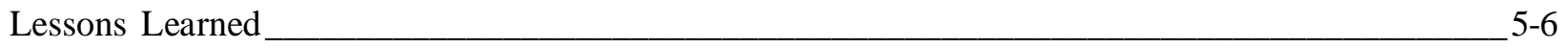

Conclusion ___ 5-6

USEFUL INFORMATION ___ UI-1

Radiation and Radioactivity ___ UI-1

Radioactive Decay ___ UI-1

Measurement of Radioactivity ____ UI-3

Measurement of Dose____ UI-4

Background Radiation ___ UI-4

Potential Health Effects of Radiation ___ UI-4

Derived Concentration Guides ___ UI-5

Data Reporting ___ UI-7

Units of Measure____ UI-8

Unit Prefixes ___ UI-8

Scientific Notation ___ UI-9

Conversion Chart____ UI-9

GLOSSARY ___ GLO-1

ACRONYMS AND ABBREVIATIONS ___ A\&A-1

REFERENCES AND BIBLIOGRAPHY ___ R\&B-1

DISTRIBUTION ___ DST-1

ACKNOWLEDGMENTS ____ ACK-1

APPENDIX A. ENVIRONMENTAL MONITORING PROGRAM MAPS ___ A-i

WVDP Annual Site Environmental Report Calendar Year 2006 


\section{Table of Contents}

\section{List of Figures}

INT-1. Location of the Western New York Nuclear Service Center

INT-2

ECS-1. WVDP SPDES Effluent Limit Exceptions

ECS-21

1-1. Annual Effective Dose Equivalent to the Maximally Exposed Off-Site Individual

1-2. Annual SPDES Effluent Limit Exceptions

1-3. Number of Immediately Reportable Spills or Releases

2-1. Comparison of Doses From Natural and Man-Made Sources to the Dose From 2006 WVDP Effluents

2-2. Ten-Year Trends of Gross Alpha, Gross Beta, and Tritium Concentrations at Sampling Location WFFELBR

2-3. Ten-Year Cesium-137 Concentrations in Sediment From Cattaraugus Creek Downstream of the WVDP (SFCCSED) Compared With Historical Average Upstream Concentrations (SFBISED)

2-4. Ten-Year Trends of Gross Alpha and Gross Beta Concentrations in Air at Rock Springs Road (AFRSPRD)

2-5. Ten-Year Trends of Environmental Radiation Levels at Perimeter TLDs

2-6. Air Emissions From Point Sources: Dose Percent by Radionuclide in CY 2006

2-7. Water Effluents: Dose Percent by Radionuclide in CY 2006

2-8. All Sources: Dose Percent by Radionuclide in CY 2006

2-9. Effective Dose Equivalent From Liquid and Airborne Effluents to a Maximally Exposed Individual Residing Near the WVDP

2-10. Collective Effective Dose Equivalent From Liquid and Airborne Effluents to the Population Residing Within 50 Miles $(80 \mathrm{~km})$ of the WVDP 


\section{Table of Contents}

List of Figures (concluded)

4-1. Geologic Cross Section Through the North Plateau __ 4-4

4-2. Geologic Cross Section Through the South Plateau __ 4-4

4-3. North Plateau Gross Beta Plume Area: Fourth-Quarter 2006 Results ____ 4-7

4-4. Average Annual Gross Beta Concentrations at Locations Closer to the Source of the North

Plateau Plume ___ 4-16

4-5. Average Annual Gross Beta Concentrations at Locations Closer to the Leading Edges of the North Plateau Plume___ 4-16

4-6. Average Annual Gross Beta Concentrations at Locations Near Former Lagoon $1 \_$_-17

4-7. Average Annual Tritium Concentrations at Selected Locations in the Sand and Gravel Unit 4-17

4-8. Concentrations of 1,2-DCE-t; 1,1,1-TCA; 1,1-DCA; and DCDFMeth at Well 8612 in the Sand and Gravel Unit __ 4-18

4-9. Concentrations of Tributyl Phosphate at Selected Locations in the Sand and Gravel Unit ___ 4-18

4-10. Annualized Average Strontium-90 Concentrations at WNSWAMP __ 4-19

A-1. West Valley Demonstration Project Base Map____ A-1

A-2. On-Site Surface Water and Soil/Sediment Sampling Locations ___ A-2

A-3. On-Site Storm Water Outfalls _____ A-3

A-4. Rail Spur Storm Water Outfalls____ A-4

A-5. Off-Site Surface Water and Soil/Sediment Sampling Locations ___ A-5

A-6. On-Site Air Monitoring and Sampling Locations ____ A-6

A-7. Off-Site Air Sampling Locations ____ A-7

A-8. Active WVDP Groundwater Monitoring Locations ____ A-8

A-9. North Plateau Groundwater Monitoring Network______ A-9

A-10. South Plateau Groundwater Monitoring Network ___ A-10

A-11. Near-Site Drinking Water and Biological Sampling Locations ___ A-11

A-12. Location of On-Site Thermoluminescent Dosimeters ___ A-12

A-13. Location of Off-Site Thermoluminescent Dosimeters Within 5 Kilometers of the WVDP _ _ A-13

A-14. Environmental Sampling Locations Between 5 and 10 Kilometers From the WVDP ___ A-14

A-15. Environmental Sampling Locations More Than 10 Kilometers From the WVDP____ A-15

A-16. Population by Sector Within 80 Kilometers of the WVDP (2002 Estimate) ___ A-16 


\section{Table of Contents}

\section{List of Tables}

Compliance Tables:

ECS-1. Compliance Status Summary for the WVDP in 2006

ECS-2

ECS-2. WVDP Environmental Permits

ECS-29

ECS-3. Summary of Waste Management Activities at the WVDP in 2006

ECS-31

ECS-4. WVDP RCRA SSWMUs and Constituent SWMUs

ECS-32

ECS-5. Pollution Prevention Progress for FY 2006

ECS-6. WVDP 2006 Air Quality Noncompliance Episodes

ECS-34

ECS-7. Status of EPCRA (SARA Title III) Reporting at the WVDP in 2006

ECS-35

ECS-8. Reportable Chemicals Above EPCRA 312 Threshold Planning Quantities Stored at the WVDP in 2006

ECS-35

ECS-9. WVDP 2006 NPDES/SPDES Permit Noncompliance Episodes ECS-35

ECS-10.WVDP Migratory Bird Nest Depredation Episodes in 2006

ECS-36

1-1. Elements of the Environmental Management System at the WVDP 1-3

1-2. 2006 Radioactivity Releases Versus 10-Year Averages 1-8

2-1. Potential Local Off-Site Exposure Pathways Under Existing WVDP Conditions $2-3$

2-2. 2006 Comparison of Radiological Results With Backgrounds and DOE DCGs $2-5$

2-3. Summary of Annual Effective Dose Equivalents to an Individual and Population From WVDP Releases in 2006 $2-20$

2-4. Release of Property Containing Residual Radioactive Material ___ 2-26

2-5. 2006 Evaluation of Dose to Aquatic and Terrestrial Biota ___ 2-28

2-6. WVDP Radiological Dose and Release Summary ___ 2-30

3-1. 2006 Comparison of Nonradiological Results With Backgrounds and Applicable Standards or Guidance Limits

4-1. Summary of Hydrogeology at the WVDP 4-3

4-2. Groundwater Monitoring Overview by Geographic Area: Monitoring Year 2006

4-3. Groundwater Monitoring Overview by Purpose: Monitoring Year 2006

4-4. Maximum Concentrations for Radiological Parameters in WVDP Wells

4-5. Summary of Organic Constituents in WVDP Groundwater Wells 4-10

UI-1. U.S. Department of Energy Radiation Protection Standards and Derived Concentration Guides UI-6 


\section{Table of Contents}

\section{List of Figures \\ (Available only on CD, as indicated by the $\mathrm{GD}$ icon.)}

H-1. 2006 Average Annual Gamma Exposure Rates Around the WVDP __ H-6

H-2. 2006 Average Annual Gamma Exposure Rates on the WVDP ___ H-6

I-1. Regional Monitoring Station Wind Frequency Rose: 10-Meter ____ I-3

I-2. Primary Monitoring Station Wind Frequency Rose: 10-Meter ___ _ I-4

I-3. Primary Monitoring Station Wind Frequency Rose: 60-Meter ___ I-5

I-4. Calendar Year 2006 Weekly Precipitation______ I-6

I-5. Calendar Year 2006 Cumulative Precipitation____ I-6 


\section{Table of Contents}

\section{List of Tables \\ (Available only on CD, as indicated by the $\mathrm{GD}$ icon.)}

APPENDIX B. 2006 ENVIRONMENTAL MONITORING PROGRAM B-i

APPENDIX C-1. SUMMARY OF WATER LIMITS, GUIDELINES, AND STANDARDS C-1

C-1A. West Valley Demonstration Project State Pollutant Discharge Elimination System Sampling Program C-3

C-1B. New York State Water Quality Standards and Guidelines C-5

C-1C. New York State Department of Health/U.S. Environmental Protection Agency Potable Water MCLs, MCLGs, and Raw Water Standards

C-1D. U.S. Department of Energy Derived Concentration Guides in Ingested Water C-8

APPENDIX C-2. PROCESS EFFLUENT DATA C-9

C-2A. Total Radioactivity of Liquid Effluents Released From Lagoon 3 (WNSP001) in 2006 C-11

C-2B. Comparison of 2006 Lagoon 3 (WNSP001) Liquid Effluent Radioactivity Concentrations With U.S. Department of Energy Guidelines C-12

C-2C. 2006 SPDES Results for Outfall 001 (WNSP001): Water Quality C-13

C-2D. 2006 SPDES Results for Outfall 001 (WNSP001): Metals C-15

C-2E. 2006 SPDES Results for Outfall 007 (WNSP007): Water Quality and Iron C-17

C-2F. 2006 SPDES Results for Sums of Outfalls 001, 007, 008, and 116: Water Quality C-18

C-2G. 2006 Annual and Semiannual SPDES Results for Outfall 001 (WNSP001): Organic Compounds C-19

C-2H. 2006 SPDES Action Level Requirement Monitoring Results for Outfalls 001, 007, and 008:

Metals, Organics, and Water Quality

C-2I. 2006 SPDES Results for Outfall 01B (WNSP01B): Water Quality C-21

C-2J. 2006 SPDES Results for Outfall 008 (WNSP008): Water Quality $\mathrm{C}-21$

C-2K. 2006 Radioactivity at Sewage Treatment Outfall 007 (WNSP007) $\mathrm{C}-22$

APPENDIX C-3. SPDES-PERMITTED STORM WATER OUTFALL DISCHARGE DATA C-23

C-3A. 2006 Storm Water Discharge Monitoring Data for Outfall Group 1: Storm Water Outfall S04 $\mathrm{C}-25$

C-3B. 2006 Storm Water Discharge Monitoring Data for Outfall Group 2: Storm Water Outfall S06 $\mathrm{C}-27$ 2006 Storm Water Discharge Monitoring Data for Outfall Group 2: Storm Water Outfall S33 C-28

C-3C. 2006 Storm Water Discharge Monitoring Data for Outfall Group 3: Storm Water Outfall S12 C-29 2006 Storm Water Discharge Monitoring Data for Outfall Group 3: Storm Water Outfall S09 C-31 


\section{Table of Contents}

List of Tables (continued)

C-3D. 2006 Storm Water Discharge Monitoring Data for Outfall Group 4: Storm Water Outfall S34 _ C-32

C-3E. 2006 Storm Water Discharge Monitoring Data for Outfall Group 5: Storm Water Outfall S17 _ C-34 2006 Storm Water Discharge Monitoring Data for Outfall Group 5: Storm Water Outfall S14 _ C-35 2006 Storm Water Discharge Monitoring Data for Outfall Group 5: Storm Water Outfall S28 _ C-36

C-3F. 2006 Storm Water Discharge Monitoring Data for Outfall Group 6: Storm Water Outfall S39 _ C-37 2006 Storm Water Discharge Monitoring Data for Outfall Group 6: Storm Water Outfall S37 _ C-38

2006 Storm Water Discharge Monitoring Data for Outfall Group 6: Storm Water Outfall S38 _ C-39

C-3G. 2006 Storm Water Discharge Monitoring Data for Outfall Group 7: Storm Water Outfall S20 __ C-40

C-3H. 2006 Storm Water Discharge Monitoring Data for Outfall Group 8: Storm Water Outfall S27 _ C-42 2006 Storm Water Discharge Monitoring Data for Outfall Group 8: Storm Water Outfall S35 __ C-43

APPENDIX C-4. SITE SURFACE DRAINAGE, SUBSURFACE DRAINAGE, AND

CONTAINED WATER DATA __ C-45

C-4A. 2006 Radioactivity and pH in Surface Water at Facility Yard Drainage (WNSP005) ___ _ C-47

C-4B. 2006 Radioactivity in Surface Water at French Drain (WNSP008)___ C-47

C-4C. 2006 Water Quality of Surface Water at the North Swamp (WNSW74A)___ C-48

C-4D. 2006 Water Quality of Surface Water at the Northeast Swamp (WNSWAMP) ___ C-51

C-4E. 2006 Water Quality Results at Storage and Disposal Area Drainage (WNNDADR) ___ _ C-54

C-4F. 2006 Water Quality Results in Subsurface Water at the NDA Interceptor Trench

(WNNDATR) __ C-54

C-4G. 2006 Radioactivity and pH in Surface Water at Cooling Tower Basin (WNCOOLW) ___ C-55

APPENDIX C-5. AMBIENT SURFACE WATER DATA ___ C-57

C-5A. 2006 Radioactivity and pH in Surface Water Downstream of the WVDP in Cattaraugus

Creek at Felton Bridge (WFFELBR) __ C-59

C-5B. 2006 Water Quality of Surface Water Downstream of the WVDP in Buttermilk Creek at

Thomas Corners Bridge (WFBCTCB) ___ C-60

C-5C. 2006 Water Quality of Surface Water Downstream of the WVDP at Frank's Creek

(WNSP006) ___ C-63

C-5D. 2006 Total Dissolved Solids From Outfall WNSP116___ C-66

C-5E. 2006 Radioactivity and pH in Surface Water at Erdman Brook (WNERB53) ___ C-66 _ _ _ C

C-5F. 2006 Radioactivity and pH in Surface Water at Frank's Creek East of the SDA (WNFRC67) _ _ C-67

C-5G. 2006 Radioactivity and pH in Surface Water at Drum Cell Drainage (WNDCELD)____ C-67

C-5H. 2006 Water Quality of Surface Water at the Standing Water Location (WNSTAW9) ___ C-68 


\section{Table of Contents}

List of Tables (continued)

APPENDIX C-6. POTABLE WATER (DRINKING WATER) DATA

C-69

C-6A. 2006 Water Quality Results in Potable Well Water Around the WVDP

C-71

C-6B. 2006 Indicator Results in Potable Water at the WVDP

C-72

C-6C. 2006 Water Quality Results in Utility Room Potable Water (WNDNKUR)

C-73

C-6D. 2006 Water Quality Results in Utility Room Raw (Untreated) Water (WNURRAW)

C-74

C-6E. 2006 Biological and Chlorine Results in Tap Water From Various Site Locations

C-74

C-6F. 2006 Nitrate Results in Tap Water From WVDP Restroom Sink

C-74

APPENDIX D. SUMMARY OF AIR MONITORING DATA D-1

D-1. 2006 Effluent Airborne Radioactivity at Main Stack (ANSTACK) D-3

D-2. 2006 Effluent Airborne Radioactivity at Vitrification System HVAC (ANVITSK) D-4

D-3. 2006 Effluent Airborne Radioactivity at 01-14 Building (ANCSSTK) D-5

D-4. 2006 Effluent Airborne Radioactivity at Contact Size-Reduction Facility (ANCSRFK) D-6

D-5. 2006 Effluent Airborne Radioactivity at Supernatant Treatment System (ANSTSTK) D-6

D-6. 2006 Effluent Airborne Radioactivity at Container Sorting and Packaging Facility (ANCSPFK) D-7

D-7. 2006 Effluent Airborne Radioactivity at Outdoor Ventilation Enclosures/Portable Ventilation Units D-8

D-8. 2006 Effluent Airborne Radioactivity at Remote-Handled Waste Facility Stack (ANRHWFK) D-9

D-9. 2006 Ambient Airborne Radioactivity at Lag Storage (ANLAGAM) D-10

D-10. 2006 Ambient Airborne Radioactivity at Rock Springs Road (AFRSPRD) D-11

D-11. 2006 Ambient Airborne Radioactivity at Fox Valley Road (AFFXVRD) D-12

D-12. 2006 Ambient Airborne Radioactivity at Route 240 (AFRT240) D-12

D-13. 2006 Ambient Airborne Radioactivity at West Valley (AFWEVAL) D-13

D-14. 2006 Ambient Airborne Radioactivity at Springville (AFSPRVL) D-13

D-15. 2006 Radioactivity in Fallout: Rain Gauge (ANRGFOP) D-14 


\section{Table of Contents}

List of Tables (continued)

APPENDIX E. SUMMARY OF GROUNDWATER MONITORING DATA E-1

Groundwater Sampling Methodology E-2

2006 Groundwater Sampling and Analysis Agenda E-3

E-1. Groundwater Monitoring Network Sorted by Geologic Unit ____ E-4

E-2. 2006 Indicator Results From the Sand and Gravel Unit ___ E-6

E-3. 2006 Indicator Results From the Lavery Till-Sand Unit ___ E-10

E-4. 2006 Indicator Results From the Weathered Lavery Till Unit____ E-11

E-5. 2006 Indicator Results From the Unweathered Lavery Till Unit___ E-12

E-6. 2006 Indicator Results From the Kent Recessional Sequence ___ E-13

E-7. 2006 Metals Results for Early Warning Monitoring Wells ___ E-13

E-8. 2006 Volatile Organic Compound Results at Selected Groundwater Monitoring Locations __ E-14

E-9. 2006 Tributyl Phosphate Results at Selected Groundwater Monitoring Locations ___ E-14

E-10. 2006 Results for Metals in Groundwater___ E-15

E-11. 2006 Radioactivity in Groundwater From Selected Monitoring Locations___ E-17

E-12. Practical Quantitation Limits _____ E-21

APPENDIX F. SUMMARY OF BIOLOGICAL DATA___ F-1

F-1. 2006 Radioactivity Concentrations in Milk ___ F-3

F-2. 2006 Radioactivity Concentrations in Venison____ F-4

F-3. 2006 Radioactivity Concentrations in Food Crops__ F-5

F-4. 2006 Radioactivity Concentrations in Edible Portions of Fish From Cattaraugus Creek ___ F-6

APPENDIX G-1. SUMMARY OF SOIL AND AQUATIC SEDIMENT GUIDELINES AND STANDARDS

G-1A. Soils Cleanup Objectives and Cleanup Levels ___ G-3

G-1B. Screening Concentrations for Contaminated Sediment

G-4

G-1C. Screening Thresholds for In-Water and Riparian Management of Sediment and Dredge Material G-5

G-1D. Radionuclide Comparison Values for Soils G-5 


\section{Table of Contents}

List of Tables (continued)

APPENDIX G-2. SOIL AND SEDIMENT DATA G-7

G-2A. 2006 Contaminants in On-Site Soils Downstream of the WVDP at Frank's Creek (SNSP006) G-9

G-2B. 2006 Contaminants in On-Site Soils From North Swamp (SNSW74A) G-11

G-2C. 2006 Contaminants in On-Site Soils From Northeast Swamp (SNSWAMP) G-13

G-2D. 2006 Radioactivity in Surface Soils Collected at Air Stations Around the WVDP G-14

G-2E. 2006 Radioactivity in Stream Sediments Around the WVDP G-15

APPENDIX H. SUMMARY OF DIRECT RADIATION MONITORING DATA $\mathrm{H}-1$

H-1. Summary of 2006 Quarterly Averages of Off-Site TLD Measurements $\mathrm{H}-3$

H-2. Summary of 2006 Quarterly Averages of On-Site TLD Measurements H-4

H-3. Third-Quarter 2006 TLD Results and Instantaneous Exposure Rate Readings With a HighPressure Ion Chamber at Each Monitoring Location H-5

APPENDIX I. SUMMARY OF METEOROLOGICAL DATA I-1

I-1. 2006 Site Precipitation Collection Data I-7

APPENDIX J. SUMMARY OF QUALITY ASSURANCE CROSSCHECK ANALYSES $\mathrm{J}-1$

J-1. Crosscheck Sample Comparisons From the DOE Mixed Analyte Performance Evaluation Program; Study 15, May 2006

J-2. Crosscheck Sample Comparisons From the DOE Mixed Analyte Performance Evaluation Program; Study 16, October 2006

J-3. Comparisons of Results From Crosscheck Samples Analyzed for Water Quality Parameters as Part of the EPA's 2006 Discharge Monitoring Report - Quality Assurance Study 26 for the National Pollutant Discharge Elimination System 


\section{EXECUTIVE SUMMARY}

\section{Purpose of This Report}

The Annual Site Environmental Report (ASER) for the West Valley Demonstration Project (WVDP or Project) is published to provide information about environmental conditions at the WVDP to members of the public living near the site and to other interested stakeholders. The WVDP is located in western New York State, about 30 miles (50 kilometers [km]) south of Buffalo, within the New York State-owned Western New York Nuclear Service Center. In accordance with United States (U.S.) Department of Energy (DOE) Order 231.1A, "Environment, Safety, and Health Reporting," this report summarizes calendar year (CY) 2006 environmental monitoring data so as to describe the performance of the WVDP's environmental management system (EMS), confirm compliance with standards and regulations, and highlight important programs. Activities at the WVDP are being conducted in cooperation with the New York State Energy Research and Development Authority.

\section{Major Site Programs}

The WVDP is located on the site of a former commercial nuclear fuel reprocessing plant, which was shut down in 1976. In 1980, Public Law 96-368 (the WVDP Act) was passed. This Act autho- rized the DOE to demonstrate a method for solidifying 600,000 gallons (2.3 million liters) of liquid high-level radioactive waste (HLW) that remained at the West Valley site. Vitrification of the HLW, begun in 1996, was completed in September 2002. Activities for decontaminating and dismantling the facilities and for managing and disposing of wastes were then initiated and continued through CY 2006. Major activities that occurred in 2006 are described below.

\section{The Decommissioning, Decontamination,} Dismantlement, and Demolition (D4) Project. As part of the D4 project, many obsolete systems and components in the main plant were packaged and shipped off site for disposal. Some of the components were part of the original Nuclear Fuel Services, Inc. reprocessing facility and had not operated in years.

Environmental Assessment (EA). In accordance with the National Environmental Policy Act, an EA evaluating the proposed decontamination, demolition, and removal of 36 facilities that are

$A$ reader opinion survey has been inserted in this report. If it is missing, please contact the WVDP Communications Department at (716) 942-2152. Additional Project information is available on the internet at http://www.wv.doe.gov. 
(or in the next four years, will be) no longer required to support site activities was issued in September 2006. The DOE issued a Finding Of No Significant Impact (FONSI) based on this EA. Subsequently, several facilities that had already been decontaminated (e.g., the 02 building, the lag storage building, the interim waste storage facility) were demolished and removed.

Waste Management and Shipping. In 2006, materials stored in a number of areas on site were sorted, consolidated, recycled, reused, or disposed. Demolition debris, excess items, and legacy radioactive and nonradioactive waste accounted for approximately 225,000 cubic feet $(6,400$ cubic meters) of industrial and low-level waste (LLW) shipped from the WVDP. That amount, combined with the waste removed from the main plant and other D4 projects on site, brought the total quantity of waste dispositioned in 2006 to about 400,000 cubic feet $(11,300$ cubic meters).

The Remote-Handled Waste Facility (RHWF). The RHWF, although out of service for repairs much of the year, was used to process four mixed waste containers in 2006.

\section{Key Initiatives}

Environmental Performance Indicators. In 2006, management at the WVDP continued efforts to meet goals established for the U.S. Environmental Protection Agency's (EPA) National Environmental Performance Track program for the three-year period of CY 2004-2006. The three goals were: (1) elimination of Halon 1301 from fire-suppression systems on site, (2) a $10 \%$ reduction in total energy usage, and (3) a $10 \%$ reduction in total radiological curies discharged in wastewater. These goals were determined in respect to a 2003 baseline level. The first commitment was completed in 2004. The second goal was met all three years. In 2006, energy usage was reduced by about $26 \%$. The third commitment was met in 2004 and 2006, although not in 2005. Corrective measures implemented in the latter part of 2005 improved performance and in 2006 total radiological curies were reduced by $13 \%$ with respect to baseline.

Pollution Prevention/Waste Minimization. In 2006, as part of the site's EMS, a long-term waste minimization and pollution prevention program to promote affirmative procurement and minimize the generation of LLW, mixed waste, hazardous waste, industrial waste, and sanitary waste continued at the WVDP. The program emphasized good business practices, source reduction, and recycling.

\section{Environmental Management System}

The WVDP EMS satisfies the requirements of DOE Order 450.1, "Environmental Protection Program." The WVDP EMS is a key part of the WVDP Integrated Safety Management System (ISMS). In 2006, WVDP employees continued to demonstrate their commitment to an all-inclusive approach to safety, coordinating the EMS with other safety management and work planning processes through the integrated environmental, health, and safety management program.

Recognition and Awards. In 2006, the WVDP reaffirmed its commitment to the DOE's Voluntary Protection Program (VPP) and was examined as part of the annual ISMS review. VPP STAR status is granted in recognition of excellent worker safety and health programs. The DOE recertified the WVDP as a DOE-VPP STAR site in 2006.

By year-end 2006, WVDP employees reached 4.58 million safe work hours and more than four years without a lost-time work accident. 
Compliance. Management at the WVDP continued to provide strong support for environmental compliance in 2006. Requirements and guidance from applicable state and federal statutes, executive orders, DOE orders, and standards are integrated into the Project's compliance program. In CY 2006:

- no notices of violation or inspection findings from any environmental regulatory agencies were received by the WVDP.

- inspections by the New York State Department of Environmental Conservation and the local department of health verified Project compliance with the applicable environmental and health regulations.

- waste management areas at the site were monitored in compliance with the Resource Conservation and Recovery Act §3008(h) Administrative Order on Consent.

- Project representatives met requirements of the Emergency Planning and Community Right-toKnow Act by collecting information about hazardous materials used at the Project and making this information available to the local community.

- no exceedances to State Pollutant Discharge Elimination System (SPDES) permit limits or to the EPA's National Emission Standards for Hazardous Air Pollutants (NESHAP) dose standard were noted in 2006.

Environmental Monitoring. As part of the EMS, environmental monitoring was continued on and near the site to detect and evaluate changes in the environment resulting from Project (or pre-Project) activities and to assess the effect of any such changes on the environment or human population. Within the environmental monitoring program, airborne and waterborne effluents were sampled and environmental surveillance of the site and nearby areas was conducted.
Radiological Releases. In 2006, the WVDP maintained six NESHAP permits for release of airborne emissions. The primary source of airborne radionuclide emissions was the main stack of the process building.

Waterborne releases were from two primary sources: lagoon 3, from which treated water is released in batches, and from a well-characterized seepage on the north plateau of the WVDP that is contaminated with strontium-90 from preWVDP operations. Six batches totaling approximately 10.4 million gallons (39.3 million liters) were discharged from lagoon 3 in 2006. Radiological concentrations and flow from north plateau seepage were closely monitored.

Estimated Dose. In 2006, the estimated dose to a maximally exposed off-site individual (MEOSI) from airborne emissions at the WVDP was $0.0011 \mathrm{mrem}(0.000011 \mathrm{mSv})$, about $0.01 \%$ of the 10 mrem NESHAP standard. Estimated dose from waterborne sources in 2006 was about $0.048 \mathrm{mrem}$ $(0.00048 \mathrm{mSv})$, with $0.012 \mathrm{mrem}(0.00012 \mathrm{mSv})$ attributable to liquid effluent releases and 0.035 mrem $(0.00035 \mathrm{mSv})$ attributable to the north plateau drainage.

Total estimated dose to the MEOSI from both airborne and waterborne sources in 2006 was $0.049 \mathrm{mrem}(0.00049 \mathrm{mSv})$, about $0.049 \%$ of the annual 100 mrem DOE standard. In comparison, the average dose to a member of the public from natural background sources is 295 mrem per year.

Estimated dose to the population within a 50-mile $(80-\mathrm{km})$ radius of the WVDP from DOE activities in 2006 was 0.22 person-rem $(0.0022$ person$\mathrm{Sv})$. This same population would have received approximately 453,000 person-rem from natural background radiation in 2006. 
Dose to Biota. An evaluation of dose to biota for CY 2006, as part of the WVDP environmental monitoring program, resulted in the conclusion that populations of aquatic and terrestrial biota (both plants and animals) are not being exposed to doses in excess of the existing DOE dose standard for aquatic animals nor the recommended standards for terrestrial biota.

Nonradiological Releases. Nonradiological releases from Project wastewater and storm water monitoring points were measured under the site's SPDES permit. In 2006, no exceedances of any permit limits were noted.

\section{Groundwater Monitoring and North Plateau} Characterization. Monitoring of groundwater at the WVDP continued in 2006, including monitoring of strontium-90 activity in and around the groundwater plume on the north plateau. In late 2006, the DOE submitted to the New York State Department of Environmental Conservation a draft "Sampling and Analysis Plan for Characterization of the North Plateau Plume Area" and a draft "Sampling Plan for Background Subsurface Soil Data on the North Plateau." These plans propose additional sampling to further characterize and evaluate groundwater and soils in the north plateau strontium-90 plume area.

Quality Assurance. In 2006, implementation of a quality assurance program for activities supporting the environmental monitoring and groundwater monitoring programs continued at the WVDP. As part of this ongoing effort, on-site and subcontract laboratories that analyze WVDP environmental samples participated in independent radiological and nonradiological constituent performance evaluation studies. In these studies, test environmental samples with concentrations known by the testing agency, but unknown by the laboratory, were analyzed. Of almost 200 performance evaluation analyses conducted by or for the WVDP, 97\% fell within acceptance limits.

Several inspections, audits, and assessments of components of the environmental monitoring program were conducted in 2006. Although actions were recommended to improve the program, nothing was found that would compromise the data quality in this report or the environmental monitoring program in general.

\section{Conclusion}

In addition to demonstrating compliance with environmental regulations and directives, evaluation of data collected in 2006 continued to indicate that WVDP activities pose no threat to public health or safety, or to the environment. 


\section{INTRODUCTION}

\section{Site Location}

The West Valley Demonstration Project (WVDP or Project) is located in western New York State, about 30 miles (50 kilometers [km]) south of Buffalo, New York (Fig. INT-1). The WVDP facilities occupy a security-fenced area of about 167 acres (68 hectares [ha]) within the 3,338-acre (1,351 ha) Western New York Nuclear Service Center (WNYNSC) located primarily in the town of Ashford in northern Cattaraugus County. The security-fenced area is referred to as the Project premises.

\section{General Environmental Setting}

Climate. Although extremes of $98.6^{\circ} \mathrm{F}\left(37^{\circ} \mathrm{C}\right)$ and $-43.6^{\circ} \mathrm{F}\left(-42^{\circ} \mathrm{C}\right)$ have been recorded in western New York, the climate is moderate, with an average annual temperature (1971-2000) of $48^{\circ} \mathrm{F}$ $\left(8.9^{\circ} \mathrm{C}\right)$. Precipitation is markedly influenced by Lake Erie to the west and, to a lesser extent, by Lake Ontario to the north. Regional winds are generally from the west and south at about 9 miles perhour (4 meters/second).

Ecology. The WNYNSC lies within the northern deciduous forest biome, and the diversity of its vegetation is typical of the region. Equally divided between forest and open land, the site provides a habitat especially attractive to white-tailed deer and various indigenous migratory birds, reptiles, and small mammals. No species on the federal endangered species list are known to reside on the WNYNSC.

Geology and Hydrology. The Project lies on New York State's Allegheny Plateau at an average elevation of about 1,300 feet (400 meters). The underlying geology includes a sequence of glacial sediments above shale bedrock. The Project is drained by three small streams (Frank's Creek, Quarry Creek, and Erdman Brook) and is divided by a stream valley (Erdman Brook) into two general areas: the north plateau and the south plateau.

Frank's Creek, which receives drainage from Erdman Brook and Quarry Creek, flows into Buttermilk Creek, which enters Cattaraugus Creek and leaves the WNYNSC. (See Figs. A-1 and A5.) Cattaraugus Creek ultimately drains into Lake Erie, to the northwest.

\section{Site Mission}

The facility that later became the WVDP was the site of a commercial nuclear fuel reprocessing plant run by Nuclear Fuel Services, Inc. (NFS) from

INT - 1 


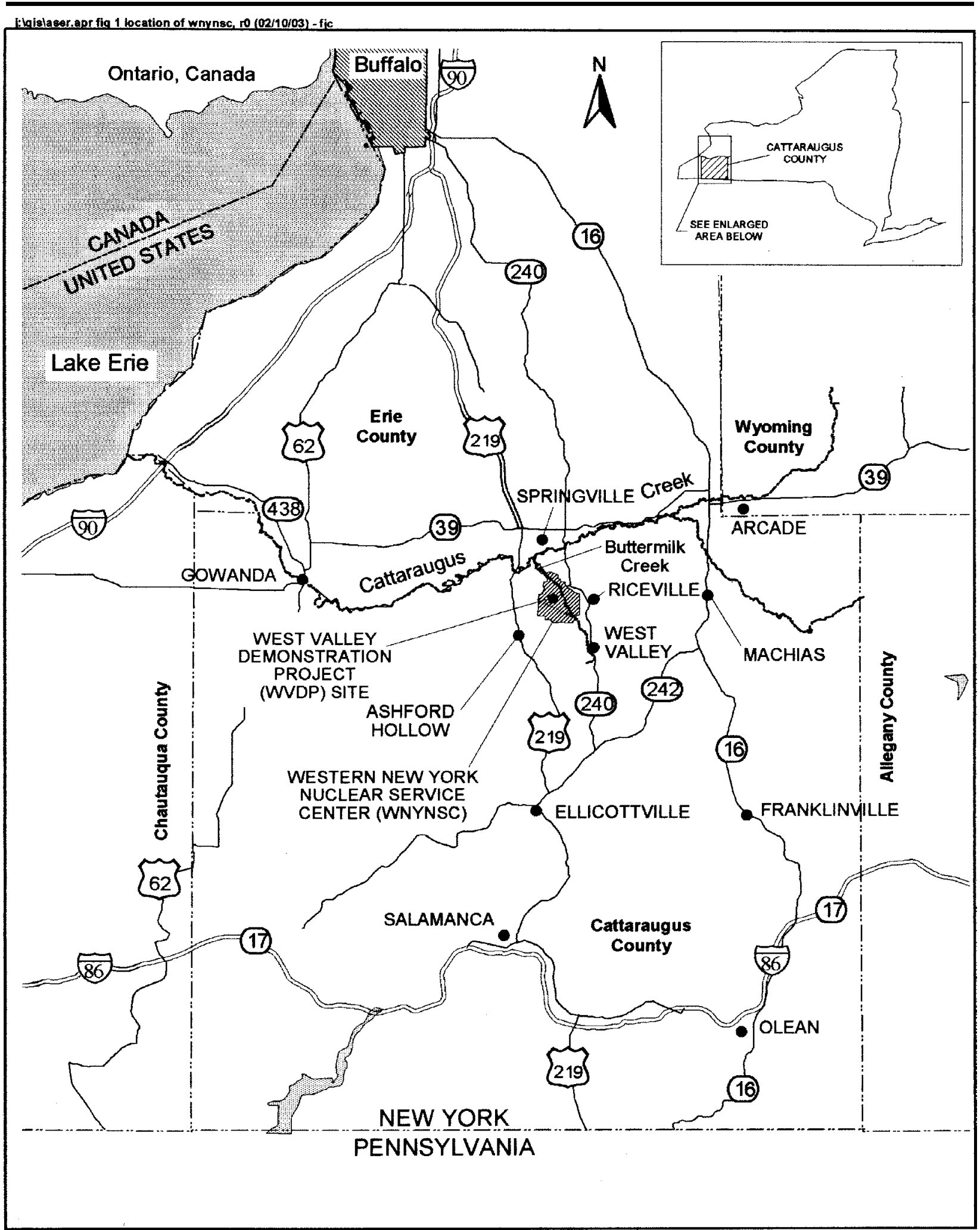

Figure INT-1. Location of the Western New York Nuclear Service Center

INT - 2 
1966 until 1972. Uranium and plutonium were recovered from spent nuclear fuel for reuse. In 1972, the reprocessing facility closed for expansion, but in 1976 NFS notified the New York State Energy Research and Development Authority that it was no longer economically feasible to continue in the fuel-reprocessing business and the plant was shut down. In 1980, Public Law 96-368 (the West Valley Demonstration Project Act) was passed. This Act authorized the United States Department of Energy (DOE) to demonstrate a method for solidifying 600,000 gallons (2.3 million liters) of liquid high-level radioactive waste (HLW) that remained at the West Valley site. For a detailed history of the site, see the Introduction of the 2003 Annual Site Environmental Report. See Appendix $\mathrm{K}^{\mathrm{GD}}$ for the complete text of the WVDP Act.

The purposes of the WVDP Act were to carry out the following activities: solidify the HLW that was left at the site from the original nuclear fuel reprocessing activities; develop suitable containers for holding and transporting the solidified waste; transport, in accordance with applicable provisions of law, the solidified waste to an appropriate Federal repository for permanent disposal; dispose of any low-level and transuranic radioactive waste resulting from the solidification of HLW; and decontaminate and decommission Project facilities used for solidification of radioactive waste.

Vitrification of the HLW began in 1996 and was completed in September 2002. Activities for decontaminating the vitrification and support facilities and for disposing of wastes were then initiated and continue through the present.

\section{Primary Operations and Activities}

The following operations and activities were initiated or continued in 2006:
The Decommissioning, Decontamination, Dismantlement, and Demolition (D4) Project. As part of the D4 project, many obsolete systems and components in the main plant were packaged and shipped off site for disposal. Some of the components were part of the original NFS nuclear reprocessing facility and had not operated in years.

Environmental Assessment (EA). An EA evaluating the proposed decontamination, demolition, and removal of 36 facilities that are (or in the next four years, will be) no longer required to support site activities was issued in September 2006. The DOE issued a Finding Of No Significant Impact (FONSI) based on this EA. Subsequently, several facilities that had already been decontaminated (e.g., the 02 building, the lag storage building, the interim waste storage facility) were demolished and removed.

Waste Management and Shipping. In 2006, materials stored in a number of areas on site were sorted, consolidated, recycled, reused, or disposed. Demolition debris, excess items, and legacy radioactive and nonradioactive waste accounted for approximately 225,000 cubic feet $(6,400$ cubic meters) of industrial and low-level waste shipped from the WVDP. That amount, combined with the waste removed from the main plant and other D4 projects on site, brought the total quantity of waste dispositioned in 2006 to about 400,000 cubic feet (11,300 cubic meters).

The Remote-Handled Waste Facility (RHWF). The RHWF, although out of service for repairs much of the year, was used to process four mixed waste (radioactive and hazardous) containers in 2006.

Treating Radioactively Contaminated Groundwater. The north plateau groundwater recovery system (NPGRS) continued to operate in 2006. The NGPRS was installed in 1995 to mitigate a 
portion of the strontium-90 groundwater plume and reduce groundwater seepage northeast of the process building. In 2006, two draft plans to further characterize and evaluate the plume area were submitted by the DOE to the New York State Department of Environmental Conservation.

Environmental Monitoring. Samples from environmental media on and near the site were collected and analyzed in accordance with the monitoring schedule described in Appendix $B^{\text {Go }}$ of this report. Measurements from air, water, sediment, and food samples, environmental dosimeters, and meteorological instruments are presented in the data tables at the end of this report. Measurements were evaluated in comparison with background measurements of the same media and with applicable environmental standards. Results are discussed in Chapters 2, 3, and 4 of this report. As in past years, in 2006 the WVDP was found to be in compliance with applicable regulatory standards pertaining to environmental effluents.

\section{Relevant Demographics}

Although several roads and a railway approach or pass through the WNYNSC, the public generally is prohibited from access to the WNYNSC for activities such as camping or fishing. Limited deer hunting in designated areas is allowed (a yearto-year decision). No public access is allowed on the Project premises.

Land near the WNYNSC is used primarily for agriculture and arboriculture. Downstream of the WNYNSC, Cattaraugus Creek is used locally for swimming, canoeing, and fishing. Although some water is taken from the creek to irrigate nearby golf course greens and tree farms, no public drinking water is drawn from the creek before it flows into Lake Erie. Water from Lake Erie is used as a public drinking water supply.
The communities of West Valley, Riceville, Ashford Hollow, and the village of Springville are located within approximately 5 miles $(8 \mathrm{~km})$ of the Project. The nearby population, approximately 9,200 residents within 6.2 miles $(10 \mathrm{~km})$ of the Project, relies largely on an agricultural economy. No major industries are located within this area. The WVDP is one of the largest employers in Cattaraugus County. 


\section{ENVIRONMENTAL COMPLIANCE SUMMARY \\ Calendar Year 2006}

\section{Compliance Program}

The United States (U.S.) Department of Energy (DOE) is currently focusing on several goals at the West Valley Demonstration Project (WVDP or Project) to support completion of the requirements identified in the WVDPAct. (See Appendix $K^{\text {G. }}$.) Activities during 2006 included decontamination and demolition of unneeded facilities, processing and packaging of low-level radioactive waste and mixed waste inventories for off-site shipment and disposal, continued limited operation of the remote-handled waste facility, reducing infrastructure, continued treatment of radioactively contaminated groundwater, and continued environmental monitoring.

Activities at the WVDP are regulated by various federal and state public, worker, and environmental protection laws. These laws are administered primarily by the U.S. Environmental Protection Agency (EPA), the U.S. Fish and Wildlife Service, the U.S. Army Corps of Engineers (USACE), the New York State Department of Environmental Conservation (NYSDEC), and the New York State Department of Health (NYSDOH) through programs and regulatory requirements for permitting, reporting, inspecting, self-monitoring, and audits. Table ECS-1 summarizes the WVDP's compliance status with applicable environmental statutes, DOE directives, and executive orders.
Because release of radiological and nonradiological materials from an active facility cannot be completely prevented, the EPA, NYSDEC, and DOE have established standards for effluents that are intended to protect human health, safety, and the environment. The DOE applies to the EPAfor permits to release limited amounts of radiological constituents to the air and applies to NYSDEC for permits to release limited amounts of nonradiological constituents to the air and water in concentrations determined to be safe for humans and the environment. In general, the permits describe release points, specify management and reporting requirements, list discharge limits on those pollutants likely to be present, and define the sampling and analysis regimen. Releases of radiological constituents in water are subject to the requirements in DOE Orders 450.1 (Environmental Protection Program) and 5400.5 (Radiation Protection of the Public and the Environment). A summary of permits may be found in Table ECS-2. (See the Compliance Tables at the end of this chapter.) No releases above allowable permit or regulatory limits occurred in 2006.

\section{Compliance Status}

The following summary describes WVDP compliance with DOE Orders 450.1, 5400.5, and 435.1 and federal and state laws and regulations applicable to the Project. 


\section{Table ECS-1}

Compliance Status Summary for the WVDP in 2006

\begin{tabular}{|c|c|c|c|}
\hline Citation & $\begin{array}{c}\text { Environmental Statute, } \\
\text { DOE Directive, Executive Order }\end{array}$ & $\begin{array}{c}\text { WVDP Compliance } \\
\text { Status } \\
\end{array}$ & $\begin{array}{l}\text { Location in } \\
2006 \text { ASER }\end{array}$ \\
\hline \begin{tabular}{|l|}
42 United States \\
Code (USC) \\
$\$ 2011$ et seq.
\end{tabular} & $\begin{array}{l}\text { The Atomic Energy Act (AEA) of } 1954 \\
\text { was enacted to assure the proper } \\
\text { management of source, special nuclear, and } \\
\text { by-product material. The AEA and the } \\
\text { statutes that amended it delegate the control } \\
\text { of nuclear energy primarily to the DOE, the } \\
\text { Nuclear Regulatory Commission (NRC), } \\
\text { and the EPA. }\end{array}$ & $\begin{array}{l}\text { See discussions of the WVDP Act } \\
\text { and of DOE Orders 435.1, 450.1, } \\
\text { and 5400.5. }\end{array}$ & $\begin{array}{l}\text { Environmental } \\
\text { Compliance } \\
\text { Summary }\end{array}$ \\
\hline \begin{tabular}{|l} 
Public Law \\
$96-368$
\end{tabular} & $\begin{array}{l}\text { The West Valley Demonstration Project } \\
\text { Act of } 1980 \text { (WVDP Act) authorized the } \\
\text { DOE to carry out a high-level liquid nuclear } \\
\text { waste demonstration project at the Western } \\
\text { New York Service Center in West Valley, } \\
\text { New York. }\end{array}$ & $\begin{array}{l}\text { The DOE is focusing on goals that } \\
\text { will lead to completion of } \\
\text { responsibilities listed in the WVDP } \\
\text { Act. }\end{array}$ & $\begin{array}{l}\text { Executive } \\
\text { Summary; } \\
\text { Introduction; } \\
\text { Appendix K }^{\text {en }}\end{array}$ \\
\hline \begin{tabular}{|l|} 
WVDP \\
Memorandum of \\
Understanding \\
(MOU) between \\
the DOE and the \\
NRC
\end{tabular} & $\begin{array}{l}\text { The MOU, mandated by the WVDP Act of } \\
\text { 1980, established procedures for review and } \\
\text { consultation by the NRC with respect to } \\
\text { activities conducted at the Western New } \\
\text { York Nuclear Service Center (WNYNSC) } \\
\text { by the DOE under the Act. The agreement } \\
\text { encompassed those development, design, } \\
\text { construction, operation, and } \\
\text { decontamination and decommissioning } \\
\text { activities that are associated with the project } \\
\text { as described in the Act. }\end{array}$ & $\begin{array}{l}\text { The NRC was authorized to } \\
\text { prescribe decontamination and } \\
\text { decommissioning criteria in } \\
\text { accordance with the Act. The NRC } \\
\text { visits the Site periodically to ensure } \\
\text { that activities are performed in } \\
\text { accordance with requirements of } \\
\text { established programs. }\end{array}$ & $\begin{array}{l}\text { Environmental } \\
\text { Compliance } \\
\text { Summary; } \\
\text { Chapter } 5\end{array}$ \\
\hline $\begin{array}{l}\text { DOE Order } \\
231.1 \mathrm{~A}\end{array}$ & $\begin{array}{l}\text { DOE O 231.1A, Environment, Safety, and } \\
\text { Health Reporting, was issued to ensure } \\
\text { timely collection, reporting, analysis, and } \\
\text { dissemination of information on } \\
\text { environment, safety, and health issues as } \\
\text { required by law or regulations or as needed } \\
\text { to ensure that the DOE and National } \\
\text { Nuclear Security Administration are kept } \\
\text { fully informed on a timely basis about } \\
\text { events that could adversely affect the health } \\
\text { and safety of the public or the workers, the } \\
\text { environment, the intended purpose of DOE } \\
\text { facilities, or the credibility of the DOE. }\end{array}$ & $\begin{array}{l}\text { This WVDP Annual Site } \\
\text { Environmental Report (ASER) is } \\
\text { prepared and submitted annually in } \\
\text { compliance with DOE O 231.1A. }\end{array}$ & $\begin{array}{l}\text { Entire } 2006 \\
\text { WVDP ASER }\end{array}$ \\
\hline
\end{tabular}

ECS - 2 
Table ECS-1 (continued)

Compliance Status Summary for the WVDP in 2006

\begin{tabular}{|c|c|c|c|}
\hline Citation & $\begin{array}{c}\text { Environmental Statute, } \\
\text { DOE Directive, Executive Order }\end{array}$ & $\begin{array}{c}\text { WVDP Compliance } \\
\text { Status }\end{array}$ & $\begin{array}{l}\text { Location in } \\
2006 \text { ASER }\end{array}$ \\
\hline $\begin{array}{l}\text { DOE Order } \\
450.1\end{array}$ & $\begin{array}{l}\text { DOE O 450.1, Environmental Protection } \\
\text { Program, required implementation of an } \\
\text { environmental management system (EMS) } \\
\text { for conducting work at DOE sites to protect } \\
\text { the air, water, land, and other natural and } \\
\text { cultural resources impacted by DOE } \\
\text { operations. }\end{array}$ & $\begin{array}{l}\text { The WVDP EMS is integrated with } \\
\text { other site safety management and } \\
\text { work planning processes. }\end{array}$ & $\begin{array}{l}\text { Environmental } \\
\text { Compliance } \\
\text { Summary; } \\
\text { Chapter } 1\end{array}$ \\
\hline $\begin{array}{l}\text { DOE Order } \\
5400.5\end{array}$ & $\begin{array}{l}\text { DOE Order 5400.5, Radiation Protection } \\
\text { of the Public and the Environment, } \\
\text { established standards and requirements for } \\
\text { operations of the DOE and DOE contractors } \\
\text { with respect to protecting members of the } \\
\text { public and the environment against undue } \\
\text { risk from radiation. }\end{array}$ & $\begin{array}{l}\text { Estimated doses from airborne and } \\
\text { waterborne releases to the } \\
\text { maximally exposed off-site } \\
\text { individual in } 2006 \text { were } 0.049 \% \text { of } \\
\text { the } 100 \text { mrem standard, and about } \\
0.02 \% \text { of natural background } \\
\text { radiation. }\end{array}$ & $\begin{array}{l}\text { Environmental } \\
\text { Compliance } \\
\text { Summary; } \\
\text { Chapter 2; } \\
\text { Appendices C } \\
\text { and } D^{\text {ब1. }}\end{array}$ \\
\hline $\begin{array}{l}\text { DOE Order } \\
435.1\end{array}$ & $\begin{array}{l}\text { DOE O 435.1, Radioactive Waste } \\
\text { Management, was issued to ensure that all } \\
\text { DOE radioactive waste is managed in a } \\
\text { manner that is protective of worker and } \\
\text { public health and safety, and the } \\
\text { environment. }\end{array}$ & $\begin{array}{l}\text { Management of radioactive waste at } \\
\text { the WVDP is conducted in } \\
\text { accordance with written site } \\
\text { policies, procedures, and manuals } \\
\text { and is fully compliant with DOE O } \\
435.1 \text {. }\end{array}$ & $\begin{array}{l}\text { Environmental } \\
\text { Compliance } \\
\text { Summary; } \\
\text { Chapter } 1\end{array}$ \\
\hline $\begin{array}{l}42 \text { USC } \$ 4321 \\
\text { et seq. }\end{array}$ & $\begin{array}{l}\text { The National Environmental Policy Act } \\
\text { of } 1969 \text { (NEPA) established a national } \\
\text { policy to ensure that protection of the } \\
\text { environment is included in federal planning } \\
\text { and decision-making. }\end{array}$ & $\begin{array}{l}\text { Alternatives for management of } \\
\text { WVDP LLW, mixed waste, high- } \\
\text { level waste (HLW), and transuranic } \\
\text { (TRU) wastes were evaluated in a } \\
\text { Waste Management Environmental } \\
\text { Impact Statement (EIS). In } 2005 \text { the } \\
\text { Waste Management Record of } \\
\text { Decision (ROD) for the WVDP was } \\
\text { issued. In 2006, an Environmental } \\
\text { Assessment (EA) DOE/EA-1552 } \\
\text { was issued that proposed } \\
\text { decontamination, demolition, and } \\
\text { removal of unneeded facilities. The } \\
\text { DOE then issued a Finding of No } \\
\text { Significant Impact (FONSI) and } \\
\text { removal of facilities began. }\end{array}$ & $\begin{array}{l}\text { Environmental } \\
\text { Compliance } \\
\text { Summary }\end{array}$ \\
\hline
\end{tabular}

ECS - 3 
Table ECS-1 (continued)

Compliance Status Summary for the WVDP in 2006

\begin{tabular}{|c|c|c|c|}
\hline Citation & $\begin{array}{c}\text { Environmental Statute, } \\
\text { DOE Directive, Executive Order }\end{array}$ & $\begin{array}{c}\text { WVDP Compliance } \\
\text { Status }\end{array}$ & $\begin{array}{l}\text { Location in } \\
2006 \text { ASER }\end{array}$ \\
\hline \begin{tabular}{|l|}
42 USC $\$ 6901$ \\
et seq. New \\
York State \\
(NYS) \\
Environmental \\
Conservation \\
Law (ECL)
\end{tabular} & $\begin{array}{l}\text { The Resource Conservation and } \\
\text { Recovery Act (RCRA) of } 1976 \text { and the } \\
\text { New York State Solid Waste Disposal Act } \\
\text { (NYS ECL Article } 27 \text { [Title 9]) govern the } \\
\text { generation, storage, handling, and disposal } \\
\text { of hazardous wastes and closure of tank } \\
\text { systems that handle these wastes. RCRA } \\
\text { was enacted to ensure that hazardous wastes } \\
\text { are managed in a way that protects human } \\
\text { health, safety, and the environment. }\end{array}$ & $\begin{array}{l}\text { Generation, storage, handling, and } \\
\text { disposal of hazardous waste, and } \\
\text { closure of tank systems that handle } \\
\text { hazardous waste at the WVDP, are } \\
\text { conducted in accordance with the } \\
\text { RCRA Part A interim status } \\
\text { regulatory requirements. }\end{array}$ & $\begin{array}{l}\text { Environmental } \\
\text { Compliance } \\
\text { Summary; } \\
\text { Chapter } 4\end{array}$ \\
\hline $\begin{array}{l}\text { Amendment to } \\
42 \text { USC } \$ 6961\end{array}$ & $\begin{array}{l}\text { The Federal Facilities Compliance Act } \\
\text { (FFCA) of } 1992 \text { (an amendment to RCRA) } \\
\text { clarified provisions concerning the } \\
\text { application of certain requirements and } \\
\text { sanctions to federal facilities. }\end{array}$ & $\begin{array}{l}\text { An Order of Consent, negotiated } \\
\text { under the FFCA, was executed } \\
\text { between NYSDEC and DOE in } \\
\text { 1996. The order established } \\
\text { commitments regarding compliance } \\
\text { with the Site Treatment Plan (STP) } \\
\text { for mixed waste inventories at the } \\
\text { WVDP. }\end{array}$ & $\begin{array}{l}\text { Environmental } \\
\text { Compliance } \\
\text { Summary }\end{array}$ \\
\hline $\begin{array}{l}\text { Docket No. II } \\
\text { RCRA-3008(h) - } \\
92-0202\end{array}$ & $\begin{array}{l}\text { The DOE and NYSERDA entered into a } \\
\text { RCRA \$3008(h) Administrative Order on } \\
\text { Consent (the Consent Order) with } \\
\text { NYSDEC and EPA in March 1992. The } \\
\text { Consent Order pertained to management of } \\
\text { hazardous waste and/or hazardous } \\
\text { constituents from solid waste management } \\
\text { units at the WNYNSC. }\end{array}$ & $\begin{array}{l}\text { Written procedures and site } \\
\text { activities are compliant with the } \\
\text { Consent Order. Compliance was } \\
\text { verified by inspections in October } \\
\text { 2006. In accordance with the } \\
\text { Consent Order, quarterly reports are } \\
\text { submitted to NYSDEC from DOE } \\
\text { which summarize all RCRA } \\
\text { \$3008(h) activities conducted at the } \\
\text { WVDP for the respective quarter. }\end{array}$ & $\begin{array}{l}\text { Environmental } \\
\text { Compliance } \\
\text { Summary; } \\
\text { Chapter } 4\end{array}$ \\
\hline $\begin{array}{l}\text { NYS Navigation } \\
\text { Law and NYS } \\
\text { ECL }\end{array}$ & $\begin{array}{l}\text { NYS Navigation Law, Article 12, et seq.; } \\
\text { NYS ECL, Article } 17 \text { (Titles } 10 \text { and 17); } \\
\text { and Article } 40 \text {. These articles regulate } \\
\text { design, operation, inspection, maintenance, } \\
\text { and closure of aboveground bulk petroleum } \\
\text { and bulk chemical storage tanks. They also } \\
\text { regulate spill reporting and cleanup. }\end{array}$ & $\begin{array}{l}\text { As of June } 2006 \text {, the last remaining } \\
\text { chemical bulk storage tank at the } \\
\text { WVDP was closed under these } \\
\text { regulations. Nine (9) registered } \\
\text { petroleum bulk storage tanks are } \\
\text { periodically inspected and } \\
\text { maintained. Spills are reported and } \\
\text { cleaned up in accordance with } \\
\text { written policies and procedures. In } \\
2006 \text { there were no spills in excess } \\
\text { of the reportable quantities. }\end{array}$ & $\begin{array}{l}\text { Environmental } \\
\text { Compliance } \\
\text { Summary; } \\
\text { Chapter 1 }\end{array}$ \\
\hline
\end{tabular}

ECS - 4 


\section{Table ECS-1 (continued)}

\section{Compliance Status Summary for the WVDP in 2006}

\begin{tabular}{|c|c|c|c|}
\hline Citation & $\begin{array}{c}\text { Environmental Statute, } \\
\text { DOE Directive, Executive Order }\end{array}$ & $\begin{array}{c}\text { WVDP Compliance } \\
\text { Status }\end{array}$ & $\begin{array}{l}\text { Location in } \\
2006 \text { ASER }\end{array}$ \\
\hline $\begin{array}{l}\text { Executive } \\
\text { Orders (E.O.) } \\
13101 \text { and } \\
13148\end{array}$ & $\begin{array}{l}\text { E.O. 13101, Greening the Government } \\
\text { Through Waste Prevention, Recycling, } \\
\text { and Federal Acquisition, promoted the use } \\
\text { of recycled and environmentally preferable } \\
\text { products and services by federal agencies. } \\
\text { E.O. 13148, Greening the Government } \\
\text { Through Leadership in Environmental } \\
\text { Management, specified that heads of } \\
\text { federal agencies are responsible for } \\
\text { integrating environmental accountability } \\
\text { into day-to-day decision-making and long- } \\
\text { term planning processes. }\end{array}$ & $\begin{array}{l}\text { Waste minimization, pollution } \\
\text { prevention, recycling, and } \\
\text { affirmative procurement objectives } \\
\text { are achieved in accordance with } \\
\text { written site policies and procedures. } \\
\text { In January 2007, these Orders were } \\
\text { revoked by E.O. 13423, } \\
\text { Strengthening Federal } \\
\text { Environmental, Energy, and } \\
\text { Transportation Management. }\end{array}$ & $\begin{array}{l}\text { Environmental } \\
\text { Compliance } \\
\text { Summary; } \\
\text { Chapter 1 }\end{array}$ \\
\hline $\begin{array}{l}42 \text { USC } \$ 7401 \\
\text { et seq.; Title } 40 \\
\text { of the Code of } \\
\text { Federal } \\
\text { Regulations } \\
\text { (CFR) 61, } \\
\text { Subpart H; Title } \\
6 \text { of the New } \\
\text { York Official } \\
\text { Compilation of } \\
\text { Codes, Rules, } \\
\text { and Regulations } \\
\text { (6 NYCRR) }\end{array}$ & $\begin{array}{l}\text { The Clean Air Act of } 1970 \text { (CAA) and the } \\
\text { NYS ECL regulate the release of air } \\
\text { pollutants through permits and air quality } \\
\text { limits. Emissions of radionuclides are } \\
\text { regulated by the EPA via the National } \\
\text { Emission Standards for Hazardous Air } \\
\text { Pollutants (NESHAP) regulations. } \\
\text { Nonradiological emissions are permitted } \\
\text { under } 6 \text { NYCRR Part 201-4 (Minor Facility } \\
\text { Registrations) }\end{array}$ & $\begin{array}{l}\text { In 2006, the DOE maintained six } \\
\text { NESHAP permits for radiological } \\
\text { emissions and one Air Facility } \\
\text { Registration Certificate for } \\
\text { nonradiological emissions at the } \\
\text { WVDP. Estimated dose from } \\
\text { radiological air emissions to the } \\
\text { maximally exposed off-site } \\
\text { individual in } 2006 \text { was } 0.01 \% \text { of } \\
\text { the } 10 \text { millirem Subpart H standard. } \\
\text { Nonradiological emissions of } \\
\text { nitrogren oxides and sulfur oxides } \\
\text { were less than } 7 \% \text { of the standard } \\
\text { for maintaining the registration } \\
\text { certificate. }\end{array}$ & $\begin{array}{l}\text { Environmental } \\
\text { Compliance } \\
\text { Summary; } \\
\text { Chapters } 2 \text { and 3; } \\
\text { Appendix D }\end{array}$ \\
\hline $\begin{array}{l}42 \text { USC } \S 11001 \\
\text { et seq. }\end{array}$ & $\begin{array}{l}\text { The Emergency Planning and } \\
\text { Community Right-to-Know Act of } 1986 \\
\text { (EPCRA) was designated to help local } \\
\text { communities protect public health, safety, } \\
\text { and the environment from chemical hazards. }\end{array}$ & $\begin{array}{l}\text { The WVDP's chemical inventory } \\
\text { was reported in 2006. No further } \\
\text { reporting was required. }\end{array}$ & $\begin{array}{l}\text { Environmental } \\
\text { Compliance } \\
\text { Summary }\end{array}$ \\
\hline
\end{tabular}

ECS - 5 
Table ECS-1 (continued)

Compliance Status Summary for the WVDP in 2006

\begin{tabular}{|c|c|c|c|}
\hline Citation & $\begin{array}{c}\text { Environmental Statute, } \\
\text { DOE Directive, Executive Order }\end{array}$ & $\begin{array}{c}\text { WVDP Compliance } \\
\text { Status }\end{array}$ & $\begin{array}{l}\text { Location in } \\
2006 \text { ASER }\end{array}$ \\
\hline $\begin{array}{l}33 \text { USC } § 1251 \\
\text { et seq. and NYS } \\
\text { ECL }\end{array}$ & $\begin{array}{l}\text { The Federal Water Pollution Control Act } \\
\text { of } 1977 \text { (Clean Water Act [CWA]) and } \\
\text { NYS ECL (Article } 17 \text { [Title 8]) seek to } \\
\text { improve surface water quality by } \\
\text { establishing standards and a system of } \\
\text { permits. Wastewater and storm water } \\
\text { discharges are regulated by NYSDEC } \\
\text { permits through the State Pollutant } \\
\text { Discharge Elimination System (SPDES). } \\
\text { Discharges of fill material are regulated } \\
\text { through permits issued by the USACE and } \\
\text { water quality certifications issued by } \\
\text { NYSDEC. }\end{array}$ & \begin{tabular}{|l|} 
In 2006, no SPDES exceedences \\
were noted and compliance with \\
permit requirements was confirmed \\
by inspections. Monitoring of \\
storm water under the SPDES \\
permit continued. In February \\
2006, DOE submitted proposed \\
permit modifications to NYSDEC \\
which were issued for public \\
comment and remain pending. \\
Effective September 1, 2006, \\
NYSDEC approved previously \\
submitted modification requests and \\
issued a modified permit.
\end{tabular} & $\begin{array}{l}\text { Environmental } \\
\text { Compliance } \\
\text { Summary; } \\
\text { Chapters } 1 \text { and 3; } \\
\text { Appendices B } \\
\text { and C } C^{\text {(1) }}\end{array}$ \\
\hline E.O. 11990 & $\begin{array}{l}\text { E.O. 11990, Protection of Wetlands, } \\
\text { directed federal agencies to avoid, where } \\
\text { possible, impacts (e.g., destruction, } \\
\text { modification, or new construction) that } \\
\text { would adversely effect wetlands wherever } \\
\text { there is a practical alternative. Activities in } \\
\text { wetlands are regulated by the USACE and } \\
\text { NYSDEC permits. }\end{array}$ & $\begin{array}{l}\text { Wetlands on the WVDP are } \\
\text { periodically identified, delineated, } \\
\text { and mapped. In } 2005 \text {, NYSDEC } \\
\text { approved the wetland delineation } \\
\text { report and the USACE performed a } \\
\text { field verification wetland } \\
\text { assessment in late } 2005 \text {. The } \\
\text { wetland boundaries were confirmed } \\
\text { by the USACE on January } 26 \text {, } \\
2006 \text {. }\end{array}$ & $\begin{array}{l}\text { Environmental } \\
\text { Compliance } \\
\text { Summary }\end{array}$ \\
\hline $\begin{array}{l}42 \text { USC } § 9601 \\
\text { et seq. }\end{array}$ & $\begin{array}{l}\text { The Comprehensive Environmental } \\
\text { Response, Compensation, and Liability } \\
\text { Act of } 1980 \text { (CERCLA, including the } \\
\text { Superfund Amendments and } \\
\text { Reauthorization Act of } 1986 \text { [SARA]) } \\
\text { provided the regulatory framework for } \\
\text { remediation of releases of hazardous } \\
\text { substances and remediation of inactive } \\
\text { hazardous waste disposal sites. }\end{array}$ & $\begin{array}{l}\text { Based on the results of a } \\
\text { Preliminary Assessment Report } \\
\text { prepared for the DOE, it was } \\
\text { determined that the WVDP did not } \\
\text { qualify for listing on the National } \\
\text { Priorities List. Therefore, no further } \\
\text { investigation pursuant to CERCLA } \\
\text { was warranted. However, if a spill } \\
\text { exceeds a reportable quantity, } \\
\text { CERCLA reporting requirements } \\
\text { may be triggered. The WVDP } \\
\text { annually reports chemical } \\
\text { inventories under EPCRA (also } \\
\text { known as SARA Title III) as } \\
\text { appropriate. }\end{array}$ & $\begin{array}{l}\text { Environmental } \\
\text { Compliance } \\
\text { Summary }\end{array}$ \\
\hline
\end{tabular}

ECS - 6 


\section{Table ECS-1 (continued)}

\section{Compliance Status Summary for the WVDP in 2006}

\begin{tabular}{|c|c|c|c|}
\hline Citation & $\begin{array}{c}\text { Environmental Statute, } \\
\text { DOE Directive, Executive Order }\end{array}$ & $\begin{array}{c}\text { WVDP Compliance } \\
\text { Status }\end{array}$ & $\begin{array}{l}\text { Location in } \\
2006 \text { ASER }\end{array}$ \\
\hline $\begin{array}{l}42 \text { USC } \S 300 f \\
\text { et seq. }\end{array}$ & $\begin{array}{l}\text { The Safe Drinking Water Act of } 1974 \\
\text { (SDWA) required that each federal agency } \\
\text { operating or maintaining a public water } \\
\text { system must comply with all federal, state, } \\
\text { and local requirements regarding safe } \\
\text { drinking water. Compliance in New York is } \\
\text { overseen by NYSDOH through the NYS } \\
\text { Public Health Law and county health } \\
\text { departments. }\end{array}$ & $\begin{array}{l}\text { CY } 2006 \text { results from analyses of } \\
\text { drinking water were reported to the } \\
\text { Cattaraugus County Health } \\
\text { Department (CCHD). All test } \\
\text { results were within drinking water } \\
\text { limits. }\end{array}$ & $\begin{array}{l}\text { Environmental } \\
\text { Compliance } \\
\text { Summary; } \\
\text { Chapter 2; } \\
\text { Chapter 3; } \\
\text { Appendix C }\end{array}$ \\
\hline $\begin{array}{l}15 \text { USC } \$ 2601 \\
\text { et seq. }\end{array}$ & $\begin{array}{l}\text { The Toxic Substances Control Act of } \\
1976 \text { (TSCA) was enacted to give the EPA } \\
\text { the ability to track industrial chemicals } \\
\text { produced or imported into the U.S. }\end{array}$ & $\begin{array}{l}\text { Asbestos-containing materials and } \\
\text { polychlorinated biphenyls (PCBs) } \\
\text { are managed in accordance with } \\
\text { written site policies and procedures. }\end{array}$ & $\begin{array}{l}\text { Environmental } \\
\text { Compliance } \\
\text { Summary }\end{array}$ \\
\hline $\begin{array}{l}7 \text { USC } \$ 136 \text { et } \\
\text { seq. }\end{array}$ & $\begin{array}{l}\text { The Federal Insecticide, Fungicide, and } \\
\text { Rodenticide Act of } 1996 \text { (FIFRA) and } \\
\text { NYS ECL provided for EPA and NYSDEC } \\
\text { control of pesticide distribution, sale, and } \\
\text { use. }\end{array}$ & $\begin{array}{l}\text { Chemical pesticides are applied at } \\
\text { the WVDP only after alternative } \\
\text { methods are evaluated by trained } \\
\text { and NYSDEC-certified } \\
\text { professionals and determined to be } \\
\text { unfeasible. } \\
\end{array}$ & $\begin{array}{l}\text { Environmental } \\
\text { Compliance } \\
\text { Summary }\end{array}$ \\
\hline $\begin{array}{l}\text { NYS ECL, } \\
\text { Article } 15, \text { Title } \\
5, \text { et seq. }\end{array}$ & $\begin{array}{l}\text { NYS ECL, Article } 15 \text {, Title } 5 \text {, Protection } \\
\text { of Water regulated the safety of dams and } \\
\text { other surface water impounding structures, } \\
\text { including construction, inspection, } \\
\text { operation, maintenance and modification of } \\
\text { these structures. }\end{array}$ & $\begin{array}{l}\text { The two surface water impounding } \\
\text { dam structures on the WNYNSC } \\
\text { were inspected in April 2006. The } \\
\text { routine inspection identified } \\
\text { maintenance corrective actions that } \\
\text { were performed and resolved in } \\
2006 \text {. }\end{array}$ & $\begin{array}{l}\text { Environmental } \\
\text { Compliance } \\
\text { Summary }\end{array}$ \\
\hline $\begin{array}{l}\text { NYS Public } \\
\text { Health Law }\end{array}$ & $\begin{array}{l}\text { Public Health Law, Article } 5 \\
\text { (Laboratories), Section } 502 \text { (Environmental } \\
\text { Laboratories, Examinations, Certifications } \\
\text { of Approval) }\end{array}$ & $\begin{array}{l}\text { The WVDP Environmental } \\
\text { Laboratory (the URS Corporation } \\
\text { Laboratory) is certified for certain } \\
\text { radiological and nonradiological } \\
\text { constituents in potable and } \\
\text { nonpotable water, as well as for } \\
\text { asbestos in solids. }\end{array}$ & $\begin{array}{l}\text { Chapter } 5 \text { and } \\
\text { Appendix } J^{\text {(t) }}\end{array}$ \\
\hline $\begin{array}{l}16 \text { USC } \$ 703 \text { et } \\
\text { seq. }\end{array}$ & $\begin{array}{l}\text { The Migratory Bird Treaty Act of } 1918 \\
\text { implemented various treaties and } \\
\text { conventions between the U.S. and foreign } \\
\text { countries for the protection of migratory } \\
\text { birds. Under the Act, taking, killing, or } \\
\text { possessing migratory birds is unlawful. }\end{array}$ & $\begin{array}{l}\text { The DOE maintains, and complies } \\
\text { with, a NYS Division of Fish and } \\
\text { Wildlife Bird Depredation License } \\
\text { and a U.S. Fish and Wildlife Bird } \\
\text { Depredation Permit for the WVDP. }\end{array}$ & $\begin{array}{l}\text { Environmental } \\
\text { Compliance } \\
\text { Summary, Table } \\
\text { ECS-10 }\end{array}$ \\
\hline
\end{tabular}

ECS - 7 
Table ECS-1 (concluded)

Compliance Status Summary for the WVDP in 2006

\begin{tabular}{|c|c|c|c|}
\hline Citation & $\begin{array}{c}\text { Environmental Statute, } \\
\text { DOE Directive, Executive Order }\end{array}$ & $\begin{array}{c}\text { WVDP Compliance } \\
\text { Status }\end{array}$ & $\begin{array}{l}\text { Location in } \\
2006 \text { ASER }\end{array}$ \\
\hline $\begin{array}{l}16 \text { USC } \S 1531 \\
\text { et seq. }\end{array}$ & $\begin{array}{l}\text { The Endangered Species Act of } 1973 \\
\text { provided for the conservation of endangered } \\
\text { and threatened species of fish, wildlife, and } \\
\text { plants. }\end{array}$ & $\begin{array}{l}\text { Several ecological surveys of the } \\
\text { WVDP premises have been } \\
\text { conducted. Except for "occasional } \\
\text { transient individuals," no plant or } \\
\text { animal species protected under this } \\
\text { Act are known to exist at the } \\
\text { WVDP. }\end{array}$ & $\begin{array}{l}\text { Surveys are } \\
\text { summarized in } \\
\text { EIS documents } \\
\text { and are not } \\
\text { reported in the } \\
\text { ASER. }\end{array}$ \\
\hline 16 USC $\$ 470$ & $\begin{array}{l}\text { The National Historic Preservation Act of } \\
1966 \text { established a program for the } \\
\text { preservation of historic properties } \\
\text { throughout the nation. }\end{array}$ & $\begin{array}{l}\text { Surveys have been conducted of the } \\
\text { WNYNSC for historic and } \\
\text { archaeological sites. }\end{array}$ & $\begin{array}{l}\text { Results are } \\
\text { summarized in } \\
\text { EIS documents } \\
\text { and are not } \\
\text { reported in the } \\
\text { ASER. } \\
\end{array}$ \\
\hline E.O. 11988 & $\begin{array}{l}\text { E.O. 11988, Floodplain Management, was } \\
\text { issued to avoid adverse impacts associated } \\
\text { with the occupancy and modification of } \\
\text { floodplains and to avoid direct or indirect } \\
\text { support of floodplain development wherever } \\
\text { there is a practicable alternative. }\end{array}$ & $\begin{array}{l}\text { No activities were performed at the } \\
\text { Site that would impact the } 100 \text {-year } \\
\text { flood plain within the WVDP } \\
\text { premises. }\end{array}$ & $\begin{array}{l}\text { Environmental } \\
\text { Compliance } \\
\text { Summary }\end{array}$ \\
\hline
\end{tabular}

Environmental Protection Program (DOE Order 450.1). DOE Order 450.1, issued in January 2003, required that DOE sites implement an environmental management system (EMS) by December 31, 2005. An EMS is a continuing cycle of systematic planning, implementing, evaluating, and improving processes and actions undertaken to achieve environmental goals.

Environmental Management System. Since 1999, the WVDP has implemented an EMS via policies and procedures that provide for accomplishing work through proactive management, environmental stewardship, and integration of appropriate technologies across all Project functions. The West Valley Nuclear Services Co. (WVNSCO) EMS satisfies the requirements of both the "Code of Environmental Management Principles" for federal agencies and the International Organization for Standardization 14001, "Environmental Management Systems: Specifications for Guidance and Use." Elements of the WVDP EMS are discussed in Chapter 1 and summarized in Table 1-1.

Integrated Safety Management System (ISMS). TheEMS is an important part of the WVDP ISMS. Sitewide management continues to demonstrate commitment to an all-inclusive approach to safety through ongoing efforts to strengthen its integrated safety management program and by encouraging worker involvement.

An annual DOE ISMS review was conducted at the WVDP in September 2006 using criteria and approach documents based principally upon ISMS core continuing expectations listed in DOE G 450.4-1B, "Integrated Safety Management Guide." This guide encompasses ISMS feedback

$E C S-8$ 
and improvement, work planning and control, hazard analysis and work performance, and DOE oversight. There were no deficiencies identified in the ISMS implementation process during 2006. Consistent with the "continuous improvement" function of the ISMS process, several areas of improvement, findings (requiring correction), observations (suggested, but not requiring correction), and program strengths were identified. The ISMS review team determined that the WVDP ISMS is both fully implemented and effective.

In 2006, WVNSCO performed the 2006 ISMS Assessment by utilizing an employee survey based on safety culture attributes contained in the ISM draft manual. Results of the survey were presented to the Safety Success Team and Central Safety Committees for recommendations to improve the WVNSCO ISMS and the supporting safety culture.

\section{Radiation Protection of the Public and the En- vironment (DOE Order 5400.5). Objectives of DOE Order 5400.5 are to ensure that (1) opera- tions are conducted so that radiation exposures to members of the public are maintained within the limits established in the Order, (2) potential expo- sures to members of the public are as far below the limits as is reasonably achievable, (3) routine and nonroutine releases are monitored and dose to the public is assessed, and (4) the environment is protected from radioactive contamination to the extent practicable.}

This Annual Site Environmental Report summarizes radiological releases from the WVDP in 2006, presents estimates of dose to the public and the environment, and compares these values with release and dose standards established by DOE Order 5400.5. (See Chapter 2 and the "Useful Information" section at the end of this report.) In 2006, both releases and estimates of dose to the public were well within applicable limits.
Radioactive Waste Management (DOE Order 435.1). The objective of DOE Order 435.1 is to ensure that all DOE radioactive waste is managed in a manner that is protective of workers and public health and safety, and the environment. To ensure compliance with DOE Order 435.1, radioactive wastes at the WVDP are managed in accordance with the "West Valley Demonstration Project (WVDP) Waste Acceptance Manual." The formal site program, updated in May 2006, defines how radioactive waste - including high-level waste (HLW), transuranic (TRU) waste, low-level waste (LLW), and the radioactive component of mixed waste - is managed at the WVDP to (1) protect the public from exposure to radioactive materials, (2) protect the environment, (3) protect workers, and (4) comply with applicable federal, state, and local laws and regulations, as well as applicable Executive Orders and other DOE directives.

Nationwide Management of Waste. In May 1997, DOE Headquarters issued the Final Waste Management Programmatic environmental impact statement (EIS) to evaluate nationwide management and siting alternatives for treatment, storage, and disposal of five types of radioactive and hazardous waste. The EIS was issued with the intent of developing and issuing a separate record of decision (ROD) for each type of waste analyzed. The alternatives addressed waste generated, stored, or buried over the next 20 years at 54 sites in the DOE complex.

In 1998, the DOE issued RODs for TRU and nonwastewater hazardous waste. In 1999, the DOE issued the ROD for HLW. This decision specified that WVDP-vitrified HLW will remain in storage on site until it is accepted for disposal at a geologic repository.

On February 25, 2000, the DOE issued its ROD for the management of LLW and mixed LLW, including West Valley's wastes. Hanford and the

ECS - 9 
Nevada Test Site (NTS) were identified as designated national DOE disposal sites for these waste types (Volume 65, Federal Register [FR], p. 10061 [65 FR 10061]). In 2001, West Valley successfully completed the program approval process for access to the NTS, and on July 17, 2001 received approval to ship waste. LLW shipments from the WVDP to the NTS have been ongoing since then.

\section{National Environmental Policy Act (NEPA).} Under NEPA, established in 1969, the DOE is required to consider the overall environmental effects of its proposed actions. The President's Council on Environmental Quality established a screening system of analyses and documentation that requires each proposed action to be categorized according to the extent of its potential environmental effect. The levels of documentation include categorical exclusions (CXs), environmental assessments (EAs), and EISs.

CXs document actions that, by their nature, will not have a significant effect on the environment. EAs are used to evaluate the extent to which a proposed action, not categorically excluded, will affect the environment. Based on the analyses presented in an EA and considering public comment, the DOE may determine that the proposed action is not a major federal action significantly affecting the quality of the human environment within the meaning of NEPA. As a result, the DOE may issue a notice indicating Finding Of No Significant Impact (FONSI) and therefore would not be required to prepare an EIS. If a proposed action has the potential for significant effects, an EIS would be prepared that describes proposed alternatives to an action and explains the effects of each.

In December 1988, the DOE published a Notice of Intent (NOI) with the New York State Energy Research and Development Authority (NYSERDA) to prepare an EIS for the completion of the WVDP Act and closure of the facilities at the Western New York Nuclear Service Center (WNYNSC).

The draft EIS, which describes the potential environmental effects associated with Project completion and various site closure alternatives, was completed in 1996 and released without a preferred alternative for a six-month public review and comment period. The West Valley Citizen Task Force (CTF; see inset), having met throughout 1997 and 1998 to review alternatives presented in the draft EIS, issued the West Valley Citizen Task Force Final Report (July 29, 1998). This report provided recommendations and advice on the development of a preferred alternative. The CTF continues to routinely meet with the site managers to discuss current issues relating to Project cleanup, closure, and/ or long-term management of the facilities.

In 2001, the DOE formally initiated a plan to split the scope of the 1996 draft EIS into two phases: (1) one for near-term waste management decisionmaking and (2) one for final decommissioning and/

\section{West Valley Citizen Task Force}

In addition to the public comment process required by the National Environmental Policy Act, NYSERDA, with participation from the DOE, formed the West Valley Citizen Task Force in January 1997. The mission of the Task Force is to provide advice on the completion of the WVDP Act and cleanup, closure, and/or long-term management of the facilities at the site. The Task Force process has helped illuminate the various interests and concerns of the community, increased the two-way flow of information between the site managers and the community, and provided an effective way for the Task Force members to establish mutually-agreed-upon recommendations for the site managers to consider in their decision-making process. 
or long-term stewardship decision-making. Each phase would be covered by a separate EIS.

The DOE published an NOI on March 26, 2001 (66 FR 16447) formally announcing its rescoping plan and preparation of the waste management EIS. The DOE also published an Advance NOI on November 6, 2001 (66 FR 56090) announcing in advance its commitment to begin work, in cooperation with NYSERDA, on the EIS for decommissioning and/or long-term stewardship.

Waste Management EIS. On May 16, 2003, the DOE issued the draft Waste Management EIS (68 FR 26587) for public comment. The Waste Management EIS presented alternatives for the management of WVDP LLW, mixed LLW, TRU waste, and HLW. The DOE addressed public comments and issued the final Waste Management EIS in January 2004.

The DOE published its decision in the Federal Register (70 FR 35073) on June 16, 2005. The decision was to implement Alternative A, the preferred alternative, for the management of WVPLLW and mixed LLW that are either currently in storage at the site or will be generated at the site over the next ten years. A decision on TRU wastes was deferred, contingent upon a determination by the DOE that the waste meets all statutory and regulatory requirements for disposal at the Waste Isolation Pilot Plant near Carlsbad, New Mexico. The HLW canisters remain in storage on site until they can be shipped directly to a geologic repository.

Facility maintenance, decontamination activities, and minor projects that supported HLW vitrification were documented and submitted for approval as CXs. Based on preliminary review of proposed activities for building removal, as part of infrastructure reduction at the WVDP, an EA was developed to evaluate potential effects on the environment.
- Environmental Assessment DOE/EA-1552 and FONSI. ADOE EA evaluating the proposed decontamination, demolition, and removal of unneeded facilities at the WVDP was finalized and signed on September 14, 2006.

The EA identified 36 facilities that are (or in the next four years will be) no longer required to safely monitor, maintain, or support future removal of the vitrified high-level radioactive waste, or the closure of other on-site facilities. The EA was circulated for review and comment to the state of New York and other interested stakeholders for a 30day comment period ending July 29, 2006.

The DOE issued a FONSI, based on the analysis contained in the EA, thereby determining that the proposed action did not constitute a major federal action significantly affecting the quality of the human environment within the meaning of NEPA. As a result, an EIS was not required.

- Waste Characterization, Packaging, and Shipping. In 2005 and 2006, upgrades were made to several facilities and areas on site to support new or increased activities to prepare Class A, B, and $\mathrm{C}$ radioactive waste for off-site shipment. Characterization of waste streams (wastes that came from the same point of origin or that had similar physical characteristics) continued throughout 2006, and shipments took place by truck. Some truck shipments ultimately involved transloading to rail. Details pertaining to all shipments in 2006 are included in Table ECS-3.

Decommissioning and/or Long-Term Stewardship EIS at the WVDP and WNYNSC. The Nuclear Regulatory Commission (NRC) is authorized by the WVDP Act to prescribe decommissioning criteria for the WVDP. From 1998 until early 2002 the NRC worked to develop decommissioning criteria through a series of draft policy papers and public meetings. On February 1, 2002,

ECS -11 
the NRC issued its "Decommissioning Criteria for the West Valley Demonstration Project (M-32) at the West Valley Site; Final Policy Statement" in the Federal Register (67 FR 5003). The Final Policy Statement applied the NRC's License Termination Rule (10 CFR Part 20, Subpart E) as the decommissioning criteria for the WVDP and as the decommissioning goal for the entire WNYNSC.

The DOE published an NOI on March 13, 2003 (68 FR 12044) announcing its intent to prepare, in cooperation with NYSERDA, the EIS for the Decommissioning and/or Long-Term Stewardship at the WVDP and the WNYNSC. The DOE and NYSERDA are joint lead agencies on this EIS, and the EPA, NRC, and NYSDEC are cooperating agencies. Work continued with the issuance of an internal multi-agency pre-decisional draft in September 2005. After a period of agency review, a large number of comments on the pre-decisional draft were received. These comments addressed a wide range of technical issues and challenges, some of which would not be readily resolved.

In August 2006, to continue progress with this process, the DOE-WVDP requested that the NRC, EPA, NYSDOH, NYSDEC, and NYSERDA participate in a collaborative process (i.e., Core Team) to resolve technical issues and make recommendations associated with the draft EIS. The Core Team began meeting in November 2006 and by the spring of 2007 all agencies were participating. The Core Team continues evaluating site challenges and making recommendations to move the focus of the Project forward.

Resource Conservation and Recovery Act (RCRA). RCRA and its implementing regulations govern the life cycle of hazardous waste from "cradle-to-grave" and mandate that generators take responsibility for ensuring the proper treatment, storage, and ultimate disposal of their wastes.
The EPA is responsible for issuing guidelines and regulations for the proper management of solid and hazardous waste (including mixed [radioactive and hazardous] waste). In New York, the EPA has delegated the authority to issue permits and enforce these regulations to NYSDEC. In addition, the U.S. Department of Transportation is responsible for issuing guidelines and regulations for labeling, packaging, and spill-reporting for hazardous and mixed wastes while in transit.

There are several programs that are implemented at the WVDP under RCRA regulation, including:

- hazardous waste permitting

- RCRA Part A Interim Status Application

- RCRA Part 373-2 Application (i.e., Part B)

- RCRA3008(h) Adminstrative Order on Consent

- hazardous waste management

- mixed waste management/site treatment plan/ Federal Facilities Compliance Act (FFCA)/FFCA agreement

- nonhazardous, regulated waste management

- waste minimization and pollution prevention

- New York State (NYS)-regulated underground storage tanks

- NYS-regulated aboveground storage tanks

- medical waste management

Discussion of the implementation of each of these programs, including status of compliance, is presented in the subsections that follow.

Hazardous Waste Permitting. A hazardous waste permit is required for facilities that treat or store

ECS -12 
large quantities of hazardous waste for more than 90 days or dispose of hazardous waste at the facility. New York State facilities in existence on the date that hazardous waste regulations impacting their operations took effect were required to apply for interim status from NYSDEC by submitting a RCRA Part A Interim Status Application in accordance with Title 6 of the Official Compilation of Codes, Rules, and Regulations of the State of New York (6 NYCRR) Part 373-3. Facility operations during interim status are limited to those described in the Part A Application and must comply with the Interim Status Standards regulations.

RCRA Part A Interim Status Application. In 1984, the DOE notified the EPA of hazardous waste activities at the WVDP and identified the WVDP as a generator of hazardous waste. In June 1990, the effective date of the NYS regulations governing treatment, storage, and disposal of mixed waste (i.e., RCRA hazardous and Atomic Energy Commission radioactive), a RCRA Part A Application for the WVDP was filed with NYSDEC for storage and treatment of hazardous and mixed wastes. The WVDP has operated under interim status ever since.

The RCRA Part A Application is revised as changes to the site's interim status waste management operations occur. An update of the RCRA Part A Interim Status Application is currently under internal review. The Application was revised to incorporate NYSDEC-requested revisions, as well as revisions identified by the DOE. The changes in process, treatment, and storage were projected to be cost-effective and provide flexibility to manage wastes generated during future waste management activities at the WVDP.

RCRA Part 373-2 Permit. In a July 16, 2003 letter to the DOE, NYSDEC made an official request for the submittal of a Part 373-2 Permit Application (i.e., Part B) for the WVDP. The complete Part 373-2 Permit Application was transmit- ted to NYSDEC on December 23, 2004. This Application included RCRA closure plans for all interim status units that continued to be managed in accordance with 6 NYCRR Part 373-3 until a final determination by NYSDEC on the Part 373-2 Permit Application is made and a 6 NYCRR Part 373-2 permit is issued.

In 2002, prior to submittal of the Part B Permit Application, the WVDP submitted interim status closure plans for the HLW tanks 8D-1 and 8D-2, the supernatant treatment system, and the vitrification facility to NYSDEC. NYSDEC responded that the closure plans did not properly address RCRA clean closure requirements. No comments were received on the vitrification facility closure plan. A revised closure plan for the vitrification facility and two additional closure plans (one for the lag storage addition \#1 [LSA \#1] and LSA \#2 hardstand, and the other for the interim waste storage facility [IWSF]) were submitted in December 2004 (separate from and prior to the submittal of the Part B Permit Application).

In April 2005, the DOE transmitted nine revised RCRA hazardous waste closure plans. The closure plans were transmitted in anticipation of implementing interim status unit closure activities in 2006 for one or more of the permitted units.

The DOE subsequently resubmitted revised closure plans to NYSDEC for eight of the original nine hazardous waste management units in a letter dated May 3, 2006. They were provided for agency review and to confirm that the respective units were planned for closure after 2005 and prior to site decommissioning EIS starting point. The reasons for the revisions were mainly administrative - to provide separate and distinct closure plans for each individual hazardous waste management unit. The previous versions of the respective closure plans covered multiple units. 
NYSDEC provided comments on the lag storage building (LSB) closure plan in a letter dated May 10,2006 . The DOE responded to NYSDEC's comments and provided a revised closure plan for the LSB in a letter dated June 30, 2006. In addition, the DOE revised the closure plan for the IWSF and submitted it to NYSDEC in a letter dated October 23, 2006 (after the completion of clean closure activities discussed in the following paragraph).

After issuance of the FONSI and DOE/EA-1552, the WVDP initiated clean closure of the IWSF and the LSB. Decontamination and demolition of both facilities was completed between June and November 2006. Activities included notifying NYSDEC of closure, removal of the waste, decontamination of the impacted areas, clean closure confirmation sampling, sample analysis, sample result evaluation, and preparation of a clean closure certification report.

The results of the clean closure confirmation sampling at the IWSF and the LSB showed levels of contaminants of concern below the cleanup levels established in the closure plans. The remaining concrete slabs are currently isolated with barriers, ropes, and postings, and will remain unavailable for use until the closure has been approved by NYSDEC.

LSA \#1 was also demolished. This included the removal of all wastes (radioactive) and demolition of the aboveground structure. Although LSA\#1 was filed as a hazardous/mixed waste management area under the RCRA Part A Interim Status Application, it was used only to store radiological waste and was never used for storage or management of hazardous or mixed waste. A closure certification report is being prepared to document that this unit was not used to manage hazardous/mixed waste.
In summary, closure plans were submitted to NYSDEC for most of the interim status units. NYSDEC comments on the closure plans will be addressed as they are received.

RCRA $\S 3008(h)$ Administrative Order on Consent. The DOE and NYSERDA entered into a RCRA §3008(h) Administrative Order on Consent (the Consent Order) with NYSDEC and the EPA in March 1992. The Consent Order required NYSERDA and the DOE's WVDP office to conduct RCRA-facility investigations (RFIs) at on-site solid waste management units (SWMUs) to determine if there had been a release or if there was a potential for release of RCRAregulated hazardous constituents from SWMUs.

Because many SWMUs are contiguous, or so close together as to make their separate monitoring impractical, many SWMUs have been grouped into larger units, referred to as super SWMUs (SSWMUs). This terminology is unique to the WVDP, and is not an official regulatory term. Descriptions of the SSWMUs, with the associated constituent SWMUs, as well as the individual SWMUs, can be found in Table ECS-4. Figures A-9 and A-10 in Appendix A show the locations of the WVDP SSWMUs.

The final RFI reports were submitted in 1997, completing the investigative activities associated with the Consent Order. No corrective actions were required at that time as a result of the RFIs.

Groundwater monitoring, as recommended in the RFI reports and approved by the EPA and NYSDEC, continued during 2006 in compliance with the requirements of the Consent Order. Groundwater monitoring results are presented in Appendix $\mathrm{E}^{\mathrm{ED}}$ and discussed in Chapter 4.

A report entitled "West Valley Demonstration Project Solid Waste Management Unit Assess- 
ment and Current Conditions Report" was submitted to NYSDEC in November 2004. This report summarized the historic activities at individual SWMUs and provided environmental monitoring data and information on site activities performed since the completion of the RFI reports.

After reviewing this report, NYSDEC determined that corrective measures studies (CMSs) pursuant to the Consent Order were required for select SWMUs at the WVDP. After discussions between the DOE and NYSDEC, the DOE submitted to NYSDEC a draft "Corrective Measures Study Work Plan for the West Valley Demonstration Project" in August 2005 to address CMS requirements for six of the SWMUs. Closure of two SWMUs was deferred to closure under State Pollutant Discharge Elimination System (SPDES) requirements. Two subsequent revisions to the work plan, containing CMS requirements for the six SWMUs, were submitted in 2006 in response to NYSDEC comments. NYSDEC provided the DOE a conditional approval of the work plan in October 2006, and the DOE is modifying the work plan to address NYSDEC's conditions.

Concurrently, the DOE prepared five draft CMS reports for the six SWMUs. Two separate SWMUs (the NRC-Licensed Disposal Area [NDA] and the NDA Interceptor Trench) were written into one CMS. The reports are currently under internal review.

Hazardous Waste Management. Hazardous wastes at the WVDP are managed in accordance with 6 NYCRR Parts 370-374 and 376. Hazardous and mixed waste activities are reported to NYSDEC annually in the WVDP's Annual Hazardous Waste Report, which specifies the quantities of waste generated, treated, and/or disposed of, and identifies the treatment, storage, and disposal facilities used. The Annual Hazardous Waste Report for 2006 was submitted to NYSDEC on February 26, 2007.
Additional reports are submitted each year todocument hazardous waste reduction efforts. Pursuant to Section 27-0908 of NYS Environmental Conservation Law (ECL), the WVDP must annually update its Hazardous Waste Reduction Plan. The updates to this plan are submitted to NYSDEC in two forms which differ slightly in scope. The plan is updated biennially to reflect changes in the types and amounts of hazardous wastes generated at the WVDP. The biennial update to the Hazardous Waste Reduction Plan for CY 2006 was submitted to NYSDEC on June 20, 2007. Every other year, the Annual Status Report is submitted, which is essentially an abbreviated version of the biennial update. The most recent Annual Status Report was submitted to NYSDEC on June 28, 2006 and was approved by NYSDEC on July 12, 2006.

Inspections to assess compliance with hazardous waste regulations were conducted by NYSDEC in both March and October 2006. No deficiencies were noted.

Mixed Waste Management/Site Treatment Plan/ FFCA/FFCA Agreement. Mixed waste contains both a radioactive component, regulated under the Atomic Energy Act, and a hazardous component, regulated under RCRA.

The Federal Facilities Compliance Act of 1992, an amendment to RCRA, requires DOE facilities to prepare a Site Treatment Plan (STP) for treating mixed waste inventories to meet land disposal restrictions and to update the plan annually to account for development of treatment technologies, capacities, and changes in mixed waste inventories. Each plan is approved by the respective state agency or the EPA after consultation with other affected states and after consideration of public comments.

The WVDP STP is comprised of two volumes: the Background Volume (that provides information on each mixed waste stream and its preferred treat-

ECS - 15 
ment method) and the Plan Volume (that includes schedules for treating the mixed waste to meet RCRA land disposal restriction requirements).

The DOE entered into a Consent Order with NYSDEC for the WVDP on August 27, 1996 that requires completing milestones identified in the Plan Volume. The Plan is updated annually to bring waste stream, inventory, treatment, and milestone information current through September 30, the end of the DOE fiscal year (FY). The Site Treatment Plan FY 2006 Update was issued in February 2007. There were a total of nine proposed milestones for waste streams managed under the WVDP STP and all were completed successfully by the end of FY 2006.

Mixed waste was shipped to approved treatment and disposal facilities from the WVDP in 2006, as summarized in Table ECS-3.

Nonhazardous, Regulated Waste Management. Nonradioactive, nonhazardous material was shipped off site to solid waste management facilities in 2006. Certain components of this waste (lead-acid batteries and spent lamps [universal wastes]) were reclaimed or recycled at off-site, authorized reclamation and recycling facilities. Digested sludge and treated wastewater from the site sanitary and industrial wastewater treatment facility were shipped to the Buffalo Sewer Authority for disposal. Quantities of nonhazardous wastes handled in 2006 are summarized in Tables ECS-3 and ECS-5.

Waste Minimization and Pollution Prevention. In 2006, WVNSCO continued a long-term program to minimize the generation of LLW, mixed waste, hazardous waste, industrial waste, and sanitary waste, and to promote affirmative procurement as directed by Executive Orders (E.O.s) 13101 and 13148. The Affirmative Procurement Program specifies responsibilities and direction for federal agencies in acquiring recycled and environmentally preferable products and services as designated by the EPA in Title 40 of the Code of Federal Regulations (CFR) Part 247, "Comprehensive Procurement Guideline for Products Containing Recovered Material."'WVNSCO annually reports to the DOE the challenges and successes associated with the purchase and use of these materials and services. WVNSCO also submits an annual pollution prevention report to the DOE summarizing recycling and waste generation information. See Table ECS-5, "Pollution Prevention Progress for FY 2006."

New York State-Regulated Underground Storage Tanks. RCRA regulations cover the use and management of underground tanks for storage of petroleum and hazardous substances and establish minimum design requirements to protect groundwater resources from releases. The regulations, specified in 40 CFR Part 280, require underground storage tanks to be equipped with overfill protection, spill prevention, corrosion protection, and leakdetection systems. New tanks must comply with regulations at the time of installation. In addition, 40 CFR 112 addresses the requirements of a spill prevention control and countermeasure (SPCC) plan for the management of oil discharged from tanks, lines, and associated transfer activities.

New York State also regulates underground storage tanks through two programs: petroleum bulk storage (6 NYCRR Parts 612-614) and chemical bulk storage (6 NYCRR Parts 595-599). State registration and minimum design requirements are similar to those of the federal program, except that petroleum tank fill ports must be color-coded using American Petroleum Institute standards to indicate the product being stored.

A single 550-gallon, double-walled, steel underground storage tank, upgraded in 1998 to bring it into compliance with the most recent EPArequire-

ECS - 16 
ments (40 CFR Part 280.21), is used to store diesel fuel for the supernatant treatment system/permanent ventilation system standby power unit. This tank is equipped with aboveground piping, an upgraded interstitial leak-detection system, and a high-level warning device, and therefore meets the state requirements of 6 NYCRR Parts 612-614. This is the only underground petroleum storage tank currently in use at the WVDP. (There are no underground chemical bulk storage tanks at the WVDP.)

A former underground petroleum storage tank, closed in place before the NYS underground storage tank program closure requirements were implemented in 1985, was removed in 1997. In accordance with a stipulation agreement with NYSDEC, a soil bioventing system was installed in August 1999 to remediate localized petroleumcontaminated soils in the vicinity of the tank. The system stimulated natural in-situ biodegradation of petroleum hydrocarbons in the soil by providing an abundant oxygen supply to existing soil microorganisms within the contaminated soil zone. Soil and groundwater samples were collected in 2002 to evaluate the level of remediation achieved. Based on the sample results, NYSDEC determined that no further remediation was required. Final disposition is pending the Decommissioning and/or Long-Term Stewardship EIS.

New York State-Regulated Aboveground Storage Tanks. New York State regulates aboveground petroleum and chemical bulk storage tanks under 6 NYCRR Parts 612-614 and Parts 595-599, respectively. These regulations require secondary containment, external gauges to indicate the content levels, monthly visual inspections of petroleum tanks, and documented daily, annual, and five-year inspections of chemical tanks. Documentation relating to these periodic inspections is maintained at the WVDP and is available for regulatory agencies to review. Pe- troleum tank fill ports also must be color-coded, and chemical tanks must be labeled to indicate the product stored. Petroleum bulk storage is also addressed through the WVDP's SPCC plan prepared in accordance with 40 CFR 112.

Tank registration for the WVDP at the end of 2006 included nine aboveground petroleum tanks (five containing diesel fuel, three containing \#2 fuel oil, and one containing unleaded gasoline).

An aboveground hazardous bulk chemical storage tank in the vitrification test facility was the last remaining chemical bulk storage tank on the WVDP registration. The tank, once containing a nitric acid mixture, was permanently closed in 2006 under the Chemical Bulk Storage Regulations in 6 NYCRR Parts 595-599.

The most current inspections by NYSDEC confirmed that the petroleum storage tanks were in compliance with NYS regulations.

Medical Waste Management. Contact with medical waste can potentially expose humans to infectious diseases and pathogens from bodily fluids. Medical evaluations, inoculations, and laboratory work at the on-site Health Services office regularly generate potentially infectious medical wastes that are securely maintained in approved containers in accordance with NYSDEC requirements (6 NYCRR Part 364.9). Volume was minimal in 2006, therefore no medical waste was shipped (as summarized in Table ECS-3).

Clean Air Act (CAA). The CAA establishes a framework for the EPA to regulate air emissions from both stationary and mobile sources. Amendments to the CAA mandate that each state establish a program to regulate operation of sources of air pollution. In New York, NYSDEC implements the requirements of the EPACAATitle $\mathrm{V}$ permitting process through 6 NYCRR Parts 200, 201, 231,

ECS - 17 
and 621. A listing of air permits in effect at the WVDP can be found in Table ECS-2. Table ECS6 presents the air quality noncompliance episodes for the WVDP in 2006. As shown in Table ECS-6, no air quality noncompliances were noted in 2006.

Radiological Emissions. Emissions of airborne radionuclides are regulated by the EPA under 40 CFR 61, National Emission Standards for Hazardous Air Pollutants (NESHAP), Subpart H, National Standards for Emissions of Radionuclides Other Than Radon From Department of Energy Facilities. The DOE currently holds permits for six point sources of radionuclide emissions at the WVDP. In 2006, stack systems in use for potential major emission points were inspected in accordance with 40 CFR 61, Appendix B, Method 114. Visual inspections, leak checks, and cleaning were carried out, as appropriate.

Monitoring results from sampling of permitted and nonpermitted air emission points (i.e., those points that, due to the low potential for release of radionuclides, do not require permitting), are presented in Appendix $\mathrm{D}^{\mathrm{GD}}$ and discussed in Chapter 2.

Results from sampling of airborne releases, estimates of releases from sources that do not require sampling, and estimates of releases from diffuse sources (such as the lagoon system) are used to estimate dose from the WVDP to the maximally exposed off-site individual. Estimated doses are summarized in annual NESHAP reports that are submitted to the EPA by June $30^{\text {th }}$ of the following calendar year (CY).

Estimated CY 2006 dose attributable to air emissions from the WVDP was approximately 1.1E-03 millirem (mrem), $0.011 \%$ of the 10 -mrem NESHAP standard. (See Tables 2-3 and 2-6 for additional information regarding airborne radiological releases and estimated dose from WVDP air emissions.)
Nonradiological Emissions. Nonradiological point sources of air emissions are regulated by NYSDEC. NYSDEC issues permits for stationary sources (e.g., stacks, ducts, vents) that emit regulated hazardous air pollutants if quantities released are above a predetermined threshold. Major source facilities are required by 6 NYCRR Part 201 to file a Title V Permit Application unless emissions are capped below threshold limits. The DOE submitted and received NYSDEC's approval of a plan for capping WVDP annual airborne releases of oxides of nitrogen $\left(\mathrm{NO}_{\mathrm{x}}\right)$ and sulfur dioxide $\left(\mathrm{SO}_{2}\right)$ at 49.5 tons each. Releases in 2006 were about $6.3 \%$ and $0.002 \%$, respectively, of the capping limits for each. Therefore, there were no nonradiological air permit regulatory exceedances in 2006.

Two utility steam boilers are the remaining Project contributors of $\mathrm{NO}_{\mathrm{x}}$ and $\mathrm{SO}_{2}$. These sources are operated and monitored as required by the NYSDEC Air Facility Registration Certificate, as modified on March 22, 2005. The certificate was issued in accordance with 6 NYCRR Part 201-4 ("Minor Facility Registrations"). No major sources of nonradiological air pollutants, as defined in 40 CFR Part 70.2, are present at the WVDP.

Emergency Planning and Community Rightto-Know Act (EPCRA). EPCRA (also known as Superfund Amendments and Reauthorization Act [SARA] Title III) was designed to create a working partnership between industry, business, state and local governments, public health and emergency response representatives, and interested citizens. EPCRA is intended to address concerns about the effects of chemicals used, stored, and released in local communities.

E.O. 13148 requires all federal agencies to comply with the following EPCRA provisions if certain thresholds are exceeded: planning notification (Sections 302-303), extremely hazardous substance (EHS) release notification (Section 304),

ECS - 18 
material safety data sheet (MSDS)/chemical inventory (Sections 311-312), and toxic release inventory (TRI) reporting (Section 313). Compliance with these provisions continued at the WVDP in 2006, as summarized below and in Table ECS-7.

-WVDP representatives participated in semiannual meetings of the Cattaraugus County Local Emergency Planning Committee (EPCRA Sections 302-303). WVDP representatives also attended meetings held by the Cattaraugus and Erie County Emergency Management Services concerning WVDP and other local emergency planning activities. Area hospitals and the West Valley Volunteer Hose Company continued to participate in on-site briefings, emergency response exercises, and information exchanges concerning hazardous substance management at the WVDP. The WVDP representatives continue to interface with off-site organizations with which Memoranda of Understanding or Letters of Agreement exist. These organizations are annually provided an opportunity to participate in a site tour and update to better understand on-site hazards for emergency response purposes.

On October 19, 2006, a WVDP Transportation Event Management Organization exercise, simulating a transportation accident, was held to test emergency response readiness. The exercise was held in the evening, with foul weather and heavy rain, and involved a simulated vehicular accident involving two cars and a waste truck from the WVDP. The WVDP organization members, including radiation protection, WVNSCO and DOE senior management, public relations, and waste management, were joined in the exercise by volunteer responders from the Cattaraugus County HazMat Team, West Valley Volunteer Hose Company, Springville Volunteer Fire Department, Machias Volunteer Fire Department, and Bertrand Chaffee Hospital. Feedback from the exercise debrief session was positive.
- There were no releases of EHS at the WVDP in 2006 that triggered the release notification requirements of EPCRA Section 304.

- Under EPCRA Section 311, WVDP personnel are required to review information about reportable chemicals every quarter. If a hazardous chemical not previously reported is present on site in an amount exceeding the threshold planning quantity, an MSDS and an updated hazardous chemical list are submitted to the state and local emergency response groups. This supplemental reporting ensures that the public and emergency responders have current information about hazardous chemicals at the WVDP. No new chemicals were added to the hazardous chemicals list in 2006 and no additional EPCRASection 311 notifications were required.

- Under EPCRA Section 312 regulations, annual reports are submitted to state and local emergency response organizations and fire departments specifying the quantity, location, and hazards associated with chemicals stored at the WVDP. In 2006, nine reportable chemicals were stored at the WVDP above threshold planning quantities. These chemicals are listed in Table ECS-8.

- Under EPCRA Section 313, information must be provided about releases to all environmental media (e.g., air, water) of EPA-listed TRI chemicals used at or above specified regulatory thresholds at the WVDP. In 2006, no chemical exceeded the reporting threshold for the EPCRA Section 313 report.

Clean Water Act (CWA). Section 404 of the CWA regulates the development of areas in and adjacent to the waters of the United States. Supreme Court interpretations of Section 404 have affirmed the inclusion of certain nonisolated wetlands in the regulatory definition of waters of the United States. Section 404 regulates the disposal of solids, in the form of dredged or fill material,

ECS - 19 
into these areas by granting the USACE the authority to designate disposal areas and issue permits for these activities. E.O. 11990 directs federal agencies to "avoid to the extent possible the longand short-term adverse impacts that destroy or modify wetlands." Article 24 of the NYS ECL also contains requirements for the protection of freshwater wetlands and adjacent buffer areas.

Section 401 of the CWA requires applicants for a federal permit (required by Section 404) to obtain certification from the host state that the proposed discharge complies with effluent- and water-quality-related limitations, guidelines, and national standards of performance, identified under Sections 301-303, 306-307, and 511(c) of the CWA. The EPA delegated administration of this program to NYS for activities within New York.

Section 402 of the CWA regulates process, sanitary, certain storm water, and other effluent discharges to surface waters. Regulated storm water discharges include those that receive runoff from areas where industrial, construction, or demolition activities are performed. Administration of Section 402 in New York is delegated to NYSDEC, which, under NYS ECL, also regulates discharges to groundwater.

The WVDP ensures compliance with the CWA and the NYS ECL regulating wastewater and storm water discharges through implementation of several programs and activities as follows:

- assessment and protection of wetlands

- State Pollutant Discharge Elimination System (SPDES) permit

- storm water discharge monitoring

- NYSDEC SPDES inspections
- process sewer integrity evaluation

- north plateau groundwater remediation and monitoring

- petroleum and chemical product spill control and reporting.

Discussion of these activities and programs with regard to their achievement of regulatory compliance is presented in the subsections that follow.

Assessment and Protection of Wetlands. Jurisdictional wetlands are defined in Section 404 of the CWA as those satisfying specific technical criteria related to vegetation, soils, and hydrologic conditions. The DOE notifies the USACE and NYSDEC of proposed actions that could affect wetland units not specifically exempted from regulation or notification.

Wetland field assessments are periodically performed and wetland maps revised accordingly, with the most recent assessment and mapping completed in 2004. This assessment identified the presence of 68 jurisdictional wetlands that range in size from 0.01 acres to 7.3 acres and cover approximately 36.5 acres within and adjacent to the WVDP premises. NYSDEC approved this wetland delineation report in December 2005. The USACE performed a field assessment and review of applicable topographic and wetland maps of the area on November 2, 2005. It was determined that 34.09 acres of wetland are waters of the United States subject to regulation under Section 404 of the CWA. The remaining 2.43 acres are considered to be isolated, nonnavigable, intrastate water that is not subject to regulation under Section 404. These Federal wetland boundaries were confirmed on January 26, 2006 by the USACE.

SPDES Permit. New York State is delegated by the EPA to administer the National Pollutant Dis-

ECS - 20 
charge Elimination System (NPDES) under an equivalent state program. At the WVDP, NYSDEC regulates point-source liquid effluent discharges to surface waters of NYS under the SPDES permit.

NYSDEC issued a modified SPDES permit for control of discharges of treated process and sanitary wastewater and storm water, effective September 1, 2006. The new implementation requirements resulted in:

- Minimum monitoring frequencies for 17 analytical parameters for outfall 001 were reduced.

- The $\mathrm{pH}$ limit for storm water runoff being dropped; the requirement was reduced to monitoring only.

- A permit modification that eliminated the requirement to use EPAMethod 245.1 for mercury analysis. NYSDEC incorporated a policy change for the control of mercury that added a requirement to use only "ultra-clean" EPAMethod 1631 for detection of low-level total mercury for com- pliance monitoring and reporting at outfalls 001 and $01 \mathrm{~B}$. As a result, the requirement to submit a comparison study report between methods 1631 and 245.1 was eliminated.

- The enforcement discharge compliance limit reporting units for total mercury concentration being changed from 0.2 micrograms per liter $(\mu \mathrm{g} / \mathrm{L})$ to 200 nanograms per liter (ng/L) at outfall 001 and from $10 \mu \mathrm{g} / \mathrm{L}$ to $10,000.0 \mathrm{ng} / \mathrm{L}$ at outfall $01 \mathrm{~B}$. The concentration limits were unchanged, but reporting units were changed from $\mu \mathrm{g} / \mathrm{L}$ to $\mathrm{ng} / \mathrm{L}$ and the number of significant digits was increased.

As shown on Figure ECS-1, the annual number of effluent limit exceptions to requirements in the site's SPDES permit has been substantially reduced over time, especially when compared to the peak of 35 exceptions noted in 1986. As indicated on this figure, there were no permit effluent limit exceptions recorded during 2006. (See also Table ECS-9.)

The compliance points for monitoring discharges to Buttermilk Creek tributaries, including Erdman

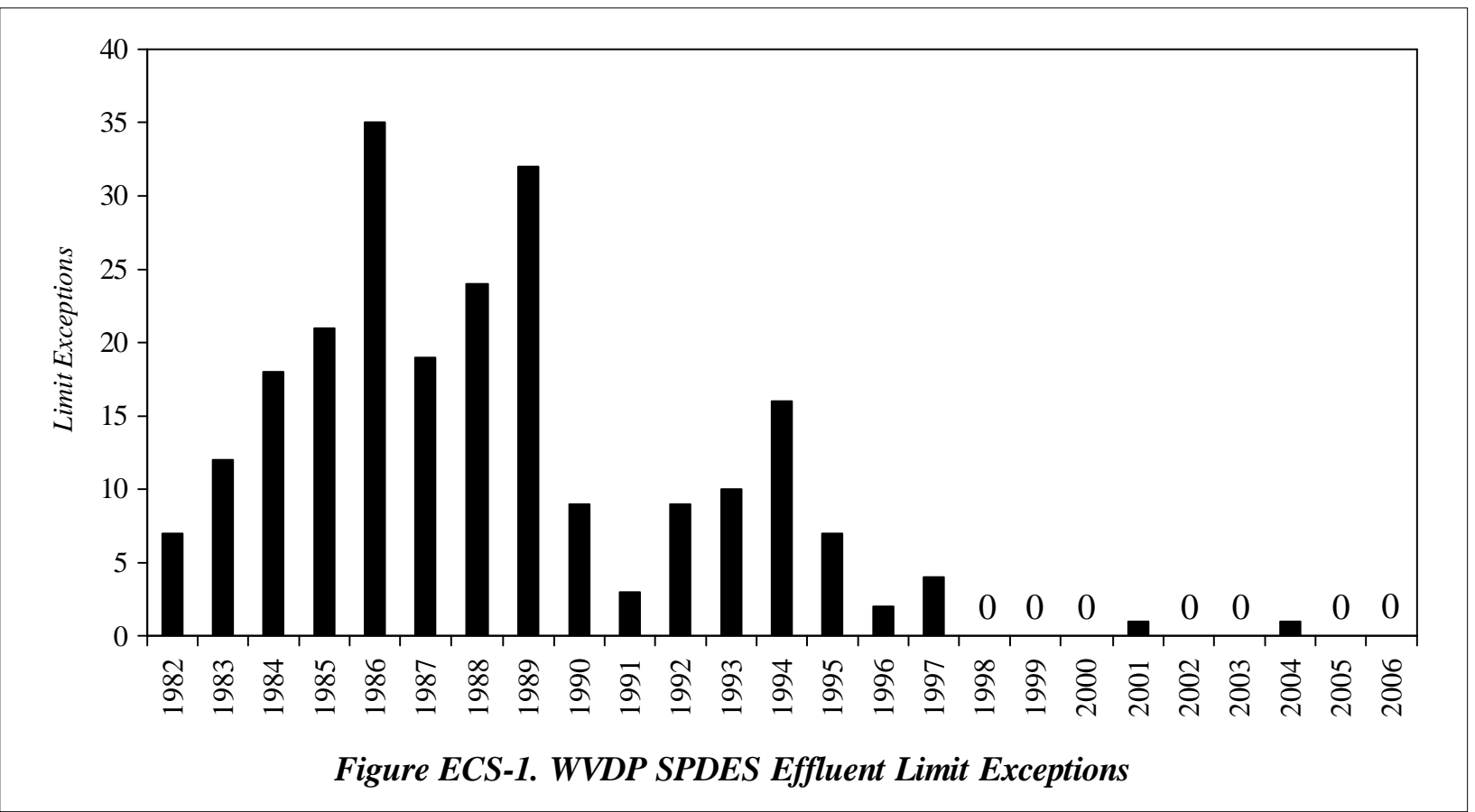

ECS - 21 
Brook, Frank's Creek, and Quarry Creek, are shown on Figures A-2, A-3, and A-4. The routine monitoring points and the storm water monitoring points are described in Appendix $\mathrm{B}^{\mathrm{CD}}$. Monitoring results for 2006 are presented in Appendix $C^{\text {GD }}$ and discussed in Chapter 3.

In February 2006, proposed modifications to the SPDES Permit were submitted to NYSDEC, and thereafter issued for public comment. The proposed modification requested by the DOE will be to reduce monitoring frequency at outfall 007 from three times per month to twice per month. Reduction in site population and pollutant loading, as well as in-depth knowledge of the system over more than ten years, support the rationale to reduce the sampling frequency. It is also proposed to remove two storm water outfalls ( $\mathrm{S} 02$ and S40) from the permitted sampling plan. The site storm water drainage configuration has changed and these outfalls no longer exist.

Storm Water Discharge Monitoring. The NPDES Permit Application Regulations for Storm Water Discharges, Final Rule (40 CFR Parts 122, 123 , and 124, as amended), and as expressed in Section 403(p) of the CWA, require that specified facilities acquire NPDES permits for storm water discharge associated with industrial activities. Permitted or interim status RCRA hazardous waste treatment, storage, and disposal facilities are specifically defined as being associated with industrial activity in the regulations (40 CFR Part 122.26[a][14][iv]).

Since the WVDP is an interim status RCRA facility, storm water discharges from the WVDP qualify as being associated with industrial activity. Six other groups of activities at the WVDP are also subject to storm water permitting: 1) aboveground container storage; 2 ) aboveground and underground tank storage; 3 ) belowground waste burial; 4) haul roads and railway lines; 5) liquid waste treatment facilities; and 6) construction activities.

There are currently 20 permitted storm water outfalls that are representative of eight drainage basins (or groups) on the WNYNSC premises. Permit requirements were achieved in 2006 by successfully sampling and analyzing a minimum of one outfall per drainage basin during each semiannual period of the calendar year. All outfalls were successfully sampled during qualifying storm events according to NYSDEC requirements. See Chapter 3 for a discussion of the storm water analytical results and Appendix $\mathrm{C}^{\mathrm{ED}}$ for a listing of the data.

NYSDEC SPDES Inspection. In March 2006, NYSDEC performed an inspection of the SPDES program. Also in March 2006, Empire GEO-Services, Inc. had reported the results of a stability analysis of the Lagoon 3 embankment performed by a NYS-licensed Professional Engineer (PE). The analysis summarized the measures being used to ensure the stability of the embankment and confirmed the original (1991) safety analysis. In November 2006, NYSDEC completed a SPDES inspection that included an examination of the condition of the embankment. No deficiencies were noted. During the November inspection, NYSDEC requested, and was later provided with, a copy of the March 2006 stability analysis report.

Process Sewer Integrity Evaluation. Video inspection of camera-accessible process sewer lines was initiated in 2003. During this inspection, a hole was discovered in a tributary line allowing laundry wastewater to discharge to subsurface soil. The breached line was removed from service and laundry wastewater was diverted to another line with known integrity. Reports of this discovery were filed with NYSDEC in 2003. Video inspection of process sewer lines was completed and the final report was submitted to NYSDEC in the fall of

ECS - 22 
2004. On February 17, 2005, the DOE transmitted a summary report to NYSDEC and the EPA for this SWMU (Breach in Laundry Wastewater Line).

A NYS-licensed PE performed an integrity evaluation of the process sewer system and prepared a final report that identified five future actions to be implemented. Work was initiated to implement these recommendations, three of which were performed immediately upon the receipt of the report from the PE. The fourth recommendation was to complete integrity testing of underground lines used to convey strontium-90-contaminated groundwater extracted from the north plateau. The pressure testing to assure sewer integrity was completed on August 17,2006. Retesting was then scheduled to be done annually as part of the preventative maintenance program. The last recommendation, to perform routine cleaning and re-inspection of accessible main service lines and operational clean-out risers, is to be fully implemented by November 2009.

North Plateau Groundwater Remediation and Monitoring. In November 1995, the north plateau groundwater recovery system (NPGRS) was installed at the WVDP to limit the advance of the plume's main western lobe and remove strontium90 from the processed groundwater. The NPGRS continued operations throughout 2006 and was closely monitored. In 1999, a pilot-scale permeable treatment wall (PTW) was installed to test in-situ passive technology for treating contaminated groundwater. The pilot PTW covered a limited portion of the strontium-90 groundwater plume. The plume has since encircled and migrated past the PTW test area. The complex geology that exists in the vicinity of the pilot PTW is believed to affect the performance of the wall, and the wall itself may be affecting the pattern of groundwater flow in the plume area. Sufficient data have been obtained to determine the effectiveness of the PTW technology. (See "North Plateau Ground- water Recovery System" and "Permeable Treatment Wall" in Chapter 4.)

Sampling and analysis plans to further characterize and evaluate the north plateau strontium-90 plume area are currently under review. In late 2006, the DOE submitted to NYSDEC a draft "Sampling and Analysis Plan for Characterization of the North Plateau Plume Area" and a draft "Sampling Plan for Background Subsurface Soil Data on the North Plateau."

Petroleum- and Chemical-Product Spill Control and Reporting. The objective of the spill notification and reporting program for the WVDP is to ensure that all spills are properly managed, documented, and remediated in accordance with applicable regulations. This policy identifies departmental responsibilities for spill management and proper spill-control procedures and stresses the responsibility of each employee to notify the plant systems operations shift supervisor when a spill is discovered. This first-line reporting requirement helps to ensure that spills are properly evaluated and managed.

Under the terms of a 1996 agreement with NYSDEC, amended in 2005, the DOE is not required to report a spill of petroleum products onto an impervious surface if the spill is less than 5 gallons (19 liters) and is cleaned up within two hours of discovery. Any spill of 5 gallons or less onto the ground is entered into a petroleum spill $\log$ that is submitted quarterly to NYSDEC.

A spill of more than 5 gallons on any surface must also be logged, and reported within two hours to the NYSDEC hotline. A spill of any amount that enters state waters must be reported to the NYSDEC hotline within two hours of discovery and, if it has reached navigable state waters, also reported to the National Response Center. No such spills occurred at the WVDP in 2006.

ECS - 23 
The WVDP operators are also required to report spills or releases of hazardous substances in accordance with reporting requirements of RCRA, the Comprehensive Environmental Response, Compensation, and Liability Act (CERCLA) (if a reportable quantity has been exceeded), the CAA, EPCRA, CWA, and Toxic Substances Control Act (TSCA). No chemical spills or releases exceeded reportable quantities and, thus, no such reporting during CY 2006 was required.

Safe Drinking Water Act (SDWA). Drinking water for the WVDP is obtained from surface water reservoirs on the WNYNSC. The WVDP system is considered a nontransient, noncommunity public water supply. The WVDP's drinking water treatment facility purifies the water by clarification, filtration, and chlorination before it is distributed on site. To ensure compliance with the SDWA, monitoring, reporting, and cross-connection control activities are routinely conducted and documented.

Monitoring and Reporting. Samples from the WVDP drinking water system are periodically collected and tested for various water quality parameters. (See Appendix $B^{\mathbf{6 0}}$ for a description of sampling frequency and analytical constituents and Appendix C- $6^{\text {[.0 }}$ for a listing of 2006 test results.) Test results are reported monthly to the Cattaraugus County Health Department, which also independently collects and analyzes a monthly sample of WVDP tap water to determine bacterial and residual chlorine content, and an annual tap water sample for nitrate (as nitrogen). All test results were within drinking water limits in 2006.

Cross-Connection Control. The SDWA requires that public water suppliers prevent cross-connections between the potable water supply and systems containing hazardous or infectious substances. Cross-connection control devices, such as double check valves and reduced-pressure zone valves, must be installed, inspected, and maintained at stra- tegic locations at facilities where hazardous materials are used in a manner that could result in their introduction into the potable water distribution system under low pressure conditions. The WVDP has a total of 13 backflow prevention devices, all of which were tested and repaired as necessary by a NYSDOH-licensed tester in 2006 to ensure that all devices were functioning properly.

Toxic Substances Control Act. TSCA regulates the manufacture, processing, distribution, and use of chemicals, including asbestos-containing material (ACM) and polychlorinated biphenyls (PCBs).

Asbestos-Containing Material. In 2006, continued compliance was maintained with all TSCA requirements pertaining to asbestos by managing ACM in accordance with the site "Asbestos Management Plan." This plan includes requirements for limiting worker exposure to ACM and for asbestos-abatement projects, maintenance activities, and periodic surveillance inspections (at least once every three years). This plan also identifies the inventory and status of on-site ACM.

Activities in 2006 included a substantial amount of demolition. Notification of demolition was submitted to the EPA Region 2 Asbestos NESHAP Coordinator for the LSA \#1 tent, north training platform, 02 building, maintenance storage area, IWSF, LSB, sample storage and packaging facility, fabrication shop, radwaste process (Hittman) building, recirculation vent system, cold chemical facility, and abandoned outdoor boiler removal project. Surveys were conducted of each structure/facility by a certified asbestos inspector to identify asbestos concerns. ACMs were present in the recirculation vent system building and the 02 building, which had nonfriable asbestos-containing built-up roof systems. This ACM was subsequently removed prior to the building demolition. Also, approximately 350 linear feet of asbestoscontaining pipe insulation and approximately 50

ECS - 24 
square feet of vessel insulation were removed from piping associated with two abandoned outdoor boilers. The ACM was managed in strict accordance with the asbestos management plan.

Maintenance of signs and labels to protect workers was also performed during all activities associated with ACM. All ACM activities were completed by personnel certified by the New York State Department of Labor (NYSDOL). WVNSCO maintains an asbestos-handling license issued by NYSDOL. (See Table ECS-2.)

Effective September 5, 2006, NYSDOL significantly revised the asbestos regulations, cited as 12 NYCRR Part 56. As a result of these regulatory changes, WVNSCO revised its operating procedures, conducted special training for the site asbestos workers, and applied for and was granted site-specific variances, as necessary.

Polychlorinated Biphenyls. Because PCBs are regulated as a hazardous waste in NYS, the DOE continued in 2006 to manage radioactively contaminated PCB waste as mixed waste and nonradioactive PCB waste as hazardous waste. Details concerning PCB-contaminated radioactive waste management, including a description of the waste, proposed treatment technologies, and schedules, can be found in the "Site Treatment Plan, Fiscal Year 2006 Update."

To comply with TSCA and PCB regulations, all activities involving the management of PCBs are done in strict accordance with the site "PCB and PCB-Contaminated Material Management Plan." The WVDP operators maintain an annual document log that details PCB use, appropriate on-site storage, and any changes in storage or disposal status. The WVDP also complies with regulations for disposal of PCBs, which conditionally allow radioactive and nonradioactive PCBs to be stored for more than one year (40 CFR Parts 750 and 761).
Federal Insecticide, Fungicide, and Rodenticide Act. Title 7, Chapter 6 of the United States Code contains regulations for environmental pesticide control. In 2006, approximately 350 pounds (160 kilograms) of a NYSDEC-registered biocide were applied by NYSDEC-licensed commercial pesticide applicators to control algae and waterborne pathogens in the site cooling water tower system. Control of the organisms is necessary to minimize the potential for cooling system damage due to fouling from algae buildup and minimize the potential for worker exposure to waterborne pathogens such as Legionella.

\section{Environmental Conservation Law - Structures} Impounding Waters and Structures in Waters. Title 5 of the NYS ECL contains regulations governing the protection and safety of dams in New York. Under the ECL, two site earthen dams, which form the site water supply, must be inspected and maintained to minimize the potential for uncontrolled releases of the impounded water. In April 2006, the dams, including the grass cover, were inspected and properly maintained in accordance with NYSDEC regulations and guidelines to prevent soil exposure to erosive forces of storm water runoff and other methods of structural failure.

\section{Current Achievements and Program Highlights}

The Decommissioning, Decontamination, Dismantlement, and Demolition (D4) Project. As part of the D4 Project efforts, obsolete buildings, systems, and components were identified, taken apart, packaged, and shipped off site for disposition, as appropriate. Projects in the main plant (the former nuclear reprocessing facility) and across the site included removal of the old utility room boilers, dismantlement of the cement solidification system, removal of the fuel receiving and storage decontamination station, and cleanout and refurbishment of the former vitrification chemis-

ECS - 25 
try laboratory. (See Chapter 1 for more information on D4 Projects.)

Environmental Assessment. The issuance of DOE/EA-1552 and the associated FONSI cleared the way for decontamination, demolition, and removal of 36 WVDP structures that were deemed obsolete. In 2006, 11 of these 36 structures were removed. Demolished facilities included the LSA \#1 tent, the north training platform, the 02 building, the maintenance storage area, the IWSF, the LSB, the sample storage and packaging facility, the fabrication shop, the radwaste process (Hittman) building, the recirculation vent system building, and the cold chemical facility. Removal of these facilities, in addition to increasing "green space" on site, will reduce the demand on resources required to maintain the obsolete structures.

Waste Management Activities. In 2006, materials stored in a number of on-site areas were sorted, consolidated, recycled, reused, or disposed. Demolition debris, excess items, and legacy radioactive and nonradioactive waste accounted for approximately 225,000 cubic feet $(6,400$ cubic meters) of waste that was eliminated from the WVDP in 2006. That amount, combined with the waste removed from the main plant, brought the total amount of waste dispositioned in 2006 to about 400,000 cubic feet (11,300 cubic meters). (See Table ECS-3 for further breakdown of waste types.)

DOE-VPPSTAR Status. In 2006, WVDP employees were responsible for extending the record for the site consecutive safe work-hours to 4.58 million, spanning a period of more than four years.

WVDP STAR status in the DOE Voluntary Protection Program (VPP) underwent DOE review in 2006. In recognition of excellent safety and health performance, the DOE recertified the
WVDP the VPP designation as a STAR site on June 1, 2006. (Also see "Voluntary Protection Program [VPP] STAR Status" in Chapter 1.)

EPA National Environmental Performance Track. The WVDP was recognized as a top environmental leader in 2000 and was accepted into the EPA's National Environmental Performance Track. The WVDP was designated as a Charter Member as part of the first group of applicants.

To qualify for the award, the WVDP had to demonstrate that it voluntarily had adopted and implemented an EMS, had attained previously specified environmental objectives, had made a commitment to achieve four future goals, had a public outreach program, and had a sustained record of environmental compliance.

The WVDP renewed its application to the Performance Track Program in 2004 by identifying three commitments to be accomplished by the end of CY 2006. The commitments and the 2006 annual reporting accomplishments were:

- Reduce Halon 1301 on-site inventory by 580 pounds - In 2004, 603 pounds of on-site Halon 1301, the entire on-site inventory, was eliminated. There were no additional activities in CY 2005 or 2006.

- Reduce total energy usage by $10 \%$ from the 2003 baseline - Total energy usage was reduced by $26.5 \%$ in CY 2006.

- Reduce radiological curies in wastewater discharges by $10 \%$ from the 2003 baseline - Total radiological curies discharged in wastewater was reduced by $13 \%$ in CY 2006. (Also see "National Environmental Performance Track" in Chapter 1.)

ECS - 26 


\section{Environmental Issues}

Unplanned Releases. No unplanned releases of pollutants or hazardous substances, radiological or nonradiological, from the WVDP occurred in 2006.

Coalition Files Suit Over WVDP EIS Process. On August 26, 2005, the Coalition on West Valley Nuclear Wastes (a citizens' group) filed a complaint in the U.S. District Court, Western District of New York, against the DOE regarding work at the WVDP.

In its complaint, the Coalition contended that the March 26, 2001 DOE announcement that revised the approach to the EIS for completion of the WVDP Act violated NEPA and the Stipulation of Compromise Settlement between the DOE and the Coalition. The EIS, which had been initiated in 1988, was revised into two separate studies: one for near-term waste management decision making and a second for final decommissioning and/ or long-term stewardship. (See "National Environmental Policy Act" earlier in this chapter.)

Reaching a ROD on the Waste Management EIS in June 2005 enabled the DOE to evaluate offsite shipment and waste disposal, which helped accelerate the shipping of LLW being stored at the site and waste being generated by routine Project activities.

Through the complaint, the Coalition sought to prevent the DOE from taking any actions as a result of the Waste Management EIS. It also requested that the DOE be ordered to complete the EIS process as outlined in 1988, requested a declaration that separating the EIS into two EISs violated NEPA, and sought a declaration that the DOE is not empowered to reclassify waste at the West Valley site using the "waste incidental to reprocessing" determination process.
As yet, no rulings have been made regarding this lawsuit.

Proposed Legislation. In 2006, the impasse continued between the DOE and NYSERDA pertaining to the respective agency responsibilities for decommissioning and/or long-term stewardship at the WVDP and the WNYNSC. In mid-2005, proposed legislation dealing with the long-term responsibility for the WVDP had been introduced into the U.S. House of Representatives by Congressmen Kuhl, Boehlert, Reynolds, and Higgins, and a companion bill was introduced into the U.S. Senate by Senators Schumer and Clinton. The bill, entitled "West Valley Remediation Act of 2005," included provisions for federal (DOE) takeover of the responsibility for the WVDP and the entire WNYNSC from the current owner, the state of New York. The legislation directed the DOE to complete and issue a draft of the site's decommissioning and long-term stewardship EIS within two years of enactment of the law. The bill also included a provision for minimum funding levels and prohibited any new waste from being transported to West Valley.

The future progress of this legislation is uncertain, as it remained in congressional committee as of the end of 2006. In January 2007, the bill was reintroduced in the U.S. Senate as the "West Valley Remediation Act of 2007." In May 2007, the legislation was re-introduced in the House of Representatives by Representative Kuhl. It remains in congressional committee.

NYSERDA Files Suit to Determine Federal Responsibilities at the West Valley Site. The NYSERDA Board of Directors voted to authorize legal action against the DOE over issues relating to ongoing cleanup responsibilities at the West Valley site. On December 11, 2006, a legal complaint was filed in U.S. District Court in Buffalo on behalf of New York State against the fed-

ECS - 27 
eral government regarding the cleanup at West Valley. NYSERDA is a plaintiff in the lawsuit, along with the state of New York and NYSDEC. New York is suing the U.S. government to clarify federal responsibilities for the West Valley site.

Currently, the litigation has been stayed pending the outcome of discussions amongst the parties regarding respective cleanup responsibilities.

\section{Environmental Actions}

\section{Construction and Demolition Debris Land-} fill (CDDL). Closure of the on-site CDDL was completed in August 1986. The solid waste landfill area was closed in accordance with NYSDEC standards for this type of landfill, following NYSDEC approval (Mitrey, 1986) of the closure plan (Standish, 1985). To meet routine post-closure requirements, the CDDL cover was inspected in the spring and fall of 2006 and found to be generally in good condition. The grass cover on the clay and soil cap is routinely maintained and cut, and drainage is maintained to ensure that no obvious ponding or soil erosion occurs.

NRC-Licensed Disposal Area (NDA). As discussed previously in this chapter, a draft "Corrective Measures Study Work Plan for the West Valley Demonstration Project" was submitted to NYSDEC in 2005 and conditionally approved in 2006. In response to Core Team comments on the NDA, the DOE is evaluating engineering controls. In early 2007, the DOE committed to design and construct infiltration controls (such as a geomembrane cap) on the NDA. In addition, plans include installation of a slurry wall upgradient of the NDA and the potential for a groundwater/surface water diversion system to deflect waters away from the NDA.

\section{Project Assessment Activities in 2006}

As the primary contractor for the DOE in CY 2006 at the WVDP, WVNSCO maintained a comprehensive review program for proposed and ongoing operations. Assessments were conducted through formal surveillances and informal programs. Formal surveillances monitored compliance with regulations, directives, and DOE Orders. The informal program was used to identify issues or potential problems that could be corrected immediately.

The local DOE Project office and other agencies with responsibilities for the WVDP also independently reviewed various aspects of the environmental and waste management programs, as discussed in preceding sections. At the conclusion of the reporting period, there were no outstanding issues that had not been satisfactorily addressed. Overall results reflected continuing, well-managed environmental programs at the WVDP. 


\section{Compliance Tables}

DOE Headquarters uses environmental compliance summary information from sites across the DOE complex to compile national environmental summary reports. The tables on the following pages were prepared to assist in this compilation.

\section{Table ECS-2}

\section{WVDP Environmental Permits}

\begin{tabular}{|c|c|c|c|c|}
\hline $\begin{array}{c}\text { Permit Name and } \\
\text { Number }\end{array}$ & $\begin{array}{c}\text { Agency/Permit } \\
\text { Type }\end{array}$ & Description & 2006 Changes & Status \\
\hline $\begin{array}{l}\text { West Valley } \\
\text { Demonstration Project } \\
\text { RCRA Part A Interim } \\
\text { Status Application EPA } \\
\text { ID \#NYD980779540 }\end{array}$ & $\begin{array}{l}\text { NYSDEC/Hazardous } \\
\text { Waste }\end{array}$ & $\begin{array}{l}\text { Provides interim status } \\
\text { under RCRA for } \\
\text { treatment and storage of } \\
\text { hazardous waste }\end{array}$ & $\begin{array}{l}\text { Submitted a revised } \\
\text { RCRA Part A Interim } \\
\text { Status Application on } \\
\text { November 1, 2006 that is } \\
\text { currently under internal } \\
\text { review. }\end{array}$ & $\begin{array}{l}\text { No expiration date. A } \\
\text { RCRA Part 373-2 Permit } \\
\text { (i.e., Part B) Application } \\
\text { was submitted to } \\
\text { NYSDEC on December } \\
\text { 23, 2004. }\end{array}$ \\
\hline $\begin{array}{l}\text { Air Facility Registration } \\
\text { Certificate } \\
(9-0422-00005 / 00099)\end{array}$ & NYSDEC/Air Emissions & $\begin{array}{l}\text { Sitewide permit includes } \\
2 \text { boilers }\end{array}$ & None & No expiration date. \\
\hline $\begin{array}{l}\text { Slurry-fed ceramic melter } \\
\text { (modification to WVDP- } \\
687-01 \text { ) process building } \\
\text { ventilation }\end{array}$ & EPA/NESHAP & $\begin{array}{l}\text { Slurry-fed ceramic melter } \\
\text { radionuclide emissions - } \\
\text { main plant stack modified } \\
\text { February } 18,1997\end{array}$ & None & $\begin{array}{l}\text { Permit approved February } \\
18,1997 . \text { No expiration } \\
\text { date. (Request to modify } \\
\text { submitted to the EPA } \\
\text { August } 1999 . \text {.) }\end{array}$ \\
\hline $\begin{array}{l}\text { Vitrification Facility } \\
\text { Heating, Ventilation, and } \\
\text { Air-Conditioning } \\
\text { (HVAC) System }\end{array}$ & EPA/NESHAP & $\begin{array}{l}\text { Vitrification facility } \\
\text { HVAC system for } \\
\text { radionuclide emissions }\end{array}$ & None & $\begin{array}{l}\text { Permit approved February } \\
18,1997 . \text { No expiration } \\
\text { date. }\end{array}$ \\
\hline $\begin{array}{l}\text { 01-14 Building } \\
\text { Ventilation System } \\
\text { (WVDP-187-01) }\end{array}$ & EPA/NESHAP & $\begin{array}{l}\text { Liquid waste treatment } \\
\text { system ventilation of } \\
\text { radionuclide emissions in } \\
\text { the } 01-14 \text { building } \\
\end{array}$ & None & $\begin{array}{l}\text { Issued October 5, } 1987 . \\
\text { Modified May 25, } 1989 . \\
\text { No expiration date. }\end{array}$ \\
\hline $\begin{array}{l}\text { Contact Size-Reduction } \\
\text { Facility } \\
(\text { WVDP-287-01) }\end{array}$ & EPA/NESHAP & $\begin{array}{l}\text { Contact size-reduction } \\
\text { and decontamination } \\
\text { facility radionuclide } \\
\text { emissions }\end{array}$ & None & $\begin{array}{l}\text { Issued October 5, } 1987 . \\
\text { No expiration date. }\end{array}$ \\
\hline $\begin{array}{l}\text { Supernatant Treatment } \\
\text { System/Permanent } \\
\text { Ventilation System } \\
\text { (WVDP-387-01) }\end{array}$ & EPA/NESHAP & $\begin{array}{l}\text { Supernatant treatment } \\
\text { system ventilation for } \\
\text { radionuclide emissions }\end{array}$ & None & $\begin{array}{l}\text { Revised January 1, } 1997 . \\
\text { No expiration date. }\end{array}$ \\
\hline $\begin{array}{l}\text { Outdoor Ventilated } \\
\text { Enclosures } \\
\text { (WVDP-587-01) }\end{array}$ & EPA/NESHAP & $\begin{array}{l}\text { Ten portable ventilation } \\
\text { units for removal of } \\
\text { radionuclides }\end{array}$ & $\begin{array}{l}\text { In early } 2005 \text {, a request } \\
\text { was made to the EPA to } \\
\text { expand the maximum } \\
\text { number of operating units } \\
\text { from } 10 \text { to } 15 .\end{array}$ & $\begin{array}{l}\text { Issued December 22, } \\
\text { 1987. No expiration date. }\end{array}$ \\
\hline
\end{tabular}

ECS - 29 


\section{Table ECS-2 (concluded) WVDP Environmental Permits}

\begin{tabular}{|c|c|c|c|c|}
\hline $\begin{array}{c}\text { Permit Name and } \\
\text { Number }\end{array}$ & $\begin{array}{c}\text { Agency/Permit } \\
\text { Type }\end{array}$ & Description & 2006 Changes & Status \\
\hline $\begin{array}{l}\text { State Pollutant Discharge } \\
\text { Elimination System } \\
(\mathrm{NY} 0000973)\end{array}$ & NYSDEC/Water & $\begin{array}{l}\text { Regulates discharges to } \\
\text { surface waters from } \\
\text { various on-site sources }\end{array}$ & $\begin{array}{l}\text { An amended permit went } \\
\text { into effect on September } \\
1,2006 .\end{array}$ & $\begin{array}{l}\text { Permit expires } \\
\text { February } 1,2009 .\end{array}$ \\
\hline $\begin{array}{l}\text { NYSDOH Environmental } \\
\text { Laboratory Approval } \\
\text { Program (ELAP) } \\
\text { Certification to URS } \\
\text { Corporation, Lab ID } \\
\# 10474\end{array}$ & $\begin{array}{l}\text { NYSDOH environmental } \\
\text { laboratory certification }\end{array}$ & \begin{tabular}{|l|} 
Certification of the \\
Environmental \\
Laboratory for the \\
analysis of potable and \\
nonpotable water samples \\
for specific radiological \\
and nonradiological \\
constituents and for \\
asbestos in friable \\
material.
\end{tabular} & $\begin{array}{l}\text { Certification was } \\
\text { transferred from } \\
\text { WVNSCO to URS } \\
\text { Corporation in April } \\
\text { 2006. The certificate was } \\
\text { revised throughout the } \\
\text { year as new constituents } \\
\text { were added. Certification } \\
\text { was renewed on April 1, } \\
2007 \text {. }\end{array}$ & $\begin{array}{l}\text { Certification expires } \\
\text { April 1, } 2008 .\end{array}$ \\
\hline $\begin{array}{l}\text { Buffalo Pollutant } \\
\text { Discharge Elimination } \\
\text { System (07-05-TR096) }\end{array}$ & $\begin{array}{l}\text { Buffalo Sewer } \\
\text { Authority/sanitary sewage } \\
\text { and sewage sludge } \\
\text { disposal }\end{array}$ & $\begin{array}{l}\text { Permit issued to hauler of } \\
\text { waste from the } \\
\text { wastewater treatment } \\
\text { facility. }\end{array}$ & $\begin{array}{l}\text { Hauler renewed permit in } \\
\text { July } 2007 .\end{array}$ & $\begin{array}{l}\text { Permit expires } \\
\text { June } 30,2008 .\end{array}$ \\
\hline $\begin{array}{l}\text { Chemical Bulk Storage } \\
\text { (CBS) (\#9-000158) }\end{array}$ & $\begin{array}{l}\text { NYSDEC regulated } \\
\text { chemical bulk storage } \\
\text { tanks }\end{array}$ & $\begin{array}{l}\text { Registration of bulk } \\
\text { storage tanks used for } \\
\text { listed hazardous } \\
\text { chemicals }\end{array}$ & $\begin{array}{l}\text { As of May 2006, the } \\
\text { WVDP no longer has } \\
\text { tanks regulated under } \\
\text { chemical bulk storage } \\
\text { regulations (6 NYCRR } \\
\text { Parts 595-599). }\end{array}$ & $\begin{array}{l}\text { If regulated CBS tanks } \\
\text { are added at the WVDP in } \\
\text { the future, WVNSCO will } \\
\text { include the existing CBS } \\
\text { Registration \# (CBS \#9- } \\
\text { 000158) when submitting } \\
\text { the application. }\end{array}$ \\
\hline $\begin{array}{l}\text { Petroleum Bulk Storage } \\
(\# 9-008885)\end{array}$ & $\begin{array}{l}\text { NYSDEC/petroleum bulk } \\
\text { storage tank registration }\end{array}$ & $\begin{array}{l}\text { Registration of bulk } \\
\text { storage tanks used for } \\
\text { petroleum }\end{array}$ & $\begin{array}{l}\text { Renewal issued } \\
\text { August 18, } 2006 .\end{array}$ & $\begin{array}{l}\text { Registration expires } \\
\text { September 2, } 2011 .\end{array}$ \\
\hline $\begin{array}{l}\text { Asbestos Handling } \\
\text { License (\#99-0427) }\end{array}$ & $\begin{array}{l}\text { NYSDOL/Asbestos } \\
\text { handling and sampling } \\
\text { activities }\end{array}$ & $\begin{array}{l}\text { WVNSCO maintains the } \\
\text { asbestos handling license } \\
\text { as well as specific } \\
\text { variances for asbestos } \\
\text { handling and monitoring. }\end{array}$ & $\begin{array}{l}\text { License renewed in } \\
\text { May } 2007 .\end{array}$ & $\begin{array}{l}\text { License expires on } \\
\text { May 31, 2008; each } \\
\text { variance has a unique } \\
\text { expiration date. }\end{array}$ \\
\hline $\begin{array}{l}\text { Bird Depredation License } \\
(32)\end{array}$ & $\begin{array}{l}\text { New York State Division } \\
\text { of Fish and Wildlife }\end{array}$ & $\begin{array}{l}\text { State license for the } \\
\text { removal of nests of } \\
\text { migratory birds }\end{array}$ & $\begin{array}{l}\text { License renewed on } \\
\text { June 30, } 2006 .\end{array}$ & $\begin{array}{l}\text { NYS license expires } \\
\text { June 30, } 2007 .\end{array}$ \\
\hline $\begin{array}{l}\text { Bird Depredation Permit } \\
(\text { MB747595-0) }\end{array}$ & $\begin{array}{l}\text { U.S. Fish and Wildlife } \\
\text { Service }\end{array}$ & $\begin{array}{l}\text { Federal permit for the } \\
\text { limited taking of } \\
\text { migratory birds and active } \\
\text { bird nests }\end{array}$ & $\begin{array}{l}\text { Permit renewed on } \\
\text { July 6, } 2007 .\end{array}$ & $\begin{array}{l}\text { Permit expires } \\
\text { June } 30,2008 .\end{array}$ \\
\hline
\end{tabular}

Note: Permit and license expiration dates are current as of August 2007.

ECS - 30 


\section{Table ECS-3}

\section{Summary of Waste Management Activities at the WVDP in 2006}

\begin{tabular}{|c|c|c|c|c|}
\hline $\begin{array}{c}\text { Waste } \\
\text { Description }\end{array}$ & Type of Project & $\begin{array}{l}2006 \text { Weight or } \\
\text { Volume }\end{array}$ & Discussion & $\begin{array}{l}\text { ASER } \\
\text { Section }\end{array}$ \\
\hline Class A & Legacy waste & $102,871 \mathrm{ft}^{3}\left(2,913 \mathrm{~m}^{3}\right)$ & Waste processed, packaged, and shipped & ECS, Chapter 1 \\
\hline Class B/C & Legacy waste & $15,761 \mathrm{ft}^{3}\left(446 \mathrm{~m}^{3}\right)$ & Waste processed, packaged, and shipped & ECS, Chapter 1 \\
\hline Industrial & Legacy waste & $51,431 \mathrm{ft}^{3}\left(1,456 \mathrm{~m}^{3}\right)$ & $\begin{array}{l}\text { Debris around the site processed, } \\
\text { packaged, and shipped (i.e., hardstands) }\end{array}$ & ECS, Chapter 1 \\
\hline Drum Cell Waste & Waste shipping & $21,010 \mathrm{ft}^{3}\left(595 \mathrm{~m}^{3}\right)$ & Waste shipped & ECS, Chapter 1 \\
\hline $\begin{array}{l}\text { Mixed Low-Level } \\
\text { Waste }\end{array}$ & $\begin{array}{l}\text { Waste shipping } \\
\text { (STP) }\end{array}$ & $2,342 \mathrm{ft}^{3}\left(66 \mathrm{~m}^{3}\right)$ & Waste packaged and shipped & ECS, Chapter 1 \\
\hline Main Plant & D4 project & $101,120 \mathrm{ft}^{3}\left(2,863 \mathrm{~m}^{3}\right)$ & Waste packaged and shipped & ECS, Chapter 1 \\
\hline Class A & D4 project & $20,992 \mathrm{ft}^{3}\left(594 \mathrm{~m}^{3}\right)$ & Waste packaged and shipped & ECS, Chapter 1 \\
\hline Industrial & D4 project & $84,558 \mathrm{ft}^{3}\left(2,394 \mathrm{~m}^{3}\right)$ & Waste sorted, packaged, and shipped & ECS, Chapter 1 \\
\hline $\begin{array}{l}\text { Radiological } \\
\text { wastewater from } \\
\text { the low-level waste } \\
\text { treatment facility } \\
\text { (LLWTF } \\
\text { [WNSP001]) }\end{array}$ & $\begin{array}{l}\text { The WVDP EPA } \\
\text { Performance Track } \\
\text { Goal for CY } 2006 \\
\text { was to reduce total } \\
\text { curies discharged at } \\
\text { outfall WNSP001 by } \\
10 \% \text {. }\end{array}$ & $\begin{array}{c}\text { About } 10.4 \text { million } \\
\text { gallons }(39.3 \text { million } \\
\text { liters })\end{array}$ & $\begin{array}{l}\text { The commitment was surpassed in } 2006 \\
\text { by achieving a } 13 \% \text { reduction, below the } \\
2003 \text { baseline, of curies discharged in } \\
\text { wastewater. This achievement was due to } \\
\text { process improvement and corrective } \\
\text { measures implemented in } 2006 \text {. }\end{array}$ & $\begin{array}{l}\text { ECS, Chapters } \\
1,2, \text { and } 3\end{array}$ \\
\hline $\begin{array}{l}\text { Treated sewage } \\
\text { and industrial } \\
\text { wastewaters } \\
\text { (WNSP007) }\end{array}$ & $\begin{array}{l}\text { Wastewater } \\
\text { processing, } \\
\text { discharge }\end{array}$ & $\begin{array}{l}3.62 \text { million gallons } \\
(13.7 \text { million liters })\end{array}$ & $\begin{array}{l}\text { The WWTF treated sewage and various } \\
\text { industrial wastewaters that were } \\
\text { discharged through WNSP007. }\end{array}$ & $\begin{array}{l}\text { ECS, Chapters } \\
1,2, \text { and } 3\end{array}$ \\
\hline $\begin{array}{l}\text { North plateau } \\
\text { groundwater } \\
\text { recovery system } \\
\text { (NPGRS) }\end{array}$ & $\begin{array}{l}\text { Pump and treat } \\
\text { strontium-90 (Sr-90) } \\
\text { contaminated } \\
\text { groundwater }\end{array}$ & $\begin{array}{l}3.31 \text { million gallons } \\
(12.5 \text { million liters })\end{array}$ & $\begin{array}{l}\text { The NPGRS operated to recover } \\
\text { groundwater from an area near the } \\
\text { leading edge of the Sr- } 90 \text { plume on the } \\
\text { north plateau. Water was treated by ion } \\
\text { exchange to remove Sr- } 90 \text {, then } \\
\text { transferred to the lagoon system. }\end{array}$ & $\begin{array}{l}\text { Chapters } 1,2 \text {, } \\
\text { and } 4\end{array}$ \\
\hline $\begin{array}{l}\text { NRC-licensed } \\
\text { disposal area } \\
\text { groundwater } \\
\text { interceptor trench } \\
\text { (WNNDATR) }\end{array}$ & $\begin{array}{l}\text { Interceptor trench } \\
\text { and groundwater pre } \\
\text { treatment }\end{array}$ & $\begin{array}{c}458.9 \text { thousand } \\
\text { gallons } \\
\text { ( } 1.74 \text { million liters) }\end{array}$ & $\begin{array}{l}\text { Groundwater was pumped and } \\
\text { transferred to the LLWTF. No n- } \\
\text { dodecane or tributyl phosphate were } \\
\text { encountered in 2006, therefore no pre- } \\
\text { treatment was necessary. }\end{array}$ & $\begin{array}{l}\text { Chapters } 1,2,3 \text {, } \\
\text { and } 4\end{array}$ \\
\hline $\begin{array}{l}\text { Digested sanitary } \\
\text { sludge }\end{array}$ & $\begin{array}{l}\text { Waste shipping and } \\
\text { disposal }\end{array}$ & $\begin{array}{c}252.4 \text { tons } \\
\text { (229.0 metric tons) }\end{array}$ & $\begin{array}{l}\text { Digested sludge from the site sanitary } \\
\text { and industrial wastewater facility was } \\
\text { shipped to the Buffalo Sewer Authority } \\
\text { for disposal. }\end{array}$ & ECS \\
\hline Medical Wastes & Disposal & $\begin{array}{l}\text { No medical waste } \\
\text { shipped off site in } \\
2006\end{array}$ & $\begin{array}{l}\text { The services of a permitted waste hauler } \\
\text { and disposal firm is retained to manage } \\
\text { medical wastes. }\end{array}$ & ECS \\
\hline Sanitary Waste & $\begin{array}{l}\text { Cleanup- } \\
\text { stabilization }\end{array}$ & $\begin{array}{c}1,689.4 \text { tons } \\
(1,532.6 \text { metric tons })\end{array}$ & $\begin{array}{l}\text { Cleanup stabilization waste included } \\
\text { industrial waste. }\end{array}$ & ECS, Chapter 1 \\
\hline
\end{tabular}

ECS - 31 


\section{Table ECS-4 \\ WVDP RCRA SSWMUs and Constituent SWMUs}

\begin{tabular}{|c|c|c|}
\hline \multicolumn{3}{|c|}{ WVDP RCRA SSWMUs and Constituent SWMUs Identified in The RFI } \\
\hline$S S W M U$ & SWMU & Constituent SWMUs \\
\hline $\begin{array}{l}\text { SSWMU \#1 - Low-Level } \\
\text { Waste Treatment Facilities } \\
\text { (LLWTF) }\end{array}$ & $\begin{array}{l}\text { \#s } 3,4,17 \\
17 \mathrm{a} \text {, and } 17 \mathrm{~b}\end{array}$ & $\begin{array}{l}\text { Former Lagoon } 1 \\
\text { LLWTF and LLWTF Lagoons 2, 3, 4, and } 5 \\
\text { Neutralization pit and interceptors }\end{array}$ \\
\hline $\begin{array}{l}\text { SSWMU \#2 - Miscellaneous } \\
\text { Small Units }\end{array}$ & $\begin{array}{l}\text { \#s } 5,6,7 \\
\text { and } 10\end{array}$ & $\begin{array}{l}\text { Demineralizer sludge ponds, and solvent dike } \\
\text { Effluent mixing basin } \\
\text { Waste paper incinerator }\end{array}$ \\
\hline $\begin{array}{l}\text { SSWMU \#3 - Liquid Waste } \\
\text { Treatment System (LWTS) }\end{array}$ & $\begin{array}{l}\# \mathrm{~s} 18 / 18 \mathrm{a} \\
\text { and } 22\end{array}$ & $\begin{array}{l}\text { LWTS } \\
\text { Cement Solidification System }\end{array}$ \\
\hline $\begin{array}{l}\text { SSWMU \#4 - High-Level } \\
\text { Waste (HLW) Storage and } \\
\text { Processing Area }\end{array}$ & $\begin{array}{l}\# \mathrm{~s} 12 / 12 \mathrm{a}, \\
13,19, \text { and } \\
20\end{array}$ & $\begin{array}{l}\text { HLW Vitrification Facility, and HLW Tank Farm } \\
\text { Vitrification Test Facility waste storage areas } \\
\text { Supernatant Treatment System }\end{array}$ \\
\hline $\begin{array}{l}\text { SSWMU \#5 - Maintenance } \\
\text { Shop Leach Field }\end{array}$ & \#8 & Maintenance Shop Leach Field \\
\hline $\begin{array}{l}\text { SSWMU \#6 - Low-Level } \\
\text { Waste Storage Area }\end{array}$ & $\begin{array}{l}\text { \#s 9/9a, 15, } \\
\text { and 16/16a }\end{array}$ & $\begin{array}{l}\text { Lag Storage (LSA \#1 and \#2 Hardstand) } \\
\text { Lag Storage Building, extension and addition (LSA \#3 and \#4) } \\
\text { Old and new hardstand storage areas }\end{array}$ \\
\hline $\begin{array}{l}\text { SSWMU \#7 - Chemical } \\
\text { Process Cell (CPC) Waste } \\
\text { Storage Area }\end{array}$ & \#14 & CPC Waste Storage Area \\
\hline $\begin{array}{l}\text { SSWMU \#8 - Construction } \\
\text { and Demolition Debris } \\
\text { Landfill (CDDL) }\end{array}$ & $\# 1$ & Construction and Demolition Debris Landfill \\
\hline $\begin{array}{l}\text { SSWMU \#9 - NRC-Licensed } \\
\text { Disposal Area (NDA) }\end{array}$ & $\begin{array}{l}\# \mathrm{~s} 2,11 / 11 \mathrm{a} \\
23, \text { and } 39\end{array}$ & $\begin{array}{l}\text { NRC-Licensed Disposal area (NDA) } \\
\text { Kerosene tanks and NDA container storage area } \\
\text { Trench interceptor project and staging area for NDA }\end{array}$ \\
\hline $\begin{array}{l}\text { SSWMU \#10 - Integrated } \\
\text { Radwaste Treatment System } \\
\text { (IRTS) }\end{array}$ & $\# 21$ & IRTS Drum Cell \\
\hline $\begin{array}{l}\text { SSWMU \#11 - New York } \\
\text { State-Licensed Disposal Area } \\
(\text { SDA })\end{array}$ & \#11 & $\begin{array}{l}\text { The SDA is a closed radioactive waste landfill that is contiguous with the } \\
\text { Project premises and is owned and managed by the New York State Energy } \\
\text { Research and Development Authority (NYSERDA). For more information, } \\
\text { see the NYSERDA website at www.nyserda.org. }\end{array}$ \\
\hline $\begin{array}{l}\text { SSWMU \#12 - Hazardous } \\
\text { Waste Storage Lockers }\end{array}$ & \#12 & Hazardous waste storage lockers 1 to 4 \\
\hline
\end{tabular}

ECS - 32 
Table ECS-4 (concluded)

WVDP RCRA SSWMUs and Constituent SWMUS

\begin{tabular}{|l|l|l|}
\hline \multicolumn{3}{|c|}{ WVDP RCRA Individual SWMUs Not Associated With an SSWMU } \\
\hline & $\# 25$ & Inactive scrap metal landfill adjacent to bulk storage warehouse \\
\hline$\# 26$ & Subcontractor maintenance area \\
\hline$\# 27$ & Fire brigade training area \\
\hline$\# 28$ & Vitrification hardstand \\
\hline$\# 29$ & Industrial waste storage area \\
\hline$\# 30$ & Cold hardstand area near the CDDL \\
\hline$\# 31$ & NDA trench soil container area \\
\hline$\# 32$ & Old sewage treatment facility \\
\hline$\# 33$ & Existing sewage treatment facility \\
\hline$\# 34$ & Storage locations for well purge water \\
\hline$\# 35$ & Construction and demolition area \\
\hline$\# 36$ & Old school house septic system \\
\hline$\# 37$ & Contact size-reduction facility (CSRF) \\
\hline$\# 38$ & Drum super compactor \\
\hline$\# 39$ & Staging area for the NDA \\
\hline$\# 40$ & Satellite Accumulation Areas and 90-day storage areas \\
\hline$\# 41$ & Designated roadways \\
\hline$\# 42$ & Product storage area \\
\hline$\# 43$ & Warehouse extension staging area \\
\hline$\# 44$ & Fuel receiving and storage area; high-intensity container and SUREPAK \\
staging area \\
\hline$\# 45$ & Breach in laundry wastewater line \\
\hline$\# 46$ & Vitrification vault and empty container hardstand \\
\hline$\# 47$ & Remote-handled waste facility \\
\hline
\end{tabular}

ECS - 33 


\section{Table ECS-5}

Pollution Prevention Progress for FY 2006

\begin{tabular}{|c|c|c|}
\hline Recycled Materials & 2006 Quantity (tons/metric tons) & $\begin{array}{l}\text { ASER Discussion } \\
\text { Section }\end{array}$ \\
\hline Office and mixed paper & 30.6 tons ( 27.8 metric tons) & ECS, Chapter 1 \\
\hline Corrugated cardboard & 21.6 tons (19.6 metric tons) & ECS, Chapter 1 \\
\hline Aluminum cans & 0.077 tons $(0.07$ metric tons $)$ & ECS, Chapter 1 \\
\hline Fluorescent bulbs & 0.43 tons ( 0.39 metric tons) & ECS, Chapter 1 \\
\hline $\begin{array}{l}\text { Plastic (overhead transparencies and } \\
\text { plastic drums) }\end{array}$ & 0.66 tons ( 0.60 metric tons) & ECS, Chapter 1 \\
\hline Styrofoam peanuts & 0.018 tons ( 0.016 metric tons) & ECS, Chapter 1 \\
\hline Stainless steel & 30.6 tons (27.8 metric tons) & ECS, Chapter 1 \\
\hline Iron/steel & 209.98 tons (190.49 metric tons) & ECS, Chapter 1 \\
\hline Other metals (steel drums) & 0.22 tons ( 0.20 metric tons) & ECS, Chapter 1 \\
\hline Toner cartridges & 0.46 tons ( 0.42 metric tons) & ECS, Chapter 1 \\
\hline $\begin{array}{l}\text { Batteries (universal waste; lead acid } \\
\text { batteries) }\end{array}$ & 8.90 tons ( 8.07 metric tons) & ECS, Chapter 1 \\
\hline Engine oils & 0.17 tons $(0.15$ metric tons $)$ & ECS, Chapter 1 \\
\hline Wood (chips, compost) & 3.12 tons ( 2.83 metric tons) & ECS, Chapter 1 \\
\hline \multirow[b]{2}{*}{ Electronics recycling } & $\begin{array}{l}10 \text { desktop computers and } 11 \text { monitors transferred } \\
\text { or donated for use. }\end{array}$ & Chapter 1 \\
\hline & $\begin{array}{l}22 \text { desktop computers, } 161 \text { monitors and } 1 \text { laptop } \\
\text { sent for recycling to Federal Prison Industries } \\
\text { (UNICOR) recycling business group }\end{array}$ & Chapter 1 \\
\hline
\end{tabular}

\section{Table ECS-6}

WVDP 2006 Air Quality Noncompliance ${ }^{a}$ Episodes

\begin{tabular}{|l|c|c|c|c|}
\hline Permit Type & Facility & Parameter & Date(s) Exceeded & $\begin{array}{c}\text { Description/ } \\
\text { Solutions }\end{array}$ \\
\hline EPA NESHAP & All & All & None & None \\
\hline NYSDEC Air & All & All & None & None \\
\hline
\end{tabular}

${ }^{a}$ There were no episodes of noncompliance in 2006.

$$
\text { ECS - } 34
$$




\section{Table ECS-7}

\section{Status of EPCRA (SARA Title III) Reporting at the WVDP in 2006}

\begin{tabular}{|l|l|l|}
\hline \multicolumn{1}{|c|}{ EPCRA Section } & \multicolumn{1}{|c|}{ Description of Reporting } & \multicolumn{1}{c|}{ Status $^{\boldsymbol{a}}$} \\
\hline EPCRA 302-303 & Planning Notification & Not Required \\
\hline EPCRA 304 & Extremely Hazardous Substance Release Notification & Not Required \\
\hline EPCRA 311 & Material Safety Data Sheet & Not Required \\
\hline EPCRA 312 & Chemical Inventory & Yes \\
\hline EPCRA 313 & Toxic Release Inventory Reporting & Not Required \\
\hline
\end{tabular}

a "Yes" indicates that the site reported under the provision.

"No" indicates that the site should have reported but did not.

"Not Required" indicates that the site was not required to report under the provision.

Table ECS-8

Reportable Chemicals Above EPCRA 312 Threshold Planning Quantities Stored at the WVDP in 2006

\begin{tabular}{|l|l|l|}
\hline Hydrogen peroxide solution (35\%) & Portland cement & Ion-exchange media \\
\hline Liquid nitrogen & Diesel fuel \#2 & Sodium hydroxide \\
\hline Oils - various grades & Gasoline & Sulfuric acid \\
\hline
\end{tabular}

\section{Table ECS-9}

WVDP 2006 NPDES/SPDES ${ }^{a}$ Permit Noncompliance Episodes

\begin{tabular}{|c|c|c|c|c|c|c|c|}
\hline $\begin{array}{c}\text { Permit } \\
\text { Type }\end{array}$ & Outfall(s) & Parameter & $\begin{array}{c}\text { No. of } \\
\text { Permit } \\
\text { Exceptions }\end{array}$ & $\begin{array}{c}\text { No. of } \\
\text { Samples } \\
\text { Taken }\end{array}$ & $\begin{array}{c}\text { No. of } \\
\text { Compliant } \\
\text { Samples }\end{array}$ & $\begin{array}{c}\text { Percent } \\
\text { Compliant } \\
\text { Samples }\end{array}$ & $\begin{array}{c}\text { Description/ } \\
\text { Solutions }\end{array}$ \\
\hline SPDES & All & All & 0 & 2,015 & 2,015 & $100 \%$ & NA \\
\hline
\end{tabular}

NA - Not applicable; no permit noncompliance episodes in 2006

${ }^{a}$ Radionuclides are not regulated under the site's SPDES permit. However, special requirements in the permit specify that the concentration of radionuclides in the discharge is subject to requirements of DOE Order 5400.5 .

ECS - 35 
Table ECS-10

WVDP Migratory Bird Nest Depredation Episodes in 2006

\begin{tabular}{|l|l|c|c|}
\hline \multicolumn{1}{|c|}{ Permit/License Type } & Parameter & $\begin{array}{c}\text { Permit/License } \\
\text { Limit }\end{array}$ & $\begin{array}{c}\text { Total Removed } \\
\text { in 2006 }\end{array}$ \\
\hline $\begin{array}{l}\text { U.S. Fish and Wildlife - } \\
\text { Bird Depredation Permit }\end{array}$ & Removal of Active Barn Swallow Nests & 15 & 4 \\
\hline $\begin{array}{l}\text { U.S. Fish and Wildlife - } \\
\text { Bird Depredation Permit }\end{array}$ & Removal of Active American Robin Nests & 15 & 0 \\
\hline $\begin{array}{l}\text { U.S. Fish and Wildlife - } \\
\text { Bird Depredation Permit }\end{array}$ & Removal of Active Eastern Phoebe Nests & 5 & 0 \\
\hline $\begin{array}{l}\text { U.S. Fish and Wildlife - } \\
\text { Bird Depredation Permit }\end{array}$ & Removal of Active Canada Goose Nests & 5 & 1 \\
\hline $\begin{array}{l}\text { NYSDEC - Bird } \\
\text { Depredation License }\end{array}$ & Removal of Inactive Migratory Bird Nests & Not limited & 7 \\
\hline
\end{tabular}

ECS - 36 


\section{ENVIRONMENTAL MANAGEMENT SYSTEM}

\section{Introduction}

The vitrified high-level radioactive waste (HLW) presently stored at the Western New York Nuclear Service Center (WNYNSC) on the West Valley Demonstration Project (WVDP or Project) premises is the by-product of the reprocessing of spent nuclear fuel during the late 1960s and early 1970s. At that time, the WNYNSC was leased by Nuclear Fuel Services, Inc. (NFS) for a commercial nuclear fuel reprocessing facility.

As the WNYNSC is no longer an active nuclear fuel reprocessing facility, the environmental monitoring program at the WVDP focuses on measuring radioactivity and chemical constituents associated with the aged residual by-products of the former NFS operations, the Project's former HLW treatment operations, and the Project's operations for management of HLW, transuranic waste, and low-level radioactive waste (LLW).

\section{Completion of Vitrification}

HLW from NFS operations was originally stored in two of four underground tanks (tanks 8D-2 and 8D-4). Contents in the tanks were pretreated to remove sodium salts and sulfates and most of the radioactive cesium. Resulting liquid wastes were fixed into about 20,000 drums of cemented LLW between 1988 and 1990 and stored on site in the drum cell. Vitrification of the HLW solids began in 1996 and continued through September 2002. (See the 2002 WVDP Annual Site Environmental Report [ASER] [West Valley Nuclear Services Company (WVNSCO) and URS, 2003] for a complete description of the vitrification process.)

Over the course of vitrification, more than 12.2 million cesium/strontium curies were transferred to the vitrification facility and 275 canisters were filled with radioactive glass. Two additional waste canisters were generated when the melter was evacuated. Canisters are in temporary storage in the main plant in a shielded cell and are being maintained until a disposal facility becomes available.

\section{Environmental Management System}

The WVDP environmental management system (EMS) satisfies the requirements of Department of Energy (DOE) Order 450.1, "Environmental Protection Program." (See the discussion of DOE Order 450.1 in the "Environmental Compliance Summary.") The EMS is also in compliance with the "Code of Environmental Management Principles" (CEMP) for federal agencies and International Organization for Standardization 14001, Environmental Management Systems: "Specifica-

$1-1$ 
tion for Guidance and Use," which is being implemented worldwide. Following the principles and performance objectives of the CEMP helps to ensure that a federal facility's environmental performance is proactive, flexible, cost-effective, and sustainable.

The Project's EMS provides the basic policy and direction for work at the WVDP through procedures that support proactive management, environmental stewardship, and the integration of appropriate technologies throughout all aspects of work. The environmental monitoring program is an important component of the EMS and the accomplishment of its mission. EMS implementation is summarized in Table 1-1.

\section{Integrated Safety Management System} (ISMS) Implementation. A plan to integrate environmental, safety, and health (ES\&H) management programs at the WVDP was developed and initiated in 1998. During this development, the EMS was identified as an integral part of the ISMS. Implementation of an ISMS at the WVDP was verified by the DOE Ohio Field Office in November 1998. Environmental subject matter experts participate in a sitewide work review group to review work plans, identify ES\&H concerns, and specify practices that ensure work is performed safely.

WVNSCO continues to improve implementation of ISMS. In addition to document and process reviews, the 2006 ISMS annual assessment utilized an employee survey based on safety culture attributes contained in the ISMS draft manual. The survey results provided a starting point for worker management discussions that clarified prospective roles and responsibilities and worker involvement. Employees and management have taken actions to increase employee involvement in work planning.

In 2006, the DOE reviewed the WVDP's ISMS. Although areas for improvement were noted, the
DOE team concluded that the WVDP ISMS is implemented and effective.

\section{Occupational Safety and Environmental Train-} ing. The safety of personnel who are involved in industrial operations under DOE cognizance is protected by standards mandated by DOE Order 440.1A, "Worker Protection Management for DOE Federal and Contractor Employees," which directs compliance with specific Occupational Safety and Health Act (OSHA) requirements. This act governs diverse occupational hazards.

Any person working at the WVDP who has a personal photo badge allowing unescorted access to administrative areas of the site receives general employee training that covers health and safety, emergency response, and environmental compliance issues. All visitors to the WVDP receive a site-specific briefing on safety and emergency procedures before being admitted to the site.

Hazardous waste operations and emergency response regulations require that employees at treatment, storage, and disposal facilities receive training appropriate to their job function and responsibilities. The WVDP environmental, health, and safety training matrix identifies the specific training requirements for such employees.

Training programs at the WVDP include, but are not limited to:

- 24-hour/40-hour hazardous waste operations

- emergency spill-response training

- decontamination techniques

- waste minimization and pollution prevention

- the WVDP environmental management program 


\section{Table 1-1 Elements of the Environmental Management System (EMS) at the WVDP}

\begin{tabular}{|c|c|}
\hline Environmental Policy & $\begin{array}{l}\text { The environmental policy for the WVDP is to conduct all activities, including design, } \\
\text { construction, testing, startup, commissioning, operation, maintenance, and decontamination } \\
\text { and decommissioning in a manner appropriate to the nature, scale, and environmental } \\
\text { impacts of these activities. The WVDP management is committed to full compliance with } \\
\text { applicable federal and New York State laws and regulations for the protection of the } \\
\text { environment, continual improvement, the prevention and/or minimization of pollution, and } \\
\text { public outreach, including stakeholder involvement. }\end{array}$ \\
\hline $\begin{array}{l}\text { vironmental Aspec } \\
\text { d Impacts }\end{array}$ & $\begin{array}{l}\text { When operations have an environmental aspect, WVNSCO implements the EMS to minimize } \\
\text { or eliminate any adverse potential impact. The EMS is a prerequisite for the United States } \\
\text { (U.S.) Environmental Protection Agency (EPA) National Environmental Performance Track } \\
\text { awarded by the EPA to the WVDP. Using the EMS, WVDP employees evaluate operations, } \\
\text { identify the aspects of operations that can impact the environment, and determine those } \\
\text { impacts that are significant. The following operational aspects have been determined to have } \\
\text { the potential to affect the environment: } \\
\text { - Waste generation and management } \\
\text { - Atmospheric emissions } \\
\text { - Liquid effluents } \\
\text { - Storage or use of chemicals and radioactive materials } \\
\text { - Natural resource usage - power and water consumption } \\
\text { - Noise } \\
\text { - Soil disturbance } \\
\text { - Disturbances to endangered species/protected habitats } \\
\text { - Contamination areas from historical operations } \\
\text { - Facility operations, maintenance, and decontamination activities } \\
\text { - Other facility-specific compliance aspects. }\end{array}$ \\
\hline $\begin{array}{l}\text { Leg } \\
\text { Req }\end{array}$ & $\begin{array}{l}\text { WVNSCO has implemented an environmental regulatory review and assessment process to } \\
\text { deliver WVDP-level requirements and guidance to all staff. New or revised requirements } \\
\text { (e.g., new regulations) are analyzed to determine their applicability to the WVDP and to } \\
\text { identify whether actions are required to achieve compliance. This may involve developing or } \\
\text { revising WVDP documents or operating procedures, implementing administrative controls, } \\
\text { providing training, installing engineered controls, or increasing monitoring. }\end{array}$ \\
\hline$\overline{\text { Obje }}$ & $\begin{array}{l}\text { The performance-based management system is designed to develop, align, balance, and } \\
\text { implement the strategic objectives for the WVDP, including environmental objectives. } \\
\text { Objectives and targets are developed by calendar year (CY). For the three-year period of CY } \\
\text { 2004-2006, WVNSCO defined three commitments under the EPA National Environmental } \\
\text { Performance Track (P-Track). These commitments, and progress toward achieving the } \\
\text { objectives, are presented in the Environmental Compliance Summary under "EPA National } \\
\text { Environmental Performance Track." }\end{array}$ \\
\hline $\begin{array}{l}\text { Environmental } \\
\text { Management Program }\end{array}$ & $\begin{array}{l}\text { A pollution prevention program to conserve resources and minimize waste generation is } \\
\text { implemented at the WVDP. The budgeting system is designed to ensure that priorities are } \\
\text { balanced and that resources essential to the implementation and control of the EMS are } \\
\text { provided. }\end{array}$ \\
\hline $\begin{array}{l}\text { Structure and } \\
\text { Responsibility }\end{array}$ & $\begin{array}{l}\text { All employees at the WVDP have specific roles and responsibilities in key areas, including } \\
\text { environmental protection. Environmental and waste management technical support personnel } \\
\text { assist the line organization with their environmental responsibilities. }\end{array}$ \\
\hline
\end{tabular}

$$
1-3
$$




\section{Table 1-1 (concluded) Elements of the Environmental Management System at the WVDP}

\begin{tabular}{|c|c|}
\hline $\begin{array}{l}\text { Training, A wareness, } \\
\text { and Competence }\end{array}$ & $\begin{array}{l}\text { Training on EMS requirements has been provided to staff whose responsibilities include } \\
\text { environmental protection. The training program includes general environmental awareness } \\
\text { for all employees, regulatory compliance training for select staff, and specific courses for } \\
\text { managers, internal assessors, EMS implementation teams, and operations personnel whose } \\
\text { work can impact the environment. }\end{array}$ \\
\hline $\begin{array}{l}\text { Communication and } \\
\text { Community } \\
\text { Involvement }\end{array}$ & $\begin{array}{l}\text { The WVDP representatives continue to improve processes for internal and external } \\
\text { communications on environmental issues. Communications with the local community include } \\
\text { monthly meetings with the local Citizen Task Force and meetings with the general public on } \\
\text { a quarterly basis. Project information, including this entire ASER, is available on the internet } \\
\text { at http: Iwww.wv.doe.gov. Notable community involvement activities by the WVDP } \\
\text { personnel in } 2006 \text { included participation in the United Way Day of Caring, and the } \\
\text { mentoring program with local schools. (See "National Environmental Policy Act" in the } \\
\text { Environmental Compliance Summary.) }\end{array}$ \\
\hline EMS Do & $\begin{array}{l}\text { Comprehensive, up-to-date environmental policies are written to describe the EMS. These } \\
\text { procedures and manuals inform staff how to control processes and perform work at the } \\
\text { WVDP in a manner that protects the environment. }\end{array}$ \\
\hline Doc & $\begin{array}{l}\text { A comprehensive electronic document control system to ensure the effective management of } \\
\text { procedural documents is maintained. When facilities require additional procedures to control } \\
\text { their work, document-control protocols are implemented to ensure that workers have access } \\
\text { to the current version of procedures. }\end{array}$ \\
\hline$\overline{\text { Ope }}$ & $\begin{array}{l}\text { Operations are evaluated for the adequacy of current controls to prevent impacts to the } \\
\text { environment. As needed, additional administrative or engineered controls are identified and } \\
\text { plans for upgrades and improvements are developed and implemented. }\end{array}$ \\
\hline $\begin{array}{l}\text { Emergency } \\
\text { Preparedness and } \\
\text { Response }\end{array}$ & $\begin{array}{l}\text { An emergency preparedness and response program with specialized staff provides timely } \\
\text { response to hazardous material releases or other environmental emergencies. This program } \\
\text { includes procedures for preventing, as well as responding to, emergencies. }\end{array}$ \\
\hline $\begin{array}{l}\text { Monitoring and } \\
\text { Measurement }\end{array}$ & $\begin{array}{l}\text { Liquid effluent and air-emission monitoring helps ensure the effectiveness of controls, } \\
\text { adherence to regulatory requirements, and timely identification and implementation of } \\
\text { corrective measures. A comprehensive, sitewide environmental monitoring program is in } \\
\text { place at the WVDP. Results are reported to regulatory agencies and summarized in this } \\
\text { ASER. In addition, monitoring data are assessed for adverse trends to determine site } \\
\text { performance, impacts from site conditions, and the need for proactive or corrective measures. }\end{array}$ \\
\hline $\begin{array}{l}\text { Nonconformance and } \\
\text { Corrective and } \\
\text { Preventive Actions } \\
\end{array}$ & $\begin{array}{l}\text { The WVDP employees continue to implement processes that identify and correct problems. } \\
\text { This includes a lessons learned program to prevent recurrences, robust self-assessment and } \\
\text { environmental assessment programs, and an electronic action tracking system. }\end{array}$ \\
\hline Records & $\begin{array}{l}\text { EMS-related records, including audit and training records, are maintained to ensure integrity, } \\
\text { facilitate retrieval, and protect from loss. }\end{array}$ \\
\hline EMS Audit & $\begin{array}{l}\text { To periodically verify that the EMS is operating as intended, assessments are conducted by } \\
\text { the DOE and its contractors. These assessments are designed to ensure that nonconformances } \\
\text { are identified and addressed. In addition, compliance with regulatory requirements is verified } \\
\text { through routine inspections, operational evaluations, and periodic assessments and self- } \\
\text { assessments. }\end{array}$ \\
\hline Management Review & $\begin{array}{l}\text { In addition to audits, a management review process has been established to involve top } \\
\text { management in the overall assessment of environmental performance, the EMS, and progress } \\
\text { toward achieving environmental goals. This review also identifies, as necessary, the need for } \\
\text { changes to and continual improvement of the EMS. }\end{array}$ \\
\hline
\end{tabular}

$$
1-4
$$


- radiation hazards and warnings

- dosimetry and respiratory protection

- medical emergency response training

- electrical safety and fire protection

Training programs have evolved into a comprehensive curriculum of knowledge and skills necessary to maintain the health and safety of employees and ensure the continued compliance of the WVDP with applicable regulations and requirements.

Safety-Trained Supervisor (STS) Program. In November 2003, WVNSCO initiated an STS certification program whereby employees complete an extensive program to become safety-certified. Certification and renewal requirements include at least 30 hours of safety-related training and successful completion of a certification exam. Standards, established by the Council on Certification of Health, Environmental, and Safety Technologists, ensure that certified individuals have a broad understanding of industrial safety. The benefits at the site include increased safety awareness among employees, an improved site safety culture, and increased confidence when dealing with safety and health matters during the planning and field phases of work. WVNSCO achieved its goal of 100 certified safety-trained supervisors in July of 2006.

10 Code of Federal Regulations (CFR) 851, "Worker Safety and Health Program." 10 CFR 851 is a new law that was issued by the DOE in February 2006 and became effective, implemented, and enforced at DOE sites in February 2007. This law establishes worker safety and health requirements that govern the conduct of DOE contractors at nuclear and non-nuclear sites. It applies to all contractors, workers, and their subcontractors who have a responsibility to perform work at a DOE site.
Similar to OSHA, the law requires that DOE contractors provide workers with a safe and healthful workplace that is free from recognized hazards that can cause death or serious physical harm. To accomplish this objective, the law establishes program requirements specific to management responsibilities, worker rights, hazard identification and prevention, safety and health standards, required training, recordkeeping, and reporting.

To ensure compliance, WVNSCO personnel have revised procedures and programs to comply with 10 CFR 851. Any modification, addition, or deletion that could invalidate a portion of the worker health and safety program requires approval by the DOE. The significant impacts to the workforce are: (1) WVNSCO is subject to inspection by the $\mathrm{DOE}$ and can be cited and fined for any violation, (2) fire protection inspection frequencies will increase to weekly or monthly from the current schedule, (3) the creation of WVDP-310, Addendum 1, "Worker Safety and Health Plan," describes how the WVDP complies with 10 CFR 851 , (4) violations to 10 CFR 851 will be tracked.

Self-Assessments. Self-assessments continued to be conducted in 2006 to review the management and effectiveness of the WVDP environmental protection and monitoring programs. Results of these self-assessments are evaluated and corrective actions are tracked through to completion. Overall, self-assessments confirmed that the WVDP employees continued to implement quality requirements and, in some cases, improve the quality of the environmental protection and monitoring program. (See the "Environmental Compliance Summary" and Chapter 5, "Quality Assurance.”)

National Environmental Performance Track. The WVDP has been recognized by the EPA as a charter member of the Performance Track (PTrack) Program for implementation of its EMS. 


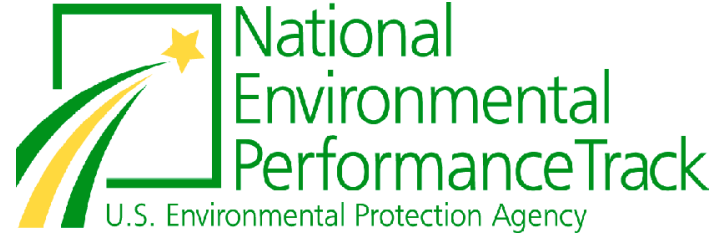

Performance Track is a partnership that recognizes top environmental performance among participating U.S. facilities of all types, sizes, and complexity, public and private. Program partners are providing leadership in many areas, including preventing pollution at its source. Currently, the program has about 400 members and welcomes all qualifying facilities.

The logo identifies those facilities that qualify for Achievement Track membership. Achievement Track facilities can participate in a peer exchange network to share experience, benchmark each other's performance, share information on successful practices and strategies, and receive recognition for their work at state and local levels. WVNSCO, in conjunction with the DOE, has applied for renewal for a threeyear membership in this program for 20072009.

The site is currently completing its second round of environmental commitments. These commitments have resulted in the elimination of Halon 1303 , the reduction of total energy usage by $25 \%$ from the 2003 baseline year, and an approximate $13 \%$ reduction in total curies released in wastewater discharges in 2006, as compared with the 2003 baseline.

Voluntary Protection Program (VPP) STAR Status. On May 5, 2000 the WVDP received VPP STAR status. This prestigious award was granted in recognition of excellent worker safety and health programs at the WVDP. (See also the "Environmental Compliance Summary.”)

The WVDP was recertified in late July 2006 for VPPSTAR status in recognition of an exemplary worker safety program. The WVDP continues to emphasize safety in the workplace as transitions in personnel, management, and work scopes create an atmosphere of uncertainty . The WVNSCO safety policy is to conduct its business at the WVDP in a manner that ensures the safety and well-being of employees and subcontractors. The goals are zero unsafe acts, injuries, occupational illnesses, unsafe conditions, environmental insults, or radiological contaminations. By the end of 2006, the Project's workers had logged more than 4.5 million consecutive safe work hours over a period of more than four years. These safety records confirm the attention workers pay to completing tasks safely. On several occasions during 2006, a "safety time out" was taken to evaluate whether a course of action was safe.

\section{Environmental Monitoring Program Overview}

Human beings are exposed to radioactivity from site activities primarily through air, water, and food. All three pathways are monitored at the WVDP, but air and surface water pathways are the two primary means by which radioactive material can move off site. For detailed information about radiation and radioactivity, measurement of radioactivity, measurement of dose, and reporting of radiological data, see the "Useful Information" section later in this report.

Site geology (types of soil and bedrock), hydrology (location and flow of surface water and groundwater), and meteorology (wind speed, patterns, and direction) are all considered when evaluating potential exposure through the major pathways. 
The on-site and off-site monitoring program at the WVDP includes measuring the concentration of alpha and beta radioactivity, conventionally referred to as "gross alpha" and "gross beta," in air and water effluents. Measuring the total alpha and beta radioactivity from key locations produces a comprehensive picture of on-site and off-site levels of radioactivity from all sources. For a DOE site such as the WVDP, frequent updating and tracking of the overall radioactivity levels in effluents is an important tool in maintaining acceptable operations.

More-detailed measurements are also made for specific radionuclides. Strontium-90 and cesium137 are measured because they have been previously detected in WVDP waste materials. Radiation from other important radionuclides, such as tritium or iodine-129, is not sufficiently energetic to be detected by gross measurement techniques, so these must be analyzed separately using methods with greater sensitivity. Heavy elements, such as uranium, plutonium, and americium, require special analysis because they exist in such low concentrations at the WVDP.

The radionuclides monitored at the Project are those that might produce relatively higher doses or that are most abundant in air and water effluents. Because man-made sources of radiation at the Project have been decaying for more than 35 years, the monitoring program does not routinely include short-lived radionuclides, that is, isotopes with a half-life of less than two years, which would be present at less than 1/1,000 of the original radioactivity levels. (See Appendix $\mathrm{B}^{\mathrm{GD}}$ for the schedule of samples collected and radionuclides measured. See Table UI-1 in the "Useful Information" section for a listing of the half-lives of radionuclides measured in WVDP samples and related DOE protection standards. See also the discussion of the derived concentration guides [DCGs] in the "Useful Information" section, later in this report.)
The WVDP monitoring program includes nonradiological wastewater discharge and storm water monitoring for water quality and chemical constituents. Permit discharge limits, water quality standards, guidelines, maximum contaminant level goals, and soil cleanup criteria reference values are provided, where available, for comparison purposes. (See Appendix $\mathrm{B}^{\mathbf{6 0}}$ for the schedule of sample locations and analytical requirements, Chapter 3 for a discussion of nonradiological program information, and Appendices $C^{\text {GD }}$ through $G^{\text {CDD }}$ for data presentations.)

\section{Environmental Management of Aqueous Ra-} dioactive Waste. Water containing radioactive material from site process operations is collected and treated in the low-level waste treatment facility (LLWTF), which includes the LLW treatment building and associated holding lagoons. (Water from the sanitary sewer is managed in a separate, nonradiological system.)

Treated process water is held, sampled, and analyzed before its release through a New York State Pollutant Discharge Elimination System (SPDES)permitted outfall. In 2006, about 10.4 million gallons (39.3 million liters) of water were treated in the LLWTF system and discharged through outfall 001, the lagoon 3 weir. Table 1-2 summarizes the estimated releases of radioactivity in the 2006 discharge waters, as compared to the previous 10year average. (Also, see "Water Effluent and Ambient Surface Water Monitoring" in Chapter 2.) Note that releases of both tritium and gross alpha and beta activity were below the 10 -year averages. 
Table 1-2. 2006 Radioactivity Releases Versus 10-Year Averages ${ }^{a}$

\begin{tabular}{|l|c|c|c|}
\hline Radionuclide & $\begin{array}{c}\text { 10-Year } \\
\text { Average } \\
\text { Curies }\end{array}$ & $\begin{array}{c}\text { 2006 } \\
\text { Curies }\end{array}$ & $\begin{array}{c}\text { \% of } \\
\text { 10-Year } \\
\text { Average }\end{array}$ \\
\hline \multicolumn{4}{|c|}{ Aqueous Discharge LLWTF } \\
\hline Tritium & 0.23 & 0.050 & $22 \%$ \\
\hline $\begin{array}{l}\text { Gross Alpha } \\
\text { and Beta }\end{array}$ & 0.018 & 0.013 & $71 \%$ \\
\hline \multicolumn{4}{|c|}{ Airborne Discharge ANSTACK } \\
\hline \multicolumn{4}{|c|}{ Gaseous } \\
\hline Tritium & 0.035 & 0.0012 & $3.5 \%$ \\
\hline Iodine-129 & 0.0018 & 0.000023 & $1.3 \%$ \\
\hline \multicolumn{4}{|c|}{ Particulate } \\
\hline $\begin{array}{l}\text { Gross Alpha } \\
\text { and Beta }\end{array}$ & 0.00025 & 0.0000099 & $3.9 \%$ \\
\hline
\end{tabular}

${ }^{a}$ All numbers were rounded to two significant digits after calculations were complete. Percentages based on the above total curie values may not exactly match those in the table.

\section{North Plateau Groundwater Recovery System} (NPGRS). The NPGRS operated throughout 2006, recovering groundwater from an area near the leading edge of the strontium-90 plume on the north plateau. Approximately 3.3 million gallons ( 12.5 million liters) were recovered during 2006. For a moredetailed discussion of the plume and the NPGRS, see "Northeast Swamp and North Swamp Drainage" in Chapter 2 and "Monitoring the Sand and Gravel Unit on the North Plateau" and "Additional Monitoring and Investigations" in Chapter 4.

\section{Nuclear Regulatory Commission-Licensed} Disposal Area (NDA) Interceptor Trench and Pretreatment System. Radioactively contaminated n-dodecane, in combination with tributyl phosphate (TBP), was discovered in groundwater at the northern boundary of the NDA in 1983, shortly after the DOE assumed control of the WVDP. To contain subsurface migration of this radioactive organic mixture, an interceptor trench and liquid pretreatment system (LPS) were installed.

As in previous years, $\mathrm{n}$-dodecane/TBP contamination was not detected in the trench water; therefore no water was pre-treated by the LPS in 2006. Approximately 458,000 gallons (1,740,000 liters) of radiologically-contaminated water were transferred from the interceptor trench to the LLWTF during the year. Results of surface and groundwater monitoring in the vicinity of the trench are discussed in Chapter 2 under "South Plateau Surface Water and Nuclear Regulatory Commission (NRC)-Licensed Disposal Area (NDA) Interceptor Trench" and in Chapter 4 under "Monitoring on the South Plateau: Weathered Lavery Till and the NDA."

\section{Environmental Management of Airborne Ra-} dioactive Emissions. During operations, ventilated air from the various WVDP facilities is continuously sampled for radioactivity in gases and particulate matter. Ventilated air is monitored and an alarm is activated if particulate matter radioactivity increases above preset levels. Samples are analyzed in the laboratory for the specific radionuclides that are present in the radioactive materials being handled. (See "Air Emission and Ambient Air Monitoring" in Chapter 2.)

Ventilation air through facilities undergoing radioactive material cleanup passes through high-efficiency filters before being released to the atmosphere. The filters are generally more effective for particulate matter than for gaseous radioactivity. For this reason, facility air treatment tends to remove a lesser percentage of gaseous radioactivity (e.g., tritium and iodine-129) than radioactivity associated with particulate matter (e.g., strontium-90 and cesium-137). However, gaseous radionuclide emissions still remain so far below the most restrictive regulatory limits for public 
safety that additional treatment technologies beyond those already provided are not necessary.

Table 1-2 shows the gaseous and particulate matter radioactivity emissions from the main plant in 2006 compared to averages from the previous 10year period. These 2006 values are low in comparison with the 10-year average that includes several years when the vitrification system was operating.

Environmental Management of Radiation Exposure. Environmental radiation is measured with thermoluminescent dosimeters (TLDs) at on-site and off-site locations. (See Figs. A-12 through A15 for the locations of on-site and off-site TLD monitoring points.) Although exposure rates at most on-site locations in 2006 were elevated with respect to background, results from perimeter TLDs that would be more representative of exposure to the public were statistically indistinguishable from background results. (See "Direct Environmental Radiation Monitoring" in Chapter 2.)

Changes in the 2006 Environmental Monitoring Program. Effective September 1, 2006, the New York State Department of Conservation (NYSDEC) issued a modified SPDES permit for control of discharges of treated process and sanitary wastewater and storm water. Minimum monitoring requirements for 17 chemical parameters at outfall 001 were reduced in collection frequency. The permit no longer specifies a $\mathrm{pH}$ limit for storm water runoff; the requirement was reduced to monitoring only. NYSDEC incorporated a policy change for the control of mercury that modified requirements to utilize only "ultra clean" EPA Method 1631 for low-level detection of total mercury for compliance monitoring and reporting. Consequently, units used to define the limits were changed from micrograms per liter $(\mu \mathrm{g} / \mathrm{L})$ to nanograms per liter (ng/L) (although the limits themselves were not changed). The measurement units to express the enforcement discharge compliance limit for total mercury concentration was revised from $0.2 \mu \mathrm{g} / \mathrm{L}$ to $200 \mathrm{ng} / \mathrm{L}$ at outfall WNSP001 and from $10 \mu \mathrm{g} / \mathrm{L}$ to $10,000.0 \mathrm{ng} / \mathrm{L}$ at outfall WNSP01B.

\section{Activities at the WVDP}

Significant components, initiatives, and accomplishments at the WVDP in 2006 are summarized below.

\section{The Decommissioning, Decontamination,} Dismantlement, and Demolition (D4) Project. Four major D4 Project efforts in the main plant were completed in 2006. Systems and components within the processing building were identified, taken apart, packaged, and shipped off site for disposal. Some of the equipment had not operated in years, including equipment that was part of the original design when the plant was reprocessing nuclear fuel. Components removed included the old utility room boilers, the cement solidification system, the fuel receiving and storage decontamination station, and items from the former vitrification chemistry laboratory.

Environmental Assessment (EA). On September 14, 2006, the DOE finalized DOE/EA1552, an assessment report, which evaluated the proposed decontamination, demolition, and removal of 36 unneeded facilities at the WVDP. These facilities are, or within the next four years will be, no longer required to safely monitor, maintain, or support future removal of the vitrified high-level radioactive waste, or the closure of other site facilities. Since the EA was issued, 11 WVDP structures have been taken out of service and removed. "Green space" on site has been increased and resources are being conserved as a result of no longer having to maintain the obsolete structures. (See the discussions of the EA and the Notice of Finding of No Significant Impact in the "National 
Environmental Policy Act [NEPA]" section of the "Environmental Compliance Summary.")

Waste Management and Shipping Activities. In 2006, materials in a number of areas were sorted, consolidated, recycled, reused, or disposed. Demolition debris, excess items, and legacy radioactive and nonradioactive waste accounted for approximately 225,000 cubic feet $(6,400$ cubic meters) of waste eliminated from the WVDP. That amount, combined with the waste removed from the main plant, brought the total amount of LLW and industrial waste disposed in 2006 to about 400,000 cubic feet (11,300 cubic meters). (See Table ECS-3 for further breakdown of waste types.)

Since July 2001, the WVDP has been approved to ship LLW to the Nevada Test Site (NTS), a DOE facility. During calendar year 2006, 118 truck shipments of LLW were safely shipped off site to NTS or EnergySolutions for disposal. LLW shipping will continue during 2007.

\section{Performance Measures}

Performance measures can be used to evaluate effectiveness, efficiency, quality, timeliness, productivity, safety, or other areas that reflect achievements related to organization or process goals, and can be used as tools to identify the need to institute changes.

The performance measures applicable to operations conducted at the WVDP reflect process performance related to (1) the potential radiological dose received by the maximally exposed off-site individual (MEOSI), (2) wastewater treatment in the LLWTF, (3) the reduction in waste generation, and (4) the identification of spills and releases.

Radiation Doses to the Maximally Exposed Off-Site Individual. An important piece of information derived from environmental monitoring program data is the potential radiological dose to an off-site individual from on-site activities. As an overall assessment of Project activities and the effectiveness of the as-low-as-reasonably-achievable concept, the low potential radiological dose to the MEOSI is an indicator of well-managed radiological operations. The effective dose equivalents for air effluent emissions, liquid effluent discharges, and other liquid releases (such as swamp drainage) from 1997 through 2006 are graphed on Figure 1-1. Note that the sum of these values is well below the DOE standard of 100 mrem per year. The consistently low effluent results indicate that radiological activities at the site are well-controlled. (See also Table 2-3 in Chapter 2, "Environmental Radiological Protection Program and Dose Assessment.")

\section{Improvements in Wastewater Treatment at} the Low-Level Waste Treatment Facility. Under the P-Track program, the WVDP committed to achieve reduction in the total annual radiological curies released in wastewater from the LLWTF by $10 \%$ with respect to a 2003 baseline over the three-year period from 2004 through 2006. After excellent performance in 2004, performance in 2005 declined to a level short of the goal, although well within DOE discharge requirements. A process improvement to the lowlevel radioactive wastewater process was identified and implemented in late 2005. Corrective actions included more rigorous system breakthrough monitoring, expedited response change-out of spent columns, and rehabilitation of treatment components. In 2006, the modifications identified by the process improvement supported achievement of the EPA Performance Track Goal, and resulted in a $13 \%$ reduction of curies discharged from outfall 001 with respect to the 2003 baseline.

SPDES Permit Limit Exceptions. Effective operation of the site wastewater treatment facilities is indicated by compliance with the applicable dis- 


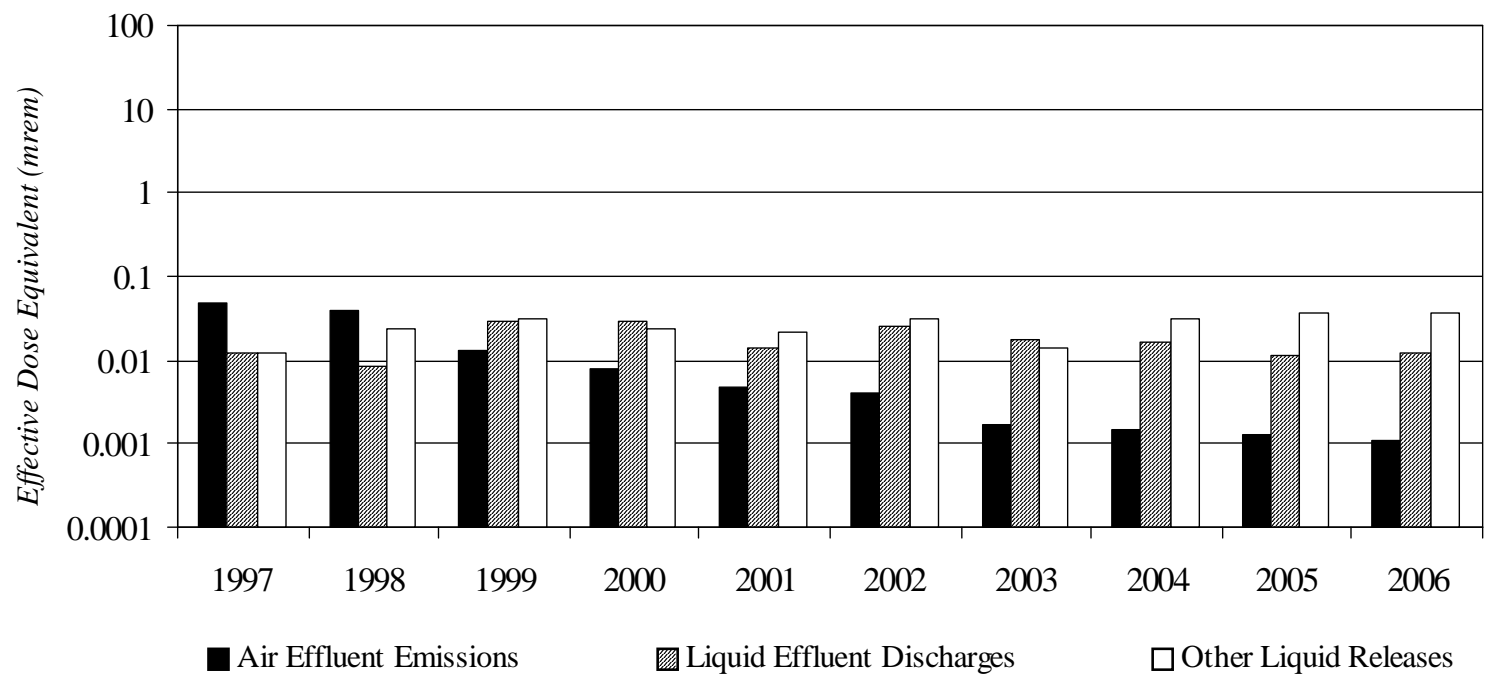

Figure 1-1. Annual Effective Dose Equivalent to the Maximally Exposed Off-Site Individual

charge permit limits. Approximately 60 chemical and water quality constituents are monitored regularly as part of the SPDES permit requirements. The analytical results are reported to NYSDEC via Discharge Monitoring Reports, required under the SPDES program.

Although the goal of the LLWTF and wastewater treatment facility operations is to maintain effluent water quality consistently within the permit requirements, occasionally SPDES permit limit exceptions do occur. SPDES permit limit exceptions are evaluated to determine their cause and to identify corrective measures.

There were no SPDES effluent limit exceptions during 2006. (See Fig. 12.) Historical limit exceptions are discussed in previous ASERs.

Although exceptions are not always related to operating deficiencies, cor- rective actions may include improved operation or treatment techniques. In 1997, the DOE notified NYSDEC of the presence of mercury in the influent wastewater to the LLWTF and of its likely presence at outfall 001 at concentrations below the detectable level of $0.2 \mu \mathrm{g} / \mathrm{L}$. In 2002, a modification to the SPDES permit required that samples being collected for measurement of mercury be analyzed in duplicate by EPAMethod 245.1 (with

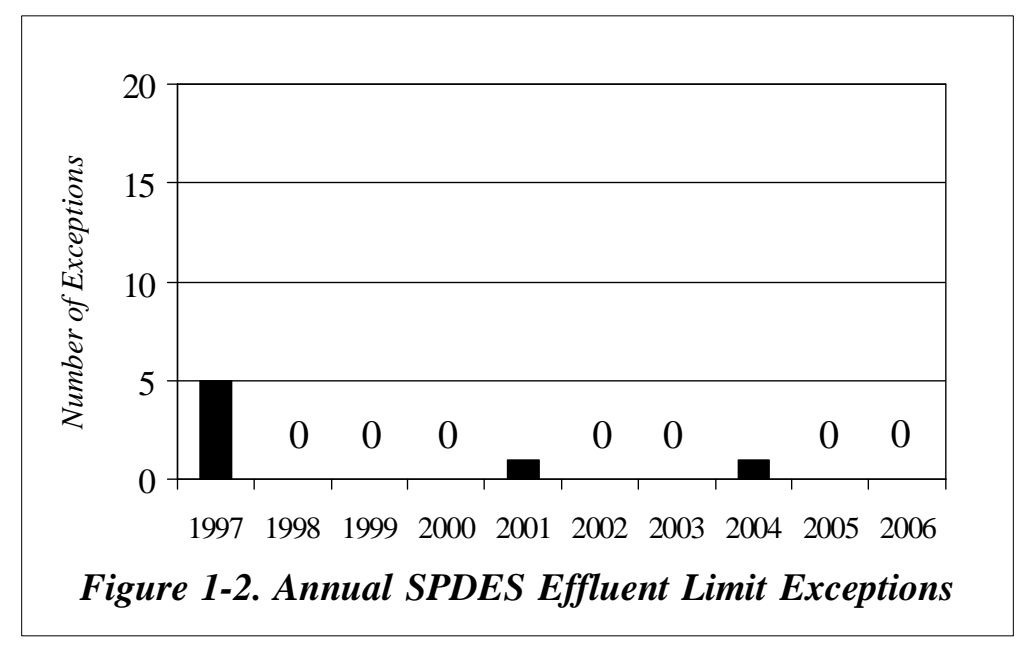


a practical quantitation limit of $0.2 \mu \mathrm{g} / \mathrm{L}$ ) and by newer, more-sensitive "ultra-clean" EPAMethod 1631 (with a minimum level of $0.5 \mathrm{ng} / \mathrm{L}$, which is equivalent to $0.0005 \mu \mathrm{g} / \mathrm{L}$ ). Results from both methods, which have been consistent with each other, have been reported to NYSDEC on a semiannual basis. (See "Mercury Analytical Method Study" in Chapter 3 for a discussion of this study.)

On September 1, 2006, NYSDEC issued a modified SPDES permit which replaced the requirement to perform mercury analysis using EPA Method 245.1 with a requirement to use the "ultra-clean" Method 1631 only and eliminated a requirement to report comparison results.

Waste Minimization and Pollution Prevention. The WVDP formalized a waste minimization program in 1991 to reduce the generation of LLW, mixed waste, hazardous waste, and industrial and sanitary waste (e.g., paper, plastic, wood, and scrap metal). This program is a comprehensive and continual effort to prevent or minimize pollution, with the overall goals of reducing health and safety risks, protecting the environment, and complying with all federal and state regulations. The program emphasizes good business practices, source reduction, and recycling. (See also the "Waste Minimization and Pollution Prevention" discussion under the "Resource Conservation and Recovery Act [RCRA]" section of the "Environmental Compliance Summary.”)

Hazardous waste and industrial waste volumes have been tracked separately for vitrification-related and nonvitrification-related waste streams since vitrification began in 1996.

In 2006, WVNSCO continued its program of reducing and eliminat- ing the amount of waste generated from site activities. The cumulative nonvitrification wasterecycling quantities for fiscal year 2006 are presented in Table ECS-5 in the "Environmental Compliance Summary."

Pollution Prevention Awareness Program. The WVDP's Pollution Prevention Awareness Program is a significant part of the Project's waste minimization program. The plan establishes the strategic framework for integrating waste minimization and pollution prevention into waste generation and reduction activities, procuring recycled products, reusing existing products, and conserving energy. A main goal of the program is to make all employees aware of the importance of pollution prevention both at work and at home.

Spills and Releases. Chemical spills greater than the applicable reportable quantity must be reported immediately to NYSDEC, the National Response Center, and other agencies as required. There were no reportable chemical spills during 2006.

Petroleum spills greater than five gallons - or of any amount that travel to waters of the state must be reported immediately to the NYSDEC spill hotline and entered into the WVDP's quarterly $\log$. There were no reportable petroleum spills

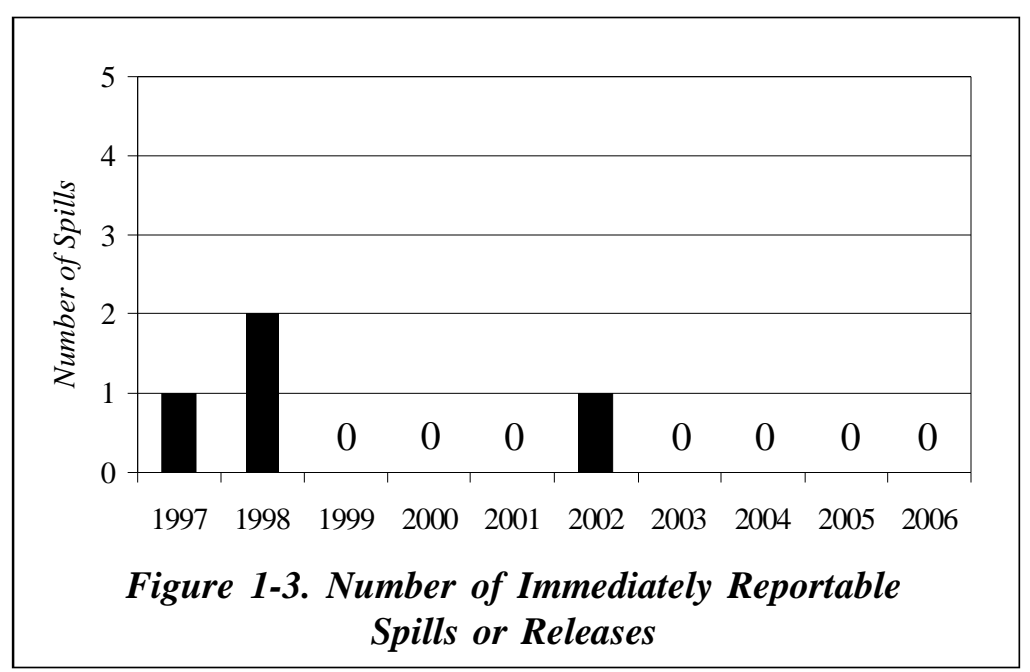


in 2006. Figure 1-3 shows immediately reportable spills from 1997 to 2006.

Prevention is the best means of protection against spills or releases of oil, chemicals, and hazardous substances. To this end, WVDP employees are trained to use equipment in accordance with standard operating procedures. Best management practices have been developed that identify potential spill sources and preventive measures that will reduce the likelihood of releases. Spill training, notification, and reporting policies have also been developed to emphasize the responsibility of each employee to report spills immediately upon discovery. First-line reporting helps to ensure that spills will be properly documented and mitigated in accordance with applicable regulations. 
This page intentionally left blank

$$
1-14
$$




\section{ENVIRONMENTAL RADIOLOGICAL PROTECTION PROGRAM AND DOSE ASSESSMENT}

\section{Radiation in the Environment}

\section{Sources of Radiation}

Members of the public are routinely exposed to natural and man-made sources of ionizing radiation. An individual living in the United States (U.S.) is estimated to receive an average annual effective dose equivalent of about 360 millirem (mrem) (3.6 millisieverts [mSv]) (National Council on Radiation Protection and Measurements Report 93, 1987). (See the "Useful Information" section at the end of this report for discussions of ionizing radiation and units of dose measurement.)

Most of the radiation dose to a member of the public, about $295 \mathrm{mrem} / \mathrm{year}$, is from natural background sources of cosmic and terrestrial origin (Fig. 2-1). The remainder, about $65 \mathrm{mrem} / \mathrm{year}$, is from man-made sources, including diagnostic and therapeutic $\mathrm{x}$-rays, nuclear medicine, consumer products such as cigarettes and smoke detectors, fallout from nuclear weapons tests, and effluents from nuclear facilities.

Radioactive materials at the West Valley Demonstration Project (WVDP or Project) are residues from the commercial reprocessing of nuclear fuel by a former site operator in the 1960s and early 1970s. Each year, very small quantities of the radioactive materials remaining at the WVDP are released to the environment, primarily in air emissions or liquid discharges generated as part of routine operations. Emissions and effluents are strictly controlled so that release quantities are kept as low as reasonably achievable (ALARA).

\section{Exposure Pathways}

An exposure pathway consists of a route for contamination to be transported by an environmental medium from a source to a receptor where exposure may occur. For example, a member of the public could be exposed to low concentrations of radioactive particles carried by a prevailing wind.

Table 2-1 summarizes the potential exposure pathways from the WVDP to the local off-site population and describes the rationale for including or excluding each pathway when calculating dose from the WVDP. Potential pathways that are considered in dose calculations include: inhalation of gases and particulates, ingestion of locally grown food products and game, and exposure to external penetrating radiation emitted from contaminated materials. Drinking water is not considered a path- 
way from the WVDP because surveys have determined that no public water supplies are drawn from downstream Cattaraugus Creek.

\section{Land Use Survey}

Periodic surveys of local residents provide information about family size, sources of food, and gardening practices. Updated population data from the calendar year (CY) 2000 census was incorporated into WVDP analysis in 2003. Population around the WVDP by sector and distance is presented in Figure A-16. Information from the most recent land use survey, conducted in early 2002, was used to confirm the locations of the nearest residences. This information is required when using computer models for annual dose assessments.

\section{Dose to the Public}

Each year an estimate is made of the potential radiological dose to the public that is attributable to operations and effluents from the WVDP during that calendar year. Estimates are calculated to verify that no individual could have received a dose exceeding the limits for protection of the public, as established by the U.S. Department of Energy (DOE) and the U.S. Environmental Protection Agency (EPA).

Figure 2-1 shows the estimated maximum individual dose from the WVDP in CY 2006 as compared with the average annual dose a U.S. resident receives from man-made and natural background sources. As can be seen, estimated dose from the WVDP would have contributed a very small amount (0.049 mrem [0.00049 mSv]) of the total annual man-made radiation dose to the maximally exposed off-site individual residing near the WVDP. This is much less than the average dose received from using consumer products and is insignificant compared with average dose from natural sources.

Estimated potential dose from the Project to an off-site resident is also far below the federal standard of 100 mrem allowed from any DOE site operation in a calendar year, confirming that ef-

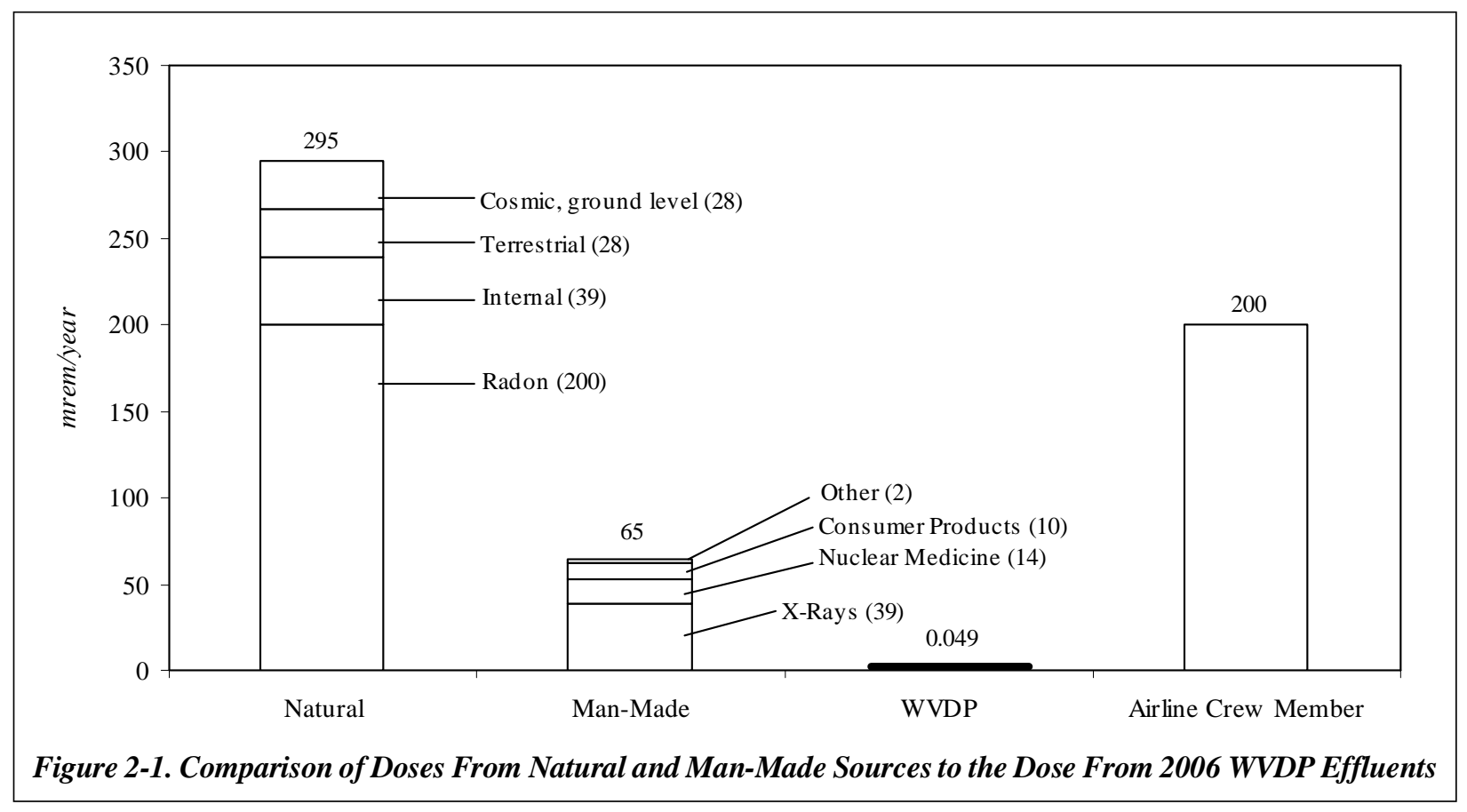

$2-2$ 
Table 2-1

Potential Local Off-Site Exposure Pathways Under Existing WVDP Conditions

\begin{tabular}{|l|l|}
\hline \multicolumn{1}{|c|}{$\begin{array}{c}\text { Exposure Pathway and Transporting } \\
\text { Medium }\end{array}$} & \multicolumn{1}{c|}{ Reason for Inclusion/Exclusion } \\
\hline Inhalation: gases and particulates in air (included) & $\begin{array}{l}\text { Off-site transport of contaminants from WVDP stacks and } \\
\text { vents or resuspended particulates from soils or water }\end{array}$ \\
\hline Ingestion: cultivated crops (included) & $\begin{array}{l}\text { Local agricultural products irrigated with potentially } \\
\text { contaminated surface or groundwater; deposition on leaves } \\
\text { and uptake of deposited airborne contaminants }\end{array}$ \\
\hline Ingestion: surface and groundwater (excluded) & $\begin{array}{l}\text { No documented use of local surface water or downgradient } \\
\text { groundwater wells as drinking water by local residents }\end{array}$ \\
\hline Ingestion: meat, milk, and vegetables (included) & $\begin{array}{l}\text { Fish exposed to contaminants in water or sediments may be } \\
\text { consumed; vegetables, venison, and milk may be consumed } \\
\text { following deposition of transported airborne and surface water } \\
\text { contaminants }\end{array}$ \\
\hline $\begin{array}{l}\text { External exposure: radiation from particulates and } \\
\text { gases directly from air or surface water or indirectly } \\
\text { from surface deposition (included) }\end{array}$ & $\begin{array}{l}\text { Transport of air particulates and gases to off-site receptors; } \\
\text { transport of contaminants in surface water and direct exposure } \\
\text { during stream use and swimming }\end{array}$ \\
\hline
\end{tabular}

forts at the WVDP to minimize radiological releases are consistent with the ALARA philosophy of radiation protection.

The following sections of this chapter describe the monitoring program used to measure radiation in the environment near the WVDP, the methods used to estimate dose, and the results of dose assessments using these measurements. 


\section{Routine Monitoring Program}

\section{Radiological Sampling Program Overview}

The goal of the environmental monitoring program is to ensure that public health and safety and the environment continue to be protected with respect to potential releases from current site activities. To achieve this goal, possible exposure pathways are monitored.

As part of the monitoring program, samples from environmental media are collected each year and measured for radioactivity.

Environmental sampling locations are shown on maps in Appendix A. The complete environmental monitoring schedule is summarized in Appendix $B^{\text {co. }}$, which includes a detailed listing of specific changes to the monitoring program in 2006 . This schedule provides information on monitoring and reporting requirements and the types and extent of sampling and monitoring at each location. An explanation of the codes that identify the sample medium and the specific sampling or monitoring location is also found in Appendix $B^{\text {GD }}$. For example, the location code AFGRVAL indicates an air sample (A), collected off-site (F), at the Great Valley (GRVAL) sampling station. Location codes are used throughout this report for ease of reference and to be consistent with the data reported in the appendices.

The primary focus of the monitoring program is on surface water and air pathways, as these are the principal means of transport of radionuclides from the WVDP.

Liquid and air effluents are monitored on site by collecting samples at locations where radioactivity is released or might be released. Release points include water effluent outfalls and plant ventilation stacks.

Surface water samples are collected within the Project area from ponds, swamps, seeps, and drainage channels that flow through the Western New York Nuclear Service Center (WNYNSC) and then into Cattaraugus Creek and off site.

Both surface water and air samples are collected at perimeter locations where the highest off-site concentrations of transported radionuclides might be expected. Samples are also collected at remote locations to provide background concentration data for comparison with data from on-site and nearsite samples.

The food pathway is monitored by collecting samples of milk and produce at near-site and remote locations, samples of fish upstream and downstream of the site, and samples of venison from deer collected near the site and at background locations. Stream sediments are sampled upstream and downstream of the WVDP. On-site groundwater and off-site residential drinking water wells are routinely sampled.

Direct radiation is monitored on site, at the perimeter of the site, in communities near the site, and at a remote background location.

Table 2-2 summarizes statistical comparisons of results from monitoring locations with results from background locations and comparisons with DOE derived concentration guides (DCGs). As in the past, although results from many on-site monitoring points exceeded background concentrations, few results from downstream points, and even fewer from near-site locations did. 
Table 2-2

2006 Comparison of Radiological Results With Backgrounds and DOE DCGs

\begin{tabular}{|c|c|c|c|c|}
\hline Sample Type & $\begin{array}{l}\text { Number of } \\
\text { Sampling } \\
\text { Locations }\end{array}$ & $\begin{array}{l}\text { Locations With } \\
\text { Results } \\
\text { Greater Than } \\
\text { DOE DCGs }\end{array}$ & $\begin{array}{c}\text { Number With } \\
\text { Results Greater } \\
\text { Than } \\
\text { Background }\end{array}$ & $\begin{array}{c}\text { Locations with Results Statistically Greater } \\
\text { than Background (Constituent) }\end{array}$ \\
\hline \multicolumn{5}{|c|}{ Air (1 background location) } \\
\hline $\begin{array}{l}\text { On-site air } \\
\text { emission points }\end{array}$ & 6 & 0 & 3 & $\begin{array}{l}\text { ANSTACK (tritium, strontium-90, iodine-129, cesium- } \\
\text { 137, plutonium-238, plutonium-239/240, americium-241); } \\
\text { ANSTSTK (iodine-129); ANCSPFK (iodine-129) }\end{array}$ \\
\hline $\begin{array}{l}\text { On-site ambient } \\
\text { air points }\end{array}$ & 1 & 0 & 0 & None \\
\hline $\begin{array}{l}\text { Off-site ambient } \\
\text { air points }\end{array}$ & 5 & 0 & 0 & None \\
\hline \multicolumn{5}{|c|}{ Surface water ( 2 background locations) } \\
\hline $\begin{array}{l}\text { On-site } \\
\text { controlled } \\
\text { effluents }\end{array}$ & 2 & 0 & 2 & $\begin{array}{l}\text { WNSP001 (gross alpha, gross beta, tritium, strontium-90, } \\
\text { technetium-99, iodine-129, cesium-137, uranium-232, } \\
\text { uranium-233/234, uranium-235/236, uranium-238, } \\
\text { plutonium-239/240); WNSP007 (gross beta) }\end{array}$ \\
\hline $\begin{array}{l}\text { On-site surface } \\
\text { waters }\end{array}$ & 10 & $\begin{array}{l}\text { WNSWAMP } \\
\text { (strontium-90) }\end{array}$ & 7 & $\begin{array}{l}\text { WNSP006 (gross beta, strontium-90, uranium-233/234, } \\
\text { uranium-238); WNSP005 (gross beta, strontium-90); } \\
\text { WNSWAMP (gross beta, strontium-90); WNSW74A } \\
\text { (gross beta, strontium-90); WNNDADR (gross beta, } \\
\text { tritium, strontium-90); WNNDATR (gross alpha, gross } \\
\text { beta, tritium, strontium-90, iodine-129); WNERB53 } \\
\text { (gross beta, strontium-90) }\end{array}$ \\
\hline $\begin{array}{l}\text { Off-site surface } \\
\text { waters }\end{array}$ & 2 & 0 & 2 & $\begin{array}{l}\text { WFBCTCB (gross beta); WFFELBR (gross alpha, gross } \\
\text { beta) }\end{array}$ \\
\hline \multicolumn{5}{|c|}{ Drinking water (2 background locations) } \\
\hline $\begin{array}{l}\text { On-site drinking } \\
\text { water }\end{array}$ & 3 & NA & 0 & None \\
\hline $\begin{array}{l}\text { Off-site drinking } \\
\text { water }\end{array}$ & 9 & NA & 0 & None \\
\hline \multicolumn{5}{|c|}{ Soil (1 background location) } \\
\hline Off-site soils & 5 & NA & NS & Next sampling in 2007 \\
\hline \multicolumn{5}{|c|}{ Sediments (2 background locations, one on Buttermilk Creek and one [historical] on Cattaraugus Creek) } \\
\hline $\begin{array}{l}\text { On-site } \\
\text { sediments/soils }\end{array}$ & 3 & NA & 3 & $\begin{array}{l}\text { SNSP006 (gross beta, strontium-90, cesium-137); } \\
\text { SNSWAMP (gross beta, strontium-90, cesium-137, } \\
\text { plutonium-238, plutonium-239/240, americium-241); } \\
\text { SNSW74A (cesium-137) }\end{array}$ \\
\hline $\begin{array}{l}\text { Off-site } \\
\text { sediments }\end{array}$ & 3 & NA & 3 & SFTCSED, SFSDSED, and SFCCSED (cesium-137) \\
\hline
\end{tabular}

Note: Results from air emission points, liquid effluent points, downstream water sampling points, and on-site sampling points for all matrices may be expected to be greater than background.

NA - DOE DCGs are not applicable for these matrices.

NS - Not sampled in CY 2006

$2-5$ 


\section{Table 2-2 (concluded)}

\section{Comparison of Radiological Results With Backgrounds and DOE DCGs}

\begin{tabular}{|c|c|c|c|c|}
\hline Sample Type & $\begin{array}{l}\text { Number of } \\
\text { Sampling } \\
\text { Locations }\end{array}$ & $\begin{array}{c}\text { Locations With } \\
\text { Results } \\
\text { Greater Than } \\
\text { DOE DCGs }\end{array}$ & $\begin{array}{c}\text { Number With } \\
\text { Results Greater } \\
\text { Than } \\
\text { Background }\end{array}$ & $\begin{array}{c}\text { Locations with Results Statistically Greater } \\
\text { than Background (Constituent) }\end{array}$ \\
\hline \multicolumn{5}{|c|}{ Biologicals ( 3 background deer; 1 background per matrix for remainder) } \\
\hline Fish & 2 & NA & $\mathrm{NR} / 0$ & None \\
\hline Milk & 4 & NA & 0 & None \\
\hline Deer & 3 & NA & 2 & BFDNEAR (cesium-137) \\
\hline $\begin{array}{l}\text { Vegetables/ } \\
\text { fruits }\end{array}$ & 3 & NA & 0 & None \\
\hline \multicolumn{5}{|c|}{ Environmental dosimetry ( 1 background) } \\
\hline $\begin{array}{l}\text { On-site, near } \\
\text { facilities }\end{array}$ & 15 & $\mathrm{NA}$ & 12 & DNTLDs \#24, 25, 26, 28, 30, 33, 35, 36, 38, 39, 40, 43 \\
\hline Perimeter & 17 & $\mathrm{NA}$ & 0 & None \\
\hline Communities & 2 & $\overline{\mathrm{NA}}$ & 0 & None \\
\hline
\end{tabular}

Note: Results from air emission points, liquid effluent points, downstream water sampling points, and on-site sampling points for all matrices may be expected to be greater than background.

NA - DOE DCGs are not applicable for these matrices.

NR - No strontium-90 data were reported for many of the fish samples because of a problem with analytical quality control.

Of the data that were acceptable, no results exceeded background levels.

\section{Water Effluent and Ambient Surface Water Monitoring}

The Project is drained by several small streams. Frank's Creek enters the Project from the south and receives drainage from the south plateau. As Frank's Creek flows northward, it is joined by a tributary, Erdman Brook, that receives effluent from the low-level waste treatment facility (LLWTF). After leaving the Project, Frank's Creek receives drainage from the north and northeast swamp areas and Quarry Creek on the north plateau. Frank's Creek continues across the WNYNSC and flows into Buttermilk Creek, which enters Cattaraugus Creek and leaves the WNYNSC (Figs. A-2 and A-5).

Three locations (the LLWTF and the two natural drainages from the northeast and north swamps) are the primary discharge sources that contribute to dose via the liquid pathway. (See "Predicted Dose From Waterborne Releases" later in this chapter for an estimate of the dose attributable to these sources.)

Low-Level Waste Treatment Facility Effluent. The LLWTF was designed to efficiently remove strontium-90 and cesium-137, the more prevalent of the long-lived fission products in WVDP wastewaters. Other radionuclides, such as uranium isotopes, are also removed to a lesser extent. Uranium and some transuranic isotopes are found in WVDP liquid waste because they were present in the nuclear fuel that was once reprocessed at the site.

The discharge from the LLWTF through the lagoon 3 weir at outfall 001 (WNSP001 on Fig. A2) into Erdman Brook is the primary controlled point source of radioactivity released to surface waters from the Project. Six batch releases total- 
ing about 10.4 million gallons (39.3 million liters) were discharged from WNSP001 in 2006.

The total amounts of radioactivity from specific radionuclides in the lagoon 3 effluent are listed in Appendix C-2 ${ }^{\mathrm{GD}}$. The annual average concentration of each radionuclide is divided by its corresponding DOE derived concentration guide (DCG) to determine what percentage of the DCG was released. As a DOE policy, the sum of the percentages calculated for all radionuclides released should not exceed $100 \%$. The combined annual average of radionuclide concentrations from lagoon 3 effluent in 2006 was approximately $20.7 \%$ of the DCGs. The three major contributors to the combined DCG (strontium-90, uranium-232, and cesium-137) accounted for about $11 \%, 6 \%$, and 2\%, respectively. (DCGs are discussed and a listing presented in the "Useful Information" section at the end of this report.)

Variations in radionuclide ratios from year to year reflect the dynamic nature of the waste streams being processed through the LLWTF. Outfall WNSP001 and other selected discharge points are also monitored for nonradiological parameters under the New York State Pollutant Discharge Elimination System Permit. See "Environmental Nonradiological Program Information" in Chapter 3.

\section{Northeast Swamp and North Swamp Drainage.}

These two drainages conduct surface water and emergent groundwater from the site's north plateau off site. The northeast swamp (WNSWAMP) is sampled to monitor surface water drainage from the northeastern portion to Frank's Creek, and the north swamp (WNSW74A) is sampled to monitor drainage to Quarry Creek from the northern portion of the plateau (Fig. A-2).

Data summaries from the two locations are found in Appendix C- $4^{\text {GD }}$. Elevated gross beta concentrations at WNSWAMP, first noted in 1993, continued to be observed through 2006. Gross beta activity at this location is largely attributable to strontium-90, concentrations of which exceeded the DOE DCG from May through September of 2006. WNSWAMP was the only point at which a DCG had been exceeded in 2006. See Chapter 4, Figure 4-10, for a graph of annualized average strontium90 concentrations at WNSWAMP in 2006. (Although concentrations were below the DCG for seven months during 2006, the annualized average remained above the DCG the entire year.)

Even though waters with elevated strontium-90 concentrations drain from WNSWAMP into Frank's Creek and ultimately into Cattaraugus Creek, concentrations in waters collected from Cattaraugus Creek downstream at the first point of access by the general public were not significantly higher than those at the upstream background location.

Other North Plateau Surface Waters and Water Effluent. Discharges from the LLWTF (WNSP001) and the sewage treatment outfall (WNSP007) leave the site through the combined facility liquid discharge into Frank's Creek at point WNSP006. Radiological results from WNSP007 and WNSP006 are summarized in Appendices $\mathrm{C}-2^{\mathrm{WD}}$ and $\mathrm{C}-5^{\mathrm{GD}}$, respectively.

Many of the constituents detected in effluent from WNSP001 were not detectable a short distance downstream at location WNSP006.

Also monitored are overland drainage and groundwater seepage on the east side of the main plant (point WNSP005) and coolant water from a contained basin within the facility (point WNCOOLW). Summaries of radiological data for WNSP005 and WNCOOLW are found in Appendix C- $4{ }^{\text {Go }}$.

Detectable results from these locations were all less than $10 \%$ of their respective DOE DCGs in CY 2006. 
South Plateau Surface Water and Nuclear Regulatory Commission (NRC)-Licensed Disposal Area (NDA) Interceptor Trench. Two inactive underground radioactive waste disposal areas, the NDA and the New York StateLicensed Disposal Area (SDA), lie on the south plateau of the site. The SDA is managed by the New York State Energy Research and Development Authority and the NDA is managed by the DOE. Also located on the south plateau is the drum cell, an aboveground structure used to store approximately 20,000 drums of processed low-level radioactive waste. (During 2006, the WVDP began shipping the drums to an off-site facility.) Surface waters are routinely monitored at several points around these areas (Fig. A-2). In addition, samples are collected by the New York State Department of Health (NYSDOH) from the two streams that receive drainage from the south plateau: Frank's Creek (WNFRC67) and Erdman Brook (WNERB53).

NRC-Licensed Disposal Area. Samples are collected from a sump at the lowest point in the collection trench system that intercepts groundwater from the northeastern and northwestern sides of the NDA (interceptor trench at sampling point WNNDATR). Water collected underground at this location is pumped to the LLWTF for treatment prior to discharge at outfall WNSP001. (See Chapters 1 and 4 for additional detail on the NDA Interceptor Trench and Pretreatment System.) If contamination were to migrate through the NDA, it would most likely be first detected at the interceptor trench. Annual concentrations from WNNDATR are listed in Appendix C- $4{ }^{\text {(0) }}$ and quarterly results are listed under "NDATR" in Appen$\operatorname{dix} \mathrm{E}^{\mathrm{ED}}$.

Surface water drainage downstream of the NDA is also monitored at point WNNDADR and at Erdman Brook (point WNERB53), before it joins with drainage from the main plant and lagoon ar- eas. Some drainage from western and northwestern portions of the SDA is also captured at these sampling points. Results from WNNDADR and WNERB53 are summarized in Appendices C- $4^{\text {[D }}$ and $\mathrm{C}-5^{\mathrm{GD}}$, respectively.

Although strontium-90 and associated gross beta results at all three locations were elevated with respect to background concentrations from Buttermilk Creek (WFBCBKG), all were far below the strontium-90 DCG. Residual soil contamination from past waste burial activities is thought to be the source of the strontium-90 activity. The NDA is thought to be the predominant source of gross beta activity observed at WNNDATR.

Tritium concentrations have generally decreased over time at both WNNDATR and WNNDADR. Since the half-life of tritium is slightly longer than 12 years, decreasing tritium concentrations may be partially attributable to radioactive decay.

New York State-Licensed Disposal Area. Immediately south of the SDA, Frank's Creek is sampled to monitor surface drainage from the area around the drum cell (point WNDCELD, on Fig. A-2). To the north of the SDA, Frank's Creek is again sampled to monitor drainage downstream of the drum cell and the eastern and southern borders of the SDA (point WNFRC67). Summaries of results from WNDCELD and WNFRC67 are found in Appendix C- $5^{\text {苑 }}$.

Off-Site Surface Water. Surface water samples are collected at four off-site locations, background and downstream locations on both Buttermilk Creek and Cattaraugus Creek. Sampling locations are shown on Fig. A-5. Results are presented in Appendix C $-5^{\text {co }}$.

Buttermilk Creek at Fox Valley Road and Thomas Corners Bridge. Buttermilk Creek is the major surface drainage from the WNYNSC. The 
background monitoring point is located upstream of the WVDP at Fox Valley Road (WFBCBKG) and the downstream point is located at Thomas Corners Bridge (WFBCTCB), just before Buttermilk Creek enters Cattaraugus Creek.

Cattaraugus Creek at Bigelow Bridge and Felton Bridge. Background samples are collected at Bigelow Bridge (WFBIGBR) before the point where Buttermilk Creek flows into Cattaraugus Creek. Downstream of that point, samples are collected at Felton Bridge (WFFELBR), the first point of public access below the WVDP.

As noted in Table 2-2, average gross beta concentrations at WFFELBR were greater than background concentrations. However, they were detected at less than $2 \%$ of the DOE DCG for strontium-90 (see Table C-5A ${ }^{\text {Gg }}$ ). Elevated gross beta concentrations may be attributed to small amounts of radioactivity moving from the site via Frank's Creek. Figure 2-2 shows gross alpha, gross beta, and tritium results over the past ten years at
Felton Bridge. For the most part, tritium concentrations represent detection limits and not detected radioactivity. Taking into account seasonal fluctuations, gross beta activity has remained relatively constant at this location over the last decade.

\section{Drinking Water Monitoring}

Drinking water (potable water) is sampled both off site and on site. Off-site drinking water samples are taken from wells that represent the closest unrestricted use of groundwater near the Project; none of these wells draw from groundwater units underlying the site. Project drinking water and utility water is drawn from two on-site surface water reservoirs.

On-Site Tap Water. On-site drinking water sources were monitored for radionuclides at four locations: the entry point at the utility room (WNDNKUR), the Environmental Laboratory (WNDNKEL), the maintenance shop (WNDNKMS), and the main plant (WNDNKMP). Data tables may be found in

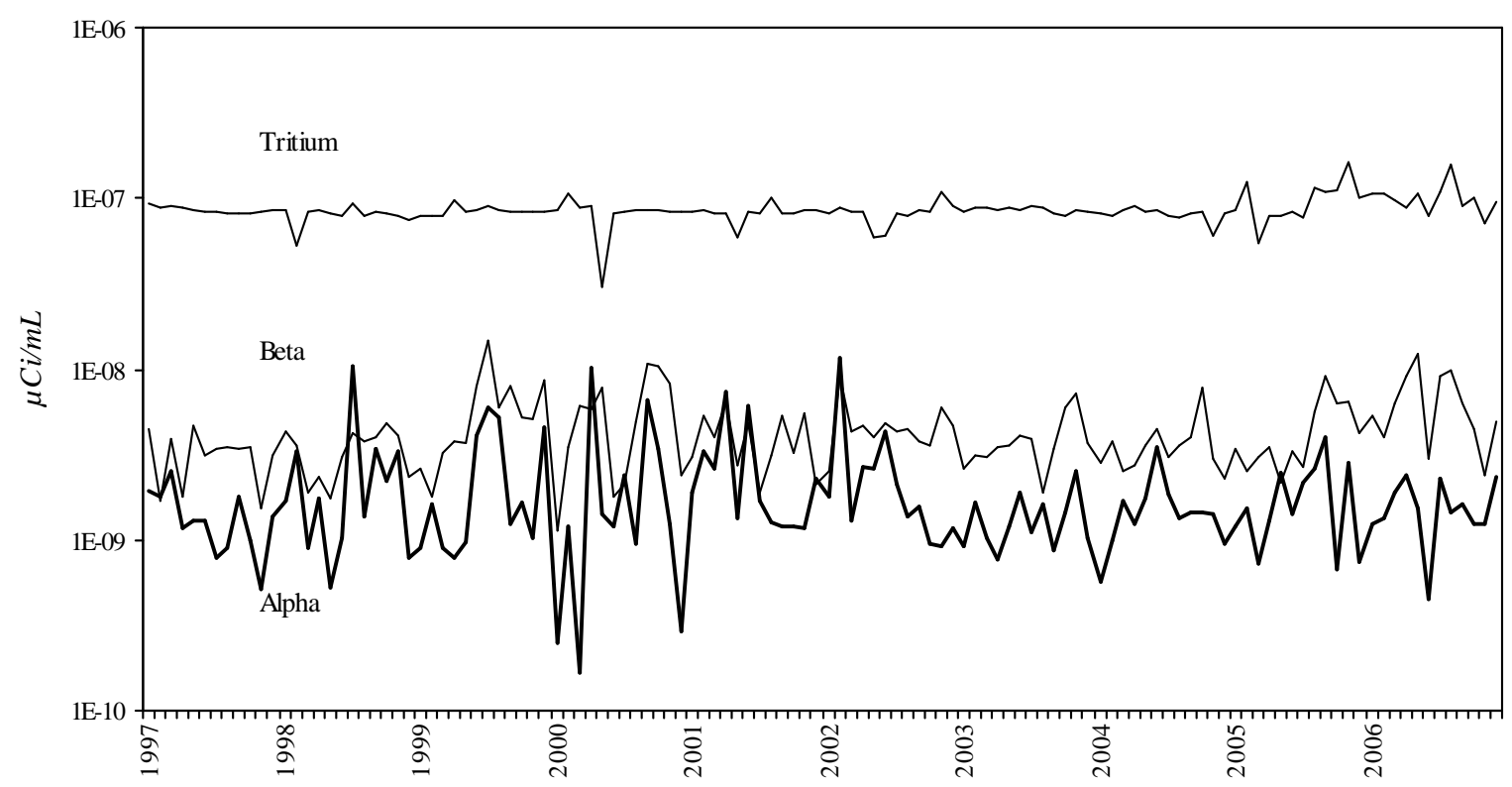

Figure 2-2. Ten-Year Trends of Gross Alpha, Gross Beta, and Tritium Concentrations at Sampling Location WFFELBR

$2-9$ 


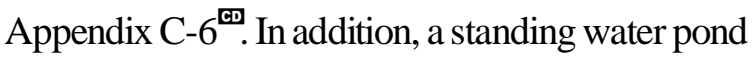
(WNSTAW9) near the site's drinking water reservoirs was monitored. Results are listed in Appendix C- $5^{\text {它 }}$.

Off-Site Drinking Water Wells. Nine off-site private residential groundwater wells near the site and a tenth background well south of the site were sampled in 2006. Sampling locations are shown on Figures A-11, A-14, and A-15. Results are presented in Appendix C- 6 .

Results from both on-site and off-site samples were statistically indistinguishable from background values.

\section{Sediment Monitoring}

Particulate matter in streams can adsorb radiological constituents in liquid effluents, settle on the bottom of the stream as sediment, and subsequently be eroded or resuspended, especially during periods of high stream flow. The resuspended sediments may provide a pathway for radiological constituents to reach humans either directly via exposure or indirectly through the food pathway.

On-Site Sediments. Sediments are collected at three on-site surface water sampling points where liquid effluents leaving the site are most likely to be radiologically contaminated: Frank's Creek where it leaves the security fence (SNSP006), the north swamp drainage swale (SNSW74A), and the northeast swamp drainage swale (SNSWAMP) (Fig. A-2). (Note that these sediment samples may be partially composed of soils, depending on annual rainfall and stream flow patterns.)

The NRC and the EPA, in a 2002 memorandum of understanding (MOU) pertaining to decommissioning and decontamination of contaminated sites, agreed upon concentrations of residual radioactivity in soil that would trigger consultation between the two agencies. Consultation "trigger" levels for contamination in both residential and industrial soil are listed in Table G- $1 \mathrm{D}^{\mathrm{GD}}$ for radionuclides found at the WVDP.

In 2006, the NRC, in a decommissioning guidance document (NUREG-1757, Vol. 2, 2006), provided concentration screening values for common radionuclides in soils that could result in a dose of 25 $\mathrm{mrem} /$ year. The screening levels for radionuclides found at the WVDP are listed in Table G-1D ${ }^{\text {cov }}$.

Results from on-site sediment samples collected in 2006 are presented in Appendix G- ${ }^{\mathrm{GO}}$. As expected, concentrations of several radionuclides exceeded concentrations in background soils. (See Table 2-2 for a listing.) Because the on-site sediment samples may be partially composed of soils, the results were compared with both the "trigger" levels from the MOU and the screening values from NUREG-1757. Results for all radionuclides except cesium-137 were lower than the MOU and NUREG-1757 values. Cesium-137 concentrations at locations SNSP006 and SNSWAMP were higher than both the MOU "trigger" levels and the NUREG-1757 screening values. Elevated cesium-137 concentrations at these locations are thought to be attributable to historical releases.

Off-Site Sediments. Sediments are collected at one background location upstream of the WVDP, Buttermilk Creek at Fox Valley Road (SFBCSED). Background data are compared with data from three downstream points: Buttermilk Creek at Thomas Corners Road (SFTCSED), Cattaraugus Creek at Felton Bridge (SFCCSED), and Cattaraugus Creek at the Springville dam (SFSDSED) (Fig. A-5). The first two points are co-located with water sampling locations. The third is behind the Springville dam where significant sediment deposition occurs, including sediments that may have adsorbed radionuclides from the site. See Appendix G- $2^{\mathrm{GD}}$ for results from off-site sediments. 


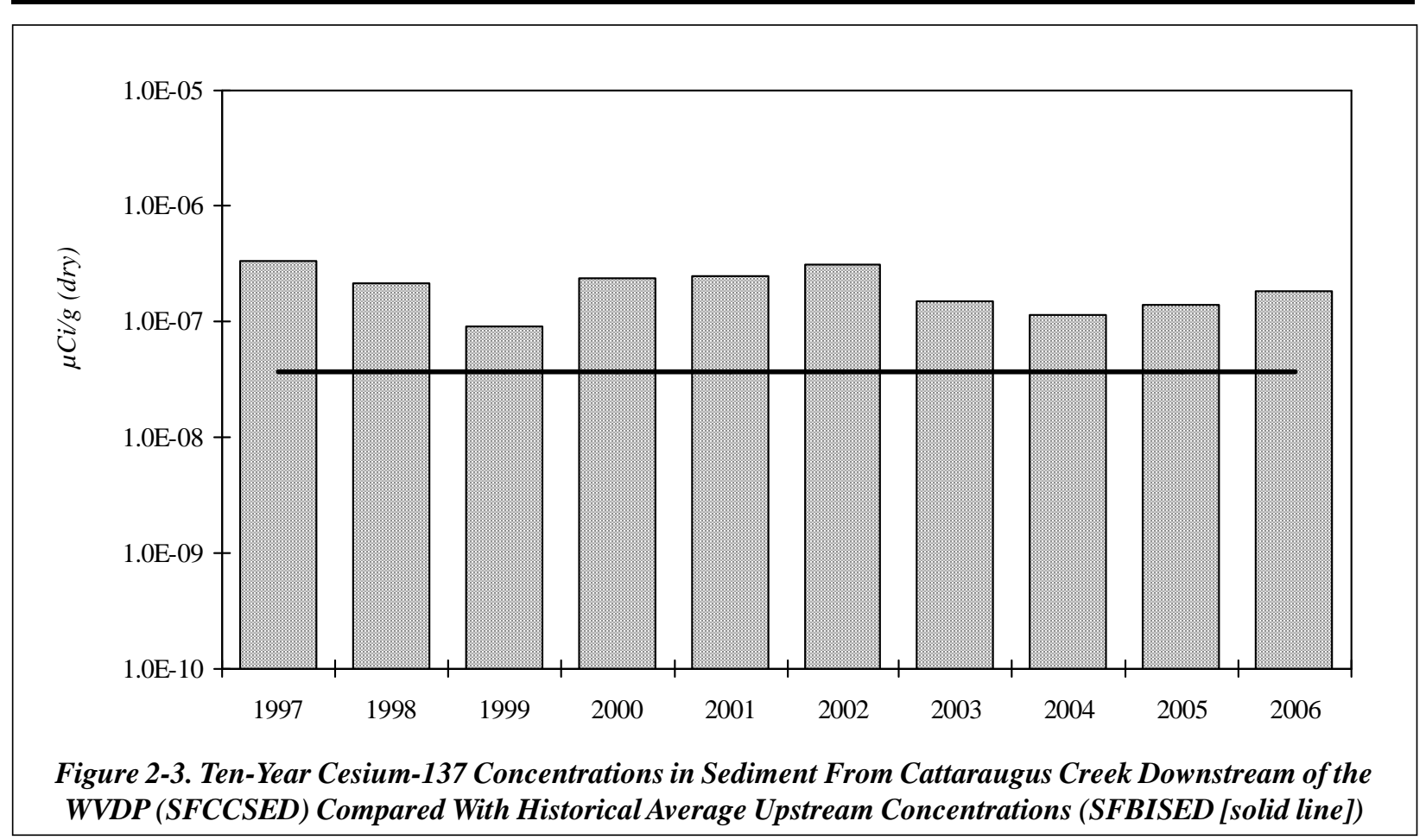

A plot of annual cesium-137 concentrations over 10 years at downstream sampling location SFCCSED is illustrated on Figure 2-3. As the figure indicates, cesium-137 concentrations at SFCCSED, although relatively stable, are consistently higher than the ten-year average cesium137 concentration at the former background location (SFBISED). Even so, the levels are far lower at these downstream locations than those of naturally occurring gamma emitters, such as potassium-40. (See Table G-2E ${ }^{\text {GD }}$.)

\section{Air Emission and Ambient Air Monitoring}

Federal laws allow air containing small amounts of radioactivity to be released from plant ventilation stacks during normal operations. The release must meet dose criteria specified in the National Emission Standards for Hazardous Air Pollutants (NESHAP) regulations to ensure that the public's health and safety and the environment are pro- tected. See "Radiological Emissions" in the Environmental Compliance Summary.

Measured radionuclide concentrations in air are also compared with DOEDCGs. Unlike NESHAP dose criteria, the DOE DCGs are expressed in units of microcuries per milliliter $(\mu \mathrm{Ci} / \mathrm{mL})$ and can be directly compared with measurements from the monitoring program. Although the DOE DCGs are applicable only where the public may breathe air containing radionuclides, the DCGs are used at the WVDP as a tool for evaluating airborne emissions at the point of release. DCGs for radionuclides of interest at the WVDP are found in Table UI-1 in the "Useful Information" section at the end of this report. When only gross alpha and beta measurements are available, activity is assumed to come from americium241 and strontium-90, respectively, because the DCGs for these radionuclides are the most limiting for major particulate emissions at the WVDP. 
Ventilation and Emission Systems. The exhaust from each EPA-permitted ventilation system is continuously filtered and the permanent systems are monitored as air is released to the atmosphere. Because radionuclide concentrations in air emissions are quite low, a large volume of air must be sampled to measure the quantities of radionuclides released from the facility. Emissions are sampled for radioactivity in both particulate forms (e.g., strontium-90 and americium-241) and gaseous forms (e.g., tritium and iodine-129). The total release of each radionuclide varies from year to year in response to changing site activities. For instance, releases of iodine-129 dropped sharply after vitrification was completed. Over the years, annual calculated dose from air emissions at the WVDP has remained a small fraction of the NESHAP standard. (See "Predicted Dose From Airborne Emissions" later in this chapter.)

The Main Plant Ventilation Stack. The main plant ventilation stack (monitoring point ANSTACK) is the primary source of airborne releases at the WVDP. This stack, which vents to the atmosphere at a height of approximately 200 feet (ft) (more than 60 meters $[\mathrm{m}]$ ), has historically released ventilation exhaust from several facilities, including the liquid waste treatment system, the analytical laboratories, and off-gas from the former vitrification system. In 2006, the main plant stack continued to release ventilation exhaust from a variety of main plant spaces.

Total curies released from the main stack in 2006 are listed in Appendix $D^{\text {GD }}$, together with annual averages, maxima, and a comparison of average isotopic concentrations with the applicable DCGs. As in previous years, the 2006 average radioactivity levels at the stack discharge point were already far below concentration guidelines for airborne radioactivity in an unrestricted environment. Airborne concentrations from the stack to the site boundary were further reduced by disper- sion. Results from air samples taken near the site boundary confirm that WVDP operations had no discernible effect on off-site air quality. (See "Perimeter and Remote Ambient Air Monitoring," later in this chapter.)

Other On-Site Air Sampling Systems. Sampling systems similar to those of the main stack are used to monitor airborne effluents from the former vitrification heating, ventilation, and air-conditioning system (ANVITSK), the 01-14 building ventilation stack (ANCSSTK), the contact size-reduction facility ventilation stack (ANCSRFK), the supernatant treatment system ventilation stack (ANSTSTK), the container sorting and packaging facility ventilation stack (ANCSPFK), and the remote-handled waste facility (ANRHWFK) (Fig. A-6).

Permitted portable outdoor ventilation enclosures (OVEs) are used to provide the ventilation necessary for the safety of personnel working with radioactive materials in areas outside permanently ventilated facilities or in areas where permanent ventilation must be augmented. Air samples from OVEs are collected continuously while emission points are discharging, and data from these portable ventilation units are included in annual evaluations of airborne emissions.

One ambient air sampler continued operating in 2006 to monitor air near the on-site lag storage area (ANLAGAM) (Fig. A-6). This sampler was put in place to monitor potential diffuse releases of radioactivity.

Appendix $D^{\text {GD }}$ presents total radioactivity released for specific radionuclides at each of the on-site sampling locations, with the exception of ANCSRFK, which did not operate in 2006. Most results were non-detects and all results were far below DOE DCGs. 
Perimeter and Remote Ambient Air Monitoring. In 2006, samples for radionuclides in air were collected at three locations around the perimeter of the site and at three remote locations. Maps of the sampling locations are found on Figures A-7, A-14, and A-15.

The perimeter locations on Fox Valley Road (AFFXVRD), Rock Springs Road (AFRSPRD), and Route 240 (AFRT240) were chosen because they provide historical continuity as former Nuclear Fuel Services, Inc. sampling locations or because they represent the most likely locations for detecting airborne radioactivity.

The remote locations provide data from nearby communities (West Valley [AFWEVAL] and Springville [AFSPRVL]) and from a more distant background area (Great Valley [AFGRVAL], 18 miles [29 km] south of the site), which is considered representative of regional background air. Data from these locations are presented in Appendix $\mathrm{D}^{\mathbf{c} \text {. }}$.
Ten-year gross alpha and gross beta concentrations at the Rock Springs Road location are shown on Figure 2-4. Within a range of seasonal and weekly fluctuations, the concentrations have been relatively constant over the past ten years.

Radioisotopic results from samples taken at the two near-site communities and from the site perimeter were statistically indistinguishable from results from the background samples, suggesting that there is no adverse site influence on the air quality at these near-site locations.

\section{Atmospheric Deposition and Soil Monitoring}

Fallout Pots. Fallout samples were collected at the rain gauge outside of the Environmental Laboratory (Fig. A-6) in 2006 to monitor short-term deposition of radionuclides. The data are presented in Appendix $\mathrm{D}^{\mathrm{GD}}$. The low levels of radioactivity released in main stack emissions did not measur-

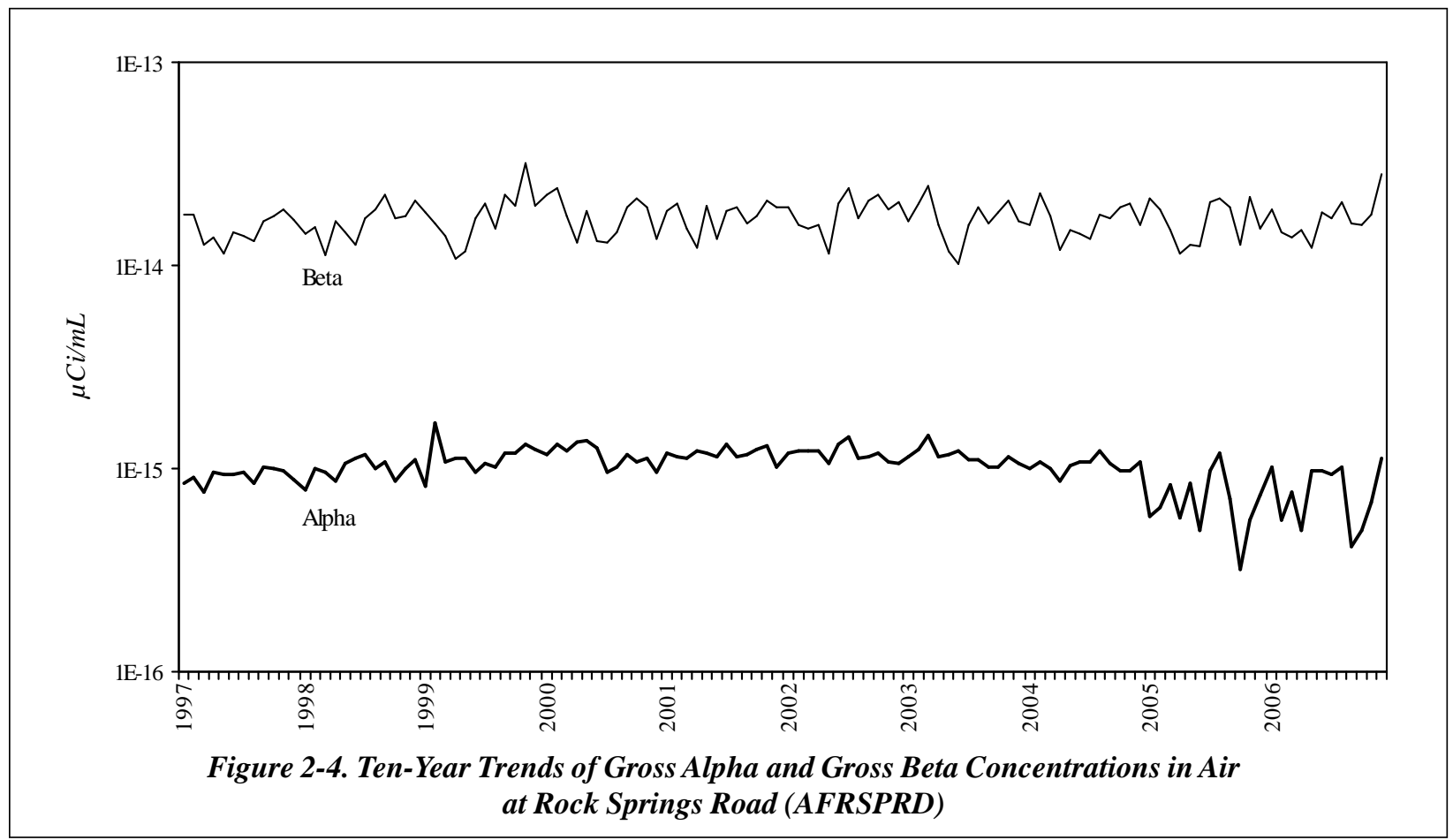


ably affect the precipitation collected in on-site fallout pots in 2006.

Off-Site Surface Soil. Surface soil near the offsite air samplers is collected to assess long-term deposition of radionuclides. Maps of the off-site surface soil sampling locations are on Figures A-5, A-14, and A-15. In 2005, the frequency of collecting off-site soil samples was reduced from annually to every three years. Samples were last collected in 2004 and will next be collected during CY 2007.

\section{Food Chain Monitoring}

Each year food samples are collected from locations near the site (Fig. A-11) and from remote locations (Figs. A-14 and A-15). Fish and deer are collected during periods when they would normally be taken by sportsmen. Corn, apples, and beans are collected annually at the time of harvest. Edible portions are analyzed for radionuclides. Results are listed in Appendix $\mathrm{F}^{\mathrm{K} \text {. }}$. Comparisons with background results are summarized in Table 2-2.

In 2006, venison from two deer contained cesium137 concentrations elevated with respect to background. However, most historical data have consistently demonstrated that the Project has little or no effect on local foodstuffs. See "Measurement of Radionuclide Concentrations in Food," later in this chapter, for a discussion of estimating doses from foodstuffs.

\section{Direct Environmental Radiation Monitoring}

On-site monitoring points are located at waste management units, at the site security fence, around the WNYNSC perimeter and the access road, and at a background location remote from the WVDP (Figs. A-12 through A-15). Quarterly and annual averages of thermoluminescent dosimeter (TLD) measurements at off-site and on-site locations are noted in Appendix $\mathrm{H}^{\text {GD }}$, Tables $\mathrm{H}-1^{\text {GD }}$ and $\mathrm{H}-2^{\mathrm{GD}}$, respectively. The results of measurements in 2006 show typical seasonal variations and are similar to results from previous years.

On-Site Radiation Monitoring. As in past years, the monitoring point with the highest exposure readings was location DNTLD24. Sealed containers of radioactive components and debris from the plant decontamination are stored near this TLD location. Exposure rates at this location have been generally decreasing over time because the radioactivity in the materials stored nearby is decaying.

As expected, results from TLDs located near onsite facilities are generally higher than background results (Table 2-2); however, these locations are well within the WNYNSC boundary and are not accessible by the public.

Perimeter and Off-Site Radiation Monitoring. The perimeter TLDs (TLDs \#1-16 and \#20) are distributed in the 16 compass sectors around the facility near the WNYNSC boundary. Results from the perimeter and community TLDs were statistically the same as results from the background TLD. The perimeter TLD quarterly averages shown on Figure 2-5 indicate seasonal fluctuations but no long-term trends.

Confirmation of Results. Performance of the environmental TLDs is confirmed periodically using a portable high-pressure ion chamber (HPIC) detection system. The HPIC serves as a secondary standard for measurement of radiation levels at each monitoring location. Results for 2006 are summarized in Table H- 3 . The TLD results include the entire third quarter of 2006; the HPIC results were each collected over a period of less than 30 minutes. 


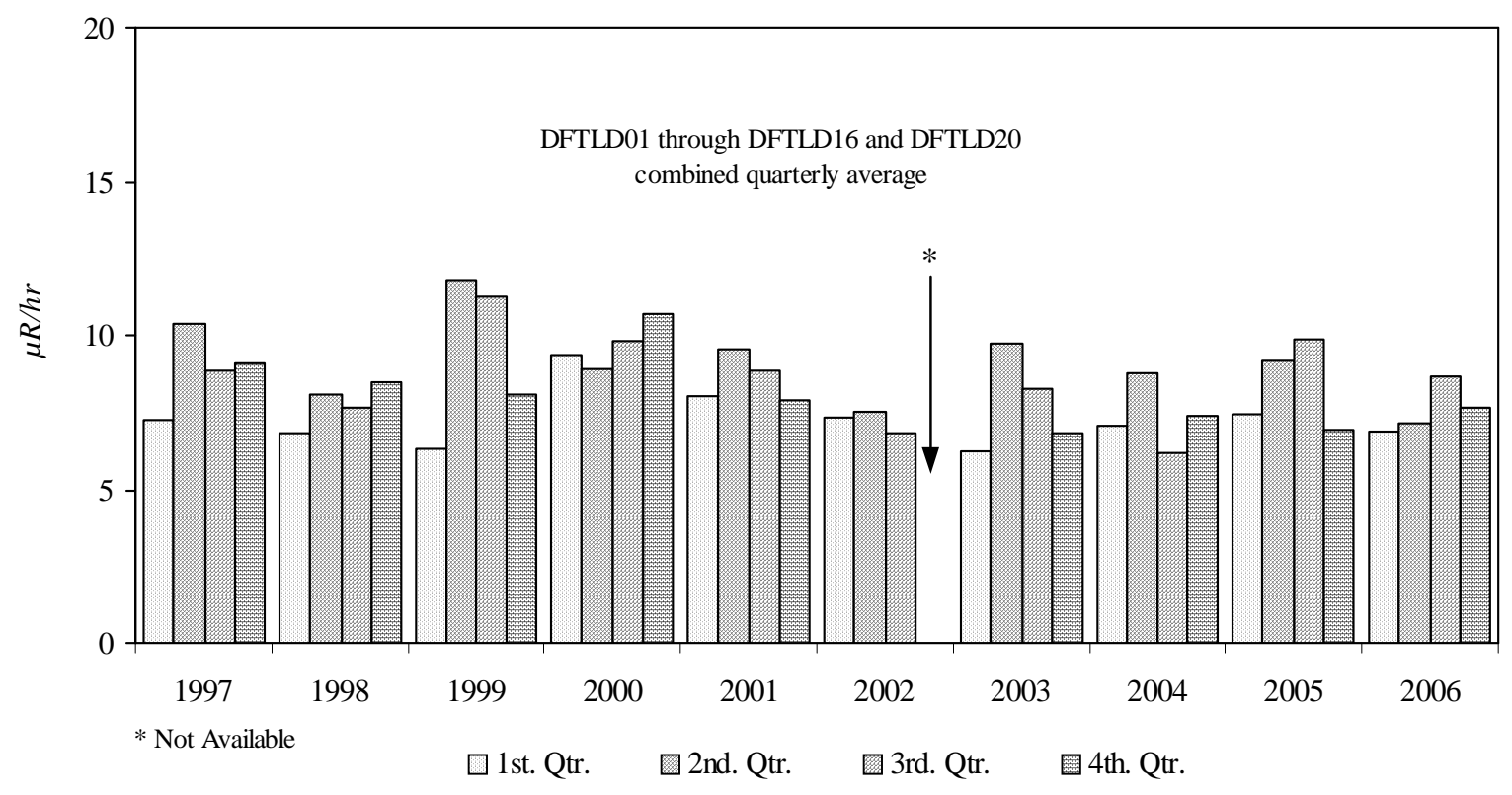

Figure 2-5. Ten-Year Trends of Environmental Radiation Levels at Perimeter TLDs

Since these measurements are made with different systems and over differing periods of time, they are not directly comparable. The average relative percent difference between the two sets of measurements was about $14 \%$, indicating general agreement between these two different measurement methods. (Guidance in American National Standards Institute N545-1975, the standard for environmental dosimetry, uses measurement agreement within $30 \%$ total uncertainty as a performance specification for TLD measurements.)

\section{Meteorological Monitoring}

Meteorological monitoring at the WVDP provides representative and verifiable data that characterize the local and regional climatology. These data are used primarily to assess potential effects of routine and nonroutine releases of airborne radioactive materials and to provide input to dispersion models used to calculate the effective dose equivalent to off-site residents. Since dispersive capabilities of the atmosphere are dependent upon wind speed, wind direction, and atmospheric stability (which includes a function of the difference in temperature between two elevations), these parameters are closely monitored and are available to the emergency response organization at the WVDP. If a release to the air occurred, meteorological data would be used to predict the direction in which the plume would move.

The on-site 197-ft (60-m) meteorological tower (Fig. A-1) continuously monitors wind speed, wind direction, and temperature at both the 197-ft (60$\mathrm{m})$ and 33-ft (10-m) elevations. In addition, an independent, remote $33-\mathrm{ft}(10-\mathrm{m})$ meteorological station, located approximately 5 miles (mi) (8 kilometers $[\mathrm{km}]$ ) south of the site on a hillcrest on Dutch Hill Road (Fig. A-14), continuously monitors wind speed and wind direction. Dewpoint, precipitation, and barometric pressure are also monitored on site.

The two meteorological locations supply data to the primary digital and analog data acquisition systems 
located within the Environmental Laboratory. Onsite systems are provided with either uninterruptible or standby power backup in case of site power failures. In 2006, the on-site system data recovery rate (the time valid data were logged versus the total elapsed time) was approximately $96.6 \%$.

Weekly and cumulative total precipitation data are presented in Appendix I ${ }^{\text {GD }}$. Precipitation in 2006 was approximately 45.1 inches (114.4 centimeters $[\mathrm{cm}])$, about $10 \%$ more than the long-term annual average $(41.0$ inches $[104 \mathrm{~cm}])$.

Documentation, such as meteorological system calibration records, site log books, and analog strip charts, is stored in protected archives. Meteorological towers and instruments are examined three times per week for proper function and are calibrated semiannually and/or whenever instrument maintenance might affect calibration.

\section{Special Monitoring}

Radiological constituents may be monitored outside the scope of the environmental monitoring program to address topics of environmental interest or as part of comprehensive investigations focusing on nonradiological constituents. In 2006, samples for radiological constituents were collected during four ongoing activities.

- As part of an extensive nonradiological storm water characterization effort, radiological samples were collected to update previous results at select outfalls. Results, to be reported at a later date, were consistent with monitoring results from nearby routine sampling locations.

- Groundwater seepage into a drained pool that was formerly used to store spent nuclear fuel rods continued to be sampled for radiological constituents in 2006. (See "Fuel Receiving and Storage Pool Water Infiltration” in Chapter 4.)
- Ambient air was monitored by the Radiation Protection Department during demolition of the 02 building. No airborne releases of radiological contamination were noted.

- Surface water samples were collected at a proposed monitoring location on Frank's Creek that would capture drainage downstream of the north plateau strontium-90 plume but upstream of larger diluting stream influents. Data are being evaluated in part to determine if the proposed monitoring point should be added to the routine environmental monitoring program.

No hazards to employees or to the public were identified as a result of special monitoring in 2006. 


\section{Radiological Effluents and Dose}

\section{Dose Assessment Methodology}

The potential radiation dose to the general public from WVDP activities is evaluated by using a twopart methodology applied in a manner consistent with the requirements of DOE Order 5400.5. The first part uses the measurements of radionuclide concentrations in liquid and air released from the Project to determine the annual total effect using computer model calculations. The second part uses measurements of radioactivity in food from locations near the Project boundaries to corroborate the modeled impact of the annual total release.

Radiological dose is evaluated using methods that consider contributions from all major exposure pathways, including external irradiation, inhalation, and ingestion of local food products. The dose contributions from each radionuclide and pathway combination are then combined to obtain the total dose estimates reported in Table 2-3.

\section{Measurement of Radionuclide Concentra- tions in Liquid and Air Releases. Because it is difficult to distinguish by direct measurement the small amount of radioactivity originating from the Project or from naturally occurring radiation in the environment, computer codes are used to model the environmental dispersion of radionuclides that originate from on-site monitored ventilation stacks and liquid discharge points.}

Actual data from air and water release-monitoring samples are collected, together with annual weather measurements and the most recent demographic information. (See Appendices A, $C^{\text {G0 }}$, $\mathrm{D}^{\mathrm{GD}}$, and $\mathrm{I}^{\mathrm{GD}}$.) The effective dose equivalent (EDE) to the maximally exposed off-site individual
(MEOSI) and the collective EDE to the population within a 50-mile $(80-\mathrm{km})$ radius are then calculated using conservative DOE- and EPA-approved models to demonstrate compliance with radiation standards. (See the inset on "Radiation Dose" and "Units of Dose Measurement.")

Measurement of Radionuclide Concentrations in Food. The second part of the dose assessment is based on actual radioactivity measurements in samples of foodstuffs grown in the vicinity of the WVDP and the comparison of these values with measurements of samples collected from locations well beyond the potential influence of site effluents.

If any of the near-site food samples contain radionuclide concentrations that are higher than the concentrations in control samples, separate dose calculations are performed to verify that the calculated foodstuff dose is consistent with the dose range estimated by computer modeling. (See "Calculated Dose From Local Foodstuff Tests," later in this chapter.)

These estimates show that the concentrations of radioactivity, whether from sites near or distant from the WVDP, are small - usually near the analytical detection limits - thereby providing additional assurance that operations at the WVDP are not adversely affecting the public.

These calculated doses are used as an independent confirmation of (not added to) the computermodeled estimates (Table 2-3) because the models already include contributions from all environmental pathways. 


\section{Radiation Dose}

The energy released from a radionuclide is eventually deposited in matter encountered along the path of the radiation. The radiation energy absorbed by a unit mass of material is referred to as the absorbed dose. The absorbing material can be either inanimate matter or living tissue.

Alpha particles leave a dense track of ionization as they travel through tissue and thus deliver the most dose per unit path-length. However, alpha particles are not penetrating and must be taken into the body by inhalation or ingestion to cause harm. Beta and gamma radiation can penetrate the protective dead skin layer of the body from the outside, resulting in exposure of the internal organs to radiation.

Because beta and gamma radiations deposit much less energy in tissue per unit path-length relative to alpha radiation, they produce fewer biological effects for the same absorbed dose. To allow for the different biological effects of different kinds of radiation, the absorbed dose is multiplied by a quality factor to yield a unit called the dose equivalent. A radiation dose expressed as a dose equivalent, rather than as an absorbed dose, permits the risks from different types of radiation exposure to be compared with each other (e.g., exposure to alpha radiation compared with exposure to gamma radiation). For this reason, regulatory agencies limit the dose to individuals in terms of total dose equivalent.

\section{Units of Dose Measurement}

The unit for dose equivalent in common use in the U.S. is the rem. The international unit of dose equivalent is the sievert (Sv), which is equal to 100 rem. The millirem (mrem) and millisievert $(\mathrm{mSv})$, used more frequently to report the low dose equivalents encountered in environmental exposures, are equal to one-thousandth of a rem or sievert, respectively. Other radioactivity unit conversions are found in the "Useful Information" section at the back of this report.

The effective dose equivalent (EDE), also expressed in units of rem or sievert, provides a means of combining unequal organ and tissue doses into a single "effective" whole body dose that represents a comparable risk probability. The probability that a given dose will result in the induction of a fatal cancer is referred to as the risk associated with that dose. The EDE is calculated by multiplying the organ dose equivalent by the organ-weighting factors developed by the International Commission on Radiological Protection (ICRP) in Publications 26 (1977) and 30 (1979). The weighting factor is a ratio of the risk from a specific organ or tissue dose to the total risk resulting from an equal whole body dose. All organ-weighted dose equivalents are then summed to obtain the EDE.

The dose from internally deposited radionuclides calculated for a fifty-year period following intake is called the fifty-year committed effective dose equivalent (CEDE). The CEDE sums the dose to an individual over fifty years to account for the biological retention of radionuclides in the body. The total EDE for one year of exposure to radioactivity is calculated by adding the CEDE to the dose equivalent from external, penetrating radiation received during the year. Unless otherwise specified, all doses discussed here are total EDE values, which include the CEDE for internal emitters.

A collective population dose is expressed in units of person-rem or person-sievert because the individual doses are summed over the entire potentially exposed population. The average individual dose can therefore be estimated by dividing the collective dose by the population.

\section{$2-18$}




\section{Predicted Dose From Airborne Emissions}

Airborne emissions of radionuclides are regulated by the EPA under the Clean Air Act and its implementing regulations. DOE facilities are subject to Title 40 of the Code of Federal Regulations (CFR) 61, Subpart H, NESHAP. Subpart H contains the national emission standards for radionuclides other than radon from DOE facilities. The applicable standard for radionuclides is a maximum of 10 mrem $(0.1 \mathrm{mSv})$ effective dose equivalent to any member of the public in any year.

Releases of airborne radioactive materials in 2006 from nominal ground-level stacks (1 to $24 \mathrm{~m}$ high) and from the main 60-meter-high stack were modeled using the EPA-approved CAP88-PC computer code (Parks, June 1997). This air dispersion code estimates effective dose equivalents for the ingestion, inhalation, air immersion, and ground surface pathways.

Site-specific data for CY 2006 nonradon radionuclide releases in curies per year are listed in Appendix $\mathrm{D}^{\mathrm{GD}}$. Applicable information from these tables was used as input to the CAP88-PC code, as were wind data collected from the on-site meteorological tower during 2006 and the most recent local population distribution information.

Resulting output from the CAP88-PC code was then used to determine the total EDE from air emissions to a maximally exposed individual and the collective dose to the population within a 50$\mathrm{mi}(80-\mathrm{km})$ radius of the WVDP.

Maximum Dose to an Off-Site Individual. Based on the nonradon airborne radioactivity released from all sources at the site during 2006 (i.e., permitted stacks, stacks that do not require permits, and nonpoint sources), it was estimated that a person living in the vicinity of the WVDP could have received a total $\mathrm{EDE}$ of $0.0011 \mathrm{mrem}$ $(0.000011 \mathrm{mSv})$ from airborne releases. The computer model estimated that this MEOSI was located $1.2 \mathrm{mi}(1.9 \mathrm{~km})$ north-northwest of the site and was assumed to eat only locally-produced foods. About $96 \%$ of the estimated airborne dose from point sources was from iodine- 129 .

When considering permitted stacks only, the maximum total EDE of $0.00037 \mathrm{mrem}(0.0000037 \mathrm{mSv})$ is far below levels that could be directly measured at the exposed individual's residence. This dose is comparable to less than one minute of natural background radiation received by an average member of the U.S. population and is well below the 10mrem (0.1-mSv) NESHAP limit established by the EPA and mandated by DOE Order 5400.5 .

Collective Population Dose. The CAP88-PC program was used to estimate the collective EDE to the population. Based upon the latest U.S. census population data collected in CY 2000, 1.54 million people were estimated to reside within $50 \mathrm{mi}$ $(80 \mathrm{~km})$ of the WVDP. This population received an estimated 0.0062 person-rem $(0.000062$ person-Sv) total EDE from radioactive nonradon airborne effluents released from WVDP point and diffuse sources during 2006. (See the discussion of radon-220 later in this chapter.) The resulting average EDE per individual was $0.000004 \mathrm{mrem}$ (0.00000004 mSv).

Iodine Emissions From the Main Stack. Iodine129, a long-lived radionuclide, has routinely been found in main stack emissions. During the vitrification of high-level waste, iodine-129 releases increased because gaseous iodine was not as efficiently removed by the vitrification process off-gas treatment system as were most other radionuclides. As more high-level radioactive waste was removed from the tanks and converted into glass, less waste was available to emit iodine-129 and the total emitted decreased. In 2006, iodine-129 concentrations continued 


\section{Table 2-3}

\section{Summary of Annual Effective Dose Equivalents to an Individual and Population From WVDP Releases in 2006}

\begin{tabular}{|c|c|c|}
\hline \multirow[t]{2}{*}{ Exposure Pathways } & \multicolumn{2}{|c|}{ Annual Effective Dose Equivalent } \\
\hline & $\begin{array}{c}\text { Maximally Exposed } \\
\text { Off-Site Individual } \\
\text { mrem }(m S v)\end{array}$ & $\begin{array}{c}\text { Collective Effective } \\
\text { Dose Equivalent }{ }^{b} \\
\text { person-rem (person-Sv) }\end{array}$ \\
\hline Airborne Releases $^{c}$ & $1.1 \mathrm{E}-03$ (1.1E-05) & $6.2 \mathrm{E}-03(6.2 \mathrm{E}-05)$ \\
\hline$\%$ EPA standard (10 mrem) & $0.01 \%$ & NA \\
\hline Waterborne Releases $^{d}$ & 4.8E-02 (4.8E-04) & 2.1E-01 (2.1E-03) \\
\hline Effluents only & $1.2 \mathrm{E}-02(1.2 \mathrm{E}-04)$ & $1.0 \mathrm{E}-02(1.0 \mathrm{E}-04)$ \\
\hline North plateau drainage & $3.5 \mathrm{E}-02(3.5 \mathrm{E}-04)$ & $2.0 \mathrm{E}-01(2.0 \mathrm{E}-03)$ \\
\hline Total From All Pathways & 4.9E-02 (4.9E-04) & 2.2E-01 (2.2E-03) \\
\hline $\begin{array}{l}\% \text { DOE standard (100 mrem) - } \\
\text { air and water combined }\end{array}$ & $0.049 \%$ & NA \\
\hline $\begin{array}{l}\% \text { of natural background } \\
\text { ( } 295 \text { mrem; } 453,000 \text { person-rem) - } \\
\text { received from air and water combined }\end{array}$ & $0.02 \%$ & $0.00005 \%$ \\
\hline Estimated Airborne Radon-220 ${ }^{e}$ & $9.9 \mathrm{E}-03(9.9 \mathrm{E}-05)^{f}$ & 3.4E-01 (3.4E-03) \\
\hline
\end{tabular}

Note: Summed values may not exactly match totals due to rounding.

NA - Not applicable. Numerical regulatory standards are not set for the collective EDE to the population.

a The maximum exposure to air discharges is estimated to occur at a residence $1.2 \mathrm{mi}$ (1.9 km) northnorthwest of the main plant building.

${ }^{b}$ A population of 1.54 million is estimated to reside within $50 \mathrm{mi}(80 \mathrm{~km})$ of the site.

${ }^{c}$ Releases are from atmospheric nonradon point and diffuse sources. Calculations use CAP88-PC to estimate individual and population doses. EPA and DOE limits for individual airborne dose are the same.

${ }^{d}$ Estimates are calculated using the methodology described in the WVDP Manual for Radiological Assessment of Environmental Releases at the WVDP (West Valley Nuclear Services Company [WVNSCO], 2003).

e Estimated airborne releases are based on indicator measurements and process knowledge. Dose estimates are calculated using CAP88-PC.

$f$ The estimated dose from radon-220 is specifically excluded by rule from NESHAP totals. 


\section{Radon-220}

Radon-220, also known as thoron, is a naturally occurring gaseous decay product of thorium-232 present in the airborne emissions from the WVDP main plant. Radon-220 is also associated with the thorium reduction extraction (THOREX) process-related thorium-232 and uranium-232 in the high-level waste.

As reported in Chapter 2 of the 1996 WVDP Site Environmental Report (WVNSCO and Dames \& Moore, June 1997), thoron levels were observed to increase during startup of the 1996 high-level waste vitrification process. An estimate of the thoron released during each waste concentration cycle was developed and used to determine a theoretical annual release. During the vitrification phase, an average of about 12 curies per day were assumed to have been released. In 2006, with the vitrification process completed, the average thoron release is estimated to be about three curies per day.

Although large numbers of curies were released relative to other radionuclides, the calculated dose from thoron is quite small because of its short decay half-life and other characteristics. The NESHAP rule specifically excludes thoron from air emission dose calculations, so a dose estimate using CAP88-PC was calculated separately. The theoretical dose to the MEOSI located $1.2 \mathrm{mi}(1.9 \mathrm{~km})$ north-northwest of the site in 2006 would have been 0.0099 mrem $(0.000099 \mathrm{mSv})$, and the collective dose to the population within an 80-kilometer radius would have been 0.34 person-rem (0.0034 person-Sv). (See Table 2-3.) These theoretical doses are within the same range as historical doses from the man-made radionuclides found in WVDP effluents.

With vitrification completed, thoron releases have decreased to pre-vitrification levels. The figure presented here provides a relative indication of recent trends in the estimated annual thoron releases.

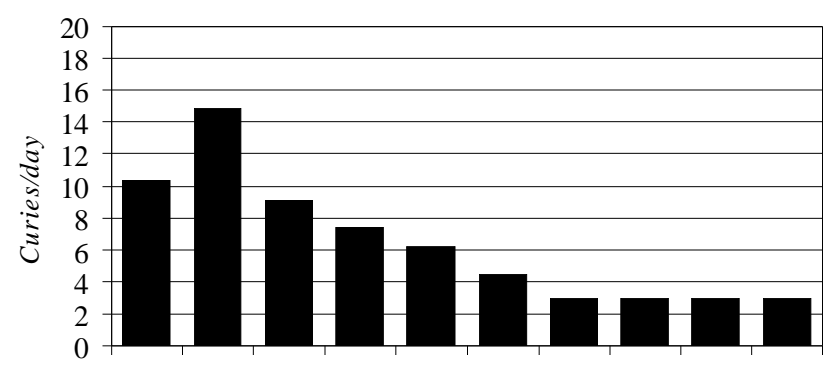

1997199819992000200120022003200420052006

Estimated Radon-220 Releases From the WVDP to be back to (or below) pre-vitrification levels. Even so, in 2006, iodine- 129 continued to account for the largest proportion of dose to an off-site individual from main stack airborne emissions. See Figure 2-6 for a comparison of doses attributable to various nuclides from WVDP air emission points.

\section{Predicted Dose From Waterborne Releases}

Currently there are no EPA standards establishing limits on the radiation dose to members of the public from liquid effluents except as applied in 40 CFR Part 141 and 40 CFR Part 143, Drinking Water Guidelines (EPA, 1984a; 1984b). Corollary limits for community water supplies are set by NYSDOH in the New York State Sanitary Code (Title 10 of the Official Compilation of Codes, Rules, and Regulations of the State of New York [NYCRR] 5-1.52). The only local private residential wells are upgradient of the WVDP and therefore do not represent a potential source of exposure to radioactivity from routine Project activities. 


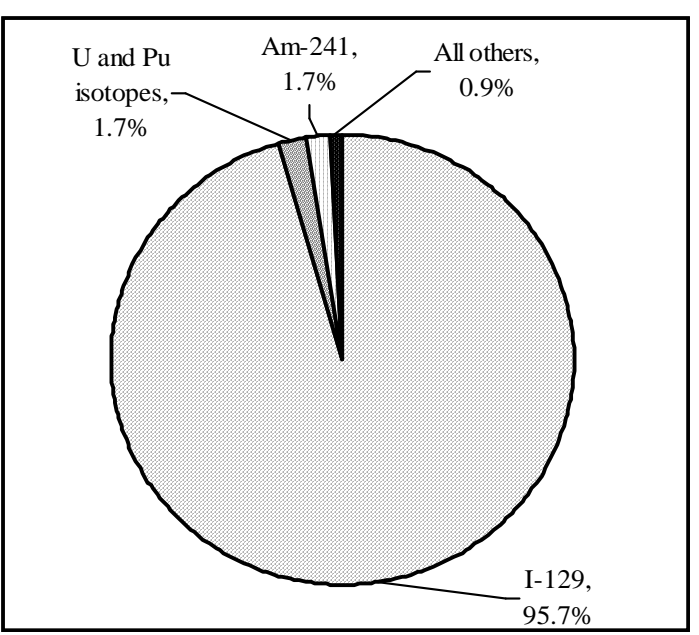

Figure 2-6. Air Emissions From Point Sources: Dose Percent by Radionuclide in CY 2006

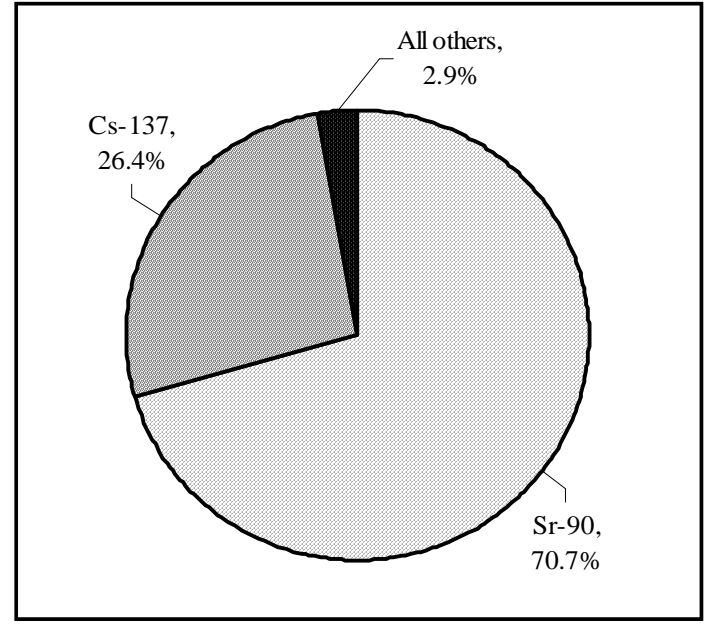

Figure 2-7. Water Effluents: Dose Percent by Radionuclide in CY 2006

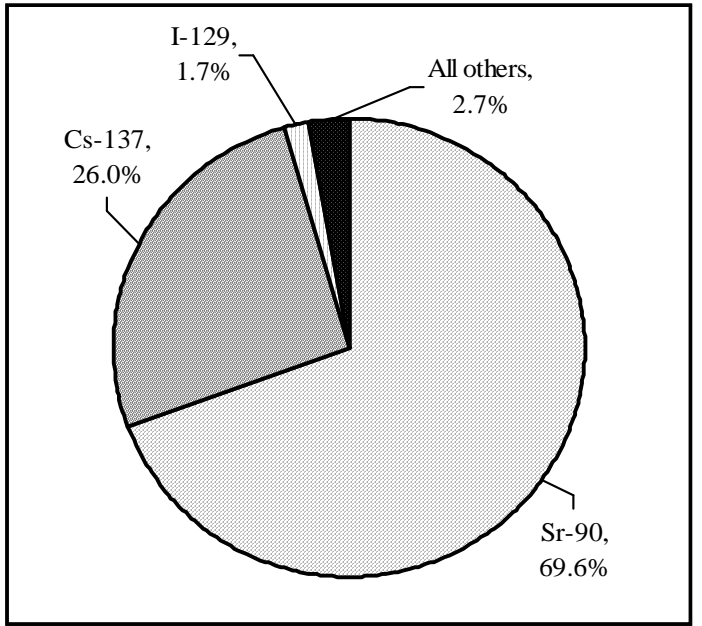

Figure 2-8. All Sources: Dose Percent by Radionuclide in CY 2006

$$
2-22
$$


Cattaraugus Creek is not used as a drinking water supply; therefore, a comparison of the predicted concentrations and doses with the 4-mrem/year (0.04-mSv/year)EPA and NYSDOH drinking water limits established in 40 CFR Part 141 and 40 CFR Part 143, and in 10 NYCRR §5-1.52, respectively, is not truly appropriate (although the values in creek samples are well below the EPA drinking water limits). The estimated radiation dose was compared to the applicable guidelines provided in DOE Order 5400.5.

Since the Project's liquid effluents eventually reach Cattaraugus Creek, the most important individual exposure pathway is the consumption of fish from this creek by local sportsmen. Exposure to external radiation from shoreline or water contamination is also included in the model for estimating radiation dose. Population dose estimates are based on the presumption that radionuclides are further diluted in Lake Erie before reaching municipal drinking water supplies.

The computer codes GENII version 1.485 (Pacific Northwest Laboratory, 1988), which implements the models in NRC Regulatory Guide 1.109 (NRC, 1977), and LADTAP II (Simpson and McGill, 1980) were used to calculate site-specific unit dose factors for routine waterborne releases and dispersion of these effluents. Input data included local stream flow and dilution, drinking water usage, and stream usage factors. The EDE to the MEOSI and the collective EDE to the population due to routine waterborne releases and natural drainage are calculated using the dose conversion factors derived from those codes and tabulated in the "WVDP Manual for Radiological Assessment of Environmental Releases at the WVDP" (WVNSCO, 2003).

Six batches of liquid effluents were released from lagoon 3 (point WNSP001) during 2006. Measurements of the radioactivity discharged in these efflu- ents, listed in Appendix C-2 ${ }^{\mathrm{cov}}$, were combined with the unit dose factors to calculate the EDE to the MEOSI and the collective EDE to the population living within a 50-mi $(80-\mathrm{km})$ radius of the WVDP.

In addition to measurements from WNSP001, radioactivity measurements from sewage treatment facility effluents (WNSP007) were included in the EDE calculations. Results from the sewage treatment facility are also presented in Appendix C$2^{\text {GD }}$. (The french drain at WNSP008, a third release point, has been sealed off since 2001 and was not included in this evaluation.)

Besides the two release points at WNSP001 and WNSP007, waters from two natural drainage channels originating on the Project premises contain measurable concentrations of radioactivity: the northeast swamp (WNSWAMP) and north swamp (WNSW74A). The measured radioactivity from these points is reported in Appendix C- $4^{\text {G0 }}$. These results are included in the EDE calculations for the MEOSI and the collective population. See Figure 2-7 for a comparison of estimated doses attributable to specific radionuclides from water effluents.

There were no unplanned releases of waterborne radioactivity to the off-site environment in 2006.

\section{Maximum Dose to an Off-Site Individual.}

Based on the radioactivity in liquid effluents discharged from the WVDP (lagoon 3 and the sewage treatment plant) during 2006, an off-site individual could have received a maximum EDE of $0.012 \mathrm{mrem}(0.00012 \mathrm{mSv})$. About $91 \%$ of this dose was from cesium-137. The maximum off-site individual EDE due to drainage from the north plateau (north swamp and northeast swamp) was 0.035 mrem $(0.00035 \mathrm{mSv})$. About $94 \%$ of dose from the north plateau was attributable to strontium-90.

The combined EDE to the maximally exposed individual from liquid effluents and drainage was 0.048 
mrem $(0.00048 \mathrm{mSv})$. This annual dose is very small in comparison to the 295-mrem (2.95-mSv) dose that is received by an average member of the U.S. population from natural background radiation.

Collective Dose to the Population. As a result of radioactivity released in liquid effluents from the WVDP during 2006, the population living within 50 $\mathrm{mi}(80 \mathrm{~km})$ of the site received an estimated collective EDE of 0.010 person-rem $(0.00010$ person$\mathrm{Sv})$. The collective dose to the population from the effluents plus the north plateau drainage was 0.21 person-rem (0.0021 person-Sv). The resulting average EDE from effluent releases and north plateau drainage (north swamp and northeast swamp) per individual is $0.00014 \mathrm{mrem}(0.0000014 \mathrm{mSv})$. This dose is an inconsequential addition to the dose that an average person receives in one year from natural background radiation.

\section{Calculated Dose From Local Foodstuff Tests}

Most radionuclide concentrations in near-site food samples were statistically indistinguishable from concentrations in background samples. Conser- vative estimates of dose due to consuming nearsite fish, deer, milk, beans, corn, and apples were about $1.7 \mathrm{mrem} /$ year $(0.017 \mathrm{mSv} /$ year $)$. The predominant potential dose from foodstuff was estimated to be from venison consumption. These independent estimates confirm the modeled dose estimates based on air and water effluent sampling results as summarized in Table 2-3.

\section{Predicted Dose From All Pathways}

The potential dose to the public from both airborne and liquid effluents released from the Project during 2006 is the sum of the individual dose contributions. (See Fig. 2-8.) The calculated maximum EDE from all pathways to a nearby resident was $0.049 \mathrm{mrem}(0.00049 \mathrm{mSv})$. This dose is $0.049 \%$ of the 100-mrem (1-mSv) annual limit in DOE Order 5400.5. The estimated dose from radon- 220 to the same nearby resident was about 0.0099 mrem $(0.000099 \mathrm{mSv})$.

The total collective EDE to the population within $50 \mathrm{mi}(80 \mathrm{~km})$ of the site was 0.22 person-rem (0.0022 person-Sv), with an average EDE of

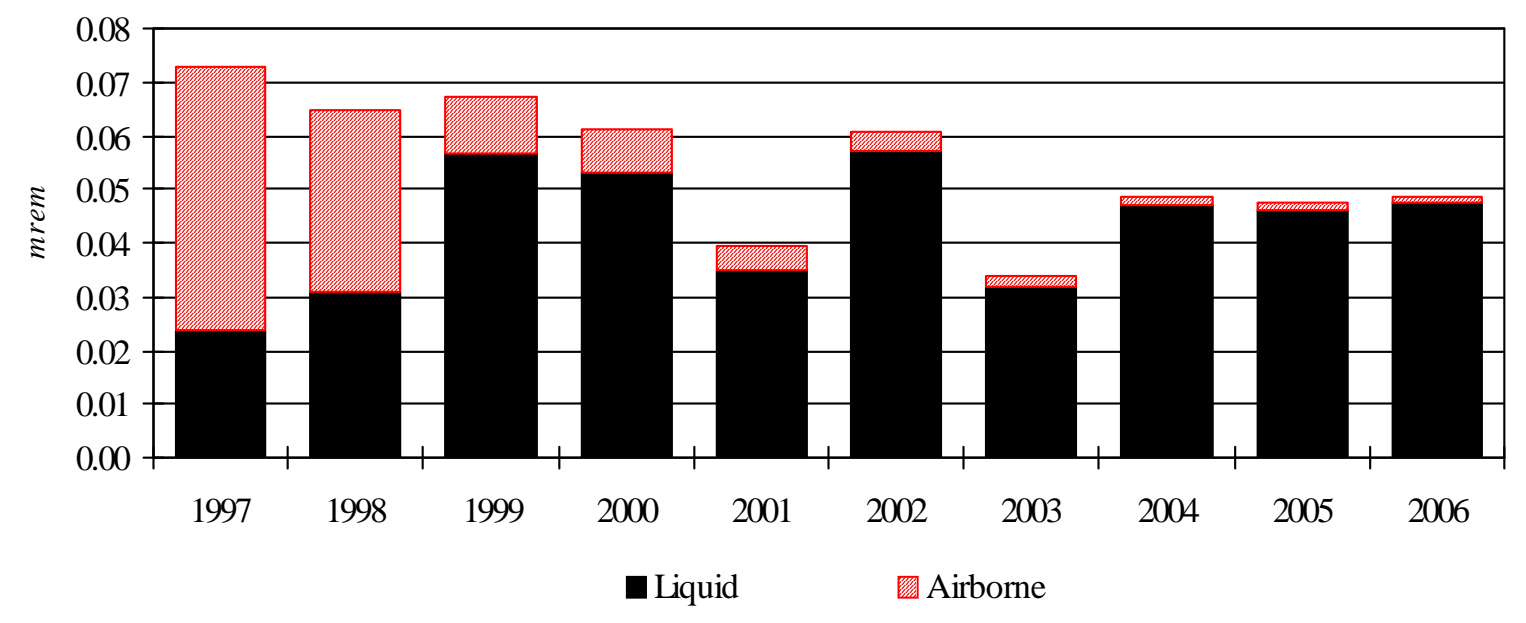

Figure 2-9. Effective Dose Equivalent From Liquid and Airborne Effluents to a Maximally Exposed Individual Residing Near the WVDP 


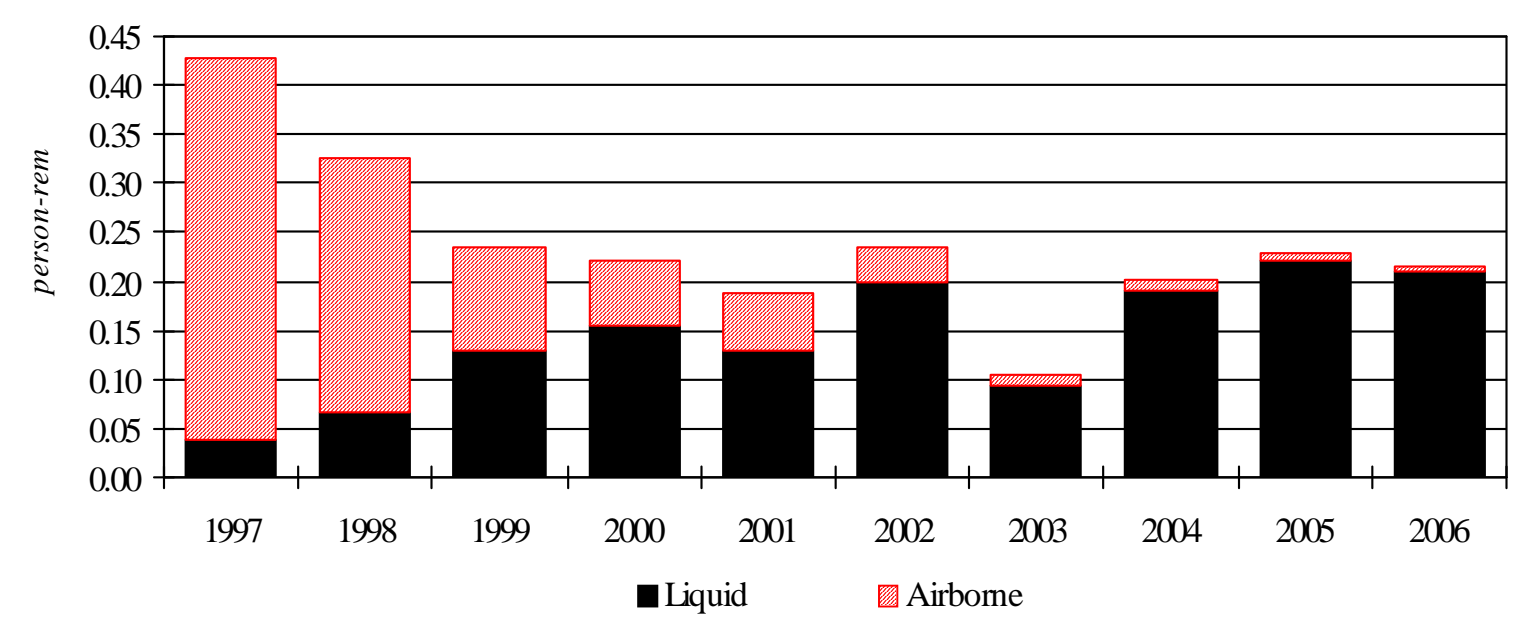

Figure 2-10. Collective Effective Dose Equivalent From Liquid and Airborne Effluents to the Population Residing Within 50 Miles $(80 \mathrm{~km})$ of the WVDP

$0.00014 \mathrm{mrem}(0.0000014 \mathrm{mSv})$ per individual. The estimated radon-220 dose to the population was approximately 0.34 person-rem $(0.0034$ person-Sv).

Table 2-3 summarizes the dose contributions from all pathways and compares the individual doses with the applicable standards.

Figure 2-9 shows the calculated annual dose to the hypothetical maximally exposed individual over the last ten years. The estimated doses for 2006 were very similar to those reported in 2005 .

Figure 2-10 shows the collective dose to the population over the last ten years. (See Fig. A-16 for a map of the population sectors.) The radioactivity in the human pathway represented by these data confirms the continued inconsequential addition to the natural background radiation dose that individuals and population around the WVDP receive from Project activities.

\section{Risk Assessment}

Estimates of cancer risk from ionizing radiation have been presented by the National Council on Radiation Protection and Measurements (NCRP) (1987) and the National Research Council's Committee on Biological Effects of Ionizing Radiation (1990).

The NCRP estimates that the probability of fatal cancer occurring is between one and five per 10,000 people who are each exposed to one rem (i.e., a risk coefficient of between 0.0001 and 0.0005). DOE guidance has, in the past, recommended using a risk coefficient of 0.0005 (ICRP, 1991) to estimate risk to a MEOSI. Recent DOE guidance recommends using the even more conservative risk coefficient of 0.0006 provided by the Interagency Steering Committee on Radiation Standards (January 2003). The estimated risk to the hypothetical individual residing near the WVDP from airborne and waterborne releases in 2006 was three per 100 million (a risk of 0.00000003 ). This risk is well below the range of 0.000001 to 0.00001 per year considered by the ICRP in Re- 
port Number 26 (1977) to be a reasonable risk for any individual member of the public.

\section{Release of Materials Contain- ing Residual Radioactivity}

The release of property containing residual radioactivity from DOE facilities is carefully controlled by DOE guidelines and procedures. In two special memoranda issued in January 2000 and July 2001, the Secretary of Energy placed a moratorium on release of contaminated materials and on unrestricted release for metal recycling from radiological areas within DOE facilities. On July 12, 2001, the DOE issued a Notice of Intent in the Federal Register (FR 36562) to prepare a programmatic environmental impact statement (PEIS) on the disposition of DOE scrap metals that may have residual surface radioactivity. On June 2, 2005, the NRC decided not to proceed with its rule-making concerning the release of solid materials; therefore the DOE PEIS is on hold. The moratorium will remain in effect until directives clarifying the release criteria have been developed and implemented. Any transfer that places property (real property, structures, equipment, or scrap metal) containing radioactivity into public use is classified as a type of environmental release.
As indicated in Table 2-4, the WVDP did not release any property in 2006 classified per DOE Order 5400.5 as material containing residual radioactivity.

\section{Dose to Biota: Aquatic and Terrestrial Wildlife}

Radionuclides from both natural and man-made sources may be found in environmental media such as water, sediments, and soils. In the past, it has been assumed that if radiological controls are sufficient to protect humans, other living things are also likely to be sufficiently protected. This assumption is no longer considered adequate, since populations of plants and animals residing in or near these media or taking food or water from these media may be exposed to a greater extent than are humans. For this reason, the DOE prepared a technical standard that provides methods and guidance to be used to evaluate doses of ionizing radiation to populations of aquatic animals, riparian animals (i.e., those that live along banks of streams or rivers), terrestrial plants, and terrestrial animals.

Methods in this technical standard, "A Graded Approach for Evaluating Radiation Doses to Aquatic and Terrestrial Biota" (DOE-STD-1153-

Table 2-4

Release of Property ${ }^{a}$ Containing Residual Radioactive Material

\begin{tabular}{|c|c|c|c|c|c|c|c|c|c|}
\hline $\begin{array}{c}\text { Approved } \\
\text { Limit }\end{array}$ & Rationale & $\begin{array}{c}\text { Date } \\
\text { of } \\
\text { Approval }\end{array}$ & $\begin{array}{c}\text { Type } \\
\text { of } \\
\text { Material }\end{array}$ & $\begin{array}{c}\text { Basis } \\
\text { for } \\
\text { Release }\end{array}$ & $\begin{array}{c}\text { End } \\
\text { Use }\end{array}$ & $\begin{array}{c}\text { Volume } \\
\text { of } \\
\text { Material }\end{array}$ & $\begin{array}{c}\text { Total } \\
\text { Activity }\end{array}$ & $\begin{array}{c}\text { Maximum } \\
\text { Individual } \\
\text { Dose }\end{array}$ & $\begin{array}{c}\text { Collective } \\
\text { Dose }\end{array}$ \\
\hline NA & NA & NA & None & NA & NA & 0 & 0 & 0 & 0 \\
\hline
\end{tabular}

NA - Not applicable

${ }^{a}$ No property containing residual radioactivity was released in 2006. 
2002, July 2002), were used in 2006 to evaluate radiation doses to aquatic and terrestrial biota within the confines of the WNYNSC, which includes the WVDP. Doses were assessed for compliance with the limit in DOE Order 5400.5 for native aquatic animal organisms (1 rad/day) and for compliance with the thresholds for terrestrial plants (also $1 \mathrm{rad} /$ day) and for terrestrial animals $(0.1 \mathrm{rad} / \mathrm{day})$, as proposed in DOE-STD-11532002. Note that the absorbed dose unit (rad) is used for biota instead of the units used for indicating human risk (rem).

The RESRAD-BIOTA Code (January 2004), a calculation tool provided by the DOE for implementing the technical standard, was used to compare existing radionuclide concentration data from environmental sampling with biota concentration guide (BCG) screening values and to estimate upper bounding doses to biota. Data were collected from surface water samples obtained in 2006 and sediments over the last five years (2002-2006). Soil data from the most recent ten years (19952004) were used because no soil sampling was conducted in 2005 or 2006. Differing time periods were used because radionuclide concentrations change more rapidly over time in surface waters than in sediments and soils, as reflected in their sampling frequencies (monthly or quarterly for water, annually or every third year for sediments and soils).

Concentration data for radionuclides in each medium were entered into the RESRAD-BIOTA Code. The value for each radionuclide was automatically divided by its corresponding BCG to calculate a partial fraction for each nuclide in each medium. Partial fractions for each medium were added to produce a sum of fractions.

Exposures from the aquatic pathway may be assumed to be less than the aquatic dose limit from DOE Order 5400.5 if the sum of fractions for the water medium plus that for the sediment medium is less than 1.0. Similarly, exposures from the terrestrial pathway may be assumed to be less than the proposed dose limits for both terrestrial plants and animals if the sum of fractions for the water medium plus that for the soil medium is less than 1.0.

It was found that the isotopes with the highest sums of fractions - the radionuclides that contributed the largest component of both aquatic and terrestrial dose to biota - were strontium- 90 and cesium- 137 . Per guidance in DOE-STD-1153-2002, the populations of organisms most sensitive to strontium-90 and cesium- 137 in this evaluation - that is, those most likely to be adversely affected via the aquatic and terrestrial pathways - were determined to be populations of riparian animals (such as the raccoon [aquatic dose]) and terrestrial animals (such as the deer mouse [terrestrial dose]). Populations of both animals are found on the WNYNSC.

In accordance with the graded approach described in DOE-STD-1153-2002, a general screening was first conducted using the maximum radionuclide concentrations from surface waters, sediments, and soils. Maximum radionuclide concentrations exceeded applicable BCG limits for both aquatic and terrestrial evaluations.

As recommended in DOE-STD-1153-2002, a sitespecific screening was then done using estimates of average radionuclide concentrations derived from measurements in surface waters, sediments, and soils. Results are summarized in Table 2-5.

At the site-specific screening level, the sums of fractions for the aquatic and terrestrial evaluations were 0.20 and 0.31 , respectively. The sum of fractions for each assessment was less than 1.0, indicating that applicable BCGs were met for both the aquatic and terrestrial evaluations.

Upper bounding doses associated with the aquatic system evaluation were $0.0062 \mathrm{rad} / \mathrm{day}$ to an 


\section{Table 2-5}

\section{Evaluation of Dose to Aquatic and Terrestrial Biota}

\begin{tabular}{|c|c|c|c|c|c|c|c|}
\hline \multicolumn{8}{|c|}{ AQUATIC SYSTEM EVALUATION } \\
\hline Nuclide & $\begin{array}{c}\text { Water } \\
\text { BCG }^{a} \\
(\mathbf{p C i} / \mathbf{L})\end{array}$ & $\begin{array}{c}\text { Mean Water } \\
\text { Value } \\
(\mathbf{p C i} / \mathrm{L})\end{array}$ & Ratio & $\begin{array}{c}\text { Sediment } \\
\text { BCG }^{a} \\
(\mathbf{p C i} / \mathrm{g})\end{array}$ & $\begin{array}{c}\text { Mean } \\
\text { Sediment } \\
\text { Value } \\
(\mathrm{pCi} / \mathrm{g}) \\
\end{array}$ & Ratio & $\begin{array}{c}\text { Water and } \\
\text { Sediment Sum } \\
\text { of Fractions }\end{array}$ \\
\hline Cesium-137 & 42.7 & 3.72 & $8.72 \mathrm{E}-02$ & 3,130 & 6.09 & $1.95 \mathrm{E}-03$ & 0.089 \\
\hline Strontium-90 & 279 & 28.8 & $1.03 \mathrm{E}-01$ & 583 & 0.649 & $1.11 \mathrm{E}-03$ & 0.10 \\
\hline All Others & NA & NA & $8.00 \mathrm{E}-04$ & NA & NA & $5.10 \mathrm{E}-04$ & $<0.001$ \\
\hline \multicolumn{3}{|c|}{ Sum of Fractions } & $1.91 \mathrm{E}-01$ & & & $3.57 \mathrm{E}-03$ & 0.20 \\
\hline \multicolumn{8}{|c|}{ Estimated upper bounding dose to an aquatic animal $=0.0062 \mathrm{rad} / \mathrm{day}$; to a riparian animal $=0.020 \mathrm{rad} / \mathrm{day}$. } \\
\hline \multicolumn{8}{|c|}{ TERRESTRIAL SYSTEM EVALUATION } \\
\hline Nuclide & $\begin{array}{c}\text { Water } \\
\text { BCG }^{a} \\
(\mathbf{p C i} / \mathbf{L})\end{array}$ & $\begin{array}{c}\text { Mean Water } \\
\text { Value } \\
(\mathrm{pCi} / \mathrm{L})\end{array}$ & Ratio & $\begin{array}{l}\text { Soil BCG } \\
\quad(\mathrm{pCi} / \mathrm{g})\end{array}$ & $\begin{array}{c}\text { Mean Soil } \\
\text { Value } \\
(\mathrm{pCi} / \mathrm{g})\end{array}$ & Ratio & $\begin{array}{c}\text { Water and } \\
\text { Soil Sum of } \\
\text { Fractions }\end{array}$ \\
\hline Cesium-137 & 599,000 & 3.72 & $6.21 \mathrm{E}-06$ & 20.8 & 4.78 & $2.30 \mathrm{E}-01$ & 0.23 \\
\hline Strontium-90 & 54,500 & 28.8 & $5.28 \mathrm{E}-04$ & 22.5 & 1.7 & $7.55 \mathrm{E}-02$ & 0.076 \\
\hline All Others & NA & NA & $1.79 \mathrm{E}-06$ & NA & NA & $5.00 \mathrm{E}-04$ & $<0.001$ \\
\hline \multicolumn{3}{|c|}{ Sum of Fractions } & $5.36 \mathrm{E}-04$ & & & $3.06 \mathrm{E}-01$ & 0.31 \\
\hline
\end{tabular}

NA - Not applicable

${ }^{a}$ The biota concentration guides (BCGs) are calculated values. Except for the sums of fractions and dose estimates, which are rounded to two significant digits, all values are expressed to three significant digits.

aquatic animal and $0.020 \mathrm{rad} /$ day to a riparian animal, far below the $1 \mathrm{rad} /$ day standard from DOE Order 5400.5 for dose to a native aquatic animal. Upper bounding doses associated with the terrestrial system evaluation were 0.031 and $0.0027 \mathrm{rad} /$ day to terrestrial animals and plants, again well below the guidance thresholds ( 0.1 and $1 \mathrm{rad} /$ day, respectively).

It was therefore concluded that populations of aquatic and terrestrial biota (both plants and animals) on the WNYNSC are not being exposed to doses in excess of the existing DOE dose standard for native aquatic animals (U.S. DOE, Feb- ruary 1990) and the international standards for terrestrial organisms (International Atomic Energy Agency [IAEA], 1992).

\section{Summary}

Predictive computer modeling of airborne and waterborne releases resulted in estimated hypothetical doses to the maximally exposed individual that were orders of magnitude below all applicable EPA standards and DOE Orders, which place limitations on the release of radioactive materials and dose to individual members of the public. The collective population dose was also assessed and 
found to be orders of magnitude below the natural background radiation dose. Additionally, estimates of dose to biota indicated that populations of biota at the WVDP are exposed at a fraction of the DOE and IAEA guidelines for dose to biota.

Based on the overall dose assessment, the WVDP was found to be in compliance with applicable effluent radiological guidelines and standards during calendar year 2006. Table 2-6 provides a summary of WVDP releases and calculated doses in the specified DOE format.

The method for estimating airborne dose to the public at the WVDP may be modified in the future. Updates to CAP88-PC, the computer code used to estimate dose, have been made and the revised code is being tested with WVDP measurements of airborne radionuclides. See the text box following Table 2-6 for a comparison of the currently used and updated versions. 


\section{Table 2-6}

\section{WVDP Radiological Dose and Release Summary}

\begin{tabular}{|c|c|c|c|c|c|c|}
\hline \multicolumn{7}{|c|}{ WVDP RADIOLOGICAL DOSE REPORTING TABLE CY 2006} \\
\hline \multicolumn{2}{|c|}{$\begin{array}{l}\text { Dose to the } \\
\text { Maximally Exposed } \\
\text { Individual }\end{array}$} & \multirow{2}{*}{$\begin{array}{c}\begin{array}{c}\text { \% of DOE } \\
\text { 100-mrem Limit }\end{array} \\
0.049\end{array}$} & \multicolumn{2}{|c|}{$\begin{array}{c}\text { Estimated } \\
\text { Population Dose }\end{array}$} & \multirow{2}{*}{$\begin{array}{c}\begin{array}{c}\text { Population } \\
\text { Within } \mathbf{5 0} \text { Miles } \\
(\mathbf{2 0 0 0} \text { census })\end{array} \\
1,536,000\end{array}$} & \multirow{2}{*}{$\begin{array}{c}\begin{array}{c}\text { Estimated Natural } \\
\text { Radiation } \\
\text { Population Dose }\end{array} \\
453,000 \\
\text { person-rem }\end{array}$} \\
\hline $\begin{array}{l}0.049 \\
\text { mrem }\end{array}$ & $\begin{array}{c}0.00049 \\
(\mathrm{mSv})\end{array}$ & & $\begin{array}{c}0.22 \\
\text { person-rem }\end{array}$ & $\begin{array}{c}0.0022 \\
\text { (person-Sv) }\end{array}$ & & \\
\hline
\end{tabular}

\begin{tabular}{|c|c|c|c|c|c|c|c|c|c|c|}
\hline \multicolumn{11}{|c|}{ WVDP RADIOLOGICAL ATMOSPHERIC EMISSIONS ${ }^{a}$ CY 2006 IN CURIES (Bq) } \\
\hline Tritium & Kr-85 & $\begin{array}{l}\text { Noble Gases } \\
\left(T_{1 / 2}<40 \text { dy }\right)\end{array}$ & $\begin{array}{c}\text { Short-Lived } \\
\text { Fission and } \\
\text { Activation } \\
\text { Products } \\
\left(\mathbf{T}_{1 / 2}<3 \mathrm{hr}\right)\end{array}$ & $\begin{array}{c}\text { Fission and } \\
\text { Activation } \\
\text { Products } \\
\left(\mathrm{T}_{1 / 2}>3 \mathrm{hr}\right)\end{array}$ & $\begin{array}{c}\text { Total } \\
\text { Radioiodine }\end{array}$ & $\begin{array}{c}\text { Total } \\
\text { Radiostrontium }\end{array}$ & $\begin{array}{c}\text { Total } \\
\text { Uranium }^{b}\end{array}$ & $\begin{array}{c}\text { Total } \\
\text { Plutonium }\end{array}$ & $\begin{array}{c}\text { Total } \\
\text { Other } \\
\text { Actinides }\end{array}$ & $\begin{array}{c}\text { Other } \\
\text { (Rn-220) }\end{array}$ \\
\hline $\begin{array}{c}1.16 \mathrm{E}-03 \\
(4.31 \mathrm{E}+07)\end{array}$ & NA & NA & NA & $\begin{array}{c}3.74 \mathrm{E}-06 \\
(1.38 \mathrm{E}+05)\end{array}$ & $\begin{array}{c}3.13 \mathrm{E}-05 \\
(1.16 \mathrm{E}+06)\end{array}$ & $\begin{array}{c}2.92 \mathrm{E}-06 \\
(1.08 \mathrm{E}+05)\end{array}$ & $\begin{array}{c}9.03 \mathrm{E}-08 \\
(3.34 \mathrm{E}+03)\end{array}$ & $\begin{array}{c}1.45 \mathrm{E}-07 \\
(5.37 \mathrm{E}+03)\end{array}$ & $\begin{array}{c}1.82 \mathrm{E}-07 \\
(6.72 \mathrm{E}+03)\end{array}$ & $\begin{array}{c}1.10 \mathrm{E}+03 \\
(4.05 \mathrm{E}+13)\end{array}$ \\
\hline
\end{tabular}

\begin{tabular}{|c|c|c|c|c|c|c|}
\hline \multicolumn{7}{|c|}{ WVDP LIQUID EFFLUENT RELEASES ${ }^{c}$ OF RADIONUCLIDE MATERIAL CY 2006 IN CURIES (Bq) } \\
\hline Tritium & $\begin{array}{c}\text { Fission and } \\
\text { Activation } \\
\text { Products } \\
\left(\mathrm{T}_{1 / 2}>3 \mathrm{hr}\right)\end{array}$ & $\begin{array}{c}\text { Total } \\
\text { Radioiodine }\end{array}$ & $\begin{array}{c}\text { Total } \\
\text { Radiostrontium }\end{array}$ & Total Uranium ${ }^{d}$ & $\begin{array}{c}\text { Total } \\
\text { Plutonium }\end{array}$ & $\begin{array}{c}\text { Total Other } \\
\text { Actinides }\end{array}$ \\
\hline $\begin{array}{c}7.84 \mathrm{E}-02 \\
(2.90 \mathrm{E}+09)\end{array}$ & $\begin{array}{c}8.34 \mathrm{E}-03 \\
(3.09 \mathrm{E}+08)\end{array}$ & $\begin{array}{c}8.95 \mathrm{E}-05 \\
(3.31 \mathrm{E}+06)\end{array}$ & $\begin{array}{c}2.25 \mathrm{E}-01 \\
(8.31 \mathrm{E}+09)\end{array}$ & $\begin{array}{c}5.44 \mathrm{E}-04 \\
(2.01 \mathrm{E}+07)\end{array}$ & $\begin{array}{c}1.30 \mathrm{E}-05 \\
(4.82 \mathrm{E}+05)\end{array}$ & $\begin{array}{c}9.21 \mathrm{E}-06 \\
(3.41 \mathrm{E}+05)\end{array}$ \\
\hline
\end{tabular}

Note: There are no known significant discharges of radioactive constituents from the site other than those reported in this table.

NA - Not applicable

${ }^{a}$ Air releases are from point sources only.

${ }^{b}$ Total uranium $($ grams $)=8.33 E-02$

${ }^{c}$ Water releases are from both controlled liquid effluent releases and from well-characterized site drainages.

${ }^{d}$ Total uranium $($ grams $)=5.03 E+02$

$$
2-30
$$




\section{Radiological Environmental Dose Assessment Using CAP88-PC Version 2.0 versus Version 3.0}

The WVDP Annual Site Environmental. Report (ASER) summarizes the airborne radioactivity released (see Appendix $C^{\mathrm{ED}}$ ) and the effect from those releases. The computer code CAP88-PC (Version 2.0) is used to perform radiation dose and risk calculations from those airborne releases.

A recent change was made to the code. Version 3.0 of CAP88-PC (Trinity Engineering Associates, Inc., March 2006) is now approved by the EPA for use. Version 3.0 incorporates updated scientific methods to calculate radiation dose and risk. Version 3.0 also considers age and gender factors, not considered in Version 2.0. Both versions use weighting factors that consider the sensitivity of various human organs to radiation. The models also calculate how long radioactive material will remain in a particular organ or system. Together, these factors are used to calculate dose and risk.

Version 2.0 used seven different organs and Version 3.0 uses 23. The risk of getting cancer from radiation exposure is calculated for 15 sites in Version 3.0 versus 10 in Version 2.0.

The net effect is that dose and risk estimates summarized in the ASER from using CAP88-PC Version 2.0 will be different when the new version of the code is used. This would be true even if the radioactivity released from WVDP and meteorology both remained constant.

As the WVDP decontaminates more facilities and removes more radioactive material, different mixtures of radionuclides will be released from one year to the next. These changes may also affect the dose and risk estimates.

CAP88-PC Version 3.0 improves the science and is more specific to the population that surrounds the facility. In a rough comparison, the 2006 dose to the maximally exposed individual near the WVDP using CAP88-PC Version 2.0 was estimated to be $0.0011 \mathrm{mrem}$; dose to the same individual using Version 3.0 was estimated to be 0.00096 mrem. In either case, the conclusion from using Version 2.0 or Version 3.0 is that the facility is in compliance with the NESHAP requirement and that the results are a small fraction of the limit. 
This page intentionally left blank

$2-32$ 


\section{ENVIRONMENTAL NONRADIOLOGICAL PROGRAM INFORMATION}

Overview of New York State Water Classifications, Water Quality Standards, and Water Effluent Limits

The objective of the Clean Water Act of 1972 (CWA) (as stated in Section 101 of the Act) is to restore and maintain the integrity of the nation's waters and ensure that, wherever attainable, waters be made useful for fishing and swimming. To achieve this goal, New York State is delegated with authority under Sections 118, 303, and 510 of the CWA to (1) classify and designate the best uses for receiving waters, such as streams and rivers, within its jurisdiction; and (2) establish and assign water quality standards - goals for achieving the designated best uses for these classified waters. In addition to achieving CWA goals for fishing and swimming, New York has further classified its jurisdictional waters and established ambient water standards, guidelines, and maximum contaminant levels (MCLs) to achieve objectives under the Safe Drinking Water Act for drinking water. These standards serve as the basis for periodic evaluation of the integrity of the receiving waters and identification of needed controls, such as New York State Pollutant Discharge Elimination System (SPDES) permits and effluent limitations.
The definitions for best usage classifications of New York's jurisdictional waters and the water quality standard goals for these classifications are provided in Title 6 of the Official Compilation of Codes, Rules, and Regulations of the State of New York (6 NYCRR) Parts 701-704. Mapping of the Cattaraugus Creek drainage basin and assignment of best usage designations and classification to each receiving water segment within this drainage basin are described in 6 NYCRR Part 838. According to these regulations, Frank's Creek, Quarry Creek, and segments of Buttermilk Creek under the influence of West Valley Demonstration Project (WVDP) water effluents are identified as Class " $C$ " receiving waters with a minimum designated best usage for fishing with conditions suitable for fish propagation and survival. Cattaraugus Creek, in the immediate downstream vicinity of the Western New York Nuclear Service Center (WNYNSC), is identified as a Class "B" receiving water with best designated usages for swimming and fishing. All fresh (nonsaline) groundwaters within New York are assigned a "GA" classification with a designated best usage as a potable water supply source.

Presented in Appendix C- $1^{\text {cod }}$ is a summary of the numerical water quality standards, guidelines, and MCLs assigned to these water classifications for those substances and parameters that are included 
in the WVDP environmental monitoring program for ambient water. Also included in Appendix $\mathrm{C}-1^{\text {(c) }}$ are SPDES permit discharge limits for site effluents.

Table 3-1 presents a summary of those nonradiological results that exceeded background results or applicable limits or guidance levels in 2006.

\section{Surface Water, Subsurface Drainage Water, and Water Effluent Monitoring}

Appendix C-2 ${ }^{\text {GD }}$ contains process effluent data with SPDES permit limits provided for comparison with these data. Appendix C- $3^{\text {[D. }}$ contains storm water runoff monitoring data for storm water outfalls designated in the WVDP SPDES permit. Appendices C $-4{ }^{\text {GD }}$ through C- $6{ }^{\text {GD }}$ present data for ambient surface water, subsurface drainage water, contained water, and potable water monitoring locations. Also provided for side-by-side comparison with these data are reference values, where available, including background ambient water monitoring data and/ or pertinent ambient water quality standards (AWQS), guidelines, or MCLs.

SPDES Permit-Required Monitoring. Liquid discharges from the WVDP are regulated under the SPDES permit as identified in Table ECS-2. This SPDES permit identifies outfalls from which liquid effluents are released to Erdman Brook (Fig. A-2), identifies 20 storm water outfalls (Figs. A-3 and A4), and specifies the sampling and analytical requirements for each. In September 2006, the permit was modified by the New York State Department of Environmental Conservation (NYSDEC) to reduce monitoring frequency requirements for 17 analytical parameters at outfall 001 and to modify the methods and requirements for monitoring mercury. The conditions and requirements of the SPDES permit are summarized in Appendix C- 1 . ${ }^{\text {co }}$. The permit identifies 25 outfalls and compliance points with monitoring requirements and discharge limits. The monitored outfalls include:

- outfall 001 (monitoring point WNSP001), discharge from the low-level waste treatment facility (LLWTF)

- outfall 007 (monitoring point WNSP007), discharge from the sanitary and industrial wastewater treatment facility

- outfall 008 (monitoring point WNSP008), a groundwater french drain around the perimeter of the LLWTF storage lagoons (closed in May 2001 but still in the permit)

- outfall 116 (pseudo-monitoring point WNSP116), a location in Frank's Creek that represents the confluence of outfalls WNSP001, WNSP007, and WNSP008, as well as storm water runoff, groundwater seepage, and augmentation water. Samples from upstream sources are used to calculate total dissolved solids (TDS) at this location and to demonstrate compliance with the SPDES permit limit for this parameter. (Outfall 116 is referred to as a "pseudo-monitoring" point on the SPDES permit.)

- outfall 01B (monitoring point WNSP01B), an internal monitoring point for the liquid waste treatment system evaporator effluent, being monitored for flow and total mercury.

- 20 storm water discharge outfalls that also receive flows from other minor sources, such as fire hydrant testing and groundwater seepage, being monitored on a rotational basis.

There were no SPDES effluent limit exceptions in CY 2006.

Mercury Analytical Method Study. In a July 2002 SPDES permit modification, NYSDEC required that samples being collected for measure- 
Surface Water, Subsurface Drainage Water, and Water Effluent Monitoring

Table 3-1

2006 Comparison of Nonradiological Results With Backgrounds and Applicable Standards or Guidance Limits

\begin{tabular}{|c|c|c|c|c|}
\hline Sample Type & $\begin{array}{l}\text { Number of } \\
\text { Sampling } \\
\text { Locations }\end{array}$ & $\begin{array}{l}\text { Locations with Results } \\
\text { Greater than Applicable } \\
\text { Limits or Screening Levels } \\
\text { (Constituent) }\end{array}$ & $\begin{array}{l}\text { Locations with } \\
\text { Results } \\
\text { Greater than } \\
\text { Background }\end{array}$ & $\begin{array}{l}\text { Locations with Results } \\
\text { Statistically Greater than } \\
\text { Background } \\
\text { (Constituent) }\end{array}$ \\
\hline \multicolumn{5}{|c|}{ Surface water (1 background location) } \\
\hline $\begin{array}{l}\text { On-site controlled } \\
\text { effluents }\end{array}$ & 2 & 0 & 1 & $\begin{array}{l}\text { WNSP001 (total dissolved } \\
\text { solids, sulfate) }\end{array}$ \\
\hline $\begin{array}{l}\text { On-site surface } \\
\text { waters }\end{array}$ & 3 & $\begin{array}{l}\text { WNSP006 (iron, sulfide, total } \\
\text { dissolved solids) }\end{array}$ & 3 & $\begin{array}{l}\text { WNSP006 (chloride, total } \\
\text { sodium); WNSWAMP (non- } \\
\text { purgeable organic carbon); } \\
\text { WNSW74A (total dissolved } \\
\text { solids) }\end{array}$ \\
\hline $\begin{array}{l}\text { Off-site surface } \\
\text { waters }^{a}\end{array}$ & 1 & WFBCTCB (iron, sulfide) & 1 & $\begin{array}{l}\text { WFBCTCB (chloride, nitrate- } \\
\text { nitrogen, total sodium) }\end{array}$ \\
\hline \multicolumn{5}{|c|}{ Standing water (1 historical background location that is no longer sampled) } \\
\hline Standing water & 1 & WNSTAW9 (iron) & 0 & None \\
\hline \multicolumn{5}{|c|}{ On-site soils/sediments (no background location) } \\
\hline $\begin{array}{l}\text { On-site soil// } \\
\text { sediments }\end{array}$ & 3 & $\begin{array}{l}\text { SNSWAMP (magnesium, zinc) }{ }^{b}, \\
\text { SNSP006 (arsenic, copper, } \\
\text { manganese, nickel) }{ }^{c}, \text { SNSW74A } \\
\text { (magnesium }^{b}, \text { manganese }^{d}, \text { zinc }^{b, d} \text { ) }\end{array}$ & NA & NA \\
\hline
\end{tabular}

NA - Not applicable; no background data for these constituents are available from the upstream location.

${ }^{a}$ Background location WFBCBKG also exceeded the water quality standard for iron.

${ }^{b}$ Recommended soil cleanup objectives from NYSDEC Technical Administrative Guidance Memorandum (TAGM) \#4046.

${ }^{c}$ Lowest effect level screening guidelines for chemical constituents from NYSDEC "Technical Guidance for Screening Contaminated Sediments"

'6 NYCRR Subpart 375-6.8(a) remedial program soil cleanup objective.

$3-3$ 
ment of mercury be analyzed by two different methods to conduct a comparison study. The methods are United States (U.S.) Environmental Protection Agency (EPA) Method 245.1 (or 245.2) with a detection level of 0.2 micrograms/liter $(\mu \mathrm{g} / \mathrm{L})$ (parts per billion) and EPA Method 1631, which allows determination of mercury at a minimum level of 0.5 nanograms/liter (ng/L) (parts per trillion). The latter ("ultra-clean") method supports the EPA's effort to make available an additional analytical method capable of measuring mercury accurately at ambient water quality criteria levels.

Since the SPDES permit enforcement compliance limit of $0.2 \mu \mathrm{g} / \mathrm{L}$ for total mercury is several orders of magnitude higher than the AWQS of 0.0007 $\mu \mathrm{g} / \mathrm{L}$ for dissolved mercury, the comparison study was required under the terms of the SPDES permit.Areport summarizing the analytical results from these two methods and its findings has been required to be submitted semiannually to NYSDEC.

Eight sets of samples from outfall 001 were analyzed for mercury by the two test methods in 2006. Samples were analyzed at Severn Trent Laboratories using Method 245.1 and at General Engineering Laboratories using Method 1631.

All sample results from Method 245.1 were less than $0.2 \mu \mathrm{g} / \mathrm{L}$, the practical quantitation limit for Method 245.1. Results generated with Method 1631 were consistent with results generated with Method 245.1. That is, all sample results generated with Method 1631 were reported at levels below $0.2 \mu \mathrm{g} / \mathrm{L}$. The average concentration for samples collected at outfall 001 using Method 1631 was $0.0057 \mu \mathrm{g} / \mathrm{L}(5.7 \mathrm{ng} / \mathrm{L})$.

The September 2006 SPDES permit modification eliminated the requirement to continue the comparison study and required the exclusive use of Method 1631 for mercury monitoring. Although compliance limits were not changed, the reporting units of measurement and significant figures were modified. The limit at outfall 001 was changed from $0.2 \mu \mathrm{g} / \mathrm{L}$ to $200 \mathrm{ng} / \mathrm{L}$ and that for outfall $01 \mathrm{~B}$ was changed from $10 \mu \mathrm{g} / \mathrm{L}$ to $10,000.0 \mathrm{ng} / \mathrm{L}$.

Storm Water Discharge Monitoring. The objectives of SPDES permit requirements for monitoring storm water runoff are to determine (1) the levels of water quality and specific chemicals in storm water discharges from specified locations on the WVDP, (2) the amount of rainfall, (3) duration of the storm event, and (4) the resulting flow at the outfalls. The 20 storm water outfalls at the WVDP are grouped into eight representative drainage basins that could potentially be influenced by industrial or construction activity runoff. One representative outfall for each of the eight outfall groups listed in Appendix $B^{\mathrm{CD}}$ must be sampled on a semiannual basis.

The SPDES permit recommends the following guidelines for a qualifying storm water event eligible for monitoring:

- a period of 72 hours between the monitored event and the previous measurable event of 0.1 inches of precipitation;

- a total rainfall of more than $0.1 \mathrm{inch}$;

- resultant storm discharge at the outfall.

In 2006, samples were collected semiannually from each of the eight groups. Appendix C- $3^{\text {CDD }}$ presents data from all storm water discharge monitoring events. The analysis of storm water discharge samples produced noticeable concentrations of indicator parameters (in particular five-day biochemical oxygen demand, TDS, and total suspended solids) and associated inorganic parameters (in particular aluminum, copper, iron, and lead). The sources for the noteworthy concentrations in storm water runoff of these naturally occurring 
substances include residuals from deicing material (sand and salt mixture) applications, fine sediments from placement of quarried materials delivered from off-site sources, residuals from corrosion of material and equipment, vegetation particles, and natural silts and fine sediments from soil erosion, including those that escape strategically placed erosion and sediment control devices, such as fabric filter fences.

\section{South Plateau Surface and Subsurface Water} Monitoring. An inactive underground radioactive waste disposal site, the U.S. Nuclear Regulatory Commission-Licensed Disposal Area (NDA), lies on the south plateau of the site. Surface waters, which flow from the south to the north, are routinely monitored at several points around this area (Fig. A-2). Two of these points, WNNDATR and WNNDADR, are used to monitor (respectively) waters within the NDA water collection trench system and surface runoff, and seepage immediately downstream of the NDA. Sampling point WNNDATR is an underground sump at the lowest point in the collection trench system that intercepts groundwater from the NDA. If radiological or nonradiological contamination were to migrate through the NDA, it would most likely be first detected in samples from WNNDATR.

Interceptor Trench and Pretreatment System. Radioactively-contaminated n-dodecane (similar to kerosene) in combination with tributyl phosphate (TBP) was discovered in groundwater at the northern boundary of the NDA in 1983. To contain migration of this subsurface radioactive organic contaminant, an interceptor trench and a liquid pretreatment system (LPS) were built. (See "Nuclear Regulatory Commission-Licensed Disposal Area [NDA] Interceptor Trench and Pretreatment System" in Chapter 1.)

The trench was designed to intercept and collect subsurface water, which could be carrying $\mathrm{n}$ -
dodecane/TBP, to prevent the material from entering the surface water drainage ditch leading into Erdman Brook, and to prevent contamination of downgradient groundwater. The LPS was installed to separate the n-dodecane/TBP and to remove iodine-129 from the collected water before its transfer to the LLWTF. The separated ndodecane/TBP would be stored for subsequent treatment and disposal.

In 2006, as in previous years, no water containing TBP was encountered in the trench. Results of surface and groundwater monitoring in the vicinity of the trench are discussed under "South Plateau Surface Water and Nuclear Regulatory Commision-Licensed Disposal Area Interceptor Trench" in Chapter 2 and "Monitoring on the South Plateau: Weathered Lavery Till and the NDA" in Chapter 4.

Total Organic Halides. Total organic halides (TOX) measurements are used as a screening mechanism to detect the presence of certain organic compounds and associated radionuclides. In 2006, no elevated concentrations of TOX requiring further investigation were detected at either WNNDATR or WNNDADR.

Other On-Site and Off-Site Surface Water Monitoring. As part of the routine monitoring program, two sets of timed continuous composite and grab samples for nonradiological parameters at WNSP006 (Frank's Creek at the security fence), WNSWAMP (northeast swamp drainage), WNSW74A (north swamp drainage), WFBCTCB (Buttermilk Creek at Thomas Corners), and WFBCBKG (Buttermilk Creek at Fox Valley) were taken in 2006. These samples were screened for organic constituents and selected anions, cations, and metals. Results were compared with background results and with applicable standards. (See Table 3-1.) 
At surface water monitoring locations WFBCTCB, WNSP006, and background reference location WFBCBKG, the maximum concentrations of total iron exceeded the water quality standard ( 0.30 milligrams/liter $[\mathrm{mg} / \mathrm{L}])$. Elevated iron concentrations are attributable to elevated background concentrations, runoff from industrial activities, fine sediments from placement of quarried materials delivered from off-site sources, and natural silts and fine sediments from soil erosion.

NYSDEC, in its 2002 CWA 303(d) report to the EPA, indicated it found the scientific basis for the $0.30 \mathrm{mg} / \mathrm{L}$ standard to be insufficient. NYSDEC also indicated that its upcoming standards review is expected to include a proposed replacement of the $0.30 \mathrm{mg} / \mathrm{L}$ standard with a $1.0 \mathrm{mg} / \mathrm{L}$ guidance value, based on 1976 EPA criteria. Nonetheless, iron concentrations at WNSP006 also exceeded this replacement value.

Results of measurements for these locations are found in Appendices C- $4{ }^{\mathrm{CD}}$ and C- $5{ }^{\mathrm{CD}}$. Measurements of nonradiological constituents remained within the range of historical values.

\section{Drinking Water Monitoring}

Site drinking water is monitored at the distribution entry point (WNDNKUR) and at other site tap water locations to verify compliance with EPA and New York State Department of Health(NYSDOH) regulations. (See "Safe Drinking Water Act" in the Environmental Compliance Summary.) Samples are collected and analyzed for metals, nitrate, fluoride, cyanide, principal organic contaminants, residual chlorine, and biological constituents. A sample from a standing water location (WNSTAW9), collected from the reservoir near the site's tap water intake, is also analyzed for select chemical parameters. A detailed sampling schedule and listing of constituents is presented in Appendix $\mathrm{B}^{\text {(DD }}$. Analytical results may be found in Appendix C- $6{ }^{\text {CDD }}$.
Results indicated that in 2006, the Project's drinking water continued to meet MCLs and drinking water standards of the EPA, NYSDOH, and the Cattaraugus County Health Department.

\section{Soil and Sediment Monitoring}

Sediments are found at the bottom of surface waters, including streams located within the WVDP and the WNYNSC premises. Sediments provide habitat for a wide variety of bottom-dwelling (benthic) organisms, as well as juvenile forms of open-water (pelagic) organisms. These organisms in sediments are in constant contact with substances that may be adsorbed to sediment particles. Contaminated sediments are potential diffuse sources of contamination to the overlying body of water.

In 1999, NYSDEC issued updated guidance for screening contaminated aquatic sediments. This guidance includes sediment quality criteria correlated to the severity of environmental impact. These criteria, which are derived from National Oceanic and Atmospheric Administration (Long and Morgan, 1990) and 1992 Ministry of Ontario "Guidelines for the Protection and Management of Aquatic Sediment Quality in Ontario" (Persaud et al., 1992), are presented in Appendix G- $1^{\text {미 }}$.

Contaminants in soils are potential sources for contamination of groundwater, ambient air, flora, and fauna. Appendix G-1 ${ }^{\text {Go }}$ includes a summary of reference criteria, including background concentration ranges for eastern United States soils and sediment screening levels. Data for soil and sediment monitoring locations are provided in Appen$\operatorname{dix}$ G-2 ${ }^{\text {Go }}$. Also, provided for side-by-side comparison with these data, are available reference values, including sediment screening levels. See Table 3-1 for a listing of constituents exceeding screening levels. 
At SNSP006, all analytical results for sediments were below the "Severe Effect Levels" and "No Appreciable Contaminant Levels" specified in the NYSDEC guidance. According to the NYSDEC "Technical Guidance for Screening Contaminated Sediments," these results suggest there is no pronounced disturbance of the sediment-dwelling biological community and that there is no significant harm to benthic life at this location.

The results for arsenic, copper, manganese, and nickel in the sediment sample obtained at SNSP006 exceeded the "Lowest Effect Levels" but were less than the "Severe Effect Levels." Based on the NYSDEC sediment screening guidance, moderate localized impacts to benthic life could be expected at this location.

At SNSW74A and SNSWAMP, concentrations of zinc exceeded the eastern United States background soil concentration range identified in the NYSDEC Technical Administrative Guidance Memorandum (TAGM) \#4046 "Determination of Soil Clean-Up Objectives and Clean-Up Levels." The manganese and zinc concentrations at SNSW74A also exceeded the 6 NYCRR Subpart 375-6.8(a) Remedial Program Cleanup Objective. Magnesium at SNSW74A and SNSWAMP exceeded the eastern background soil concentration range. Concentrations of these naturally occurring metals above background may be indicative of localized, naturally elevated concentrations of these metals in soils. Magnesium is also a constituent used in deicing salts on site, and runoff from road-salting could be effecting these locations.

\section{Air Emission Monitoring}

Nonradiological air emissions are permitted under NYSDEC and EPA regulations. The regulations that apply to the WVDP are listed in the "Environmental Compliance Summary," Table ECS-1. The New York State Air Facility Registration Cer- tificate for the WVDP is described in the WVDP Environmental Permits table, ECS-2, in the "Environmental Compliance Summary."

The nonradiological air certificate covers emissions of regulated pollutants that include nitrogen oxides and sulfur dioxide.

The main source of oxides of nitrogen and sulfur at the WVDP was the vitrification system melter, which was shut down in September 2002. Two site utility steam boilers are left as the only sources of nitrogen and sulfur oxides, at levels much lower than those emitted by the melter. During 2006, approximately 2,800 kilograms (kg) (3.1 tons) of nitrogen oxides and less than $1 \mathrm{~kg}$ (0.0011 tons) of sulfur dioxide were emitted from these remaining units. Together, these releases comprised about $6.3 \%$ and $0.002 \%$, respectively, of the 49.5-ton annual capping limit for each.

\section{Special Monitoring}

Special monitoring refers to that conducted outside the scope of the routine environmental monitoring program. Two special monitoring efforts for nonradiological constituents were conducted in 2006.

In 2006, questions arose regarding the possible environmental impact to wetlands from the live fire range (LFR) on the WNYNSC. The LFR is a small arms range used by the WVDP security force and the Cattaraugus County Sheriff's Department for practice and for firearms qualification courses. The primary contaminant of concern was lead, in both particulate and soluble forms. Lead, especially in soluble form, may be transported by storm water runoff away from the LRF and into surface waters.

Late in 2006, four surface water samples were collected near the LFR and analyzed for total and soluble lead. Results provided information for char- 
acterizing the locations, identifying potential environmental concerns that may exist, and developing management plans for current and future usage (and eventual closure) of the LFR. A nearby storm water runoff location was tentatively identified and a full suite of storm water characterization samples was collected in 2007. The analytical results will be submitted to NYSDEC, as well as other SPDES permit modifications that are expected to be submitted in 2007.

In accordance with the Resource Conservation and Recovery Act, clean closure was initiated in 2006 at two facilities: the lag storage building and the interim waste storage facility. Sampling for hazardous constituents was performed in accordance with the RCRA closure plans for the facilities. The results of the clean closure confirmation sampling showed levels of contaminants of concern below the cleanup levels established in the closure plans. Clean closure certification reports are being prepared and will be submitted by the DOE to NYSDEC. 


\section{GROUNDWATER PROTECTION PROGRAM}

\section{Groundwater Monitoring Program Overview}

Groundwater monitoring at the West Valley Demonstration Project (WVDP or Project) complies with all applicable state and federal regulations and meets the requirements of United States (U.S.) Department of Energy (DOE) Order 450.1. Data obtained from the program enable site managers to determine baseline groundwater conditions, facilitate early detection of existing and potential groundwater contamination sources, provide surveillance of these sources, and provide information for decision-making.

The "WVDP Groundwater Protection Management Program Plan" documents the Project's approach to the protection of groundwater from on-site activities. The WVDP's groundwater monitoring program is outlined in the "Groundwater Monitoring Plan," which discusses groundwater characterization, the current groundwater sampling agenda, and compliance with long-term monitoring requirements as identified in the $\mathrm{Re}$ source Conservation and Recovery Act (RCRA) facility investigation (RFI) and DOE Orders.

Site groundwater is not used for drinking or operational purposes, nor is effluent discharged directly to groundwater. Surveys have determined that no public water supplies are drawn from downstream Cattaraugus Creek. Upgradient of the site, groundwater is used as a public and private drinking water supply by local residents.

\section{Surface Water Hydrology}

The 167-acre (68-hectare [ha]) Project site is located within the Western New York Nuclear Service Center (WNYNSC), which comprises approximately 3,338 acres (1,351 ha) and is located near the northern border of Cattaraugus County. The WNYNSC lies within the Cattaraugus Creek watershed, which flows northwestward to Lake Erie. Buttermilk Creek, a tributary of Cattaraugus Creek, drains most of the WNYNSC.

The WVDP, which lies within the WNYNSC, is drained by Quarry Creek, Erdman Brook, and Frank's Creek, which flow into Buttermilk Creek. (See Fig. A-1 in Appendix A.) Erdman Brook bisects the WVDP into the north and south plateaus. The main plant, waste tanks, and lagoons are located on the north plateau. The drum cell, the U.S. Nuclear Regulatory Commission (NRC)-Licensed Disposal Area (NDA), and the New York State-Licensed Disposal Area (SDA) are located on the south plateau. 


\section{Geology}

The WNYNSC is situated upon a layered sequence of glacial-age sediments that fill a steepsided bedrock valley that is composed of interbedded shales and siltstones (Rickard, 1975).

The glacial sediments overlying the bedrock consist of a sequence of three glacial tills of Lavery, Kent, and possibly Olean age. The tills are separated by stratified fluvio-lacustrine deposits (silty or silty/sandy lakebed sediments). On the Project's north plateau, the Lavery till is capped by coarsegrained alluvial-fluvial deposits (sandy/silty/gravelly streambed sediments).

\section{Hydrogeology}

The sediments above the Kent till - the Kent recessional sequence, the weathered and unweathered Lavery till, the intra-Lavery till-sand, and the alluvial sand and gravel - are generally regarded as containing all of the potential routes for contaminant migration from the Project via groundwater. (See Figs. 4-1 and 4-2.) Table 4-1 describes each of these units and their distribution beneath the site. The Kent till has a relatively low permeability and does not provide a pathway for contaminant movement from the WVDP; therefore, it is not discussed here.

Hydrologic conditions of the site are more fully described in "Environmental Information Document, Volume III: Hydrology, Part 4" (West Valley Nuclear Services Co. [WVNSCO], March 1996) and in the "RCRAFacility Investigation Report Vol. 1: Introduction and General Site Overview" (WVNSCO and Dames \& Moore, July 1997).

\section{Routine Groundwater Monitoring Program} Groundwater Monitoring Program Highlights
1982 Through 2006. Program content is dictated by regulatory requirements in conjunction with current operating practices and historical knowledge of previous site activities.

- Groundwater monitoring at the WVDP began in 1982 and continued to expand through 1992 with the addition of new wells, groundwater seep locations, a french drain outfall, and the NDA interceptor trench sump.

- In 1993, monitoring results indicated elevated gross beta activity in groundwater from the sand and gravel unit on the north plateau. Subsequent investigation of this area delineated a plume of contamination with a southwest to northeast orientation. (See "Monitoring of the Sand and Gravel Unit on the North Plateau" and Figure 4-3 in this chapter for more detail.)

- An RFI expanded characterization program was conducted during 1993 and 1994 to fully assess potential releases of hazardous wastes or constituents from on-site SSWMUs. This investigation, which consisted of two rounds of sampling for a wide range of radiological and chemical parameters, provided valuable information regarding groundwater conditions near each SSWMU. Evaluation of these results influenced monitoring program modifications.

- Long-term monitoring needs were the focus of a 1995 groundwater monitoring program evaluation. After a comprehensive assessment, the number of sampling locations was reduced from 91 to 65 and analytical parameters were tailored to each sampling location for a more focused, efficient, and cost-effective program.

- In 1996, several groundwater seep monitoring locations on the northeast edge of the north plateau were added to the monitoring program and the french drain outfall was deleted for groundwater purposes. Five seep locations continue to be monitored. 
Table 4-1

Summary of Hydrogeology at the WVDP

\begin{tabular}{|c|c|c|c|c|}
\hline Geologic Unit & Description & $\begin{array}{c}\text { Groundwater Flow } \\
\text { Characteristics }\end{array}$ & $\begin{array}{c}\text { Hydraulic } \\
\text { Conductivity }\end{array}$ & Location \\
\hline Sand and Gravel & $\begin{array}{l}\text { Silty sand and gravel layer } \\
\text { composed of older } \\
\text { Pleistocene-age } \\
\text { glaciofluvial deposits } \\
\text { overlain by younger } \\
\text { Holocene alluvial deposits }\end{array}$ & $\begin{array}{l}\text { Flow is generally northeast } \\
\text { across the plateau toward } \\
\text { Frank's Creek, with } \\
\text { groundwater near the } \\
\text { northwestern and } \\
\text { southeastern margins } \\
\text { flowing radially outward } \\
\text { toward Quarry Creek and } \\
\text { Erdman Brook }\end{array}$ & $\begin{array}{l}16.4 \mathrm{ft} / \text { day }(6 \mathrm{E}-03 \\
\mathrm{cm} / \mathrm{sec}) \text { or } 200 \mathrm{in} / \text { day }\end{array}$ & North plateau \\
\hline Lavery Till Sand & $\begin{array}{l}\text { Thin, sandy unit of limited } \\
\text { areal extent and variable } \\
\text { thickness }\end{array}$ & $\begin{array}{l}\text { Flow to the east-southeast } \\
\text { toward Erdman Brook }\end{array}$ & $\begin{array}{l}3.8 \mathrm{ft} / \text { day }(1 \mathrm{E}-03 \\
\mathrm{cm} / \mathrm{sec}) \text { or } 46 \\
\text { inches/day }\end{array}$ & $\begin{array}{l}\text { Primarily beneath } \\
\text { the southeastern } \\
\text { portion of the north } \\
\text { plateau }\end{array}$ \\
\hline $\begin{array}{l}\text { Weathered } \\
\text { Lavery Till }\end{array}$ & $\begin{array}{l}\text { Upper zone of the Lavery } \\
\text { Till exposed at the ground } \\
\text { surface; weathered and } \\
\text { fractured to a depth of } \\
3-16 \mathrm{ft}(0.9-4.9 \text { m); brown } \\
\text { in color due to oxidation; } \\
\text { contains numerous } \\
\text { dessicant cracks and root } \\
\text { tubes }\end{array}$ & $\begin{array}{l}\text { Flow has both horizontal } \\
\text { and vertical components } \\
\text { allowing groundwater to } \\
\text { move laterally across the } \\
\text { south plateau before } \\
\text { moving downward into the } \\
\text { unweathered lavery till or } \\
\text { discharging to nearby } \\
\text { incised stream channels } \\
\end{array}$ & \begin{tabular}{|l|}
$5 \mathrm{E}-02 \mathrm{ft} / \mathrm{day}(2 \mathrm{E}-05$ \\
$\mathrm{cm} / \mathrm{sec})$ or 0.6 \\
$\mathrm{in} /$ day; the highest \\
conductivities are \\
associated with dense \\
fracture zones found \\
within the upper $7 \mathrm{ft}$ \\
$(2 \mathrm{~m})$ of the unit
\end{tabular} & South plateau \\
\hline $\begin{array}{l}\text { Unweathered } \\
\text { Lavery Till }\end{array}$ & $\begin{array}{l}\text { Olive gray silty clay with } \\
\text { intermittent lenses of silt } \\
\text { and sand; ranges up to } 130 \\
\mathrm{ft}(40 \text { meters) in thickness }\end{array}$ & $\begin{array}{l}\text { Flow is vertically } \\
\text { downward at a relatively } \\
\text { slow rate }\end{array}$ & $\begin{array}{l}1 \mathrm{E}-04 \mathrm{ft} / \mathrm{day} \\
(3.5 \mathrm{E}-08 \mathrm{~cm} / \mathrm{sec}) \text { or } \\
0.001 \mathrm{inches} / \text { day }\end{array}$ & $\begin{array}{l}\text { Underlies both the } \\
\text { north and south } \\
\text { plateaus }\end{array}$ \\
\hline $\begin{array}{c}\text { Kent Recessional } \\
\text { Sequence }\end{array}$ & $\begin{array}{l}\text { Interbedded clay and silty } \\
\text { clay layers locally overlain } \\
\text { by coarser-grained sands } \\
\text { and gravels }\end{array}$ & $\begin{array}{l}\text { Flows to the northeast; } \\
\text { recharge from the overlying } \\
\text { till and from bedrock to the } \\
\text { southwest; discharges into } \\
\text { Buttermilk Creek }\end{array}$ & $\begin{array}{l}2 \mathrm{E}-01 \mathrm{ft} / \text { day }(8 \mathrm{E}-05 \\
\mathrm{cm} / \mathrm{sec}) \text { or } 2.6 \mathrm{in} / \text { day }\end{array}$ & $\begin{array}{l}\text { Underlies entire } \\
\text { Project }\end{array}$ \\
\hline
\end{tabular}

$$
4-3
$$




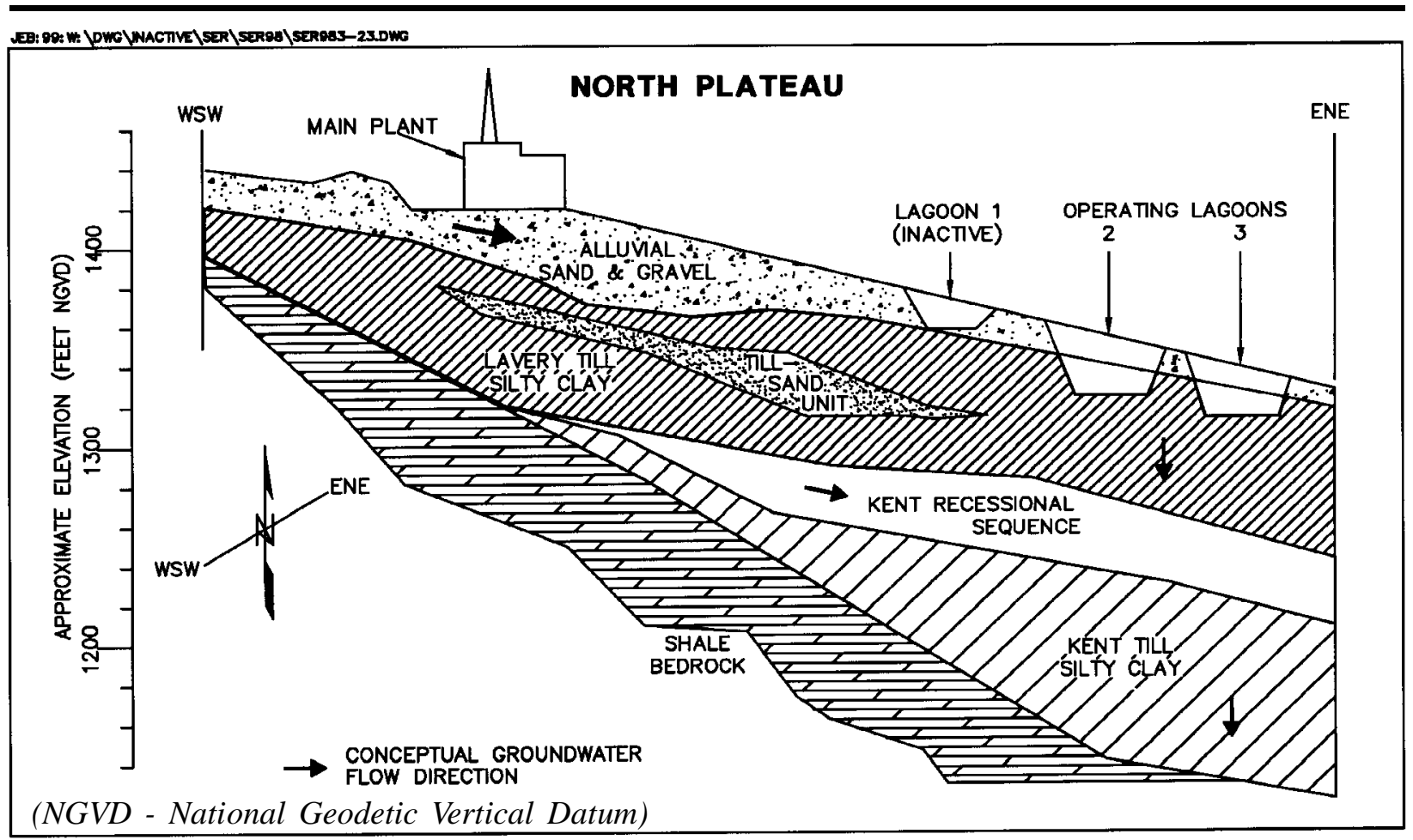

Figure 4-1. Geologic Cross Section Through the North Plateau (Vertical Exaggeration Approx. 2:1)

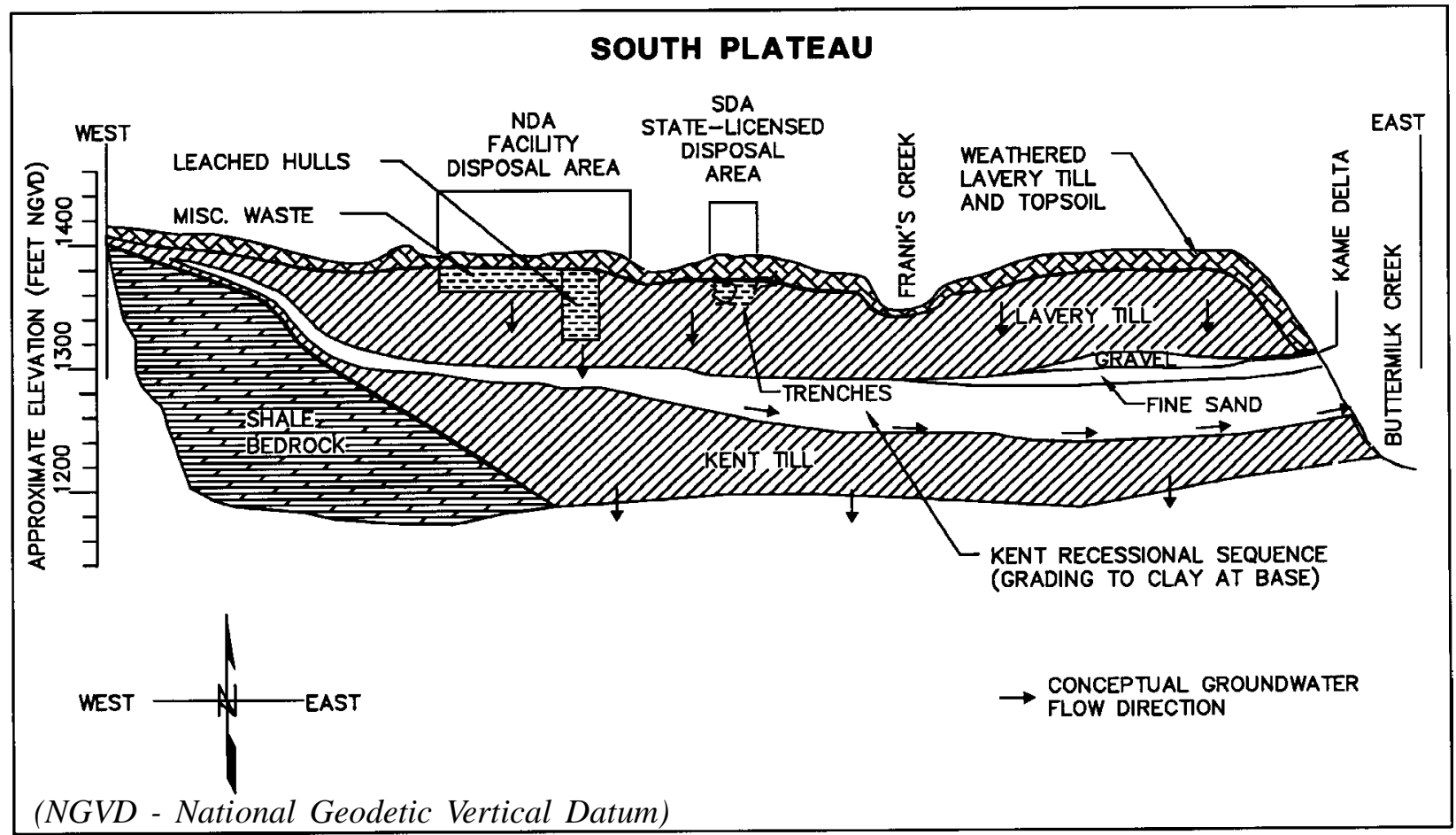

Figure 4-2. Geologic Cross Section Through the South Plateau (Vertical Exaggeration Approx. 2.5:1)

$$
4-4
$$


Table 4-2

Groundwater Monitoring Overview by Geographic Area:

Monitoring Year 2006

\begin{tabular}{|l|c|c|c|c|}
\hline \multicolumn{1}{|c|}{ Number of... } & Total WVDP & $\begin{array}{c}\text { North } \\
\text { Plateau }\end{array}$ & $\begin{array}{c}\text { South } \\
\text { Plateau }\end{array}$ & $\begin{array}{c}\text { Off-Site } \\
\text { Residential }\end{array}$ \\
\hline Monitoring Points Sampled - Analytical $^{a}$ & 79 & 54 & 15 & 10 \\
\hline Monitoring Points - Water Elevations Only & 55 & 39 & 16 & 0 \\
\hline Monitoring Events & 5 & 4 & 4 & 1 \\
\hline Analyses & 1,183 & 979 & 158 & 46 \\
\hline Results & 9,933 & 8,621 & 1,205 & 107 \\
\hline Percent of Nondetectable Results & $87 \%$ & $87 \%$ & $86 \%$ & $62 \%$ \\
\hline Water Elevation Measurements & 464 & 340 & 124 & 0 \\
\hline
\end{tabular}

${ }^{a}$ Total number includes 69 on-site monitoring points and 10 off-site monitoring points.

Table 4-3

Groundwater Monitoring Overview by Purpose:

Monitoring Year 2006

\begin{tabular}{|l|c|c|}
\hline \multicolumn{1}{|c|}{ Number of... } & $\begin{array}{c}\text { Regulatory/ } \\
\text { Waste Management }\end{array}$ & $\begin{array}{c}\text { Environmental } \\
\text { Surveillance }\end{array}$ \\
\hline Monitoring Points Sampled - Analytical ${ }^{a}$ & 34 & 45 \\
\hline Monitoring Points - Water Elevations Only & 0 & 55 \\
\hline Monitoring Events & 4 & 5 \\
\hline Analyses & 590 & 593 \\
\hline Results & 5,244 & 4,689 \\
\hline Percent of Nondetectable Results & $86 \%$ & $87 \%$ \\
\hline Water Elevation Measurements & 128 & 336 \\
\hline
\end{tabular}

NA - Not applicable

${ }^{a}$ Total number includes 69 on-site points and 10 off-site points

$$
4-5
$$


- Four new groundwater monitoring wells were installed during August 2003 to provide upgradient and downgradient monitoring coverage for the remote-handled waste facility.

- Reductions in analytes or sampling frequencies were implemented at 14 monitoring locations in early 2005 .

Groundwater is routinely monitored in the five hydrogeologic units described in Table 4-1. In 2006, a total of 69 on-site groundwater monitoring locations were sampled. These locations included 63 monitoring wells and well points, five groundwater seepage points, and one sump/manhole. Tables 4-2 and 4-3 provide an overview of groundwater monitoring during 2006 organized by geographic area and by monitoring purpose.

Monitoring Well Network. The WVDP groundwater monitoring network is a vital component of the Environment Protection Program implemented under DOE Order 450.1. Many of the routine groundwater monitoring wells were installed to monitor one or more solid waste management units (SWMUs) on the WVDP premises. (See "RCRA $\S 3008$ (h) Administrative Order on Consent" [the Consent Order] under "Resource Conservation and Recovery Act" in the "Environmental Compliance Summary.”)

Table E- $1{ }^{\text {God }}$ lists the wells in the network, sorted by the geologic unit, and the analytes measured in 2006. The frequency of monitoring and the constituents measured are a function of regulatory requirements, as well as current operating practices and historical knowledge of previous site activities. Note that monitoring of certain wells, marked by an asterisk, is specified in RFI reports prepared in accordance with the Consent Order for the WVDP.

Groundwater Elevation Monitoring. Potentiometric (water level) measurements are collected from wells in conjunction with the quarterly analytical sampling schedule (Appendix $\mathrm{E}^{\mathrm{GS}}$ ). Groundwater elevation data are used to produce groundwater contour maps that delineate flow directions and gradients. Long-term trend graphs are used to illustrate variations in groundwater elevations over time, such as seasonal fluctuations. In 2006, water levels were routinely measured in wells listed in Table E- $1^{\text {co }}$, as well as at 44 additional locations. (See Figs. A-8 through A-10 in Appendix A.)

Surface water elevation measurements are also taken at 11 locations on the north plateau where the water table in the sand and gravel unit intersects the ground surface, resulting in standing water. These measurements are correlated with groundwater elevations measured at nearby monitoring wells to provide data in areas where monitoring well coverage is sparse or nonexistent.

Analytical Trigger Level Evaluation. A computerized data-screening program uses "trigger levels" - preset conservative values for chemical and radiological concentrations and groundwater elevation measurements - to promptly identify anomalies in monitoring results that may require further investigation. The trigger levels are based on regulatory limits, detection limits, or statistically derived values.

\section{Results of Routine Groundwater Monitoring}

Sampling results for radiological and nonradiological analytes are provided in the tables in Appendix $\mathrm{E}^{\mathrm{CD}}$ grouped by hydrogeologic unit. The wells in each table or figure are arranged by hydraulic position, from upgradient to downgradient, within the same hydrogeologic unit. Wells identified as "UP" refer to either background wells or wells that are upgradient of WVDP facilities. Wells identified as "DOWN" are 
Results of Routine Groundwater Monitoring

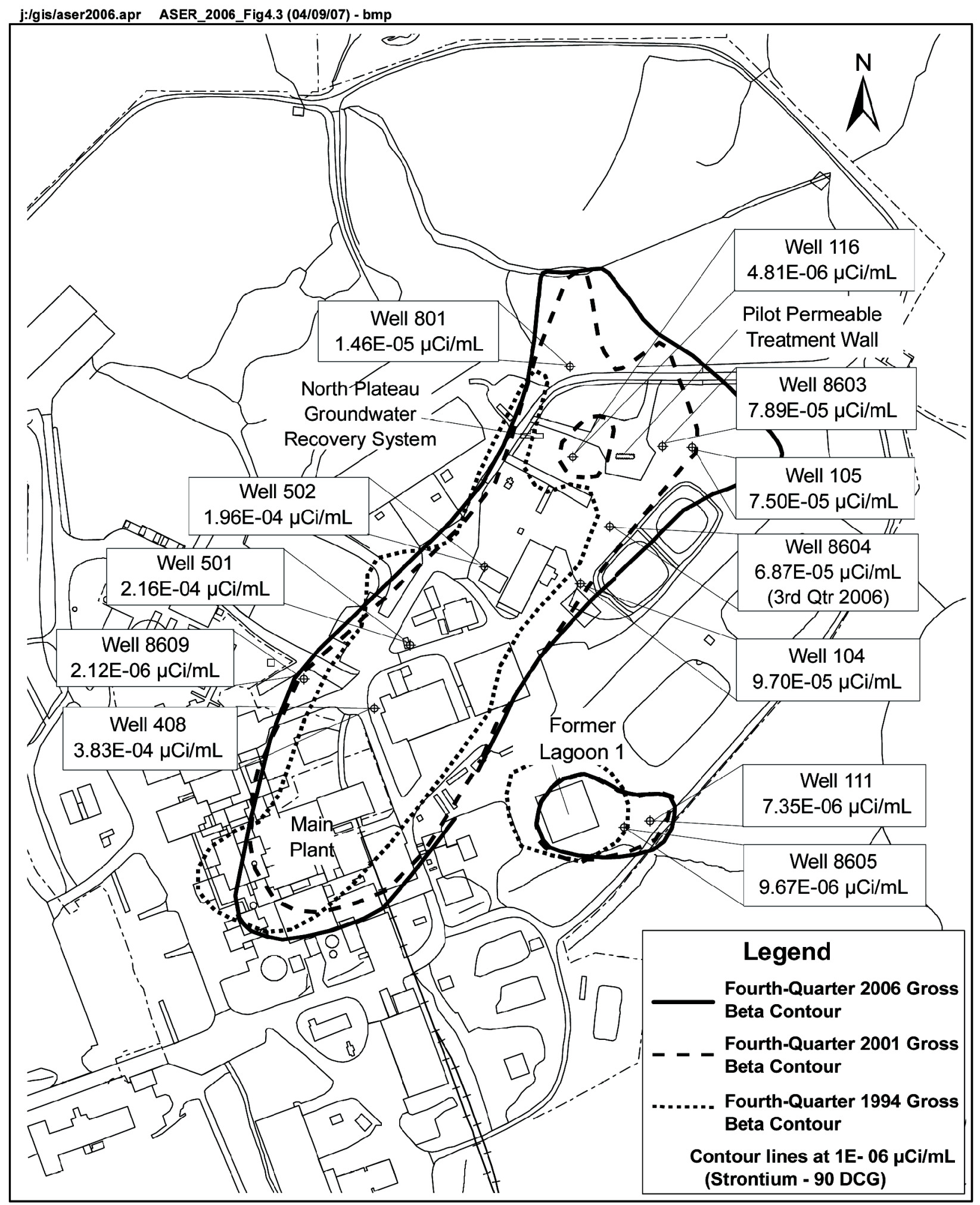

Figure 4-3. North Plateau Gross Beta Plume Area: Fourth-Quarter 2006 Results

$4-7$ 


\section{Table 4-4 \\ Maximum Concentrations For Radiological Parameters in WVDP Wells}

\begin{tabular}{|l|c|c|c|c|}
\hline \multirow{3}{*}{ Radionuclide } & \multicolumn{2}{|c|}{ Regulatory/Waste Management } & \multicolumn{2}{c|}{ Environmental Surveillance } \\
\cline { 2 - 5 } & Well ID & $\begin{array}{c}\text { Maximun } \\
\text { Concentration } \\
(\boldsymbol{\mu C i} / \mathbf{m L})\end{array}$ & Well ID & $\begin{array}{c}\text { Maximun } \\
\text { Concentration } \\
(\boldsymbol{\mu C i} / \mathbf{m L})\end{array}$ \\
\hline Gross Beta & Well 408 & $3.83 \mathrm{E}-04$ & Well 104 & $9.70 \mathrm{E}-05$ \\
\hline Strontium-90 & Well 408 & $8.55 \mathrm{E}-05$ & Well 8603 & $3.53 \mathrm{E}-05$ \\
\hline Tritium & WNNDATR & $4.27 \mathrm{E}-06$ & WP-C & $3.57 \mathrm{E}-05$ \\
\hline
\end{tabular}

downgradient of WVDP facilities. Table E- $12^{\text {(10 }}$ lists the practical quantitation limits (PQLs) for monitored organic compounds and metals.

\section{Monitoring the Sand and Gravel Unit on the North Plateau}

A total of 40 monitoring locations are routinely sampled in the sand and gravel unit on the north plateau. This total includes 32 monitoring wells, three well points, and five groundwater seepage locations. Results for all sand and gravel monitoring locations can be found in Table E- $2^{\text {Go }}$ and in Tables E- $7^{\text {GD }}$ through E-11 ${ }^{\text {co }}$. A discussion of the more relevant results is provided in the following paragraphs.

Plume on the North Plateau. Elevated gross beta activity was detected in the early 1990s in groundwater from the surficial sand and gravel unit northeast of the building where Nuclear Fuel Services, Inc. reprocessed nuclear fuel (the "Main Plant" on Fig. 4-3). In 1993, elevated gross beta concentrations were detected in surface water near the northeastern edge of the north plateau. Strontium-90 and its daughter product, yttrium-90, were identified as the major isotopic components of the gross beta activity (WVNSCO, 1995). Extensive subsurface investigations delineated the extent of the plume (Fig. 4-3), which continues to be closely monitored.
Maximum concentrations of gross beta and strontium-90 in wells are listed in Table 4-4. Gross beta activity was also detected in the area of former lagoon 1, which had been backfilled in 1984. The source of this radiological activity was presumed to be radiologically contaminated sediments from former lagoon 1.

Gross Alpha. Gross alpha concentrations in the sand and gravel unit are typically very low; most are lower than the detection level, with the exception of those from well 8605.

Low concentrations of gross alpha activity detected in groundwater from well 8605 are attributed to its location downgradient of former lagoon 1 . Historical gross alpha measurements from well 8605 of $3 \mathrm{E}-08$ microcuries per milliliter $(\mu \mathrm{Ci} / \mathrm{mL})$ or greater have been observed, but over the past two years the concentrations have remained below $1 \mathrm{E}-08 \mu \mathrm{Ci} / \mathrm{mL}$. Well 111, also located downgradient of former lagoon 1, exhibits lower gross alpha concentrations that are close to or within background levels.

Gross Beta and the Strontium-90 Plume. The strontium-90 plume extends from beneath the main plant to the northeast quadrant of the north plateau. The presumed source of the strontium- 90 activity can be traced to soils beneath the southwest corner of the main plant. Gross beta activity of ground- 
water within and around the plume continues to be monitored closely. Ten monitoring wells within the strontium-90 plume exhibit gross beta concentrations above the DOE derived concentration guide (DCG) for strontium- 90 of $1.0 \mathrm{E}-06 \mu \mathrm{Ci} / \mathrm{mL}$. (See the "Useful Information" section at the end of this report for a discussion of the DOEDCGs, and Table UI-1 for a listing of the DCGs for all radionuclides of interest at the WVDP.)

Two wells (8605 and 111) located downgradient of former lagoon 1 (identified as the source) also exhibit gross beta concentrations above the DOE DCG.

Figure 4-3, which lists gross beta results from the plume area in 2006, plots the edges of the plume area with concentrations exceeding the strontium90 DCG in 1994, 2001, and 2006. A lengthening and shifting of the contours to the northeast over time can be seen, indicating migration of the plume in conjunction with the direction of groundwater flow.

Groundwater is also monitored along the northeast edge of the north plateau where groundwater seeps from the steep banks of the stream channels incised by Erdman Brook and Frank's Creek. (See Fig. A-9 in Appendix A. See Table $\mathrm{E}-2^{\mathrm{GD}}$ for sampling results.)

Most radiological monitoring results from the north plateau seepage area do not indicate migration of the strontium- 90 plume to that distance. Gross beta concentrations from all seep monitoring locations, with the exception of SP11, were close to or within background levels during 2006. However, gross beta concentrations at SP11 have increased from 1999 through 2006 . The gross beta activity at SP11 is believed to be attributable to re-infiltration of contaminated water that has surfaced from the strontium-90 groundwater plume upgradient of this location. The levels of this gross beta activity are well below the DOE DCG for strontium-90.
Analytical results from the locations shown in Figure 4-3 are discussed below and the concentration data trends over the last ten years are displayed in Figures 4-4 through 4-7.

Figure 4-4 shows gross beta concentrations in wells $104,408,501,502$, and 8609 , which are centrally located on the north plateau within the main portion of the plume. As in previous years, groundwater from well 408 continues to exhibit the highest gross beta concentrations of all routine monitoring wells in the plume. Gross beta concentrations in well 408 and wells 104, 501, and 502 increased in 2006 as compared to 2005 , after exhibiting steady or decreasing concentrations from 2002 through 2005. The gross beta concentration in well 8609 decreased slightly in 2006 when compared with 2005, but is still relatively high in relation to the historical concentration trend since 1997.

Figure 4-5 shows gross beta concentrations in wells $105,116,801,8603$, and 8604 . These wells are located further northeast than the preceeding group of wells and are further downgradient from the plume's presumed source beneath the main plant. Groundwater from this group of wells exhibited increases in gross beta concentrations from 2005 to 2006 . Groundwater from well 105 showed the steepest increase in concentrations from 1997 through 2006.

Figure 4-6 shows gross beta concentrations at wells 111 and 8605, located downgradient of former lagoon 1. Average gross beta concentrations at these two wells have remained relatively steady over time. Concentrations in 2006 were very similar to those from 2005. (See "Evaluation of NearTerm and Long-Term Plume Management Activities" later in this chapter.)

Tritium. Essentially all sand and gravel well monitoring locations where tritium concentrations have been elevated in the past now exhibit decreasing 
trends, as shown in Figure 4-7. The presence of tritium activity on the WVDP north plateau is believed to be mainly residual (i.e., as a result of previous activities on site during the period of fuel reprocessing operations). Over time, the tritium activity has decreased as a result of radiological decay, as well as dilution from groundwater recharge and surface water infiltration. Tritium concentrations at many of these locations are currently close to or within the background range.

A small isolated area of higher tritium concentrations is found northeast of the main plant. This area is monitored by well points WP-A, WP-C, and WP-H (see Table E-2 ${ }^{\mathrm{Kg}}$ ). Historically, elevated levels of tritium have been found in groundwater from wells adjacent to or downgradient of the lagoon system and adjacent to the hardstand and lag storage areas. Well point WP-C contains the highest tritium concentrations of WVDP environmental surveillance wells (see Table 4-4). However, tritium concentrations in groundwater from all these areas are decreasing.

Tritium concentrations in the seeps along the northeast edge of the north plateau are slightly higher than levels in background wells of the sand and gravel unit. Concentrations are similar to those seen in sand and gravel unit wells monitoring the lagoon areas of the north plateau, but are still far below the DOE DCG for tritium.

\section{Results for Volatile and Semivolatile Organic} Compounds (VOCs and SVOCs). Many wells within the sand and gravel unit are monitored for VOCs and SVOCs, as required by the Consent Order, which specifies that groundwater conditions upgradient and downgradient of specific site

Table 4-5

Summary of Organic Constituents in WVDP Groundwater Wells

\begin{tabular}{|c|c|c|}
\hline \multirow{2}{*}{ Constituent } & \multicolumn{2}{|c|}{$\begin{array}{c}\text { Regulatory/Waste Management } \\
\text { Monitoring Program }\end{array}$} \\
\hline & Well With the Highest Concentration & Concentration Range $(\mu \mathrm{g} / \mathrm{L})$ \\
\hline 1,1-Dichloroethane & 8612 & $6.9-9.7^{a}$ \\
\hline 1,1,1-Trichloroethane & 8612 & $0.82-1.0^{b}$ (estimated) \\
\hline 1,2-Dichloroethylene (total) & 8612 & $21-27^{a}$ \\
\hline 1,4-Dioxane & 111 & ND-1.0 $0^{b}$ (estimated) \\
\hline Dichlorodiflouromethane & 8612 & $2.3-3.4^{b}$ (estimated) \\
\hline Ethyl benzene & 803 & ND-1.0 $0^{b}$ (estimated) \\
\hline Tributyl phosphate & 8605 & $190-280^{a}$ \\
\hline Trichloroethylene & 501 & ND-3.0 $0^{b}$ (estimated) \\
\hline Vinyl chloride & 8612 & $\mathrm{ND}-0.4^{b}$ (estimated) \\
\hline Xylene & 803 & ND-6. $7^{b}$ \\
\hline
\end{tabular}

ND - Not detected

${ }^{a}$ These values are the lowest or highest of two analytical results reported at these wells during 2006; the values calculated and reported for these wells in Table E-9 ${ }^{\text {w }}$ is the average of the replicate analyses.

${ }^{b}$ Compounds presented as "estimated" were reported at an estimated concentration less than the minimum detection limit. 
SWMUs be monitored. Monitoring at additional wells is used to establish background and upgradient conditions within unaffected areas of the unit, or to monitor conditions downgradient of locations where positive detections of VOCs and/ or SVOCs are currently or have previously been reported.

Currently, the only sand and gravel monitoring location with consistent positive detections of VOCs is well 8612, located northeast of the closed construction and demolition debris landfill (CDDL) at the northeast edge of the north plateau. (See Figure A- 8 and Table E- $8^{\text {(DD }}$.) The presence of VOCs in this area is presumed to be the result of wastes buried in the CDDL. In the past, VOCs were repeatedly detected at a few additional monitoring locations, such as wells 803 and 8609 and seepage monitoring locations GSEEP and SP12 (see Table E- ${ }^{\mathrm{CD}}$ ), but recent analytical results from these monitoring locations have not detected those VOCs. In fact, VOCs have not been positively detected at GSEEP since 1993, or at SP12 since 2002, so these monitoring locations are no longer included in the graphs in this chapter. (See Tables E- $8^{\mathrm{CD}}$ and E-9 ${ }^{\mathrm{CD}}$ for 2006 sampling results and Table E-12 ${ }^{\text {GD }}$ for a list of sampled analytes.) With the exception of the analytes in wells 8612 and a detection of xylene in well 803 during one sampling event in 2006, no VOCs have been detected. The range of organic compounds in selected groundwater monitoring wells showing the maximum concentration is presented in Table 4-5.

\section{1,1-Dichloroethane (1,1-DCA). Concentrations} of 1,1-DCA at well 8612 decreased rather steeply from 1995 through 2006 (Fig. 4-8). The compound was not detected at wells 8609,803 , or groundwater seeps GSEEP or SP12 during 2006.

1,1,1-Trichloroethane (1,1,1-TCA). The compound 1,1,1-TCA was detected in well 8612 during 2006 at estimated levels below the PQL (Fig.
4-8), but was not detected in well 803, 8609, or in seep monitoring locations GSEEP or SP12.

Total 1,2-Dichloroethylene (1,2-DCE-t). Positive concentrations of 1,2-DCE-t were first detected at well 8612 in 1995. Concentrations of 1,2-DCE-t increased from 1995 through 2002, but showed an overall decrease from 2002 through 2006 (Fig. 4-8).

Dichlorodifluoromethane (DCDFMeth). DCDFMeth was detected at well 8612 during 2006 at relatively low concentrations near or below the PQL (Fig. 4-8), but was not detected in wells 803, 8609 , or seep monitoring locations GSEEP or SP12.

Other VOCs historically detected at one or more of these monitoring locations, such as trans-1,2dichloroethylene (t-12-dce) and trichloroethylene, were not detected in 2006.

The VOCs 1,1-DCA, DCDFMeth, and 1,1,1-TCA are often found in combination with 1,2-DCE-t. In well 8612, each compound first exhibited an increasing trend that, after several years, was followed by a long-term decreasing trend. It is expected that 1,2-DCE-t will exhibit similar behavior, as indicated by its generally decreasing trend in recent years.

Tributyl Phosphate (TBP). Concentrations of TBP were detected in 2006 groundwater samples from well 8605, near former lagoon 1 , at concentrations slightly lower than in 2005 and almost onehalf of those in 2004. TBP also was previously detected in well 111, located near well 8605, but at levels much lower than those at well 8605 . During 2006, TBP was detected at well 111 at concentrations similar to those reported in 2005. Since 2001, TBP concentrations at well 111 have been fluctuating near the PQL of $10 \mu \mathrm{g} / \mathrm{L}$. The range of concentrations reported in well 8605 is shown in Table 4-5. Analytical results for SVOCs at other monitoring locations remain nondetectable. 
Ongoing detection of TBP in this localized area may be related to previously detected concentrations of iodine-129 and uranium-232 in wells 111 and 8605, as noted in previous Annual Site Environmental Reports. The presence of these contaminants may reflect residual contamination from liquid waste management activities in the former lagoon 1 area during earlier nuclear fuel reprocessing.

Additional monitoring locations are sampled for VOCs and/or SVOCs because they are downgradient of locations that have shown positive results or to comply with the Consent Order. No VOCs or SVOCs have been detected at these locations.

North Plateau Groundwater Recovery System. In 1995, the north plateau groundwater recovery system (NPGRS) was installed to minimize the advance of the gross beta plume. (See Figure 4-3.) The NPGRS consists of three wells that extract contaminated groundwater, which is then treated by ion exchange to remove strontium- 90 . Treated water is transferred to the lagoon system and is ultimately discharged to Erdman Brook.

The NPGRS operated throughout 2006, processing about 3.31 million gallons (gal) (12.5 million liters [L]) of water. The system has recovered and processed approximately 46 million gal (176 million L) since November 1995.

Permeable Treatment Wall. A pilot-scale permeable treatment wall (PTW) was constructed in 1999 in the sand and gravel unit within the eastern lobe of the north plateau plume to test this passive, in-situ remediation technology. The PTW is a trench that is backfilled with clinoptilolite, a medium selected for its ability to adsorb strontium-90 ions from groundwater. Continued monitoring indicates that strontium-90 concentrations are lower in wells within the PTW, indicating that strontium90 is being removed from the water that passes through the wall. However, the plume has since encircled and migrated past the PTW test area. The complex geology that exists in the vicinity of the pilot PTW is believed to affect the performance of the wall, and the wall itself may be affecting the pattern of groundwater flow in the plume area. Sufficient data have been obtained to determine the effectiveness of the PTW technology.

Northeast Swamp Drainage Monitoring. Routine radiological sampling continued during 2006 at surface water location WNSWAMP (Appendix C$4^{\mathrm{GD}}$. While gross beta and strontium- 90 concentrations continued to fluctuate due to seasonal effects, the annualized average exceeded the DOE DCG during all of CY 2006 (Fig. 4-10). The main source of the elevated strontium- 90 is groundwater from the north plateau plume seeping into a ditch upstream of WNSWAMP. (See Figure 4-3 in this Chapter and Figure A-2 in Appendix A.) An estimated 48 million gal (180 million L) of water flowed through this monitoring point during 2006.

The annualized average concentration of strontium-90 in surface water at sampling location WNSWAMP (on the WVDP premises) remained elevated with respect to background. Even so, monitoring downstream at the first point of public access in Cattaraugus Creek, Felton Bridge (location code WFFELBR), continued to show gross beta concentrations that were only slightly higher than those at the Cattaraugus Creek background location at Bigelow Bridge (WFBIGBR). (See also "Northeast Swamp and North Swamp Drainage" in Chapter 2.)

North Plateau Characterization. In late 2006, the DOE submitted to the New York State Department of Environmental Conservation a draft "Sampling and Analysis Plan for Characterization of the North Plateau Plume Area" and a draft "Sampling Plan for Background Subsurface Soil Data on the North Plateau." These plans propose 
additional sampling to further characterize and evaluate the north plateau strontium-90 plume area.

\section{Evaluation of Near-Term and Long-Term} Plume Management Activities. Alternatives for management of the plume are currently being evaluated. Groundwater monitoring data are being used to evaluate the current conditions of the plume and to model the future plume configuration under differing near-term and long-term scenarios.

Near-term strategies are focused on ways to reduce migration of the downgradient leading edges of the plume, thereby minimizing expansion beyond its current mapped limits and migration into downgradient surface water and seepage points. The proposed management strategies may include implementation of permeable reactive barrier technology, hydraulic barriers such as an interceptor trench, groundwater extraction wells, or a combination of these technologies in various configurations. The implementation of the near-term plume management strategy is integral to the Enhanced Interim End State objective for the WVDP, to manage and minimize off-site contamination while the WVDP Environmental Impact Statement (EIS) is finalized.

Long-term strategies are those that will include the entire plume, with the objective of long-term management and/or remediation. The objective is to contain the plume within its current boundaries so that it can be effectively removed and/or allowed to decay in-place within the WVDP premises. These strategies will be integrated with the near-term plume management options and will be evaluated in the WVDP EIS.

\section{Monitoring on the South Plateau: Weathered Lavery Till and the NDA}

In 1990, a trench system was constructed along the northeast and northwest sides of the NDA to collect groundwater that may be contaminated with a mixture of n-dodecane and TBP. (See also "Nuclear Regulatory Commission-Licensed Disposal Area [NDA] Interceptor Trench and Pretreatment System" in Chapter 1.) Monitoring results in 2006 indicated no n-dodecane or TBP in groundwater near the NDA. Groundwater elevations are monitored quarterly in and around the trench to ensure that an inward gradient is maintained, thereby minimizing outward migration of potentially contaminated groundwater.

WNNDATR and Well 909. Gross beta and tritium concentrations in groundwater from sampling location WNNDATR, a sump at the lowest point of the interceptor trench, and from well 909, downgradient of WNNDATR (Fig. A-8 in Appen$\operatorname{dix} \mathrm{A})$, continued to be elevated with respect to background monitoring locations on the south plateau. WNNDATR contained the highest tritium concentrations reported of the WVDP regulatory compliance groundwater monitoring locations (see Table 4-4). Concentrations were still well below the DOE DCG for tritium.

During 2006, tritium concentrations at WNNDATR were similar to those in 2005, but overall have decreased since 1994. In contrast, gross beta concentrations have increased with time, with even steeper increases observed during 2005 and 2006. Residual activity from historical site operations in the NDA is the presumed source of this gross beta activity. Currently, groundwater passing through the NDA is collected at WNNDATR and is transferred to the low-level waste treatment facility for processing. Interim measures are being planned for the NDA to curb the migration of groundwater at the NDA.

Radiological indicator results at well 909 showed increasing gross beta and tritium concentrations until 1999, when concentrations of both declined. Values have stabilized over the last few years. 
Residual soil contamination near well 909 is thought to be the source of the gross beta activity.

In 2006, methods for reducing infiltration of water into the NDA were considered by the DOE. As of early 2007, plans are underway for placing a geomembrane cap on the NDA, building a slurry wall upgradient of the NDA, as well as constructing a system for diverting groundwater and surface water away from the NDA. (See the "NRC-Licensed Disposal Area [NDA]" section in the "Environmental Compliance Summary.")

\section{Additional Monitoring and Investigations}

Results of Radioisotopic Sampling. Groundwater samples for radioisotopic analyses are collected regularly from selected monitoring points in the sand and gravel unit and the weathered Lavery till (Table E-11 ${ }^{\text {Ge }}$. Strontium-90 concentrations were found to be elevated in monitoring wells in the north plateau plume area, as discussed earlier in this chapter, and also downgradient of the NDA on the south plateau. Concentrations of other radioisotopic analytes remained similar to previous historical results. Most analyses found no detectable concentrations of the other radionuclides.

Historical monitoring and special investigations have detected carbon-14, technetium-99, and iodine-129 at a few locations. One or more of these isotopes have been detected in the sand and gravel unit at wells within the gross beta plume (wells 408,501 , and 502), downgradient of former lagoon 1 (wells 111 and 8605) or in the weathered Lavery till downgradient of the NDA (well 909).

When detected, the nuclides were found at low percentages of their DCGs and they accounted for only a small portion of the gross beta concentrations. Frequent gross beta monitoring provides sufficient surveillance to identify trends in major gross beta constituents. Periodic radioisotopic analyses are effective in tracking those nuclides that contribute only a small fraction of the gross beta activity.

North Plateau Groundwater Quality Early Warning Monitoring. Early-warning monitoring of water recovered by the NPGRS is performed because this water is ultimately discharged offsite via the New York State Pollutant Discharge Elimination System (SPDES)-permitted outfall 001. Semiannual monitoring results from well 502, located directly upgradient of the NPGRS, can be used to identify metals concentrations in groundwater that may affect compliance with the SPDES-permitted effluent limits. Results of sampling for metals at well 502 can be found in Tables E- $7^{\mathrm{GD}}$ and E- $10^{\mathrm{GD}}$.

Investigation of Chromium and Nickel in the Sand and Gravel Unit and Evaluation of Corrosion in Groundwater Monitoring Wells. A 1997 and 1998 study of the effect of modifying sampling equipment and methodology on concentrations of chromium and nickel in groundwater samples from the sand and gravel unit noted that such modifications produced decreases in these concentrations. This finding supported the hypothesis (which is documented in the technical literature) that elevated concentrations were not representative of actual groundwater conditions, but were caused by release of metals from subsurface corrosion of stainless-steel well materials (WVNSCO and Dames \& Moore, June 1998).

To ensure that the integrity of the monitoring wells is maintained, and to ensure that high-quality samples representative of actual groundwater conditions are collected, wells are periodically inspected for corrosion. Approximately threefourths of the stainless-steel wells monitoring the sand and gravel unit were internally inspected for corrosion during 2001. At that time, wells with cor- 
rosion were cleaned and reinspected to verify that corrosion had been removed. Wells suspected of containing corrosion will be inspected in 2007.

Fuel Receiving and Storage (FRS) Pool Water Infiltration. During mid-2005, water was found trickling into the empty FRS pool during a quarterly inspection. The water had accumulated to approximately four to six inches. The water is directed by a slope in the floor to the deeper stainless-steel-lined cask unloading pool (CUP). Analytical data for the FRS CUP water indicate that groundwater seepage is the source of the water. During periods of high precipitation or snow melt, slight seepage has entered along the south wall. The elevated cesium-137 concentrations are believed to be from residuals that adhered to the FRS walls when the pool was full. Groundwater seeping into the pool is thought to have dissolved some of the cesium. Since the water does not pose operational or safety concerns, it has been left in the CUP under routine monitoring. Currently, the water level in the CUP is measured by facility operators daily.

Off-Site Groundwater Monitoring. Groundwater is used as a potable water supply at off-site private residences near the WVDP. Groundwater samples are collected routinely from nine offsite residential supply wells that represent the closest unrestricted use of groundwater near the Project. Wells are located within 4.3 miles (7 kilometers $[\mathrm{km}]$ ) of the facility. One additional well, located 18 miles $(29 \mathrm{~km})$ south of the site, is used for background purposes. None of the wells draw from groundwater units that underly the site. Additional information is provided in "Drinking Water Monitoring" in Chapter 2. 


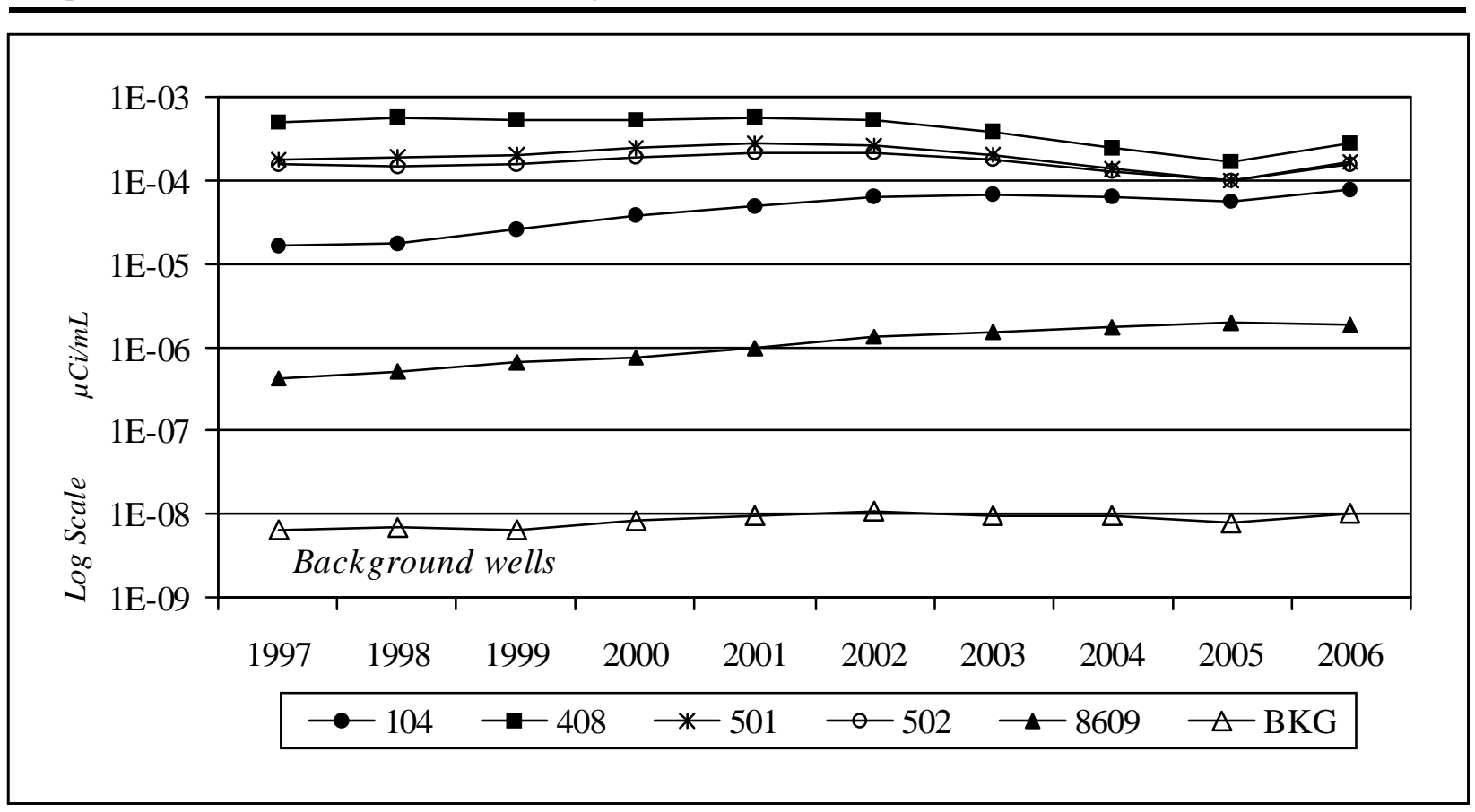

Figure 4-4. Average Annual Gross Beta Concentrations at Locations Closer to the Source of the North Plateau Plume

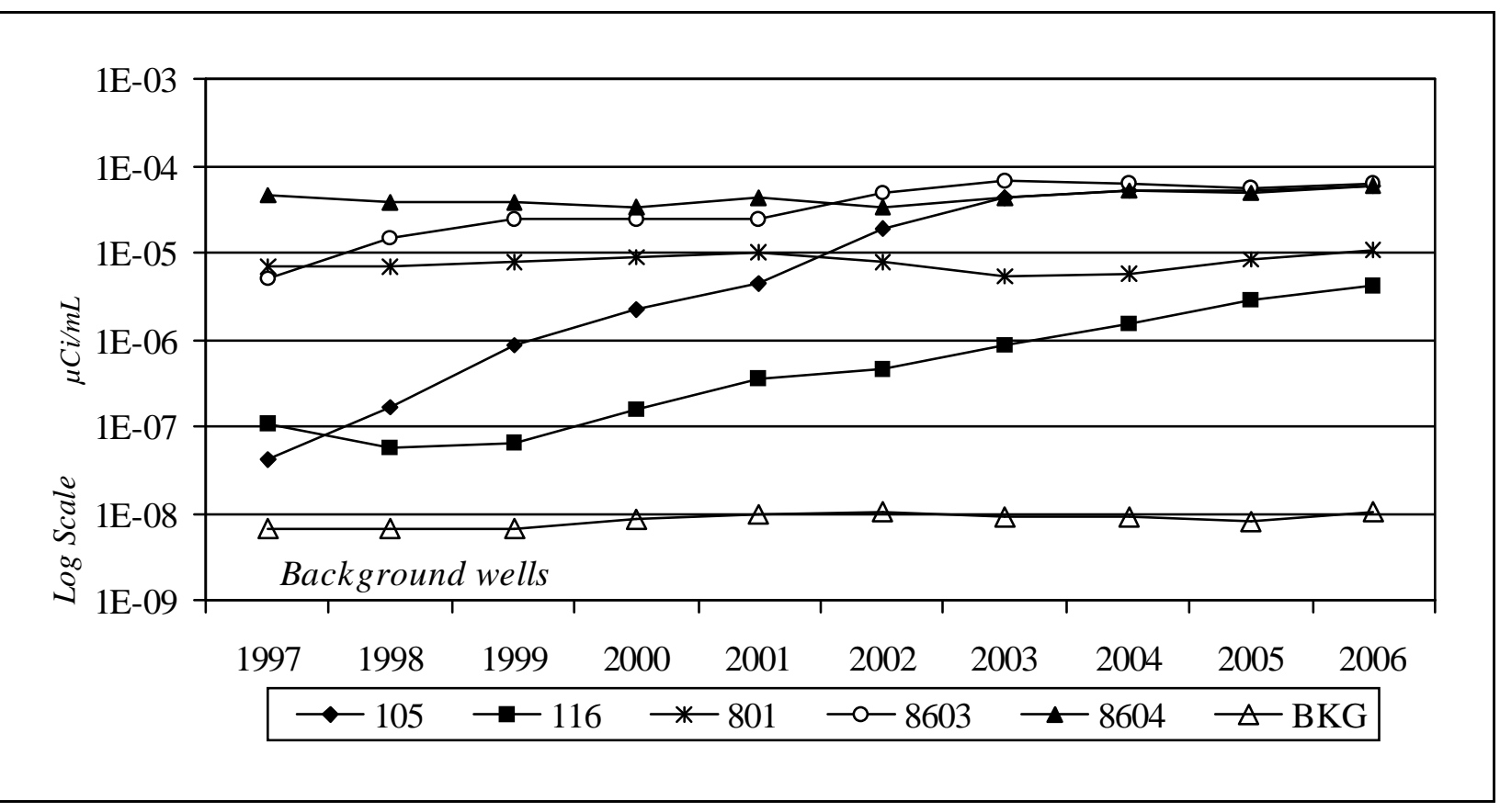

Figure 4-5. Average Annual Gross Beta Concentrations at Locations Closer to the Leading Edges of the North Plateau Plume 


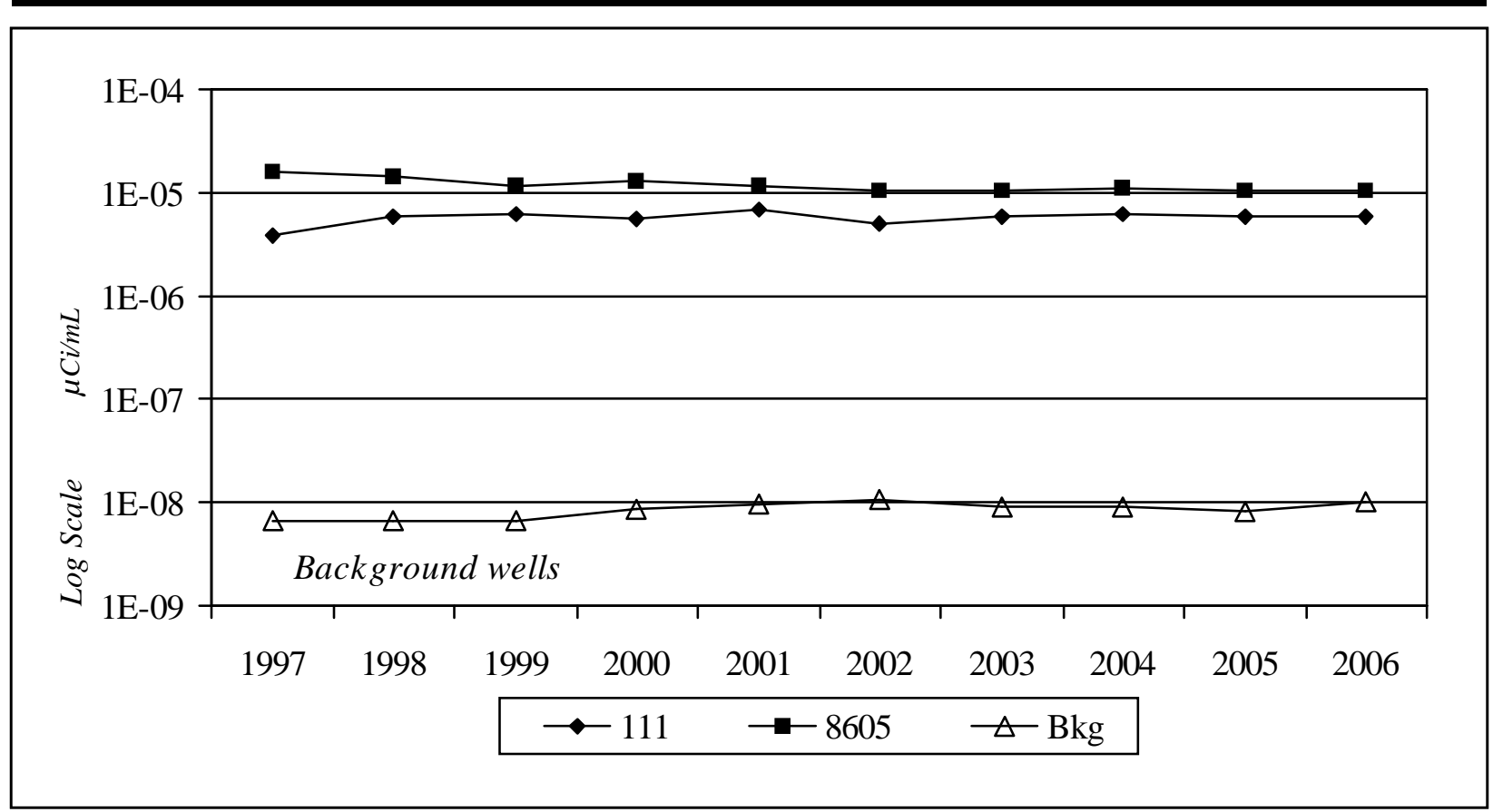

Figure 4-6. Average Annual Gross Beta Concentrations at Locations Near Former Lagoon 1

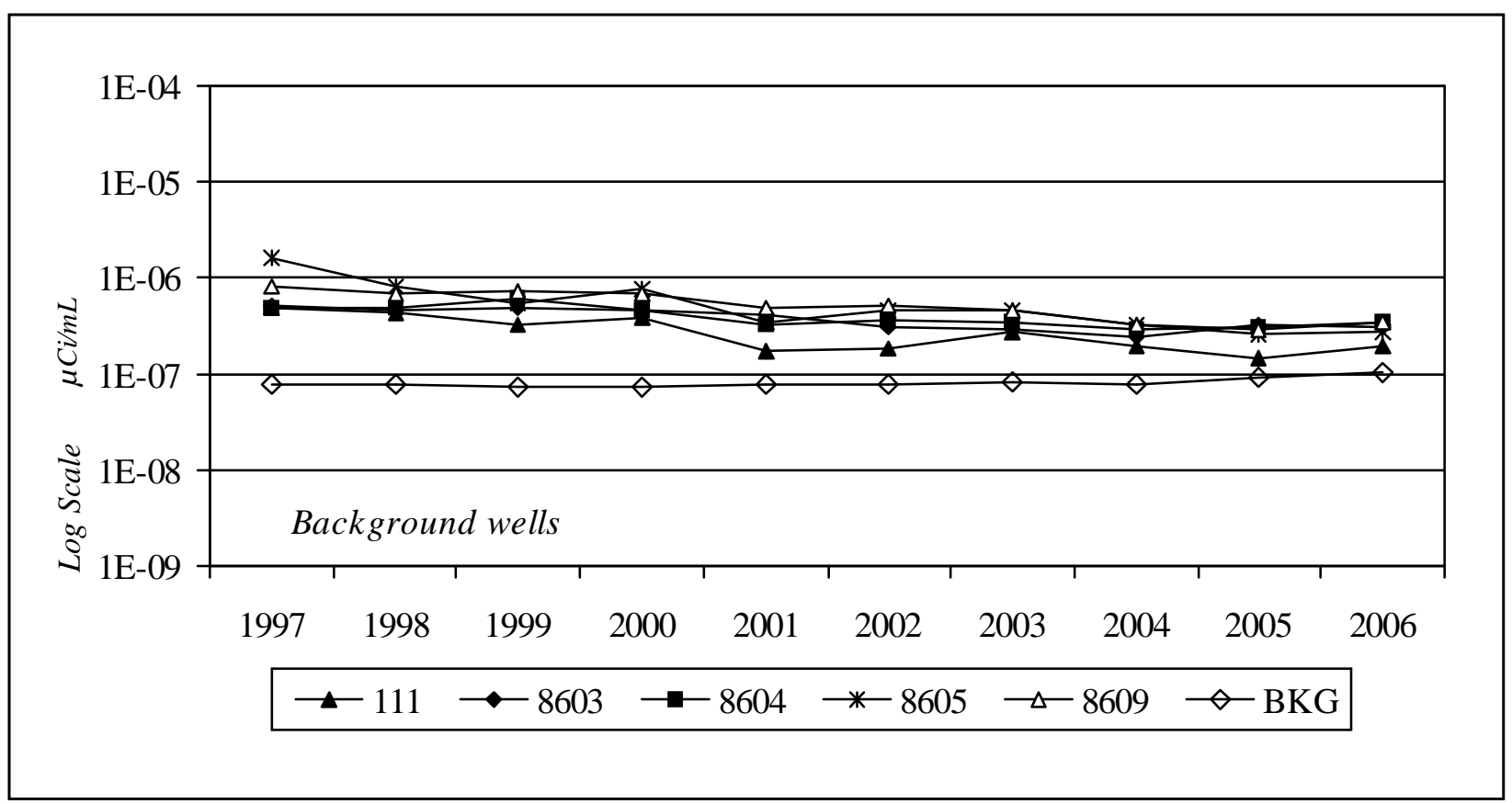

Figure 4-7. Average Annual Tritium Concentrations at Selected Locations in the Sand and Gravel Unit 


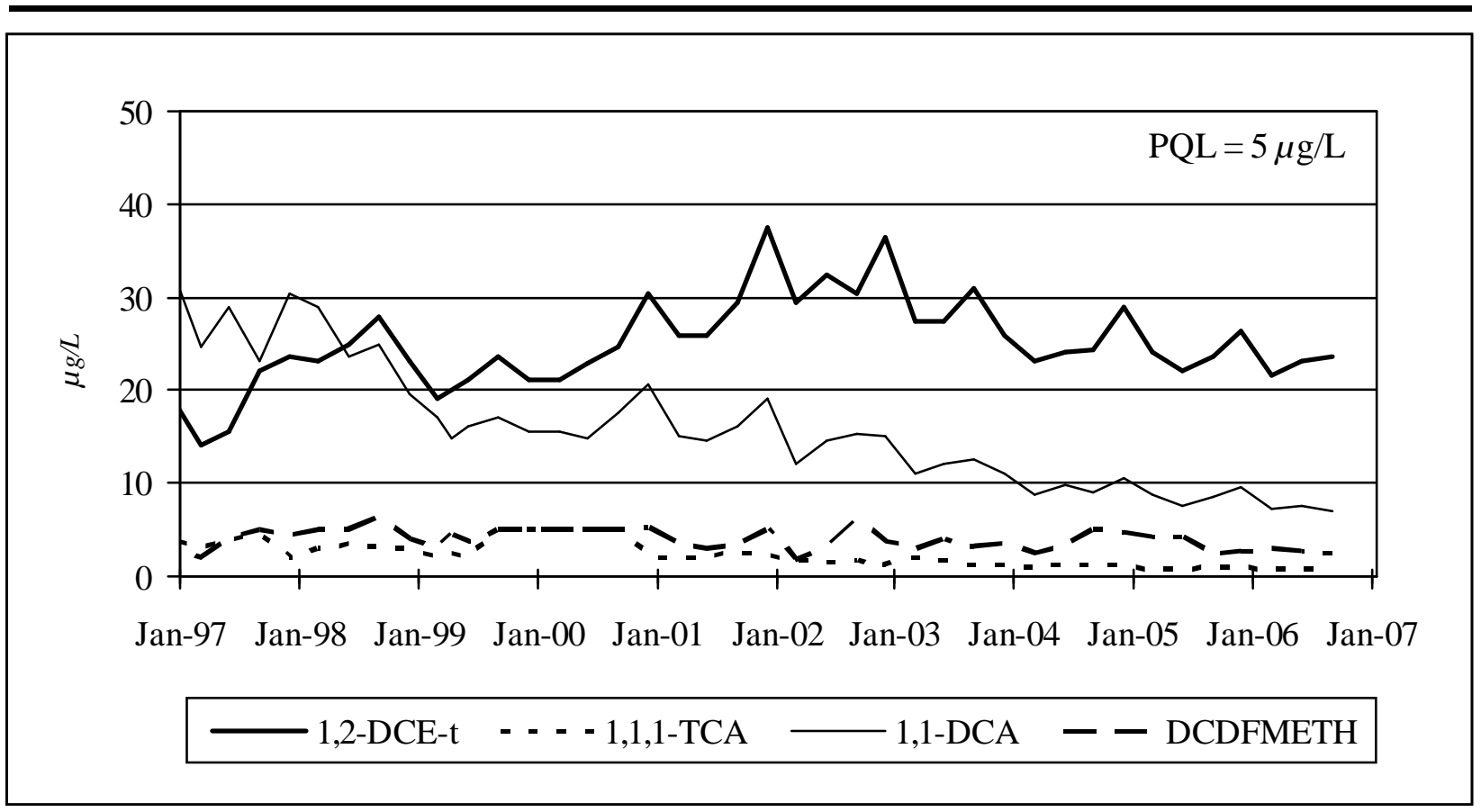

Figure 4-8. Concentrations of 1,2-DCE-t, 1,1,1-TCA, 1,1-DCA, and DCDFMeth at Well 8612 in the Sand and Gravel Unit

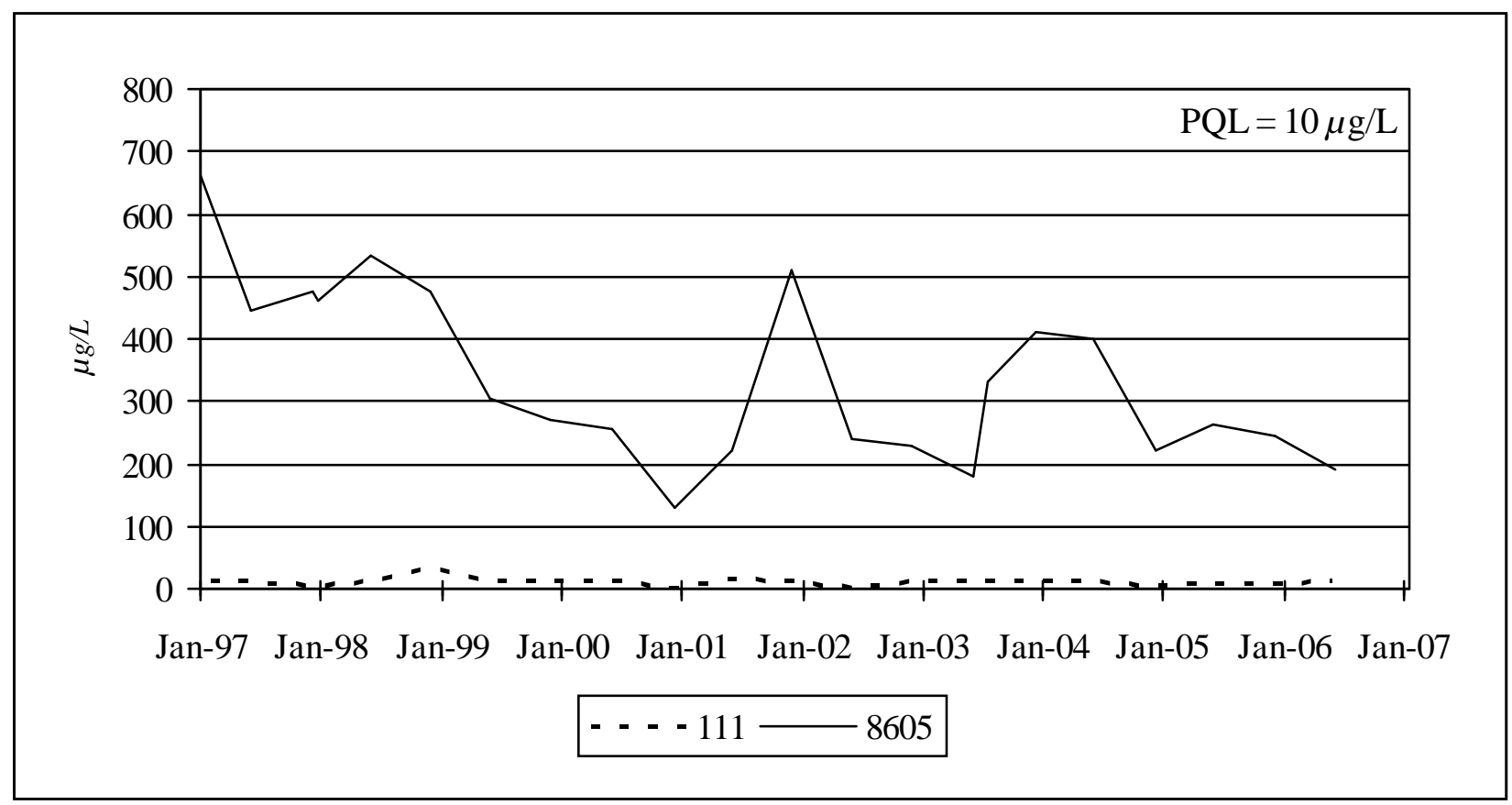

Figure 4-9. Concentrations of Tributyl Phosphate at Selected Locations in the Sand and Gravel Unit 


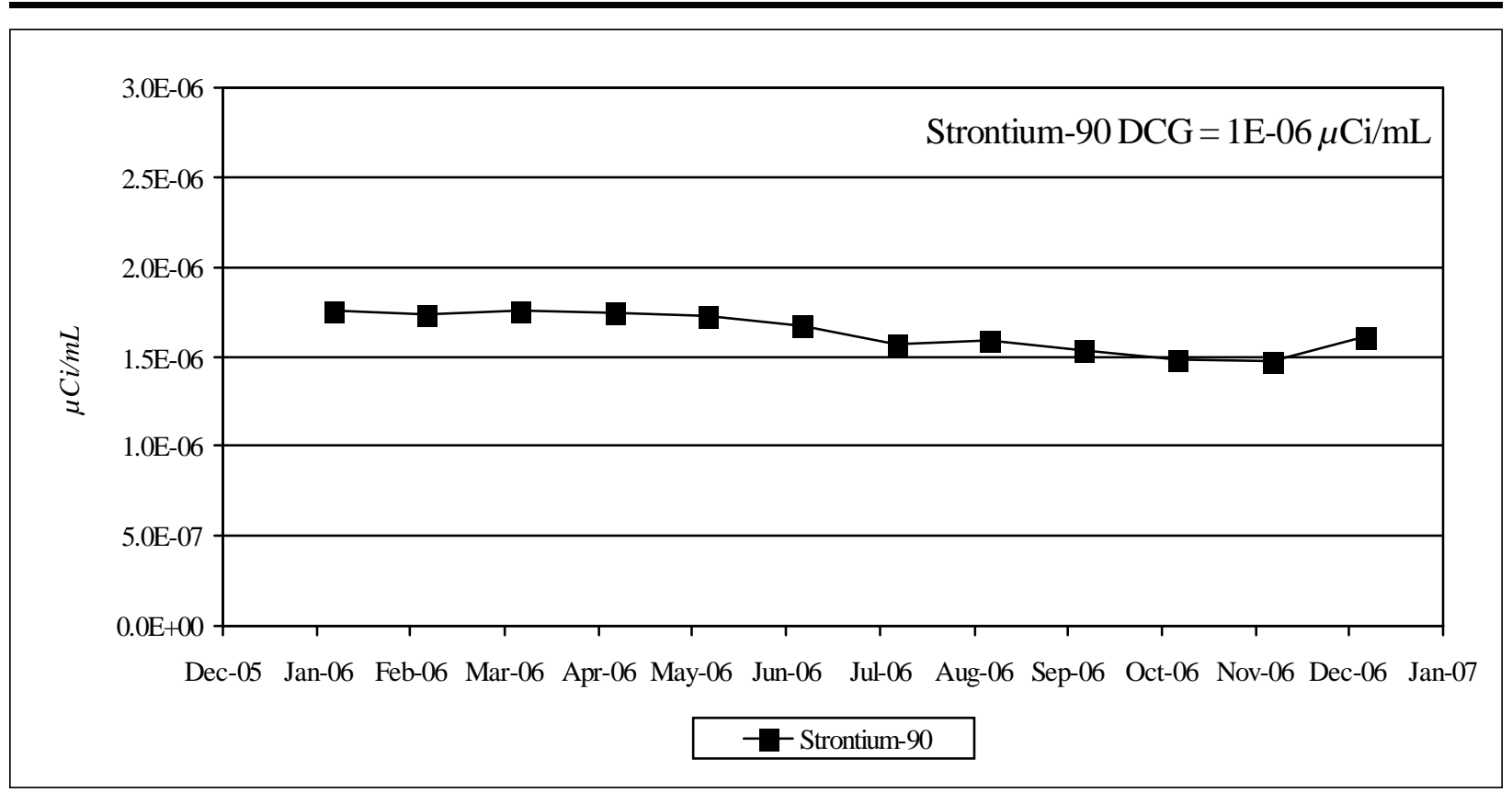

Figure 4-10. Annualized Average Strontium-90 Concentrations at WNSWAMP

Note: DCGs are used as an evaluation tool for results from on-site locations as part of the routine environmental monitoring program. However, DOE DCGs are applicable only at locations where members of the public could be exposed to water containing contaminants, that is, locations outside of the site boundary.

$$
4-19
$$


This page intentionally left blank

$4-20$ 


\section{QUALITY ASSURANCE}

\section{Quality Assurance Program}

The quality assurance (QA) program at the West Valley Demonstration Project (WVDP or Project) provides for and documents consistency, precision, and accuracy in collecting and analyzing environmental samples and in interpreting and reporting environmental monitoring data. West Valley Nuclear Services Co. (WVNSCO), by contract with the United States Department of Energy (DOE), implements the QA program at the WVDP. Subcontractor laboratories providing analytical services for the environmental monitoring program are contractually required to maintain a QA program consistent with WVNSCO requirements.

The quality requirements of Title 10 Code of Federal Regulations Part 830, Subpart A, "Quality Assurance Requirements," Section 830.122, "Quality Assurance Criteria," and DOE Order 414.1A, "Quality Assurance" (DOE, 1999), provide the QA program policies and requirements applicable to activities at the WVDP. The WVDP QA program serves as an implementation process for meeting the DOE Order 450.1 requirement to provide "a consistent system for collecting, assessing, and documenting environmental data of known and documented quality." The integrated QA program also incorporates the requirements from the con- sensus standard "Quality Assurance Program Requirements for Nuclear Facilities" (American Society of Mechanical Engineers NQA-1, 1989). Controlled documents specific to the WVDP are used to implement the integrated QA program. General areas addressed by the QA program include the following:

Responsibility. Responsibilities for overseeing, managing, and conducting an activity must be clearly defined. Personnel who verify that an activity has been completed correctly must be independent of those who performed it. Managers of programs, projects, and tasks at the WVDP are responsible for ensuring that QA requirements applicable to activities under their cognizance are implemented.

Planning. Work activities must be planned beforehand, the plan followed, and activities documented. Purchases of quality-affecting equipment or items must be planned, specified precisely, and verified for correctness upon receipt.

Training. Anyone performing an activity in support of the WVDP environmental monitoring program must be trained in the appropriate procedures and qualified accordingly before carrying out the activity. 
Control of Design, Procedures, Items, and Documents. Any activity, equipment, or construction must be clearly described or defined and tested. Changes in the design must be tested and documented. Procedures must clearly state how activities will be conducted. New procedures must be developed each time an activity is added to the monitoring program. Procedures are reviewed periodically, updated when necessary, and are controlled so that only approved and current procedures are used.

Equipment or particular items affecting the quality of environmental data must be identified, inspected, calibrated, and tested before use. Calibration status must be clearly indicated. Items that do not conform to requirements must be identified as nonconforming and segregated so as to prevent inadvertent use.

Corrective Action. Conditions adverse to quality must be promptly identified, a corrective action planned, responsibility assigned, and the problem remedied.

Documentation. Records of all activities must be kept to verify what was done and by whom. Records must be clearly traceable to an item or activity. Records such as field data sheets, chainof-custody forms, requests for analysis, sample shipping documents, sample logs, data packages, training records, and weather measurements, in addition to other records in both paper and electronic form, are maintained as documentation for the environmental monitoring program.

Audits and Assessments. Audits and assessments must be conducted to verify compliance with all aspects of the QA program and to determine its effectiveness. The WVDP environmental monitoring program is subjected to audits by external agencies and to internal management and self-assessments.

\section{Quality Control}

More than 8,000 environmental samples were collected and analyzed in 2006 as part of the WVDP environmental monitoring program. Quality control (QC), an integral part of QA, is used to ensure that samples are collected and analyzed in a consistent and repeatable manner. QC methods are applied both in the field and in the laboratory.

Field QC. Procedures are defined for collecting each type of sample, such as surface water, groundwater, soil, and air. Trained Environmental Laboratory (ELAB) field personnel collect the samples. Field sampling locations are clearly marked to ensure that routine samples are collected in the same location each time. Collection equipment that remains in the field is routinely inspected, calibrated, and maintained, and automated sampling stations are kept locked to prevent tampering. Samples are collected into certified precleaned containers of an appropriate material and capacity. Containers are labeled with information about the sample, such as date and time of collection, sample collection personnel, and special field conditions. Collection information is documented and kept as part of the sample record.

Chain-of-custody documentation is maintained so as to trace sample possession from time of collection through analysis. Samples are stored in a lockup before analysis or shipping. Samples sent off site for analysis are accompanied by an additional chain-of-custody form. Subcontract laboratories are required by contract to maintain internal chain-of-custody records and to store the samples under secure conditions.

Special field QC samples are collected and analyzed to assess the sampling process. Duplicate field samples are used to assess sample homogeneity and sampling precision. Field and trip blanks (laboratory-deionized water in sample containers) 
are used to detect contamination potentially introduced during sampling or shipping. Environmental background samples (samples of air, water, vegetation, venison, and milk taken from locations remote from the WVDP) are collected and analyzed to provide baseline information for comparison with on-site or near-site samples so that site influences can be evaluated.

Laboratory QC. In 2006, environmental monitoring samples were analyzed at several on-site and off-site laboratories. On-site analyses were conducted by the ELAB (radiological indicator parameters, gamma spectroscopy, and field $\mathrm{pH}$ and conductivity), the Wastewater Treatment Facility Laboratory (total residual chlorine, $\mathrm{pH}$, and settleable solids), and the Analytical and Process Chemistry Laboratory (A\&PC, total dissolved solids). In 2006, laboratories at the WVDP were reorganized and the A\&PC was placed under ELAB cognizance.

In 2006, the combined ELAB and former A\&PC facilities, operated by URS Corporation, became certified by the New York State Department of Health (NYSDOH) for gross alpha, gross beta, tritium, and gamma spectroscopy analyses in potable and nonpotable water.

Off-site analyses were performed by General Engineering Laboratories (GEL, in Charleston, South Carolina) for multimedia radiochemical parameters and chemical parameters, including low-level mercury; Severn Trent Laboratories (STL, in Buffalo, New York) for chemical analyses; Lionville Laboratory, Inc. (LVLI, in Lionville, Pennsylvania) for chemical analysis of radiologically contaminated samples; and Bechtel BWXT Idaho, LLC (at the Idaho National Laboratory) for environmental thermoluminescent dosimeters. Subcontract laboratories are required to maintain all relevant certifications, participate in applicable crosscheck programs, and maintain a level of QC as defined in their contracts with WVNSCO.

To achieve and maintain certification to analyze environmental samples from the state of New York, both on-site and subcontract analytical laboratories are required to demonstrate evidence of satisfactory performance on samples provided by the NYSDOH Environmental Laboratory Approval Program (ELAP).

Laboratory QC practices specific to each analytical method are described in approved references or procedures. QC practices include proper training of analysts, maintaining and calibrating measuring equipment and instrumentation, and routinely processing laboratory QC samples such as standards and spikes (to assess method accuracy), duplicates and replicates (to assess precision), and blanks (to assess the possibility of contamination). Standard reference materials (materials with known quantities or concentrations of constituents of interest) traceable to the National Institute of Standards and Technology are used to calibrate counting and test instruments and to monitor their performance.

In 2006, problems with analytical QC during analysis of WVDP fish samples resulted in a determination that much of the strontium-90 data was unreliable. Therefore, only partial strontium-90 data were reported for fish collected in calendar year 2006. This evaluation was based upon low recoveries for laboratory control samples. Corrective actions were identified and implemented at the vendor laboratory to prevent recurrence of this problem in the future.

Independent Comparisons and Crosschecks. To allow for independent confirmation of environmental monitoring data, samples of air filters, water, milk, fish, vegetation, and sediments are split 
or separately collected from the same location and sent to NYSDOH for measurement and independent reporting to the public. Locations at which co-located samples are taken are listed in Appen$\operatorname{dix} \mathrm{B}^{\mathrm{GD}}$ of this report.

Crosscheck samples (performance evaluation samples) contain a quantity or concentration of a constituent of interest known to the agency conducting the crosscheck, but unknown to the participating laboratory. Crosscheck programs provide an additional means of testing accuracy of environmental measurements. Subcontract laboratories are required to perform satisfactorily on crosschecks, with satisfactory performance defined as having at least $80 \%$ of reported results falling within control limits. Crosscheck results that fall outside of control limits are addressed by formal corrective actions to determine any conditions that could adversely affect sample data and to ensure that actual sample results are reliable.

The WVDP participates in formal crosscheck programs for both radiological and nonradiological analyses.

Radiological Crosschecks. Organizations performing radiological analyses as part of effluent or environmental monitoring are encouraged by the DOE to participate in formal crosscheck programs to test the quality of environmental measurements being reported to the DOE by its contractors. Crosscheck samples for radiological constituents are analyzed on site by the ELAB and off site by GEL.

In 2006, the WVDP participated in the DOE Radiological Environmental Sciences Laboratory Mixed Analyte Performance Evaluation Program (MAPEP). Results are listed in Appendix $\mathrm{J}^{\mathrm{GD}}$. A total of 71 radiological crosscheck analyses were performed by or for the WVDP. Of these results, $70(98.6 \%)$ were within acceptance limits.
Nonradiological Crosschecks. As a New York State Pollutant Discharge Elimination System (SPDES) Permittee, the WVDP is required to participate in the U.S. Environmental Protection Agency Discharge Monitoring Report - Quality Assurance performance evaluation studies for the National Pollutant Discharge Elimination System. Samples from this program are analyzed both on site and by subcontract laboratories. In addition, subcontract laboratories performing nonradiological analyses of samples that contain radiological contamination participate in the DOE MAPEP program. This mixed analyte program provides performance evaluation samples for both radiological and nonradiological constituents.

In 2006, nonradiological crosschecks were analyzed by the WVDP Wastewater Treatment Facility Laboratory, the ELAB, LVLI, and STL. Results are summarized in Appendix $\mathrm{J}^{\mathrm{CD}}$. A total of 125 nonradiological crosscheck analyses were performed by or for the WVDP. Of these results, a total of $120(96.0 \%)$ were within acceptance limits.

\section{Data Management}

The Environmental Laboratory Information Management System (LIMS) is a database system used at the WVDP for establishing sample identification number, maintaining the sample data log, tracking samples, managing field and analytical data, and recording status and results of data validation. The LIMS is used as a controlled-source database for generating reports and statistical evaluations of data sets to support environmental surveillance activities. Subcontract laboratories are requested to provide data in electronic format for direct entry into the LIMS by WVDP personnel.

All software packages used to generate data are verified and validated before use. All analytical data produced in the ELAB at the bench level are 
reviewed and signed off by a qualified person other than the one who performed the analysis. A similar in-house review is contractually required from subcontractor laboratories.

\section{Data Verification and Validation}

Data validation is the process by which analytical data from both on-site and off-site laboratories are reviewed to verify proper documentation of sample processing and data reporting, and to determine the quality and usability of the data. A graded approach is applied that, based upon data quality objectives, dictates the rigor of review of the documentation associated with sample collection and/ or sample analysis. In the WVDP environmental program, each data point is validated per approved standard procedures before it is assigned approval status and made ready for data assessment.

\section{Data Assessment and Reporting}

Validated analytical data, field information, and historical project data are integrated and evaluated to determine whether the constituents of interest are actually present and, if so, at what concentrations. Data problems identified at this level are investigated and appropriately resolved.

Data from the environmental monitoring program are then evaluated to assess the effect, if any, of the site operations and activities on the environment and the public. Data from each sampling location are compared with historical results from the same location, with comparable background measurements, and (if applicable) with regulatory limits or guidance standards. Standard statistical methods are used to evaluate the data.

Before each technical report is issued, the final document is comprehensively reviewed by one or more persons who are knowledgeable in the technical aspects of the work.

\section{Audits and Assessments}

External. ADOE review team completed an annual assessment of the WVDP's integrated safety management system (ISMS) in 2006. Although areas for improvement were identified, the team determined that the WVDP ISMS is implemented and effective. The DOE also conducted a radiation protection technical safety appraisal to evaluate field implementation of radiological controls. No programmatic deficiencies were identified.

The Nuclear Regulatory Commission (NRC) visited the site twice in 2006. The two monitoring visits specifically addressed the groundwater monitoring program, status of the strontium- 90 groundwater plume, maintenance of the NRC-licensed disposal area, and characterization of waste streams. The NRC visits included tours of the ELAB and the north plateau. The NRC monitor determined that the activities reviewed were being performed in accordance with the requirements of established programs.

In 2006, the New York State Department of Environmental Conservation (NYSDEC) performed two Resource Conservation and Recovery Act hazardous waste inspections at the WVDP. No findings or concerns were identified. NYSDEC also conducted routine site visits in 2006 as part of the SPDES program.

Internal. In 2006, the WVNSCO QA Department conducted several surveillances of activities (such as waste processing and packaging) and inspections of equipment (such as ventilation systems and aboveground petroleum tanks) pertaining to environmental management, safety, or monitoring. No deficiencies were noted. 
In 2006, as part of the DOE Consolidated Audit Program (DOECAP), representatives from the WVDP participated in DOECAP audits of two vendor laboratories: GEL and STL Buffalo. Several conditions adverse to quality were identified and the laboratories were requested to submit and implement corrective action plans to remedy the conditions. Completion of the corrective actions will be verified during future audits.

In 2006, the WVNSCO QA Department conducted an audit of the laboratories operated by URS Corporation (the ELAB and the former A\&PC Laboratory) against NYSDOH ELAP requirements, the National Environmental Laboratory Accreditation Committee standard, and WVNSCO QA program requirements. The review also included training, software control, analytical procedures, and materials and testing equipment. No negative findings were noted.

In February 2006, the WVNSCO Environmental Affairs Department performed an assessment of a chemical bulk storage tank in the vitrification facility to verify that the closure requirements had been met in accordance with 6 NYCRR Part 598.10 to permanently close the tank. This assessment verified the permanent closure under regulations and allowed removal of the tank from the Hazardous Substance Bulk Storage registration certificate \#9-000158.

Summary. Although areas for improvement were identified in the course of audits and assessments, nothing was found that would compromise the quality of the data in this report or the environmental monitoring program in general.

\section{Lessons Learned}

Lessons learned data from audits, appraisals, and self-assessments are shared internally and externally through the WVDP lessons learned program.
The WVDP maintains this system to promote the recurrence of desirable events and to minimize the recurrence of undesirable events.

\section{Conclusion}

The QA elements described in this chapter ensure that environmental monitoring data are consistent, precise, accurate, and complete. The multiple levels of scrutiny built into generating, verifying, validating, evaluating, and reporting data from the environmental monitoring program ensure that reliable data are reported. The effectiveness of the environmental monitoring program is evidenced by continuing favorable QA assessments. 


\section{USEFUL INFORMATION}

\section{Radiation and Radioactivity}

Radioactivity is a property of atoms with unstable nuclei. The unstable nuclei spontaneously decay by emitting radiation in the form of energy (such as gamma rays) or particles (such as alpha and beta particles) (see inset on following page). If the emitted energy or particle has enough energy to break a chemical bond or to knock an electron loose from another atom, a charged particle (an "ion") may be created. This radiation is known as "ionizing radiation."

As used in this Annual Site Environmental Report (ASER), the term "radiation" refers only to ionizing radiation and does not include nonionizing forms of radiation such as visible light, radio waves, microwaves, infrared light, or ultraviolet light.

\section{Radioactive Decay}

An atom is the smallest particle of an element. It cannot be broken down by chemical means. An atom consists of a central core (the nucleus), composed of positively charged particles (protons) and particles with no charge (neutrons), surrounded by negatively charged particles (electrons) that revolve in orbits in the region surrounding the nucleus. The protons and neutrons are much more massive than the electrons, therefore most of an atom's mass is in the nucleus.

An element is defined by the number of protons in its nucleus, its atomic number. For example, the atomic number of hydrogen is one (one proton), the atomic number of strontium is 38 ( 38 protons), and the atomic number of cesium is 55 ( 55 protons).

Note: Much of the background information in this section was taken from The Handbook of Health Physics and Radiological Health (Shleien, 1998), from the Environmental Protection Agency website (www.epa.gov/radiation/understand), and from The Health Physics Society website (http://hps.org/publicinformation).

$$
U I-1
$$




\section{Some Types of Ionizing Radiation}

Alpha Particles. An alpha particle is a fragment of a much larger nucleus. It consists of two protons and two neutrons (similar to the nucleus of a helium atom) and is positively charged. Compared to beta particles, alpha particles are relatively large and heavy and do not travel very far when ejected by a decaying nucleus. Therefore, alpha radiation is easily stopped by a few centimeters of air or a thin layer of material, such as paper or skin. However, if radioactive material is ingested or inhaled, the alpha particles released inside the body can damage soft internal tissues because their energy can be absorbed by tissue cells in the immediate vicinity of the decay. An example of an alpha-emitting radionuclide is the uranium isotope with an atomic weight of 232 (uranium-232). Uranium-232 was in the high-level waste (HLW) mixture at the West Valley Demonstration Project (WVDP) as a result of a thorium-based nuclear fuel reprocessing campaign conducted by Nuclear Fuel Services, Inc. Uranium-232 has been detected in liquid waste streams.

Beta Particles. A beta particle is an electron emitted during the breakdown of a neutron in a radioactive nucleus. Compared to alpha particles, beta particles are smaller, have less of a charge, travel at a higher speed (close to the speed of light), and can be stopped by wood or a thin sheet of aluminum. If released inside the body, beta particles do much less damage than an equal number of alpha particles because beta particles deposit energy in tissue cells over a larger volume than alpha particles. Strontium-90, a fission product found in the liquids associated with the $H L W$, is an example of a beta-emitting radionuclide.

Gamma Rays. Gamma rays are high-energy "packets" of electromagnetic radiation, called photons, that are emitted from the nucleus. Gamma rays are similar to $x$-rays, but are generally more energetic. If an alpha or beta particle released by a decaying nucleus does not carry off all the energy generated by the nuclear disintegration, the excess energy may be emitted as gamma rays. If the released energy is high, a very penetrating gamma ray is produced that can be effectively reduced only by shielding consisting of several inches of a dense material, such as lead, or of water or concrete several feet thick. Although large amounts of gamma radiation are dangerous, gamma rays are also used in lifesaving medical procedures. An example of a gamma-emitting radionuclide is barium-137m, a short-lived daughter product of cesium-137. Both barium-137m and its precursor, cesium-137, are major constituents of the WVDP HLW.

The mass number of an atom, its atomic weight, is equal to the total number of protons and neutrons in its nucleus. For example, although an atom of hydrogen will always have one proton in its nucleus, the number of neutrons may vary. Hydrogen atoms with zero, one, or two neutrons will have atomic weights of one, two, or three, respectively. These atoms are known as isotopes (or nuclides) of the element hydrogen. Elements may have many isotopes. For instance, the elements strontium and cesium have more than 30 isotopes each.

Isotopes may be stable or unstable. An atom from an unstable isotope will spontaneously change to another atom. The process by which this change occurs, that is, the spontaneous emission from the nucleus of alpha

$U I-2$ 
or beta particles, often accompanied by gamma radiation, is known as radioactive decay. Depending upon the type of radioactive decay, an atom may be transformed to another isotope of the same element or, if the number of protons in the nucleus has changed, to an isotope of another element.

Isotopes (nuclides) that undergo radioactive decay are called radioactive and are known as radioisotopes or radionuclides. Radionuclides are customarily referred to by their atomic weights. For instance, the radionuclides of hydrogen, strontium, and cesium measured at the WVDP are hydrogen-3 (also known as tritium), strontium-90, and cesium-137. For some radionuclides, such as cesium-137, a short-lived intermediate is formed that decays by gamma emission. This intermediate radionuclide may be designated by the letter " $\mathrm{m}$ " (for metastable) following the atomic weight. For cesium-137, the intermediate radionuclide is barium-137m, with a half-life of less than three minutes.

The process of radioactive decay will continue until only a stable, nonradioactive isotope remains. Depending on the radionuclide, this process can take anywhere from less than a second to billions of years. The time required for half of the radioactivity to decay is called the radionuclide's half-life. Each radionuclide has a unique half-life. The half-life of hydrogen- 3 is slightly more than 12 years, both strontium- 90 and cesium- 137 have half-lives of approximately 30 years, and plutonium-239 has a half-life of more than 24,000 years.

Knowledge of radionuclide half-lives is often used to estimate past and future inventories of radioactive material. For example, a 1.0 millicurie source of cesium-137 in 2006 would have measured 2.0 millicuries in 1976 and will be 0.5 millicuries in 2036. For a list of half-lives of radionuclides applicable to the WVDP, see Table UI-1.

\section{Measurement of Radioactivity}

As they decay, radionuclides emit one or more types of radiation at characteristic energies that can be measured and used to identify the radionuclide. Detection instruments measure the quantity of radiation emitted over a specified time. From this measurement, the number of decay events (nuclear transformations) over a fixed time can be calculated.

Radioactivity is measured in units of curies (Ci) or becquerels $(\mathrm{Bq})$. One $\mathrm{Ci}$ (based on the rate of decay of one gram of radium-226) is defined as the "quantity of any radionuclide that undergoes an average transformation rate of 37 billion transformations per second." In the International System of Units (SI), one Bq is equal to one transformation per second. In this ASER, radioactivity is customarily expressed in units of $\mathrm{Ci}$ followed by the equivalent SI unit in parentheses, as follows: $1 \mathrm{Ci}(3.7 \mathrm{E}+10 \mathrm{~Bq})$.

In this report, measurements of radioactivity in a defined volume of an environmental media, such as air or water, are presented in units of concentration. Since levels of radioactivity in the environment are typically very low, concentrations may be expressed in microcuries per milliliter, with SI units (becquerels per liter) in parentheses, as follows: $1.00 \mathrm{E}-06 \mu \mathrm{Ci} / \mathrm{mL}(3.7 \mathrm{E}+01 \mathrm{~Bq} / \mathrm{L})$. (One microcurie is equal to one millionth of a curie.)

$U I-3$ 


\section{Measurement of Dose}

The amount of energy absorbed by a material that receives radiation is measured in rads. A rad is 100 ergs of radiation energy absorbed per gram of material. (An erg is the approximate amount of energy necessary to lift a mosquito one-sixteenth of an inch.) "Dose" is a means of expressing the amount of energy absorbed, taking into account the effects of different kinds of radiation.

Alpha, beta, and gamma radiation affect the body to different degrees. Each type of radiation is given a quality factor that indicates the extent of human cell damage it can cause compared with equal amounts of other ionizing radiation energy. Alpha particles cause 20 times as much damage to internal tissues as $\mathrm{x}$-rays, so alpha radiation has a quality factor of 20 , compared to gamma rays, $\mathrm{x}$-rays, or beta particles, each of which have a quality factor of one.

The unit of dose measurement to humans is the rem. The number of rem is equal to the number of rads multiplied by the quality factor for each type of radiation. In the SI system, dose is expressed in sieverts. One sievert (Sv) equals $100 \mathrm{rem}$. This ASER expresses dose in standard units, followed by equivalent SI units in parentheses, as follows: $1 \mathrm{mrem}(0.01 \mathrm{~Sv})$. For a more-detailed discussion of radiation dose and units of dose measurement, see the "Radiological Effluents and Dose" section of Chapter 2.

\section{Background Radiation}

Background radiation is always present, and everyone is constantly exposed to low levels of such radiation from both naturally occurring and man-made sources. In the United States the average total annual exposure to lowlevel background radiation is estimated to be about 360 millirem (mrem) or 3.6 millisieverts (mSv). Most of this radiation, approximately $295 \mathrm{mrem}(2.95 \mathrm{mSv})$, comes from natural sources. The rest comes from medical procedures, consumer products, and other man-made sources (National Council on Radiation Protection and Measurements Report 93, 1987). (See Figure 2-1 in Chapter 2.)

Background radiation includes cosmic rays; the decay of natural elements, such as potassium, uranium, thorium, and radon; and radiation from sources such as chemical fertilizers, smoke detectors, and cigarettes. Actual doses vary depending on such factors as geographic location, building ventilation, and personal health and habits.

\section{Potential Health Effects of Radiation}

The three primary pathways by which people may be exposed to radiation are (1) direct exposure, (2) inhalation, and (3) ingestion. Exposure from radiation may be from a source outside the body (external exposure) or from radioactive particles that have been taken in by breathing or eating and have become lodged inside the body (internal exposure). Radionuclides that are taken in are not distributed in the same way throughout the body. Radionuclides of strontium, plutonium, and americium concentrate in the skeleton, while radioisotopes of iodine concentrate in the thyroid. Radionuclides such as hydrogen-3 (tritium), carbon-14, or cesium-137, however, will be distributed uniformly throughout the body.

$U I-4$ 
Living tissue in the human body can be damaged by ionizing radiation. The severity of the damage depends upon several factors, among them the amount of exposure (low or high), the duration of the exposure (longterm [chronic] or short-term [acute]), the type of radiation (alpha, beta, and gamma radiations of various energies), and the sensitivity of the human (or organ) receiving the radiation. The human body has mechanisms that repair damage from exposure to radiation, however, repair processes are not always successful.

Biological effects of exposure to radiation may be either somatic or genetic. Somatic effects are limited to the exposed individual. For example, a sufficiently high exposure could cause clouding of the lens of the eye or a decrease in the number of white blood cells. Genetic effects may show up in future generations. Radiation could damage chromosomes, causing them to break or join incorrectly with other chromosomes. Radiation-produced genetic defects and mutations in the offspring of an exposed parent, while not positively identified in humans, have been observed in some animal studies.

Assessing the biological damage from low-level radiation is difficult because other factors can cause the same symptoms as radiation exposure. Moreover, the body is able to repair damage caused by low-level radiation. Epidemiological studies have not demonstrated adverse health effects in individuals exposed to small doses (less than $10 \mathrm{rem}$ ) over a period of years. (For comparison, note that average background radiation in the United States is about $0.36 \mathrm{rem} /$ year, and estimated annual dose from activities at the WVDP in 2006 was about $0.000049 \mathrm{rem} /$ year [0.049 mrem/year].)

The effect most often associated with exposure to relatively high levels of radiation appears to be an increased risk of cancer. However, scientists have not been able to demonstrate with certainty that exposure to low-level radiation causes an increase in injurious biological effects, nor have they been able to determine if there is a level of radiation exposure below which there are no adverse biological effects.

\section{Derived Concentration Guides}

A derived concentration guide (DCG) is defined in DOE Order 5400.5, "Radiation Protection of the Public and the Environment," as the concentration of a radionuclide in air or water that, under conditions of continuous exposure by one exposure mode (i.e., ingestion of water, immersion in air, or inhalation) for one year, would result in an effective dose equivalent of $100 \mathrm{mrem}(1 \mathrm{mSv})$ to a "reference man." DCGs are applicable only at locations where members of the public could be exposed to air or water containing contaminants. DCGs for radionuclides measured at the WVDP are listed in Table UI-1.

At the WVDP, DCGs are used as a reference tool for evaluating liquid effluents and airborne emissions. In this ASER, tables of radionuclide measurements from air and water effluent points include a comparison with the DOE DCGs. (See Appendices $\mathrm{C}^{\mathrm{m}}$ and $\mathrm{D}^{\mathrm{m}}$.) In each table, measured radionuclide concentrations are divided by the appropriate DCGs and the percentages are summed. If the total is less than $100 \%$, the effluent stream is assumed to be in compliance with the DOE guideline.

Although DCGs may be used as a screening tool, they are not directly used at the WVDP to estimate dose. DOE Orders and federal regulations require that the hypothetical dose to the public from facility effluents be estimated using specific computer codes. For further information, see "Dose Assessment Methodology" in Chapter 2.

$U I-5$ 


\section{Table UI-1 \\ U.S. Department of Energy Radiation Protection Standards and Derived Concentration Guides ${ }^{a}$}

\begin{tabular}{|c|c|c|c|c|c|c|c|}
\hline \multicolumn{8}{|c|}{$\begin{array}{l}\text { Effective Dose Equivalent Radiation Standard for Protection of the Public } \\
\text { Continuous exposure of any member of the public from routine activities: } \\
\text { All exposure pathways }=100 \text { mrem/year }(1 \mathrm{mSv} / \mathrm{yr}) \text { effective dose equivalent }\end{array}$} \\
\hline \multicolumn{8}{|c|}{$\begin{array}{c}\text { U.S. Department of Energy Derived Concentration Guides (DCGs) } \\
\text { for Inhaled Air or Ingested Water }(\mu \mathrm{Ci} / \mathrm{mL})\end{array}$} \\
\hline Radionuclide & $\begin{array}{c}\text { Half-life }^{b} \\
\text { (years) }\end{array}$ & In Air & In Water & Radionuclide & $\begin{array}{c}\text { Half-life }^{b} \\
\text { (years) }\end{array}$ & In Air & In Water \\
\hline H-3 $3^{c}$ & $1.23 \mathrm{E}+01$ & $1 \mathrm{E}-07$ & $2 \mathrm{E}-03$ & Eu-152 & $1.35 \mathrm{E}+01$ & $5 \mathrm{E}-11$ & $2 \mathrm{E}-05$ \\
\hline$C-14^{c}$ & $5.70 \mathrm{E}+03$ & $6 \mathrm{E}-09$ & 7E-05 & Eu-154 & $8.59 \mathrm{E}+00$ & $5 \mathrm{E}-11$ & 2E-05 \\
\hline K-40 & $1.25 \mathrm{E}+09$ & $9 \mathrm{E}-10$ & 7E-06 & Eu-155 & $4.75 \mathrm{E}+00$ & $3 \mathrm{E}-10$ & $1 \mathrm{E}-04$ \\
\hline Fe-55 & $2.74 \mathrm{E}+00$ & $5 \mathrm{E}-09$ & 2E-04 & Th-232 & $1.40 \mathrm{E}+10$ & $7 \mathrm{E}-15$ & $5 \mathrm{E}-08$ \\
\hline $\mathrm{Co}-60^{c}$ & $5.27 \mathrm{E}+00$ & $8 \mathrm{E}-11$ & $5 E-06$ & $\mathrm{U}-232^{c}$ & $6.89 \mathrm{E}+01$ & $2 \mathrm{E}-14$ & $1 \mathrm{E}-07$ \\
\hline Ni-59 & $7.60 \mathrm{E}+04$ & $4 \mathrm{E}-09$ & 7E-04 & $\mathrm{U}-233^{c}$ & $1.59 \mathrm{E}+05$ & $9 \mathrm{E}-14$ & $5 \mathrm{E}-07$ \\
\hline Ni-63 & $1.00 \mathrm{E}+02$ & 2E-09 & $3 E-04$ & $\mathrm{U}-234^{c}$ & $2.46 \mathrm{E}+05$ & $9 \mathrm{E}-14$ & $5 \mathrm{E}-07$ \\
\hline $\mathrm{Sr}-90^{c}$ & $2.89 \mathrm{E}+01$ & $9 \mathrm{E}-12$ & $1 \mathrm{E}-06$ & $\mathrm{U}-235^{c}$ & $7.04 \mathrm{E}+08$ & $1 \mathrm{E}-13$ & $6 \mathrm{E}-07$ \\
\hline Y-90 & $7.31 \mathrm{E}-03$ & $1 \mathrm{E}-09$ & $1 \mathrm{E}-05$ & $\mathrm{U}-236^{c}$ & $2.34 \mathrm{E}+07$ & $1 \mathrm{E}-13$ & $5 \mathrm{E}-07$ \\
\hline Zr-93 & $1.53 \mathrm{E}+06$ & $4 \mathrm{E}-11$ & $9 E-05$ & $\mathrm{U}-238^{c}$ & $4.47 \mathrm{E}+09$ & $1 \mathrm{E}-13$ & $6 \mathrm{E}-07$ \\
\hline Nb-93m & $1.61 \mathrm{E}+01$ & $4 \mathrm{E}-10$ & $3 \mathrm{E}-04$ & Np-239 & $6.45 \mathrm{E}-03$ & $5 \mathrm{E}-09$ & $5 \mathrm{E}-05$ \\
\hline $\mathrm{Tc}-99^{c}$ & $2.11 \mathrm{E}+05$ & 2E-09 & $1 \mathrm{E}-04$ & $\mathrm{Pu}-238^{c}$ & $8.77 \mathrm{E}+01$ & $3 \mathrm{E}-14$ & $4 \mathrm{E}-08$ \\
\hline Ru-106 & $1.02 \mathrm{E}+00$ & $3 \mathrm{E}-11$ & $6 \mathrm{E}-06$ & $\mathbf{P u}-239^{c}$ & $2.41 \mathrm{E}+04$ & $2 \mathrm{E}-14$ & 3E-08 \\
\hline Cd-113m & $1.41 \mathrm{E}+01$ & $8 \mathrm{E}-12$ & 9E-07 & $\mathrm{Pu}-240^{c}$ & $6.56 \mathrm{E}+03$ & $2 \mathrm{E}-14$ & 3E-08 \\
\hline Sn-126 & $2.30 \mathrm{E}+05$ & $1 \mathrm{E}-10$ & $8 \mathrm{E}-06$ & Pu-241 & $1.43 \mathrm{E}+01$ & $1 \mathrm{E}-12$ & $2 \mathrm{E}-06$ \\
\hline Sb-125 & $2.76 \mathrm{E}+00$ & 1E-09 & $5 \mathrm{E}-05$ & $A m-241^{c}$ & $4.32 \mathrm{E}+02$ & $2 \mathrm{E}-14$ & $3 \mathrm{E}-08$ \\
\hline Te-125m & $1.57 \mathrm{E}-01$ & 2E-09 & $4 \mathrm{E}-05$ & Am-242m & $1.41 \mathrm{E}+02$ & $2 \mathrm{E}-14$ & $3 \mathrm{E}-08$ \\
\hline $\mathbf{I}-129^{c}$ & $1.57 \mathrm{E}+07$ & $7 \mathrm{E}-11$ & $5 \mathrm{E}-07$ & Am-243 & $7.37 \mathrm{E}+03$ & $2 \mathrm{E}-14$ & $3 \mathrm{E}-08$ \\
\hline Cs-134 & $2.07 \mathrm{E}+00$ & $2 \mathrm{E}-10$ & $2 \mathrm{E}-06$ & Cm-243 & $2.91 \mathrm{E}+01$ & $3 \mathrm{E}-14$ & $5 \mathrm{E}-08$ \\
\hline Cs-135 & $2.30 \mathrm{E}+06$ & 3E-09 & $2 \mathrm{E}-05$ & Cm-244 & $1.81 \mathrm{E}+01$ & $4 \mathrm{E}-14$ & $6 \mathrm{E}-08$ \\
\hline $\mathrm{Cs}-137^{c}$ & $3.00 \mathrm{E}+01$ & $4 \mathrm{E}-10$ & $3 \mathrm{E}-06$ & Gross Alpha & NA & $2 \mathrm{E}-14$ & 3E-08 \\
\hline Pm-147 & $2.62 \mathrm{E}+00$ & $3 \mathrm{E}-10$ & $1 \mathrm{E}-04$ & (as Am-241) & & & \\
\hline Sm-151 & $9.00 \mathrm{E}+01$ & $4 \mathrm{E}-10$ & 4E-04 & $\begin{array}{l}\text { Gross Beta } \\
\text { (as Sr-90) }\end{array}$ & NA & $9 \mathrm{E}-12$ & $1 \mathrm{E}-06$ \\
\hline
\end{tabular}

NA - Not applicable.

${ }^{a}$ DOE Order 5400.5 (February 8, 1990). Effective May 8, 1990. (See Derived Concentration Guides in Chapter 1, Environmental Program Information.)

${ }^{b}$ Nuclear Wallet Cards. April 2005. National Nuclear Data Center. Brookhaven National Laboratory. Upton, New York.

${ }^{c}$ Radionuclides measured in WVDP effluent.

$U I-6$ 


\section{Data Reporting}

In the text of this ASER, traditional radiological units (e.g., rem, rad, curie) are presented first, followed by SI units in parentheses. Nonradiological measurements are presented in English units, followed by metric units in parentheses. A conversion chart for comparing traditional and SI radiological units and English and metric nonradiological units is presented under "Units of Measure," later in this section. Units for regulatory or guidance standards are presented as they appear in the source document.

The number of significant digits reported depends on the precision of the measurement technique. Integer counts will be reported without rounding. Calculated values are customarily reported to three significant figures. Dose estimates may be reported to two significant figures.

Radiological Data. Because the decay of radioactive atoms is a random process, an inherent uncertainty is associated with all measurements of environmental radioactivity. This can be demonstrated by repeatedly measuring the number of atoms that decay in a radioactive sample over some fixed period of time. The result of such an experiment would be a range of values for which the average value would provide the best indication of how many radioactive atoms were present in the sample.

In actual practice, an environmental sample is usually measured for radioactivity only once over a period of time. The inherent random uncertainty of the measurement, in an efficient process, is the major reason that the reported measurement is probably higher or lower than the "true" value. Radiological results are calculated by subtracting background measurements from sample measurements; therefore, when little or no radioactivity is present in the sample, results may be zero or negative.

The term "confidence interval" is used to describe the range of measurement values above and below the test result within which the "true" value is expected to lie. This interval is derived statistically. The width of the interval is based primarily on a predetermined confidence level, that is, the probability that the confidence interval actually encompasses the "true" value. The WVDP environmental monitoring program uses a $95 \%$ confidence level (about two standard deviations above and below the mean) for all radioactivity measurements and calculates and reports confidence intervals accordingly.

The confidence interval around a measured value is indicated by the plus-or-minus $( \pm)$ symbol following the result (e.g., 5.30 $\pm 3.6 \mathrm{E}-09 \mu \mathrm{Ci} / \mathrm{mL}$ ), with the exponent of $10^{-9}$ expressed as "E-09." Expressed in decimal form, the result $5.30 \pm 3.6 \mathrm{E}-09$ would be $0.00000000530 \pm 0.0000000036 \mu \mathrm{Ci} / \mathrm{mL}$. A sample measurement expressed this way is correctly interpreted to mean "there is a $95 \%$ probability that the concentration of radioactivity in this sample is between $1.7 \mathrm{E}-09 \mu \mathrm{Ci} / \mathrm{mL}$ and $8.9 \mathrm{E}-09 \mu \mathrm{Ci} / \mathrm{mL}$." If the confidence interval for the measured value includes zero (e.g., $5.30 \pm 6.5 \mathrm{E}-09 \mu \mathrm{Ci} / \mathrm{mL}$ ), the value is considered to be below the detection limit. In other words, no radiation was detected in the sample.

Chemical Data. In general, the detection limit is the minimum amount of a constituent detected by an instrument or method that can be distinguished from background and instrument noise. Thus, the detection limit is the lowest value at which a sample result shows a statistically positive difference from a sample in which no constituent is present. Nonradiological data are conventionally presented without an associated uncertainty and are expressed by the detection limit prefaced by a "less than" symbol $(<)$ if that analyte were not measurable.

\section{$U I-7$}




\section{Units of Measure}

\begin{tabular}{|c|c|c|c|c|c|}
\hline Radioactivity & Symbol & Name & Volume & Symbol & Name \\
\hline & $\begin{array}{l}\mathrm{G} \\
\mathrm{mCi} \\
\mu \mathrm{Ci} \\
\mathrm{nCi} \\
\mathrm{pCi} \\
\mathrm{Bq} \\
\mathrm{d} / \mathrm{s}\end{array}$ & $\begin{array}{l}\text { curie } \\
\text { millicurie }(1 \mathrm{E}-03 \mathrm{Ci}) \\
\text { microcurie }(1 \mathrm{E}-06 \mathrm{Ci}) \\
\text { nanocurie }(1 \mathrm{E}-09 \mathrm{Ci}) \\
\text { picocurie }(1 \mathrm{E}-12 \mathrm{Ci}) \\
\text { becquerel }(27 \mathrm{pCi}) \\
\text { disintegrations per second }\end{array}$ & & $\begin{array}{l}\mathrm{cm}^{3} \\
\mathrm{~L} \\
\mathrm{~mL} \\
\mathrm{~m}^{3} \\
\mathrm{gal}^{\mathrm{a}} \\
\mathrm{ft}^{3}\end{array}$ & $\begin{array}{l}\text { cubic centimeter } \\
\text { liter } \\
\text { milliliter } \\
\text { cubic meter } \\
\text { gallon } \\
\text { cubic feet }\end{array}$ \\
\hline \multirow[t]{2}{*}{$\underline{\text { Dose }}$} & Symbol & Name & Area & Symbol & Name \\
\hline & $\begin{array}{l}\mathrm{Sv} \\
\mathrm{mSv} \\
\mathrm{Gy} \\
\text { mrem }\end{array}$ & $\begin{array}{l}\text { sievert }(100 \mathrm{rem}) \\
\text { millisievert }(1 \mathrm{E}-03 \mathrm{~Sv}) \\
\text { gray }(100 \mathrm{rad}) \\
\text { millirem }(1 \mathrm{E}-03 \mathrm{rem})\end{array}$ & & ha & hectare $\left(10,000 \mathrm{~m}^{2}\right)$ \\
\hline \multirow[t]{2}{*}{ Concentration } & $\underline{\text { Symbol }}$ & Name & $\underline{\text { Length }}$ & Symbol & Name \\
\hline & $\begin{array}{l}\mu \mathrm{Ci} / \mathrm{mL} \\
\mathrm{mL} / \mathrm{L} \\
\mu \mathrm{Ci} / \mathrm{g} \\
\mathrm{mg} / \mathrm{L} \\
\mathrm{mg} / \mathrm{kg} \\
\mu \mathrm{g} / \mathrm{mL} \\
\mathrm{pCi} / \mathrm{L} \\
\mathrm{ng} / \mathrm{L} \\
\mu \mathrm{g} / \mathrm{L} \\
\mu \mathrm{g} / \mathrm{g} \\
\mathrm{Bq} / \mathrm{L} \\
\mathrm{ppm} \\
\mathrm{ppb} \\
\mathrm{ppt} \\
\mathrm{NTU} \\
\mathrm{SU}\end{array}$ & $\begin{array}{l}\text { microcuries per milliliter } \\
\text { milliliters per liter } \\
\text { microcuries per gram } \\
\text { milligrams per liter }(\mathrm{ppm}) \\
\text { milligrams per kilogram }(\mathrm{ppm}) \\
\text { micrograms per milliliter }(\mathrm{ppm}) \\
\text { picocuries per liter } \\
\text { nanograms per liter }(\mathrm{ppt}) \\
\text { micrograms per liter }(\mathrm{ppb}) \\
\text { micrograms per gram }(\mathrm{ppm}) \\
\text { becquerels per liter } \\
\text { parts per million } \\
\text { parts per billion } \\
\text { parts per trillion } \\
\text { nephelometric turbidity units } \\
\text { standard units }\end{array}$ & Exposure & $\begin{array}{l}\text { Symbol } \\
\mu \mathrm{R} \\
\mathrm{mR}\end{array}$ & $\begin{array}{l}\text { meter } \\
\text { kilometer }(1 \mathrm{E}+03 \mathrm{~m}) \\
\text { centimeter }(1 \mathrm{E}-02 \mathrm{~m}) \\
\text { millimeter(1E-03 m) } \\
\text { micrometer(1E-06 m) }\end{array}$ \\
\hline \multirow[t]{2}{*}{ Mass } & Symbol & Name & $\frac{\text { Flow Rate }}{\text { or Speed }}$ & $\underline{\text { Symbol }}$ & Name \\
\hline & $\begin{array}{l}\mathrm{g} \\
\mathrm{kg} \\
\mathrm{mg} \\
\mu \mathrm{g} \\
\mathrm{ng} \\
\mathrm{t}\end{array}$ & $\begin{array}{l}\text { gram } \\
\text { kilogram }(1 \mathrm{E}+03 \mathrm{~g}) \\
\text { milligram }(1 \mathrm{E}-03 \mathrm{~g}) \\
\text { microgram }(1 \mathrm{E}-06 \mathrm{~g}) \\
\text { nanogram }(1 \mathrm{E}-09 \mathrm{~g}) \\
\text { metric ton }(1 \mathrm{E}+06 \mathrm{~g})\end{array}$ & & $\begin{array}{l}\text { mgd } \\
\text { cfm } \\
\text { lpm } \\
\text { gpd } \\
\mathrm{m} / \mathrm{sec}\end{array}$ & $\begin{array}{l}\text { million gallons per day } \\
\text { cubic feet per minute } \\
\text { liters per minute } \\
\text { gallons per day } \\
\text { meters per second }\end{array}$ \\
\hline
\end{tabular}

\section{Unit Prefixes}

$\begin{array}{ll}\text { centi } & 1 / 100=1 \times 10^{-2}=0.01=\mathrm{E}-02 \\ \text { milli } & 1 / 1,000=1 \times 10^{-3}=0.001=\mathrm{E}-03 \\ \text { micro } & 1 / 1,000,000=1 \times 10^{-6}=0.000001=\mathrm{E}-06 \\ \text { nano } & 1 / 1,000,000,000=1 \times 10^{-9}=0.000000001=\mathrm{E}-09 \\ \text { pico } & 1 / 1,000,000,000,000=1 \times 10^{-12}=0.000000000001=\mathrm{E}-12\end{array}$

$$
U I-8
$$




\section{Scientific Notation}

Scientific notation may be used to express very large or very small numbers. A number smaller than 1 is expressed with a negative exponent (e.g., $1.3 \times 10^{-6}$ ). To convert this number to decimal form, the decimal point is moved left by the number of places equal to the exponent. Thus, $1.3 \times 10^{-6}$ becomes 0.0000013 .

A number larger than 10 is expressed with a positive exponent (e.g., $\left.1.3 \times 10^{6}\right)$. To convert this number to decimal form, the decimal point is moved right by the number of places equal to the exponent. Thus, $1.3 \times 10^{6}$ becomes $1,300,000$.

The power of 10 also is expressed as E. For example, $1.3 \times 10^{-6}$ also can be written as $1.3 \mathrm{E}-06$. The chart below shows equivalent exponential and decimal values.

$\begin{array}{lllll}1.0 \times 10^{2}= & 1 \mathrm{E}+02= & 100 \\ 1.0 \times 10^{1}= & 1 \mathrm{E}+01= & 10 \\ 1.0 \times 10^{0}= & 1 \mathrm{E}+00= & 1 \\ 1.0 \times 10^{-1}= & 1 \mathrm{E}-01= & 0.1 \\ 1.0 \times 10^{-2}= & 1 \mathrm{E}-02= & 0.01 \\ 1.0 \times 10^{-3}= & 1 \mathrm{E}-03= & 0.001 \\ 1.0 \times 10^{-4}= & 1 \mathrm{E}-04= & 0.0001 & \\ 1.0 \times 10^{-5}= & 1 \mathrm{E}-05= & 0.00001 & \\ 1.0 \times 10^{-6}= & 1 \mathrm{E}-06= & 0.000001 & \\ 1.0 \times 10^{-7}= & 1 \mathrm{E}-07= & 0.0000001 & \\ 1.0 \times 10^{-8}= & 1 \mathrm{E}-08= & 0.00000001 & \\ & & & \end{array}$

Both traditional radiological units (curie, roentgen, rad, rem) and the Systeme Internationale (SI) units (becquerel, gray, sievert) are used in this report. Nonradiological measurements are presented in both English and metric units. Frequently-used radioactivity and dose conversions are bolded.

$\begin{array}{lll}1 \text { centimeter }(\mathrm{cm}) & = & 0.3937 \text { inches }(\mathrm{in}) \\ 1 \text { meter }(\mathrm{m}) & = & 39.37 \text { inches }(\mathrm{in})=3.28 \text { feet }(\mathrm{ft}) \\ 1 \text { kilometer }(\mathrm{km}) & = & 0.62 \text { miles }(\mathrm{mi}) \\ 1 \text { milliliter }(\mathrm{mL}) & = & 0.0338 \text { ounces }(\mathrm{oz}) \\ & = & 0.061 \text { cubic inches }\left(\mathrm{in}^{3}\right) \\ & = & 1 \text { cubic centimeter }\left(\mathrm{cm}^{3}\right) \\ 1 \text { liter }(\mathrm{L}) & = & 1.057 \text { quarts }(\mathrm{qt}) ; 0.2641721 \text { gallons }(\mathrm{gal}) \\ & = & 61.02 \text { cubic inches }\left(\mathrm{in}^{3}\right) \\ 1 \text { gram }(\mathrm{g}) & = & 0.0353 \text { ounces }(\mathrm{oz}) \\ & = & 0.0022 \text { pounds }(\mathrm{lbs}) \\ 1 \text { kilogram }(\mathrm{kg}) & = & 2.2 \text { pounds }(\mathrm{lbs}) \\ 1 \text { curie }(\mathrm{Ci}) & = & 3.7 \mathrm{E}+10 \text { disintegrations per second }(\mathrm{d} / \mathrm{s}) \\ \mathbf{1} \text { becquerel }(\mathbf{B q}) & = & \mathbf{1} \text { disintegration per second }(\mathbf{d} / \mathbf{s}) \\ & = & \mathbf{2 7} \text { picocuries }(\mathbf{p C i}) \\ 1 \text { roentgen }(\mathrm{R}) & = & 2.58 \mathrm{E}-04 \text { coulombs per kilogram of air }(\mathrm{C} / \mathrm{kg}) \\ \mathbf{1} \text { rad } & = & \mathbf{0 . 0 1} \text { gray }(\mathbf{G y}) \\ \mathbf{1} \text { rem } & = & \mathbf{0 . 0 1} \text { sievert }(\mathbf{S v}) \\ 1 \text { millirem }(\mathrm{mrem}) & = & 0.001 \text { rem } \\ \mathbf{1} \text { sievert }(\mathbf{S v}) & = & \mathbf{1 0 0} \text { rem }\end{array}$


This page intentionally left blank

$U I-10$ 


\section{GLOSSARY}

Note: Definitions given in many cases are specifically related to the West Valley Demonstration Project (WVDP), and are not intended to be comprehensive.

$-\mathbf{A}$

accuracy. The degree of agreement between a measurement and its true value. The accuracy of a data set is assessed by evaluating results from standards or sample spikes containing known quantities of an analyte.

action plan. An action plan addresses assessment findings and root causes that have been identified in an audit or an assessment report. It is intended to define specific actions that the responsible group will undertake to remedy deficiencies. The plan includes a timetable and resource requirements for implementation of the planned activities.

alluvial fan. A cone-shaped deposit of alluvium made by a stream where it runs out onto a level plain.

alluvium. Sedimentary material deposited by flowing water, such as a river.

aquifer. A water-bearing unit of permeable rock or soil that will yield water in usable quantities via wells. Confined aquifers are bounded above and below by less permeable layers. Groundwater in a confined aquifer may be under a pressure greater than the atmospheric pressure. Unconfined aquifers are bounded below by less permeable material, but are not bounded above. The pressure on the groundwater at the surface of an unconfined aquifer is equal to that of the atmosphere.

as low as reasonably achievable (ALARA). An approach to radiation protection that advocates controlling or managing exposures (both individual and collective) to the work force and the general public and releases of radioactive material to the environment as low as social, technical, economic, practical, and public policy considerations permit. As used in United States Department of Energy (DOE) Order 5400.5, ALARA is not a dose limit but, rather, a process that has as its objective the attainment of dose levels as far below the applicable limits of the Order as practicable.

$$
G L O-1
$$


B

background radiation. Natural and man-made radiation such as cosmic radiation and radiation from naturally radioactive elements and from commercial sources and medical procedures.

becquerel (Bq). A unit of radioactivity equal to one nuclear transformation per second.

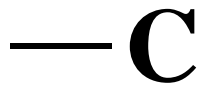

categorical exclusion $(\mathbf{C X})$. A proposed action that normally does not require an environmental assessment or an environmental impact statement and that the DOE has determined does not individually or cumulatively have a significant effect on the human environment. See 10 Code of Federal Regulations (CFR) 1021.410.

Class A, B, and C low-level waste. Waste classifications from the Nuclear Regulatory Commission's 10 CFR Part 61 rule. Maximum concentration limits are set for specific isotopes. Class A waste disposal is minimally restricted with respect to the form of the waste. Class B waste must meet more rigorous requirements to ensure physical stability after disposal. Higher concentration limits are set for the same isotopes in Class $\mathrm{C}$ waste, which also must meet physical stability requirements. Moreover, special measures must be taken at the disposal facility to protect against inadvertent intrusion.

compliance findings. Conditions that may not satisfy applicable environmental or safety and health regulations, DOE Orders and memoranda, enforcement actions, agreements with regulatory agencies, or permit conditions.

confidence coefficient or factor. The chance or probability, usually expressed as a percentage, that a confidence interval includes some defined parameter of a population. The confidence coefficients usually associated with confidence intervals are $90 \%, 95 \%$, and $99 \%$.

confidence interval. The range of values within which some parameter may be expected to lie with a stated degree of confidence. For example, a value of 10 with an uncertainty of 5 calculated at the $95 \%$ confidence level $(10 \pm 5)$ indicates there is a $95 \%$ probability that the true value of that parameter lies between 5 and 15.

consistency. The condition of showing steady conformity to practices. In the environmental monitoring program, approved procedures are in place so that data collection activities are carried out in a consistent manner to minimize variability.

$$
G L O-2
$$


Core Team. The "core team approach" to environmental cleanup is a formalized, consensus-based process in which those individuals with decision-making authority, including the U.S. Department of Energy (DOE), the U.S. Environmental Protection Agency (EPA), and State remedial project managers, work together to reach agreement on key remediation decisions (DOE/EH-413-9911, October 1999). In August 2006, the DOE-West Valley Demonstration Project (DOE-WVDP) requested that the New York State Department of Health (NYSDOH), the U.S. Nuclear Regulatory Commission (NRC), the EPA (region 2), the New York State Department of Environmental Conservation (NYSDEC), and the New York State Energy Research and Development Authority (NYSERDA) participate in a collaborative process (i.e., Core Team) to resolve technical issues associated with the "Draft Environmental Impact Statement for Decommissioning and/or Long-Term Stewardship at the West Valley Demonstration Project and Western New York Nuclear Service Center" (DEIS). The WVDP Core Team has been participating in this process since then.

cosmic radiation. High-energy subatomic particles from outer space that bombard the earth's atmosphere. Cosmic radiation is part of natural background radiation.

counting error. The variability caused by the inherent random nature of radioactive disintegration and by the detection process.

curie (Ci). A unit of radioactivity equal to 37 billion $\left(3.7 \times 10^{10}\right)$ nuclear transformations per second.

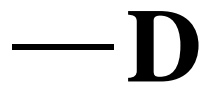

data set. A group of data (e.g., factual information such as measurements or statistics) used as a basis for reasoning, discussion, or calculation.

decay (radioactive). Disintegration of the nucleus of an unstable nuclide by spontaneous emission of charged particles and/or photons or by spontaneous fission.

derived concentration guide (DCG). The concentration of a radionuclide in air and water that, under conditions of continuous human exposure for one year by one exposure mode (i.e., ingestion of water, submersion in air, or inhalation), would result in an effective dose equivalent of $100 \mathrm{mrem}(1 \mathrm{mSv})$. See Table UI-1 in the "Useful Information" section of this report.

detection limit or level (DL). This term may also be expressed as "method detection limit" (MDL). The smallest amount of a substance that can be distinguished in a sample by a given measurement procedure at a given confidence level. (See lower limit of detection.)

dispersion (airborne). The process whereby particulates or gases are spread and diluted in air as they move away from a source.

$G L O-3$ 
dispersion (groundwater). The process whereby solutes are spread or mixed as they are transported by groundwater as it moves through the subsurface.

dosimeter. A portable device for measuring the total accumulated exposure to ionizing radiation.

downgradient. The direction of water flow from a reference point to a selected point of interest at a lower elevation than the reference point. (See gradient.)

$-\mathbf{E}$

effective dose. (See effective dose equivalent under radiation dose.)

effluent. Any treated or untreated air emission or liquid discharge to the environment.

effluent monitoring. Sampling or measuring specific liquid or gaseous effluent streams for the presence of pollutants to determine compliance with applicable standards, permit requirements, and administrative controls.

enhanced work planning. A process used to evaluate and improve the program by which work is identified, planned, approved, controlled, and executed. The key elements are line management ownership, a graded approach to work management based on risk and complexity, worker involvement beginning at the earliest phases of work management, organizationally diverse teams, and organized, institution-wide communication.

environmental assessment (EA). An evaluation that provides sufficient evidence and analysis for determining whether an environmental impact statement is required or a finding of no significant impact should be issued. Detailed information may be found in Section 102(2)(C) of the National Environmental Policy Act and in 40 CFR 1508.9.

environmental impact statement (EIS). A detailed statement that includes the environmental impact of the proposed action, any adverse environmental effects that cannot be avoided should the proposal be implemented, and alternatives to the proposed action. Detailed information may be found in Section 102 (2) (C) of the National Environmental Policy Act and in 40 CFR 1508.11.

environmental management system (EMS). The systematic application of business management practices to environmental issues, including defining the organizational structure, planning for activities, identifying responsibilities, and defining practices, procedures, processes, and resources.

environmental monitoring. The collection and analysis of samples or the direct measurement of environmental media. Environmental monitoring consists of two major activities: effluent monitoring and environmental surveillance.

$G L O-4$ 
environmental surveillance. The collection and analysis of samples or the direct measurement of air, water, soil, foodstuff, and biota in the environs of a facility of interest to determine compliance with applicable standards and to detect trends and environmental pollutant transport.

erg. One-billionth (1E-09) of the energy released by a 100-watt bulb in one second. One dyne-cm.

evapotranspiration. The combined total precipitation returned to the air through direct evaporation and by transpiration of vegetation.

exposure. The subjection of a target (usually living tissue) to radiation.

$-\mathbf{F}$

fallout. The settling to earth of radioactive materials mixed into the earth's atmosphere.

finding. A DOE compliance term. A finding is a statement of fact concerning a condition in the Environmental, Safety, and Health program that was investigated during an appraisal. Findings include best management practice findings, compliance findings, and noteworthy practices. A finding may be a simple statement of proficiency or a description of deficiency (i.e., a variance from procedures or criteria). (See also selfassessment.)

fission. The act or process of splitting into parts. A nuclear reaction in which an atomic nucleus splits into fragments (i.e., fission products, usually fragments of comparable mass) with the evolution of approximately 100 million to several hundred million electron volts of energy.

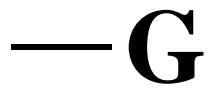

gamma isotopic (also gamma scan). An analytical method by which the quantity of several gamma rayemitting radioactive isotopes may be determined simultaneously. Typical nuclear fuel cycle isotopes determined by this method include, but are not limited to, cobalt-60, zirconium-95, ruthenium-106, silver-110m, antimony-125, cesium-134, cesium-137, and europium-154. Naturally occurring isotopes for which samples also often are analyzed are beryllium-7, potassium-40, radium-224, and radium-226.

gradient. Change in value of one variable with respect to another variable, such as a vertical change over a horizontal distance.

groundwater. Subsurface water in the pore spaces and fractures of soil and bedrock units.

$$
G L O-5
$$


half-life. The time in which half the atoms of a radionuclide disintegrate into another nuclear form. The halflife may vary from a fraction of a second to billions of years.

hazardous waste. A waste or combination of wastes that because of quantity, concentration, or physical, chemical, or infectious characteristics may: a) cause or significantly contribute to an increase in mortality or an increase in serious irreversible or incapacitating reversible illness; or (b) pose a substantial present or potential hazard to human health or the environment when improperly treated, stored, transported, disposed of, or otherwise managed.

high-level waste (HLW). The highly radioactive waste material that results from the reprocessing of spent nuclear fuel, including liquid waste produced directly in reprocessing and solid waste derived from the liquid, that contains a combination of transuranic waste and fission products in concentrations sufficient to require permanent isolation. (See also transuranic waste.)

hydraulic conductivity. The ratio of flow velocity to driving force for viscous flow under saturated conditions of a specified liquid in a porous medium; the ratio describing the rate at which water can move through a permeable medium.

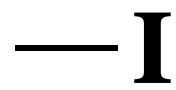

integrated safety management system (ISMS). The ISMS describes the programs, policies, and procedures used by West Valley Nuclear Services Company (WVNSCO) and the DOE to ensure that WVNSCO establishes a safe workplace for the employees, the public, and the environment. The guiding principles of ISMS are line management responsibility for safety; clear roles and responsibilities; competence commensurate with responsibilities; balanced priorities; identification of safety standards and requirements; hazard controls; and operations authorization.

interim status. The status of any currently existing facility that becomes subject to the requirement to have a Resource Conservation and Recovery Act (RCRA) permit because of a new statutory or regulatory amendment to RCRA.

interstitial. The (annular) space between the inner and outer tank walls in a double-walled storage tank.

ion. An atom or group of atoms with an electric charge.

ion exchange. The reversible exchange of ions contained in solution with other ions that are part of the ionexchange material.

$$
G L O-6
$$


isotope. Different forms of the same chemical element that are distinguished by having the same number of protons but a different number of neutrons in the nucleus. An element can have many isotopes. For example, the three isotopes of hydrogen are protium, deuterium, and tritium, with one, two, and three neutrons in the nucleus, respectively.

\section{$\mathbf{K}$}

kame delta. A deposit, often triangular, formed where a glacial stream entered into a proglacial lake.

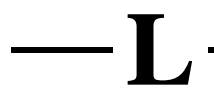

lacustrine sediments. A sedimentary deposit consisting of material pertaining to, produced by, or formed in a lake or lakes.

land disposal restrictions (LDR). Regulations promulgated by the United States Environmental Protection Agency (EPA) (and by the New York State Department of Environmental Conservation [NYSDEC] in New York State) governing the land disposal of hazardous wastes. The wastes must be treated using the best demonstrated available technology or must meet certain treatment standards before being disposed.

lower limit of detection (LLD). The lowest limit of a given parameter that an instrument is capable of detecting. A measurement of analytical sensitivity.

low-level waste (LLW). Radioactive waste not classified as high-level waste, transuranic waste, spent fuel, or uranium mill tailings. (See Class $A, B$, and C low-level waste.)

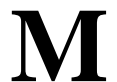

maximally exposed individual (MEI). On-site (occupational) or off-site (nonoccupational) person that receives the highest dose from a release scenario.

maximally exposed off-site individual (MEOSI). Member of the general public receiving the highest dose from the effluent release.

mean. The average value of a series of measurements.

metric ton. (See ton, metric.)

$G L O-7$ 
millirem (mrem). A unit of radiation dose equivalent that is equal to one one-thousandth of a rem. An individual member of the public can receive up to $500 \mathrm{mrem}$ per year according to DOE standards. This limit does not include radiation received for medical treatment or the roughly $360 \mathrm{mrem}$, on average, that people receive annually from background radiation.

minimum detectable concentration (MDC) or method detection limit (MDL). Depending on the sample medium, the smallest amount or concentration of a radioactive or nonradioactive analyte that can be reliably detected using a specific analytical method. Calculations of the minimum detectable concentrations are based on the lower limit of detection.

mixed waste (MW). A waste that is both radioactive and RCRA hazardous.

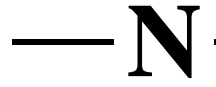

n-Dodecane/tributyl phosphate. An organic solution composed of $30 \%$ tributyl phosphate (TBP) dissolved in n-dodecane used to first separate the uranium and plutonium from the fission products in dissolved nuclear fuel and then to separate the uranium from the plutonium.

neutron. An electrically neutral subatomic particle in the baryon family with a mass 1,839 times that of an electron, stable when bound in an atomic nucleus, and having a mean lifetime of approximately 16.6 minutes as a free particle.

notice of violation (NOV). Generally, an official notification from a regulatory agency of noncompliance with permit requirements. (An example would be a letter of notice from a regional water engineer in response to an instance of significant noncompliance with a State Pollutant Discharge Elimination System [SPDES] permit.)

nucleus. The positively-charged central region of an atom, made up of protons and neutrons and containing almost all of the mass of the atom.

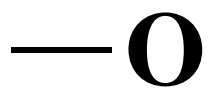

outfall. The discharge end of a drain or pipe that carries wastewater or other effluents into a ditch, pond, or river.

$$
G L O-8
$$




\section{$\mathbf{P}$}

parameter. Any of a set of physical properties whose values determine the characteristics or behavior of something (e.g., temperature, pressure, density of air). In relation to environmental monitoring, a monitoring parameter is a constituent of interest. Statistically, the term "parameter" is a calculated quantity, such as a mean or variance, that describes a statistical population.

particulates. Solid particles and liquid droplets small enough to become airborne.

person-rem. The sum of the individual radiation dose equivalents received by members of a certain group or population. It may be calculated by multiplying the average dose per person by the number of persons exposed. For example, a thousand people each exposed to one millirem would have a collective dose of one person-rem.

plume. The distribution of a pollutant in air or water after being released from a source.

practical quantitation limits (PQLs). The PQL is the minimum concentration of an analyte that can be measured within specified limits of precision during routine laboratory operations (New York State Department of Environmental Conservation, 1991).

precision. The degree of reproducibility of a measurement under a given set of conditions. Precision in a data set is assessed by evaluating results from duplicate field or analytical samples.

proglacial lake. A lake occupying a basin in front of a glacier, generally in direct contact with the ice.

proton. A stable, positively-charged subatomic particle in the baryon family with a mass 1,836 times that of an electron.

pseudo-monitoring point. A theoretical monitoring location rather than an actual physical location; a calculation based on analytical test results of samples obtained from other associated, tributary, monitored locations. (Point 116 at the WVDP is classified as a "pseudo" monitoring point because samples are not physically collected at that location. Rather, using analytical results from samples collected from "real" upstream outfall locations, compliance with the total dissolved solids limit in the WVDP's SPDES permit is calculated for this theoretical point.)

$G L O-9$ 
$-\mathbf{Q}$

quality factor (QF). The extent of tissue damage caused by different types of radiation of the same energy. The greater the damage, the higher the quality factor. More specifically, the factor by which absorbed doses are multiplied to obtain a quantity that indicates the degree of biological damage produced by ionizing radiation. See radiation dose.) The factor is dependent upon radiation type (alpha, beta, gamma, or x-ray) and exposure (internal or external).

\section{$\mathbf{R}$}

rad. Radiation absorbed dose. One hundred ergs of energy absorbed per gram of solid material.

radiation. The process of emitting energy in the form of rays or particles that are thrown off by disintegrating atoms. The rays or particles emitted may consist of alpha, beta, or gamma radiation.

alpha radiation. The least penetrating type of radiation. Alpha radiation (similar to a helium nucleus) can be stopped by a sheet of paper or the outer dead layer of skin.

beta radiation. Electrons emitted from a nucleus during fission and nuclear decay. Beta radiation can be stopped by an inch of wood or a thin sheet of aluminum.

gamma radiation. A form of electromagnetic, high-energy radiation emitted from a nucleus. Gamma rays are essentially the same as x-rays and require heavy shielding such as lead, concrete, or steel to be stopped.

internal radiation. Radiation originating from a source within the body as a result of the inhalation, ingestion, or implantation of natural or man-made radionuclides in body tissues.

\section{radiation dose:}

absorbed dose. The amount of energy absorbed per unit mass in any kind of matter from any kind of ionizing radiation. Absorbed dose is measured in rads or grays.

collective dose equivalent. The sum of the dose equivalents for all the individuals comprising a defined population. The per capita dose equivalent is the quotient of the collective dose equivalent divided by the population. The unit of collective dose equivalent is person-rem or person-sievert.

collective effective dose equivalent. The sum of the effective dose equivalents for the individuals comprising a defined population. Units of measurement are person-rem or

$$
G L O-10
$$


person-sievert. The per capita effective dose equivalent is obtained by dividing the collective dose equivalent by the population. Units of measurement are rem or sievert.

committed dose equivalent. A measure of internal radiation. The predicted total dose equivalent to a tissue or organ over a fifty-year period after a known intake of a radionuclide into the body. It does not include contributions from sources of external penetrating radiation. Committed dose equivalent is measured in rem or sievert.

committed effective dose equivalent. The sum of the committed dose equivalents to various tissues in the body, each multiplied by the appropriate weighting factor. Committed effective dose equivalent is measured in rem or sievert.

total effective dose equivalent. The summation of the products of the dose equivalent received by specified tissues of the body and the appropriate weighting factors. It includes the dose from radiation sources internal and/or external to the body. The effective dose equivalent is expressed in units of rem or seivert.

radioactivity. A property possessed by some elements (such as uranium) whereby alpha, beta, or gamma rays are spontaneously emitted.

radioisotope. A radioactive isotope of a specified element. Carbon-14 is a radioisotope of carbon. Tritium is a radioisotope of hydrogen. (See isotope.)

radionuclide. A radioactive nuclide. Radionuclides are variations (isotopes) of elements. They have the same number of protons and electrons but different numbers of neutrons, resulting in different atomic masses. There are hundreds of known nuclides, both man-made and naturally occurring.

reference man. A hypothetical aggregation of human physical and physiological characteristics arrived at by international consensus. These characteristics may be used by researchers and public health workers to standardize results of experiments and to relate biological insult to a common base.

rem. An acronym for Roentgen Equivalent Man. A unit of radiation exposure that indicates the potential effect of radiation on human cells.

remote-handled waste. At the WVDP, waste that has an external surface dose rate that exceeds 100 millirem per hour or a high level of alpha and/or beta surface contamination and, therefore, must be handled in such a manner that it does not come into physical contact with workers.

roentgen. A unit of exposure to ionizing radiation. It is that quantity of gamma or x-rays required to produce ions carrying one electrostatic unit of electrical charge in one cubic centimeter of dry air under standard conditions. The unit is named after Wilhelm Roentgen, German scientist who discovered x-rays in 1895.

$G L O-11$ 
self-assessment. Appraisals of work at the WVDP by individuals, groups, or organizations responsible for overseeing and/or performing the work. Self-assessments are intended to provide an internal review of performance to determine that specific functional areas are in programmatic and site-specific compliance with applicable DOE directives, WVDP procedures, and regulations.

finding. A direct and significant violation of applicable DOE, regulatory, or other procedural or programmatic requirements. A finding requires documented corrective action.

observation. A condition that, while not a direct and significant violation of applicable DOE, regulatory, or other procedural or programmatic requirements, could result in a finding if not corrected. An observation requires documented corrective action.

good practice. A statement of proficiency or confirmed excellence worthy of documenting.

sievert. A unit of dose equivalent from the International System of Units (Systeme Internationale). Equal to one joule per kilogram.

solid waste management unit (SWMU). Any discernible unit at which solid wastes have been placed at any time, irrespective of whether the unit was intended for the management of solid or hazardous waste. Such units include any area at a facility at which solid wastes have been routinely and systematically released or created. (See also super solid waste management unit.)

spent fuel. Nuclear fuel that has been used in a nuclear reactor; this fuel contains uranium, activation products, fission products, and plutonium.

spill. A spill or release is defined as "any spilling, leaking, pumping, pouring, emitting, emptying, discharging, injecting, escaping, leaching, dumping, or otherwise disposing of substances from the ordinary containers employed in the normal course of storage, transfer, processing, or use."

stakeholder. A person or group that has an investment, share, or interest in something. At the WVDP stakeholders include Project management, scientists, other employees, politicians, regulatory agencies, local and national interest groups, and members of the general public.

standard deviation. An indication of the dispersion of a set of results around their average.

super solid waste management unit (SSWMU). Individual solid waste management units that have been grouped and ranked into larger units - super solid waste management units - because some individual units are contiguous or so close together as to make monitoring of separate units impractical. (See also solid waste management unit.)

$G L O-12$ 
surface water. Water that is exposed to the atmospheric conditions of temperature, pressure, and chemical composition at the surface of the earth.

surveillance. The act of monitoring or observing a process or activity to verify conformance with specified requirements.

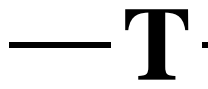

thermoluminescent dosimeter (TLD). A device that luminesces upon heating after being exposed to radiation. The amount of light emitted is proportional to the amount of radiation to which the luminescent material has been exposed.

ton, metric (also tonne). A unit of mass equal to 1,000 kilograms.

ton (short ton). A unit of weight equal to 2,000 pounds or 907.1847 kilograms.

transuranic (TRU) waste. Waste containing transuranic elements, that is, those elements with an atomic number greater than 92, including neptunium, plutonium, americium, and curium.

$-\mathbf{U}$

universal wastes. Wastes subject to special management provisions that are intended to ease the management burden and facilitate recycling of such materials. Four types of waste are currently covered under the universal waste regulations: hazardous waste batteries, hazardous waste pesticides that are either recalled or collected in waste pesticide collection programs, hazardous waste thermostats, and hazardous waste lamps.

upgradient. Referring to the flow of water or air, "upgradient" is analogous to upstream. Upgradient is a point that is "before" an area of study and that is used as a baseline for comparison with downstream or downgradient data. (See gradient and downgradient.)

\section{$\mathbf{V}$}

vitrification. A waste treatment process that encapsulates or immobilizes radioactive wastes in a glassy matrix to prevent them from reacting in disposal sites. Vitrification involves adding chemicals, glass formers, and waste to a heated vessel and melting the mixture into a glass that is then poured into a canister.

$G L O-13$ 


\section{$\mathbf{W}$}

watershed. The area contained within a drainage divide above a specified point on a stream or river.

water table. The upper surface in a body of groundwater; the surface in an unconfined aquifer or confining bed at which the pore water pressure is equal to atmospheric pressure.

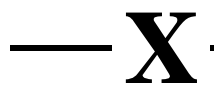

x-ray. Penetrating electromagnetic radiations having wave lengths shorter than those of visible light. They are usually produced by bombarding a metallic target with fast electrons in a high vacuum. In nuclear reactions it is customary to refer to photons originating in the nucleus as gamma rays and those originating in the extranuclear part of the atom as x-rays. These rays are sometimes called Roentgen rays after their discoverer, W.C. Roentgen. 


\title{
ACRONYMS AND ABBREVIATIONS
}

\author{
A\&PC \\ Analytical and Process Chemistry Laboratory \\ ACM \\ Asbestos-Containing Material \\ AEA \\ Atomic Energy Act \\ ALARA \\ As Low As Reasonably Achievable \\ ANSI \\ ASER \\ American National Standards Institute \\ ASME \\ ASQ \\ AWQS \\ Annual Site Environmental Report \\ American Society of Mechanical Engineers \\ American Society for Quality \\ Ambient Water Quality Standard \\ BAT \\ Best Available Technology \\ BCG \\ Biota Concentration Guide \\ BEIR \\ Biological Effects of Ionizing Radiation \\ $\mathrm{BOD}_{5}$ \\ BSW \\ Biochemical Oxygen Demand (5-day) \\ Bulk Storage Warehouse \\ CAA \\ Clean Air Act \\ CBS \\ Chemical Bulk Storage \\ CCHD \\ Cattaraugus County Health Department \\ CCZ \\ CD \\ Criticality Control Zone \\ CDDL \\ Compact Disk \\ CEDE \\ Construction and Demolition Debris Landfill \\ CEMP \\ Committed Effective Dose Equivalent \\ CERCLA \\ CFR \\ CMS \\ CPC \\ CPC-WSA \\ CSPF \\ Code of Environmental Management Principles (for Federal Agencies) \\ Comprehensive Environmental Response, Compensation, and Liability Act \\ Code of Federal Regulations \\ Corrective Measures Study \\ Chemical Process Cell \\ Chemical Process Cell Waste Storage Area \\ Container Sorting and Packaging Facility
}

$A \& A-1$ 


\begin{tabular}{|c|c|}
\hline CSRF & Contact Size-Reduction Facility \\
\hline CSS & Cement Solidification System \\
\hline CTF & (West Valley) Citizen Task Force \\
\hline CUP & Cask Unloading Pool \\
\hline CWA & Clean Water Act \\
\hline $\mathbf{C X}$ & Categorical Exclusion \\
\hline CY & Calendar Year \\
\hline D4 & Decommissioning, Decontamination, Dismantlement, and Demolition (Project) \\
\hline D\&D & Decontamination and Decommissioning \\
\hline DCDFMeth & Dichlorodifluoromethane \\
\hline DCG & Derived Concentration Guide \\
\hline DL & Detection Limit or Detection Level \\
\hline DMR & Discharge Monitoring Report \\
\hline DOE & (U.S.) Department of Energy \\
\hline DOE-EM & Department of Energy, Office of Environmental Restoration and Waste Management \\
\hline DOE-HQ & Department of Energy, Headquarters Office \\
\hline DOE-OH & Department of Energy, Ohio Field Office \\
\hline DOE-WVDP & Department of Energy, West Valley Demonstration Project (title as of June 2006) \\
\hline DOECAP & Department of Energy Consolidated Audit Program \\
\hline DOT & (U.S.) Department of Transportation \\
\hline E.O. & Executive Order \\
\hline EA & Environmental Assessment \\
\hline ECL & (New York State) Environmental Compliance Law \\
\hline EDE & Effective Dose Equivalent \\
\hline EHS & Extremely Hazardous Substance \\
\hline EIS & Environmental Impact Statement \\
\hline ELAB & (WVDP) Environmental Laboratory \\
\hline ELAP & (New York State Department of Health) Environmental Laboratory Approval Program \\
\hline EMS & Environmental Management System \\
\hline EPA & (U.S.) Environmental Protection Agency \\
\hline EPCRA & Emergency Planning and Community Right-to-Know Act \\
\hline ERA & Environmental Research Associates \\
\hline ES\&H & Environmental, Safety, and Health \\
\hline ESR & (WVDP) Effluent Summary Report \\
\hline FFCA & Federal Facilities Compliance Act \\
\hline FIFRA & Federal Insecticide, Fungicide, and Rodenticide Act \\
\hline FONSI & Finding of No Significant Impact \\
\hline FR & Federal Register \\
\hline FRS & Fuel Receiving and Storage \\
\hline FY & Fiscal Year \\
\hline
\end{tabular}

A\&A - 2 
GEL

GTAR

HEPA

HLW

HPIC

HTO

HVAC

IAEA

ICRP

INL

IRTS

ISCORS

ISMS

ISO

IWSF

LAS

LDR

LFR

LIMS

LLD

LLW

LLW2

LLWTF

LPS

LSA

LSA \#1

LSA \#2

LSB

LTR

LVLI

LWTS

MAPEP

MCL

MCLG

MDC

MDL

MEI

MEOSI

MGD
General Engineering Laboratory

Groundwater Trend Analysis Report

High-Efficiency Particulate Air (filter)

High-Level (radioactive) Waste

High-Pressure Ion Chamber

Hydrogen Tritium Oxide

Heating, Ventilation, and Air Conditioning

International Atomic Energy Agency

International Commission on Radiological Protection

Idaho National Laboratory

Integrated Radwaste Treatment System

Interagency Steering Committee on Radiation Standards

Integrated Safety Management System

International Organization for Standardization

Interim Waste Storage Facility

Linear Alkylate Sulfonate

Land Disposal Restriction

Live Fire Range

Laboratory Information Management System

Lower Limit of Detection

Low-Level (radioactive) Waste

Low-Level (liquid) Waste Treatment Facility (new)

Low-Level (liquid) Waste Treatment Facility (old)

Liquid Pretreatment System

Lag Storage Area

Lag Storage Addition\#1

Lag Storage Hardstand \#2

Lag Storage Building

License Termination Rule

Lionville Laboratory, Inc.

Liquid Waste Treatment System

Mixed Analyte Performance Evaluation Program

Maximum Contaminant Level

Maximum Contaminant Level Goal

Minimum Detectable Concentration

Method Detection Limit (also Minimum Detection Level)

Maximally Exposed Individual

Maximally Exposed Off-Site Individual

Million Gallons per Day

$A \& A-3$ 


\begin{tabular}{|c|c|}
\hline MOU & Memorandum of Understanding \\
\hline MSDS & Material Safety Data Sheet \\
\hline MW & (Radioactive and Hazardous) Mixed Waste \\
\hline NCRP & National Council on Radiation Protection and Measurements \\
\hline NDA & Nuclear Regulatory Commission (NRC)-Licensed Disposal Area \\
\hline NEPA & National Environmental Policy Act \\
\hline NESHAP & National Emission Standards for Hazardous Air Pollutants \\
\hline NFS & Nuclear Fuel Services, Inc. \\
\hline NGVD & National Geodetic Vertical Datum \\
\hline $\mathbf{N H}_{3}$ & Ammonia \\
\hline NIST & National Institute of Standards and Technology \\
\hline NOAA & National Oceanic and Atmospheric Administration \\
\hline NOI & Notice of Intent \\
\hline NOV & Notice of Violation \\
\hline $\mathbf{N O}_{\mathbf{x}}$ & Nitrogen Oxides \\
\hline NPDES & National Pollutant Discharge Elimination System \\
\hline NPGRS & North Plateau Groundwater Recovery System \\
\hline NPOC & Nonpurgeable Organic Carbon \\
\hline NRC & (U.S.) Nuclear Regulatory Commission \\
\hline NTS & Nevada Test Site \\
\hline NTU & Nephelometric Turbidity Unit \\
\hline NYCRR & New York Official Compilation of Codes, Rules, and Regulations \\
\hline NYS & New York State \\
\hline NYSDEC & New York State Department of Environmental Conservation \\
\hline NYSDOH & New York State Department of Health \\
\hline NYSDOH ELAP & (NYSDOH) Environmental Laboratory Approval Program \\
\hline NYSDOL & New York State Department of Labor \\
\hline NYSERDA & New York State Energy Research and Development Authority \\
\hline NYSGS & New York State Geological Survey \\
\hline OH/WVDP & Department of Energy, West Valley Demonstration Project (prior to June 2006) \\
\hline OSHA & Occupational Safety and Health Administration \\
\hline OVE & Outdoor Ventilated Enclosure \\
\hline PCB & Polychlorinated Biphenyl \\
\hline PE & Professional Engineer \\
\hline PNL & Pacific Northwest Laboratory \\
\hline POC & Principal Organic Contaminant \\
\hline PQL & Practical Quantitation Limit \\
\hline PTW & Permeable Treatment Wall \\
\hline PUREX & Plutonium Uranium Reduction Extraction \\
\hline
\end{tabular}

$A \& A-4$ 


\begin{tabular}{|c|c|}
\hline PVS & Permanent Ventilation System \\
\hline PVU & Portable Ventilation Unit \\
\hline QA & Quality Assurance \\
\hline QAP & Quality Assessment Program (also Quality Assurance Program) \\
\hline QC & Quality Control \\
\hline QF & Quality Factor \\
\hline QTAR & Quarterly Trend Analysis Report \\
\hline RCRA & Resource Conservation and Recovery Act \\
\hline REM & Roentgen Equivalent Man \\
\hline RFI & RCRA Facility Investigation \\
\hline RHWF & Remote-Handled Waste Facility \\
\hline ROD & Record of Decision \\
\hline SAR & Safety Analysis Report \\
\hline SARA & Superfund Amendments and Reauthorization Act \\
\hline SD & Standard Deviation \\
\hline SDA & (New York) State-Licensed Disposal Area \\
\hline SDWA & Safe Drinking Water Act \\
\hline SI & Systeme Internationale (International System of Units) \\
\hline SMS & Safety Management System \\
\hline $\mathrm{SO}_{2}$ & Sulfur Dioxide \\
\hline SPCC & Spill Prevention, Control, and Countermeasures (Plan) \\
\hline SPDES & (New York) State Pollutant Discharge Elimination System \\
\hline SRM & Standard Reference Material \\
\hline SSWMU & Super Solid Waste Management Unit \\
\hline STL & Severn Trent Laboratories \\
\hline STP & Site Treatment Plan \\
\hline STS & Supernatant Treatment System \\
\hline SU & Standard Unit \\
\hline SVOC & Semivolatile Organic Compound \\
\hline SWMU & Solid Waste Management Unit \\
\hline TAGM & Technical and Administrative Guidance Memorandum \\
\hline TAR & Trend Analysis Report \\
\hline TBP & Tributyl Phosphate \\
\hline TCE & Trichloroethylene \\
\hline TDS & TotalDissolved Solids \\
\hline TEDE & Total Effective Dose Equivalent \\
\hline THOREX & Thorium Reduction Extraction \\
\hline TKN & Total Kjeldahl Nitrogen \\
\hline
\end{tabular}

$A \& A-5$ 


$\begin{array}{ll}\text { TLD } & \text { Thermoluminescent Dosimeter } \\ \text { TOC } & \text { Total Organic Carbon } \\ \text { TOGS } & \text { Technical and Operational Guidance Series } \\ \text { TOX } & \text { Total Organic Halides } \\ \text { TRI } & \text { Toxic Release Inventory } \\ \text { TRU } & \text { Transuranic } \\ \text { TSCA } & \text { Toxic Substances Control Act } \\ \text { TSDF } & \text { Treatment, Storage, and Disposal Facility } \\ \text { TSS } & \text { Total Suspended Solids } \\ & \\ \text { U.S. } & \text { United States } \\ \text { USACE } & \text { U.S. Army Corps of Engineers } \\ \text { URS } & \text { URS Group, Inc. } \\ \text { USC } & \text { United States Code } \\ \text { USGS } & \text { United States Geological Survey } \\ & \\ \text { VOC } & \text { Volatile Organic Compound } \\ \text { VPP } & \text { (U.S. DOE) Voluntary Protection Program } \\ & \\ \text { WNYNSC } & \text { Western New York Nuclear Service Center } \\ \text { WVDP } & \text { West Valley Demonstration Project } \\ \text { WVNS } & \text { West Valley Nuclear Services Company (now WVNSCO) } \\ \text { WVNSCO } & \text { West Valley Nuclear Services Company } \\ \text { WWTF } & \text { Wastewater Treatment Facility } \\ \end{array}$

$A \& A-6$ 


\section{REFERENCES AND BIBLIOGRAPHY}

(For a bibliographical listing that includes basis documents not specifically cited in the text, see the WVDP Annual Site Environmental Report for 2003.)

American National Standards Institute, Inc. August 20, 1975. American National Standard: Performance Testing, and Procedural Specifications for Thermoluminescent Dosimetry (Environmental Applications). ANSI N545-1975.

American Society of Mechanical Engineers. 1989. Quality Assurance Program Requirements for Nuclear Facilities. ASME-NQA-1. New York: The American Society of Mechanical Engineers.

Brookhaven National Laboratory. April 2005. Nuclear Wallet Cards. National Nuclear Data Center. Upton, New York.

Citizen Task Force. July 29, 1998. West Valley Citizen Task Force Final Report.

Executive Order 11988. May 24, 1977. Floodplain Management. 42 FR 26951.

Executive Order 11990. May 25, 1977. Protection of Wetlands. 42 FR 26961.

Executive Order 13101. September 16, 1998. Greening the Government Through Waste Prevention, Recycling, and Federal Acquisition. 63 FR 49643.

Executive Order 13148. April 26, 2000. Greening the Government Through Leadership in Environmental Management. 65 FR 24595.

International Atomic Energy Agency (IAEA). 1992. Effects of Ionizing Radiation on Plants and Animals at Levels Implied by Current Radiation Protection Standards. Technical Report Series No. 332, IAEA, Vienna, Austria.

International Commission on Radiological Protection. 1977. Recommendations of the International Commission on Radiological Protection. ICRP Publication 26. Oxford: Pergamon Press.

$$
R \& B-1
$$


1979. Recommendations of the International Commission on Radiological

Protection - Limits for Intakes of Radionuclides by Workers. ICRP Publication 30. Oxford:

Pergamon Press.

1991. Recommendations of the International Commission on Radiological

Protection. ICRP Publication 60, Pergamon Press, New York.

International Organization for Standardization. 1996. Environmental Management Systems. ISO 14001:1996.

Long, E.R., and L.G. Morgan. 1990. The Potential for Biological Effects of Sediment-Sorbed Contaminants Tested in the National States and Trends Program. National Oceanic Atmospheric Administration (NOAA) Technical Memorandum No. 5, OMA52, NOAA National Ocean Service, Seattle, Washington.

Mitrey, R.J. October 28, 1986. Correspondence from New York State Department of Environmental Conservation to J.P. Hamric, Department of Energy, Idaho Operations Office, West Valley Project Office, regarding the construction landfill.

National Council on Radiation Protection and Measurements. 1987. Ionizing Radiation Exposure of the Population of the United States. NCRP-93. Bethesda, Maryland.

National Environmental Laboratory Accreditation Conference (NELAC) Standard. June 2003, effective July 2005.

National Research Council. 1990. Health Effects of Exposure to Low Levels of Ionizing Radiation. Biological Effects of Ionizing Radiation (BEIR) V. Washington: National Academy Press.

New York State. nd. Environmental Conservation Law (ECL). Article 27, Collection, treatment, and Disposal of Refuse and Other Solid Waste. Title 9. Industrial Hazardous Waste Management. . nd. ECL. Article 15. Water Resources. Title 5. Protection of Water. nd. ECL. Article 17. Water Pollution Control. Title 8. State Pollutant Discharge Elimination System.

. nd. ECL. Article 40. Hazardous Substances Bulk Storage Act. nd. Navigation Law. Article 12. Oil Spill Prevention, Control, and Compensation. . nd. Public Health Law. Article 5. Laboratories. Section 502. Environmental Laboratories, Certifications of Approval.

$R \& B-2$ 
New York State Department of Environmental Conservation. nd. Title 6, New York Codes, Rules, and Regulations (6 NYCRR). Environmental Conservation Rules and Regulations.

. January 24, 1994. Determination of Soil Cleanup Objectives and Cleanup Levels. Technical and Administrative Guidance Memorandum (TAGM) \#4046.

. 1995. Appendix 33 - Groundwater Monitoring List. Title 6 NYCRR Subpart 373-2.

. September 3, 1996. Federal Facility Compliance Act: Order on Consent.

. June 1998. Ambient Water Quality Standards and Guidance Values and Groundwater Effluent Limitations. Technical and Operational Guidance Series (TOGS) 1.1.1.

. January 25, 1999. Technical Guidance for Screening Contaminated Sediments.

. March 19, 1999. Stipulation of Agreement Pursuant to Section 17-0303 of the Environmental Conservation Law and Section 176 of the Navigation Law.

January 2003. Draft Technical and Operational Guidance Series (TOGS) \#5.1.9.

In-Water and Riparian Management of Sediment and Dredge Material.

. February 1, 2004 and modification dates January 1, 2005 and September 1, 2006. State Pollutant Discharge Elimination System (SPDES) Discharge Permit NY0000973.

October 21, 2004. Air Facility Registration Certificate in accordance with 6 NYCRR Part 201-4.

New York State Department of Health. nd. Environmental Laboratory Approval Program (ELAP) Certification Manual.

. nd. Title 10, New York Code, Rules, and Regulations (10 NYCRR). Sources of Water Supply. Part 5 (Drinking Water Supplies) and Part 170 (Sources of Water Supply).

Pacific Northwest Laboratory (PNL). November 1988. Napier, B.A., Strenge, D.L., Pelequin, R.A., and Ramsdell, J.V. GENII - The Hanford Environmental Radiation Dosimetry Software System. Version 1.485, PNL-6584.

Parks B.L. March 1992. User's Guide for CAP88-PC. Version 1.0. Las Vegas, NV: U.S. Environmental Protection Agency Office of Radiation Programs. 402-B-92-001. June 1997. CAP88-PC Version 2.0 User's Guide. Germantown, Maryland. U.S. Department of Energy.

$R \& B-3$ 
Persaud, D., Jaagumagi, R., and A. Hayton. 1992. Guidelines for the Protection and Management of Aquatic Sediment Quality in Ontario. Ontario Ministry of the Environment, Queen's Printer for Ontario.

Rickard, L.V. 1975. Correlation of the Silurian and Devonian Rocks in New York State. New York State Museum and Science Service Map and Chart Series No. 24.

Simpson, D.B., and B.L. McGill. 1980. LADTAP II: A Computer Program for Calculating Radiation Exposure to Man from Routine Release of Nuclear Reactor Liquid Effluents. Technical Data Management Center. ORNL/NUREG/TDMC-1.

Standish, P.N. 1985. Closure of the Construction Landfill Site. Letter (WD:85:0434) to W.H. Hannum, Department of Energy, West Valley Project Office.

Trinity Engineering Associates, Inc. March 2006. CAP88-PC Version 3.0 User Guide.

U.S. Congress. 1918. Migratory Bird Treaty Act. 16 United States Code (USC) $§ 703$ et seq. 1954. Atomic Energy Act of 1954. 42 USC §2011 et seq.

. 1966. National Historic Preservation Act of 1966. 16 USC $\$ 470$ et seq.

. 1969. National Environmental Policy Act of 1969. 42 USC $\$ 4321$ et seq. 1970. Clean Air Act of 1970. 42 USC $\$ 7401$ et seq.

. 1973. Endangered Species Act of 1973. 16 USC $§ 1531$ et seq. 1974. Safe Drinking Water Act. 42 USC $\$ 300 f$ et seq.

. 1976. Resource Conservation and Recovery Act of 1976. Public Law 94-580, 90 Stat. 2795, 42 USC $\$ 6901$ et seq.

. 1976. Toxic Substances Control Act. 15 USC $\$ 2601$ et seq.

. 1977. Federal Water Pollution Control Act of 1977. 33 USC $\$ 1251$ et seq. (Also known as the Clean Water Act)

October 1, 1980. An Act to Authorize the Department of Energy to Carry Out a High-Level Liquid Nuclear Waste Management Demonstration Project at the Western New York Service Center in West Valley, New York. Public Law 96-368 [S. 2443]. Congressional Record, Vol. 126. (Also known as the WVDP Act)

$R \& B-4$ 
1980. Comprehensive Environmental Response, Compensation, and Liability Act of 1980. Public Law 96-510, 42 USC $\$ 9601$ et seq.

1986. Emergency Planning and Community Right-to-Know Act of 1986. 42 USC $\S 11001$ et seq.

. October 17, 1986. Superfund Amendments and Reauthorization Act (SARA) of 1986. Public Law 99-499, 100 Stat. 1613, Title 10.

. 1992. Federal Facilities Compliance Act of 1992. Amendment to Section 6001 of the Solid Waste Disposal Act (42 USC 6961).

. 1996. Federal Insecticide, Fungicide, and Rodenticide Act. 7 USC $\$ 136$ et seq.

U.S. Department of Commerce. U.S. Census Bureau. Census 2000.

U.S. Department of Energy. nd. Quality Assurance Criteria. 10 CFR 830.122.

1981. West Valley Demonstration Project Memorandum of Understanding

Between the U.S. Department of Energy and the U.S. Nuclear Regulatory Commission.

. July 1981. A Guide for Environmental Radiological Surveillance at U.S.

Department of Energy Installations. DOE/EP-0023. Washington, D.C.

. July 1983. A Guide for Effluent Radiological Measurements at DOE Installations. DOE/EP-0096. Washington, D.C.

. May 15, 1984. Environmental Protection, Safety, and Health Protection Standards. DOE Order 5480.4, including Change 4 (January 7, 1993).

. February 8, 1990. Radiation Protection of the Public and the Environment. DOE Order 5400.5, including Change 2 (January 7, 1993). Washington, D.C.

. January 1991. Environmental Regulatory Guide for Radiological Effluent Monitoring and Environmental Surveillance. DOE/EH-0173T. Washington, D.C.

. January 1996. Draft Environmental Impact Statement for Completion of the West Valley Demonstration Project and Closure or Long-Term Management of Facilities at the Western New York Nuclear Services Center. DOE/EIS-0226-D.

. May 1997. Final Waste Management Programmatic Environmental Impact Statement for Managing Treatment, Storage, and Disposal of Radioactive and Hazardous Waste. DOE/EIS-0200-F. 
. March 27, 1998. Worker Protection Management for DOE Federal and Contractor Employees. DOE Order 440.1A. Washington, D.C.

. July 9, 1999. Radioactive Waste Management. DOE Order 435.1, including Change 1 (August 28, 2001). Washington, D.C.

September 29, 1999. Quality Assurance. DOE Order 414.1A, including Change 1 (July 12, 2001). Washington D.C. (DOE Order 414.1A [currently in the WVNSCO contract] was canceled by DOE Order 414.1B on April 29, 2004. DOE Order 414.1B was canceled by DOE Order 414.1C on June 17, 2005.)

October 1999. Expediting Cleanup Through a Core Team Approach. DOE/EH-413-9911.

. February 25, 2000. Record of Decision for the DOE's Waste Management Program: Treatment and Disposal of Low-Level Waste and Mixed Low-Level Waste; Amendment of the Record of Decision for the Nevada Test Site. 65 FR 10061.

. October 26, 2000. National Environmental Policy Act Compliance Program. DOE Order 451.1B, including Change 1 (September 28, 2001). Washington, D.C.

. March 1, 2001. Integrated Safety Management System Guide for Use With Safety Management System Policies (DOE P 450.4, DOE P 450.5, and DOE P 450.6); the Functions, Responsibilities, and Authorities Manual; and the DOE Acquisition Manual (DOE G 450.4-1B) (Volumes 1 and 2).

. March 26, 2001. Revised Strategy for the Environmental Impact Statement for Completion of the West Valley Demonstration Project and Closure or Long-Term Management of Facilities at the Western New York Nuclear Service Center and Solicitation of Scoping Comments. 66 FR 16447.

. May 2, 2001. Department of Energy Management of Cultural Resources. DOE Policy 141.1.

. November 6, 2001. Advance Notice of Intent to Prepare an Environmental Impact Statement to Evaluate Decommissioning and/or Long-Term Stewardship at the West Valley Demonstration Project and Western New York Nuclear Service Center. 66 FR 56090.

. July 2002. DOE Standard: A Graded Approach for Evaluating Radiation Doses to Aquatic and Terrestrial Biota. DOE-STD-1153-2002. Washington, D.C.

. September 23, 2002. Radioactive Material Transportation Practices Manual. DOE M 460.2-1. 
. January 2003. Estimating Radiation Risk from Total Effective Dose Equivalent (TEDE). Interagency Steering Committee on Radiation Standards (ISCORS) Technical Report No. 1. DOE/EH-412/0015/0502, Rev. 1.

January 15, 2003. Environmental Protection Program. DOE Order 450.1, including Changes 1 (January 24, 2005) and 2 (December 7, 2005). Washington, D.C. (Canceled DOE Order 5400.1, General Environmental Protection Program, November 9, 1988, including Change 1 [June 29, 1990].)

March 13, 2003. Notice of Intent to Prepare an Environmental Impact Statement for Decommissioning and/or Long-Term Stewardship at the West Valley Demonstration Project and Western New York Nuclear Services Center. 68 FR 12044.

May 16, 2003. Notice of Availability of the West Valley Demonstration Project Draft Waste Management Environmental Impact Statement. 68 FR 26587.

. August 19, 2003. Environment, Safety, and Health Reporting. DOE Order 231.1A, including Change 1 (June 3, 2004). Washington, D.C.

December 2003. West Valley Demonstration Project Waste Management Environmental Impact Statement. DOE/EIS-0337F.

. January 2004. Users Guide: RESRAD-BIOTA: A Tool for Implementing a Graded Approach to Biota Dose Evaluation. Version 1. DOE/EH-0676. (ISCORS Technical Report 2004-2).

. March 19, 2004. Environment, Safety, and Health Reporting Manual.

DOE M 231.1-1A, including Change 1 (September 9, 2004).

. June 16, 2005. Record of Decision for WVDP Waste Management Activities. 70 FR 35073.

February 2006. Worker Safety and Health Program. 10 CFR 851.

September 14, 2006. Environmental Assessment for the Decontamination, Demolition, and Removal of Certain Facilities at the West Valley Demonstration Project. DOE/EA-1552. West Valley, New York.

U.S. Department of Energy and New York State Energy Research and Development Authority. 1981. Cooperative Agreement between United States Department of Energy and New York State Energy Research and Development Authority on the Western New York Nuclear Service Center at West Valley, New York, effective October 1, 1980, as amended September 18, 1981.

$R \& B-7$ 
U.S. Environmental Protection Agency. nd. 40 Code of Federal Regulations, Protection of the Environment, Chapter 1, Environmental Protection Agency.

. March 1983. Mercury, Method 245.1 (Manual Cold Vapor Technique). Methods for Chemical Analysis of Water and Wastes. Environmental Monitoring and Support Laboratory. Cincinnati, Ohio.

1984a. Drinking Water Guidelines. 40 CFR 141, National Secondary Drinking Water Regulations, Subpart B, Maximum Contaminant Levels.

. 1984b. Drinking Water Guidelines. 40 CFR 143, National Secondary Drinking Water Regulations, Section 143.3, Secondary Maximum Contaminant Levels.

December 15, 1989. National Emission Standards for Hazardous Air Pollutants: Standards for Radionuclides. 40 CFR 61, including update of September 9, 2002. Subpart H. National Emission Standards for Emissions of Radionuclides Other Than Radon From Department of Energy Facilities. Washington, D.C.: U.S. Government Printing Office.

. 1992. Region II Administrative Order on Consent. Docket No. II RCRA 3008(h) 92-0202. In the Matter of: Western New York Nuclear Service Center.

1995. Comprehensive Procurement Guidelines for Products Containing Recovered Material. 40 CFR 247.

October 16, 1996. Code of Environmental Management Principles. 61 FR 54062.

August 2002. Method 1631, Revision E: Mercury in Water by Oxidation, Purge and Trap, and Cold Vapor Atomic Fluorescence Spectrometry. EPA-821-R-02-019.

October 9, 2002. Memorandum of Understanding Between the Environmental Protection Agency and the Nuclear Regulatory Commission. Consultation and Finality on Decommissioning and Decontamination of Contaminated Sites.

U.S. Nuclear Regulatory Commission. October 1977. Regulatory Guide 1.109: Calculation of Annual Doses to Man from Routine Releases of Reactor Effluents for the Purpose of Evaluating Compliance with 10 CFR Part 50, Appendix I.

July 1997. Radiological Criteria for License Termination. 10 CFR Part 20, Appendix E.

. February 1, 2002. Decommissioning Criteria for the West Valley Demonstration Project (M-32) at the West Valley Site; Final Policy Statement. 67 FR 5003. 
September 2006. Consolidated Decommissioning Guidance: Characterization, Survey, and Determination of Radiological Criteria. NUREG-1757, Vol. 2.

URS Group, Inc. April 8, 2002. Land Use Survey. Rev. 0. AR \#2002-171.

West Valley Nuclear Services Co., Inc. May 1, 1995. Subsurface Probing Investigation on the North Plateau at the West Valley Demonstration Project. Rev. 0. WVDP-220.

. March 1996. Environmental Information Document, Volume III: Hydrology, Part 4. WVDP-EIS-009.

June 11, 1999. 1998 Geoprobe ${ }^{\circledR}$ Investigation in the Core Area of the North Plateau Groundwater Plume. Rev. 0. WVDP-346.

. October 26, 1999. Asbestos Management Plan. Rev. 5. WVDP-072.

. April 15, 2003. Manual for Radiological Assessment of Environmental Releases at the WVDP. Rev. 4. WVDP-065.

. December 27, 2005. Environmental Monitoring Program Plan. Rev. 13. WVDP-098.

. April 22, 2004 and November 27, 2006. WVDP Environmental Management System. Rev. 16 and Rev. 17. WV-980.

. July 1, 2004. Annual Status Report for the Hazardous Waste Reduction Program.

. December 21, 2004. Clean Water Act/State Pollutant Discharge Elimination System Best Management Practices and Storm Water Pollution Prevention Plan for the West Valley Demonstration Project. Rev. 1. WVDP-206.

. December 30, 2004. Waste Minimization/Pollution Prevention Awareness Plan. Rev. 8. WVDP-087.

February 28, 2005. New York State Department of Environmental Conservation Hazardous Waste Report for 2004.

. March 30, 2005. Monitoring Plan for Storm Water Discharges at the West Valley Demonstration Project. Rev. 2. WVDP-233.

. September 19, 2005. Groundwater Monitoring Plan. Rev. 9. WVDP-239. 
November 3, 2005. WVDP Groundwater Protection Management Program Plan. Rev. 7. WVDP-091.

. November 17, 2005. PCB and PCB-Contaminated Material Management Plan. Rev. 8. WVDP-080.

January 2006. Draft Corrective Measures Study Work Plan for the West Valley Demonstration Project.

January 5, 2006 and September 19, 2006. WVDP Safety Management System (SMS) Description. Revs. 10, 11, and 12. WVDP-310, including Addendum 1, WVDP Worker Safety and Health Plan, Rev. 0, February 9, 2007.

February 1, 2007. Site Treatment Plan: Fiscal Year 2006 Update. Rev. 12. WVDP-299.

. February 26, 2007. Annual Hazardous Waste Report for 2006.

West Valley Nuclear Services Co., Inc. and Dames \& Moore. June 1997. West Valley Demonstration Project Site Environmental Report, Calendar Year 1996.

July 1997. Resource Conservation and Recovery Act Facility Investigation Report, Vol.1: Introduction and General Site Overview. WVDP-RFI-017.

. June 1998. Final Report: Evaluation of the Pilot Program to Investigate Chromium and Nickel Concentrations in Groundwater in the Sand and Gravel Unit.

West Valley Nuclear Services Co. and URS Group, Inc. January 2001. Results of Corrosion Evaluation in Selected Stainless Steel Monitoring Wells on the North Plateau and Recommendations for Long-Term Management.

August 2003. West Valley Demonstration Project Annual Site Environmental Report, Calendar Year 2002.

August 2004. West Valley Demonstration Project Annual Site Environmental Report, Calendar Year 2003.

$R \& B-10$ 


\section{Distribution}

$\underline{\text { Recipient }}$

Federal Organization

DOE Office of Scientific and Technical Information

$\begin{array}{ll}\text { C. Anderson } & \text { DOE - HQ } \\ \text { D. Geiser } & \text { DOE - HQ } \\ \text { R. Hardwick } & \text { DOE - HQ } \\ \text { A. Lawrence } & \text { DOE - HQ } \\ \text { C. Lewis } & \text { DOE - HQ } \\ \text { F. Marcinowski } & \text { DOE - HQ } \\ \text { R. Natoli } & \text { DOE - HQ } \\ \text { B. Peterson } & \text { DOE - HQ } \\ \text { G. Podonsky } & \text { DOE - HQ } \\ \text { M. Rhoderick } & \text { DOE - HQ }\end{array}$

L. Camper

C. Glenn

G. Suber

M. Roberts

R. Chaput

J. Eng

P. Giardina

J. Reidy

W. Kappel

T. Reynolds

B. Higgins

L. Slaughter

R. Kuhl

H. Clinton

C. Schumer
NRC - HQ

NRC - HQ

NRC - Region 1

U.S. EPA - Region II

U.S. EPA - Region II

U.S. EPA - Region II

U.S. EPA - Region II

USGS

U.S. Congress, 26th Dist.

U.S. Congress, 27th Dist.

U.S. Congress, 28th Dist.

U.S. Congress, 29th Dist.

U.S. Senate, New York

U.S. Senate, New York
NRC - HQ

\section{$\underline{\text { Recipient }}$}

L. White

D. Munro

E. Dassatti

S. Hammond

J. Nasca

R. Phaneuf

T. Rice

M. Wang

B. Youngberg

L. Winterberger

B. Bartz

P. Concannon

S. Doleski

M. Jackson

J. Sciascia

J. Strickland

L. Sturman

G. Baker

B. Ignatz

A. Salame Alfie

P. Bembia

H. Brodie

J. Spath

P. Tonko

D. Gabryszak

M. Schroeder

J. Quinn

D. Burling

J. Giglio

C. Young

W. Stachowski

D. Volker $\underline{\text { State Organization }}$

NYS Attorney Generals Office

NYS Assistant Attorney General

NYSDEC - Albany

NYSDEC - Albany

NYSDEC - Albany

NYSDEC - Albany

NYSDEC - Albany

NYSDEC - Albany

NYSDEC - Albany

NYSDEC - Albany

NYSDEC - Region 9

NYSDEC - Region 9

NYSDEC - Region 9

NYSDEC - Region 9

NYSDEC - Region 9

NYSDEC - Region 9

NYSDOH - Albany

NYSDOH - Buffalo

NYSDOH - Buffalo

NYSDOH - Troy

NYSERDA

NYSERDA - Albany

NYSERDA - Albany

NYSERDA - Albany (President)

New York Assembly, 143rd Dist.

New York Assembly, 145th Dist.

New York Assembly, 146th Dist.

New York Assembly, 147th Dist.

New York Assembly, 149th Dist.

New York Senate, 57th Dist.

New York Senate, 58th Dist.

New York Senate, 59th Dist.

DST - 1 


\section{Distribution}

\begin{tabular}{|c|c|c|c|}
\hline$\underline{\text { Recipient }}$ & Local Organization & $\underline{\text { Recipient }}$ & Local Or \\
\hline E. Wohlers & Cattaraugus County Health Dept. & W. Krebs & Mayor, \\
\hline G. Beck & Cattaraugus County Health Dept. & $\begin{array}{l}\text { W. King } \\
\text { G. Eppolito }\end{array}$ & $\begin{array}{l}\text { Superviso } \\
\text { Superviso }\end{array}$ \\
\hline C. Abers & Cattaraugus County Legislature & C. Gerwitz & Council, \\
\hline G. Felton & Cattaraugus County Legislature & J. Pfeffer & Council, \\
\hline C. Couture & Cattaraugus County Legislature & M. Hutchinson & Sup \\
\hline J. Burrell & Cattaraugus County Legislature & & \\
\hline A. Billittier IV & Erie County Health Department & & \\
\hline C. Pawenski & \multicolumn{3}{|c|}{ Erie County Department of Environmental Planning } \\
\hline M. John & \multicolumn{3}{|l|}{ President, Seneca Nation of Indians } \\
\hline S. Patterson & \multicolumn{3}{|c|}{ Seneca Nation of Indians Environmental Protection Department } \\
\hline D. Rychnowski & Southern Tier West RPDP & & \\
\hline
\end{tabular}

Publication

Buffalo News ${ }^{a}$, Buffalo, New York

Salamanca Republican Press ${ }^{a}$, Salamanca, New York

Springville Journal ${ }^{a}$, Springville, New York

Olean Times Herald, Olean, New York

${ }^{a}$ Notice of public availability

\section{$\underline{\text { Library }}$}

Town of Concord Hulbert Library, Springville, New York

Seneca Nation of Indians Library, Cattaraugus Reservation, Irving, New York

Seneca Nation of Indians Library, Allegheny Reservation, Salamanca, New York

DST - 2 


\title{
Acknowledgments
}

This report was compiled and edited by N.A. McNeil, P.J. Hadden-Carter, and E.D. Picazo (team leader) of the URS West Valley Demonstration Project staff. J.M. Wilcox, also of the URS WVDP staff, provided editing support and desktop publishing services. Other technical preparers and reviewers are listed below.

\author{
Allen, S.J. \\ Biedermann, C.A. \\ Biela, D. \\ Chamberlain, J.D. \\ Chilson, L.J. \\ Cohen, F.J. \\ Curcio, J.P. \\ Davidson, B.S. \\ Dundas, J.M. \\ Fox, J.R. \\ Gerber, J.R. \\ Haywood, F. \\ Hoch, J.J. \\ Kean, W.N. \\ Klenk, D.P. \\ Love, R.D. \\ Luckett, L. \\ Maloney, M.N. \\ McGuire, M.E. \\ McKune, B.N.
}

\author{
Michalczak, L.M. \\ Moore, H.R. \\ Paskuly, S.J. \\ Payne, H.L. \\ Pendl, M.P. \\ Quinby, J.B. \\ Roesch, C.T. \\ Scalise, D.M. \\ Schalberg, T.E. \\ Scharf, R.L. \\ Steiner, A.F. \\ Sullivan, K.D. \\ Warren, S.D. \\ Wedvik, S.K. \\ Werchowski, R.L. \\ Westcott, D.R. \\ Westcott, S.M. \\ Whelan, T.E. \\ Willett, M.J. \\ Wrotniak, C.M.
}

ACK - 1 
This page intentionally left blank

$A C K-2$ 


\section{Appendix A \\ Environmental Monitoring Program Maps}

$A-i$ 
This page intentionally left blank

$A-i i$ 


\section{Environmental Monitoring Program Sample Points}

The following maps contain points sampled as part of the West Valley Demonstration Project (WVDP) routine environmental monitoring program for 2006. This program met or exceeded the requirements of U.S. Department of Energy (DOE) Order 450.1, DOE Order 5400.5, and DOE/EH-0173T. Specific methods and recommended monitoring program elements are found in DOE/EP-0096, "A Guide for Effluent Radiological Measurements at DOE Installations," and DOE/EP-0023, "A Guide for Environmental Radiological Surveillance at U.S. Department of Energy Installations," which were the bases for selecting most of the sampling locations. Additional monitoring was mandated by air and water discharge permits (40 CFR 61 and SPDES).

The index on pages A-iv through A-viii is a list of the codes used to identify the various sampling locations, which are shown on Figures A-2 through A-15. The sample location code describes the physical location where the sample is collected. The code consists of seven or eight characters: The first character identifies the sample medium as Air, Water, Soil/Sediment, Biological, or Direct Measurement. The second character specifies oN-site or oFf-site. For purposes of the WVDP environmental monitoring pgoram, the WNYNSC fenceline is considered the "site" boundary since it efffectively defines an area from which the public is excluded. Locations desginated "on-site" are within the Project facility area; "off-site" lcations, however, may fall just inside WNYNSC boundaries. The remaining characters describe the specific location (e.g., AFGRVAL is Air oFf-site at GReat VALley). Distances are measured in a straight line from the on-site main stack to the sampling location. Sampling points located inside buildings (e.g., on-site drinking water) or points that do not have a fixed location (e.g., outdoor ventilated enclosures) are not shown on these maps. Areas labeled as "wetlands" do not depict the WVDP's formally delineated wetlands inventory. As an aid to the reader, these polygons indicate relatively low-lying areas that almost always contain wet surface soils or standing water during years with typical precipitation totals.

\section{List of Maps}

A-1. West Valley Demonstration Project Base Map A-1

A-2. On-Site Surface Water and Soil/Sediment Sampling Locations ___ A-2

A-3. On-Site Storm Water Outfalls _____ A-3

A-4. Rail Spur Storm Water Outfalls_______ A-4

A-5. Off-Site Surface Water and Soil/Sediment Sampling Locations ___ A-5

A-6. On-Site Air Monitoring and Sampling Locations ____ A-6

A-7. Off-Site Air Sampling Locations ___ A-7

A-8. Active WVDP Groundwater Monitoring Locations ___ A-8

A-9. North Plateau Groundwater Monitoring Network____ A-9

A-10. South Plateau Groundwater Monitoring Network ___ A-10

A-11. Near-Site Drinking Water and Biological Sampling Locations ___ A-11

A-12. Location of On-Site Thermoluminescent Dosimeters (TLDs) ___ A-12

A-13. Location of Off-Site Thermoluminescent Dosimeters (TLDs) Within 5 Kilometers of the WVDP _ A-13

A-14. Environmental Sampling Locations Between 5 and 10 Kilometers From the WVDP ___ A-14

A-15. Environmental Sampling Locations More Than 10 Kilometers From the WVDP____ A-15

A-16. Population by Sector Within 80 Kilometers of the WVDP (2002 Estimate) ___ A-16 


\title{
List of Sampling Locations
}

On-Site Surface Water and Soil/Sediment Sampling Locations (Fig. A-2)

WNSP001

WNSP006

SNSP006

WNSP116

WNSP007

WNSWAMP

SNSWAMP

WNSW74A

SNSW74A

WNSP008

WNSP005

WNCOOLW

WNFRC67

WNERB53

WNNDADR

WNDCELD

WNNDATR

\author{
Lagoon 3 Weir Point \\ Facility Main Drainage \\ Soil at WNSP006 \\ Pseudo-Monitoring Point in Frank's Creek \\ Sanitary Waste Discharge \\ Northeast Swamp Drainage Point \\ Soil at WNSWAMP \\ North Swamp Drainage Point \\ Soil at WNSW74A \\ French Drain LLWTF Area \\ South Facility Drainage \\ Cooling Tower \\ Frank's Creek East \\ Erdman Brook \\ Disposal Area Drainage \\ Drum Cell Drainage \\ NDA Trench Interceptor Project
}

\section{Storm Water Outfalls (Figs. A-3 and A-4)}

$\underline{\text { WNSO-Series Storm Water Outfalls }}$

\author{
GROUP 1 \\ WNSO02 \\ WNSO04 \\ North Swamp Drainage (WNSW74A) \\ GROUP2 \\ WNSO06 \\ WNSO33 \\ Northeast Swamp Drainage (WNSWAMP) \\ LAG Storage Drainage \\ $\underline{\text { GROUP } 3}$ \\ WNSO09 \\ WNSO12 \\ Substation \\ South Facility Drainage (WNSP005) \\ GROUP 4 \\ WNSO34 \\ Rail Spur Culvert
}

CPC Waste Storage Area Swale (pending removal from the SPDES Permit)

$A-i v$ 


\title{
List of Sampling Locations (continued)
}

\author{
Storm Water Outfalls (Figs. A-3 and A-4) (concluded) \\ GROUP 5 \\ WNSO14 \\ WNSO17 \\ WNSO28 \\ NDA Service Road Drainage North \\ NDA Service Road Drainage South \\ Drum Cell West Road \\ GROUP 6 \\ WNSO36 \\ WNSO37 \\ Firing Range Wetland Drainage \\ Pump House Roadway \\ WNSO38 \\ Lake Two Roadway North \\ WNSO39 \\ Lake Two Roadway South \\ WNSO40 \\ Land Between the Lakes (Pending Removal from Permit) \\ WNSO41 \\ WNSO42 \\ Lake One Roadway \\ Pre-Railroad Spur Wetland Area (Near WFBCBKG) \\ GROUP 7 \\ WNSO20 \\ DisposalArea Drainage (WNNDADR) \\ $\underline{\text { GROUP } 8}$ \\ WNSO27 \\ WNSO35 \\ Drum Cell Drainage West \\ Drum Cell Drainage East \\ WNSWR01 \\ Storm Water Precipitation pH Measurement Location Near the Site Rain Gauge
}

Off-Site Surface Water and Soil/Sediment Sampling Locations (Fig. A-5)

$\begin{array}{ll}\text { WFBCBKG } & \text { Buttermilk Creek near Fox Valley, Background } \\ \text { WFBCTCB } & \text { Buttermilk Creek at Thomas Corners } \\ \text { WFBIGBR } & \text { Cattaraugus Creek at Bigelow Bridge, Background } \\ \text { WFFELBR } & \text { Cattaraugus Creek at Felton Bridge } \\ \text { SFSDSED } & \text { Cattaraugus Creek at Springville Dam, Sediment } \\ \text { SFCCSED } & \text { Cattaraugus Creek at Felton Bridge, Sediment } \\ \text { SFTCSED } & \text { Buttermilk Creek at Thomas Corners, Sediment } \\ \text { SFBCSED } & \text { Buttermilk Creek at Fox Valley Road, Background Sediment } \\ \text { SFRSPRD } & \text { Soil at Rock Springs Road Air Sampler } \\ \text { SFRT240 } & \text { Soil at Route 240 Air Sampler } \\ \text { SFFXVRD } & \text { Soil at Fox Valley Road Air Sampler } \\ \text { WNSTAW9 } & \text { Standing Water - Lake 2 }\end{array}$

$A-v$ 


\section{List of Sampling Locations (continued)}

On-Site Air Monitoring and Sampling Locations (Fig. A-6)

$\begin{array}{ll}\text { ANSTACK } & \text { Main Plant } \\ \text { ANSTSTK } & \text { Supernatant Treatment System } \\ \text { ANCSSTK } & \text { 01-14 Building } \\ \text { ANCSRFK } & \text { Size-Reduction Facility } \\ \text { ANCSPFK } & \text { Container Sorting and Packaging Facility } \\ \text { ANVITSK } & \text { Vitrification Heating, Ventilation, and Air Conditioning } \\ \text { ANLAGAM } & \text { Lag Storage Area (ambient air) } \\ \text { ANRGFOP } & \text { Rain Gauge Fallout } \\ \text { ANRHWFK } & \text { Remote-Handled Waste Facility }\end{array}$

Off-Site Air Sampling Locations (Fig. A-7)

AFFXVRD Fox Valley Sampler

AFRT240 Route 240 Sampler

AFRSPRD Rock Springs Road Sampler

$A-v i$ 


\section{List of Sampling Locations (continued)}

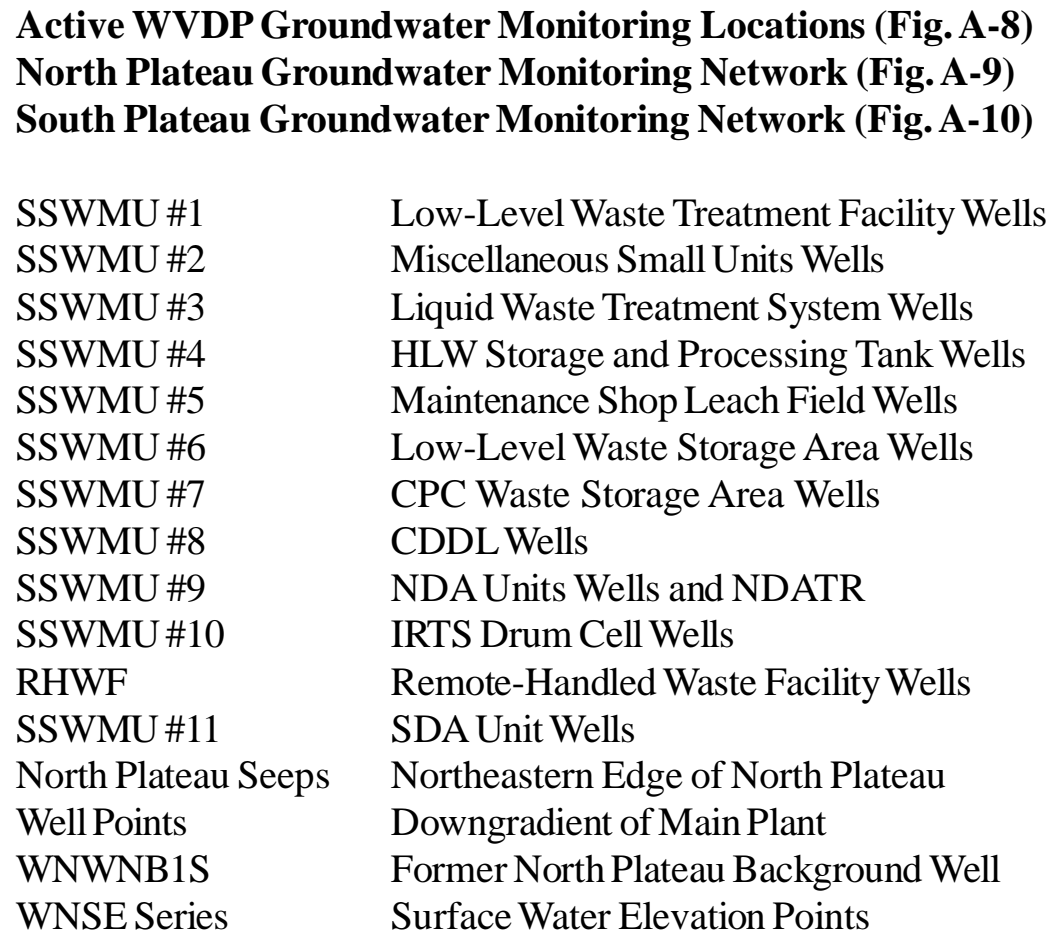

Near-Site Drinking Water and Biological Sampling Locations (Fig. A-11)

$\begin{array}{ll}\text { BFFCATC } & \text { Cattaraugus Creek Fish, Downstream } \\ \text { BFFCATD } & \text { Cattaraugus Creek Fish, Downstream of Springville Dam } \\ \text { BFMWIDR } & \text { Southeast Milk, Near-Site } \\ \text { BFMSCHT } & \text { South Milk, Near-Site } \\ \text { BFMBLSY } & \text { West-Northwest Milk, Near-Site } \\ \text { BFVNEAR } & \text { Produce, Near-Site } \\ \text { BFDNEAR } & \text { Venison, Near-Site } \\ \text { WFWEL Series } & \text { Private Wells }\end{array}$

Location of On-Site Thermoluminescent Dosimeters (TLDs) (Fig. A-12)

DNTLD Series $\quad$ On-Site Direct Radiation

Location of Off-Site Thermoluminescent Dosimeters (TLDs) Within 5 Kilometers of the WVDP (Fig. A-13)

DFTLD Series $\quad$ Off-Site Direct Radiation

$$
A-v i i
$$




\section{List of Sampling Locations (concluded)}

Environmental Sampling Locations Between 5 and 10 Kilometers From the WVDP(Fig. A-14)

$\begin{array}{ll}\text { AFSPRVL } & \text { Springville Air Sampler } \\ \text { SFSPRVL } & \text { Soil at Springville Air Sampler } \\ \text { DFTLD21 } & \text { TLD at Springville Air Sampler } \\ \text { WFWEL10 } & \text { Drinking Water at Springville Air Sampler } \\ \text { BFVNEAR } & \text { Produce, Near-site } \\ \text { DFTLD22 } & \text { TLD at West Valley Air Sampler } \\ \text { SFWEVAL } & \text { Soil at West Valley Air Sampler } \\ \text { AFWEVAL } & \text { West Valley Air Sampler }\end{array}$

Environmental Sampling Locations More Than 10 Kilometers From the WVDP(Fig. A-15)

BFMCTLS

BFVCTRL

BFFCTRL

BFDCTRL

AFGRVAL

SFGRVAL

DFTLD23

WFWEL06

\author{
Milk, South, Background \\ Produce, Background \\ Cattaraugus Creek Fish, Background \\ Venison, Background \\ Great Valley Air Sampler, Background \\ Soil at Great Valley Air Sampler, Background \\ TLD at Great Valley Air Sampler \\ Drinking Water at Great Valley Air Sampler
}

A - viii 


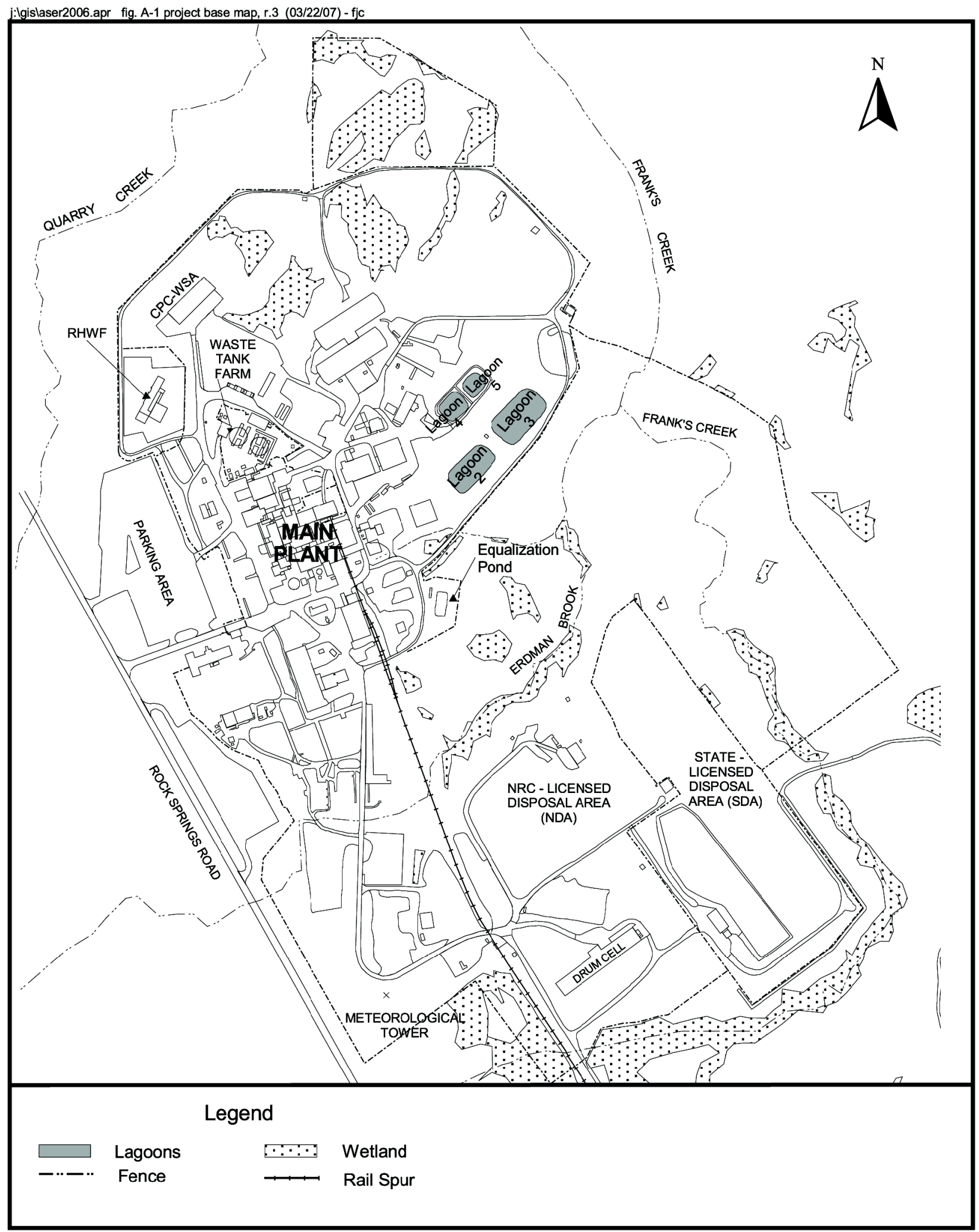

Figure A-1. West Valley Demonstration Project Base Map

$$
\text { A - } 1
$$




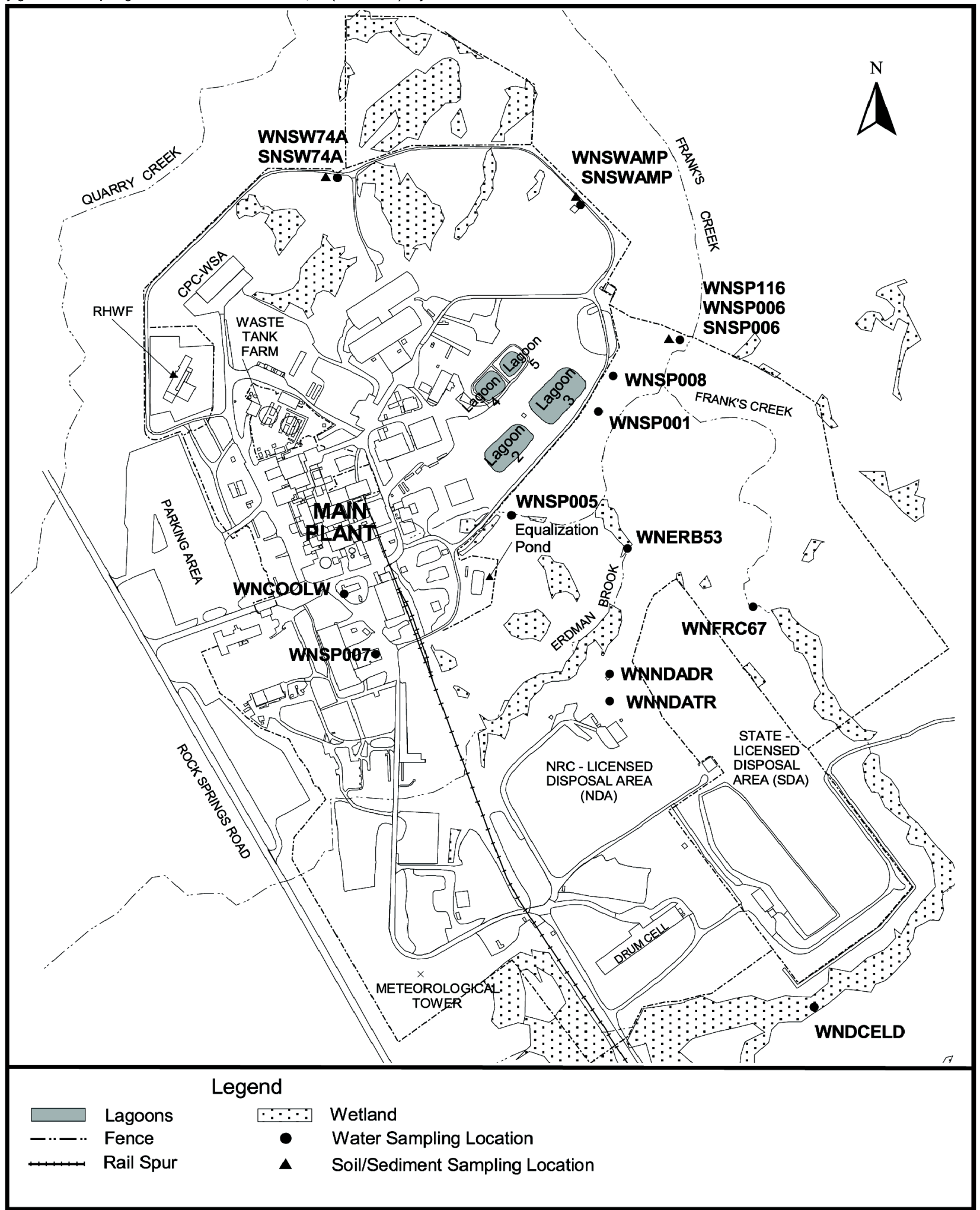

Figure A-2. On-Site Surface Water and Soil/Sediment Sampling Locations

A - 2 


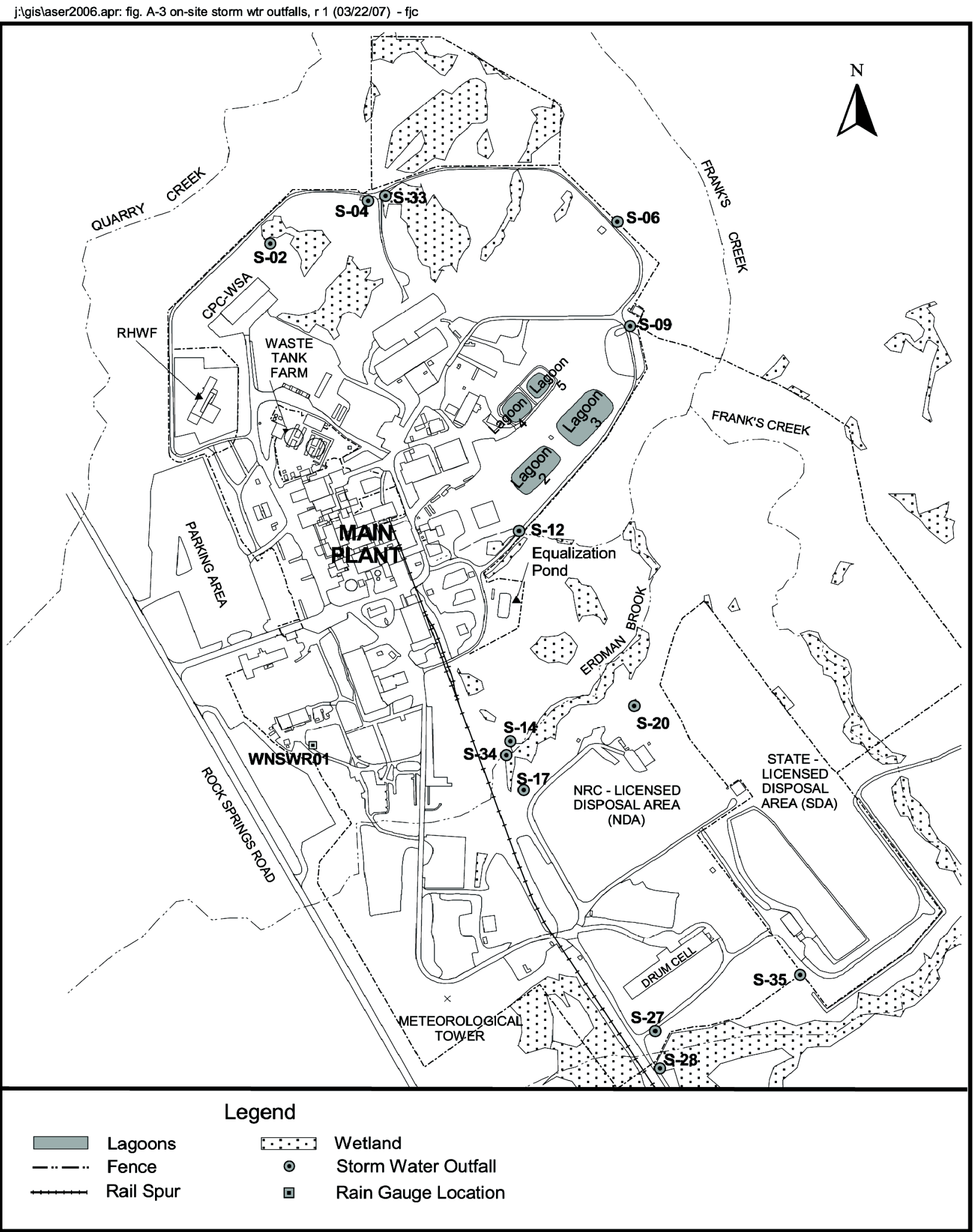

Figure A-3. On-Site Storm Water Outfalls

A - 3 


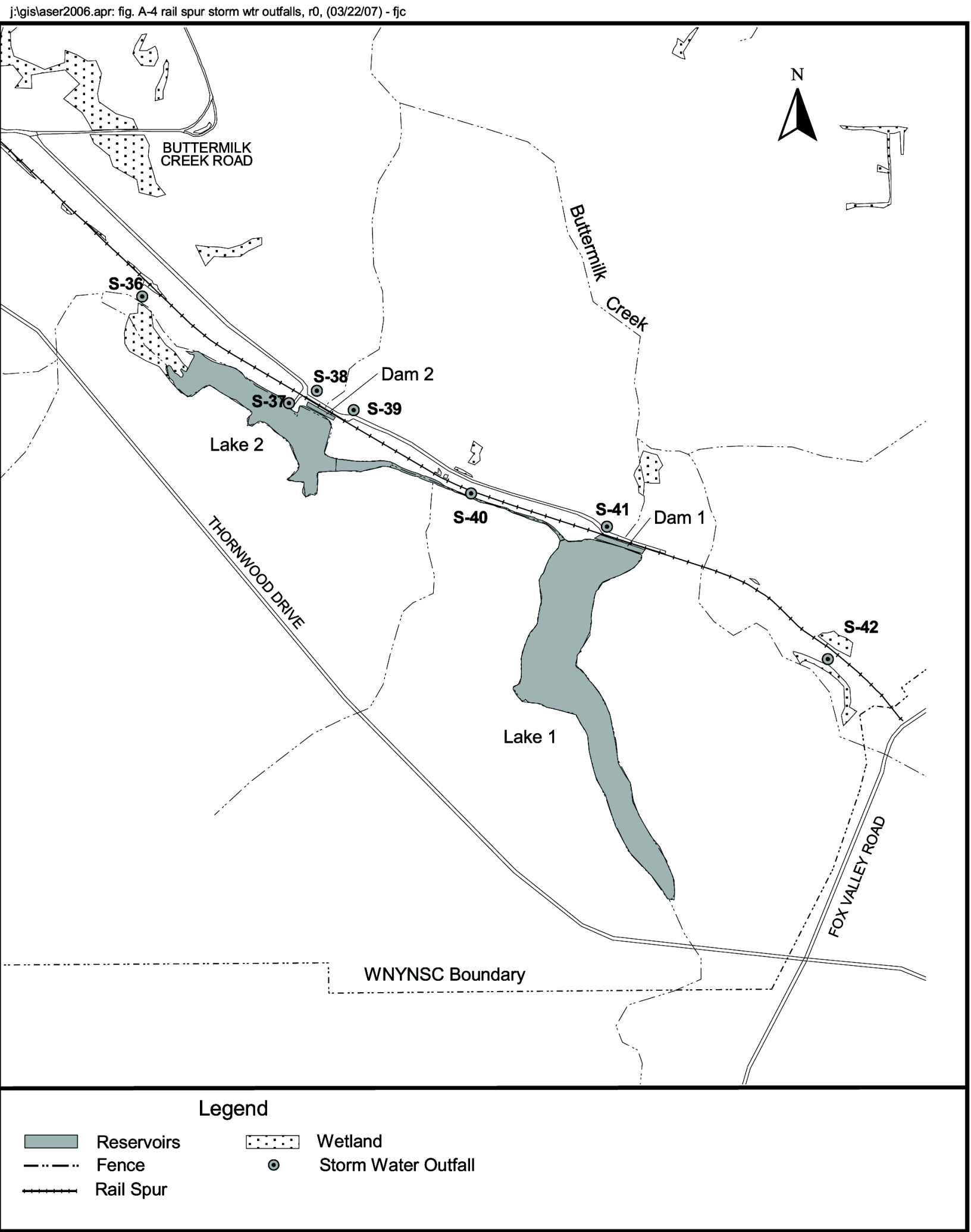

Figure A-4. Rail Spur Storm Water Outfalls

$$
\text { A - } 4
$$


j:Igislaser2006.apr fig. A-5 off-site surf water \& soil/sed, r4 (03/22/2007) - fjc

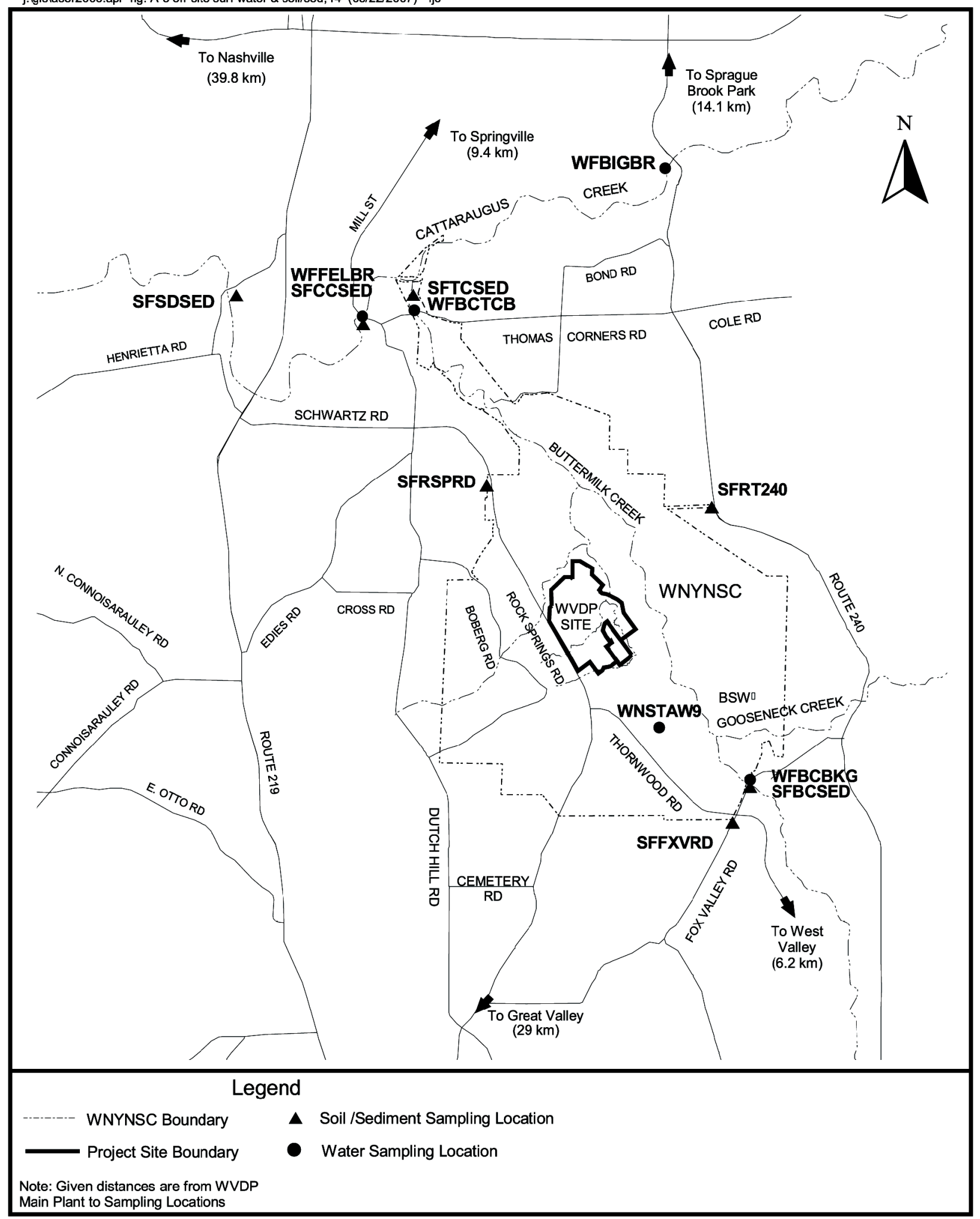

Figure A-5. Off-Site Surface Water and Soil/Sediment Sampling Locations

$$
\text { A - } 5
$$




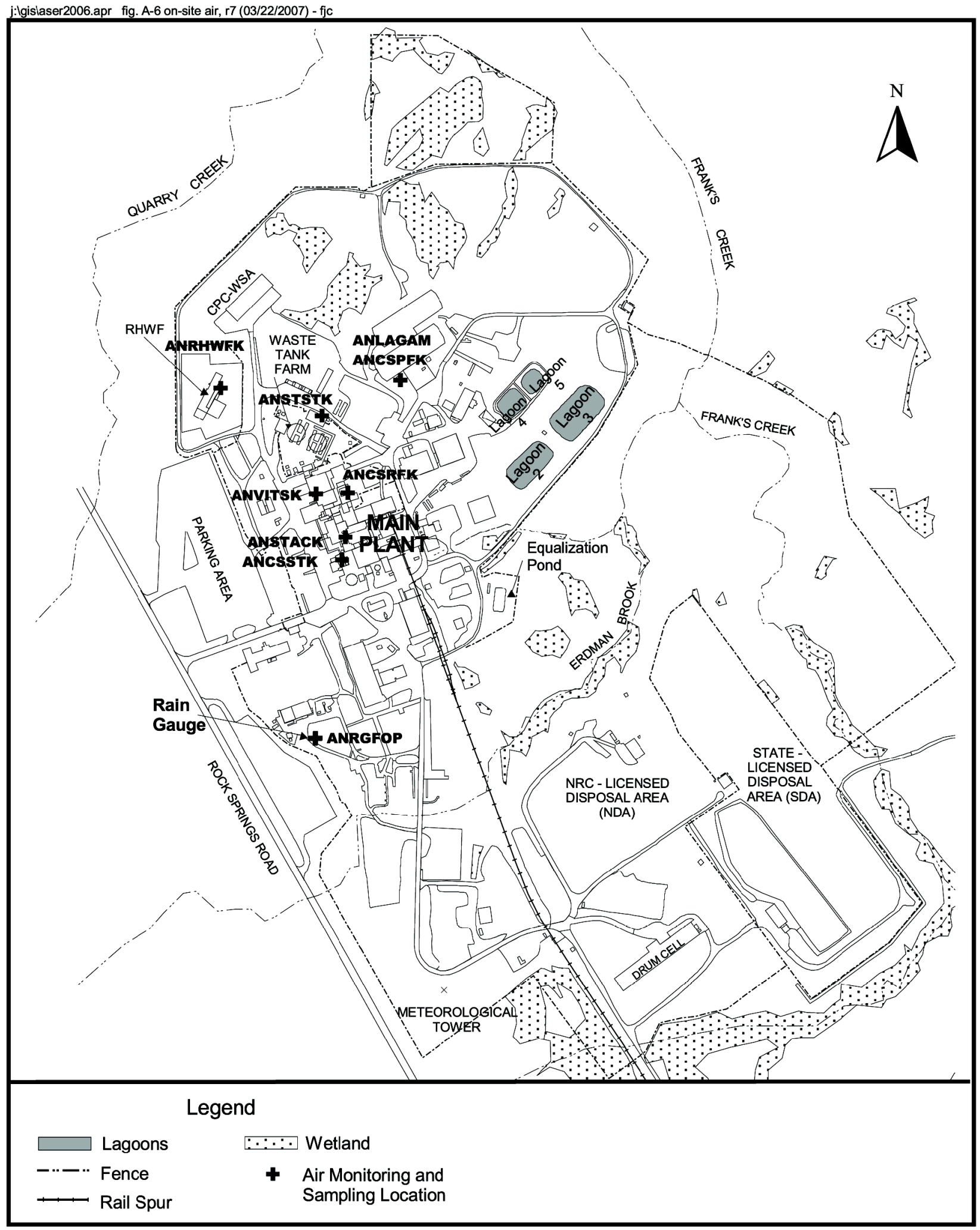

Figure A-6. On-Site Air Monitoring and Sampling Locations

A - 6 


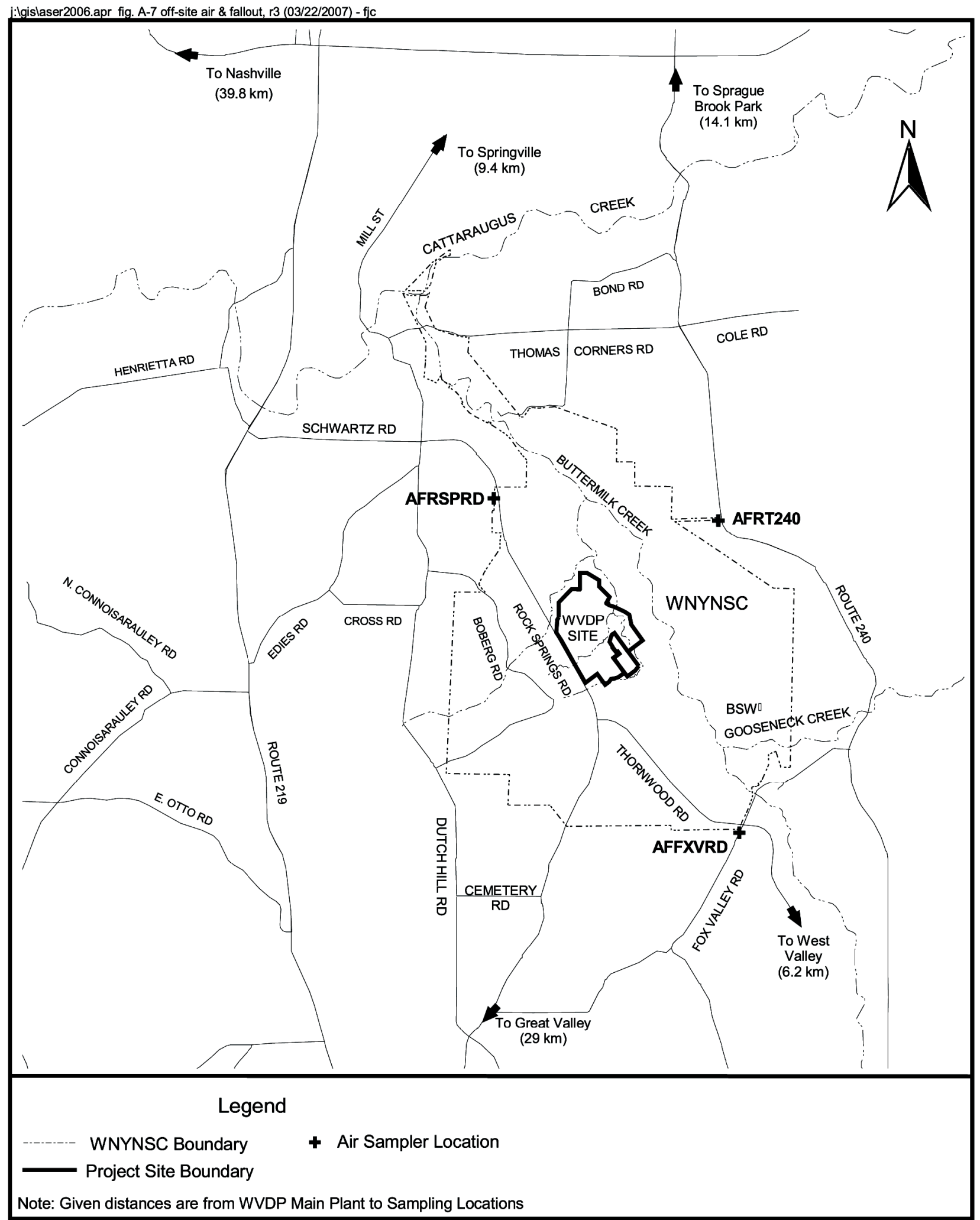

Figure A-7. Off-Site Air Sampling Locations

A - 7

WVDP Annual Site Environmental Report

Calendar Year 2006 


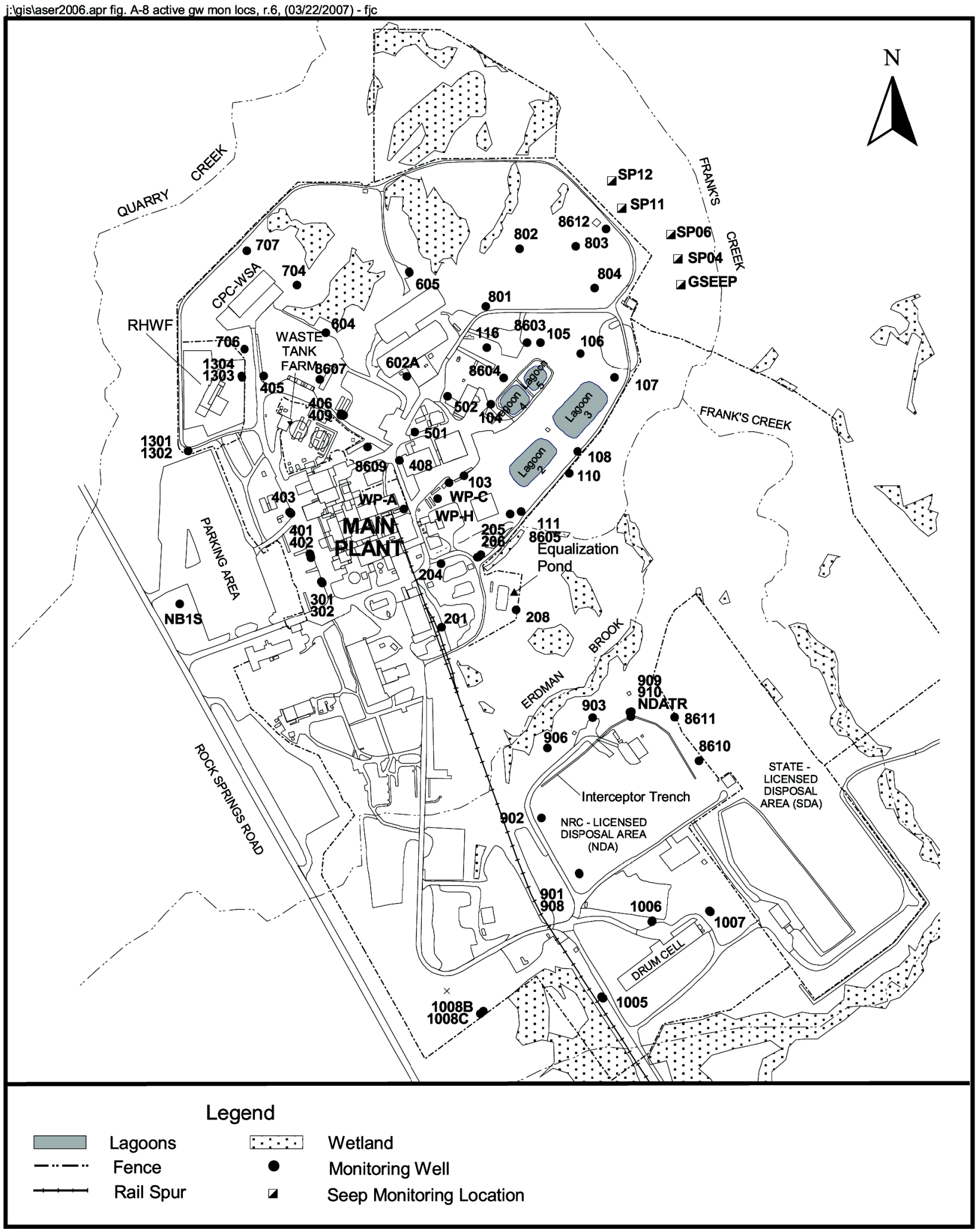

Figure A-8. Active WVDP Groundwater Monitoring Locations

A - 8 


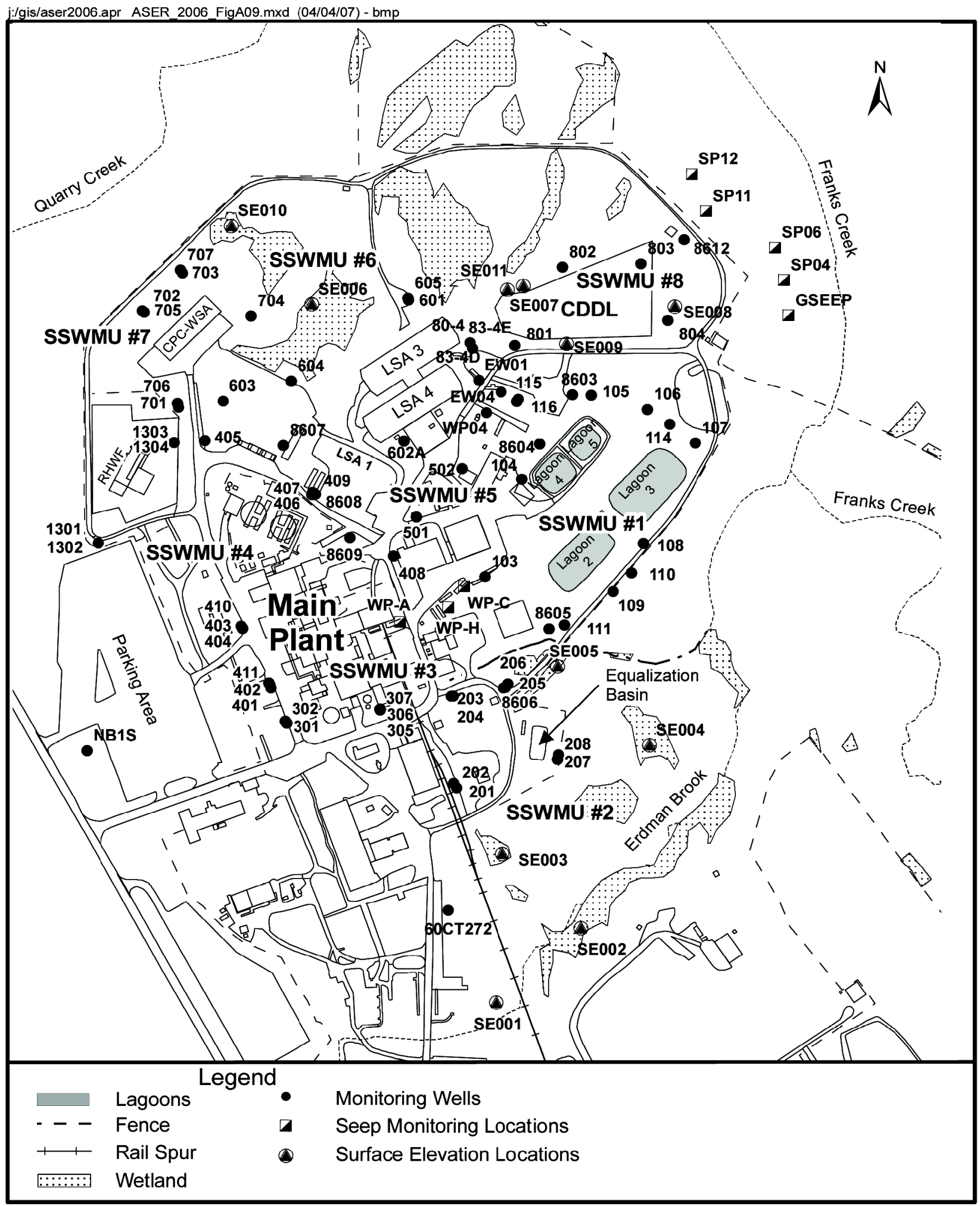

Figure A-9. North Plateau Groundwater Monitoring Network (Includes Wells Used for Water-Level Measurements)

$$
\text { A - } 9
$$




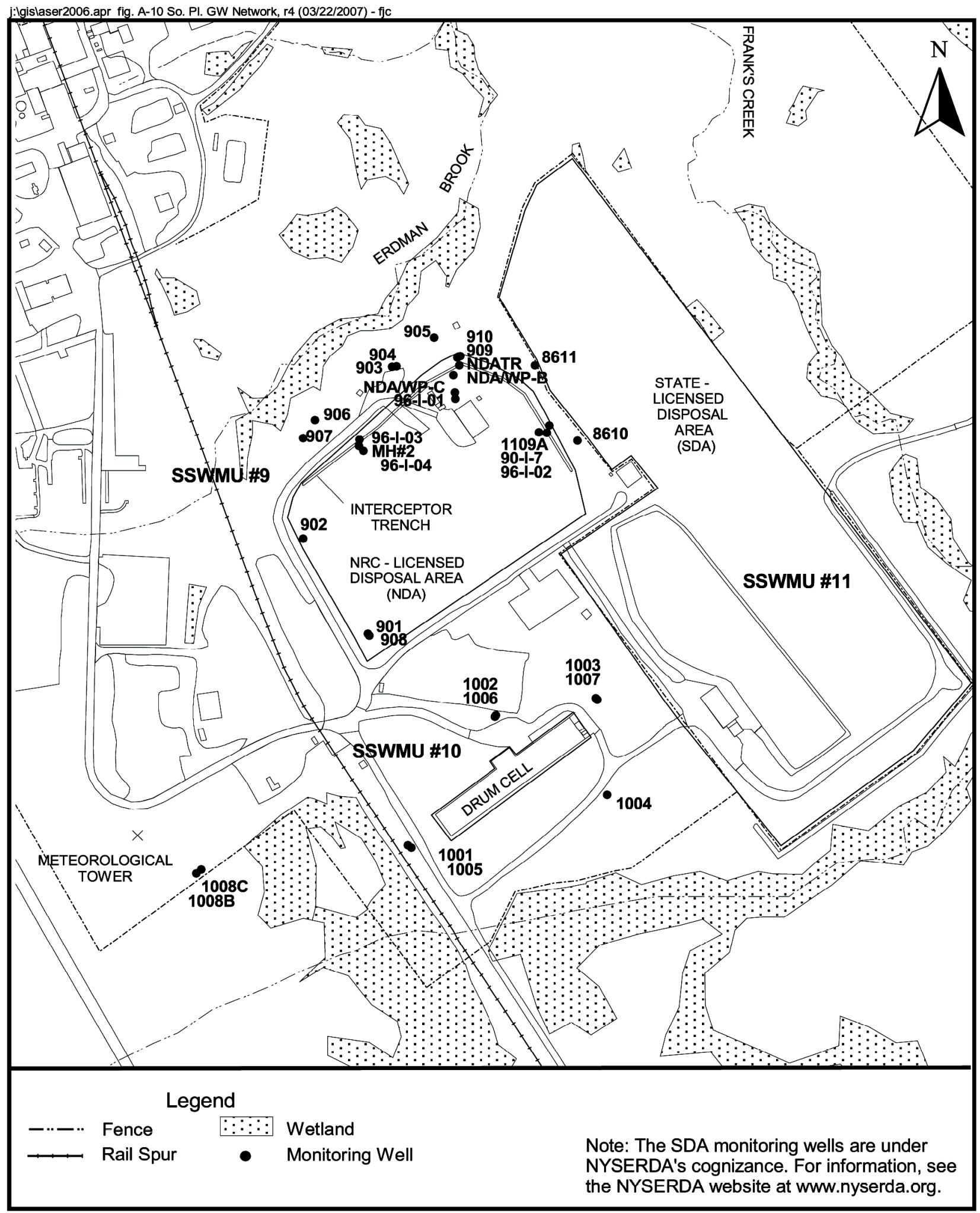

Figure A-10. South Plateau Groundwater Monitoring Network (Includes Wells Used for Water-Level Measurements)

A -10 


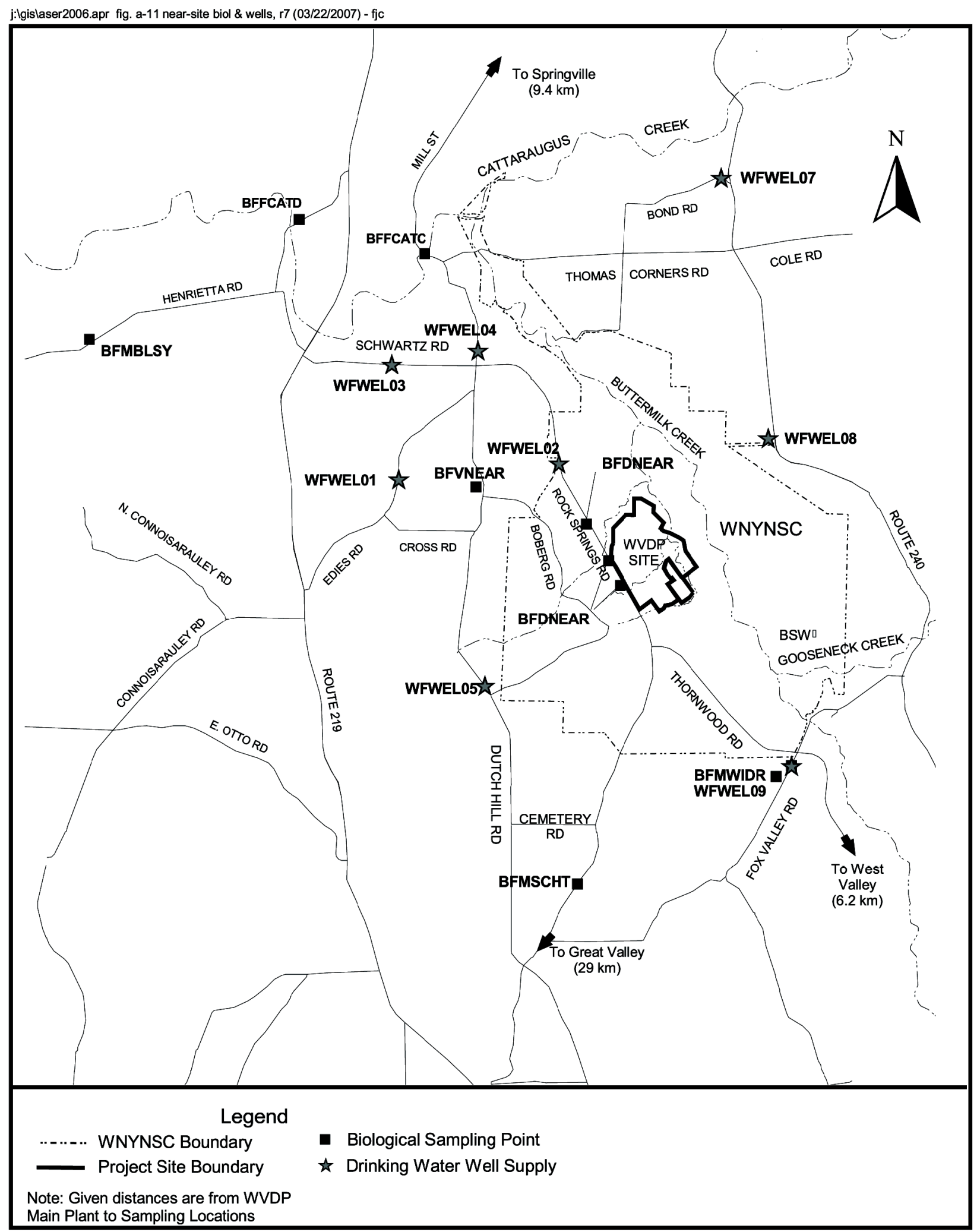

Figure A-11. Near-Site Drinking Water and Biological Sampling Locations

$$
\text { A - } 11
$$




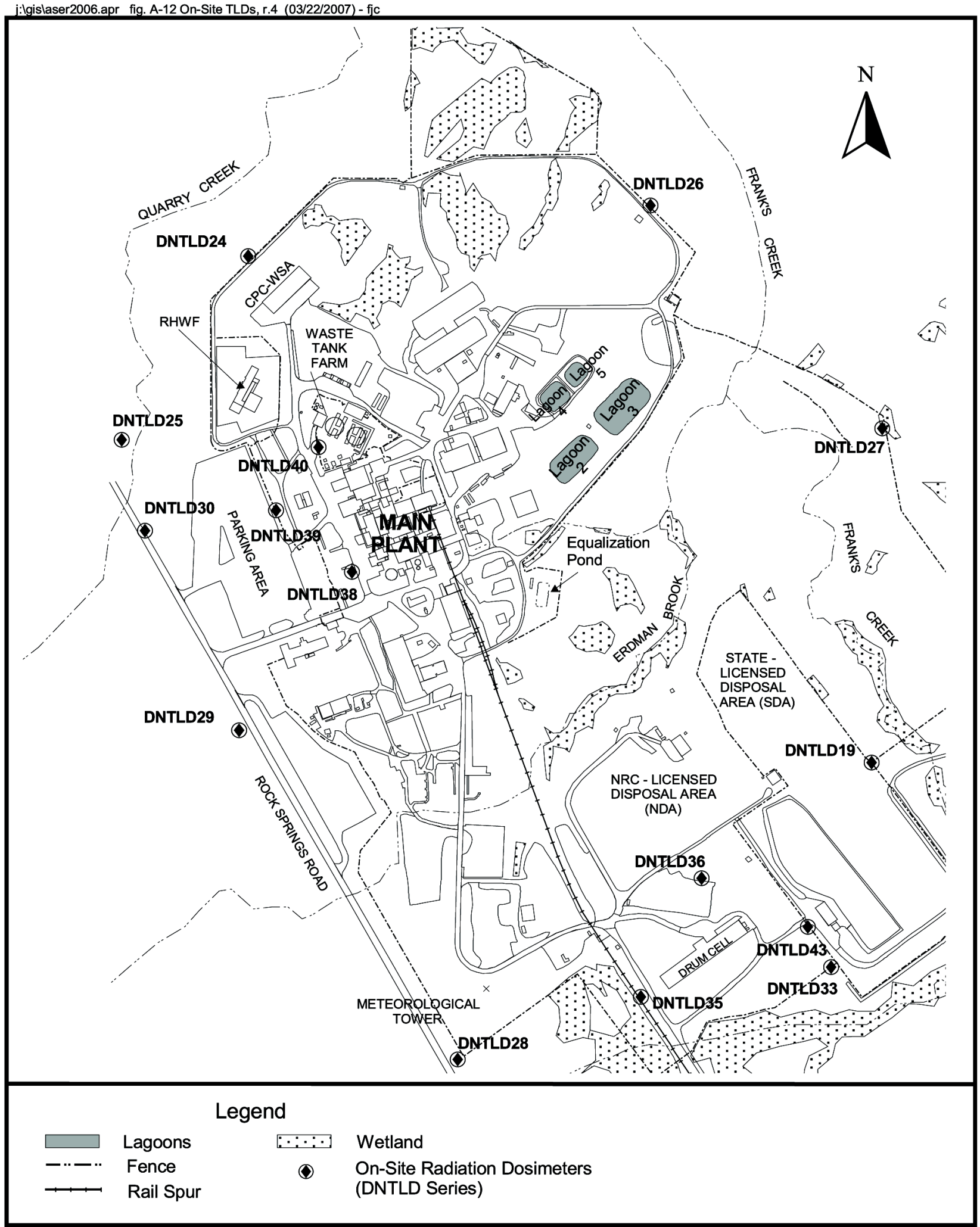

Figure A-12. Location of On-Site Thermoluminescent Dosimeters (TLDs)

$$
\text { A - } 12
$$




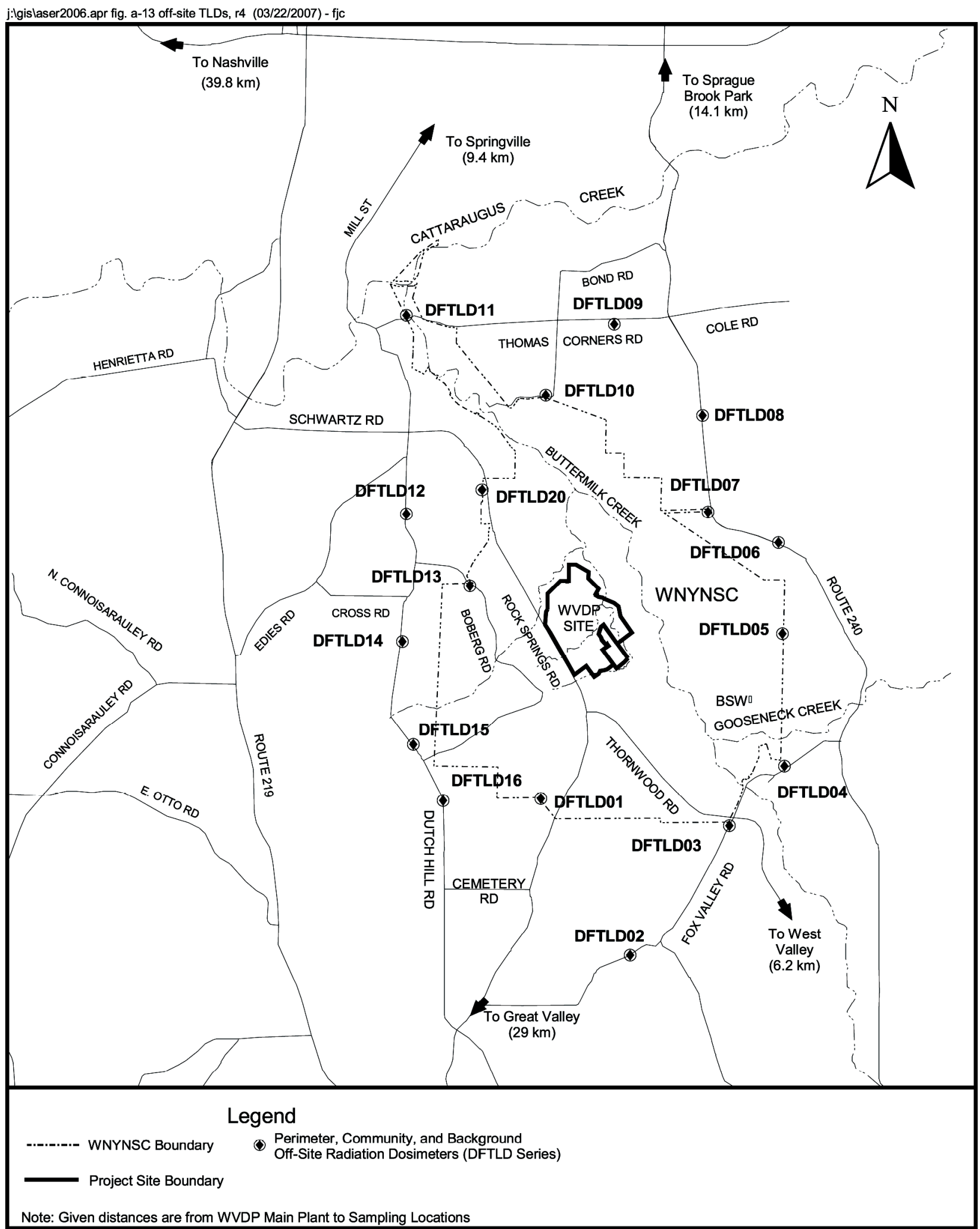

Figure A-13. Location of Off-Site Thermoluminescent Dosimeters (TLDs) Within 5 Kilometers of the WVDP

$$
\text { A - } 13
$$


j:Igislaser2006.apr fig A-14 env samp loc bet 5-10 km from wvdp, 16 (03/22/07) - fjc

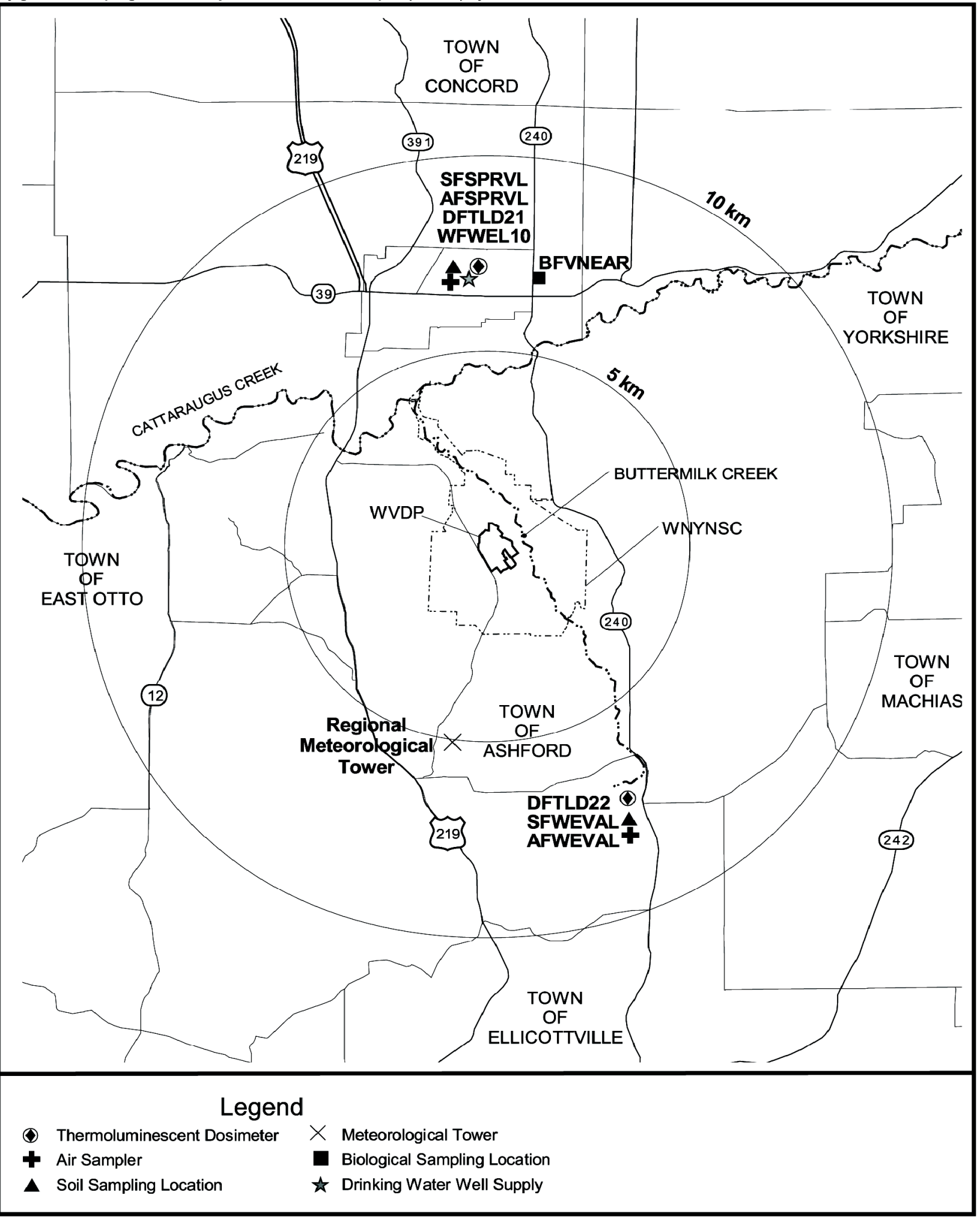

Figure A-14. Environmental Sampling Locations Between 5 and 10 Kilometers From the WVDP

$$
\text { A - } 14
$$




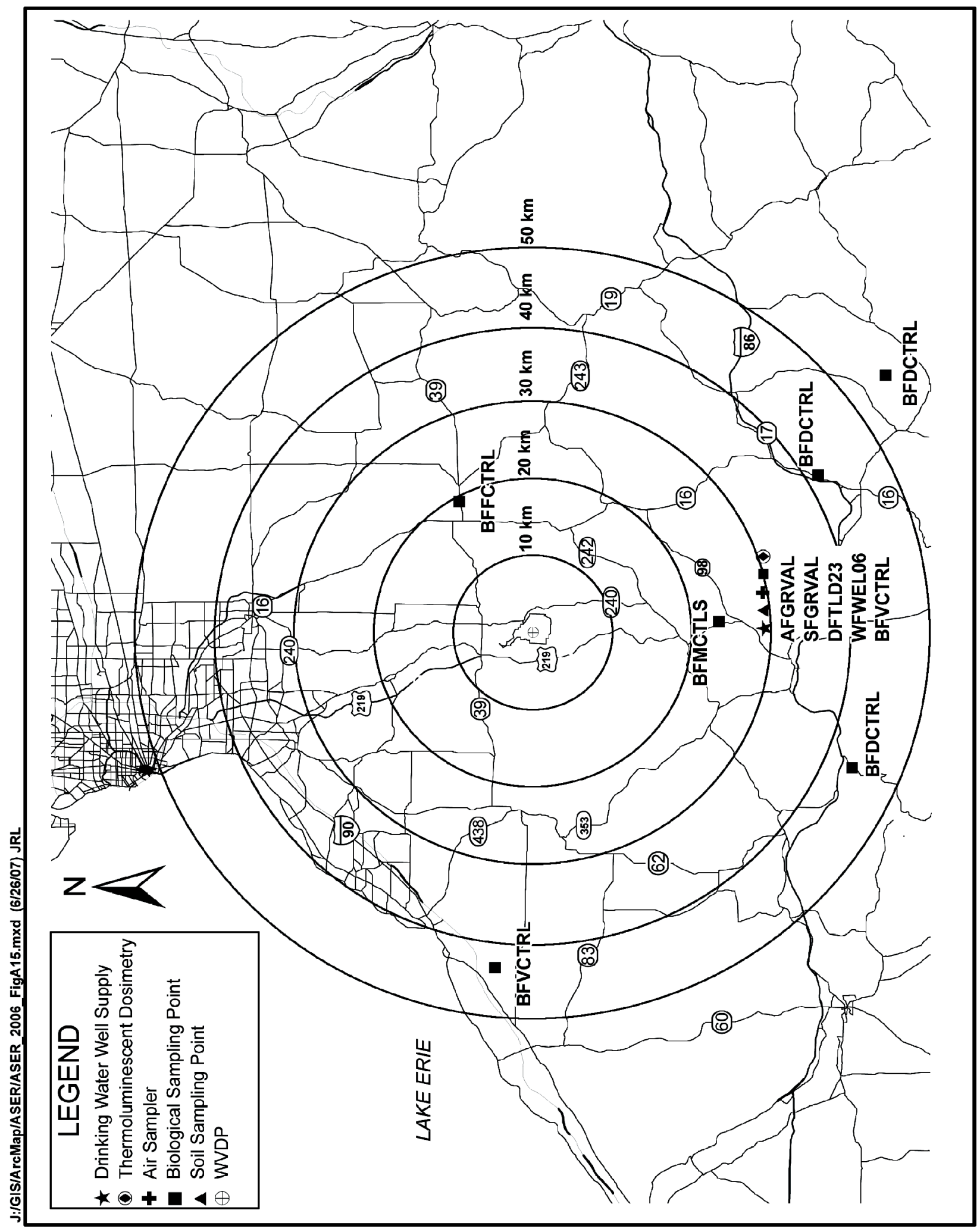

Figure A-15. Environmental Sampling Locations More Than 10 Kilometers From the WVDP

A - 15 


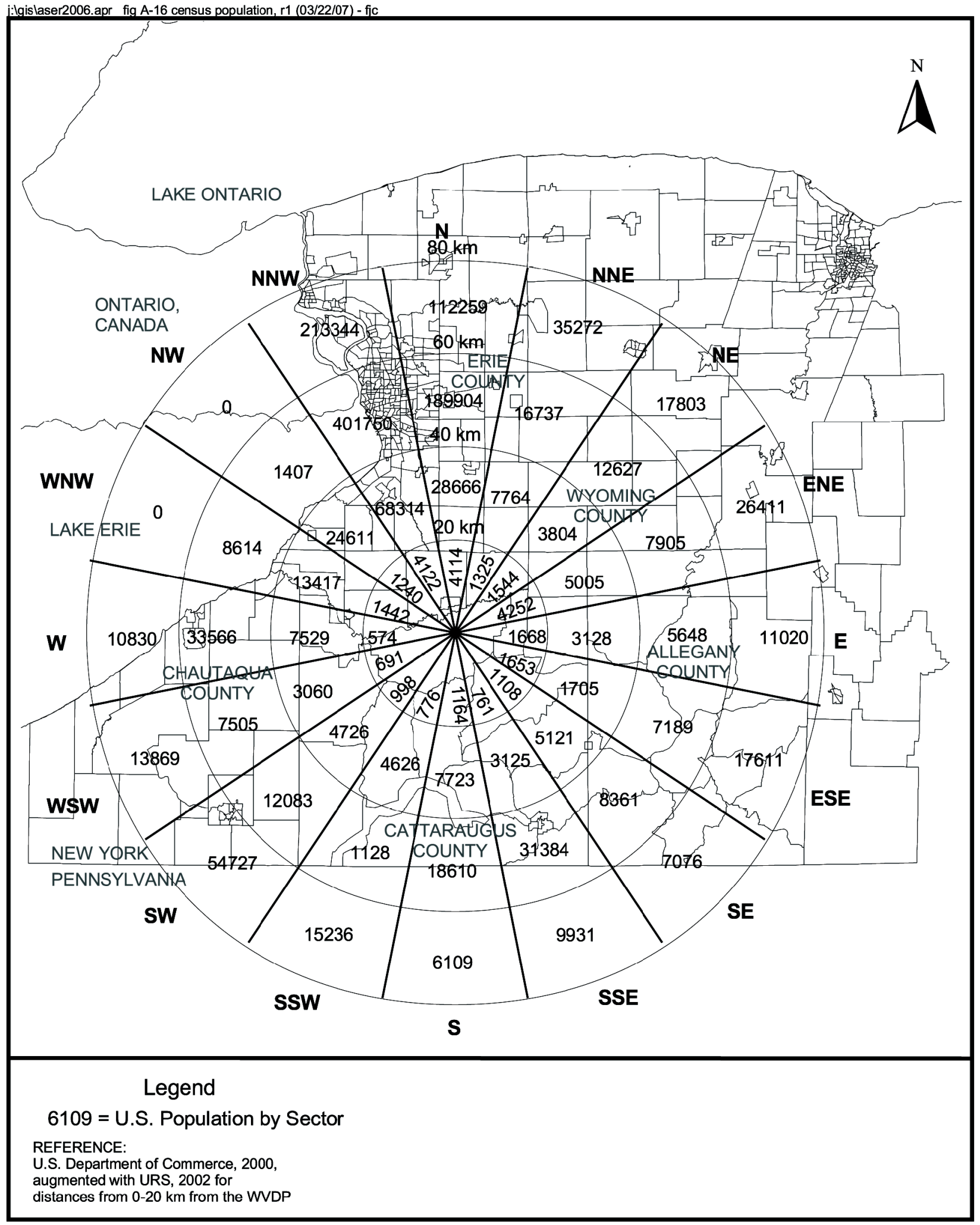

Figure A-16. Population by Sector Within 80 Kilometers of the WVDP (2002 Estimate)

$$
\text { A - } 16
$$




\section{Appendix $B$ 2006 Environmental Monitoring Program}

$B-i$ 
This page intentionally left blank

$B-i i$ 


\section{Environmental Monitoring Program}

The following schedule represents the West Valley Demonstration Project (WVDP) routine environmental monitoring program for 2006. This schedule met or exceeded the requirements of DOE Order 450.1, DOE Order 5400.5, and DOE/EH-0173T. Specific methods and recommended monitoring program elements are found in DOE/EP-0096, A Guide for Effluent Radiological Measurements at DOE Installations, and DOE/EP-0023, A Guide for Environmental Radiological Surveillance at U.S. Department of Energy Installations, which were the bases for selecting most of the schedule specifics. Additional monitoring was mandated by air and water discharge permits (40 CFR 61 and SPDES), which also required formal reports. Specifics are identified in the schedule under Monitoring/Reporting Requirements.

A computerized environmental data-screening system identifies analytical data that exceed preset limits. All locations are checked routinely for trends or notable results in accordance with criteria established in Documentation and Reporting of Environmental Data (West Valley Nuclear Services Co., December 27, 2004). Reportable results are then described in Trend Analysis Reports (TARs) for radiological screening and isotopic parameters together with possible causes and corrective actions, if indicated. WVDP Effluent Summary Reports (ESRs) are transmitted with the TAR. For CY 2006, the Trend Analysis Reports were reported on a quarterly basis. The WVDP groundwater monitoring radiological screening and chemical results are reported in the quarterly Groundwater Trend Analysis Reports (GTARs).

\section{Schedule of Environmental Sampling}

The index on pages B-v through B-viii is a list of the codes used to identify the various sampling locations, which are shown on Figures A-2 through A-15 in Appendix A. The schedule of environmental sampling at the WVDP is found in this appendix. Table headings in the schedule are as follows:

- Sample Location Code. Describes the physical location where the sample is collected. The code consists of seven or eight characters: The first character identifies the sample medium as Air, Water, Soil/Sediment, Biological, or Direct Measurement. The second character specifies oN-site or oFf-site. The remaining characters describe the specific location (e.g., AFGRVAL is Air oFf-site at GReat VALley). Distances noted at sampling locations are as measured in a straight line from the main stack on site.

- Monitoring/Reporting Requirements. Notes the bases for monitoring the location, any additional references to permits, and the reports that are generated from the sample data. Routine reports cited in this appendix are the Effluent Summary Report (ESR), the Trend Analysis Report (TAR), the State Pollutant Discharge Elimination System Discharge Monitoring Report (SPDES DMR), the Air Emissions Report (NESHAP), the Annual Site Environmental Report (ASER), and the quarterly Groundwater Trend Analysis Report (GTAR).

- Sampling Type/Medium. Describes the collection method and the physical characteristics of the medium.

- Collection Frequency. Indicates how often the samples are collected or retrieved.

- Total Annual Sample Collections. Specifies the number of discrete physical samples collected annually for each group of analytes.

- Analyses Performed/Composite Frequency. Notes the type of analyses of the samples taken at each collection, the frequency of composite, and the analytes determined for the composite samples.

$B-i i i$

WVDP Annual Site Environmental Report

Calendar Year 2006 


\section{Summary of Monitoring Program Changes in 2006}

Location Code

WNSP001

WFWEL07

BFMCTLS

\section{Description of Changes}

The SPDES permit was renewed effective September 1, 2006, and sampling frequency for some chemical constituents was modified. The complete parameter list and the frequency of sample collections are presented on pp. B-5 and B-6.

The owner of the residence at off-site drinking water location \#7 no longer resides at that location. The next nearest location in the same vicinity was substituted as a replacement sampling point for off-site potable water.

The dairy that previously provided the annual south control milk sample was sold in 2006. Sampling of milk from a substitute dairy farm, $22 \mathrm{~km}$ south of the site, was added to the program in the fall of 2006.

$B-i v$ 


\title{
Index of Environmental Monitoring Program Sample Points
}

\author{
Air Effluent and On-Site Ambient Air (Fig. A-6) \\ $\begin{array}{lll}\text { ANSTACK } & \text { Main Plant } & \text { B-1 }\end{array}$ \\ $\begin{array}{lll}\text { ANSTSTK } & \text { Supernatant Treatment System } & \text { B-1 }\end{array}$ \\ $\begin{array}{lll}\text { ANCSSTK 01-14Building } & \text { B-1 }\end{array}$ \\ ANCSRFK Size-Reduction Facility $\quad$ B-1 \\ $\begin{array}{lll}\text { ANCSPFK } & \text { Container Sorting and Packaging Facility } & \text { B-1 }\end{array}$ \\ ANVITSK Vitrification Heating, Ventilation, and Air Conditioning $\quad$ B-1 \\ ANRHWFK Remote-Handled Waste Facility $\quad$ B-1 \\ OVEs/PVUs $^{a} \quad$ Outdoor Ventilated Enclosures/Portable Ventilation Units $\quad$ B-3 \\ $\begin{array}{lll}\text { ANLAGAM } & \text { Lag Storage Area (ambient air) } & \text { B-3 }\end{array}$
}

Liquid Effluent, On-Site Water, and Storm Water Outfalls (Figs. A-2 through A-5)

WNSP001 Lagoon 3 Weir Point B-5

$\begin{array}{lll}\mathrm{WNSP} 1 \mathrm{~B}^{a} & \text { Internal Process Monitoring Point } & \text { B-7 }\end{array}$

$\begin{array}{lll}\text { WNSP116 } & \text { Pseudo-Monitoring Point Outfall } 116 & \text { B-7 }\end{array}$

$\begin{array}{lll}\text { WNSP007 } & \text { Sanitary Waste Discharge } & \text { B-7 }\end{array}$

WNSP006 Facility Main Drainage $\quad$ B-9

WNURRAW $^{a} \quad$ Utility Room Raw Water $\quad$ B-9

$\underline{\text { WNSO-Series Storm Water Outfalls }}$

GROUP 1

WNSO02 CPC Waste Storage Area Swale $\quad$ B-11

WNSO04 North Swamp Drainage (WNSW74A) $\quad$ B-11

$\underline{\text { GROUP } 2}$

WNSO06

Northeast Swamp Drainage (WNSWAMP) B-11

WNSO33 LAG Storage Drainage $\quad$ B-11

GROUP 3

WNSO09

Substation

B-11

WNSO12

South Facility Drainage (WNSP005)

B-11

$\underline{\text { GROUP } 4}$

WNSO34

Rail Spur Culvert

B-13

${ }^{a}$ Not detailed on map.

$$
B-v
$$




\section{Index of Environmental Monitoring Program Sample Points (continued)}

\section{Liquid Effluent, On-Site Water, and Storm Water Outfalls (Figs. A-2 through A-5) (concluded)}

GROUP 5

WNSO14

WNSO17

WNSO28

GROUP6

WNSO36

WNSO37

WNSO38

WNSO39

WNSO40

WNSO41

WNSO42

GROUP 7

WNSO20

GROUP 8

WNSO27

WNSO35

WNSWR01

WNSWAMP

WNSW74A

WNSP008

WNSP005

WNCOOLW

WNFRC67

WNERB53

WNNDADR

WNDCELD

WNNDATR

WNSTAW 9

WNDNK Series $^{a}$
NDA Service Road Drainage North

B-13

NDA Service Road Drainage South

B-13

Drum Cell West Road

B-13

Firing Range Wetland Drainage

B-15

Pump House Roadway

B-15

Lake Two Roadway North

B-15

Lake Two Roadway South

B-15

Land Between the Lakes (Pending Removal from Permit)

B-15

Lake One Roadway

B-15

Pre-Railroad Spur Wetland Area (Near WFBCBKG)

B-15

Disposal Area Drainage (WNNDADR)

B-15

Drum Cell Drainage West

B-17

Drum Cell Drainage East

B-17

Storm Water Precipitation $\mathrm{pH}$ Measurement Location Near the Site

Rain Gauge

B-17

Northeast Swamp Drainage Point

B-19

North Swamp Drainage Point

B-19

French Drain LLWTF Area

B-21

South Facility Drainage

B-21

Cooling Tower

B-21

B-23

Frank's Creek East

B-23

Erdman Brook

B-23

Disposal Area Drainage

B-23

Drum Cell Drainage

B-25

NDA Trench Interceptor Project

B-25

Standing Water Near North Reservoir Intake

B-27

${ }^{a}$ Not detailed on map.

$$
B-v i
$$




\section{Index of Environmental Monitoring Program Sample Points (continued)}

On-Site Ground water and Seeps (Figs. A-8 through A-10)

SSWMU\#1

Low-Level Waste Treatment Facility Wells

B-29

SSWMU \#2

Miscellaneous Small Units Wells

B-29

SSWMU\#3

Liquid Waste Treatment System Wells

B-29

HLW Storage and Processing Tank Wells

B-31

SSWMU\#5

Maintenance Shop Leach Field Wells

B-31

SSWMU\#6

Low-Level Waste Storage Area Wells

B-31

CPC Waste Storage Area Wells

B-31

SSWMU \#8

CDDL Wells

B-33

NDA Unit Wells and NDATR

B-33

IRTS Drum Cell Wells

B-33

Remote-Handled Waste Facility Wells

B-33

SDA Unit Wells

B-35

Northeastern Edge of North Plateau

B-35

Downgradient of Main Plant

B-35

Former North Plateau Background Well

B-35

Surface Water Elevation Points

B-35

\section{Off-Site Surface Water (Fig. A-5)}

WFBCBKG

Buttermilk Creek Near Fox Valley, Background

B-37

WFBCTCB

Buttermilk Creek at Thomas Corners

B-37

WFBIGBR

Cattaraugus Creek at Bigelow Bridge, Background

B-39

WFFELBR

Cattaraugus Creek at Felton Bridge

B-39

Off-Site Drinking Water (Figs. A-11, A-14, and A-15)

WFWEL Series Private Local Wells

B-41

Off-Site Ambient Air (Figs. A-7, A-14, and A-15)

AFFXVRD

AFRT240

AFSPRVL

AFWEVAL

AFRSPRD

AFGRVAL
Fox Valley Sampler

Route 240 Sampler

Springville Sampler

West Valley Sampler

Rock Springs Road Sampler

Great Valley Sampler, Background
B-43

B-43

B-43

B-43

B-43

B-43

$$
B-v i i
$$




\section{Index of Environmental Monitoring Program Sample Points (concluded)}

Fallout, Sediment, and Soil (Figs. A-2, A-5, A-6, A-14, and A-15)

ANRGFOP

SF Soil Series

SFCCSED

SFSDSED

SFTCSED

SFBCSED

SN Soil Series:
Rain Gauge Fallout

B-45

Air Sampler Area Soil

Cattaraugus Creek at Felton Bridge, Sediment

Cattaraugus Creek at Springville Dam, Sediment

Buttermilk Creek at Thomas Corners, Sediment

Buttermilk Creek at Fox Valley Road, Background Sediment On-Site Soils/Sediments
B-45

B-45

B-45

B-45

B-45

B-45

B-45

B-45

B-45

SNSWAMP

SNSP006

B-47

B-47

B-47

B-47

B-47

B-47

B-47

B-49

B-49

B-49

B-49

BFDCTRL

Venison, Near-Site

Venison, Background

\section{Direct Measurement Dosimetry (Figs. A-12 through A-15)}

DFTLD Series

DNTLD Series
Off-Site Direct Radiation

B-51

On-Site Direct Radiation
B-53

${ }^{a}$ Near-site and background produce samples (corn, apples, and beans) are identified specifically as follows: corn = BFVNEAC and BFVCTRC; apples = BFVNEAAF and BFVCTRA; beans = BFVNEAB and BFVCTRB. 
This page intentionally left blank

$B-i x$ 


\section{Monitoring Program \\ On-Site Effluent Monitoring}

Air Effluents

\begin{tabular}{|c|c|c|c|c|c|c|c|c|}
\hline $\begin{array}{l}\text { Sample Location } \\
\text { Code }\end{array}$ & $\begin{array}{l}\text { Monitoring/Reporting } \\
\text { Requirements }\end{array}$ & $\begin{array}{c}\text { Sampling } \\
\text { Type/Medium }\end{array}$ & & $\begin{array}{l}\text { Collection } \\
\text { Frequency }\end{array}$ & & $\begin{array}{c}\text { Total Annual } \\
\text { Sample Collections }\end{array}$ & & $\begin{array}{l}\text { Analyses Performed/ } \\
\text { Composite Frequency }\end{array}$ \\
\hline $\begin{array}{l}\text { ANSTACK } \\
\text { Main Plant Ventilation } \\
\text { Exhaust Stack }\end{array}$ & & $\begin{array}{l}\text { Continuous } \\
\text { off-line air } \\
\text { particulate } \\
\text { monitors }\end{array}$ & $\rightarrow$ & $\begin{array}{l}\text { Continuous } \\
\text { measurement of } \\
\text { fixed filter; } \\
\text { replaced biweekl }\end{array}$ & $\begin{array}{l}\rightarrow \\
\text { kly }\end{array}$ & NA & $\rightarrow$ & $\begin{array}{l}\text { Real-time alpha and } \\
\text { beta monitoring }\end{array}$ \\
\hline $\begin{array}{l}\text { ANSTSTK } \\
\text { Supernatant Treatment } \\
\text { System (STS) Ventila- } \\
\text { tion Exhaust }\end{array}$ & $\begin{array}{l}\text { Airborne radioac- } \\
\text { tive effluent points, } \\
\text { including the LWTS }\end{array}$ & $\begin{array}{l}\text { Continuous } \\
\text { off-line air } \\
\text { particulate }\end{array}$ & $\rightarrow$ & Biweekly & $\rightarrow$ & $\begin{array}{l}26 \text { each } \\
\text { location }\end{array}$ & $\rightarrow$ & $\begin{array}{l}\text { Gross alpha/beta, } \\
\text { gamma isotopic }^{a} \\
\text { upon collection, flow }\end{array}$ \\
\hline $\begin{array}{l}\text { ANCSSTK } \\
\text { 01-14 Building } \\
\text { Ventilation Exhaust } \\
\text { ANCSRFK } \\
\text { Contact Size-Reduction } \\
\text { Facility Exhaust }\end{array}$ & $\begin{array}{l}\text { Required by: } \\
\text { - } 40 \text { CFR } 61 \\
\text { Reported in: } \\
\text { - ESR }\end{array}$ & filters & & & & $\begin{array}{l}\text { Biweekly } \\
\text { filters } \\
\text { composited to } \\
2 \text { each } \\
\text { location }\end{array}$ & $\rightarrow$ & $\begin{array}{l}\text { Semiannual compos- } \\
\text { ites for Sr-90, U-232, } \\
\mathrm{U}-233 / 234, \\
\mathrm{U}-235 / 236, \mathrm{U}-238, \\
\text { total U, Pu-238, } \\
\mathrm{Pu}-239 / 240, \mathrm{Am}-241 \text {, } \\
\text { gamma isotopic, flow }\end{array}$ \\
\hline $\begin{array}{l}\text { ANCSPFK } \\
\text { Container Sorting and } \\
\text { Packaging Facility } \\
\text { Exhaust } \\
\text { ANVITSK } \\
\text { Vitrification HVAC } \\
\text { Exhaust }\end{array}$ & $\begin{array}{l}\text { - TAR } \\
\text { - ASER } \\
\text { - Air Emissions } \\
\text { Annual Report } \\
\text { (NESHAP) }\end{array}$ & $\begin{array}{l}\text { Continuous } \\
\text { off-line } \\
\text { desiccant } \\
\text { columns for } \\
\text { water vapor } \\
\text { collection }\end{array}$ & $\rightarrow$ & Biweekly & $\rightarrow$ & $\begin{array}{l}26 \text { at each of } \\
\text { two locations }\end{array}$ & $\rightarrow$ & $\begin{array}{l}\text { H-3 (ANSTACK and } \\
\text { ANSTSTK only), flow }\end{array}$ \\
\hline $\begin{array}{l}\text { ANRHWFK } \\
\text { Remote-Handled Waste } \\
\text { Facility Exhaust }\end{array}$ & & $\begin{array}{l}\text { Continuous } \\
\text { off-line } \\
\text { charcoal } \\
\text { cartridges }\end{array}$ & $\rightarrow$ & Biweekly & $\rightarrow$ & $\begin{array}{l}\text { Biweekly } \\
\text { cartridges } \\
\text { composited to } \\
2 \text { each } \\
\text { location }\end{array}$ & $\rightarrow$ & $\begin{array}{l}\text { Semiannual composite } \\
\text { for I-129 }\end{array}$ \\
\hline
\end{tabular}

NA - Not applicable.

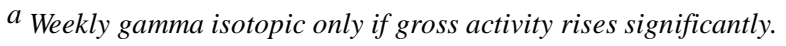

$$
B-1
$$




\section{Sampling Rationale}

ANSTACK

ANSTSTK

ANCSRFK

ANCSPFK

ANVITSK

ANRHWFK
DOE/EH-0173T, 3.0; DOE/EP-0096, 3.3

Monitors and samples HEPA-filtered ventilation from most process areas (and inactive process areas), including cell ventilation, vessel off-gas, fuel receiving and storage (FRS), head end ventilation, and an analytical aisle. Requires continuous effluent monitoring per 40 CFR Subpart H, Section 61.93(b) because potential emissions may exceed the 0.1-mrem limit.

DOE/EH-0173T, 3.0; DOE/EP-0096, 3.3

Monitors and samples HEPA-filtered ventilation (permanent ventilation system [PVS]) from building areas formerly involved in treatment of high-level waste supernatant. Requires continuous effluent monitoring per 40 CFR Subpart H, Section 61.93(b) because potential emissions may exceed the 0.1-mrem limit.

DOE/EH-0173T, 3.0; DOE-EP-0096, 3.3

Monitors and samples HEPA-filtered ventilation from the 01-14 building, which houses equipment formerly used to treat the ceramic melter off-gas. Requires effluent monitoring per 40 CFR Subpart H, Section 61.93(b) to confirm that emissions are less than the 0.1 -mrem limit.

DOE/EH-0173T, 3.0; DOE-EP-0096, 3.3

Monitors and samples HEPA-filtered ventilation from a process area where radioactive tanks, pipes, and other equipment are size reduced.

DOE/EH-0173T, 3.0; DOE-EP-0096, 3.3

Monitors and samples ventilation from lag storage area 4, the container sorting and packaging facility.

DOE/EH-0173T, 3.0; DOE-EP-0096, 3.3

Vitrification facility heating, ventilation, and air conditioning (HVAC) effluent exhaust stack. Monitors and samples HEPA-filtered ventilation from building areas formerly involved in treatment of high-level waste supernatant. Requires effluent monitoring per 40 CFR Subpart H, Section 61.93(b) because potential emissions may exceed the 0.1-mrem limit.

DOE/EH-0173T, 3.0; DOE-EP-0096, 3.3

Monitors and samples HEPA-filtered ventilation from the remote-handled waste facility (RHWF), where contaminated waste equipment (e.g., pumps, tanks, piping) are size reduced before being packaged for disposal.

Sampling locations are shown on Figure A-6.

$$
B-2
$$




\section{Monitoring Program \\ On-Site Effluent Monitoring}

Air Effluents

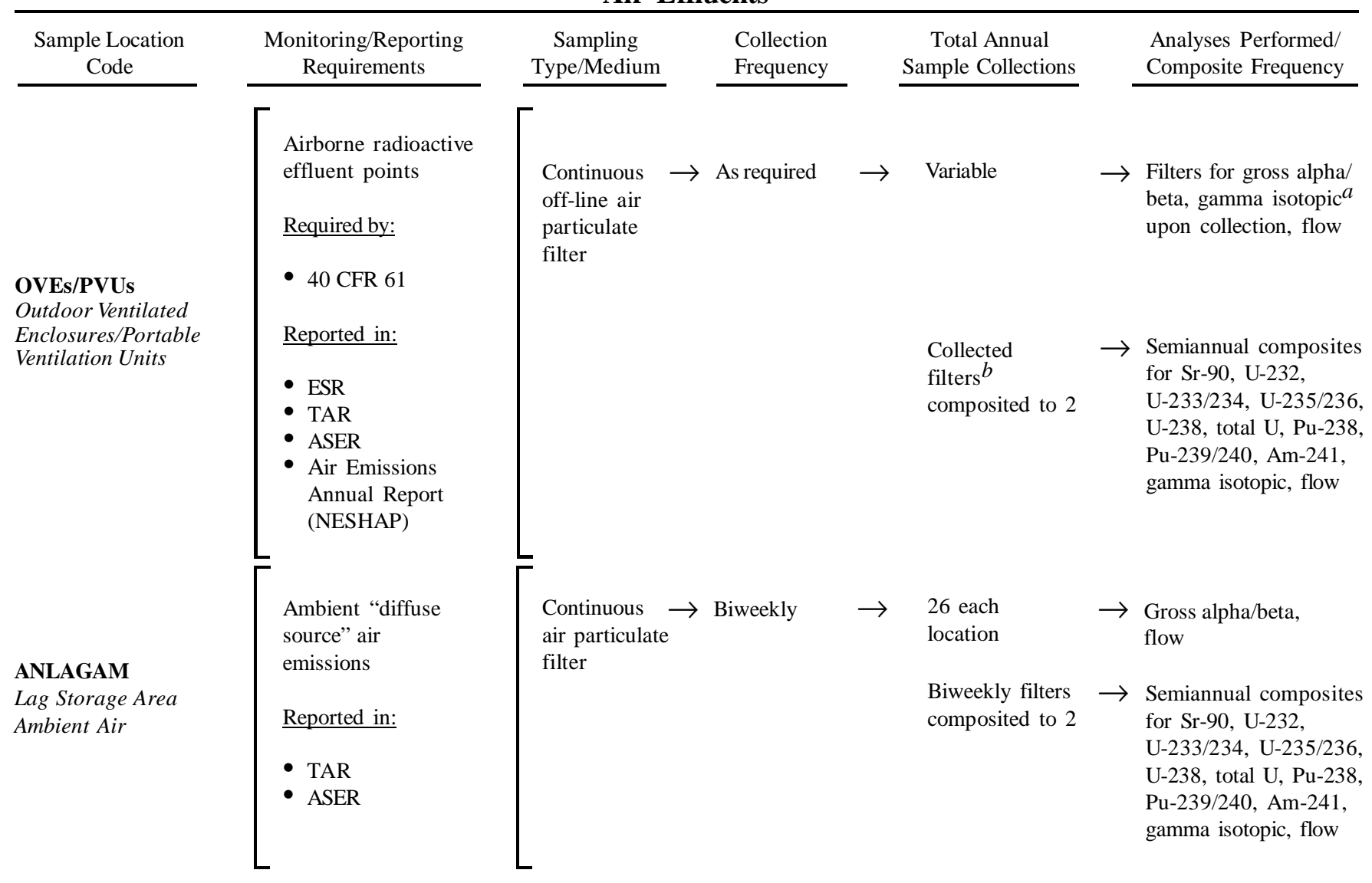

${ }^{a}$ Gamma isotopic only if gross activity rises significantly.

${ }^{b}$ If gross determination of individual filter is significantly higher than background, the individual sample would be submitted immediately for isotopic analysis.

$$
B-3
$$




\section{Sampling Rationale}

\section{OVEs/PVUs DOE/EH-0173T, 3.0; DOE/EP-0096, 3.3}

Outdoor ventilated enclosures/portable ventilation units used for handling radioactive materials or for decontamination in areas not having containment ventilation. Emissions are monitored to confirm that they are below the 0.1-mrem limit.

Sampling locations are not shown on figures, as the units are portable.

ANLAGAM

DOE/EH-0173T, 3.3.2

Monitors ambient air in the lag storage area, a possible diffuse source of air emissions.

Sampling locations are shown on Figure A-6.

$$
B-4
$$




\section{Monitoring Program \\ On-Site Effluent Monitoring}

\section{Liquid Effluents}

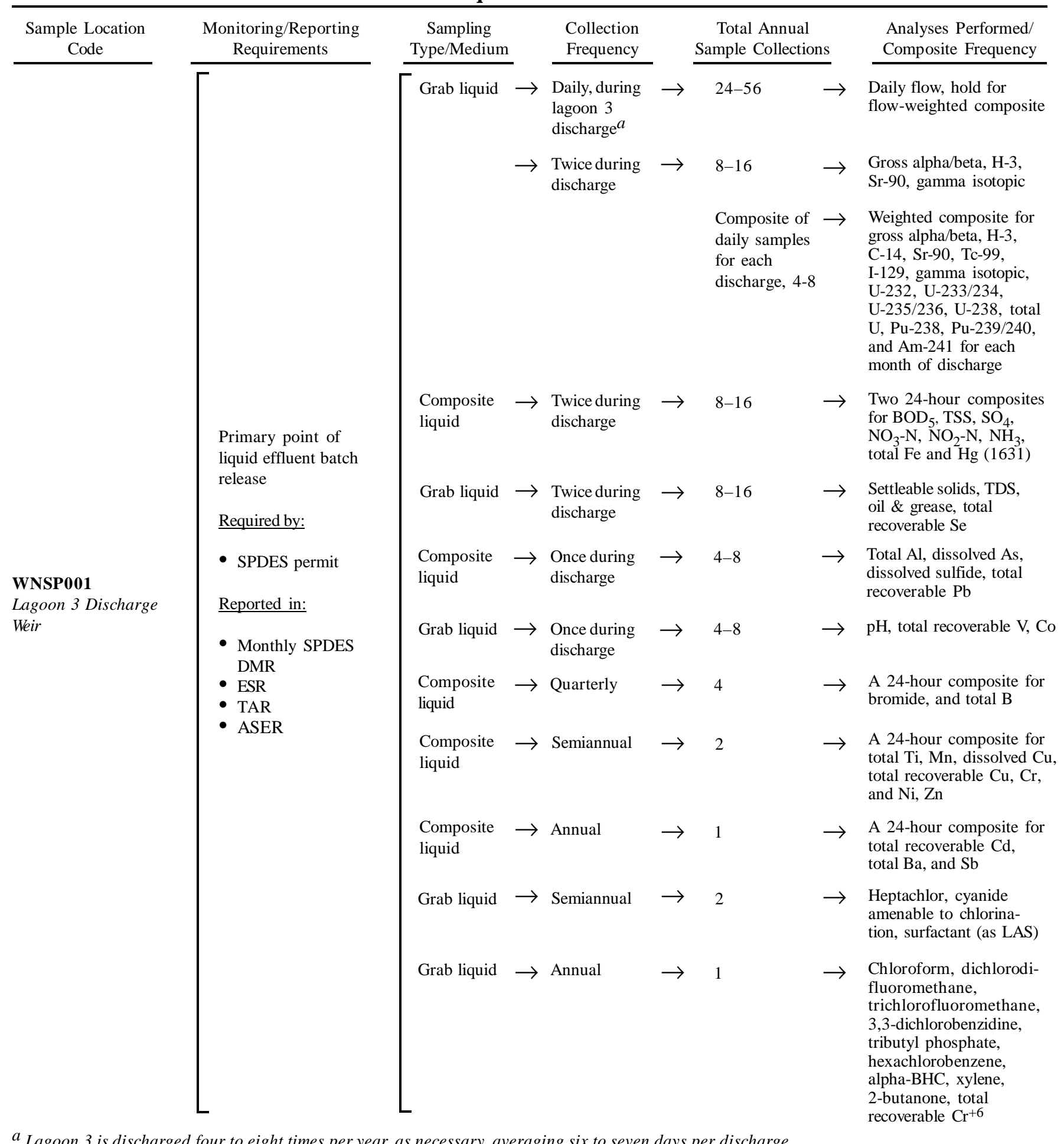

$$
\text { B - } 5
$$




\section{Sampling Rationale}

WNSP001 DOE Order 5400.5; DOE/EH-0173T, 2.3.3; New York State SPDES Permit no. NY0000973; NYSDOH ELAP (nonpotable water)

By DOE Order all liquid effluent streams from DOE facilities shall be evaluated and their potential for release of radionuclides addressed. These requirements for radiological parameters are met by daily grab sampling during periods of lagoon 3 discharge.

Sampling for chemical constituents is performed near the beginning and end of each discharge period to meet the site SPDES permit. Both grab samples and 24-hour composite samples are collected. A renewed SPDES permit, effective September 1, 2006, outlined modified monitoring requirements for some chemical constituents to less frequent sample collections and analyses.

For permit requirements, total $\mathrm{Hg}$ is analyzed in accordance with EPA Method 1631.

Sampling location is shown on Figure A-2.

$$
B-6
$$




\section{Monitoring Program \\ On-Site Effluent Monitoring}

\section{Liquid Effluents}

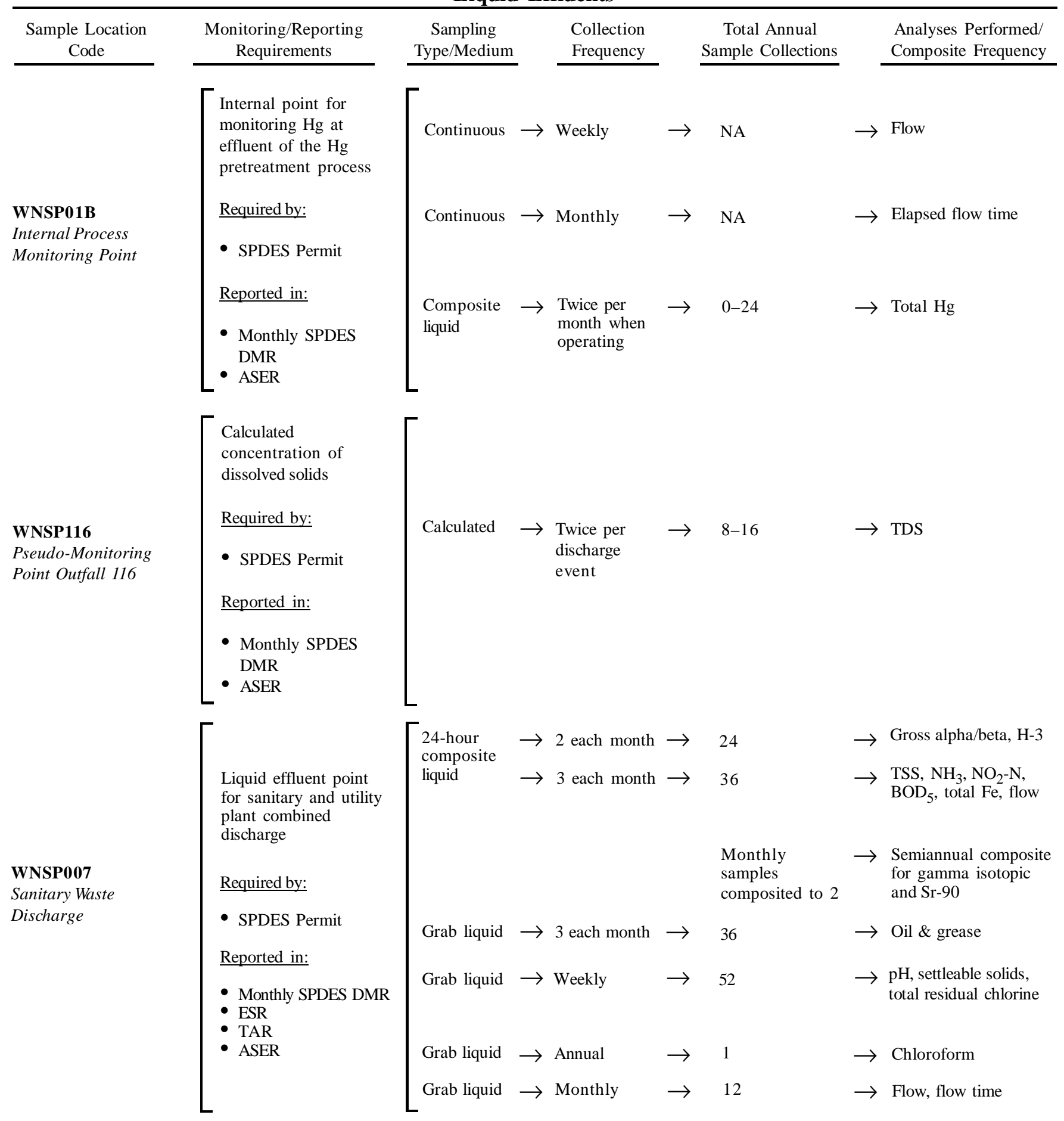

$$
B-7
$$




\section{Sampling Rationale}

WNSP01B New York State SPDES Permit no. NY0000973; NYSDOH ELAP (nonpotable water)

This internal point is used to monitor mercury in effluent from the mercury pretreatment process. Effluent from this point is subsequently released to the LLWTF, which is monitored at point WNSP001.

For permit requirements, total mercury is analyzed in accordance with EPA Method 1631.

WNSP116 New York State SPDES Permit no. NY0000973; NYSDOH ELAP (nonpotable water)

This "pseudo-monitoring point," assumed to be in Frank's Creek, is calculated from actual total dissolved solids (TDS) measurements and flow measurements from points WNSP001 and WNSP006 and from augmentation water.

WNSP007 DOE Order 5400.5; DOE/EH-0173T, 2.3.3; New York State SPDES Permit no. NY0000973; NYSDOH ELAP (nonpotable water)

Monitoring of treated effluent from the sanitary and industrial wastewater treatment facility is performed in accordance with the New York State SPDES Permit no. NY0000973 and DOE Order 5400.5 criteria.

Sampling locations WNSP116 and WNSP007 are shown on Figure A-2. Sampling location WNSP01B is not shown on the figures.

$$
B-8
$$




\section{Monitoring Program \\ On-Site Effluent Monitoring}

\section{Liquid Effluents}

\begin{tabular}{|c|c|c|c|c|c|c|c|c|}
\hline $\begin{array}{l}\text { Sample Location } \\
\text { Code } \\
\end{array}$ & $\begin{array}{c}\text { Monitoring/Reporting } \\
\text { Requirements }\end{array}$ & $\begin{array}{c}\text { Sampling } \\
\text { Type/Medium } \\
\end{array}$ & & $\begin{array}{l}\text { Collection } \\
\text { Frequency }\end{array}$ & & $\begin{array}{c}\text { Total Annual } \\
\text { Sample Collections } \\
\end{array}$ & & $\begin{array}{l}\text { Analyses Performed/ } \\
\text { Composite Frequency }\end{array}$ \\
\hline \multirow{6}{*}{$\begin{array}{l}\text { WNSP006 } \\
\text { Frank's Creek at the } \\
\text { Security Fence }\end{array}$} & \multirow{6}{*}{$\begin{array}{l}\begin{array}{l}\text { Combined facility liquid } \\
\text { discharge }\end{array} \\
\text { Required by: } \\
\text { - SPDES Permit } \\
\text { Reported in: } \\
\text { - Monthly SPDES DMR } \\
\text { - TAR } \\
\text { - ASER }\end{array}$} & $\begin{array}{l}\text { Timed } \\
\text { continuous } \\
\text { composite } \\
\text { liquid }\end{array}$ & $\rightarrow$ & $\begin{array}{l}\text { Weekly during } \\
\text { Lagoon } 3 \\
\text { discharge, } \\
\text { otherwise } \\
\text { biweekly }\end{array}$ & $\rightarrow$ & $\begin{array}{l}\text { Biweekly, } \\
\text { weekly } \\
\text { samples } \\
\text { composited to } 12\end{array}$ & $\rightarrow$ & $\begin{array}{l}\text { Monthly composite } \\
\text { for gamma isotopic } \\
\text { and Sr-90 (shared } \\
\text { with NYSDOH) }\end{array}$ \\
\hline & & & & & & $\begin{array}{l}\text { Weekly, } \\
\text { biweekly } \\
\text { samples } \\
\text { composited to } 4\end{array}$ & $\rightarrow$ & $\begin{array}{l}\text { Quarterly composite for } \\
\text { C-14, Tc-99, I-129, } \\
\text { U-232, U-233/234, } \\
\text { U-235/236, U-238, total } \\
\text { U, Pu-238, Pu-239/240, } \\
\text { Am-241 }\end{array}$ \\
\hline & & Grab liquid & $\rightarrow$ & $\begin{array}{l}\text { Five per } \\
\text { discharge; } \\
\text { baseline, before } \\
\text { start, near start, } \\
\text { near end, and } \\
\text { after end }\end{array}$ & $\rightarrow$ & $20-40$ & $\rightarrow$ & TDS \\
\hline & & Grab liquid & $\rightarrow$ & Monthly & $\rightarrow$ & 12 & $\rightarrow$ & Hardness ( $\mathrm{Ca}$ and $\mathrm{Mg}$ ) \\
\hline & & Grab liquid & $\rightarrow$ & Semiannual $^{a}$ & $\rightarrow$ & 2 & $\rightarrow$ & $\begin{array}{l}\text { Temperature (field), } \\
\text { pH (field), dissolved } \\
\text { oxygen (field), TOX, } \\
\text { oil \& grease }\end{array}$ \\
\hline & & $\begin{array}{l}\text { 24-hour } \\
\text { timed } \\
\text { continuous } \\
\text { composite }\end{array}$ & $\rightarrow$ & Semiannual $^{a}$ & $\rightarrow$ & 2 & $\rightarrow$ & $\begin{array}{l}\text { TSS, NPOC, } \mathrm{NH}_{3} \text { (as N), } \\
\mathrm{NO}_{3} \text { (as N), } \mathrm{NO}_{2} \text { (as N), } \\
\text { bromide, fluoride, } \\
\text { chloride, sulfate, total } \\
\text { sulfide, surfactant (as } \\
\mathrm{LAS} \text { ), alpha-BHC, } \mathrm{B}, \mathrm{Ba} \text {, } \\
\mathrm{Co}, \mathrm{Fe}, \mathrm{Na}, \mathrm{Mn}, \mathrm{Sb}, \mathrm{Ti}, \\
\mathrm{Tl}, \mathrm{V}, \text { dissolved Al, As, } \\
\mathrm{Cd}, \mathrm{Cr}, \mathrm{Cu}, \mathrm{Hg} \text { (method } \\
\text { 1631), Ni, Pb, Se, Zn }\end{array}$ \\
\hline \multirow{3}{*}{$\begin{array}{l}\text { WNURRAW } \\
\text { Utility Room Raw Water }\end{array}$} & \multirow{3}{*}{$\begin{array}{l}\text { Source water } \\
\text { Required by: } \\
\text { - SPDES Permit } \\
\text { Reported in: } \\
\text { - Monthly SPDES DMR }\end{array}$} & $\begin{array}{l}\text { Composite } \\
\text { liquid }\end{array}$ & $\rightarrow$ & Weekly & $\rightarrow$ & 52 & $\rightarrow$ & Total Fe \\
\hline & & Grab liquid & $\rightarrow$ & $\begin{array}{l}\text { Three per } \\
\text { discharge, } \\
\text { baseline, near } \\
\text { start, and near } \\
\text { end }\end{array}$ & $\rightarrow$ & $12-24$ & $\rightarrow$ & TDS \\
\hline & & Grab liquid $b$ & $\rightarrow$ & Monthly & $\rightarrow$ & 12 & $\rightarrow$ & TOC, alkalinity \\
\hline
\end{tabular}

a Semiannual samples collected when points WNSP001 and WNSP007 are discharging.

${ }^{b}$ Cattaraugus County Department of Health

$$
\text { B }-9
$$




\section{Sampling Rationale}

WNSP006 DOE/EH-0173T, 5.10.1.1; New York State SPDES Permit no. NY0000973; 6 NYCRR, Parts 702-704;

NYSDOH ELAP (nonpotable water)

By DOE Order all liquid effluent streams from DOE facilities shall be evaluated and their potential for release of radionuclides addressed.

TDS is measured before the discharge begins, shortly after it begins, near the end, and after the end of each lagoon 3 discharge period to meet requirements of the site SPDES Permit. Measurements of TDS and flow are used to calculate TDS at pseudo-monitoring point outfall 116 in Frank's Creek.

Semiannual samples are collected when WNSP001 and WNSP007 are discharging.

WNURRAW New York State SPDES Permit no. NY0000973; 10 NYCRR, Part 5, Subpart 5-1; NYSDOH ELAP (nonpotable water)

TDS is measured near the beginning and end of each lagoon 3 discharge. Results are used for outfall 116 calculations. (See WNSP006 above.)

Sampling location WNSP006 is shown on Figure A-2. Sampling location WNURRAW is not shown on the figures.

$B-10$ 
2006 Monitoring Program

Environmental Surveillance

Storm Water Outfalls

\begin{tabular}{|c|c|c|c|c|c|c|c|c|}
\hline $\begin{array}{l}\text { Sample Location } \\
\text { Code }\end{array}$ & $\begin{array}{l}\text { Monitoring/Reporting } \\
\text { Requirements }\end{array}$ & $\begin{array}{c}\text { Sampling } \\
\text { Type/Medium }\end{array}$ & & $\begin{array}{l}\text { Collection } \\
\text { Frequency }\end{array}$ & & $\begin{array}{c}\text { Total Annual } \\
\text { Sample Collections }\end{array}$ & & $\begin{array}{l}\text { Analyses Performed/ } \\
\text { Composite Frequency }\end{array}$ \\
\hline \multirow[t]{2}{*}{$\begin{array}{l}\text { GROUP } 1 \\
\text { WNSO02 } \\
\text { WNSO2) } \\
\text { WNO4) }\end{array}$} & $\begin{array}{l}\text { Storm water runoff } \\
\text { Required by: } \\
\text { - SPDES Permit }\end{array}$ & {$\left[\begin{array}{l}\text { First flush } \\
\text { grab liquid }\end{array}\right.$} & $\rightarrow$ & Semiannual & $\rightarrow$ & 2 & $\rightarrow$ & $\begin{array}{l}\mathrm{pH}, \text { oil \& grease, } \\
\mathrm{BOD}, \mathrm{TSS}, \mathrm{TDS} \text {, total } \\
\mathrm{P}, \mathrm{Al}, \mathrm{Fe} \text {, total } \\
\text { recoverable } \mathrm{Cu}, \mathrm{Pb}, \mathrm{Zn} \text {, } \\
\mathrm{Cd}, \mathrm{Cr}, \mathrm{Se}, \mathrm{V}, \mathrm{Cr}+6 \\
\mathrm{TKN}, \text { ammonia }(\mathrm{as} \\
\mathrm{NH}_{3} \text { ), } \mathrm{NO}_{3}-\mathrm{N}, \mathrm{NO}_{2}-\mathrm{N} \text {, } \\
\text { total nitrogen (as } \mathrm{N})\end{array}$ \\
\hline & $\begin{array}{l}\text { Reported in: } \\
\text { - Monthly SPDES } \\
\text { DMR } \\
\text { - ASER }\end{array}$ & $\begin{array}{l}\text { Flow- } \\
\text { weighted } \\
\text { composite } \\
\text { liquid }\end{array}$ & $\rightarrow$ & Semiannual & $\rightarrow$ & 2 & $\rightarrow$ & $\begin{array}{l}\text { Total flow, } \mathrm{BOD}_{5}, \mathrm{TSS} \text {, } \\
\mathrm{TDS} \text {, total } \mathrm{P}, \mathrm{Al}, \mathrm{Fe} \text {, } \\
\text { total recoverable } \mathrm{Cu} \text {, } \\
\mathrm{Pb}, \mathrm{Zn}, \mathrm{Cd}, \mathrm{Cr}, \mathrm{Se}, \mathrm{V} \text {, } \\
\mathrm{Cr}^{+6}, \mathrm{TKN}, \text { ammonia } \\
\left(\mathrm{as}_{3}\right), \mathrm{NO}_{3}-\mathrm{N} \text {, } \\
\mathrm{NO}_{2}-\mathrm{N}, \text { total nitrogen }\end{array}$ \\
\hline \multirow{2}{*}{$\begin{array}{l}\text { GROUP } 2 \\
\text { WNSO06 } \\
\text { WNSO33 }(\mathrm{S33})\end{array}$} & $\begin{array}{l}\text { Storm water runoff } \\
\text { Required by: } \\
\text { - SPDES Permit }\end{array}$ & $\begin{array}{l}\text { First flush } \\
\text { grab liquid }\end{array}$ & $\rightarrow$ & Semiannual & $\rightarrow$ & 2 & $\rightarrow$ & $\begin{array}{l}\mathrm{pH} \text {, oil \& grease, } \\
\mathrm{BOD}_{5}, \mathrm{TSS}, \mathrm{TDS} \text {, total } \\
\mathrm{P}, \mathrm{Al}, \mathrm{Fe}, \text { total } \\
\text { recoverable } \mathrm{Cu}, \mathrm{Pb}, \mathrm{Zn} \text {, } \\
\text { surfactant (as LAS) }\end{array}$ \\
\hline & $\begin{array}{l}\text { Reported in: } \\
\text { - Monthly SPDES } \\
\text { DMR } \\
\text { - ASER }\end{array}$ & $\begin{array}{l}\text { Flow- } \\
\text { weighted } \\
\text { composite } \\
\text { liquid }\end{array}$ & $\rightarrow$ & Semiannual & $\rightarrow$ & 2 & $\rightarrow$ & $\begin{array}{l}\text { Total flow, } \mathrm{BOD}_{5} \text {, TSS, } \\
\text { TDS, total } \mathrm{P}, \mathrm{Al}, \mathrm{Fe} \text {, } \\
\text { total recoverable } \mathrm{Cu} \text {, } \\
\mathrm{Pb}, \mathrm{Zn} \text {, surfactant (as } \\
\mathrm{LAS} \text { ) }\end{array}$ \\
\hline \multirow[t]{2}{*}{$\begin{array}{l}\frac{\text { GROUP } 3}{\text { WNSO09 }} \text { (S09) } \\
\text { WNSO12 }(\text { S12) }\end{array}$} & $\begin{array}{l}\text { Storm water runoff } \\
\text { Required by: } \\
\text { - SPDES Permit } \\
\text { Reported in: }\end{array}$ & $\begin{array}{l}\text { First flush } \\
\text { grab liquid }\end{array}$ & $\rightarrow$ & 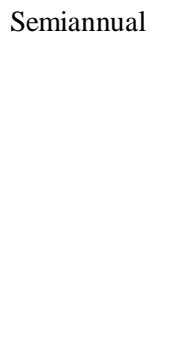 & $\rightarrow$ & 2 & $\rightarrow$ & $\begin{array}{l}\mathrm{pH}, \text { oil \& grease, } \\
\mathrm{BOD}_{5}, \mathrm{TSS}, \mathrm{TDS} \text {, total } \\
\mathrm{P}, \mathrm{Al}, \mathrm{Fe} \text {, total } \\
\text { recoverable } \mathrm{Cu}, \mathrm{Pb}, \mathrm{Zn} \text {, } \\
\mathrm{TKN}, \text { ammonia (as } \\
\mathrm{NH}_{3} \text { ), } \mathrm{NO}_{3}-\mathrm{N}, \mathrm{NO}_{2}-\mathrm{N}, \\
\text { alpha-BHC, total } \\
\text { nitrogen }\end{array}$ \\
\hline & $\begin{array}{l}\text { - Monthly SPDES } \\
\text { DMR } \\
\text { - ASER }\end{array}$ & $\begin{array}{l}\text { Flow- } \\
\text { weighted } \\
\text { composite } \\
\text { liquid }\end{array}$ & $\rightarrow$ & Semiannual & $\rightarrow$ & 2 & $\rightarrow$ & $\begin{array}{l}\text { Total flow, } \mathrm{BOD}_{5}, \mathrm{TSS} \text {, } \\
\text { TDS, total } \mathrm{P}, \mathrm{Al}, \mathrm{Fe} \text {, } \\
\text { total recoverable } \mathrm{Cu} \text {, } \\
\mathrm{Pb}, \mathrm{Zn}, \mathrm{TKN}, \text { ammonia } \\
\left(\text { as } \mathrm{NH}_{3}\right), \mathrm{NO}_{3}-\mathrm{N}, \\
\mathrm{NO}_{2}-\mathrm{N}, \text { alpha-BHC, } \\
\text { total nitrogen }\end{array}$ \\
\hline
\end{tabular}

$B-11$ 


\section{Sampling Rationale}

\begin{abstract}
Storm Water
Outfalls

New York State SPDES Permit no. NY0000973; NYSDOH ELAP (nonpotable water)

The National Pollutant Discharge Elimination System Permit (NPDES) Application Regulations for Storm Water Discharges, Final Rule (40 CFR 122, 123, and 124 as amended), and as expressed in Section 403(p) of the Clean Water Act, require that specified facilities acquire NPDES permits for the discharge of storm water associated with industrial activities. Permitted or interim status Resource Conservation and Recovery Act (RCRA) hazardous waste treatment, storage, and disposal facilities are specifically defined as associated with industrial activity in the regulations (40 CFR 122.26 [a][14][iv]). Because the West Valley Demonstration Project (WVDP) is an interim status RCRA facility, the storm water discharges from the WVDP qualify as being associated with industrial activity. Five other groups of activities at the WVDP also are subject to storm water permitting: 1) aboveground container storage; 2) aboveground and underground tank storage; 3) underground waste burial; 4) haul roads and railway lines; 5) liquid waste treatment facilities and construction activities and industrial activities.
\end{abstract}

GROUP 1

WNSO02

WNSO04

GROUP 2

WNSO06

WNSO33

GROUP 3

WNSO09

WNSO12

New York State is delegated by the U.S. Environmental Protection Agency (EPA) to administer the National Pollutant Discharge Elimination System under an equivalent state program, the State Pollutant Discharge Elimination System (SPDES).

Runoff from areas associated with remote-handled waste facility (RHWF) operation, RCRA hazardous and radioactive waste storage, radioactive waste from the vitrification facility, nonradioactive process wastewater storage and transfer, equipment and material fabrication, oil storage, North Plateau groundwater infiltration reduction/storm water diversion, and service roads. The RHWF processes expended contaminated vitrification materials and equipment for shipment and disposal. Hazardous radioactive waste storage (except for the LSA-2 Hardstand), equipment/material fabrication, oil storage, and RHWF operations occur indoors.

Runoff from areas associated with containerized radioactive waste, inactive burial area for construction and demolition debris, spent nuclear fuel receiving, storage, and shipping, high-level radioactive waste tanks, low-level radioactive wastewater evaporator and mercury abatement system, radiologically contaminated groundwater plume pumping operation, vehicle maintenance shop, and associated service roads. Vehicle maintenance, evaporator, mercury abatement, groundwater pumping operations, and spent nuclear fuel storage occur indoors. Industrial practices for the construction and demolition debris burial area include perpetual maintenance of the grass earthen cover.

Runoff areas associated with wastewater/storm water treatment lagoons, fire and potable water production, oil storage, maintenance shop, cement silo storage, and service roads. Maintenance oil, and cement storage occur indoors.

Sampling locations are shown on Figure A-3.
$B-12$ 
2006 Monitoring Program

\section{Environmental Surveillance}

\section{Storm Water Outfalls}

\begin{tabular}{|c|c|c|c|c|c|c|c|c|}
\hline $\begin{array}{l}\text { Sample Location } \\
\text { Code }\end{array}$ & $\begin{array}{l}\text { Monitoring/Reporting } \\
\text { Requirements }\end{array}$ & $\begin{array}{c}\text { Sampling } \\
\text { Type/Medium }\end{array}$ & & $\begin{array}{l}\text { Collection } \\
\text { Frequency }\end{array}$ & & $\begin{array}{c}\text { Total Annual } \\
\text { Sample Collections }\end{array}$ & & $\begin{array}{l}\text { Analyses Performed/ } \\
\text { Composite Frequency }\end{array}$ \\
\hline \multirow{2}{*}{$\frac{\text { GROUP } 4}{\text { WNSO34 }}$} & $\begin{array}{l}\text { Storm water runoff } \\
\text { Required by: }\end{array}$ & $\begin{array}{l}\text { First flush } \\
\text { grab liquid }\end{array}$ & $\rightarrow$ & Semiannual & $\rightarrow$ & 2 & $\rightarrow$ & $\begin{array}{l}\mathrm{pH} \text {, oil \& grease, } \\
\mathrm{BOD}_{5}, \mathrm{TSS}, \mathrm{TDS} \text {, total } \\
\mathrm{P}, \mathrm{Al}, \mathrm{Fe}, \text { total } \\
\text { recoverable } \mathrm{Cu}, \mathrm{Pb}, \mathrm{Zn} \text {, } \\
\text { surfactant (as LAS) }\end{array}$ \\
\hline & $\begin{array}{l}\text { - Monthly SPDES } \\
\text { DMR } \\
\text { - ASER }\end{array}$ & $\begin{array}{l}\text { Flow- } \\
\text { weighted } \\
\text { composite } \\
\text { liquid }\end{array}$ & $\rightarrow$ & Semiannual & $\rightarrow$ & 2 & $\rightarrow$ & $\begin{array}{l}\text { Total flow, } \mathrm{BOD}_{5}, \mathrm{TSS} \text {, } \\
\text { TDS, total } \mathrm{P}, \mathrm{Al}, \mathrm{Fe} \text {, } \\
\text { total recoverable } \mathrm{Cu} \text {, } \\
\mathrm{Pb}, \mathrm{Zn} \text {, surfactant (as } \\
\mathrm{LAS} \text { ) }\end{array}$ \\
\hline \multirow[t]{2}{*}{$\begin{array}{l}\text { GROUP } 5 \\
\text { WNSO14 } \\
\text { WN14) } \\
\text { WNO17 (S17) } \\
\text { WNSO28 } \\
\text { (S28) }\end{array}$} & $\begin{array}{l}\text { Storm water runoff } \\
\text { Required by: } \\
\text { - SPDES Permit } \\
\text { Reported in: }\end{array}$ & $\begin{array}{l}\text { First flush } \\
\text { grab liquid }\end{array}$ & $\rightarrow$ & Semiannual & $\rightarrow$ & 2 & $\rightarrow$ & $\begin{array}{l}\mathrm{pH} \text {, oil \& grease, } \\
\mathrm{BOD}_{5} \text {, TSS, TDS, total } \\
\mathrm{P}, \mathrm{Al}, \mathrm{Fe} \text {, total } \\
\text { recoverable } \mathrm{Cu}, \mathrm{Pb}, \mathrm{Zn} \text {, } \\
\mathrm{V}, \mathrm{TKN}, \text { ammonia (as } \\
\mathrm{NH}_{3} \text { ), } \mathrm{NO}_{3}-\mathrm{N}, \mathrm{NO}_{2}-\mathrm{N}, \\
\text { surfactant (as LAS), } \\
\text { sulfide, settleable solids, } \\
\text { total nitrogen }\end{array}$ \\
\hline & $\begin{array}{l}\text { - Monthly SPDES } \\
\text { DMR } \\
\text { - } \text { ASER }\end{array}$ & $\begin{array}{l}\text { Flow- } \\
\text { weighted } \\
\text { composite } \\
\text { liquid }\end{array}$ & $\rightarrow$ & Semiannual & $\rightarrow$ & 2 & $\rightarrow$ & $\begin{array}{l}\text { Total flow, } \mathrm{BOD}_{5}, \mathrm{TSS} \text {, } \\
\text { TDS, total } \mathrm{P}, \mathrm{Al}, \mathrm{Fe} \text {, } \\
\text { total recoverable } \mathrm{Cu} \text {, } \\
\mathrm{Pb}, \mathrm{Zn}, \mathrm{V}, \mathrm{TKN}, \\
\text { ammonia }\left(\text { as } \mathrm{NH}_{3} \text { ), }\right. \\
\mathrm{NO}_{3}-\mathrm{N}, \mathrm{NO}_{2}-\mathrm{N}, \\
\text { surfactant (as LAS), } \\
\text { sulfide, settleable solids, } \\
\text { total nitrogen }\end{array}$ \\
\hline
\end{tabular}

$B-13$ 


\title{
Sampling Rationale
}

\begin{abstract}
Storm Water New York State SPDES Permit no. NY0000973; NYSDOH ELAP (nonpotable water) Outfalls

The National Pollutant Discharge Elimination System Permit (NPDES) Application Regulations for Storm Water Discharges, Final Rule (40 CFR 122, 123, and 124 as amended), and as expressed in Section 403(p) of the Clean Water Act, require that specified facilities acquire NPDES permits for the discharge of storm water associated with industrial activities. Permitted or interim status Resource Conservation and Recovery Act (RCRA) hazardous waste treatment, storage, and disposal facilities are specifically defined as associated with industrial activity in the regulations (40 CFR 122.26 [a][14][iv]). Because the West Valley Demonstration Project (WVDP) is an interim status RCRA facility, the storm water discharges from the WVDP qualify as being associated with industrial activity. Five other groups of activities at the WVDP also are subject to storm water permitting: 1) aboveground container storage; 2) aboveground and underground tank storage; 3 ) underground waste burial; 4) haul roads and railway lines; 5) liquid waste treatment facilities and construction activities and industrial activities.
\end{abstract}

New York State is delegated by the U.S. Environmental Protection Agency (EPA) to administer the National Pollutant Discharge Elimination System under an equivalent state program, the State Pollutant Discharge Elimination System (SPDES).

\section{GROUP 4}

Runoff from areas associated with railroad spur within WVDP premises, industrial and sanitary wastewater WNSO34

GROUP 5 WNSO14 parking, outdoor equipment staging and storage. Warehouse, oil storage, wastewater treatment, and sewage sludge storage occur indoors.

Runoff from areas associated with service roads, railroad spur, and rail staging and loading depot within WVDP premises.

Sampling locations are shown on Figure A-3.

\section{$B-14$}


2006 Monitoring Program

Environmental Surveillance

Storm Water Outfalls

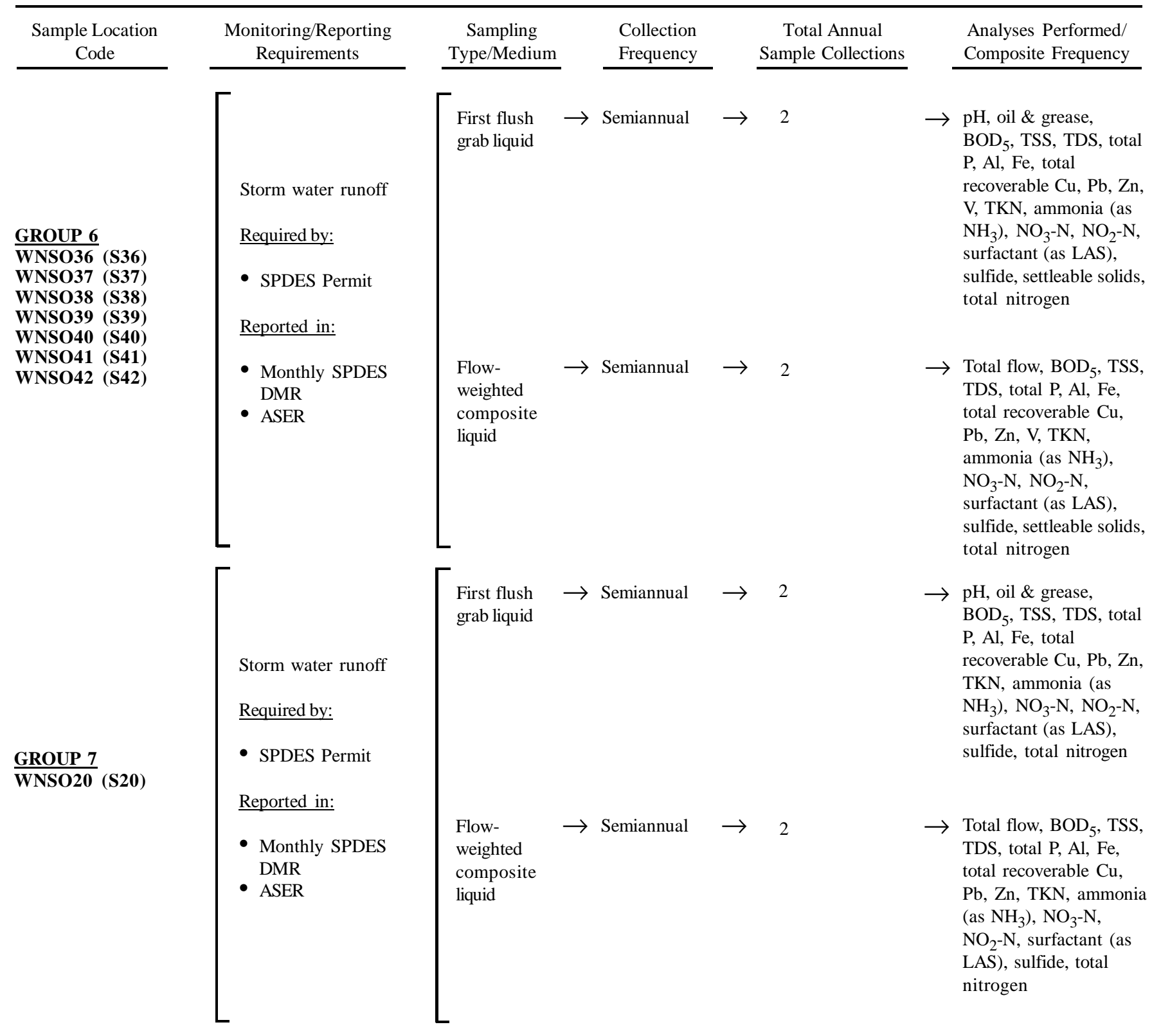

$B-15$ 


\title{
Sampling Rationale
}

\begin{abstract}
Storm Water New York State SPDES Permit no. NY0000973; NYSDOH ELAP (nonpotable water) Outfalls

The National Pollutant Discharge Elimination System Permit (NPDES) Application Regulations for Storm Water Discharges, Final Rule (40 CFR 122, 123, and 124 as amended), and as expressed in Section 403(p) of the Clean Water Act, require that specified facilities acquire NPDES permits for the discharge of storm water associated with industrial activities. Permitted or interim status Resource Conservation and Recovery Act (RCRA) hazardous waste treatment, storage, and disposal facilities are specifically defined as associated with industrial activity in the regulations (40 CFR 122.26 [a][14][iv]). Because the West Valley Demonstration Project (WVDP) is an interim status RCRA facility, the storm water discharges from the WVDP qualify as being associated with industrial activity. Five other groups of activities at the WVDP also are subject to storm water permitting: 1) aboveground container storage; 2) aboveground and underground tank storage; 3) underground waste burial; 4) haul roads and railway lines; 5) liquid waste treatment facilities and construction activities and industrial activities.

New York State is delegated by the U.S. Environmental Protection Agency (EPA) to administer the National Pollutant Discharge Elimination System under an equivalent state program, the State Pollutant Discharge Elimination System (SPDES).
\end{abstract}

GROUP 6 WNSO36

WNSO37

WNSO38

WNSO39

WNSO40

WNSO41

WNSO42

GROUP 7

WNSO20
Runoff from areas along the segment of the railroad spur and service road within the Western New York Nuclear Service Center (WNYNSC) outside the WVDP fenced area.
Runoff from areas associated with inactive waste burial, groundwater/leachate storage and treatment and service roads. Groundwater/leachate storage and treatment occurs indoors. Management practices for the inactive radioactive waste burial areas include perpetual maintenance of the earthen cover.

Sampling locations are shown on Figures A-3 and A-4.

$B-16$ 
2006 Monitoring Program

\section{Environmental Surveillance}

\section{Storm Water Outfalls}

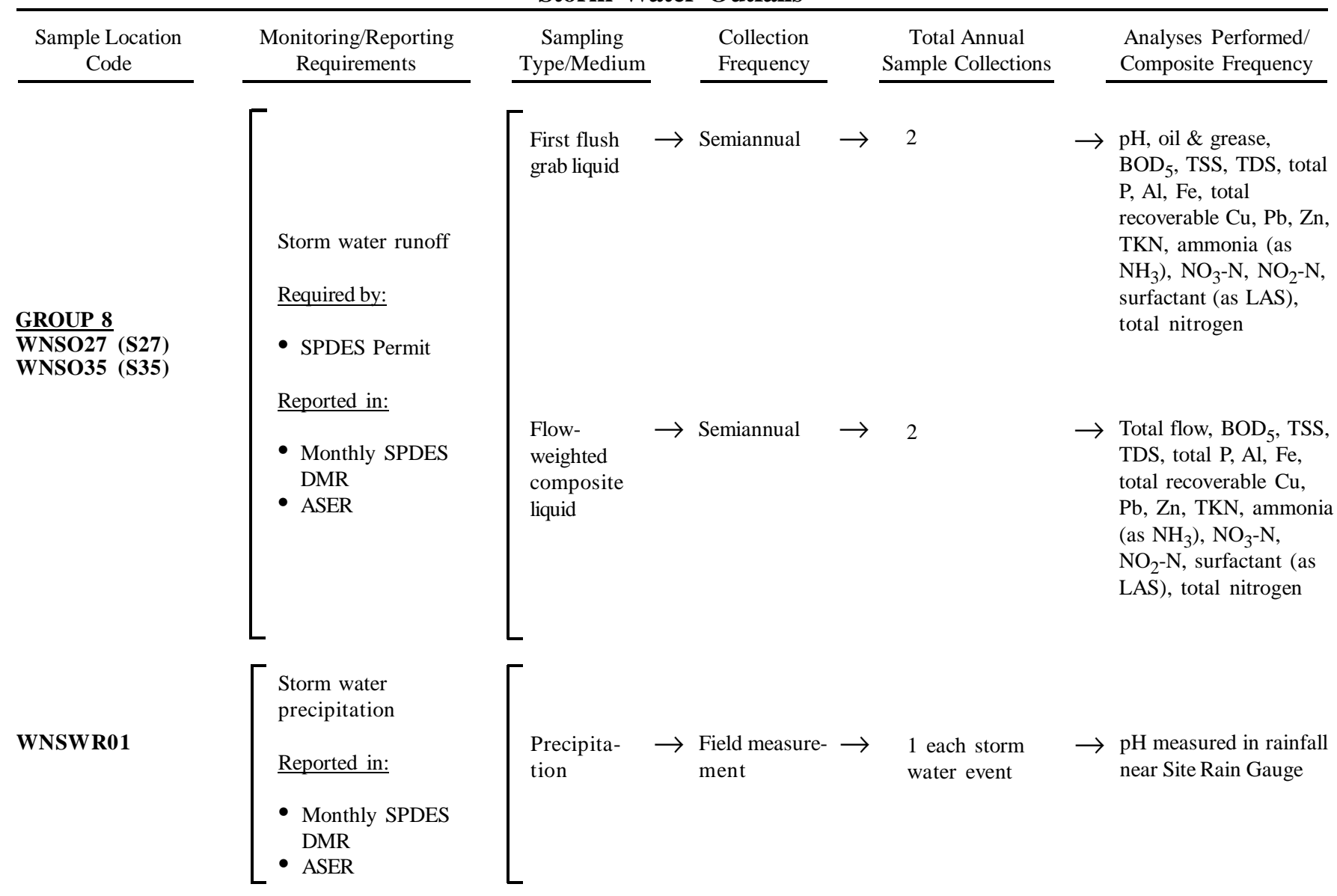

B -17 


\title{
Sampling Rationale
}

\begin{abstract}
Storm Water New York State SPDES Permit no. NY0000973; NYSDOH ELAP (nonpotable water)
Outfalls

The National Pollutant Discharge Elimination System Permit (NPDES) Application Regulations for Storm Water Discharges, Final Rule (40 CFR 122, 123, and 124 as amended), and as expressed in Section 403(p) of the Clean Water Act, require that specified facilities acquire NPDES permits for the discharge of storm water associated with industrial activities. Permitted or interim status Resource Conservation and Recovery Act (RCRA) hazardous waste treatment, storage, and disposal facilities are specifically defined as associated with industrial activity in the regulations (40 CFR 122.26 [a][14][iv]). Because the West Valley Demonstration Project (WVDP) is an interim status RCRA facility, the storm water discharges from the WVDP qualify as being associated with industrial activity. Five other groups of activities at the WVDP also are subject to storm water permitting: 1) aboveground container storage; 2) aboveground and underground tank storage; 3 ) underground waste burial; 4) haul roads and railway lines; 5) liquid waste treatment facilities and construction activities and industrial activities.
\end{abstract}

New York State is delegated by the U.S. Environmental Protection Agency (EPA) to administer the National Pollutant Discharge Elimination System under an equivalent state program, the State Pollutant Discharge Elimination System (SPDES).

GROUP 8 Runoff associated with equipment staging and indoor containerized storage of cement solidified low-level WNSO27 radioactive waste.

WNSO35

WNSWR01

New York State SPDES Permit no. NY0000973; NYSDOH ELAP (nonpotable water)

The $\mathrm{pH}$ of rainfall is measured near the site rain gauge fallout pot during each storm water discharge sampling event.

Sampling locations are shown on Figure A-3.

$B-18$ 


\section{Monitoring Program \\ Environmental Surveillance}

On-Site Surface Water

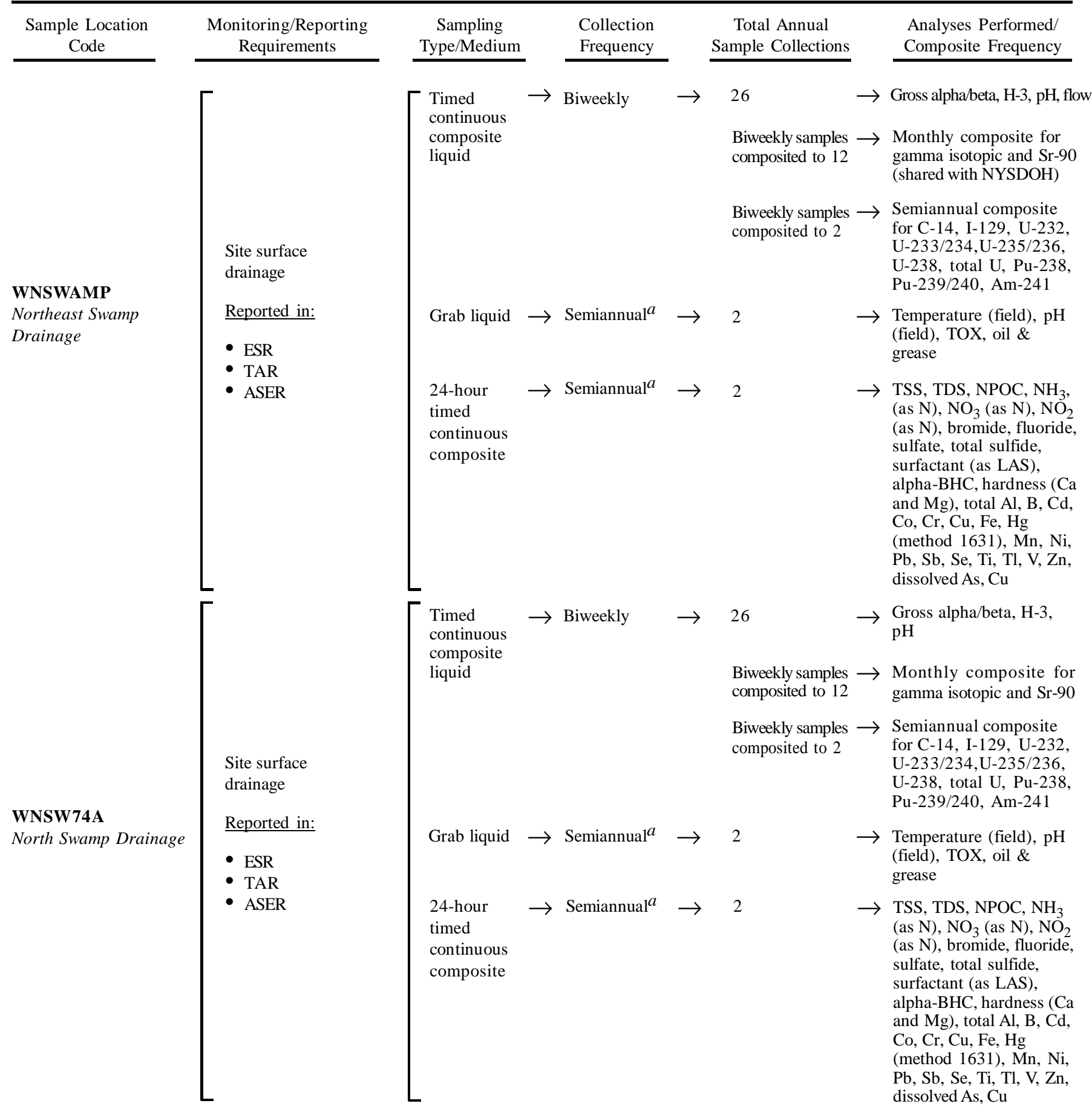

a Sampled during ambient (i.e., non-wet weather) conditions.

B - 19 


\section{Sampling Rationale}

\section{WNSWAMP DOE/EH-0173T, 5.10.1.1; 40 CFR, Part 122.26; NYSDOH ELAP (nonpotable water)}

Northeast site surface water drainage; provides for sampling of uncontrolled surface waters from this discrete drainage path just before they leave the site's controlled boundary. Waters represent surface and subsurface drainages from the construction and demolition debris landfill (CDDL), old hardstand areas, and other possible north plateau sources of radiological or nonradiological contamination on the north plateau.

Monitoring for nonradiological parameters is performed during ambient conditions to verify authorized non-storm water flows. Storm water monitoring is performed per WVDP-233, "Monitoring Plan for Storm Water Discharges at the West Valley Demonstration Project."

WNSW74A DOE/EH-0173T, 5.10.1.1; 40 CFR, Part 122.26; NYSDOH ELAP (nonpotable water)

North site surface water drainage; provides for sampling of uncontrolled surface waters from this discrete drainage path just before they leave the site's controlled boundary. Waters represent surface and subsurface drainages from lag storage areas and other possible sources of radiological or nonradiological contamination on the north plateau.

Monitoring for nonradiological parameters is performed during ambient conditions to verify authorized non-storm water flows. Storm water monitoring is performed per WVDP-233.

Sampling locations are shown on Figure A-2.

$B-20$ 
2006 Monitoring Program

Environmental Surveillance

On-Site Surface Water

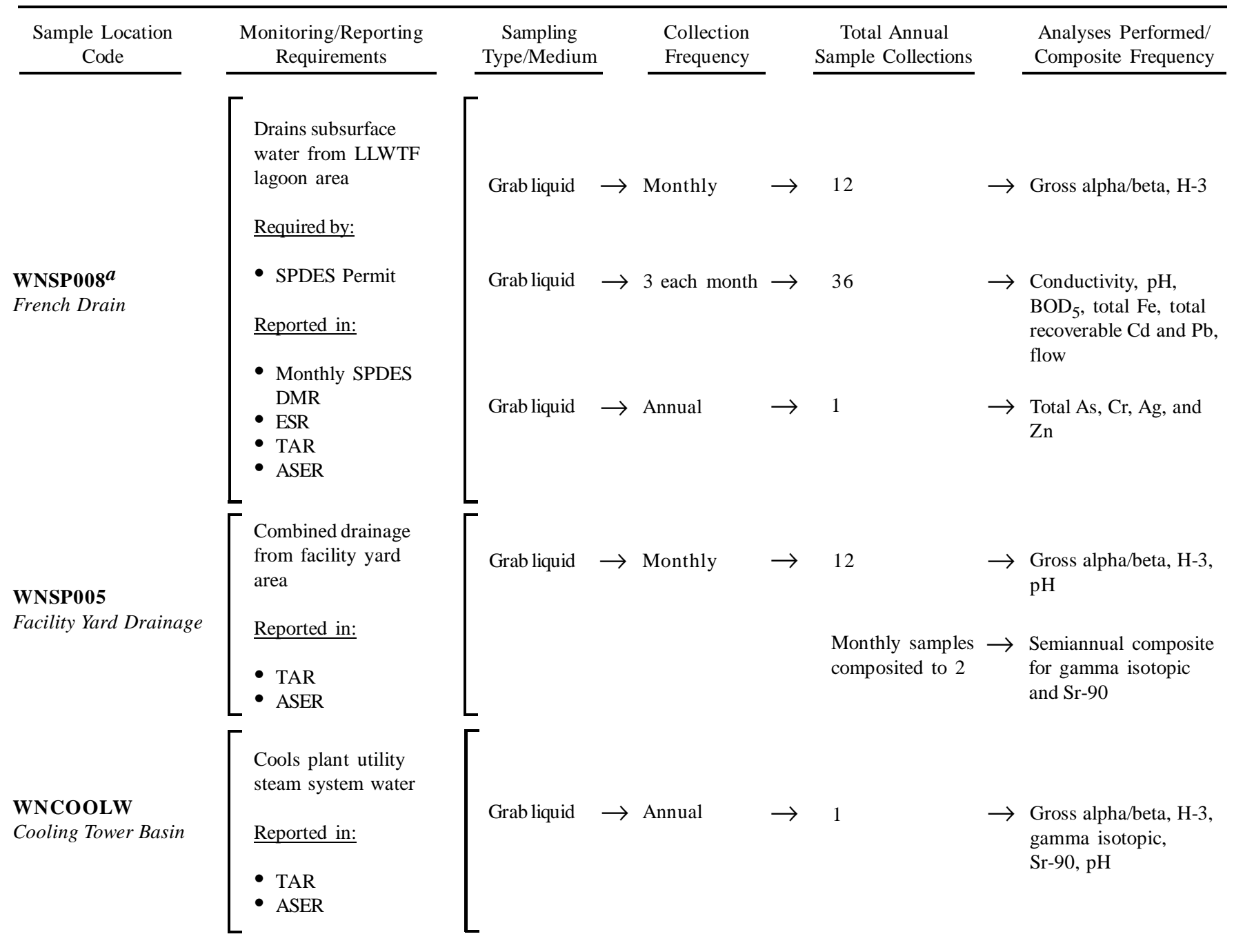

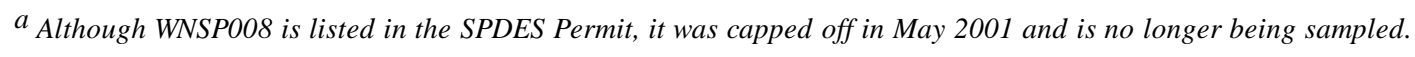

B - 21 
Sampling Rationale

WNSP008 DOE/EH-0173T, 5.10.1.3; New York State SPDES Permit no. NY0000973

French drain of subsurface water from lagoon (LLWTF) area. The SPDES Permit also provides for sampling of uncontrolled subsurface water from this discrete drainage path before these waters flow into Erdman Brook. Waters represent subsurface drainages from downward infiltration around the LLWTF and lagoon systems. This point would also monitor any subsurface spillover from the overfilling of lagoons 2 and 3. Sampling is of significance for both radiological and nonradiological contamination. This point was capped off in May 2001 and is routinely checked to verify that there is no discharge.

WNSP005 Generally in accordance with DOE/EH-0173T, 5.10.1.1 (previously in accordance with SPDES permit no. NY0000973); NYSDOH ELAP (nonpotable water)

Provides for the sampling of uncontrolled surface waters from this discrete drainage path after outfall 007 discharge into the drainage and before these waters flow into Erdman Brook. Waters represent surface and subsurface drainages primarily from the main plant yard area. Historically, this point was used to monitor sludge pond and utility room discharges to the drainage. These two sources have been rerouted. Migration of residual site contamination around the main plant dictates surveillance of this point, primarily for radiological parameters.

WNCOOLW Generally in accordance with DOE/EH-0173T, 5.10.1.1; NYSDOH ELAP (nonpotable water)

Operational sampling carried out to confirm that radiological contamination is not migrating into the primary coolant loop of the high-level waste treatment facility and/or plant utility steam systems. Migration from either source might indicate radiological control failure.

Sampling locations are shown on Figure A-2.

$B-22$ 


\section{Monitoring Program \\ Environmental Surveillance}

\section{On-Site Surface Water}

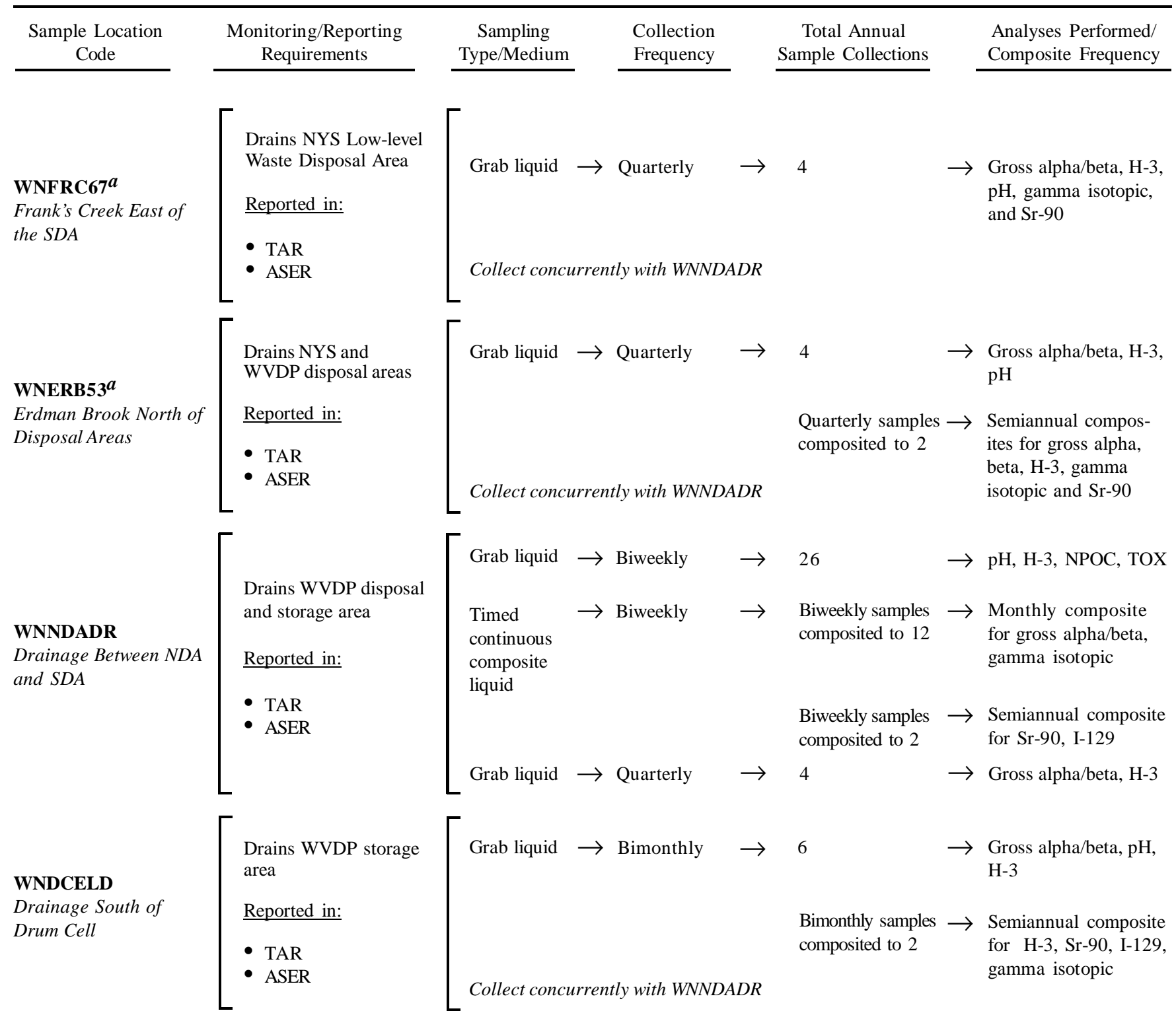

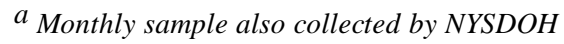


Sampling Rationale

WNFRC67 DOE/EH-0173T, 5.10.1.1; NYSDOH ELAP (nonpotable water)

Monitors the potential influence of both the SDA and drum cell drainage into Frank's Creek east of the SDA and upstream of its confluence with Erdman Brook.

WNERB53 DOE/EH-0173T, 5.10.1.1; NYSDOH ELAP (nonpotable water)

Monitors the potential influence of the drainages from the SDA and the WVDP storage and disposal area into Erdman Brook upstream of its confluence with Frank's Creek.

WNNDADR DOE/EH-0173T, 5.10.1.1; NYSDOH ELAP (nonpotable water)

Monitors the potential influence of the drainages from the SDA and the WVDP storage and disposal area into Lagoon Road creek upstream of the creek's confluence with Erdman Brook.

WNDCELD DOE/EH-0173T, 5.10.1.1; NYSDOH ELAP (nonpotable water)

Monitors the potential influence of drum cell drainage into Frank's Creek south of the SDA and upstream of WNFRC67.

Sampling locations are shown on Figure A-2.

$B-24$ 


\section{Monitoring Program \\ Environmental Surveillance}

\section{On-Site Surface Water}

\begin{tabular}{|c|c|c|c|c|c|c|c|c|}
\hline $\begin{array}{l}\text { Sample Location } \\
\text { Code }\end{array}$ & $\begin{array}{l}\text { Monitoring/Reporting } \\
\text { Requirements }\end{array}$ & $\begin{array}{c}\text { Sampling } \\
\text { Type/Medium }\end{array}$ & & $\begin{array}{l}\text { Collection } \\
\text { Frequency }\end{array}$ & & $\begin{array}{c}\text { Total Annual } \\
\text { Sample Collections }\end{array}$ & & $\begin{array}{l}\text { Analyses Performed/ } \\
\text { Composite Frequency }\end{array}$ \\
\hline \multirow[t]{2}{*}{$\begin{array}{l}\text { WNNDATR } \\
\text { NDA Trench Interceptor } \\
\text { Project }\end{array}$} & $\begin{array}{l}\begin{array}{l}\text { On-site groundwa- } \\
\text { ter interception }\end{array} \\
\text { Reported in: }\end{array}$ & Grab liquid & $\rightarrow$ & Monthly & $\rightarrow$ & 12 & $\rightarrow$ & $\begin{array}{l}\text { Gross alpha/beta, H-3, } \\
\text { gamma isotopic, } \\
\text { NPOC, TOX }\end{array}$ \\
\hline & $\begin{array}{ll}\text { - } & \text { TAR } \\
\text { - } & \text { ASER }\end{array}$ & & & & & $\begin{array}{l}\text { Monthly samples } \\
\text { composited to } 2\end{array}$ & $\rightarrow$ & $\begin{array}{l}\text { Semiannual composite } \\
\text { for I- } 129\end{array}$ \\
\hline $\begin{array}{l}\text { WNSTAW9 } \\
\text { North Reservoir Near } \\
\text { Intake }\end{array}$ & $\begin{array}{l}\text { Standing water near } \\
\text { reservoir that } \\
\text { provides site } \\
\text { drinking water } \\
\text { Reported in: } \\
\text { - TAR } \\
\text { - ASER }\end{array}$ & Grab liquid & $\rightarrow$ & Annual & $\rightarrow$ & 1 & $\rightarrow$ & $\begin{array}{l}\text { Gross alpha/beta, } \mathrm{H}-3 \text {, } \\
\mathrm{Sr}-90 \text {, gamma isotopic, } \\
\text { pH, conductivity, } \mathrm{Cl} \text {, } \\
\mathrm{Fe}, \mathrm{Mn}, \mathrm{Na}, \\
\mathrm{NO}_{3}+\mathrm{NO}_{2}-\mathrm{N}, \mathrm{SO}_{4}\end{array}$ \\
\hline
\end{tabular}

${ }^{a}$ Coordinated with Main Plant Operations

B - 25 


\section{Sampling Rationale}

WNNDATR Generally in accordance with DOE/EH-0173T, 5.10.1.1; NYSDOH ELAP (nonpotable water)

Monitors groundwater in the vicinity of the NDA interceptor trench project. The grab sample is taken directly from the trench collection system.

WNSTAW9 DOE/EH-0173T, 5.10.1.1; NYSDOH ELAP (nonpotable water)

Although this location does not receive effluent, on-site standing water from the north reservoir near the intake is sampled to provide radiological data for standing water near the source of the site potable water supply south of main plant facilities, as part of the "ingestion" pathway.

Sampling locations are shown on Figures A-2 and A-5.

$B-26$ 


\section{Monitoring Program \\ Environmental Surveillance}

On-Site Potable Water

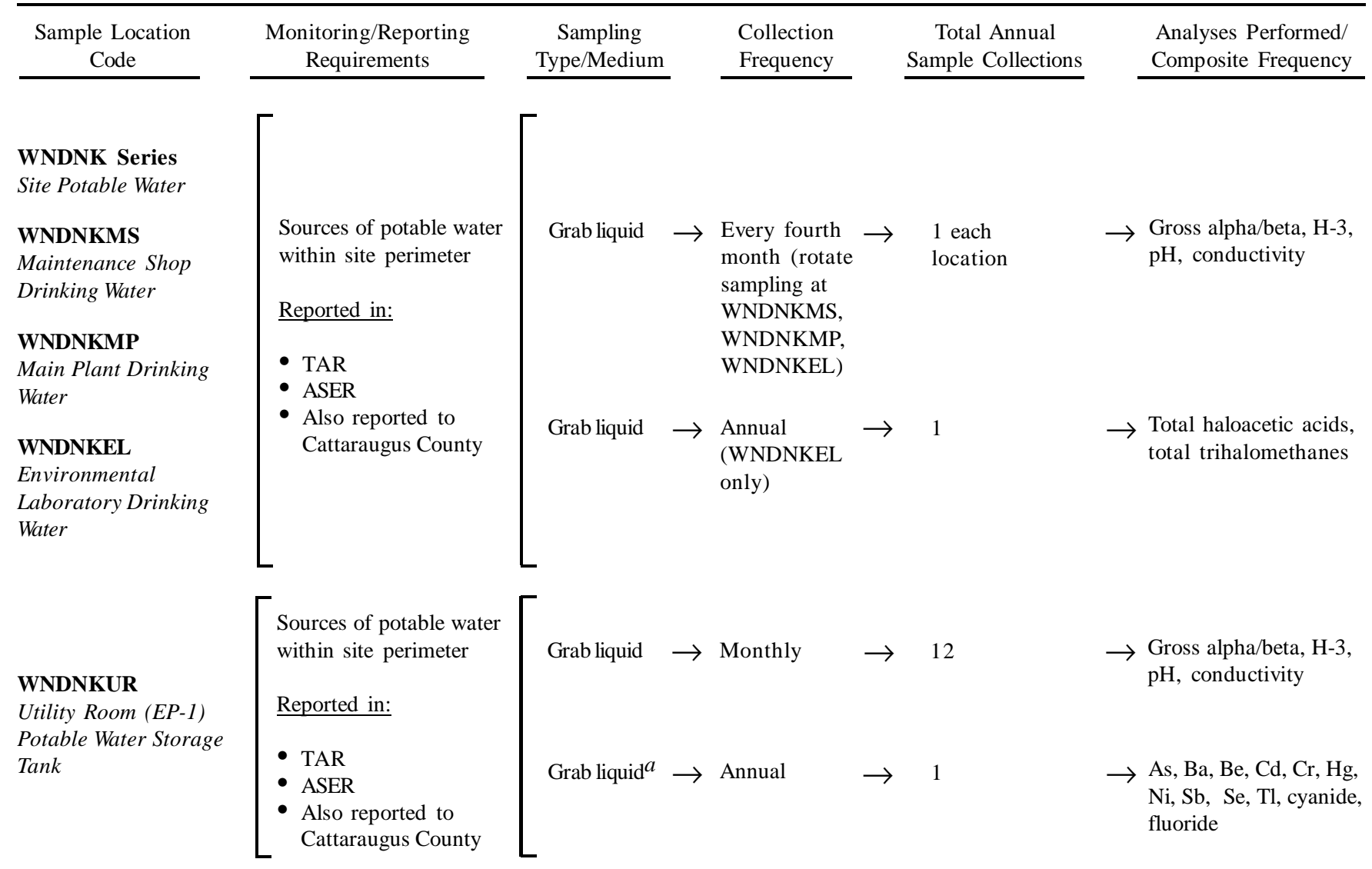

\footnotetext{
a Sample for $\mathrm{NO}_{3}$ (as total nitrate) is collected by the Cattaraugus County Health Department. Pb and Cu also are sampled at this site based upon Cattaraugus County Health Department guidance.
}

B - 27 


\section{Sampling Rationale}

WNDNK Series Site drinking water; generally according to DOE/EH-0173T, 5.10.1.2; 10 NYCRR, Part 5, Subpart 5-1; NYSDOH ELAP (potable water)

Potable water sampling to confirm no migration of radiological and/or nonradiological contamination into the site's drinking water supply.

WNDNKMS Potable water sampled at the maintenance shop in order to monitor a point that is at antermediate distance from the point of potable water generation and that is used heavily by site personnel.

WNDNKMP Same rationale as WNDNKMS but sampled at the break room sink in the main plant.

WNDNKEL Potable water sampled at the Environmental Laboratory. Disinfectant by-products are sampled at WNDNKEL, the furthest location from the entry point (WNDNKUR).

WNDNKUR Sampled at the utility room potable water storage tank before the site drinking water distribution system. Sample location is entry point EP-1.

Sampling locations are within the site facilities and are not detailed on figures.

$B-28$ 
2006 Monitoring Program

Environmental Surveillance

On-Site Groundwater

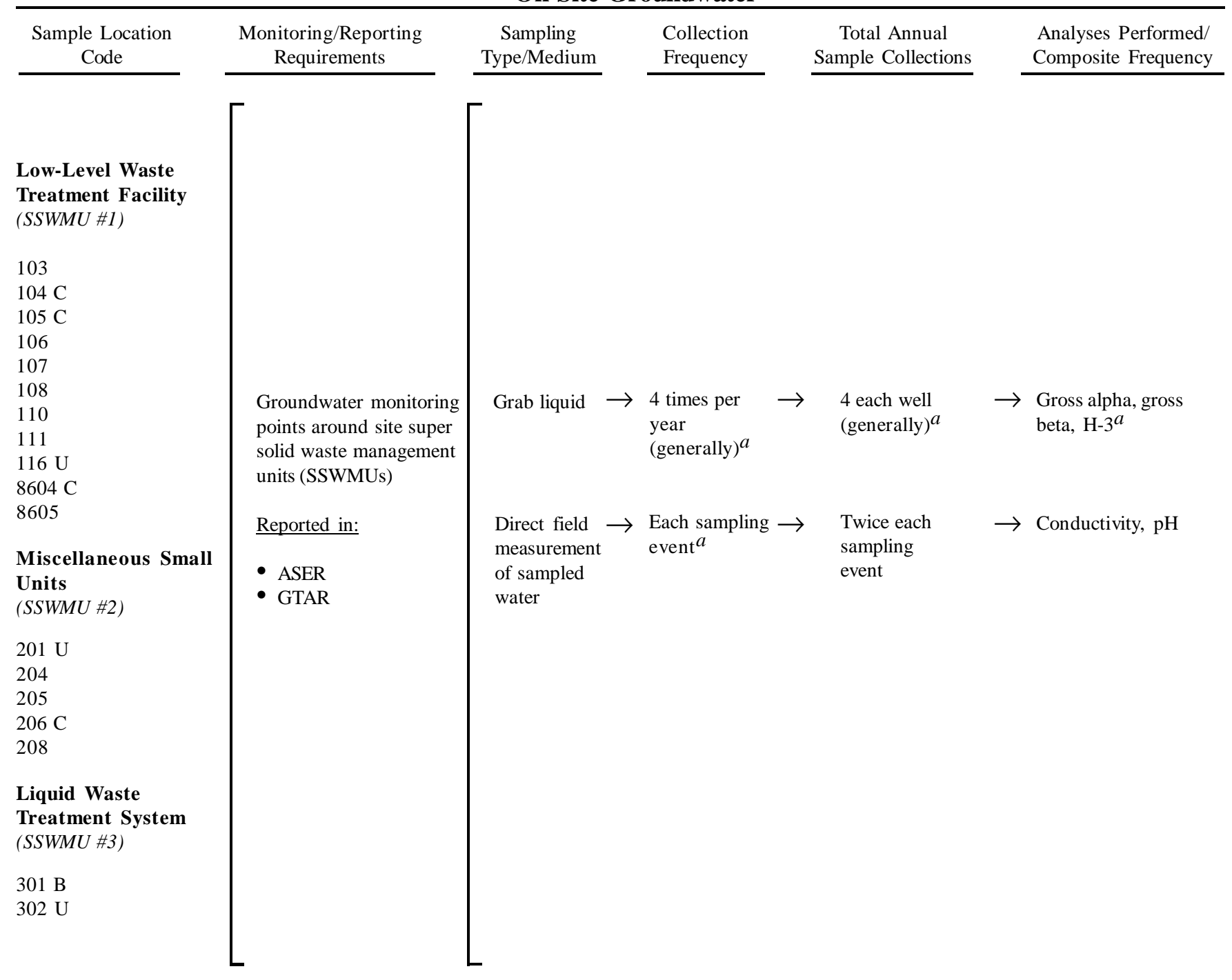

Note: "U" designates upgradient, " $B$ " designates background, and " $C$ " designates crossgradient wells. The remainder are downgradient.

${ }^{a}$ Sampling frequency and analytes vary from point to point. See Appendix $E^{\mathbf{C D}}$ for a summary listing of all monitored analytes, a listing of analytes monitored at each location, and results from each location.

$$
\text { B - } 29
$$




\title{
Sampling Rationale
}

\begin{abstract}
On-Site $\quad$ DOE/EH-0173T, 5.10.1.3; 40 CFR, Parts 264 and 265, Subpart F; NYSDOH ELAP (nonpotable water)
Groundwater

The on-site WVDP groundwater monitoring program provides for the determination of water quality, focusing on radiological and chemical surveillance of both active and inactive super solid waste management units (SSWMUs). In addition, using wells situated hydraulically upgradient (background) and downgradient of SSWMUs allows both detection of groundwater contamination and evaluation of the effects associated with the individual SSWMUs. Groundwater protection is addressed in the "Groundwater Protection Management Program Plan," WVDP-091. Groundwater monitoring is detailed in the "Groundwater Monitoring Plan," WVDP-239.
\end{abstract}

SSWMU \#1 Low-level waste treatment facilities, including four active lagoons - lagoons 2, 3, 4, and 5 - and an inactive, filledin lagoon - lagoon 1.

SSWMU \#2 Miscellaneous small units, including the sludge pond, the solvent dike, the paper incinerator, the equalization basin, and the kerosene tank.

SSWMU \#3 Liquid waste treatment system containing effluent from the supernatant treatment system.

Sampling locations are shown on Figures A-8 and A-9.

B - 30 
2006 Monitoring Program

Environmental Surveillance

On-Site Groundwater

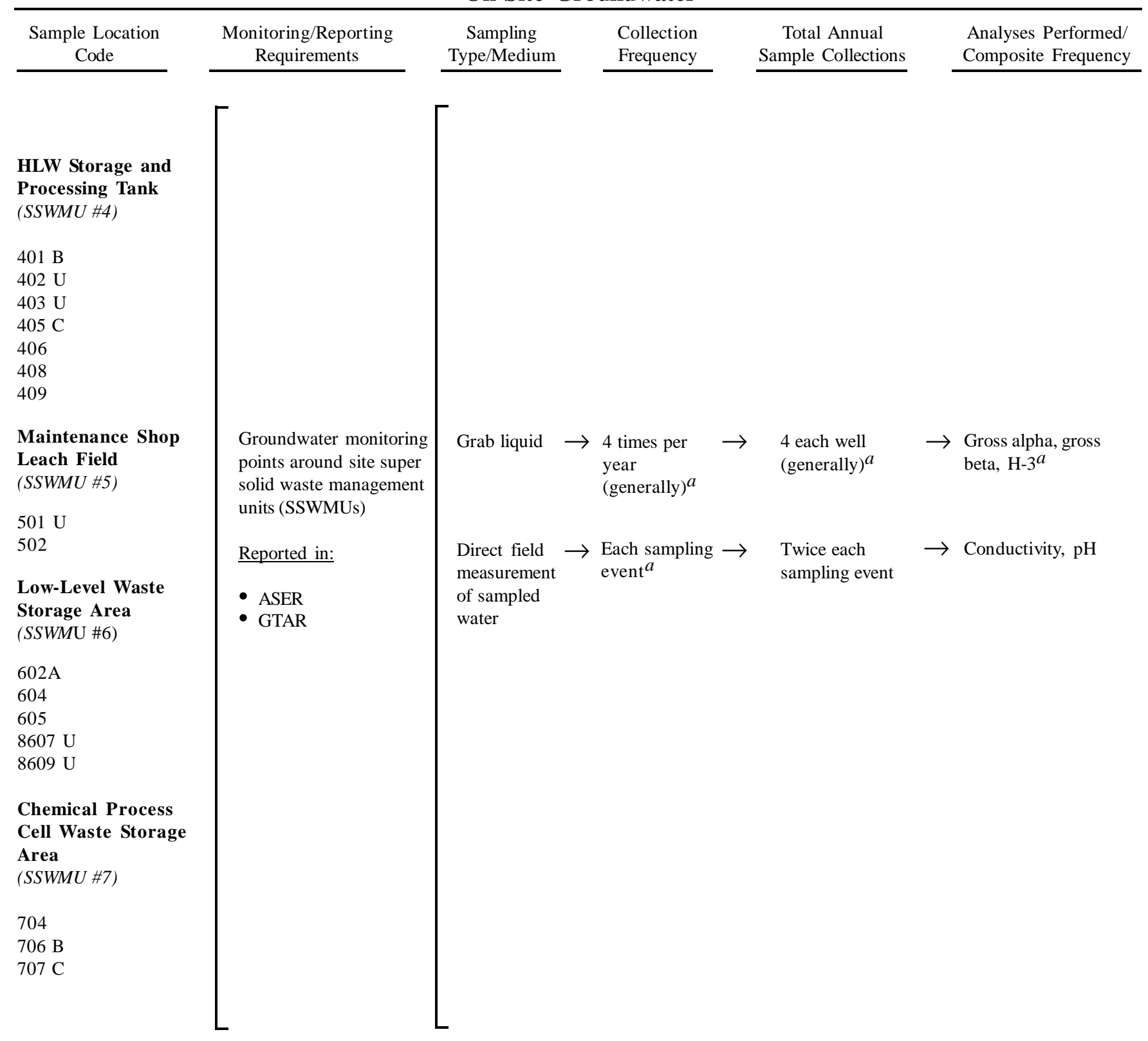

Note: "U" designates upgradient, " $B$ " designates background, and " $C$ " designates crossgradient wells. The remainder are downgradient.

a Sampling frequency and analytes vary from point to point. See Appendix $E^{\mathbf{C D}}$ for a summary listing of all monitored analytes, a listing of analytes monitored at each location, and results from each location.

$$
B-31
$$




\section{Sampling Rationale}

\section{On-Site $\quad$ DOE/EH-0173T, 5.10.1.3; 40 CFR, Parts 264 and 265, Subpart F; NYSDOH ELAP (nonpotable water)}

Groundwater

The on-site WVDP groundwater monitoring program provides for the determination of water quality, focusing on radiological and chemical surveillance of both active and inactive super solid waste management units (SSWMUs). In addition, using wells situated hydraulically upgradient (background) and downgradient of SSWMUs allows both detection of groundwater contamination and evaluation of the effects associated with the individual SSWMUs. Groundwater protection is addressed in the "Groundwater Protection Management Program Plan," WVDP-091. Groundwater monitoring is detailed in the "Groundwater Monitoring Plan," WVDP-239.

SSWMU \#4 High-level waste storage and processing area, including the high-level radioactive waste tanks, the supernatant treatment system, and the vitrification facility.

SSWMU \#5 Maintenance shop sanitary leach field, formerly used by Nuclear Fuel Services and the WVDP to process domestic sewage generated by the maintenance shop.

SSWMU \#6 Low-level waste storage area; includes metal and fabric structures housing low-level radioactive waste being stored for future disposal.

SSWMU \#7 Chemical process cell (CPC) waste storage area, which contains packages of pipes, vessels, and debris from decontamination and cleanup of the chemical process cell in the former reprocessing plant.

Sampling locations are shown on Figures A-8 and A-9.

$B-32$ 
2006 Monitoring Program

Environmental Surveillance

On-Site Groundwater

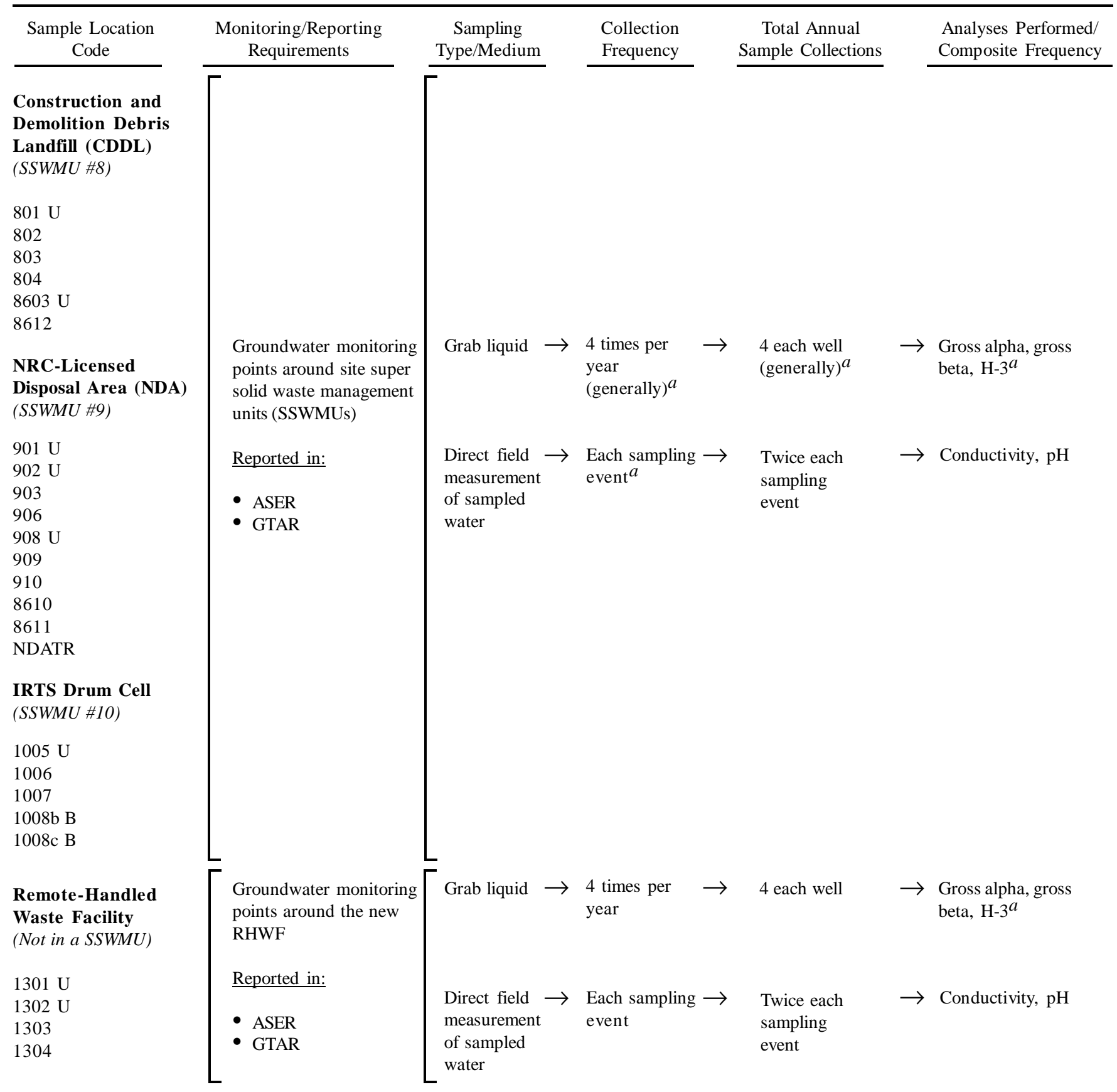

NOTE: " $U$ " designates upgradient, " $B$ " designates background, and " $C$ " designates crossgradient wells. The remainder are downgradient.

${ }^{a}$ Sampling frequency and analytes vary from point to point. See Appendix $E^{\boldsymbol{C D}}$ for a summary listing of all monitored analytes, a listing of analytes monitored at each location, and results from each location.

$$
B-33
$$




\title{
Sampling Rationale
}

\begin{abstract}
On-Site DOE/EH-0173T, 5.10.1.3; 40 CFR, Parts 264 and 265, Subpart F; NYSDOH ELAP (nonpotable water)
Groundwater

The on-site WVDP groundwater monitoring program provides for the determination of water quality, focusing on radiological and chemical surveillance of both active and inactive super solid waste management units (SSWMUs). In addition, using wells situated hydraulically upgradient (background) and downgradient of SSWMUs allows both detection of groundwater contamination and evaluation of the effects associated with the individual SSWMUs. Groundwater protection is addressed in the "Groundwater Protection Management Program Plan," WVDP-091. Groundwater monitoring is detailed in the "Groundwater Monitoring Plan," WVDP-239.

SSWMU \#8 The construction and demolition debris landfill (CDDL); formerly used by Nuclear Fuel Services and the WVDP to dispose of nonhazardous and nonradioactive materials.

SSWMU \#9 The NRC-licensed disposal area (NDA); contains radioactive wastes generated by NFS and the WVDP. The NDA is bounded on its downgradient (northwest and northeast) perimeters by the interceptor trench, which is sampled at monitoring point NDATR.
\end{abstract}

SSWMU \#10 The integrated radioactive waste system (IRTS) treatment drum cell; stores cement-stablized low-level radioactive waste.

Remote-Handled Monitor groundwater in the vicinity of the remote-handled waste facility (RHWF). Waste Facility

Sampling locations are shown on Figures A-8 through A-10.

$$
B-34
$$




\section{Monitoring Program \\ Environmental Surveillance}

\section{On-Site Groundwater and Seeps}

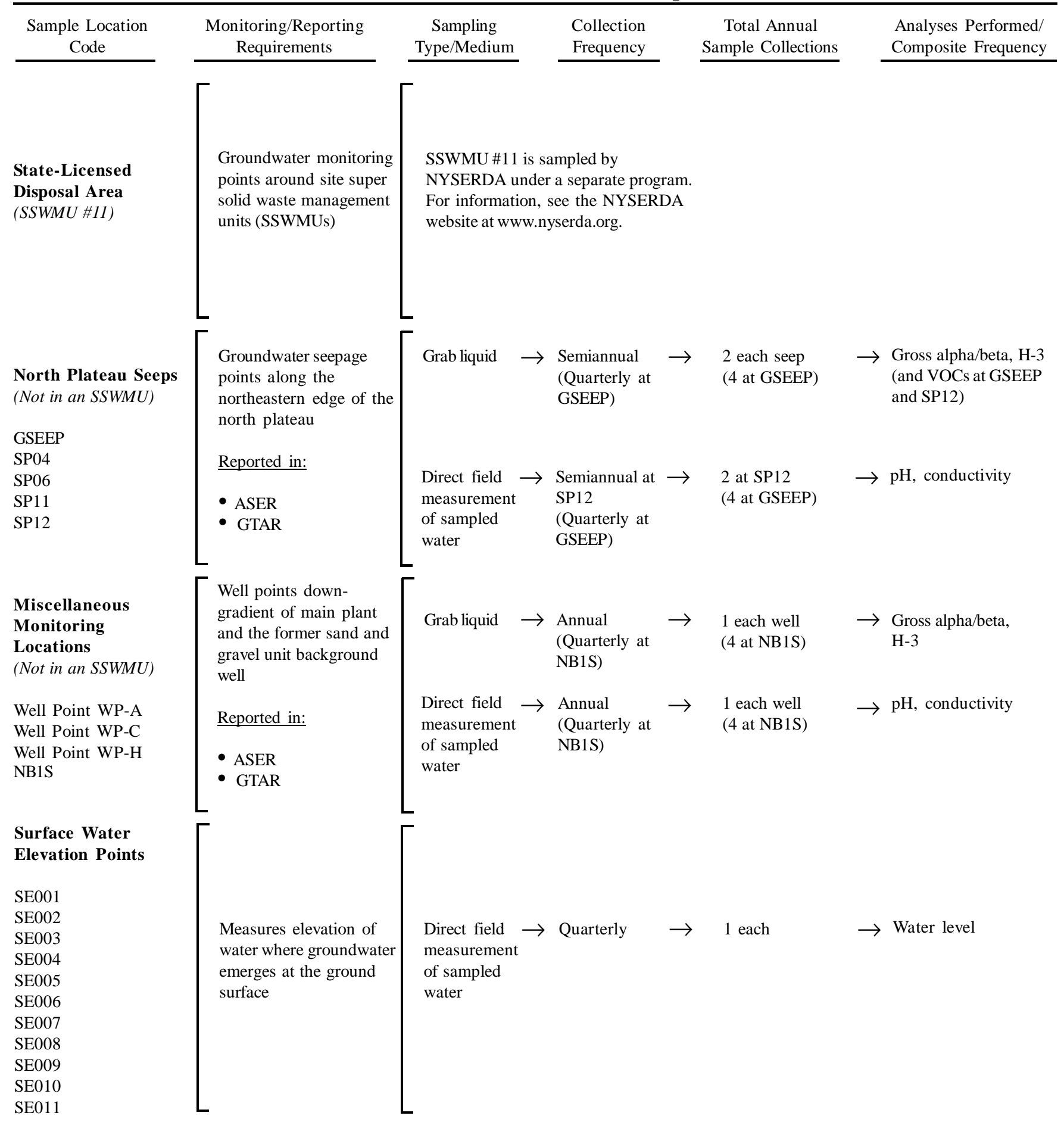

$$
B-35
$$




\title{
Sampling Rationale
}

\begin{abstract}
On-Site DOE/EH-0173T, 5.10.1.3; 40 CFR, Parts 264 and 265, Subpart F; NYSDOH ELAP (nonpotable water)
Groundwater

The on-site WVDP groundwater monitoring program provides for the determination of water quality, focusing on radiological and chemical surveillance of both active and inactive super solid waste management units (SSWMUs). In addition, using wells situated hydraulically upgradient (background) and downgradient of SSWMUs allows both detection of groundwater contamination and evaluation of the effects associated with the individual SSWMUs. Groundwater protection is addressed in the "Groundwater Protection Management Program Plan," WVDP-091. Groundwater monitoring is detailed in the "Groundwater Monitoring Plan," WVDP-239.
\end{abstract}

SSWMU \#11 The New York State-licensed disposal area (SDA) was operated by Nuclear Fuel Services as a commercial low-level disposal facility; it also received wastes from NFS reprocessing operations.

North Plateau Monitor groundwater emanating from the ground surface along the edge of the site's north plateau.

Seeps

Well Points

Monitor groundwater of known subsurface contamination in the north plateau area. All well points are downgradient of the main plant.

NB1S Former background well on the north plateau.

WNSE Series Water level measurements from the WNSE series of points are used in conjunction with water level measurements from groundwater monitoring wells. These surface elevation points provide data in areas of the north plateau where monitoring well coverage is sparse or nonexistent.

Sampling locations are shown on Figures A-8 through A-10.

$$
B-36
$$


2006 Monitoring Program

Environmental Surveillance

Off-Site Surface Water

\begin{tabular}{|c|c|c|c|c|c|c|c|c|}
\hline $\begin{array}{l}\text { Sample Location } \\
\text { Code }\end{array}$ & $\begin{array}{l}\text { Monitoring/Reporting } \\
\text { Requirements }\end{array}$ & $\begin{array}{c}\text { Sampling } \\
\text { Type/Medium }\end{array}$ & & $\begin{array}{l}\text { Collection } \\
\text { Frequency }\end{array}$ & & $\begin{array}{c}\text { Total Annual } \\
\text { Sample Collections }\end{array}$ & & $\begin{array}{l}\text { Analyses Performed/ } \\
\text { Composite Frequency }\end{array}$ \\
\hline \multirow{7}{*}{$\begin{array}{l}\text { WFBCBKG } \boldsymbol{a} \\
\text { Buttermilk Creek Near } \\
\text { Fox Valley } \\
\text { (Background) }\end{array}$} & \multirow{7}{*}{$\begin{array}{l}\text { Unrestricted surface } \\
\text { water, background }\end{array}$} & \multirow[t]{2}{*}{$\begin{array}{l}\text { Timed } \\
\text { continuous } \\
\text { composite } \\
\text { liquid }\end{array}$} & \multirow[t]{2}{*}{$\rightarrow$} & \multirow[t]{2}{*}{ Weekly } & \multirow[t]{2}{*}{$\rightarrow$} & $\begin{array}{l}52 \text { weekly } \\
\text { samples } \\
\text { composited to } 12\end{array}$ & $\rightarrow$ & $\begin{array}{l}\text { Monthly composite for } \\
\text { gross alpha/beta, H-3 }\end{array}$ \\
\hline & & & & & & $\begin{array}{l}\text { Weekly samples } \\
\text { composited to } 4\end{array}$ & $\rightarrow$ & $\begin{array}{l}\text { Quarterly composite for } \\
\text { gamma isotopic, C-14, } \\
\text { Sr-90, Tc-99, I-129, U-232, } \\
\text { U-233/234, U-235/236, } \\
\text { U-238, total U, Pu-238, } \\
\text { Pu-239/240, Am-241 }\end{array}$ \\
\hline & & Grab liquid & $\rightarrow$ & Monthly & $\rightarrow$ & 12 & $\rightarrow$ & Hardness ( $\mathrm{Ca}$ and $\mathrm{Mg}$ ) \\
\hline & & Grab liquid & $\rightarrow$ & Semiannual $^{b}$ & $\rightarrow$ & 2 & $\rightarrow$ & $\begin{array}{l}\text { Temperature (field), } \mathrm{pH} \\
\text { (field), dissolved } \\
\text { oxygen (field), TOX, } \\
\text { oil \& grease }\end{array}$ \\
\hline & & $\begin{array}{l}\text { 24-hour } \\
\text { timed } \\
\text { continuous } \\
\text { composite }\end{array}$ & $\rightarrow$ & Semiannual $^{b}$ & $\rightarrow$ & 2 & $\rightarrow$ & $\begin{array}{l}\text { TSS, TDS, NPOC, } \mathrm{NH}_{3} \\
\text { (as N), } \mathrm{NO}_{3} \text { (as N), } \\
\mathrm{NO}_{2} \text { (as N), bromide, } \\
\text { fluoride, chloride, } \\
\text { sulfate, total sulfide, } \\
\text { surfactant (as LAS), } \\
\text { alpha-BHC, B, Ba, Co, } \\
\mathrm{Fe}, \mathrm{Na}, \mathrm{Mn}, \mathrm{Sb}, \mathrm{Ti}, \mathrm{Tl}, \\
\text { V, dissolved Al, As, Cd, } \\
\mathrm{Cr}, \mathrm{Cu}, \mathrm{Hg} \text { (method } \\
\text { 1631), Ni, } \mathrm{Pb}, \mathrm{Se}, \mathrm{Zn}\end{array}$ \\
\hline & & $\begin{array}{l}\text { Timed } \\
\text { continuous } \\
\text { composite } \\
\text { liquid }\end{array}$ & $\rightarrow$ & Biweekly & $\rightarrow$ & $\begin{array}{l}26 \text { biweekly } \\
\text { samples } \\
\text { composited to } 12\end{array}$ & $\rightarrow$ & $\begin{array}{l}\text { Monthly composite for } \\
\text { gross alpha/beta, H-3 }\end{array}$ \\
\hline & & & & & & $\begin{array}{l}\text { Biweekly samples } \\
\text { composited to } 2\end{array}$ & $\rightarrow$ & $\begin{array}{l}\text { Semiannual composite } \\
\text { for gamma isotopic, } \\
\text { Sr-90, Tc-99 }\end{array}$ \\
\hline $\mathrm{WFBCTCB}^{a}$ & $\begin{array}{l}\text { Restricted surface waters } \\
\text { receiving }\end{array}$ & Grab liquid & $\rightarrow$ & Monthly & $\rightarrow$ & 12 & $\rightarrow$ & Hardness ( $\mathrm{Ca}$ and $\mathrm{Mg}$ ) \\
\hline $\begin{array}{l}\text { Buttermilk Creek } \\
\text { Upstream of } \\
\text { Confluence With } \\
\text { Cattaraugus Creek at }\end{array}$ & Reported in: & Grab liquid & $\rightarrow$ & Semiannual $b$ & $\rightarrow$ & 2 & $\rightarrow$ & $\begin{array}{l}\text { Temperature (field), } \mathrm{pH} \\
\text { (field), dissolved } \\
\text { oxygen (field), TOX, } \\
\text { oil \& grease }\end{array}$ \\
\hline Thomas Corners Road & - ASER & $\begin{array}{l}\text { 24-hour } \\
\text { timed } \\
\text { continuous } \\
\text { composite }\end{array}$ & $\rightarrow$ & Semiannual $^{b}$ & $\rightarrow$ & 2 & $\rightarrow$ & $\begin{array}{l}\text { TSS, TDS, NPOC, } \mathrm{NH}_{3} \\
\text { (as N), } \mathrm{NO}_{3} \text { (as N), } \\
\mathrm{NO}_{2} \text { (as N), bromide, } \\
\text { fluoride, chloride, } \\
\text { sulfate, total sulfide, } \\
\text { surfactant (as LAS), } \\
\text { alpha-BHC, B, Ba, Co, } \\
\mathrm{Fe}, \mathrm{Na}, \mathrm{Mn}, \mathrm{Sb}, \mathrm{Ti}, \mathrm{Tl} \text {, } \\
\text { V, dissolved Al, As, Cd, } \\
\mathrm{Cr}, \mathrm{Cu}, \mathrm{Hg}(\mathrm{method} \\
\text { 1631), Ni, } \mathrm{Pb}, \mathrm{Se}, \mathrm{Zn}\end{array}$ \\
\hline
\end{tabular}

$$
B-37
$$




\section{Sampling Rationale}

WFBCBKG DOE/EH-0173T, 5.10.1.1; 6 NYCRR, Part 702-704; NYSDOH ELAP (nonpotable water)

Monitors background conditions of Buttermilk Creek upstream of the WVDP; allows for comparison to downstream conditions. Monitoring for nonradiological parameters performed during discharges from WNSP001 and WNSP007 for comparison with downstream conditions.

WFBCTCB DOE/EH-0173T, 5.10.1.1; 6 NYCRR, Part 702-704; NYSDOH ELAP (nonpotable water)

Buttermilk Creek is the surface water that receives all WVDP liquid effluents. WFBCTCB monitors the potential influence of WVDP drainage into Buttermilk Creek upstream of Buttermilk Creek's confluence with Cattaraugus Creek. Monitoring for nonradiological parameters performed during discharges from WNSP001 and WNSP007 for comparison with New York State ambient water quality standards (6 NYCRR, Part 702-704).

Sampling locations are shown on Figure A-5.

$B-38$ 


\section{Monitoring Program \\ Environmental Surveillance}

Off-Site Surface Water

\begin{tabular}{|c|c|c|c|c|c|c|c|c|}
\hline $\begin{array}{l}\text { Sample Location } \\
\text { Code }\end{array}$ & $\begin{array}{l}\text { Monitoring/Reporting } \\
\text { Requirements }\end{array}$ & $\begin{array}{c}\text { Sampling } \\
\text { Type/Medium }\end{array}$ & & $\begin{array}{l}\text { Collection } \\
\text { Frequency }\end{array}$ & & $\begin{array}{c}\text { Total Annual } \\
\text { Sample Collections }\end{array}$ & & $\begin{array}{l}\text { Analyses Performed/ } \\
\text { Composite Frequency }\end{array}$ \\
\hline $\begin{array}{l}\text { WFBIGBR } \\
\text { Cattaraugus Creek at } \\
\text { Bigelow Bridge } \\
\text { (Background) }\end{array}$ & $\begin{array}{l}\text { Unrestricted surface } \\
\text { water, background } \\
\text { Reported in: } \\
\text { - TAR } \\
\text { - ASER }\end{array}$ & Grab liquid & $\rightarrow$ & Quarterly & $\rightarrow$ & 4 & $\rightarrow$ & $\begin{array}{l}\text { Gross alpha/beta, } \mathrm{H}-3 \text {, } \\
\text { Sr-90, gamma isotopic, } \\
\mathrm{pH}\end{array}$ \\
\hline $\begin{array}{l}\text { WFFELBR }^{\boldsymbol{a}} \\
\text { Cattaraugus Creek at } \\
\text { Felton Bridge }\end{array}$ & $\begin{array}{l}\text { Unrestricted surface } \\
\text { waters receiving plant } \\
\text { effluents } \\
\text { Reported in: } \\
\text { - TAR } \\
\text { - ASER }\end{array}$ & $\begin{array}{l}\text { Timed } \\
\text { continuous } \\
\text { composite } \\
\text { liquid }\end{array}$ & $\rightarrow$ & $\begin{array}{l}\text { Weekly during } \\
\text { lagoon } 3 \\
\text { discharge, } \\
\text { otherwise } \\
\text { biweekly }\end{array}$ & $\rightarrow$ & $\begin{array}{l}26-34 \\
\text { Weekly and } \\
\text { biweekly samples } \\
\text { composited to } 12\end{array}$ & $\begin{array}{l}\rightarrow \\
\rightarrow \\
\rightarrow\end{array}$ & $\begin{array}{l}\text { Flow-weighted } \\
\text { monthly composite } \\
\text { for gross alpha/beta, } \\
\text { H-3, Sr-90, and } \\
\text { gamma isotopic } \\
\text { Semiannual composite } \\
\text { for Tc-99 }\end{array}$ \\
\hline
\end{tabular}

${ }^{a}$ Monthly composites are also sent to NYSDOH.

B - 39 


\section{Sampling Rationale}

WFBIGBR DOE/EH-0173T, 5.10.1.1; NYSDOH ELAP (nonpotable water)

Monitors background conditions of Cattaraugus Creek at Bigelow Bridge, upstream of the WVDP; allows for comparison to downstream conditions.

WFFELBR DOE/EH-0173T, 5.10.1.1; NYSDOH ELAP (nonpotable water)

Because Buttermilk Creek empties into Cattaraugus Creek, WFFELBR monitors the potential influence of WVDP drainage into Cattaraugus Creek directly downstream of the Cattaraugus Creek confluence with Buttermilk Creek.

Sampling locations are shown on Figure A-5.

$B-40$ 
2006 Monitoring Program

Environmental Surveillance

Off-Site Drinking Water

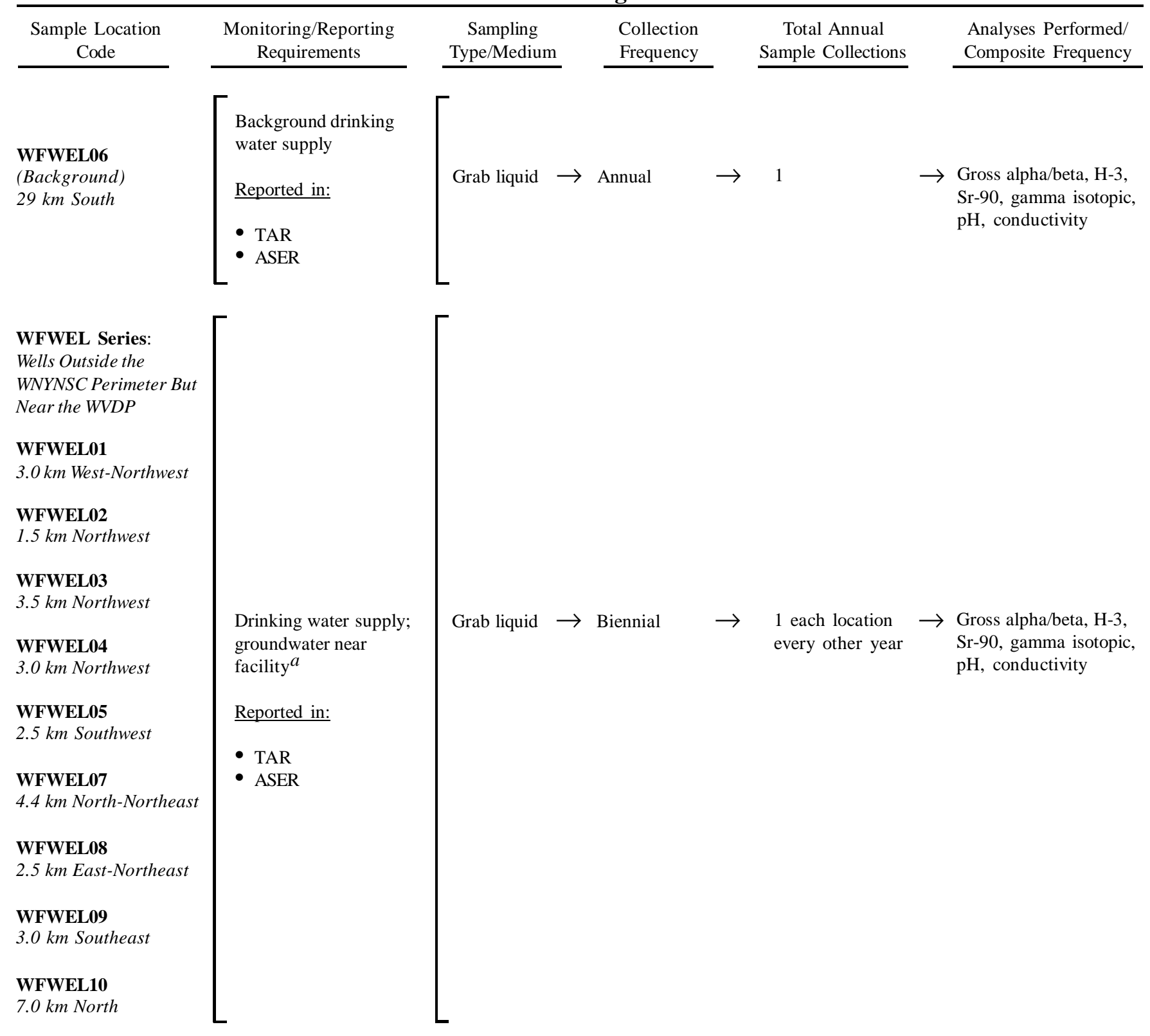

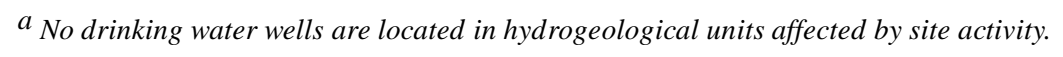

$B-41$ 


\section{Sampling Rationale}

Off-Site DOE/EH-0173T, 5.10.1.2; NYSDOH ELAP (potable water)

Drinking Water

WFWEL Series

Eight of the ten listed off-site private residential drinking water wells represent the nearest unrestricted uses of groundwater close to the WVDP. The ninth sample (WFWEL10) is taken from a public water supply from deep wells. The tenth drinking water well, WFWEL06, is located 29 kilometers south of the Project and is considered a background drinking water source.

Sampling locations are shown on Figures A-11, A-14, and A-15.

$B-42$ 
2006 Monitoring Program

Environmental Surveillance

Off-Site Air

\begin{tabular}{|c|c|c|c|c|c|c|}
\hline $\begin{array}{l}\text { Sample Location } \\
\text { Code }\end{array}$ & $\begin{array}{l}\text { Monitoring/Reporting } \\
\text { Requirements }\end{array}$ & $\begin{array}{c}\text { Sampling } \\
\text { Type/Medium }\end{array}$ & $\begin{array}{l}\text { Collection } \\
\text { Frequency }\end{array}$ & & $\begin{array}{c}\text { Total Annual } \\
\text { Sample Collections }\end{array}$ & $\begin{array}{l}\text { Analyses Performed/ } \\
\text { Composite Frequency }\end{array}$ \\
\hline $\begin{array}{l}\text { AFFXVRD } \\
3.0 \mathrm{~km} \text { South-Southeast } \\
\text { at Fox Valley }\end{array}$ & & $\begin{array}{l}\text { Continuous } \rightarrow \\
\text { air } \\
\text { particulate }\end{array}$ & Biweekly & $\rightarrow$ & 26 each location $\rightarrow$ & Gross alpha/beta, flow \\
\hline $\begin{array}{l}\text { AFRT240 }^{\boldsymbol{a}} \\
2.0 \text { km Northeast on } \\
\text { Route } 240\end{array}$ & Air samples around & filter & & & $\begin{array}{l}\text { Biweekly filters } \rightarrow \\
\text { composited to } 2 \\
\text { each location }\end{array}$ & $\begin{array}{l}\text { Semiannual composite } \\
\text { for Sr-90, gamma } \\
\text { isotopic, flow }\end{array}$ \\
\hline $\begin{array}{l}\text { AFSPRVL } \\
9.4 \text { km North at } \\
\text { Springville }\end{array}$ & $\begin{array}{l}\text { WNYNSC perimeter } \\
\text { and background }\end{array}$ & & & & & $\begin{array}{l}\text { In addition, semiannual } \\
\text { composite at } \\
\text { AFRSPRD and }\end{array}$ \\
\hline $\begin{array}{l}\text { AFWEVAL } \\
6.2 \mathrm{~km} \text { South-Southeast } \\
\text { at West Valley }\end{array}$ & $\begin{array}{l}\text { Reported in: } \\
\text { - TAR } \\
\text { - ASER }\end{array}$ & & & & & $\begin{array}{l}\text { AFGRVAL for } \\
\text { U-232, U-233/234, } \\
\text { U-235/236, U-238, } \\
\text { total U, Pu-238, }\end{array}$ \\
\hline $\begin{array}{l}\text { AFRSPRD } \\
1.5 \mathrm{~km} \text { Northwest on }\end{array}$ & & & & & & $\mathrm{Pu}-239 / 240$, Am-241 \\
\hline $\begin{array}{l}\text { Rock Springs Road } \\
\text { AFGRVAL } \\
29 \mathrm{~km} \text { South at Great } \\
\text { Valley (Background) }\end{array}$ & & $\begin{array}{l}\text { Continuous } \rightarrow \\
\text { charcoal } \\
\text { cartridge at } \\
\text { AFRSPRD and } \\
\text { AFGRVAL }\end{array}$ & Monthly & $\rightarrow$ & $\begin{array}{l}12 \text { composited to } \rightarrow \\
2 \text { each location }\end{array}$ & $\begin{array}{l}\text { Semiannual composite } \\
\text { for I-129 }\end{array}$ \\
\hline
\end{tabular}

${ }^{a}$ Filter from duplicate sampler sent to NYSDOH.

$B-43$ 


\section{Sampling Rationale}

AFFXVRD DOE/EH-0173T, 5.7.4

AFRT240

Air samplers put into service by NFS as part of the site's original monitoring program at perimeter locations chosen to obtain data from places most likely to provide highest concentrations. Choice of location based on meteorological data.

AFSPRVL DOE/EH-0173T, 5.7.4; DOE/EP-0023, 4.2.3

Off-site (remote) sampler located on private property in a nearby community within 15 kilometers of the site (north).

AFWEVAL DOE/EH-0173T, 5.7.4; DOE/EP-0023, 4.2.3

Off-site (remote) sampler located in a nearby community within 15 kilometers of the site (southeast).

AFRSPRD

DOE/EH-0173T, 5.7.4

Perimeter location chosen to obtain data from the place most likely to provide the highest ground-level release concentrations. AFRSPRD is on WNYNSC property outside the main plant operations fenceline. I-129 is sampled here because the sampling train was easy to incorporate and the location was most likely to receive effluent releases. Choice of location based on meteorological data.

AFGRVAL DOE/EH-0173T, 5.7.4; DOE/EP-0023, 4.2.3

Off-site (remote) sampler considered representative of natural background radiation. Located on privately owned property 29 kilometers south of the site (typically upwind). I-129 sampled here also.

Sampling locations are shown on Figures A-7, A-14, and A-15.

$B-44$ 


\section{Monitoring Program \\ Environmental Surveillance}

Fallout, Sediment, and Soil

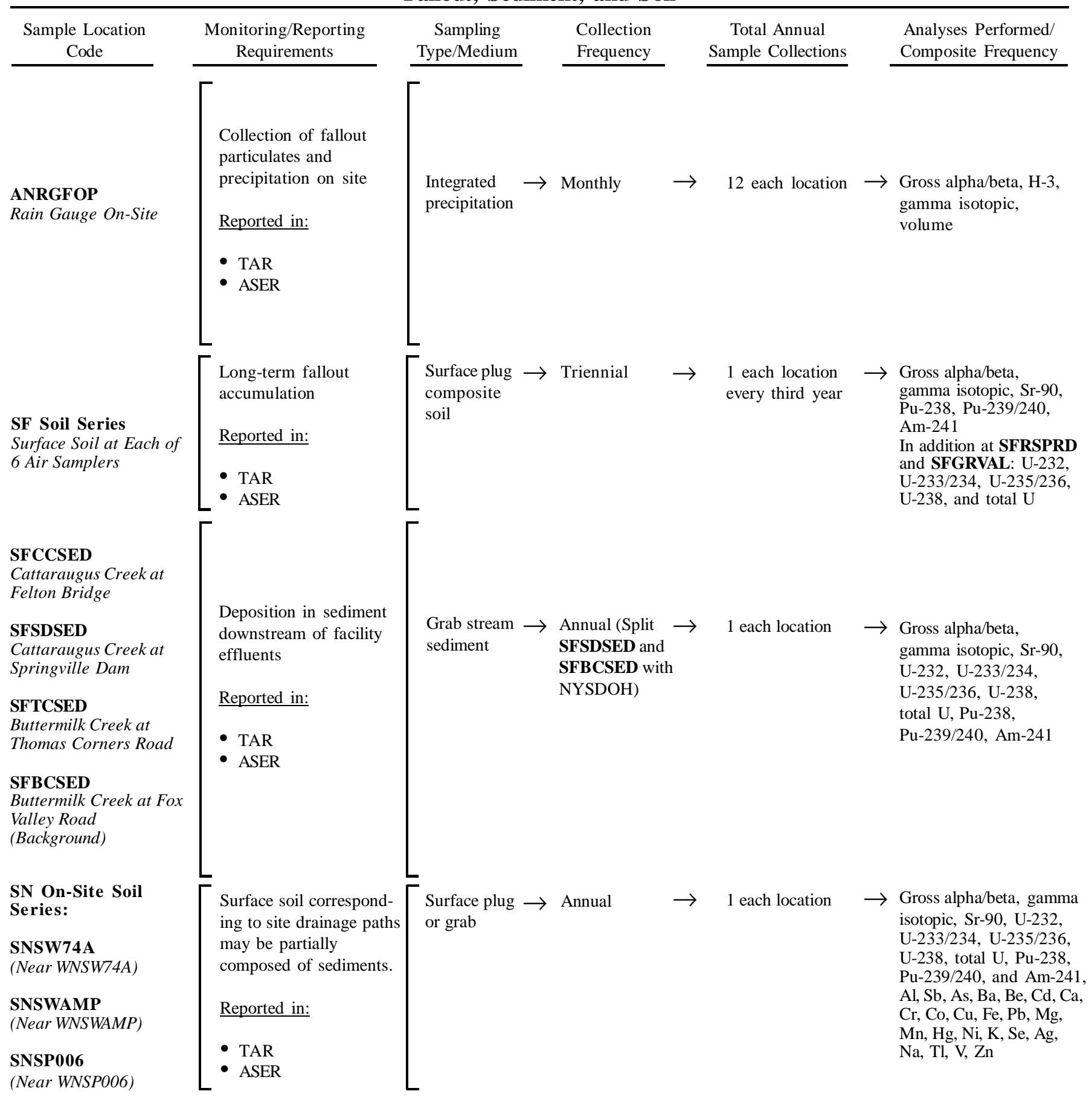

$B-45$ 


\section{Sampling Rationale}

ANRGFOP DOE/EP-0023, 4.7

Fallout particles and precipitation collected on site by the Environmental Laboratory at the rain gauge. Indicates short-term effects.

SF Soil Series

DOE/EH-0173T, 5.9.1

Off-site soils collected at air sampling locations: SFWEVAL (West Valley), SFFXVRD (Fox Valley Road), SFSPRVL (Springville), SFRT240 (Route 240), SFGRVAL (Great Valley), and SFRSPRD (Rock Springs Road): Collection of long-term fallout data at established air sampler locations via soil sampling.

SFCCSED

DOE/EH-0173T, 5.12.1

Sediment deposition in Cattaraugus Creek at Felton Bridge. Location is the first point of public access to Cattaraugus Creek downstream of its confluence with Buttermilk Creek.

SFSDSED $\quad$ DOE/EH-0173T, 5.12.1

Sediment deposition in Cattaraugus Creek at Springville Dam. Reservoir provides ideal settling and collection location for sediments downstream of the Buttermilk Creek confluence with Cattaraugus Creek. Located downstream of SFCCSED.

SFTCSED DOE/EH-0173T, 5.12 .1

Sediment deposition in Buttermilk Creek at Thomas Corners immediately downstream of all facility liquid effluents.

SFBCSED

DOE/EH-0173T, 5.12.1

Sediment deposition in Buttermilk Creek upsteam of facility effluents (background).

SN Soil Series DOE/EH-0173T, 5.9.1.

On-site soil. (Samples may be partially composed of sediments.) SNSW74A (surface soil near WNSW74A), SNSWAMP (surface soil near WNSWAMP), and SNSP006 (surface soil near WNSP006): Locations to be specifically defined by geographic coordinates. Correspond to site drainage pattern flows (i.e., most likely area of radiological deposition/accumulation).

Sampling locations are shown on Figures A-2, A-5, A-6, A-14, and A-15.

$B-46$ 


\section{Monitoring Program}

\section{Environmental Surveillance}

\section{Off-Site Biological}

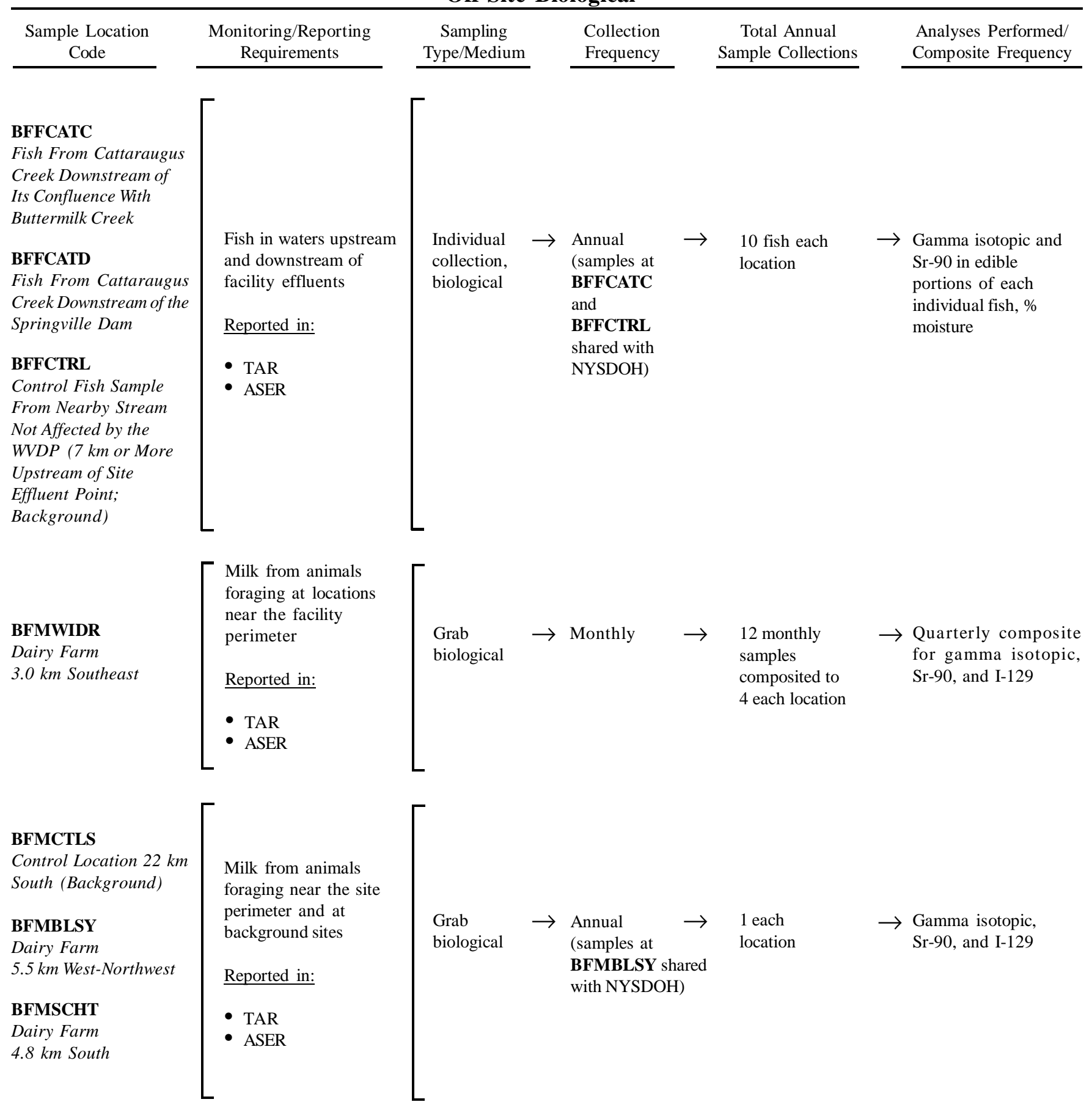

$B-47$ 


\title{
Sampling Rationale
}

\author{
BFFCATC DOE/EH-0173T, 5.11.1.1 \\ BFTCATD \\ Radioactivity may enter a food chain in which fish are a major component and are consumed by the local \\ population. \\ BFFCTRL Control fish sample; provides background data for comparison with data from fish caught downstream of facility \\ effluents. \\ BFMWIDR DOE/EH-0173T, 5.8.2.1 \\ BFMCTLS \\ BFMBLSY \\ BFMSCHT \\ Milk is consumed by all age groups and is frequently the most important food that could contribute to the \\ radiation dose. Dairy animals pastured near the site allow adequate monitoring. Control milk samples are collected \\ far from the site to provide background data for comparison with data from near-site milk samples.
}

Sampling locations are shown on Figures A-11, A-14, and A-15.

$B-48$ 


\section{Monitoring Program \\ Environmental Surveillance}

Off-Site Biological

\begin{tabular}{|c|c|c|c|c|c|c|c|c|}
\hline $\begin{array}{l}\text { Sample Location } \\
\text { Code }\end{array}$ & $\begin{array}{l}\text { Monitoring/Reporting } \\
\text { Requirements }\end{array}$ & $\begin{array}{c}\text { Sampling } \\
\text { Type/Medium }\end{array}$ & & $\begin{array}{l}\text { Collection } \\
\text { Frequency }\end{array}$ & & $\begin{array}{c}\text { Total Annual } \\
\text { Sample Collections }\end{array}$ & & $\begin{array}{l}\text { Analyses Performed/ } \\
\text { Composite Frequency }\end{array}$ \\
\hline $\begin{array}{l}\text { BFVNEAR }^{\boldsymbol{a}} \\
\text { Nearby Locations } \\
\text { BFVCTRL }^{\boldsymbol{a}} \\
\text { Remote Locations (16 } \\
\text { km or More From } \\
\text { Facility; Background) }\end{array}$ & $\begin{array}{l}\text { Fruit and vegetables } \\
\text { grown near facility } \\
\text { perimeter, downwind if } \\
\text { possible, and at back- } \\
\text { ground locations } \\
\text { Reported in: } \\
\text { - TAR } \\
\text { - ASER }\end{array}$ & $\begin{array}{l}\text { Grab } \\
\text { biological } \\
\text { (fruits and } \\
\text { vegetables) }\end{array}$ & $\rightarrow$ & $\begin{array}{l}\text { Annual } \\
\text { (at harvest) }\end{array}$ & $\rightarrow$ & $\begin{array}{l}3 \text { each (split with } \\
\text { NYSDOH) }\end{array}$ & $\rightarrow$ & $\begin{array}{l}\text { Gamma isotopic and } \\
\text { Sr-90 analysis of } \\
\text { edible portions, H-3 in } \\
\text { free moisture, } \% \\
\text { moisture }\end{array}$ \\
\hline $\begin{array}{l}\text { BFDNEAR } \\
\text { Deer in Vicinity of the } \\
\text { Site }\end{array}$ & $\begin{array}{l}\text { Venison (deer foraging } \\
\text { near facility perimeter } \\
\text { and at background } \\
\text { locations) }\end{array}$ & $\begin{array}{l}\text { Individual } \\
\text { collection, } \\
\text { biological }\end{array}$ & $\rightarrow$ & $\begin{array}{l}\text { Annual, during } \\
\text { hunting season } \\
\text { (BFDNEAR } \\
\text { sample split } \\
\text { with NYSDOH) }\end{array}$ & $\rightarrow$ & 3 & $\rightarrow$ & $\begin{array}{l}\text { Gamma isotopic and } \\
\text { Sr-90 analysis of } \\
\text { meat, H-3 in free } \\
\text { moisture, \% moisture }\end{array}$ \\
\hline $\begin{array}{l}\text { BFDCTRL } \\
\text { Control Deer } 16 \text { km or } \\
\text { More From the Facility } \\
\text { (Background) }\end{array}$ & $\begin{array}{l}\text { Reported in: } \\
\text { - TAR } \\
\text { - ASER }\end{array}$ & & & $\begin{array}{l}\text { During year as } \\
\text { available } \\
\text { (BFDCTRL } \\
\text { sample split } \\
\text { with NYSDOH) }\end{array}$ & $\rightarrow$ & 3 & $\rightarrow$ & $\begin{array}{l}\text { Gamma isotopic and } \\
\text { Sr-90 analysis of } \\
\text { meat, H-3 in free } \\
\text { moisture, \% moisture }\end{array}$ \\
\hline
\end{tabular}

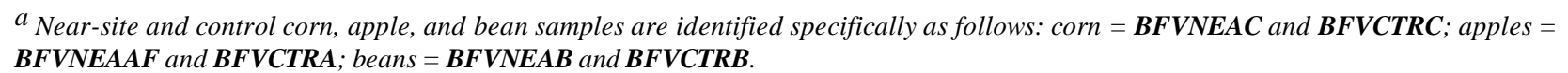

B -49 


\section{Sampling Rationale}

\section{BFVNEAR DOE/EH-0173T, 5.8.2.2}

Fruits and vegetables (corn, apples, and beans or leafy vegetables, if available) collected from areas near the site. These samples are collected, if possible, from areas near the site predicted to have worst-case downwind concentrations of radionuclides in air and soil. Sample analysis reflects steady state/chronic uptake or contamination of foodstuffs as a result of site activities. Possible pathway directly to humans or indirectly through animals.

BFVCTRL

DOE/EH-0173T, 5.8.2.2

Fruits and vegetables collected from an area remote from the site. Background fruits and vegetables collected for comparison with near-site samples. Collected in area(s) of no possible site effects.

BFDNEAR DOE/EH-0173T, 5.8.3

Venison from near-site deer. Samples are taken from deer killed in collisions with vehicles. Edible portion is analyzed to determine possible radionuclide content passable directly to humans.

BFDCTRL

DOE/EH-0173T, 5.8.3

Venison from deer living far from the site. Background deer meat collected for comparison with near-site samples. Collected in area(s) of no possible site effects.

Sampling locations are shown on Figures A-11, A-14, and A-15. 


\section{Monitoring Program \\ Environmental Surveillance}

\section{Off-Site Direct Radiation}

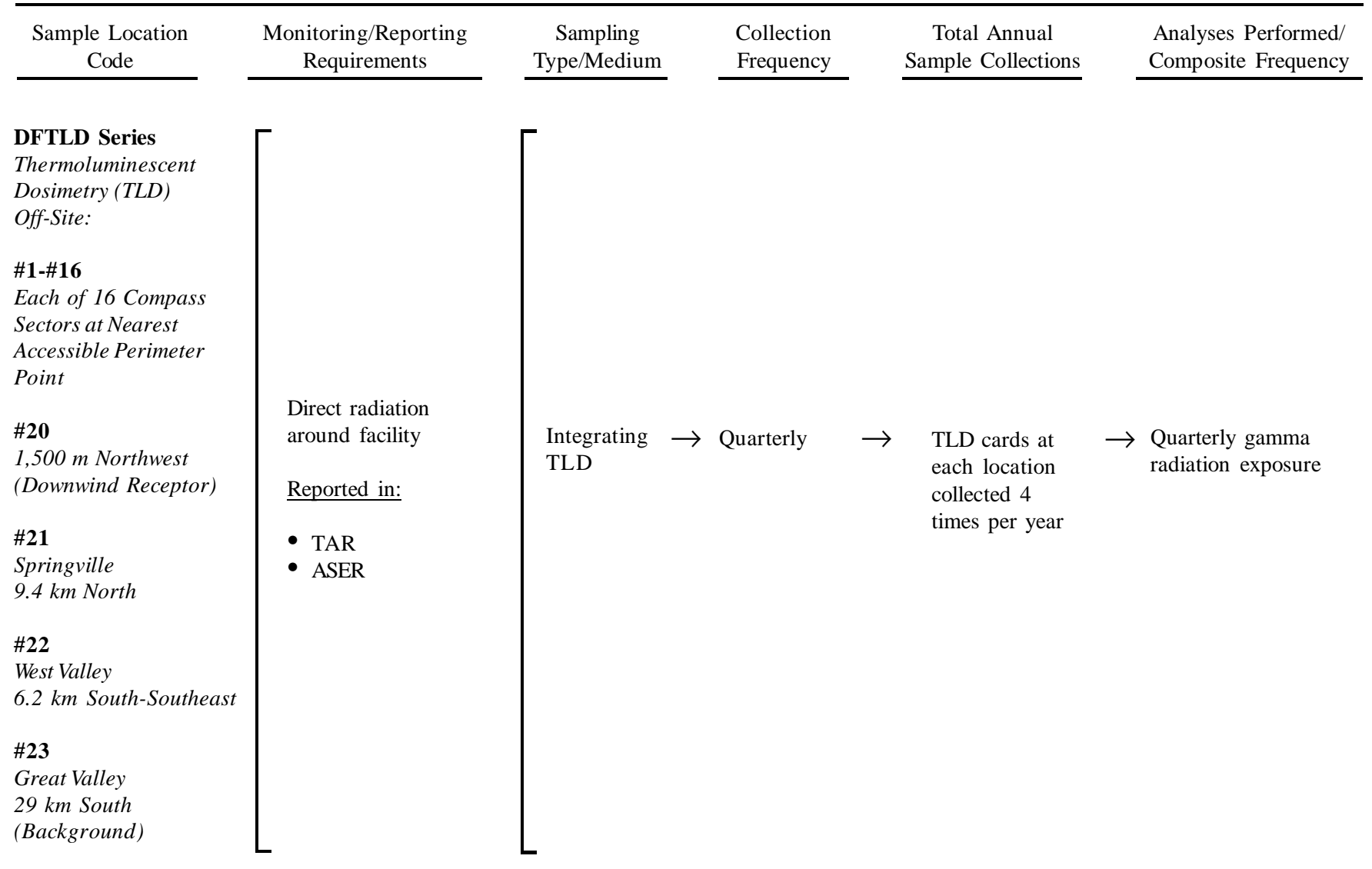

$B-51$ 


\section{Sampling Rationale}

Direct Radiation DOE/EH-0173T, 5.5; DOE/EP-0023, 4.6.3

Off-Site

TLDs offer continuous integrated environmental gamma-ray monitoring. Off-site TLDs are used to verify that site activities have not adversely affected the surrounding environs and that the potential dose rate to the general public (e.g., at Rock Springs Road) is less than 100 mrem/year $(1 \mathrm{mSv} / \mathrm{year})$ from site activities.

A high-pressure ion chamber (HPIC) gamma radiation measurement was completed at all locations in order to confirm that TLD measurements fall within the expected exposure range.

Sampling locations are shown on Figures A-13 through A-15.

$B-52$ 


\section{Monitoring Program}

Environmental Surveillance

On-Site Direct Radiation

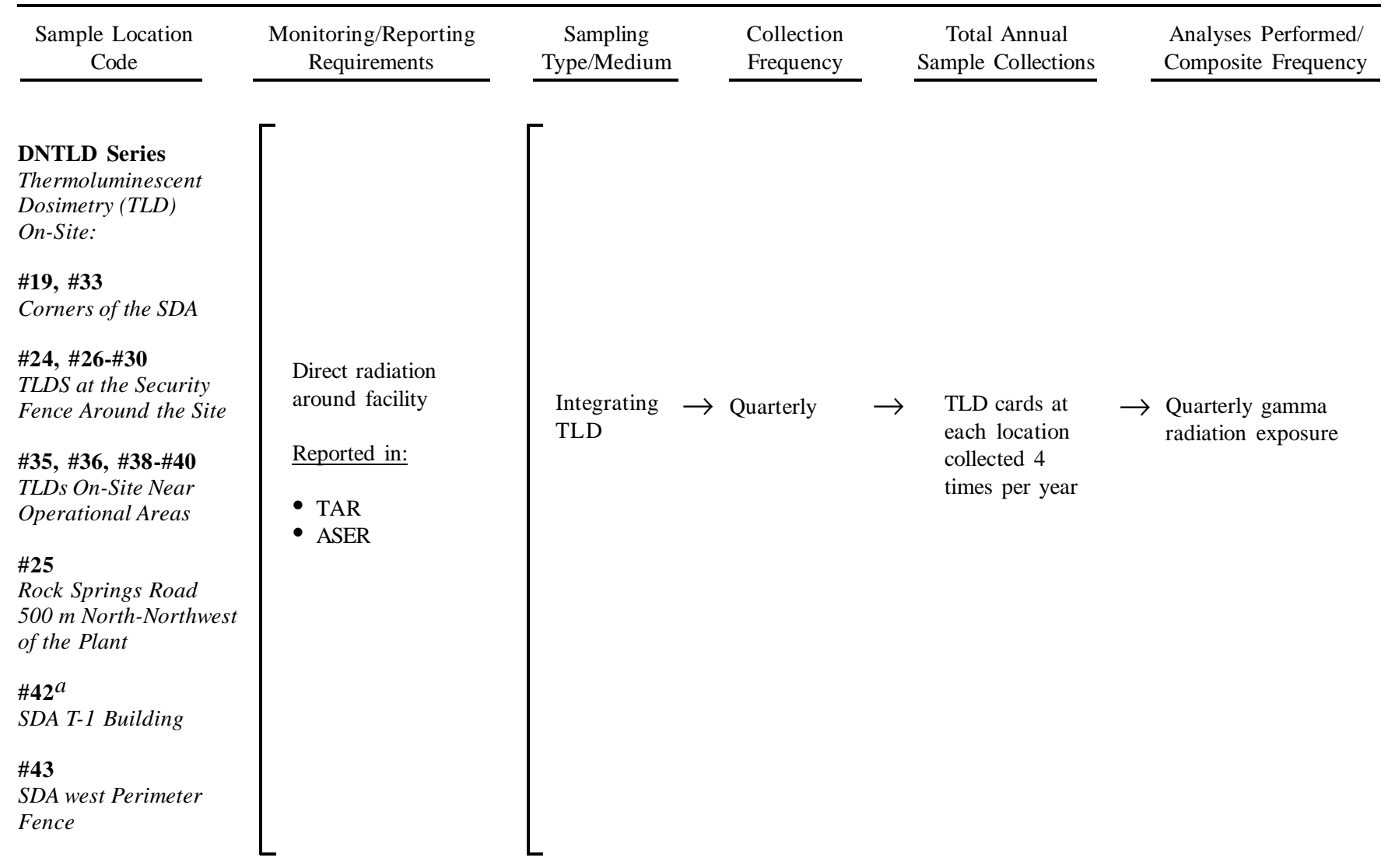

${ }^{a}$ The TLD at location DNTLD42 was discontinued at the end of 1st-quarter 2006.

$$
\text { B }-53
$$




\section{Sampling Rationale}

\section{Direct Radiation DOE/EH-0173T, 5.4 and 5.5 \\ On-Site}

TLDs offer continuous integrated environmental gamma-ray monitoring. TLDs have been deployed systematically about the site near process facilities, waste storage areas, and waste management units to monitor site activities.

A high-pressure ion chamber (HPIC) gamma radiation measurement was completed at all locations in order to confirm that TLD measurements fall within the expected exposure range.

Potential TLD sampling locations are continually evaluated with respect to site activities.

Sampling locations are shown on Figure A-12.

$$
B-54
$$


This page intentionally left blank

$$
\text { B - } 55
$$




\section{Appendix C-1 \\ Summary of Water Limits, Guidelines, and Standards}

$C-1$ 
This page intentionally left blank

$C-2$ 


\section{Table C-1A \\ West Valley Demonstration Project State Pollutant Discharge Elimination System (SPDES) Sampling Program}

Outfall

001 (Process and Storm Wastewater)

\section{Parameter}

Flow

Aluminum, total

Ammonia $\left(\mathrm{NH}_{3}\right)$

Arsenic, dissolved

$\mathrm{BOD}_{5}$

Iron, total

Zinc, total recoverable

Solids, total suspended

Cyanide, amenable to chlorination

Settleable solids

$\mathrm{pH}$ (range)

Oil and grease

Sulfate (as S)

Sulfide, dissolved

Manganese, total

Nitrate (as N)

Nitrite (as N)

Chromium, total recoverable

Chromium, hexavalent, total recoverable

Cadmium, total recoverable

Copper, total recoverable

Copper, dissolved

Lead, total recoverable

Nickel, total recoverable

Dichlorodifluoromethane

Trichlorofluoromethane

3,3-dichlorobenzidine

Tributyl phosphate

Vanadium, total recoverable

Cobalt, total recoverable

Selenium, total recoverable

Hexachlorobenzene

Alpha - BHC

Heptachlor

Surfactants (as LAS)

Xylene

2-butanone

Total dissolved solids

Mercury, total

\section{Daily Maximum Limit ${ }^{a}$}

Monitor

$14.0 \mathrm{mg} / \mathrm{L}$

Monitor

$0.15 \mathrm{mg} / \mathrm{L}$

$10.0 \mathrm{mg} / \mathrm{L}$

Monitor

$0.48 \mathrm{mg} / \mathrm{L}$

$45 \mathrm{mg} / \mathrm{L}$

$0.022 \mathrm{mg} / \mathrm{L}$

$0.3 \mathrm{~mL} / \mathrm{L}$

$6.5-8.5 \mathrm{SU}$

$15.0 \mathrm{mg} / \mathrm{L}$

Monitor

$0.4 \mathrm{mg} / \mathrm{L}$

$2.0 \mathrm{mg} / \mathrm{L}$

Monitor

$0.1 \mathrm{mg} / \mathrm{L}$

$0.3 \mathrm{mg} / \mathrm{L}$

$0.011 \mathrm{mg} / \mathrm{L}$

$0.002 \mathrm{mg} / \mathrm{L}$

$0.030 \mathrm{mg} / \mathrm{L}$

Monitor

$0.006 \mathrm{mg} / \mathrm{L}$

$0.14 \mathrm{mg} / \mathrm{L}$

$0.01 \mathrm{mg} / \mathrm{L}$

$0.01 \mathrm{mg} / \mathrm{L}$

$0.01 \mathrm{mg} / \mathrm{L}$

$32 \mathrm{mg} / \mathrm{L}$

$0.014 \mathrm{mg} / \mathrm{L}$

$0.005 \mathrm{mg} / \mathrm{L}$

$0.004 \mathrm{mg} / \mathrm{L}$

$0.02 \mathrm{mg} / \mathrm{L}$

$0.00001 \mathrm{mg} / \mathrm{L}$

$0.00001 \mathrm{mg} / \mathrm{L}$

$0.4 \mathrm{mg} / \mathrm{L}$

$0.05 \mathrm{mg} / \mathrm{L}$

$0.5 \mathrm{mg} / \mathrm{L}$

Monitor

200 ng/L
Sample Frequency

2/discharge

$1 /$ discharge

2/discharge

$1 /$ discharge

2/discharge

$2 /$ discharge

$2 /$ year

2/discharge

$2 /$ year

2/discharge

1/discharge

2/discharge

$2 /$ discharge

$1 /$ discharge

$2 /$ year

$2 /$ discharge

$2 /$ discharge

$2 /$ year

1/year

$1 /$ year

$2 /$ year

$2 /$ year

4/year

2/year

1/year

1/year

$1 /$ year

1/year

1/discharge

$1 /$ discharge

2/discharge

$1 /$ year

1/year

$2 /$ year

$2 /$ year

1/year

1/year

2/discharge

$2 /$ discharge

${ }^{a}$ Daily average limitations are also identified in the permit but require only monitoring for all parameters except total aluminum (daily average limit $-7.0 \mathrm{mg} / \mathrm{L}$ ); total suspended solids (daily average limit - $30 \mathrm{mg} / \mathrm{L}$ ); $B O D_{5}$ for the sum of outfalls 001, 007, and 008 (daily average limit $-5.0 \mathrm{mg} / \mathrm{L}$ ); and ammonia for the sum of outfalls 001 and 007 (daily average limit $-1.49 \mathrm{mg} / \mathrm{L}$ ).

$$
\text { C- } 3
$$




\section{Table C-1A (concluded) \\ West Valley Demonstration Project State Pollutant Discharge Elimination System (SPDES) Sampling Program}

\begin{tabular}{|c|c|}
\hline Outfall & Parameter \\
\hline 001 (concluded) & $\begin{array}{l}\text { Barium } \\
\text { Antimony } \\
\text { Chloroform } \\
\text { Titanium } \\
\text { Bromide } \\
\text { Boron }\end{array}$ \\
\hline $\begin{array}{l}\text { 01B (Internal Process } \\
\text { Monitoring Point) }\end{array}$ & $\begin{array}{l}\text { Flow } \\
\text { Mercury, total }\end{array}$ \\
\hline $\begin{array}{l}007 \text { (Sanitary and } \\
\text { Utility Wastewater) }\end{array}$ & $\begin{array}{l}\text { Flow } \\
\text { Ammonia }\left(\text { as } \mathrm{NH}_{3}\right) \\
\mathrm{BOD}_{5} \\
\text { Iron, total } \\
\text { Solids, total suspended } \\
\text { Solids, settleable } \\
\text { pH(range) } \\
\text { Nitrite (as N) } \\
\text { Oil and grease } \\
\text { Chlorine, total residual } \\
\text { Chloroform }\end{array}$ \\
\hline $\begin{array}{l}008 \text { (French Drain } \\
\text { Wastewater) }\end{array}$ & $\begin{array}{l}\text { Flow } \\
\text { BOD }_{5} \\
\text { Iron, total } \\
\text { pH (range) } \\
\text { Cadmium, total recoverable } \\
\text { Lead, total recoverable } \\
\text { Silver, total } \\
\text { Zinc, total } \\
\text { Arsenic } \\
\text { Chromium }\end{array}$ \\
\hline $\begin{array}{l}\text { Sum of Outfalls 001, } \\
007 \text {, and } 008\end{array}$ & $\begin{array}{l}\text { Iron, total } \\
\mathrm{BOD}_{5}\end{array}$ \\
\hline $\begin{array}{l}\text { Sum of Outfalls } 001 \\
\text { and } 007\end{array}$ & Ammonia (as $\mathrm{NH}_{3}$ ) \\
\hline $\begin{array}{l}\text { Pseudo-monitoring } \\
\text { point (116) }\end{array}$ & Solids, total dissolved \\
\hline
\end{tabular}

\section{Daily Maximum Limit ${ }^{a}$}

$0.5 \mathrm{mg} / \mathrm{L}$

$1.0 \mathrm{mg} / \mathrm{L}$

$0.3 \mathrm{mg} / \mathrm{L}$

$0.65 \mathrm{mg} / \mathrm{L}$

$5.0 \mathrm{mg} / \mathrm{L}$

$2.0 \mathrm{mg} / \mathrm{L}$

Monitor

$10.0 \mu \mathrm{g} / \mathrm{L}$

Monitor

Monitor

$10.0 \mathrm{mg} / \mathrm{L}$

Monitor

$45 \mathrm{mg} / \mathrm{L}$

$0.3 \mathrm{~mL} / \mathrm{L}$

6.5-8.5 SU

$0.1 \mathrm{mg} / \mathrm{L}$

$15.0 \mathrm{mg} / \mathrm{L}$

$0.1 \mathrm{mg} / \mathrm{L}$

$0.20 \mathrm{mg} / \mathrm{L}$

Monitor

$5.0 \mathrm{mg} / \mathrm{L}$

Monitor

6.5-8.5 SU

$0.002 \mathrm{mg} / \mathrm{L}$

$0.006 \mathrm{mg} / \mathrm{L}$

$0.008 \mathrm{mg} / \mathrm{L}$

$0.100 \mathrm{mg} / \mathrm{L}$

$0.17 \mathrm{mg} / \mathrm{L}$

$0.13 \mathrm{mg} / \mathrm{L}$

$0.30 \mathrm{mg} / \mathrm{L}$

Monitor

$2.1 \mathrm{mg} / \mathrm{L}$

$500 \mathrm{mg} / \mathrm{L}$
Sample Frequency

annual

annual

annual

semiannual

quarterly

quarterly

weekly

2/month

3/month

3/month

3/month

3/month

3/month

weekly

weekly

3/month

3/month

weekly

annual

3/month

3/month

3/month

3/month

3/month

3/month

annual

annual

annual

annual

3/month

3/month

3/month

2/discharge

${ }^{a}$ Daily average limitations are also identified in the permit but require only monitoring for all parameters except total aluminum (daily average limit - $7.0 \mathrm{mg} / \mathrm{L}$ ); total suspended solids (daily average limit - $30 \mathrm{mg} / \mathrm{L}$ ); $B O D_{5}$ for the sum of outfalls 001, 007, and 008 (daily average limit $-5.0 \mathrm{mg} / \mathrm{L}$ ); and ammonia for the sum of outfalls 001 and 007 (daily average limit $-1.49 \mathrm{mg} / \mathrm{L}$ ).

$$
\text { C- } 4
$$


Table C-1B

New York State Water Quality Standards and Guidelines ${ }^{a}$

\begin{tabular}{|c|c|c|c|c|c|c|}
\hline Parameter & Units & Class A & Class B & Class C & Class D & Class GA \\
\hline Gross Alpha $^{b}$ & $\mathrm{pCi} / \mathrm{L}(\mu \mathrm{Ci} / \mathrm{mL})$ & 15 (1.5E-08) & -- & -- & -- & $15(1.5 \mathrm{E}-08)$ \\
\hline Gross Beta $^{c}$ & $\mathrm{pCi} / \mathrm{L}(\mu \mathrm{Ci} / \mathrm{mL})$ & $1,000(1 \mathrm{E}-06)$ & -- & -- & -- & $1,000(1 \mathrm{E}-06)$ \\
\hline Tritium (H-3) & $\mathrm{pCi} / \mathrm{L}(\mu \mathrm{Ci} / \mathrm{mL})$ & $20,000(2 \mathrm{E}-05)$ & -- & -- & -- & -- \\
\hline Strontium-90 & $\mathrm{pCi} / \mathrm{L}(\mu \mathrm{Ci} / \mathrm{mL})$ & 8 (8E-09) & -- & -- & -- & -- \\
\hline Alpha BHC & $\mathrm{mg} / \mathrm{L}$ & 0.000002 & 0.000002 & 0.000002 & 0.000002 & 0.00001 \\
\hline Aluminum, Dissolved & $\mathrm{mg} / \mathrm{L}$ & 0.10 & 0.10 & 0.10 & -- & -- \\
\hline Aluminum, Total & $\mathrm{mg} / \mathrm{L}$ & -- & -- & -- & -- & -- \\
\hline Ammonia, Total as $\mathbf{N}$ & $\mathrm{mg} / \mathrm{L}$ & $0.09-2.1$ & $0.09-2.1$ & $0.09-2.1$ & $0.67-29$ & 2.0 \\
\hline Antimony, Total & $\mathrm{mg} / \mathrm{L}$ & 0.003 & -- & -- & -- & 0.003 \\
\hline Arsenic, Dissolved & $\mathrm{mg} / \mathrm{L}$ & 0.050 & 0.150 & 0.150 & 0.340 & -- \\
\hline Arsenic, Total & $\mathrm{mg} / \mathrm{L}$ & 0.050 & -- & -- & -- & 0.025 \\
\hline Barium, Total & $\mathrm{mg} / \mathrm{L}$ & 1.00 & -- & -- & -- & 1.00 \\
\hline Beryllium, Total & $\mathrm{mg} / \mathrm{L}$ & 0.003 & $d$ & $d$ & -- & 0.003 \\
\hline Boron, Total & $\mathrm{mg} / \mathrm{L}$ & 10.0 & 10.0 & 10.0 & -- & 1.00 \\
\hline Bromide & $\mathrm{mg} / \mathrm{L}$ & 2.00 & -- & -- & -- & 2.00 \\
\hline Cadmium, Dissolved $^{e}$ & $\mathrm{mg} / \mathrm{L}$ & -- & -- & -- & -- & -- \\
\hline Cadmium, Total & $\mathrm{mg} / \mathrm{L}$ & 0.005 & -- & -- & -- & 0.005 \\
\hline Calcium, Total & $\mathrm{mg} / \mathrm{L}$ & -- & -- & -- & -- & -- \\
\hline Chloride & $\mathrm{mg} / \mathrm{L}$ & 250 & -- & -- & -- & 250 \\
\hline Chromium, Dissolved $^{e}$ & $\mathrm{mg} / \mathrm{L}$ & -- & -- & -- & -- & -- \\
\hline Chromium, Total & $\mathrm{mg} / \mathrm{L}$ & 0.05 & -- & -- & -- & 0.05 \\
\hline Cobalt, Total ${ }^{f}$ & $\mathrm{mg} / \mathrm{L}$ & 0.005 & 0.005 & 0.005 & 0.110 & -- \\
\hline Conductivity & $\mu \mathrm{mhos} / \mathrm{cm} @ 25^{\circ} \mathrm{C}$ & -- & -- & -- & -- & -- \\
\hline Copper, Dissolved $^{e}$ & $\mathrm{mg} / \mathrm{L}$ & -- & -- & -- & -- & -- \\
\hline Copper, Total & $\mathrm{mg} / \mathrm{L}$ & 0.20 & -- & -- & -- & 0.20 \\
\hline Cyanide & $\mathrm{mg} / \mathrm{L}$ & 0.0052 & 0.0052 & 0.0052 & 0.22 & 0.200 \\
\hline Dissolved Oxygen (minimum) & $\mathrm{mg} / \mathrm{L}$ & 4.0 & 4.0 & 4.0 & 3.0 & -- \\
\hline Fluoride $^{e}$ & $\mathrm{mg} / \mathrm{L}$ & -- & -- & -- & -- & 1.5 \\
\hline Hardness & $\mathrm{mg} / \mathrm{L}$ & -- & -- & -- & -- & -- \\
\hline Iron and Manganese (sum) & $\mathrm{mg} / \mathrm{L}$ & -- & -- & -- & -- & 0.500 \\
\hline
\end{tabular}

-- No applicable guideline or reference standard available

Note: All water quality and metals standards are presented in $\mathrm{mg} / \mathrm{L}$ (ppm) to provide consistency in comparisons.

a Source: 6 NYCRR Parts 701-704; The most stringent applicable pathway (e.g., wildlife, aquatic, human health)

values are reported.

${ }^{b}$ Gross alpha standard includes radium-226, but excludes radon and uranium; however WVDP results include

these isotopes.

${ }^{c}$ Gross beta standard excludes strontium-90 and alpha emitters, however WVDP results include these isotopes.

${ }^{d}$ Beryllium standard for classes " $B$ " and " $C$ " are based on stream hardness values.

${ }^{e}$ Standards for these constituents vary according to stream location hardness values.

${ }^{f}$ Standards for cobalt, thallium, and vanadium are applicable to the acid-soluble fraction.

${ }^{g}$ Applies to the sum of those organic substances which have individual human health water source standards listed at $0.100 \mathrm{mg} / \mathrm{L}$ or less in 6 NYCRR Part 703.5

${ }^{h} \mathrm{pH}$ shall not be lower than 6.5 or the $\mathrm{pH}$ of natural groundwater, whichever is lower, nor shall pH be greater than 8.5 or the $\mathrm{pH}$ of the natural groundwater, whichever is greater.

$C-5$ 


\section{Table C-1B (concluded)}

\section{New York State Water Quality Standards and Guidelines ${ }^{a}$}

\begin{tabular}{|c|c|c|c|c|c|c|}
\hline Parameter & Units & Class A & Class B & Class C & Class D & Class GA \\
\hline Iron, Total & $\mathrm{mg} / \mathrm{L}$ & 0.30 & 0.30 & 0.30 & 0.30 & 0.30 \\
\hline Lead, Dissolved $^{e}$ & $\mathrm{mg} / \mathrm{L}$ & -- & -- & -- & -- & -- \\
\hline Lead, Total & $\mathrm{mg} / \mathrm{L}$ & 0.050 & -- & -- & -- & 0.025 \\
\hline Magnesium, Total & $\mathrm{mg} / \mathrm{L}$ & 35.0 & -- & -- & -- & 35.0 \\
\hline Manganese, Total & $\mathrm{mg} / \mathrm{L}$ & 0.30 & -- & -- & -- & 0.30 \\
\hline Mercury, Dissolved & $\mathrm{mg} / \mathrm{L}$ & 0.0000007 & 0.0000007 & 0.0000007 & 0.0000007 & -- \\
\hline Mercury, Total & $\mathrm{mg} / \mathrm{L}$ & 0.0007 & -- & -- & -- & 0.0007 \\
\hline Nickel, Dissolved $^{e}$ & $\mathrm{mg} / \mathrm{L}$ & -- & -- & -- & -- & -- \\
\hline Nickel, Total & $\mathrm{mg} / \mathrm{L}$ & 0.10 & -- & -- & -- & 0.10 \\
\hline Nitrate-N & $\mathrm{mg} / \mathrm{L}$ & 10.0 & -- & -- & -- & 10.0 \\
\hline Nitrate + Nitrite & $\mathrm{mg} / \mathrm{L}$ & 10.0 & 10.0 & 10.0 & 10.0 & 10.0 \\
\hline Nitrite-N & $\mathrm{mg} / \mathrm{L}$ & 0.10 & 0.10 & 0.10 & -- & 1.00 \\
\hline NPOC $^{g}$ & $\mathrm{mg} / \mathrm{L}$ & 0.10 & -- & -- & -- & -- \\
\hline Oil \& Grease & $\mathrm{mg} / \mathrm{L}$ & -- & -- & -- & -- & -- \\
\hline pH & SU & $6.5-8.5^{h}$ & $6.5-8.5^{h}$ & $6.5-8.5^{h}$ & $6.0-9.5$ & $6.5-8.5^{h}$ \\
\hline Potassium, Total & $\mathrm{mg} / \mathrm{L}$ & -- & -- & -- & -- & -- \\
\hline Selenium, Dissolved & $\mathrm{mg} / \mathrm{L}$ & 0.0046 & 0.0046 & 0.0046 & -- & -- \\
\hline Selenium, Total & $\mathrm{mg} / \mathrm{L}$ & 0.01 & -- & -- & -- & 0.01 \\
\hline Silver, Total & $\mathrm{mg} / \mathrm{L}$ & 0.05 & -- & -- & -- & 0.05 \\
\hline Sodium, Total & $\mathrm{mg} / \mathrm{L}$ & -- & -- & -- & -- & 20.0 \\
\hline Solids, Settleable & $\mathrm{mg} / \mathrm{L}$ & -- & -- & -- & -- & -- \\
\hline Solids, Total Dissolved & $\mathrm{mg} / \mathrm{L}$ & 500 & 500 & 500 & -- & 500 \\
\hline Solids, Total Suspended & $\mathrm{mg} / \mathrm{L}$ & -- & -- & -- & -- & -- \\
\hline Sulfate & $\mathrm{mg} / \mathrm{L}$ & 250 & -- & -- & -- & 250 \\
\hline Sulfide (undissociated form) & $\mathrm{mg} / \mathrm{L}$ & 0.002 & 0.002 & 0.002 & -- & 0.050 (as HS) \\
\hline Surfactants (as LAS) & $\mathrm{mg} / \mathrm{L}$ & 0.04 & 0.04 & 0.04 & -- & -- \\
\hline Thallium, Total ${ }^{f}$ & $\mathrm{mg} / \mathrm{L}$ & 0.0005 & 0.008 & 0.008 & 0.020 & 0.0005 \\
\hline Titanium, Total & $\mathrm{mg} / \mathrm{L}$ & -- & -- & -- & -- & -- \\
\hline TOX (total organic halides) ${ }^{g}$ & $\mathrm{mg} / \mathrm{L}$ & 0.10 & -- & -- & -- & -- \\
\hline Vanadium, Totaf & $\mathrm{mg} / \mathrm{L}$ & 0.014 & 0.014 & 0.014 & 0.190 & -- \\
\hline Zinc, Dissolved $^{e}$ & $\mathrm{mg} / \mathrm{L}$ & -- & -- & -- & -- & -- \\
\hline Zinc, Total & $\mathrm{mg} / \mathrm{L}$ & 2.00 & -- & -- & -- & 2.00 \\
\hline
\end{tabular}

-- No applicable guideline or reference standard available

Note: All water quality and metals standards are presented in $\mathrm{mg} / \mathrm{L}(\mathrm{ppm})$ to provide consistency in comparisons. $H S$ - Hydrogen sulfide

${ }^{a}$ Source: 6 NYCRR Parts 701-704; The most stringent applicable pathway (e.g., wildlife, aquatic, human health) values are reported.

${ }^{b}$ Gross alpha standard includes radium-226, but excludes radon and uranium; however WVDP results include these isotopes.

${ }^{c}$ Gross beta standard excludes strontium-90 and alpha emitters, however WVDP results include these isotopes.

"Beryllium standard for classes " $B$ " and " $C$ " are based on stream hardness.

"Standards for these constituents vary according to stream location hardness values.

${ }^{f}$ Standards for cobalt, thallium, and vanadium are applicable to the acid-soluble fraction.

${ }^{g}$ Applies to the sum of those organic substances which have individual human health water source standards listed at $0.100 \mathrm{mg} / \mathrm{L}$ or less in 6 NYCRR Part 703.5

${ }^{h} \mathrm{pH}$ shall not be lower than 6.5 or the $\mathrm{pH}$ of natural groundwater, whichever is lower, nor shall $\mathrm{pH}$ be greater than 8.5 or the $\mathrm{pH}$ of the natural groundwater, whichever is greater.

$$
C-6
$$


Table C-1C

New York State Department of Health/U.S. Environmental Protection Agency Potable Water MCLs, MCLGs, and Raw Water Standards

\begin{tabular}{|c|c|c|c|c|}
\hline Parameter & Units & $\begin{array}{l}\text { NYSDOH or } \\
\text { EPA MCL }^{a}\end{array}$ & $\operatorname{EPA~MCLG}^{b}$ & $\begin{array}{c}\text { NYSDOH Raw } \\
\text { Water Standards }^{c}\end{array}$ \\
\hline Gross Alpha & $\mathrm{pCi} / \mathrm{L}(\mu \mathrm{Ci} / \mathrm{mL})$ & $15(1.5 \mathrm{E}-08)^{d}$ & 0 & -- \\
\hline Gross Beta & $\mathrm{pCi} / \mathrm{L}(\mu \mathrm{Ci} / \mathrm{mL})$ & $50(5 \mathrm{E}-08)^{e}$ & 0 & $1,000(1 \mathrm{E}-06)$ \\
\hline Tritium (H-3) & $\mathrm{pCi} / \mathrm{L}(\mu \mathrm{Ci} / \mathrm{mL})$ & $20,000(2 \mathrm{E}-05)$ & -- & -- \\
\hline Strontium-90 & $\mathrm{pCi} / \mathrm{L}(\mu \mathrm{Ci} / \mathrm{mL})$ & $8(8 E-09)$ & -- & $10(1 \mathrm{E}-08)$ \\
\hline Antimony, Total & $\mathrm{mg} / \mathrm{L}$ & 0.006 & 0.006 & -- \\
\hline Arsenic, Total & $\mathrm{mg} / \mathrm{L}$ & 0.05 & -- & 0.05 \\
\hline Barium, Total & $\mathrm{mg} / \mathrm{L}$ & 2.00 & 2.00 & 1.0 \\
\hline Beryllium, Total & $\mathrm{mg} / \mathrm{L}$ & 0.004 & 0.004 & -- \\
\hline Cadmium, Total & $\mathrm{mg} / \mathrm{L}$ & 0.005 & 0.005 & 0.01 \\
\hline Chromium, Total & $\mathrm{mg} / \mathrm{L}$ & 0.10 & 0.10 & -- \\
\hline Conductivity & $\mu \mathrm{mhos} / \mathrm{cm} @ 25^{\circ} \mathrm{C}$ & -- & -- & -- \\
\hline Copper, Total & $\mathrm{mg} / \mathrm{L}$ & 1.3 & 1.3 & $<0.2$ \\
\hline Cyanide & $\mathrm{mg} / \mathrm{L}$ & 0.2 & 0.2 & $<0.1$ \\
\hline E. Coli & NA & one positive sample & 0 & -- \\
\hline Fluoride & $\mathrm{mg} / \mathrm{L}$ & 2.2 & -- & $<1.5$ \\
\hline Free Residual Chlorine & $\mathrm{mg} / \mathrm{L}$ & $0.02(\min ) \quad 4.0(\max )$ & -- & -- \\
\hline Haloacetic Acids-Five (5) & $\mathrm{mg} / \mathrm{L}$ & 0.060 & -- & -- \\
\hline Iron, Total & $\mathrm{mg} / \mathrm{L}$ & 0.3 & -- & -- \\
\hline Lead, Total & $\mathrm{mg} / \mathrm{L}$ & 0.015 & 0 & 0.05 \\
\hline Mercury, Total & $\mathrm{mg} / \mathrm{L}$ & 0.002 & 0.002 & 0.005 \\
\hline Nickel, Total & $\mathrm{mg} / \mathrm{L}$ & -- & -- & -- \\
\hline Nitrate-N & $\mathrm{mg} / \mathrm{L}$ & 10 & 10 & -- \\
\hline pH & SU & -- & -- & $6.5-8.5$ \\
\hline POC (Principle Organic Contaminant) & $\mathrm{mg} / \mathrm{L}$ & -- & 0.0005 & -- \\
\hline Selenium, Total & $\mathrm{mg} / \mathrm{L}$ & 0.05 & 0.05 & 0.01 \\
\hline Solids, Total Dissolved & $\mathrm{mg} / \mathrm{L}$ & -- & -- & 500 \\
\hline Thallium, Total & $\mathrm{mg} / \mathrm{L}$ & 0.002 & 0.0005 & -- \\
\hline Total Coliform & NA & 2 or more positive samples & 0 & -- \\
\hline Total Trihalomethanes & $\mathrm{mg} / \mathrm{L}$ & 0.080 & -- & -- \\
\hline Turbidity & NTU & $1(\max )$ & -- & -- \\
\hline
\end{tabular}

-- No applicable guideline or reference standard available

Note: All water quality and metals standards are presented in $\mathrm{mg} / \mathrm{L}$ (ppm) to provide consistency in comparisons. NA - Not applicable

${ }^{a}$ MCL - Listed is NYSDOH or EPA Maximum Contaminant Level. Sources: 40 CFR 141 and/or 5 NYCRR 5-1.52, whichever is more stringent.

${ }^{b}$ MCLG - Maximum Contaminant Level Goal (non-enforceable) as listed in 40 CFR Part 141

c Source: 10 NYCRR Part 170.4

${ }^{d}$ Alpha guideline includes radium-226, but excludes uranium; however, WVDP results include these isotopes.

${ }^{e}$ Average annual concentration assumed to produce a total body organ dose of $4 \mathrm{mrem} /$ year

$C-7$ 
Table C-1D

\section{U.S. Department of Energy Derived Concentration Guides (DCGs) ${ }^{a}$ in Ingested Water}

\begin{tabular}{|c|c|c|}
\hline Radionuclide & Units & Concentration in Ingested Water \\
\hline Gross Alpha (as Am-241) $^{b}$ & $\mu \mathrm{Ci} / \mathrm{mL}$ & $3 \mathrm{E}-08$ \\
\hline Gross Beta (as Sr-90) ${ }^{b}$ & $\mu \mathrm{Ci} / \mathrm{mL}$ & $1 \mathrm{E}-06$ \\
\hline Tritium (H-3) & $\mu \mathrm{Ci} / \mathrm{mL}$ & $2 \mathrm{E}-03$ \\
\hline Carbon-14 (C-14) & $\mu \mathrm{Ci} / \mathrm{mL}$ & 7E-05 \\
\hline Potassium-40 (K-40) & $\mu \mathrm{Ci} / \mathrm{mL}$ & 7E-06 \\
\hline Cobalt-60 (Co-60) & $\mu \mathrm{Ci} / \mathrm{mL}$ & $5 \mathrm{E}-06$ \\
\hline Strontium-90 (Sr-90) & $\mu \mathrm{Ci} / \mathrm{mL}$ & $1 \mathrm{E}-06$ \\
\hline Technetium-99 (Tc-99) & $\mu \mathrm{Ci} / \mathrm{mL}$ & $1 \mathrm{E}-04$ \\
\hline Iodine-129 (I-129) & $\mu \mathrm{Ci} / \mathrm{mL}$ & $5 \mathrm{E}-07$ \\
\hline Cesium-137 (Cs-137) & $\mu \mathrm{Ci} / \mathrm{mL}$ & 3E-06 \\
\hline Europium-154 (Eu-154) & $\mu \mathrm{Ci} / \mathrm{mL}$ & $2 \mathrm{E}-05$ \\
\hline Uranium-232 (U-232) & $\mu \mathrm{Ci} / \mathrm{mL}$ & $1 \mathrm{E}-07$ \\
\hline Uranium-233 (U-233) & $\mu \mathrm{Ci} / \mathrm{mL}$ & $5 \mathrm{E}-07$ \\
\hline Uranium-234 (U-234) & $\mu \mathrm{Ci} / \mathrm{mL}$ & $5 \mathrm{E}-07$ \\
\hline Uranium-235 (U-235) & $\mu \mathrm{Ci} / \mathrm{mL}$ & $6 \mathrm{E}-07$ \\
\hline Uranium-236 (U-236) & $\mu \mathrm{Ci} / \mathrm{mL}$ & $5 \mathrm{E}-07$ \\
\hline Uranium-238 (U-238) & $\mu \mathrm{Ci} / \mathrm{mL}$ & $6 \mathrm{E}-07$ \\
\hline Plutonium-238 (Pu-238) & $\mu \mathrm{Ci} / \mathrm{mL}$ & 4E-08 \\
\hline Plutonium-239 (Pu-239) & $\mu \mathrm{Ci} / \mathrm{mL}$ & $3 \mathrm{E}-08$ \\
\hline Plutonium-240 (Pu-240) & $\mu \mathrm{Ci} / \mathrm{mL}$ & 3E-08 \\
\hline Americium-241 (Am-241) & $\mu \mathrm{Ci} / \mathrm{mL}$ & 3E-08 \\
\hline
\end{tabular}

${ }^{a}$ DCGs are established in DOE Order 5400.5 and are defined as the concentration of a radionuclide that, under conditions of continuous exposure for one year by one exposure mode, would result in an effective dose equivalent of $100 \mathrm{mrem}(1 \mathrm{mSv})$.

${ }^{b}$ Because there are no DCGs for gross alpha and gross beta concentrations, the DCGs for the most restrictive alpha and beta emitters at the WVDP, americium-241 and strontium-90 (3E-08 and $1 \mathrm{E}-06 \mu \mathrm{Ci} / \mathrm{mL}$, respectively) are used as a conservative basis for comparison at locations for which there are no radionuclide-specific data, in which case a more appropriate DCG may be applied. 


\section{Appendix C-2 Process Effluent Data}

C -9 
Table C-2A contains a bolding convention devised to help the reader, when viewing the data, to quickly see the range of detectable measurements within a data series. A data series is a set of chemical or radionuclide measurements (e.g., gross alpha, gross beta, tritium) from a single location or from similar locations. Note that some tables contain data that should not be technically evaluated under this convention.

\section{Key to bolding convention:}

Results for each constituent constitute a single data series. If a radiological result is larger than the uncertainty term, the measurement is considered positive. Otherwise, a result is considered nondetectable. Chemical results preceded by "less than" (<) are considered nondetectable.

If all results in a data series are positive, the lowest and highest values are bolded. If a data series contains some positive results, the highest value is bolded. If all values in a data series are nondetectable, no values are bolded. 


\section{Table C-2A}

\section{Total Radioactivity (curies) of Liquid Effluents Released From Lagoon 3}

(WNSP001) in 2006

\begin{tabular}{|c|c|c|c|c|c|}
\hline Isotope & 1st Quarter & 2nd Quarter & 3rd Quarter & 4th Quarter & Annual Total \\
\hline Gross Alpha & $1.59 \pm 0.25 \mathrm{E}-04$ & $1.76 \pm 0.22 \mathrm{E}-04$ & $5.25 \pm 1.27 \mathrm{E}-05$ & $1.93 \pm 0.31 \mathrm{E}-04$ & $5.81 \pm 0.48 \mathrm{E}-04$ \\
\hline Gross Beta & $4.24 \pm 0.08 \mathrm{E}-03$ & $3.36 \pm 0.06 \mathrm{E}-03$ & $1.03 \pm 0.03 E-03$ & $3.40 \pm 0.07 \mathrm{E}-03$ & $1.20 \pm 0.01 \mathrm{E}-02$ \\
\hline H-3 & $1.03 \pm 0.13 \mathrm{E}-02$ & $1.41 \pm 0.11 \mathrm{E}-02$ & $7.67 \pm 0.91 E-03$ & $1.80 \pm 0.15 \mathrm{E}-02$ & $5.00 \pm 0.24 \mathrm{E}-02$ \\
\hline C-14 & $1.27 \pm 1.65 \mathrm{E}-04$ & $0.56 \pm 2.66 \mathrm{E}-04$ & $1.19 \pm 1.58 \mathrm{E}-04$ & $1.60 \pm 3.21 \mathrm{E}-04$ & $4.61 \pm 4.76 \mathrm{E}-04$ \\
\hline K-40 & $1.52 \pm 4.42 \mathrm{E}-04$ & $2.31 \pm 2.43 \mathrm{E}-04$ & $1.67 \pm 1.66 \mathrm{E}-04$ & $2.88 \pm 5.65 \mathrm{E}-04$ & $8.38 \pm 7.76 \mathrm{E}-04$ \\
\hline Co-60 & $0.32 \pm 2.91 \mathrm{E}-05$ & $-0.77 \pm 1.95 \mathrm{E}-05$ & $0.14 \pm 1.40 \mathrm{E}-05$ & $-0.64 \pm 2.24 \mathrm{E}-05$ & $-0.94 \pm 4.39 \mathrm{E}-05$ \\
\hline Sr-90 & $1.35 \pm 0.04 \mathrm{E}-03$ & $9.67 \pm 0.37 \mathrm{E}-04$ & $4.11 \pm 0.21 \mathrm{E}-04$ & $1.54 \pm 0.06 \mathrm{E}-03$ & $4.29 \pm 0.08 \mathrm{E}-03$ \\
\hline Tc-99 & $1.81 \pm 0.19 \mathrm{E}-04$ & $1.68 \pm 0.41 \mathrm{E}-04$ & $5.87 \pm 1.27 \mathrm{E}-05$ & $1.69 \pm 0.23 \mathrm{E}-04$ & $5.77 \pm 0.52 \mathrm{E}-04$ \\
\hline I-129 & $9.36 \pm 8.31 \mathrm{E}-06$ & $1.20 \pm 0.70 \mathrm{E}-05$ & $0.00 \pm 3.70 \mathrm{E}-06$ & $3.40 \pm 1.10 \mathrm{E}-05$ & $5.54 \pm 1.59 \mathrm{E}-05$ \\
\hline Cs-137 & $8.01 \pm 1.15 \mathrm{E}-04$ & $9.43 \pm 0.79 \mathrm{E}-04$ & $1.40 \pm 0.29 \mathrm{E}-04$ & $5.74 \pm 0.53 \mathrm{E}-04$ & $2.46 \pm 0.15 \mathrm{E}-03$ \\
\hline U-232 & $5.88 \pm 0.52 \mathrm{E}-05$ & $9.03 \pm 0.42 E-05$ & $2.18 \pm 0.25 E-05$ & $5.00 \pm 0.37 \mathrm{E}-05$ & $2.21 \pm 0.08 \mathrm{E}-04$ \\
\hline U-233/234 & $3.14 \pm 0.37 \mathrm{E}-05$ & $5.67 \pm 0.34 \mathrm{E}-05$ & $1.36 \pm 0.22 \mathrm{E}-05$ & $3.10 \pm 0.31 \mathrm{E}-05$ & $1.34 \pm 0.06 \mathrm{E}-04$ \\
\hline U-235/236 & $3.60 \pm 1.27 \mathrm{E}-06$ & $4.79 \pm 0.99 \mathrm{E}-06$ & $3.41 \pm 4.45 \mathrm{E}-07$ & $1.77 \pm 0.79 \mathrm{E}-06$ & $1.05 \pm 0.18 \mathrm{E}-05$ \\
\hline U-238 & $3.33 \pm 0.38 \mathrm{E}-05$ & $5.42 \pm 0.33 \mathrm{E}-05$ & $9.63 \pm 1.83 \mathrm{E}-06$ & $2.73 \pm 0.28 \mathrm{E}-05$ & $1.24 \pm 0.06 \mathrm{E}-04$ \\
\hline Total U (g) & $1.05 \pm 0.02 \mathrm{E}+02$ & $1.59 \pm 0.03 \mathrm{E}+02$ & $3.36 \pm 0.07 \mathrm{E}+01$ & $8.85 \pm 0.14 \mathrm{E}+01$ & $3.86 \pm 0.04 \mathrm{E}+02$ \\
\hline Pu-238 & $5.29 \pm 3.56 \mathrm{E}-07$ & $6.87 \pm 3.57 \mathrm{E}-07$ & $1.34 \pm 2.17 \mathrm{E}-07$ & $6.47 \pm 5.22 \mathrm{E}-07$ & $2.00 \pm 0.76 \mathrm{E}-06$ \\
\hline Pu-239/240 & $4.41 \pm 3.62 \mathrm{E}-07$ & $5.72 \pm 3.24 \mathrm{E}-07$ & $-0.35 \pm 1.27 \mathrm{E}-07$ & $6.79 \pm 4.89 \mathrm{E}-07$ & $1.66 \pm 0.70 \mathrm{E}-06$ \\
\hline Am-241 & $7.49 \pm 4.68 \mathrm{E}-07$ & $7.53 \pm 3.80 \mathrm{E}-07$ & $1.68 \pm 2.21 \mathrm{E}-07$ & $2.18 \pm 3.64 \mathrm{E}-07$ & $1.89 \pm 0.74 \mathrm{E}-06$ \\
\hline
\end{tabular}

Note: Bolding convention applied to these data. See page C-10. 
Table C-2B

\section{Comparison of 2006 Lagoon 3 (WNSP001) Liquid Effluent Radioactivity Concentrations With U.S. Department of Energy Guidelines}

\begin{tabular}{|c|c|c|c|c|c|}
\hline Isotope $^{a}$ & $\begin{array}{c}\text { Discharge Activity }^{b} \\
\text { (Ci) }\end{array}$ & $\begin{array}{r}\text { Radioactivity }^{c} \\
\text { (Becquerels) }\end{array}$ & $\begin{array}{c}\text { Average } \\
\text { Concentration } \\
(\mu \mathrm{Ci} / \mathrm{mL})\end{array}$ & $\begin{array}{c}\text { DCG } \\
(\mu \mathrm{Ci} / \mathrm{mL})\end{array}$ & \% of DCG \\
\hline Gross Alpha & $5.81 \pm 0.48 \mathrm{E}-04$ & $2.15 \pm 0.18 \mathrm{E}+07$ & $1.48 \pm 0.12 \mathrm{E}-08$ & $\mathrm{NA}^{d}$ & NA \\
\hline Gross Beta & $1.20 \pm 0.01 \mathrm{E}-02$ & $4.45 \pm 0.05 E+08$ & $3.06 \pm 0.03 \mathrm{E}-07$ & $\mathrm{NA}^{d}$ & NA \\
\hline H-3 & $5.00 \pm 0.24 \mathrm{E}-02$ & $1.85 \pm 0.09 \mathrm{E}+09$ & $1.27 \pm 0.06 \mathrm{E}-06$ & 2E-03 & 0.064 \\
\hline C-14 & $4.61 \pm 4.76 \mathrm{E}-04$ & $1.71 \pm 1.76 \mathrm{E}+07$ & $1.17 \pm 1.21 \mathrm{E}-08$ & 7E-05 & $<0.02$ \\
\hline K-40 & $8.38 \pm 7.76 \mathrm{E}-04$ & $3.10 \pm 2.87 \mathrm{E}+07$ & $2.13 \pm 1.97 \mathrm{E}-08$ & $\mathrm{NA}^{e}$ & NA \\
\hline Co-60 & $-0.94 \pm 4.39 \mathrm{E}-05$ & $-0.35 \pm 1.62 \mathrm{E}+06$ & $-0.24 \pm 1.12 \mathrm{E}-09$ & $5 \mathrm{E}-06$ & $<0.02$ \\
\hline Sr-90 & $4.29 \pm 0.08 \mathrm{E}-03$ & $1.59 \pm 0.03 \mathrm{E}+08$ & $1.09 \pm 0.02 \mathrm{E}-07$ & $1 \mathrm{E}-06$ & 10.9 \\
\hline Tc-99 & $5.77 \pm 0.52 \mathrm{E}-04$ & $2.13 \pm 0.19 \mathrm{E}+07$ & $1.47 \pm 0.13 \mathrm{E}-08$ & 1E-04 & 0.01 \\
\hline I-129 & $5.54 \pm 1.59 \mathrm{E}-05$ & $2.05 \pm 0.59 \mathrm{E}+06$ & $1.41 \pm 0.40 \mathrm{E}-09$ & $5 \mathrm{E}-07$ & 0.28 \\
\hline Cs-137 & $2.46 \pm 0.15 \mathrm{E}-03$ & $9.09 \pm 0.56 \mathrm{E}+07$ & $6.25 \pm 0.39 \mathrm{E}-08$ & $3 \mathrm{E}-06$ & 2.08 \\
\hline $\mathrm{U}-232^{f}$ & $2.21 \pm 0.08 \mathrm{E}-04$ & $8.18 \pm 0.30 \mathrm{E}+06$ & $5.62 \pm 0.20 \mathrm{E}-09$ & 1E-07 & 5.62 \\
\hline $\mathrm{U}-\mathbf{2 3 3} / 234^{f}$ & $1.34 \pm 0.06 \mathrm{E}-04$ & $4.94 \pm 0.23 \mathrm{E}+06$ & $3.40 \pm 0.16 \mathrm{E}-09$ & $5 \mathrm{E}-07$ & 0.68 \\
\hline $\mathrm{U}-235 / 236^{f}$ & $1.05 \pm 0.18 \mathrm{E}-05$ & $3.89 \pm 0.68 \mathrm{E}+05$ & $2.67 \pm 0.47 \mathrm{E}-10$ & $5 \mathrm{E}-07^{g}$ & 0.05 \\
\hline $\mathbf{U}-238 f$ & $1.24 \pm 0.06 \mathrm{E}-04$ & $4.61 \pm 0.22 \mathrm{E}+06$ & $3.16 \pm 0.15 \mathrm{E}-09$ & $6 \mathrm{E}-07$ & 0.53 \\
\hline Pu-238 & $2.00 \pm 0.76 \mathrm{E}-06$ & $7.39 \pm 2.80 \mathrm{E}+04$ & $5.08 \pm 1.92 \mathrm{E}-11$ & $4 \mathrm{E}-08$ & 0.13 \\
\hline Pu-239/240 & $1.66 \pm 0.70 \mathrm{E}-06$ & $6.13 \pm 2.59 \mathrm{E}+04$ & $4.21 \pm 1.78 \mathrm{E}-11$ & 3E-08 & 0.14 \\
\hline Am-241 & $1.89 \pm 0.74 \mathrm{E}-06$ & $6.98 \pm 2.73 \mathrm{E}+04$ & $4.80 \pm 1.88 \mathrm{E}-11$ & 3E-08 & 0.16 \\
\hline \multicolumn{5}{|c|}{ Total \% of DCGs } & 20.7 \\
\hline
\end{tabular}

NA - Not applicable

${ }^{a}$ Half-lives are listed in Table UI-1.

${ }^{b}$ Total volume released: $3.93 E+10 \mathrm{~mL}(1.04 E+07 \mathrm{gal})$

${ }^{c} 1$ curie $(\mathrm{Ci})=3.7 \mathrm{E}+10$ becquerels $(\mathrm{Bq}) ; 1 \mathrm{~Bq}=2.7 \mathrm{E}-11 \mathrm{Ci}$

${ }^{d}$ DOE-derived concentration guides (DCGs) do not exist for indicator parameters gross alpha and gross beta.

${ }^{e}$ Potassium-40 activity is not applicable because of its natural origin.

${ }^{f}$ Total $U(\mathrm{~g})=3.86 \pm 0.04 E+02 ;$ Average $U(\mu \mathrm{g} / \mathrm{mL})=9.82 \pm 0.10 E-03$

${ }^{g}$ DCG for $U-236$ is used for this comparison. 


\section{Table C-2C}

\section{SPDES Results for Outfall 001 (WNSP001): Water Quality}

\begin{tabular}{|c|c|c|c|c|c|c|c|c|}
\hline & \multicolumn{2}{|c|}{$\begin{array}{c}\text { Ammonia } \\
(\mathrm{mg} / \mathrm{L})\end{array}$} & \multicolumn{2}{|c|}{$\begin{array}{c}\text { BOD }_{5} \text { day } \\
(\mathrm{mg} / \mathrm{L})\end{array}$} & \multicolumn{2}{|c|}{$\begin{array}{c}\text { Cyanide } \\
\text { (amenable to } \\
\text { chlorination) }(\mathrm{mg} / \mathrm{L})\end{array}$} & \multicolumn{2}{|c|}{$\begin{array}{l}\text { Discharge Rate } \\
\text { (MGD) }\end{array}$} \\
\hline Permit limit & \multicolumn{2}{|c|}{ Monitor } & \multicolumn{2}{|c|}{$\begin{array}{l}10.0 \mathrm{mg} / \mathrm{L} \text { daily } \\
\text { maximum }\end{array}$} & \multicolumn{2}{|c|}{$\begin{array}{l}0.022 \mathrm{mg} / \mathrm{L} \text { daily } \\
\text { maximum }\end{array}$} & \multicolumn{2}{|c|}{ Monitor } \\
\hline Month & Avg & Max & Avg & Max & Avg & Max & Avg & $\operatorname{Max}$ \\
\hline January $^{a}$ & -- & -- & -- & -- & -- & -- & -- & -- \\
\hline February & $<0.011$ & $<0.011$ & $<2.0$ & $<2.0$ & $<0.0030$ & $<0.0030$ & 0.284 & 0.321 \\
\hline $\operatorname{March}^{a}$ & -- & -- & -- & -- & -- & -- & -- & -- \\
\hline April & $<0.052$ & 0.093 & $<2.0$ & $<2.0$ & $<0.0030$ & $<0.0030$ & 0.245 & 0.274 \\
\hline May & $<0.012$ & 0.012 & $<2.3$ & 2.6 & $<0.0030$ & $<0.0030$ & 0.195 & 0.263 \\
\hline June ${ }^{a}$ & -- & -- & -- & -- & -- & -- & -- & -- \\
\hline July $^{a}$ & -- & -- & -- & -- & -- & -- & -- & -- \\
\hline August & $<0.011$ & $<0.011$ & $<2.3$ & 2.5 & $<0.0030$ & $<0.0030$ & 0.128 & 0.149 \\
\hline September $^{a}$ & -- & -- & -- & -- & -- & -- & -- & -- \\
\hline October & 0.020 & 0.020 & $<2.0$ & $<2.0$ & b & $b$ & 0.180 & 0.209 \\
\hline November & 0.049 & 0.058 & $<2.0$ & $<2.0$ & b & $b$ & 0.338 & 0.517 \\
\hline December $^{a}$ & -- & -- & -- & -- & -- & -- & -- & -- \\
\hline
\end{tabular}

\begin{tabular}{|c|c|c|c|c|c|c|}
\hline & \multicolumn{2}{|c|}{$\begin{array}{c}\text { Nitrate (as N) } \\
(\mathrm{mg} / \mathrm{L})\end{array}$} & \multicolumn{2}{|c|}{$\begin{array}{c}\text { Nitrite (as N) } \\
(\mathrm{mg} / \mathrm{L})\end{array}$} & \multicolumn{2}{|c|}{$\begin{array}{l}\text { Oil \& Grease } \\
(\mathrm{mg} / \mathrm{L})\end{array}$} \\
\hline Permit limit & \multicolumn{2}{|c|}{ Monitor } & \multicolumn{2}{|c|}{$\begin{array}{l}0.1 \mathrm{mg} / \mathrm{L} \text { daily } \\
\text { maximum }\end{array}$} & \multicolumn{2}{|c|}{$\begin{array}{l}15.0 \mathrm{mg} / \mathrm{L} \text { daily } \\
\text { maximum }\end{array}$} \\
\hline Month & Avg & Max & Avg & Max & Avg & Max \\
\hline January $^{a}$ & -- & -- & -- & -- & - & -- \\
\hline February & 0.34 & 0.39 & $<0.02$ & $<0.02$ & $<2.2$ & $<2.2$ \\
\hline March $^{a}$ & -- & -- & -- & -- & -- & -- \\
\hline April & 0.56 & 0.56 & $<0.02$ & $<0.02$ & $<2.2$ & 2.2 \\
\hline May & 0.25 & 0.34 & $<0.02$ & $<0.02$ & $<2.2$ & $<2.2$ \\
\hline June ${ }^{a}$ & -- & -- & -- & -- & -- & -- \\
\hline July $^{a}$ & -- & -- & -- & -- & -- & -- \\
\hline August & $<0.011$ & $<0.011$ & $<0.02$ & $<0.02$ & $<2.2$ & $<2.2$ \\
\hline September ${ }^{a}$ & -- & -- & -- & -- & -- & -- \\
\hline October & $<0.016$ & 0.020 & $<0.02$ & $<0.02$ & $<2.2$ & $<2.2$ \\
\hline November & 0.35 & 0.36 & $<0.02$ & $<0.02$ & $<2.2$ & $<2.2$ \\
\hline December $^{a}$ & -- & -- & -- & -- & -- & -- \\
\hline
\end{tabular}

Note: No results exceeded the permit limits.

${ }^{a}$ No discharge this month

${ }^{b}$ Modifications to the SPDES permit in September 2006 reduced the required monitoring frequency of these compounds. 


\section{Table C-2C (concluded)}

2006 SPDES Results for Outfall 001 (WNSP001):

Water Quality

\begin{tabular}{|c|c|c|c|c|c|c|c|c|}
\hline \multirow{3}{*}{$\begin{array}{l}\text { Permit limit } \\
\text { Month }\end{array}$} & \multicolumn{2}{|c|}{$\begin{array}{c}\mathbf{p H} \\
\text { (standard units) }\end{array}$} & \multicolumn{2}{|c|}{$\begin{array}{c}\text { Solids } \\
\text { Settleable } \\
(\mathrm{mL} / \mathrm{L})\end{array}$} & \multicolumn{2}{|c|}{$\begin{array}{c}\text { Solids } \\
\text { Total Dissolved } \\
(\mathrm{mg} / \mathrm{L})\end{array}$} & \multicolumn{2}{|c|}{$\begin{array}{c}\text { Solids } \\
\text { Total Suspended } \\
(\mathrm{mg} / \mathrm{L})\end{array}$} \\
\hline & \multicolumn{2}{|c|}{$6.5-8.5$} & \multicolumn{2}{|c|}{$\begin{array}{l}0.3 \mathrm{~mL} / \mathrm{L} \text { daily } \\
\text { maximum }\end{array}$} & \multicolumn{2}{|c|}{ Monitor } & \multicolumn{2}{|c|}{$\begin{array}{c}45 \mathrm{mg} / \mathrm{L} \text { daily maximum; } \\
30 \text { daily average }\end{array}$} \\
\hline & Min & Max & Avg & Max & Avg & Max & Avg & Max \\
\hline January $^{a}$ & -- & -- & -- & -- & -- & -- & -- & -- \\
\hline February & 6.9 & 7.2 & $<0.1$ & $<0.1$ & 668 & 670 & $<7.5$ & 11.0 \\
\hline $\operatorname{March}^{a}$ & -- & -- & -- & -- & -- & -- & -- & -- \\
\hline April & 7.7 & 7.7 & $<0.1$ & $<0.1$ & 722 & 730 & $<4.0$ & $<4.0$ \\
\hline May & 7.2 & 7.8 & $<0.1$ & $<0.1$ & 812 & 814 & $<4.0$ & $<4.0$ \\
\hline June ${ }^{a}$ & -- & -- & -- & -- & -- & -- & -- & -- \\
\hline July $^{a}$ & -- & -- & -- & -- & -- & -- & -- & -- \\
\hline August & 7.6 & 7.8 & $<0.1$ & $<0.1$ & 864 & 872 & $<4.0$ & $<4.0$ \\
\hline September $^{a}$ & -- & -- & -- & -- & -- & -- & -- & -- \\
\hline October & 7.8 & 7.8 & $<0.1$ & $<0.1$ & 852 & 865 & $<4.0$ & $<4.0$ \\
\hline November & 7.3 & 7.3 & $<0.1$ & $<0.1$ & 773 & 784 & $<4.5$ & 5.0 \\
\hline December $^{a}$ & -- & -- & -- & -- & -- & -- & -- & -- \\
\hline
\end{tabular}

\begin{tabular}{|c|c|c|c|c|c|c|}
\hline \multirow{3}{*}{$\begin{array}{l}\text { Permit limit } \\
\text { Month }\end{array}$} & \multicolumn{2}{|c|}{$\begin{array}{l}\text { Sulfate (as S) } \\
(\mathrm{mg} / \mathrm{L})\end{array}$} & \multicolumn{2}{|c|}{$\begin{array}{c}\text { Sulfide (as S) } \\
\text { Dissolved } \\
(\mathrm{mg} / \mathrm{L})\end{array}$} & \multicolumn{2}{|c|}{$\begin{array}{c}\text { Surfactant } \\
\text { as LAS } \\
(\mathrm{mg} / \mathrm{L})\end{array}$} \\
\hline & \multicolumn{2}{|c|}{ Monitor } & \multicolumn{2}{|c|}{$\begin{array}{l}0.4 \mathrm{mg} / \mathrm{L} \text { daily } \\
\text { maximum }\end{array}$} & \multicolumn{2}{|c|}{$\begin{array}{l}0.4 \mathrm{mg} / \mathrm{L} \text { daily } \\
\text { maximum }\end{array}$} \\
\hline & Avg & $\operatorname{Max}$ & Avg & Max & Avg & Max \\
\hline January $^{a}$ & -- & -- & -- & -- & -- & -- \\
\hline February & 46 & 47 & $<0.02$ & $<0.02$ & 0.04 & 0.04 \\
\hline $\operatorname{March}^{a}$ & - & -- & - & -- & - & -- \\
\hline April & 39 & 43 & $<0.03$ & 0.04 & 0.03 & 0.03 \\
\hline May & 49 & 50 & 0.05 & 0.05 & 0.02 & 0.03 \\
\hline June $^{a}$ & - & -- & -- & -- & - & -- \\
\hline July $^{a}$ & -- & -- & -- & -- & -- & -- \\
\hline August & 53 & 56 & $<0.02$ & $<0.02$ & 0.05 & 0.07 \\
\hline September ${ }^{a}$ & -- & -- & -- & -- & -- & -- \\
\hline October & 63 & 65 & $<0.02$ & $<0.02$ & $b$ & $b$ \\
\hline November & 55 & 57 & $<0.02$ & $<0.02$ & $b$ & $b$ \\
\hline December $^{a}$ & -- & -- & -- & -- & -- & -- \\
\hline
\end{tabular}

Note: No results exceeded the permit limits.

a No discharge this month

${ }^{b}$ Modifications to the SPDES permit in September 2006 reduced the required monitoring frequency of these compounds. 
Table C-2D

2006 SPDES Results for Outfall 001 (WNSP001):

Metals

\begin{tabular}{|c|c|c|c|c|c|c|c|c|}
\hline \multirow{3}{*}{$\begin{array}{l}\text { Permit limit } \\
\text { Month }\end{array}$} & \multicolumn{2}{|c|}{$\begin{array}{c}\text { Aluminum } \\
\text { Total } \\
(\mathrm{mg} / \mathrm{L})\end{array}$} & \multicolumn{2}{|c|}{$\begin{array}{l}\text { Arsenic } \\
\text { Dissolved } \\
(\mathrm{mg} / \mathrm{L})\end{array}$} & \multicolumn{2}{|c|}{$\begin{array}{c}\text { Cadmium } \\
\text { Total Recoverable } \\
(\mathrm{mg} / \mathrm{L})\end{array}$} & \multicolumn{2}{|c|}{$\begin{array}{c}\text { Cobalt } \\
\text { Total Recoverable } \\
(\mathrm{mg} / \mathrm{L})\end{array}$} \\
\hline & \multicolumn{2}{|c|}{$\begin{array}{l}14.0 \mathrm{mg} / \mathrm{L} \text { daily maximum; } \\
7.0 \mathrm{mg} / \mathrm{L} \text { daily average }\end{array}$} & \multicolumn{2}{|c|}{$\begin{array}{l}0.15 \mathrm{mg} / \mathrm{L} \text { daily } \\
\text { maximum }\end{array}$} & \multicolumn{2}{|c|}{$\begin{array}{l}0.002 \mathrm{mg} / \mathrm{L} \text { daily } \\
\text { maximum }\end{array}$} & \multicolumn{2}{|c|}{$\begin{array}{l}0.005 \mathrm{mg} / \mathrm{L} \text { daily } \\
\text { maximum }\end{array}$} \\
\hline & Avg & Max & Avg & Max & Avg & Max & Avg & Max \\
\hline January $^{a}$ & -- & -- & - & -- & - & -- & -- & -- \\
\hline February & 0.72 & 1.08 & $<0.0034$ & $<0.0034$ & $<0.0003$ & $<0.0003$ & $<0.0008$ & 0.0008 \\
\hline March $^{a}$ & -- & -- & - & -- & - & -- & -- & -- \\
\hline April & 1.27 & 1.38 & $<0.0034$ & $<0.0034$ & $<0.0003$ & $<0.0003$ & $<0.0008$ & $<0.0008$ \\
\hline May & 0.219 & 0.236 & $<0.00024$ & $<0.0034$ & $<0.0003$ & $<0.0003$ & $<0.0009$ & 0.0009 \\
\hline June $^{a}$ & -- & -- & - & -- & - & -- & -- & -- \\
\hline July $^{a}$ & -- & -- & - & -- & - & -- & -- & -- \\
\hline August & 0.098 & 0.136 & $<0.0034$ & $<0.0034$ & $<0.0003$ & $<0.0003$ & $<0.0008$ & $<0.0008$ \\
\hline September $^{a}$ & -- & -- & - & -- & - & -- & -- & -- \\
\hline October & 0.0672 & 0.0672 & 0.0013 & 0.0013 & $b$ & $b$ & 0.001 & 0.001 \\
\hline November & 0.122 & 0.122 & 0.0013 & 0.0013 & $b$ & $b$ & $<0.0008$ & $<0.0008$ \\
\hline December $^{a}$ & -- & -- & - & -- & - & -- & -- & -- \\
\hline
\end{tabular}

\begin{tabular}{|c|c|c|c|c|c|c|c|c|}
\hline \multirow{3}{*}{$\begin{array}{l}\text { Permit limit } \\
\text { Month }\end{array}$} & \multirow{2}{*}{\multicolumn{2}{|c|}{$\begin{array}{c}\text { Chromium } \\
\text { Total Recoverable } \\
(\mathrm{mg} / \mathrm{L})\end{array}$}} & \multirow{2}{*}{\multicolumn{2}{|c|}{$\begin{array}{c}\text { Chromium VI } \\
\text { Total Recoverable } \\
(\mathrm{mg} / \mathrm{L}) \\
0.011 \mathrm{mg} / \mathrm{L} \text { daily } \\
\text { maximum }\end{array}$}} & \multirow{2}{*}{\multicolumn{2}{|c|}{$\begin{array}{c}\text { Copper } \\
\text { Dissolved } \\
(\mathrm{mg} / \mathrm{L})\end{array}$}} & \multirow{2}{*}{\multicolumn{2}{|c|}{$\begin{array}{c}\text { Copper } \\
\text { Total Recoverable } \\
(\mathrm{mg} / \mathrm{L})\end{array}$}} \\
\hline & & & & & & & & \\
\hline & Avg & Max & Avg & Max & Avg & Max & Avg & Max \\
\hline January $^{a}$ & -- & -- & - & -- & - & -- & -- & -- \\
\hline February & $<0.001$ & 0.001 & $<0.008$ & $<0.008$ & $<0.0021$ & 0.0026 & $<0.0025$ & 0.0034 \\
\hline March $^{a}$ & -- & -- & - & -- & - & -- & -- & -- \\
\hline April & 0.001 & 0.001 & $<0.008$ & $<0.008$ & 0.0032 & 0.0040 & 0.0027 & 0.0032 \\
\hline May & $<0.0007$ & 0.0009 & $<0.008$ & $<0.008$ & 0.0042 & 0.0048 & 0.0048 & 0.0057 \\
\hline June ${ }^{a}$ & -- & -- & -- & -- & - & -- & -- & -- \\
\hline July $^{a}$ & -- & -- & - & -- & - & -- & -- & -- \\
\hline August & $<0.0005$ & 0.0005 & $<0.008$ & $<0.008$ & 0.0017 & 0.0024 & 0.0017 & 0.0022 \\
\hline September $^{a}$ & -- & -- & - & -- & - & -- & -- & -- \\
\hline October & $b$ & $b$ & $b$ & $b$ & $b$ & $b$ & $b$ & $b$ \\
\hline November & $b$ & $b$ & $b$ & $b$ & $b$ & $b$ & $b$ & $b$ \\
\hline December $^{a}$ & -- & -- & -- & -- & - & -- & -- & -- \\
\hline
\end{tabular}

Note: No results exceeded the permit limits.

${ }^{a}$ No discharge this month

${ }^{b}$ Modifications to the SPDES permit in September 2006 reduced the required monitoring frequency of these compounds. 


\section{Table C-2D (concluded)}

\section{SPDES Results for Outfall 001 (WNSP001): Metals}

\begin{tabular}{|c|c|c|c|c|c|c|c|c|c|c|}
\hline & \multicolumn{2}{|c|}{$\begin{array}{l}\text { Iron } \\
\text { Total } \\
(\mathrm{mg} / \mathrm{L})\end{array}$} & \multicolumn{2}{|c|}{$\begin{array}{c}\text { Lead } \\
\text { Total Recoverable } \\
(\mathrm{mg} / \mathrm{L})\end{array}$} & \multicolumn{2}{|c|}{$\begin{array}{c}\text { Manganese } \\
\text { Total } \\
(\mathrm{mg} / \mathrm{L})\end{array}$} & \multicolumn{2}{|c|}{$\begin{array}{l}\text { Mercury, Total } \\
\text { per EPA Method } \\
\text { 245.1) }(\mathrm{mg} / \mathrm{L})\end{array}$} & \multicolumn{2}{|c|}{$\begin{array}{c}\text { Mercury, Total } \\
\text { (per EPA Method } \\
\text { 1631 }(\mu \mathrm{g} / \mathrm{L})\end{array}$} \\
\hline Permit limit & & & $\begin{array}{r}0.006 \mathrm{~m} \\
\max \end{array}$ & $\begin{array}{l}\text { L daily } \\
\text { num }\end{array}$ & $\begin{array}{r}2.0 \mathrm{~m} \\
\mathrm{ma}\end{array}$ & daily & $\begin{array}{r}0.0002 \mathrm{n} \\
\max \end{array}$ & $\begin{array}{l}\mathrm{g} / \mathrm{L} \text { daily } \\
\text { num }\end{array}$ & $\begin{array}{r}0.2 \mu \mathrm{g} \\
\max \end{array}$ & $\begin{array}{l}\text { L daily } \\
\text { mum }\end{array}$ \\
\hline Month & Avg & Max & Avg & Max & Avg & Max & Avg & Max & Avg & Max \\
\hline January $^{a}$ & -- & -- & -- & -- & -- & -- & -- & -- & - & -- \\
\hline February & 0.568 & 0.808 & 0.0008 & 0.0008 & 0.024 & 0.026 & $<0.0002$ & $<0.0002$ & 0.0129 & 0.0135 \\
\hline March $^{a}$ & -- & -- & -- & -- & -- & -- & -- & -- & -- & -- \\
\hline April & 0.785 & 0.785 & 0.001 & 0.001 & 0.025 & 0.026 & $<0.0002$ & $<0.0002$ & 0.0289 & 0.0307 \\
\hline May & 0.167 & 0.174 & 0.0003 & 0.0004 & 0.068 & 0.070 & $<0.0002$ & $<0.0002$ & 0.00917 & 0.0108 \\
\hline June ${ }^{a}$ & -- & -- & -- & -- & -- & -- & -- & -- & -- & -- \\
\hline July $^{a}$ & -- & -- & -- & -- & -- & -- & -- & -- & -- & -- \\
\hline August & 0.127 & 0.162 & 0.0002 & 0.0002 & 0.081 & 0.11 & $<0.0002$ & $<0.0002$ & 0.00205 & 0.00238 \\
\hline September ${ }^{a}$ & -- & -- & -- & -- & -- & -- & -- & -- & -- & -- \\
\hline October & 0.070 & 0.078 & 0.0001 & 0.0001 & & $b$ & c & c & 0.00218 & 0.00257 \\
\hline November & 0.113 & 0.116 & 0.00022 & 0.00022 & $b$ & $b$ & $c$ & $c$ & 0.00303 & 0.00340 \\
\hline December $^{a}$ & -- & -- & -- & -- & -- & -- & -- & -- & -- & -- \\
\hline
\end{tabular}

\begin{tabular}{|c|c|c|c|c|c|c|c|c|}
\hline \multirow{3}{*}{$\begin{array}{l}\text { Permit limit } \\
\text { Month }\end{array}$} & \multirow{2}{*}{\multicolumn{2}{|c|}{$\begin{array}{c}\begin{array}{c}\text { Nickel } \\
\text { Total Recoverable } \\
(\mathrm{mg} / \mathrm{L})\end{array} \\
0.14 \mathrm{mg} / \mathrm{L} \text { daily } \\
\text { maximum }\end{array}$}} & \multirow{2}{*}{\multicolumn{2}{|c|}{$\begin{array}{c}\text { Selenium } \\
\text { Total Recoverable } \\
(\mathrm{mg} / \mathrm{L})\end{array}$}} & \multirow{2}{*}{\multicolumn{2}{|c|}{$\begin{array}{c}\text { Vanadium } \\
\text { Total Recoverable } \\
(\mathrm{mg} / \mathrm{L})\end{array}$}} & \multirow{2}{*}{\multicolumn{2}{|c|}{$\begin{array}{c}\text { Zinc } \\
\begin{array}{c}\text { Total Recoverable } \\
(\mathrm{mg} / \mathrm{L})\end{array} \\
\begin{array}{c}0.48 \mathrm{mg} / \mathrm{L} \text { daily } \\
\text { maximum }\end{array} \\
\end{array}$}} \\
\hline & & & & & & & & \\
\hline & Avg & Max & Avg & Max & Avg & Max & Avg & Max \\
\hline January $^{a}$ & -- & -- & -- & -- & - & -- & -- & -- \\
\hline February & 0.0024 & 0.0024 & $<0.0004$ & $<0.0004$ & 0.0019 & 0.0020 & 0.019 & 0.029 \\
\hline March $^{a}$ & -- & -- & -- & -- & -- & -- & -- & -- \\
\hline April & 0.0022 & 0.0023 & $<0.0005$ & 0.0005 & 0.0025 & 0.0025 & 0.0084 & 0.0094 \\
\hline May & 0.0026 & 0.0027 & $<0.0004$ & $<0.0004$ & $<0.0012$ & 0.0015 & 0.0071 & 0.0079 \\
\hline June $^{a}$ & -- & -- & -- & -- & -- & -- & -- & -- \\
\hline July $^{a}$ & -- & -- & -- & -- & -- & -- & -- & -- \\
\hline August & $<0.0014$ & $<0.0014$ & $<0.0004$ & $<0.0004$ & $<0.00098$ & $<0.00098$ & $<0.0047$ & 0.0058 \\
\hline September $^{a}$ & -- & -- & -- & -- & -- & -- & -- & -- \\
\hline October & $b$ & $b$ & $<0.0004$ & $<0.0004$ & $<0.00098$ & $<0.00098$ & $b$ & \\
\hline November & b & $b$ & $<0.0004$ & $<0.0004$ & 0.0011 & 0.0011 & $b$ & b \\
\hline December $^{a}$ & -- & -- & -- & -- & -- & -- & -- & -- \\
\hline
\end{tabular}

Note: No results exceeded the permit limits.

a No discharge this month

${ }^{b}$ Modifications to the SPDES permit in September 2006 reduced the required monitoring frequency of these compounds.

${ }^{c}$ The requirement to monitor for total Mercury by EPA Method 245.1 was removed from the modified SPDES permit effective September 1, 2006. 


\section{Table C-2E}

\section{SPDES Results for Outfall 007 (WNSP007): \\ Water Quality and Iron}

\begin{tabular}{|c|c|c|c|c|c|c|c|c|c|c|}
\hline & \multicolumn{2}{|c|}{$\begin{array}{c}\text { Ammonia } \\
\left.\text { (as NH } \mathbf{N H}_{3}\right) \\
(\mathrm{m} \mathrm{g} / \mathrm{L})\end{array}$} & \multicolumn{2}{|c|}{$\begin{array}{l}\mathbf{B O D}_{\mathbf{5}} \\
(\mathrm{mg} / \mathrm{L})\end{array}$} & \multicolumn{2}{|c|}{$\begin{array}{c}\text { Chlorine } \\
\text { Total Residual } \\
\text { (mg/L) }\end{array}$} & \multicolumn{2}{|c|}{$\begin{array}{l}\text { Discharge Rate } \\
\text { (MGD) }\end{array}$} & \multicolumn{2}{|c|}{$\begin{array}{l}\text { Iron } \\
\text { Total } \\
(\mathrm{mg} / \mathrm{L})\end{array}$} \\
\hline $\begin{array}{c}\text { Permit } \\
\text { limit }\end{array}$ & \multicolumn{2}{|c|}{ Monitor } & \multicolumn{2}{|c|}{$\begin{array}{l}10.0 \mathrm{mg} / \mathrm{L} \text { daily } \\
\text { maximum }\end{array}$} & \multicolumn{2}{|c|}{$\begin{array}{l}0.1 \mathrm{mg} / \mathrm{L} \text { daily } \\
\text { maximum }\end{array}$} & \multicolumn{2}{|c|}{ Monitor } & \multicolumn{2}{|c|}{ Monitor } \\
\hline Month & Avg & Max & Avg & Max & Avg & Max & Avg & Max & Avg & Max \\
\hline January & $<0.011$ & $<0.011$ & $<2.2$ & 2.6 & 0.01 & 0.01 & 0.011 & 0.017 & 0.0912 & 0.116 \\
\hline February & $<0.011$ & $<0.011$ & $<2.0$ & $<2.0$ & 0.01 & 0.02 & 0.011 & 0.014 & 0.108 & 0.157 \\
\hline March & $<0.035$ & 0.055 & $<2.0$ & $<2.0$ & $<0.02$ & 0.03 & 0.012 & 0.014 & 0.0873 & 0.104 \\
\hline April & $<0.032$ & 0.075 & $<2.0$ & $<2.0$ & $<0.01$ & 0.01 & 0.011 & 0.013 & $<0.0937$ & 0.133 \\
\hline May & $<0.033$ & 0.070 & $<2.0$ & $<2.0$ & $<0.01$ & 0.02 & 0.012 & 0.013 & 0.141 & 0.158 \\
\hline June & $<0.011$ & $<0.011$ & $<2.0$ & $<2.0$ & $<0.01$ & 0.01 & 0.008 & 0.014 & 0.0541 & 0.0894 \\
\hline July & $<0.014$ & 0.021 & $<2.0$ & $<2.0$ & $<0.01$ & 0.01 & 0.007 & 0.007 & 0.0632 & 0.0725 \\
\hline August & $<0.011$ & $<0.011$ & $<2.2$ & 2.6 & $<0.01$ & 0.01 & 0.008 & 0.010 & 0.044 & 0.060 \\
\hline September & $<0.022$ & 0.040 & $<2.0$ & $<2.0$ & 0.01 & 0.01 & 0.008 & 0.010 & $<0.0501$ & 0.0873 \\
\hline October & 0.041 & 0.045 & $<2.0$ & $<2.0$ & 0.02 & 0.03 & 0.009 & 0.010 & 0.068 & 0.086 \\
\hline November & $<0.028$ & 0.053 & $<2.0$ & $<2.0$ & 0.01 & 0.02 & 0.011 & 0.012 & 0.0968 & 0.130 \\
\hline December & $<0.012$ & 0.013 & $<2.5$ & 3.5 & $<0.01$ & 0.02 & 0.012 & 0.020 & 0.100 & 0.127 \\
\hline
\end{tabular}

\begin{tabular}{|c|c|c|c|c|c|c|c|c|c|c|}
\hline & \multirow{2}{*}{\multicolumn{2}{|c|}{$\begin{array}{l}\begin{array}{l}\text { Nitrite } \\
(\text { as N) }\end{array} \\
(\mathrm{mg} / \mathrm{L}) \\
.1 \mathrm{mg} / \mathrm{L} \text { daily } \\
\text { maximum }\end{array}$}} & \multirow{2}{*}{\multicolumn{2}{|c|}{$\begin{array}{c}\begin{array}{c}\text { Oil \& Grease } \\
(\mathrm{mg} / \mathrm{L})\end{array} \\
\begin{array}{c}15.0 \mathrm{mg} / \mathrm{L} \text { daily } \\
\text { maximum }\end{array} \\
\end{array}$}} & \multicolumn{2}{|c|}{$\begin{array}{c}\mathbf{p H} \\
\text { (standard units) }\end{array}$} & \multicolumn{2}{|c|}{$\begin{array}{c}\text { Solids } \\
\text { Settleable } \\
(\mathrm{mL} / \mathrm{L})\end{array}$} & \multicolumn{2}{|c|}{$\begin{array}{c}\text { Solids } \\
\text { Total Suspended } \\
(\mathrm{mg} / \mathrm{L})\end{array}$} \\
\hline $\begin{array}{l}\text { Permit } \\
\text { limit }\end{array}$ & & & & & & & $\begin{array}{r}0.3 \mathrm{r} \\
\mathrm{m}\end{array}$ & $\begin{array}{l}\text { daily } \\
\text { Im }\end{array}$ & $\begin{array}{r}45 \mathrm{mg} / \mathrm{L} \\
30 \mathrm{c}\end{array}$ & $\begin{array}{l}\text { laximum; } \\
\text { erage }\end{array}$ \\
\hline Month & Avg & Max & Avg & Max & Min & Max & Avg & Max & Avg & Max \\
\hline Janиаry & $<0.02$ & $<0.02$ & $<2.2$ & $<2.2$ & 7.4 & 7.7 & $<0.1$ & $<0.1$ & $<4.0$ & $<4.0$ \\
\hline February & $<0.02$ & $<0.02$ & $<2.2$ & $<2.2$ & 7.5 & 7.7 & $<0.1$ & $<0.1$ & $<4.0$ & $<4.0$ \\
\hline March & $<0.02$ & $<0.02$ & $<3.7$ & 6.4 & 7.2 & 7.9 & $<0.1$ & $<0.1$ & $<4.0$ & $<4.0$ \\
\hline April & $<0.02$ & $<0.02$ & $<2.2$ & 2.2 & 7.1 & 7.6 & $<0.1$ & $<0.1$ & $<4.0$ & $<4.0$ \\
\hline May & $<0.02$ & $<0.02$ & $<3.0$ & 4.7 & 7.2 & 7.6 & $<0.1$ & $<0.1$ & $<4.0$ & $<4.0$ \\
\hline June & $<0.02$ & $<0.02$ & $<2.2$ & $<2.2$ & 7.2 & 7.7 & $<0.1$ & $<0.1$ & $<4.0$ & $<4.0$ \\
\hline July & $<0.02$ & $<0.02$ & $<2.2$ & $<2.2$ & 7.6 & 7.8 & $<0.1$ & $<0.1$ & $<4.0$ & $<4.0$ \\
\hline August & $<0.02$ & $<0.02$ & $<2.2$ & $<2.2$ & 7.4 & 8.0 & $<0.1$ & $<0.1$ & $<4.0$ & $<4.0$ \\
\hline September & $<0.02$ & $<0.02$ & $<2.2$ & 2.2 & 7.4 & 7.6 & $<0.1$ & $<0.1$ & $<4.0$ & $<4.0$ \\
\hline October & $<0.02$ & $<0.02$ & $<2.2$ & $<2.2$ & 7.2 & 8.0 & $<0.1$ & $<0.1$ & $<4.3$ & 5.0 \\
\hline November & $<0.02$ & $<0.02$ & $<2.2$ & $<2.2$ & 7.7 & 8.0 & $<0.1$ & $<0.1$ & $<4.3$ & 5.0 \\
\hline December & $<0.02$ & $<0.02$ & $<3.2$ & 5.2 & 7.1 & 7.9 & $<0.1$ & $<0.1$ & $<4.0$ & $<4.0$ \\
\hline
\end{tabular}

Note: No results exceeded the permit limits. 
Table C-2F

2006 SPDES Results for Sums of Outfalls 001, 007, 008, and 116:

Water Quality

2006 Results for Sums of Outfalls 001, 007 and 008

\begin{tabular}{|c|c|c|c|c|c|c|}
\hline \multirow{3}{*}{$\begin{array}{l}\text { Permit limit } \\
\text { Month }\end{array}$} & \multicolumn{2}{|c|}{$\begin{array}{c}\text { Ammonia }^{a} \\
\text { Flow-Weighted } \\
(\mathrm{mg} / \mathrm{L})\end{array}$} & \multirow{2}{*}{\multicolumn{2}{|c|}{ 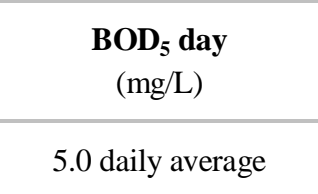 }} & \multicolumn{2}{|c|}{$\begin{array}{c}\text { Iron Total } \\
\text { Flow-Weighted } \\
(\mathrm{mg} / \mathrm{L})\end{array}$} \\
\hline & \multirow{2}{*}{$\begin{array}{l}1.49 \text { daily } \\
\text { average } \\
\text { Avg }\end{array}$} & \multirow{2}{*}{$\begin{array}{l}2.1 \text { daily } \\
\text { maximum } \\
\mathbf{M a x}\end{array}$} & & & Monitor & 0.30 daily \\
\hline & & & Avg & Max & Avg & Max \\
\hline January & $<0.011$ & $<0.011$ & $<2.2$ & 2.6 & 0.00 & 0.00 \\
\hline February & $<0.011$ & $<0.011$ & $<2.0$ & $<2.0$ & 0.27 & 0.27 \\
\hline March & $<0.035$ & 0.055 & $<2.0$ & $<2.0$ & 0.00 & 0.00 \\
\hline April & $<0.025$ & $<0.053$ & $<2.0$ & $<2.0$ & $<0.19$ & $<0.19$ \\
\hline May & $<0.031$ & 0.070 & $<2.2$ & $<2.6$ & 0.00 & 0.00 \\
\hline June & $<0.011$ & $<0.011$ & $<2.0$ & $<2.0$ & 0.00 & 0.00 \\
\hline July & $<0.014$ & 0.021 & $<2.0$ & $<2.0$ & 0.00 & 0.00 \\
\hline August & $<0.011$ & $<0.011$ & $<2.4$ & 2.6 & 0.00 & 0.00 \\
\hline September & $<0.022$ & 0.040 & $<2.0$ & $<2.0$ & 0.00 & 0.00 \\
\hline October & 0.027 & 0.040 & $<2.0$ & $<2.0$ & 0.00 & 0.00 \\
\hline November & $<0.050$ & $<0.057$ & $<2.0$ & $<2.0$ & 0.00 & 0.00 \\
\hline December & $<0.012$ & 0.013 & $<2.5$ & 3.5 & 0.00 & 0.00 \\
\hline
\end{tabular}

\section{$\underline{2006}$ Results for Outfall 116}

\begin{tabular}{|l|c|c|}
\hline \multirow{2}{*}{} & \multicolumn{2}{|c|}{$\begin{array}{c}\text { Total Dissolved Solids } \\
\text { (mg/L) }\end{array}$} \\
\hline Permit limit & \multicolumn{2}{|c|}{$\begin{array}{r}\text { A00 mg/L daily } \\
\text { maximum }\end{array}$} \\
\hline Month & Avg & Max \\
\hline January ${ }^{b}$ & -- & -- \\
\hline February & 374 & 473 \\
\hline March ${ }^{b}$ & -- & -- \\
\hline April & 237 & 239 \\
\hline May & 304 & 331 \\
\hline June ${ }^{b}$ & -- & -- \\
\hline July ${ }^{b}$ & -- & -- \\
\hline August & 334 & 338 \\
\hline September ${ }^{b}$ & -- & -- \\
\hline October & 186 & 193 \\
\hline November & 310 & 312 \\
\hline December ${ }^{b}$ & -- & -- \\
\hline
\end{tabular}

Note: No results exceeded the permit limits.

${ }^{a}$ Sum of Outfalls 001 and 007 only

${ }^{b}$ No discharge this month 


\section{Table C-2G}

\section{Annual and Semiannual SPDES Results for Outfall 001: Organic Compounds}

\begin{tabular}{|c|c|c|c|c|}
\hline Permit Limit Parameters & Permit Limit & $\begin{array}{l}\text { Monitoring } \\
\text { Frequency }\end{array}$ & $\begin{array}{c}\text { Collection } \\
\text { Date }\end{array}$ & $\begin{array}{c}\text { Maximum } \\
\text { Measured (mg/L) }\end{array}$ \\
\hline 2-Butanone & $\begin{array}{l}0.5 \mathrm{mg} / \mathrm{L} \text { daily } \\
\text { maximum }\end{array}$ & Once/year & February 2006 & $<0.005$ \\
\hline 3,3-Dichlorobenzidine & $\begin{array}{l}0.01 \mathrm{mg} / \mathrm{L} \text { daily } \\
\text { maximum }\end{array}$ & Once/year & February 2006 & $<0.002$ \\
\hline Alpha-BHC & $\begin{array}{l}0.00001 \mathrm{mg} / \mathrm{L} \text { daily } \\
\text { maximum }\end{array}$ & Once/year & February 2006 & $<0.000001$ \\
\hline Dichlorodifluoromethane & $\begin{array}{l}0.01 \mathrm{mg} / \mathrm{L} \text { daily } \\
\text { maximum }\end{array}$ & Once/year & February 2006 & $<0.002$ \\
\hline Heptachlor & $\begin{array}{l}0.00001 \mathrm{mg} / \mathrm{L} \text { daily } \\
\text { maximum }\end{array}$ & Twice/year & $\begin{array}{c}\text { February } 2006 \\
\text { October } 2006\end{array}$ & $\begin{array}{c}<0.0000008 \\
<0.000002\end{array}$ \\
\hline Hexachlorobenzene & $\begin{array}{l}0.02 \mathrm{mg} / \mathrm{L} \text { daily } \\
\text { maximum }\end{array}$ & Once/year & February 2006 & $<0.0008$ \\
\hline Tributyl Phosphate & $\begin{array}{l}32 \mathrm{mg} / \mathrm{L} \text { daily } \\
\text { maximum }\end{array}$ & Once/year & February 2006 & $<0.010$ \\
\hline Trichlorofluoromethane & $\begin{array}{l}0.01 \mathrm{mg} / \mathrm{L} \text { daily } \\
\text { maximum }\end{array}$ & Once/year & February 2006 & $<0.002$ \\
\hline Xylene & $\begin{array}{l}0.05 \mathrm{mg} / \mathrm{L} \text { daily } \\
\text { maximum }\end{array}$ & Once/year & February 2006 & $<0.007$ \\
\hline
\end{tabular}


Table C-2H

2006 SPDES Action Level Requirement Monitoring Results for Outfalls 001, 007, and 008: Metals, Organics, and Water Quality

\begin{tabular}{|c|c|c|c|c|c|}
\hline Outfall & $\begin{array}{l}\text { Action Level } \\
\text { Parameters }\end{array}$ & Action Level & $\begin{array}{l}\text { Monitoring } \\
\text { Frequency }\end{array}$ & $\begin{array}{c}\text { Collection } \\
\text { Date }\end{array}$ & $\begin{array}{c}\text { Maximum } \\
\text { Measured }(\mathrm{mg} / \mathrm{L})\end{array}$ \\
\hline \multirow{6}{*}{001} & Antimony, Total & $\begin{array}{l}1.0 \mathrm{mg} / \mathrm{L} \text { daily } \\
\text { maximum }\end{array}$ & Annual & February 2006 & $<0.0055$ \\
\hline & Barium, Total & $\begin{array}{l}0.5 \mathrm{mg} / \mathrm{L} \text { daily } \\
\text { maximum }\end{array}$ & Annual & February 2006 & 0.03 \\
\hline & Boron, Total & $\begin{array}{l}2.0 \mathrm{mg} / \mathrm{L} \text { daily } \\
\text { maximum }\end{array}$ & Quarterly & $\begin{array}{c}\text { February } 2006 \\
\text { May } 2006 \\
\text { August } 2006 \\
\text { November } 2006\end{array}$ & $\begin{array}{l}0.027 \\
0.062 \\
0.045 \\
0.042\end{array}$ \\
\hline & Bromide, Total & $\begin{array}{l}5.0 \mathrm{mg} / \mathrm{L} \text { daily } \\
\text { maximum }\end{array}$ & Quarterly & $\begin{array}{c}\text { February } 2006 \\
\text { May } 2006 \\
\text { August } 2006 \\
\text { November } 2006\end{array}$ & $\begin{array}{c}0.75 \\
1.3 \\
0.059 \\
1.0\end{array}$ \\
\hline & Chloroform & $\begin{array}{l}0.3 \mathrm{mg} / \mathrm{L} \text { daily } \\
\text { maximum }\end{array}$ & Annual & February 2006 & $<0.0009$ \\
\hline & Titanium, Total & $\begin{array}{c}0.65 \mathrm{mg} / \mathrm{L} \text { daily } \\
\text { maximum }\end{array}$ & Semiannual & $\begin{array}{c}\text { February } 2006 \\
\text { August } 2006\end{array}$ & $\begin{array}{c}0.025 \\
0.0009\end{array}$ \\
\hline 007 & Chloroform & $\begin{array}{l}0.20 \mathrm{mg} / \mathrm{L} \text { daily } \\
\text { maximum }\end{array}$ & Annual & February 2006 & 0.0019 \\
\hline \multirow{4}{*}{008} & Arsenic, Total & $\begin{array}{c}0.17 \mathrm{mg} / \mathrm{L} \text { daily } \\
\text { maximum }\end{array}$ & Annual & $a$ & -- \\
\hline & Chromium, Total & $\begin{array}{l}0.13 \mathrm{mg} / \mathrm{L} \text { daily } \\
\text { maximum }\end{array}$ & Annual & $a$ & -- \\
\hline & Silver, Total & $\begin{array}{c}0.008 \mathrm{mg} / \mathrm{L} \text { daily } \\
\text { maximum }\end{array}$ & Annual & $a$ & -- \\
\hline & Chloroform & $\begin{array}{c}0.13 \mathrm{mg} / \mathrm{L} \text { daily } \\
\text { maximum }\end{array}$ & Annual & $a$ & -- \\
\hline
\end{tabular}

${ }^{a}$ No discharge at this outfall, drainage pipe was capped in May 2001. 
Table C-2I

2006 SPDES Results for Outfall 01B (WNSP01B):

Water Quality

\begin{tabular}{|c|c|c|c|c|c|c|c|}
\hline \multirow{3}{*}{$\begin{array}{l}\text { Permit limit } \\
\text { Month }\end{array}$} & \multirow{2}{*}{\multicolumn{2}{|c|}{$\begin{array}{l}\text { Discharge Rate } \\
\text { (GPD) }\end{array}$}} & \multirow[t]{3}{*}{$\mathbf{N}$} & \multirow{2}{*}{\multicolumn{2}{|c|}{$\begin{array}{c}\text { Mercury, Total } \\
\text { (per EPA Method 245.1) } \\
(\mu \mathrm{g} / \mathrm{L})\end{array}$}} & \multirow{2}{*}{\multicolumn{2}{|c|}{$\begin{array}{c}\begin{array}{c}\text { Mercury, Total } \\
(\text { per EPA Method 1631) } \\
(\mu \mathrm{g} / \mathrm{L})\end{array} \\
10.0 \mu \mathrm{g} / \mathrm{L} \text { daily maximum }\end{array}$}} \\
\hline & & & & & & & \\
\hline & Avg & Max & & Avg & Max & Avg & Max \\
\hline January & -- & -- & -- & -- & -- & -- & -- \\
\hline February & -- & -- & -- & -- & -- & -- & -- \\
\hline March & -- & -- & -- & -- & -- & -- & -- \\
\hline April & -- & -- & -- & -- & -- & -- & -- \\
\hline May & -- & -- & -- & -- & -- & -- & -- \\
\hline June & -- & -- & -- & -- & -- & -- & -- \\
\hline July & -- & -- & -- & -- & -- & -- & -- \\
\hline August & 133 & 133 & 1 & $<0.2$ & $<0.2$ & 0.0155 & 0.0155 \\
\hline September & -- & -- & -- & -- & -- & -- & -- \\
\hline October & -- & -- & -- & -- & -- & -- & -- \\
\hline November & -- & -- & -- & -- & -- & -- & -- \\
\hline December & -- & -- & -- & -- & -- & -- & -- \\
\hline
\end{tabular}

Table C-2J

2006 SPDES Results for Outfall 008 (WNSP008):

Water Quality

NO DISCHARGE;

DRAINAGE PIPE CAPPED IN MAY 2001

WVDP Annual Site Environmental Report

C - 21

Calendar Year 2006 


\section{Table C-2K}

\section{Radioactivity at Sewage Treatment Outfall 007 (WNSP007)}

\begin{tabular}{|c|c|c|c|c|c|c|}
\hline Isotope $^{a}$ & $\mathbf{N}$ & $\begin{array}{l}\text { Discharge } \\
\text { Activity }^{b} \\
\text { (Ci) }\end{array}$ & $\begin{array}{c}\text { Radioactivity }^{c} \\
\text { Becquerels }\end{array}$ & $\begin{array}{c}\text { Average } \\
\text { Concentration } \\
(\mu \mathrm{Ci} / \mathrm{mL})\end{array}$ & $\begin{array}{c}\text { DCG } \\
(\mu \mathrm{Ci} / \mathrm{mL})\end{array}$ & $\%$ of DCG \\
\hline Gross Alpha & 24 & $-5.21 \pm 8.44 \mathrm{E}-06$ & $-1.93 \pm 3.12 \mathrm{E}+05$ & $-3.81 \pm 6.17 \mathrm{E}-10$ & $\mathrm{NA}^{d}$ & NA \\
\hline Gross Beta & 24 & $1.33 \pm 0.19 \mathrm{E}-04$ & $4.93 \pm 0.71 \mathrm{E}+06$ & $9.72 \pm 1.40 \mathrm{E}-09$ & $\mathrm{NA}^{d}$ & NA \\
\hline Tritium & 24 & $1.23 \pm 0.42 \mathrm{E}-03$ & $4.53 \pm 1.55 \mathrm{E}+07$ & $8.95 \pm 3.06 \mathrm{E}-08$ & $2 \mathrm{E}-03$ & $<0.01 \%$ \\
\hline Sr-90 & 2 & $8.59 \pm 5.73 \mathrm{E}-06$ & $3.18 \pm 2.12 \mathrm{E}+05$ & $6.27 \pm 4.18 \mathrm{E}-10$ & $1 \mathrm{E}-06$ & $0.06 \%$ \\
\hline Cs-137 & 2 & $0.32 \pm 4.26 \mathrm{E}-05$ & $0.12 \pm 1.58 \mathrm{E}+06$ & $0.24 \pm 3.11 \mathrm{E}-09$ & $3 \mathrm{E}-06$ & $0.10 \%$ \\
\hline \multicolumn{6}{|l|}{ Total \% DCG } & $0.17 \%$ \\
\hline
\end{tabular}

$N$ - Number of samples

NA - Not applicable

${ }^{a}$ Half-lives are listed in Table UI- 1 .

${ }^{b}$ Total volume released: $1.37 E+10 \mathrm{~mL}(3.62 \mathrm{E}+06 \mathrm{gal})$

${ }^{c} 1$ curie $(\mathrm{Ci})=3.7 E+10$ becquerels $(\mathrm{Bq}) ; 1 \mathrm{~Bq}=2.7 \mathrm{E}-11 \mathrm{Ci}$

${ }^{d}$ DOE-derived concentration guides (DCGs) do not exist for indicator parameters gross alpha and gross beta.

$$
C-22
$$




\section{Appendix C-3 \\ SPDES-Permitted Storm Water Outfall Discharge Data}

$$
\text { C }-23
$$


This page intentionally left blank

$$
\text { C }-24
$$


Table C-3A

\section{Storm Water Discharge Monitoring Data for Outfall Group 1}

Storm Water Outfall S04

\begin{tabular}{|c|c|c|c|c|}
\hline Analyte & Units & $\mathbf{N}$ & $\begin{array}{c}\text { First Flush Grab } \\
5 / 11 / 06 \\
\end{array}$ & $\begin{array}{c}\text { Flow-weighted Composite } \\
5 / 11 / 06 \\
\end{array}$ \\
\hline Aluminum, Total & $\mathrm{mg} / \mathrm{L}$ & 3 & $23.0 / 15.3$ & 9.95 \\
\hline Ammonia $\left(\right.$ as $\left.\mathrm{NH}_{3}\right)$ & $\mathrm{mg} / \mathrm{L}$ & 3 & $0.29 / 0.27$ & 0.14 \\
\hline $\mathrm{BOD}_{5}$ & $\mathrm{mg} / \mathrm{L}$ & 3 & $>18.5 />18.6$ & 8.5 \\
\hline Cadmium, Total Recoverable & $\mathrm{mg} / \mathrm{L}$ & 3 & $0.00039 / 0.00028$ & 0.000085 \\
\hline Chromium, Total Recoverable & $\mathrm{mg} / \mathrm{L}$ & 3 & $0.0322 / 0.0241$ & 0.0132 \\
\hline Chromium, Hexavalent, Total Recoverable & $\mathrm{mg} / \mathrm{L}$ & 3 & $<0.016 /<0.040$ & $<0.016$ \\
\hline Copper, Total Recoverable & $\mathrm{mg} / \mathrm{L}$ & 3 & $0.0311 / 0.0271$ & 0.0172 \\
\hline Iron, Total & $\mathrm{mg} / \mathrm{L}$ & 3 & $41.3 / 24.9$ & 16.0 \\
\hline Lead, Total Recoverable & $\mathrm{mg} / \mathrm{L}$ & 3 & $0.0227 / 0.0137$ & 0.0098 \\
\hline Nitrogen, Nitrate (as N) & $\mathrm{mg} / \mathrm{L}$ & 3 & $1.1 / 0.59$ & 0.58 \\
\hline Nitrogen, Nitrite (as N) & $\mathrm{mg} / \mathrm{L}$ & 3 & $0.083 / 0.095$ & 0.044 \\
\hline Nitrogen, Total (as N) & $\mathrm{mg} / \mathrm{L}$ & 3 & $4.5 / 3.2$ & 1.01 \\
\hline Nitrogen, Total Kjeldahl & $\mathrm{mg} / \mathrm{L}$ & 3 & $3.3 / 2.5$ & 0.39 \\
\hline Oil \& Grease ${ }^{a}$ & $\mathrm{mg} / \mathrm{L}$ & 2 & $<2.2 /<2.2$ & NR \\
\hline $\mathrm{pH}^{b}$ & SU & 1 & 7.58 & NR \\
\hline Phosphorous, Total & $\mathrm{mg} / \mathrm{L}$ & 3 & $0.55 / 0.50$ & 0.360 \\
\hline Selenium, Total Recoverable & $\mathrm{mg} / \mathrm{L}$ & 3 & $<0.00044 /<0.00044$ & $<0.00044$ \\
\hline Solids, Total Dissolved & $\mathrm{mg} / \mathrm{L}$ & 3 & $633 / 844$ & 383 \\
\hline Solids, Total Suspended & $\mathrm{mg} / \mathrm{L}$ & 3 & $1,020 / 1,160$ & 326 \\
\hline Vanadium, Total Recoverable & $\mathrm{mg} / \mathrm{L}$ & 3 & $0.0349 / 0.0266$ & 0.0167 \\
\hline Zinc, Total Recoverable & $\mathrm{mg} / \mathrm{L}$ & 3 & $0.199 / 0.163$ & 0.108 \\
\hline \multicolumn{5}{|c|}{ Rain Event Summary } \\
\hline pH of Rainfall During Sampling Event & SU & 1 & \multicolumn{2}{|c|}{6.39} \\
\hline Rainfall During Sampling Event & inches & -- & \multicolumn{2}{|c|}{0.53} \\
\hline Total Flow During Sampling Event & gallons & -- & \multicolumn{2}{|c|}{479,745} \\
\hline Maximum Flow Rate During Sampling Event & gpm & -- & \multicolumn{2}{|c|}{4,795} \\
\hline
\end{tabular}

Note: The first flush grab samples were sampled and analyzed in duplicate.

$N$ - Number of samples

$N R$ - Not required by permit

${ }^{a}$ The SPDES permit specifies that oil and grease concentrations shall not exceed $15 \mathrm{mg} / \mathrm{L}$.

${ }^{b}$ The SPDES permit specifies that $\mathrm{pH}$ shall not be less than the measured $\mathrm{pH}$ of rainfall collected from the site rain gauge at WNSWRO1 during storm water discharge sampling or $6.0 \mathrm{SU}$, whichever is less, and the pH shall not exceed 9.0. 


\section{Table C-3A (concluded) \\ 2006 Storm Water Discharge Monitoring Data for Outfall Group 1}

\begin{tabular}{|c|c|c|c|c|}
\hline \multicolumn{5}{|c|}{ Storm Water Outfall S04 } \\
\hline Analyte & Units & $\mathbf{N}$ & $\begin{array}{c}\text { First Flush Grab } \\
9 / 28 / 06\end{array}$ & $\begin{array}{c}\text { Flow-weighted Composite } \\
\text { 9/28/06 }\end{array}$ \\
\hline Aluminum, Total & $\mathrm{mg} / \mathrm{L}$ & 3 & $0.134 / 0.176$ & 1.85 \\
\hline Ammonia $\left(\right.$ as $\left.\mathrm{NH}_{3}\right)$ & $\mathrm{mg} / \mathrm{L}$ & 3 & $<0.011 /<0.011$ & 0.044 \\
\hline $\mathrm{BOD}_{5}$ & $\mathrm{mg} / \mathrm{L}$ & 3 & $<2.0 /<2.0$ & 2.3 \\
\hline Cadmium, Total Recoverable & $\mathrm{mg} / \mathrm{L}$ & 3 & $<0.00005 /<0.00005$ & 0.000055 \\
\hline Chromium, Total Recoverable & $\mathrm{mg} / \mathrm{L}$ & 3 & $0.0016 / 0.008$ & 0.0029 \\
\hline Chromium, Hexavalent, Total Recoverable & $\mathrm{mg} / \mathrm{L}$ & 3 & $<0.008 /<0.008$ & $<0.008$ \\
\hline Copper, Total Recoverable & $\mathrm{mg} / \mathrm{L}$ & 3 & $0.0036 / 0.0037$ & 0.0036 \\
\hline Iron, Total & $\mathrm{mg} / \mathrm{L}$ & 3 & $1.72 / 2.22$ & 2.63 \\
\hline Lead, Total Recoverable & $\mathrm{mg} / \mathrm{L}$ & 3 & $0.00081 / 0.0010$ & 0.0026 \\
\hline Nitrogen, Nitrate (as N) & $\mathrm{mg} / \mathrm{L}$ & 3 & $0.050 / 0.043$ & 0.13 \\
\hline Nitrogen, Nitrite (as N) & $\mathrm{mg} / \mathrm{L}$ & 3 & $<0.020 /<0.020$ & $<0.020$ \\
\hline Nitrogen, Total (as N) & $\mathrm{mg} / \mathrm{L}$ & 3 & $<0.16 /<0.15$ & $<0.24$ \\
\hline Nitrogen, Total Kjeldahl & $\mathrm{mg} / \mathrm{L}$ & 3 & $<0.087 /<0.087$ & $<0.087$ \\
\hline Oil \& Grease $^{a}$ & $\mathrm{mg} / \mathrm{L}$ & 2 & $<2.2 /<2.2$ & NR \\
\hline $\mathrm{pH}^{b}$ & SU & 1 & 7.68 & NR \\
\hline Phosphorous, Total & $\mathrm{mg} / \mathrm{L}$ & 3 & $0.099 / 0.100$ & 0.083 \\
\hline Selenium, Total Recoverable & $\mathrm{mg} / \mathrm{L}$ & 3 & $<0.00044 /<0.00044$ & $<0.00044$ \\
\hline Solids, Total Dissolved & $\mathrm{mg} / \mathrm{L}$ & 3 & $817 / 800$ & 311 \\
\hline Solids, Total Suspended & $\mathrm{mg} / \mathrm{L}$ & 3 & $133 / 122$ & 76 \\
\hline Vanadium, Total Recoverable & $\mathrm{mg} / \mathrm{L}$ & 3 & $0.0019 /<0.00098$ & 0.0027 \\
\hline Zinc, Total Recoverable & $\mathrm{mg} / \mathrm{L}$ & 3 & $0.0143 / 0.0179$ & 0.0329 \\
\hline \multicolumn{5}{|c|}{ Rain Event Summary } \\
\hline pH of Rainfall During Sampling Event & SU & 1 & \multicolumn{2}{|c|}{5.64} \\
\hline Rainfall During Sampling Event & inches & -- & \multicolumn{2}{|c|}{0.53} \\
\hline Total Flow During Sampling Event & gallons & -- & \multicolumn{2}{|c|}{833,930} \\
\hline Maximum Flow Rate During Sampling Event & gpm & -- & \multicolumn{2}{|c|}{8,783} \\
\hline
\end{tabular}

Note: The first flush grab samples were sampled and analyzed in duplicate.

$N$ - Number of samples

NR - Not required by permit

${ }^{a}$ The SPDES permit specifies that oil and grease concentrations shall not exceed $15 \mathrm{mg} / \mathrm{L}$.

${ }^{b}$ The September 1, 2006 modified SPDES permit no longer specifies a pH limit; the requirement was reduced to monitoring only. 
Table C-3B

2006 Storm Water Discharge Monitoring Data for Outfall Group 2

Storm Water Outfall S06

\begin{tabular}{|c|c|c|c|c|}
\hline Analyte & Units & $\mathbf{N}$ & $\begin{array}{c}\text { First Flush Grab } \\
6 / 19 / 06\end{array}$ & $\begin{array}{c}\text { Flow-weighted Composite } \\
6 / 19 / 06\end{array}$ \\
\hline Aluminum, Total & $\mathrm{mg} / \mathrm{L}$ & 2 & 0.115 & 1.04 \\
\hline $\mathrm{BOD}_{5}$ & $\mathrm{mg} / \mathrm{L}$ & 2 & 2.0 & 2.0 \\
\hline Copper, Total Recoverable & $\mathrm{mg} / \mathrm{L}$ & 2 & 0.0156 & 0.006 \\
\hline Iron, Total & $\mathrm{mg} / \mathrm{L}$ & 2 & 0.251 & 2.22 \\
\hline Lead, Total Recoverable & $\mathrm{mg} / \mathrm{L}$ & 2 & 0.0027 & 0.0034 \\
\hline Oil \& Grease $^{a}$ & $\mathrm{mg} / \mathrm{L}$ & 1 & $<1.0$ & NR \\
\hline $\mathrm{pH}^{b}$ & SU & 1 & 7.17 & NR \\
\hline Phosphorous, Total & $\mathrm{mg} / \mathrm{L}$ & 2 & 0.12 & 0.26 \\
\hline Solids, Total Dissolved & $\mathrm{mg} / \mathrm{L}$ & 2 & 970 & 280 \\
\hline Solids, Total Suspended & $\mathrm{mg} / \mathrm{L}$ & 2 & 11.2 & 53.8 \\
\hline Surfactant & $\mathrm{mg} / \mathrm{L}$ & 2 & $<0.10$ & 0.10 \\
\hline Zinc, Total Recoverable & $\mathrm{mg} / \mathrm{L}$ & 2 & 0.0151 & 0.0455 \\
\hline \multicolumn{5}{|c|}{ Rain Event Summary } \\
\hline pH of Rainfall During Sampling Event & SU & 1 & \multicolumn{2}{|c|}{6.39} \\
\hline Rainfall During Sampling Event & inches & -- & \multicolumn{2}{|c|}{0.66} \\
\hline Total Flow During Sampling Event & gallons & -- & \multicolumn{2}{|c|}{55,601} \\
\hline Maximum Flow Rate During Sampling Event & gpm & -- & \multicolumn{2}{|c|}{859} \\
\hline
\end{tabular}

$N$ - Number of samples

$N R$ - Not required by permit

${ }^{a}$ The SPDES permit specifies that oil and grease concentrations shall not exceed $15 \mathrm{mg} / \mathrm{L}$.

${ }^{b}$ The SPDES permit specifies that $\mathrm{pH}$ shall not be less than the measured $\mathrm{pH}$ of rainfall collected from the site rain gauge at WNSWROI during storm water discharge sampling or $6.0 \mathrm{SU}$, whichever is less, and the pH shall not exceed 9.0. 
Table C-3B (concluded)

2006 Storm Water Discharge Monitoring Data for Outfall Group 2

Storm Water Outfall S33

\begin{tabular}{|l|c|c|c|c|}
\hline \multicolumn{1}{|c|}{ Analyte } & Units & N & $\begin{array}{c}\text { First Flush Grab } \\
\mathbf{9 / 2 8 / 0 6}\end{array}$ & $\begin{array}{c}\text { Flow-weighted Composite } \\
\mathbf{9 / 2 8 / 0 6}\end{array}$ \\
\hline Aluminum, Total & $\mathrm{mg} / \mathrm{L}$ & 2 & 1.42 & 0.171 \\
\hline BOD $_{5}$ & $\mathrm{mg} / \mathrm{L}$ & 2 & 4.2 & 0.0012 \\
\hline Copper, Total Recoverable & $\mathrm{mg} / \mathrm{L}$ & 2 & 0.0041 & 2.69 \\
\hline Iron, Total & $\mathrm{mg} / \mathrm{L}$ & 2 & 43.9 & 0.00043 \\
\hline Lead, Total Recoverable $^{a}$ & $\mathrm{mg} / \mathrm{L}$ & 2 & 0.0032 & $\mathrm{NR}$ \\
\hline Oil \& Grease $^{\text {( }}$ & $\mathrm{mg} / \mathrm{L}$ & 1 & $<2.2$ & $\mathrm{NR}$ \\
\hline pH $^{b}$ & $\mathrm{SU}$ & 1 & 7.04 & 0.050 \\
\hline Phosphorous, Total & $\mathrm{mg} / \mathrm{L}$ & 2 & 0.67 & 357 \\
\hline Solids, Total Dissolved & $\mathrm{mg} / \mathrm{L}$ & 2 & 394 & 21.0 \\
\hline Solids, Total Suspended & $\mathrm{mg} / \mathrm{L}$ & 2 & 115.0 & 0.026 \\
\hline Surfactant & $\mathrm{mg} / \mathrm{L}$ & 2 & 0.062 & 0.0081 \\
\hline Zinc, Total Recoverable & $\mathrm{mg} / \mathrm{L}$ & 2 & 0.021 & \\
\hline
\end{tabular}

$N$ - Number of samples

NR - Not required by permit

${ }^{a}$ The SPDES permit specifies that oil and grease concentrations shall not exceed $15 \mathrm{mg} / \mathrm{L}$.

${ }^{b}$ The September 1, 2006 modified SPDES permit no longer specifies a pH limit; the requirement was reduced to monitoring only. 
Table C-3C

2006 Storm Water Discharge Monitoring Data for Outfall Group 3

Storm Water Outfall S12

\begin{tabular}{|c|c|c|c|c|}
\hline Analyte & Units & $\mathbf{N}$ & $\begin{array}{c}\text { First Flush Grab } \\
6 / 19 / 06 \\
\end{array}$ & $\begin{array}{c}\text { Flow-weighted Composite } \\
6 / 19 / 06 \\
\end{array}$ \\
\hline Alpha-BHC & $\mathrm{mg} / \mathrm{L}$ & 2 & 0.0000068 & $<0.0000014$ \\
\hline Aluminum, Total & $\mathrm{mg} / \mathrm{L}$ & 2 & 21.5 & 5.86 \\
\hline Ammonia (as $\mathrm{NH}_{3}$ ) & $\mathrm{mg} / \mathrm{L}$ & 2 & 0.14 & 0.028 \\
\hline $\mathrm{BOD}_{5}$ & $\mathrm{mg} / \mathrm{L}$ & 2 & $<2.0$ & 2.0 \\
\hline Copper, Total Recoverable & $\mathrm{mg} / \mathrm{L}$ & 2 & 0.0351 & 0.0042 \\
\hline Iron, Total & $\mathrm{mg} / \mathrm{L}$ & 2 & 34.9 & 6.44 \\
\hline Lead, Total Recoverable & $\mathrm{mg} / \mathrm{L}$ & 2 & 0.0239 & $<0.0001$ \\
\hline Nitrogen, Nitrate (as N) & $\mathrm{mg} / \mathrm{L}$ & 2 & 0.21 & 0.23 \\
\hline Nitrogen, Nitrite (as N) & $\mathrm{mg} / \mathrm{L}$ & 2 & $<0.020$ & $<0.020$ \\
\hline Nitrogen, Total (as N) & $\mathrm{mg} / \mathrm{L}$ & 2 & $<0.32$ & $<0.34$ \\
\hline Nitrogen, Total Kjeldahl & $\mathrm{mg} / \mathrm{L}$ & 2 & $<0.087$ & $<0.087$ \\
\hline Oil \& Grease ${ }^{a}$ & $\mathrm{mg} / \mathrm{L}$ & 1 & $<2.2$ & NR \\
\hline $\mathrm{pH}^{b}$ & SU & 1 & 7.61 & NR \\
\hline Phosphorous, Total & $\mathrm{mg} / \mathrm{L}$ & 2 & 0.63 & 0.16 \\
\hline Solids, Total Dissolved & $\mathrm{mg} / \mathrm{L}$ & 2 & 135 & 128 \\
\hline Solids, Total Suspended & $\mathrm{mg} / \mathrm{L}$ & 2 & 452 & 119 \\
\hline Zinc, Total Recoverable & $\mathrm{mg} / \mathrm{L}$ & 2 & 0.201 & 0.0072 \\
\hline \multicolumn{5}{|c|}{ Rain Event Summary } \\
\hline pH of Rainfall During Sampling Event & SU & 1 & \multicolumn{2}{|c|}{6.39} \\
\hline Rainfall During Sampling Event & inches & -- & \multicolumn{2}{|c|}{0.66} \\
\hline Total Flow During Sampling Event & gallons & -- & \multicolumn{2}{|c|}{38,178} \\
\hline Maximum Flow Rate During Sampling Event & gpm & -- & \multicolumn{2}{|c|}{1,072} \\
\hline
\end{tabular}

$N$ - Number of samples

NR - Not required by permit

${ }^{a}$ The SPDES permit specifies that oil and grease concentrations shall not exceed $15 \mathrm{mg} / \mathrm{L}$.

${ }^{b}$ The SPDES permit specifies that $\mathrm{pH}$ shall not be less than the measured $\mathrm{pH}$ of rainfall collected from the site rain gauge at WNSWRO1 during storm water discharge sampling or $6.0 \mathrm{SU}$, whichever is less, and the pH shall not exceed 9.0. 
Table C-3C (continued)

2006 Storm Water Discharge Monitoring Data for Outfall Group 3

Storm Water Outfall S12

\begin{tabular}{|c|c|c|c|c|}
\hline Analyte & Units & $\mathbf{N}$ & $\begin{array}{c}\text { First Flush Grab } \\
9 / 28 / 06 \\
\end{array}$ & $\begin{array}{c}\text { Flow-weighted Composite } \\
9 / 28 / 06\end{array}$ \\
\hline Alpha-BHC & $\mathrm{mg} / \mathrm{L}$ & 2 & $<0.0000014$ & $<0.0000014$ \\
\hline Aluminum, Total & $\mathrm{mg} / \mathrm{L}$ & 2 & 4.3 & 1.26 \\
\hline Ammonia (as $\mathrm{NH}_{3}$ ) & $\mathrm{mg} / \mathrm{L}$ & 2 & 0.047 & $<0.011$ \\
\hline $\mathrm{BOD}_{5}$ & $\mathrm{mg} / \mathrm{L}$ & 2 & 2.4 & $<2.0$ \\
\hline Copper, Total Recoverable & $\mathrm{mg} / \mathrm{L}$ & 2 & 0.0106 & 0.0070 \\
\hline Iron, Total & $\mathrm{mg} / \mathrm{L}$ & 2 & 10.8 & 2.38 \\
\hline Lead, Total Recoverable & $\mathrm{mg} / \mathrm{L}$ & 2 & 0.0054 & 0.0016 \\
\hline Nitrogen, Nitrate (as N) & $\mathrm{mg} / \mathrm{L}$ & 2 & 0.052 & 0.11 \\
\hline Nitrogen, Nitrite (as N) & $\mathrm{mg} / \mathrm{L}$ & 2 & $<0.020$ & $<0.020$ \\
\hline Nitrogen, Total (as N) & $\mathrm{mg} / \mathrm{L}$ & 2 & $<0.16$ & $<0.22$ \\
\hline Nitrogen, Total Kjeldahl & $\mathrm{mg} / \mathrm{L}$ & 2 & $<0.087$ & $<0.087$ \\
\hline Oil \& Grease ${ }^{a}$ & $\mathrm{mg} / \mathrm{L}$ & 1 & 7.6 & NR \\
\hline $\mathrm{pH}^{b}$ & SU & 1 & 7.19 & NR \\
\hline Phosphorous, Total & $\mathrm{mg} / \mathrm{L}$ & 2 & 0.27 & 0.10 \\
\hline Solids, Total Dissolved & $\mathrm{mg} / \mathrm{L}$ & 2 & 356 & 191 \\
\hline Solids, Total Suspended & $\mathrm{mg} / \mathrm{L}$ & 2 & 187 & 67 \\
\hline Zinc, Total Recoverable & $\mathrm{mg} / \mathrm{L}$ & 2 & 0.0526 & 0.0257 \\
\hline \multicolumn{5}{|c|}{ Rain Event Summary } \\
\hline pH of Rainfall During Sampling Event & SU & 1 & \multicolumn{2}{|c|}{5.64} \\
\hline Rainfall During Sampling Event & inches & -- & \multicolumn{2}{|c|}{0.53} \\
\hline Total Flow During Sampling Event & gallons & -- & \multicolumn{2}{|c|}{19,415} \\
\hline Maximum Flow Rate During Sampling Event & gpm & -- & \multicolumn{2}{|c|}{269} \\
\hline
\end{tabular}

$N$ - Number of samples

NR - Not required by permit

${ }^{a}$ The SPDES permit specifies that oil and grease concentrations shall not exceed $15 \mathrm{mg} / \mathrm{L}$.

${ }^{b}$ The September 1, 2006 modified SPDES permit no longer specifies a pH limit; the requirement was reduced to monitoring only. 
Table C-3C (concluded)

2006 Storm Water Discharge Monitoring Data for Outfall Group 3

Storm Water Outfall S09

\begin{tabular}{|c|c|c|c|c|}
\hline Analyte & Units & $\mathbf{N}$ & $\begin{array}{c}\text { First Flush Grab } \\
10 / 4 / 06\end{array}$ & \begin{tabular}{|c|} 
Flow-weighted Composite \\
10/4/06
\end{tabular} \\
\hline Alpha-BHC & $\mathrm{mg} / \mathrm{L}$ & 2 & $<0.0000014$ & $<0.0000014$ \\
\hline Aluminum, Total & $\mathrm{mg} / \mathrm{L}$ & 2 & 0.729 & 0.879 \\
\hline Ammonia (as $\mathrm{NH}_{3}$ ) & $\mathrm{mg} / \mathrm{L}$ & 2 & 0.044 & 0.011 \\
\hline $\mathrm{BOD}_{5}$ & $\mathrm{mg} / \mathrm{L}$ & 2 & 2.9 & $<2.0$ \\
\hline Copper, Total Recoverable & $\mathrm{mg} / \mathrm{L}$ & 2 & 0.0019 & 0.0023 \\
\hline Iron, Total & $\mathrm{mg} / \mathrm{L}$ & 2 & 0.817 & 1.07 \\
\hline Lead, Total Recoverable & $\mathrm{mg} / \mathrm{L}$ & 2 & 0.0011 & 0.0015 \\
\hline Nitrogen, Nitrate (as N) & $\mathrm{mg} / \mathrm{L}$ & 2 & 0.27 & 0.059 \\
\hline Nitrogen, Nitrite (as N) & $\mathrm{mg} / \mathrm{L}$ & 2 & $<0.020$ & $<0.020$ \\
\hline Nitrogen, Total (as N) & $\mathrm{mg} / \mathrm{L}$ & 2 & $<0.17$ & $<0.38$ \\
\hline Nitrogen, Total Kjeldhal & $\mathrm{mg} / \mathrm{L}$ & 2 & $<0.087$ & $<0.087$ \\
\hline Oil \& Grease ${ }^{a}$ & $\mathrm{mg} / \mathrm{L}$ & 1 & $<2.2$ & NR \\
\hline $\mathrm{pH}^{b}$ & $\mathrm{SU}$ & 1 & 7.83 & NR \\
\hline Phosphorous, Total & $\mathrm{mg} / \mathrm{L}$ & 2 & 0.046 & 0.044 \\
\hline Solids, Total Dissolved & $\mathrm{mg} / \mathrm{L}$ & 2 & 83 & 84 \\
\hline Solids, Total Suspended & $\mathrm{mg} / \mathrm{L}$ & 2 & 37 & 29 \\
\hline Zinc, Total Recoverable & $\mathrm{mg} / \mathrm{L}$ & 2 & 0.0112 & 0.0103 \\
\hline \multicolumn{5}{|c|}{ Rain Event Summary } \\
\hline pH of Rainfall During Sampling Event & SU & 1 & \multicolumn{2}{|c|}{5.71} \\
\hline Rainfall During Sampling Event & inches & -- & \multicolumn{2}{|c|}{0.68} \\
\hline Total Flow During Sampling Event & gallons & -- & \multicolumn{2}{|c|}{32,139} \\
\hline Maximum Flow Rate During Sampling Event & gpm & -- & \multicolumn{2}{|c|}{245} \\
\hline
\end{tabular}

$N$ - Number of samples

NR - Not required by permit

${ }^{a}$ The SPDES permit specifies that oil and grease concentrations shall not exceed $15 \mathrm{mg} / \mathrm{L}$.

${ }^{b}$ The September 1, 2006 modified SPDES permit no longer specifies a pH limit; the requirement was reduced to monitoring only. 
Table C-3D

2006 Storm Water Discharge Monitoring Data for Outfall Group 4

Storm Water Outfall S34

\begin{tabular}{|c|c|c|c|c|}
\hline Analyte & Units & $\mathbf{N}$ & $\begin{array}{c}\text { First Flush Grab } \\
\text { 5/11/06 }\end{array}$ & $\begin{array}{c}\text { Flow-weighted Composite } \\
5 / 11 / 06\end{array}$ \\
\hline Aluminum, Total & $\mathrm{mg} / \mathrm{L}$ & 2 & 24.5 & 11.9 \\
\hline $\mathrm{BOD}_{5}$ & $\mathrm{mg} / \mathrm{L}$ & 2 & $>17.5$ & 13.0 \\
\hline Copper, Total Recoverable & $\mathrm{mg} / \mathrm{L}$ & 2 & $<0.00022$ & 0.0187 \\
\hline Iron, Total & $\mathrm{mg} / \mathrm{L}$ & 2 & 46.2 & 20.9 \\
\hline Lead, Total Recoverable & $\mathrm{mg} / \mathrm{L}$ & 2 & 0.0278 & 0.0134 \\
\hline Oil \& Grease ${ }^{a}$ & $\mathrm{mg} / \mathrm{L}$ & 1 & $<2.2$ & NR \\
\hline $\mathrm{pH}^{b}$ & SU & 1 & 7.84 & NR \\
\hline Phosphorous, Total & $\mathrm{mg} / \mathrm{L}$ & 2 & 0.790 & 0.580 \\
\hline Solids, Total Dissolved & $\mathrm{mg} / \mathrm{L}$ & 2 & 472 & 298 \\
\hline Solids, Total Suspended & $\mathrm{mg} / \mathrm{L}$ & 2 & 1680 & 427 \\
\hline Surfactant & $\mathrm{mg} / \mathrm{L}$ & 2 & 0.026 & 0.026 \\
\hline Zinc, Total Recoverable & $\mathrm{mg} / \mathrm{L}$ & 2 & 0.206 & 0.134 \\
\hline \multicolumn{5}{|c|}{ Rain Event Summary } \\
\hline pH of Rainfall During Sampling Event & SU & 1 & \multicolumn{2}{|r|}{6.39} \\
\hline Rainfall During Sampling Event & inches & -- & \multicolumn{2}{|r|}{0.53} \\
\hline Total Flow During Sampling Event & gallons & -- & \multicolumn{2}{|c|}{136,300} \\
\hline Maximum Flow Rate During Sampling Event & gpm & -- & \multicolumn{2}{|c|}{2,376} \\
\hline
\end{tabular}

$N$ - Number of samples

$N R$ - Not required by permit

${ }^{a}$ The SPDES permit specifies that oil and grease concentrations shall not exceed $15 \mathrm{mg} / \mathrm{L}$.

${ }^{b}$ The SPDES permit specifies that $\mathrm{pH}$ shall not be less than the measured $\mathrm{pH}$ of rainfall collected from the site rain gauge at WNSWRO1 during storm water discharge sampling or $6.0 \mathrm{SU}$, whichever is less, and the pH shall not exceed 9.0. 
Table C-3D (concluded)

2006 Storm Water Discharge Monitoring Data for Outfall Group 4

Storm Water Outfall S34

\begin{tabular}{|c|c|c|c|c|}
\hline Analyte & Units & $\mathbf{N}$ & $\begin{array}{c}\text { First Flush Grab } \\
\text { 9/28/06 }\end{array}$ & $\begin{array}{c}\text { Flow-weighted Composite } \\
9 / 28 / 06\end{array}$ \\
\hline Aluminum, Total & $\mathrm{mg} / \mathrm{L}$ & 2 & 10.4 & 3.34 \\
\hline $\mathrm{BOD}_{5}$ & $\mathrm{mg} / \mathrm{L}$ & 2 & $<2.0$ & 2.2 \\
\hline Copper, Total Recoverable & $\mathrm{mg} / \mathrm{L}$ & 2 & 0.0118 & 0.0041 \\
\hline Iron, Total & $\mathrm{mg} / \mathrm{L}$ & 2 & 18.4 & 3.8 \\
\hline Lead, Total Recoverable & $\mathrm{mg} / \mathrm{L}$ & 2 & 0.0119 & 0.0035 \\
\hline Oil \& Grease $^{a}$ & $\mathrm{mg} / \mathrm{L}$ & 1 & $<2.2$ & NR \\
\hline $\mathrm{pH}^{b}$ & SU & 1 & 7.64 & NR \\
\hline Phosphorous, Total & $\mathrm{mg} / \mathrm{L}$ & 2 & 0.28 & 0.077 \\
\hline Solids, Total Dissolved & $\mathrm{mg} / \mathrm{L}$ & 2 & 294 & 98 \\
\hline Solids, Total Suspended & $\mathrm{mg} / \mathrm{L}$ & 2 & 3,010 & 194 \\
\hline Surfactant & $\mathrm{mg} / \mathrm{L}$ & 2 & 0.064 & 0.062 \\
\hline Zinc, Total Recoverable & $\mathrm{mg} / \mathrm{L}$ & 2 & 0.183 & 0.0537 \\
\hline \multicolumn{5}{|c|}{ Rain Event Summary } \\
\hline pH of Rainfall During Sampling Event & SU & 1 & \multicolumn{2}{|c|}{5.64} \\
\hline Rainfall During Sampling Event & inches & -- & \multicolumn{2}{|c|}{0.53} \\
\hline Total Flow During Sampling Event & gallons & -- & \multicolumn{2}{|c|}{854,772} \\
\hline Maximum Flow Rate During Sampling Event & gpm & -- & \multicolumn{2}{|c|}{5,551} \\
\hline
\end{tabular}

$N$ - Number of samples

NR - Not required by permit

${ }^{a}$ The SPDES permit specifies that oil and grease concentrations shall not exceed $15 \mathrm{mg} / \mathrm{L}$.

${ }^{b}$ The September 1, 2006 modified SPDES permit no longer specifies a pH limit; the requirement was reduced to monitoring only. 
Table C-3E

2006 Storm Water Discharge Monitoring Data for Outfall Group 5

Storm Water Outfall S17

\begin{tabular}{|c|c|c|c|c|}
\hline Analyte & Units & $\mathbf{N}$ & $\begin{array}{c}\text { First Flush Grab } \\
6 / 19 / 06\end{array}$ & $\begin{array}{c}\text { Flow-weighted Composite } \\
6 / 19 / 06\end{array}$ \\
\hline Aluminum, Total & $\mathrm{mg} / \mathrm{L}$ & 2 & 3.44 & 2.01 \\
\hline Ammonia (as $\mathrm{NH}_{3}$ ) & $\mathrm{mg} / \mathrm{L}$ & 2 & 0.057 & $<0.011$ \\
\hline $\mathrm{BOD}_{5}$ & $\mathrm{mg} / \mathrm{L}$ & 2 & 8.9 & $<2.0$ \\
\hline Copper. Total Recoverable & $\mathrm{mg} / \mathrm{L}$ & 2 & 0.0066 & 0.0034 \\
\hline Iron, Total & $\mathrm{mg} / \mathrm{L}$ & 2 & 3.43 & 1.24 \\
\hline Lead, Total Recoverable & $\mathrm{mg} / \mathrm{L}$ & 2 & 0.0022 & 0.0012 \\
\hline Nitrogen, Nitrate (as N) & $\mathrm{mg} / \mathrm{L}$ & 2 & 0.084 & 0.33 \\
\hline Nitrogen, Nitrite (as N) & $\mathrm{mg} / \mathrm{L}$ & 2 & $<0.020$ & $<0.020$ \\
\hline Nitrogen, Total (as N) & $\mathrm{mg} / \mathrm{L}$ & 2 & $<0.19$ & $<0.44$ \\
\hline Nitrogen, Total Kjeldahl & $\mathrm{mg} / \mathrm{L}$ & 2 & $<0.087$ & $<0.087$ \\
\hline Oil \& Grease ${ }^{a}$ & $\mathrm{mg} / \mathrm{L}$ & 1 & 2.3 & NR \\
\hline $\mathrm{pH}^{b}$ & SU & 1 & 7.77 & NR \\
\hline Phosphorous, Total & $\mathrm{mg} / \mathrm{L}$ & 2 & 0.22 & 0.073 \\
\hline Solids, Setttleable & $\mathrm{mL} / \mathrm{L}$ & 2 & 0.5 & 0.2 \\
\hline Solids, Total Dissolved & $\mathrm{mg} / \mathrm{L}$ & 2 & 270 & 217 \\
\hline Solids, Total Suspended & $\mathrm{mg} / \mathrm{L}$ & 2 & 131 & 36 \\
\hline Sulfide & $\mathrm{mg} / \mathrm{L}$ & 2 & 0.23 & 0.093 \\
\hline Surfactant & $\mathrm{mg} / \mathrm{L}$ & 2 & 0.057 & 0.039 \\
\hline Vanadium, Total Recoverable & $\mathrm{mg} / \mathrm{L}$ & 2 & 0.0065 & 0.0041 \\
\hline Zinc, Total Recoverable & $\mathrm{mg} / \mathrm{L}$ & 2 & 0.0227 & 0.0632 \\
\hline \multicolumn{5}{|c|}{ Rain Event Summary } \\
\hline pH of Rainfall During Sampling Event & SU & 1 & \multicolumn{2}{|c|}{6.39} \\
\hline Rainfall During Sampling Event & inches & -- & \multicolumn{2}{|c|}{0.66} \\
\hline Total Flow During Sampling Event & gallons & -- & \multicolumn{2}{|c|}{68,281} \\
\hline Maximum Flow Rate During Sampling Event & gpm & -- & \multicolumn{2}{|c|}{467} \\
\hline
\end{tabular}

$N$ - Number of samples

NR - Not required by permit

${ }^{a}$ The SPDES permit specifies that oil and grease concentrations shall not exceed $15 \mathrm{mg} / \mathrm{L}$.

${ }^{b}$ The SPDES permit specifies that $\mathrm{pH}$ shall not be less than the measured $\mathrm{pH}$ of rainfall collected from the site rain gauge at WNSWRO1 during storm water discharge sampling or $6.0 \mathrm{SU}$, whichever is less, and the pH shall not exceed 9.0. 


\section{Table C-3E (continued) \\ 2006 Storm Water Discharge Monitoring Data for Outfall Group 5}

Storm Water Outfall S14

\begin{tabular}{|c|c|c|c|c|}
\hline Analyte & Units & $\mathbf{N}$ & $\begin{array}{c}\text { First Flush Grab } \\
9 / 28 / 06 \\
\end{array}$ & $\begin{array}{c}\text { Flow-weighted Composite } \\
9 / 28 / 06 \\
\end{array}$ \\
\hline Aluminum, Total & $\mathrm{mg} / \mathrm{L}$ & 2 & 1.67 & 0.262 \\
\hline Ammonia $\left(\right.$ as $\left.\mathrm{NH}_{3}\right)$ & $\mathrm{mg} / \mathrm{L}$ & 2 & $<0.011$ & $<0.011$ \\
\hline $\mathrm{BOD}_{5}$ & $\mathrm{mg} / \mathrm{L}$ & 2 & 5.4 & 2.8 \\
\hline Copper. Total Recoverable & $\mathrm{mg} / \mathrm{L}$ & 2 & 0.0048 & 0.0017 \\
\hline Iron, Total & $\mathrm{mg} / \mathrm{L}$ & 2 & 22.8 & 1.84 \\
\hline Lead, Total Recoverable & $\mathrm{mg} / \mathrm{L}$ & 2 & 0.0023 & 0.00032 \\
\hline Nitrogen, Nitrate (as N) & $\mathrm{mg} / \mathrm{L}$ & 2 & 0.075 & 0.057 \\
\hline Nitrogen, Nitrite (as N) & $\mathrm{mg} / \mathrm{L}$ & 2 & $<0.020$ & $<0.020$ \\
\hline Nitrogen, Total (as N) & $\mathrm{mg} / \mathrm{L}$ & 2 & $<0.22$ & $<0.16$ \\
\hline Nitrogen, Total Kjeldahl & $\mathrm{mg} / \mathrm{L}$ & 2 & 0.12 & $<0.087$ \\
\hline Oil \& Grease ${ }^{a}$ & $\mathrm{mg} / \mathrm{L}$ & 1 & $<2.2$ & NR \\
\hline $\mathrm{pH}^{b}$ & SU & 1 & 7.25 & NR \\
\hline Phosphorous, Total & $\mathrm{mg} / \mathrm{L}$ & 2 & 0.44 & 0.056 \\
\hline Solids, Setttleable & $\mathrm{mL} / \mathrm{L}$ & 2 & 4.5 & 1.2 \\
\hline Solids, Total Dissolved & $\mathrm{mg} / \mathrm{L}$ & 2 & 426 & 482 \\
\hline Solids, Total Suspended & $\mathrm{mg} / \mathrm{L}$ & 2 & 279 & 9 \\
\hline Sulfide & $\mathrm{mg} / \mathrm{L}$ & 2 & $<0.022$ & $<0.022$ \\
\hline Surfactant & $\mathrm{mg} / \mathrm{L}$ & 2 & 0.074 & 0.042 \\
\hline Vanadium, Total Recoverable & $\mathrm{mg} / \mathrm{L}$ & 2 & 0.0032 & $<0.00098$ \\
\hline Zinc, Total Recoverable & $\mathrm{mg} / \mathrm{L}$ & 2 & 0.0117 & 0.0042 \\
\hline \multicolumn{5}{|c|}{ Rain Event Summary } \\
\hline pH of Rainfall During Sampling Event & SU & 1 & \multicolumn{2}{|c|}{5.64} \\
\hline Rainfall During Sampling Event & inches & -- & \multicolumn{2}{|c|}{0.53} \\
\hline Total Flow During Sampling Event & gallons & -- & \multicolumn{2}{|c|}{379} \\
\hline Maximum Flow Rate During Sampling Event & gpm & -- & \multicolumn{2}{|c|}{2.1} \\
\hline
\end{tabular}

$N$ - Number of samples

NR - Not required by permit

${ }^{a}$ The SPDES permit specifies that oil and grease concentrations shall not exceed $15 \mathrm{mg} / \mathrm{L}$.

${ }^{b}$ The September 1, 2006 modified SPDES permit no longer specifies a pH limit; the requirement was reduced to monitoring only. 
Table C-3E (concluded)

2006 Storm Water Discharge Monitoring Data for Outfall Group 5

\section{Storm Water Outfall S28}

\begin{tabular}{|c|c|c|c|c|}
\hline Analyte & Units & $\mathbf{N}$ & $\begin{array}{c}\text { First Flush Grab } \\
10 / 4 / 06\end{array}$ & $\begin{array}{c}\text { Flow-weighted Composite } \\
10 / 4 / 06\end{array}$ \\
\hline Aluminum, Total & $\mathrm{mg} / \mathrm{L}$ & 2 & 0.740 & 1.06 \\
\hline Ammonia (as $\mathrm{NH}_{3}$ ) & $\mathrm{mg} / \mathrm{L}$ & 2 & $<0.011$ & 0.011 \\
\hline $\mathrm{BOD}_{5}$ & $\mathrm{mg} / \mathrm{L}$ & 2 & 3.4 & 2.8 \\
\hline Copper. Total Recoverable & $\mathrm{mg} / \mathrm{L}$ & 2 & 0.0018 & 0.0022 \\
\hline Iron, Total & $\mathrm{mg} / \mathrm{L}$ & 2 & 0.660 & 1.53 \\
\hline Lead, Total Recoverable & $\mathrm{mg} / \mathrm{L}$ & 2 & 0.00034 & 0.0017 \\
\hline Nitrogen, Nitrate (as N) & $\mathrm{mg} / \mathrm{L}$ & 2 & 0.039 & 0.093 \\
\hline Nitrogen, Nitrite (as N) & $\mathrm{mg} / \mathrm{L}$ & 2 & $<0.020$ & $<0.020$ \\
\hline Nitrogen, Total (as N) & $\mathrm{mg} / \mathrm{L}$ & 2 & $<0.15$ & $<0.20$ \\
\hline Nitrogen, Total Kjeldahl & $\mathrm{mg} / \mathrm{L}$ & 2 & $<0.087$ & $<0.087$ \\
\hline Oil \& Grease $^{a}$ & $\mathrm{mg} / \mathrm{L}$ & 1 & $<2.2$ & NR \\
\hline $\mathrm{pH}^{b}$ & SU & 1 & 7.31 & NR \\
\hline Phosphorous, Total & $\mathrm{mg} / \mathrm{L}$ & 2 & 0.010 & 0.052 \\
\hline Solids, Setttleable & $\mathrm{mL} / \mathrm{L}$ & 2 & 0.1 & 0.2 \\
\hline Solids, Total Dissolved & $\mathrm{mg} / \mathrm{L}$ & 2 & 386 & 170 \\
\hline Solids, Total Suspended & $\mathrm{mg} / \mathrm{L}$ & 2 & 17 & 51 \\
\hline Sulfide & $\mathrm{mg} / \mathrm{L}$ & 2 & $<0.022$ & $<0.022$ \\
\hline Surfactant & $\mathrm{mg} / \mathrm{L}$ & 2 & 0.069 & 0.051 \\
\hline Vanadium, Total Recoverable & $\mathrm{mg} / \mathrm{L}$ & 2 & $<0.00098$ & 0.0015 \\
\hline Zinc, Total Recoverable & $\mathrm{mg} / \mathrm{L}$ & 2 & 0.0068 & 0.0112 \\
\hline \multicolumn{5}{|c|}{ Rain Event Summary } \\
\hline pH of Rainfall During Sampling Event & SU & 1 & \multicolumn{2}{|c|}{5.71} \\
\hline Rainfall During Sampling Event & inches & -- & \multicolumn{2}{|c|}{0.68} \\
\hline Total Flow During Sampling Event & gallons & -- & \multicolumn{2}{|c|}{10,138} \\
\hline Maximum Flow Rate During Sampling Event & gpm & -- & \multicolumn{2}{|c|}{136} \\
\hline
\end{tabular}

$N$ - Number of samples

$N R$ - Not required by permit

${ }^{a}$ The SPDES permit specifies that oil and grease concentrations shall not exceed $15 \mathrm{mg} / \mathrm{L}$.

${ }^{b}$ The September 1, 2006 modified SPDES permit no longer specifies a pH limit; the requirement was reduced to monitoring only. 
Table C-3F

2006 Storm Water Discharge Monitoring Data for Outfall Group 6

Storm Water Outfall S39

\begin{tabular}{|c|c|c|c|c|}
\hline Analyte & Units & $\mathbf{N}$ & $\begin{array}{c}\text { First Flush Grab } \\
6 / 27 / 06 \\
\end{array}$ & $\begin{array}{c}\text { Flow-weighted Composite } \\
6 / 27 / 06\end{array}$ \\
\hline Aluminum, Total & $\mathrm{mg} / \mathrm{L}$ & 2 & 21.2 & 14.2 \\
\hline Ammonia (as $\mathrm{NH}_{3}$ ) & $\mathrm{mg} / \mathrm{L}$ & 2 & 0.13 & $<0.011$ \\
\hline $\mathrm{BOD}_{5}$ & $\mathrm{mg} / \mathrm{L}$ & 2 & 8.4 & 2.3 \\
\hline Copper, Total Recoverable & $\mathrm{mg} / \mathrm{L}$ & 2 & 0.0272 & 0.0136 \\
\hline Iron, Total & $\mathrm{mg} / \mathrm{L}$ & 2 & 15.3 & 11.5 \\
\hline Lead, Total Recoverable & $\mathrm{mg} / \mathrm{L}$ & 2 & 0.0062 & 0.0049 \\
\hline Nitrogen, Nitrate (as N) & $\mathrm{mg} / \mathrm{L}$ & 2 & 0.080 & 0.043 \\
\hline Nitrogen, Nitrite (as N) & $\mathrm{mg} / \mathrm{L}$ & 2 & $<0.020$ & $<0.020$ \\
\hline Nitrogen, Total (as N) & $\mathrm{mg} / \mathrm{L}$ & 2 & $<0.94$ & $<0.33$ \\
\hline Nitrogen, Total Kjeldahl & $\mathrm{mg} / \mathrm{L}$ & 2 & 0.84 & 0.27 \\
\hline Oil \& Grease ${ }^{a}$ & $\mathrm{mg} / \mathrm{L}$ & 1 & 3.1 & NR \\
\hline $\mathrm{pH}^{b}$ & SU & 1 & 7.69 & NR \\
\hline Phosphorous, Total & $\mathrm{mg} / \mathrm{L}$ & 2 & 0.24 & 0.35 \\
\hline Solids, Settleable & $\mathrm{mL} / \mathrm{L}$ & 2 & 0.7 & 0.2 \\
\hline Solids, Total Dissolved & $\mathrm{mg} / \mathrm{L}$ & 2 & 318 & 330 \\
\hline Solids, Total Suspended & $\mathrm{mg} / \mathrm{L}$ & 2 & 588 & 190 \\
\hline Sulfide & $\mathrm{mg} / \mathrm{L}$ & 2 & 0.055 & 0.19 \\
\hline Surfactant & $\mathrm{mg} / \mathrm{L}$ & 2 & 0.039 & 0.037 \\
\hline Vanadium, Total Recoverable & $\mathrm{mg} / \mathrm{L}$ & 2 & 0.0205 & 0.0178 \\
\hline Zinc, Total Recoverable & $\mathrm{mg} / \mathrm{L}$ & 2 & 0.146 & 0.198 \\
\hline \multicolumn{5}{|c|}{ Rain Event Summary } \\
\hline pH of Rainfall During Sampling Event & SU & 1 & \multicolumn{2}{|c|}{4.79} \\
\hline Rainfall During Sampling Event & inches & -- & \multicolumn{2}{|c|}{1.24} \\
\hline Total Flow During Sampling Event & gallons & -- & \multicolumn{2}{|c|}{23,349} \\
\hline Maximum Flow Rate During Sampling Event & gpm & -- & \multicolumn{2}{|c|}{324} \\
\hline
\end{tabular}

$N$ - Number of samples

NR - Not required by permit

${ }^{a}$ The SPDES permit specifies that oil and grease concentrations shall not exceed $15 \mathrm{mg} / \mathrm{L}$.

${ }^{b}$ The SPDES permit specifies that $\mathrm{pH}$ shall not be less than the measured $\mathrm{pH}$ of rainfall collected from the site rain gauge at WNSWRO1 during storm water discharge sampling or $6.0 \mathrm{SU}$, whichever is less, and the pH shall not exceed 9.0. 
Table C-3F (continued)

2006 Storm Water Discharge Monitoring Data for Outfall Group 6

Storm Water Outfall S37

\begin{tabular}{|c|c|c|c|c|}
\hline Analyte & Units & $\mathbf{N}$ & $\begin{array}{c}\text { First Flush Grab } \\
10 / 4 / 06\end{array}$ & $\begin{array}{c}\text { Flow-weighted Composite } \\
10 / 4 / 06\end{array}$ \\
\hline Aluminum, Total & $\mathrm{mg} / \mathrm{L}$ & 2 & 0.906 & 0.787 \\
\hline Ammonia (as $\mathrm{NH}_{3}$ ) & $\mathrm{mg} / \mathrm{L}$ & 2 & 0.035 & $<0.011$ \\
\hline $\mathrm{BOD}_{5}$ & $\mathrm{mg} / \mathrm{L}$ & 2 & 2.3 & $<2.0$ \\
\hline Copper, Total Recoverable & $\mathrm{mg} / \mathrm{L}$ & 2 & 0.0023 & 0.0019 \\
\hline Iron, Total & $\mathrm{mg} / \mathrm{L}$ & 2 & 0.866 & 0.818 \\
\hline Lead, Total Recoverable & $\mathrm{mg} / \mathrm{L}$ & 2 & 0.00084 & 0.00070 \\
\hline Nitrogen, Nitrate (as N) & $\mathrm{mg} / \mathrm{L}$ & 2 & 0.084 & $<0.011$ \\
\hline Nitrogen, Nitrite (as N) & $\mathrm{mg} / \mathrm{L}$ & 2 & $<0.020$ & $<0.020$ \\
\hline Nitrogen, Total (as N) & $\mathrm{mg} / \mathrm{L}$ & 2 & $<0.12$ & $<0.19$ \\
\hline Nitrogen, Total Kjeldahl & $\mathrm{mg} / \mathrm{L}$ & 2 & $<0.087$ & $<0.087$ \\
\hline Oil \& Grease $^{a}$ & $\mathrm{mg} / \mathrm{L}$ & 1 & $<2.2$ & NR \\
\hline $\mathrm{pH}^{b}$ & SU & 1 & 7.47 & NR \\
\hline Phosphorous, Total & $\mathrm{mg} / \mathrm{L}$ & 2 & $<0.008$ & $<0.008$ \\
\hline Solids, Settleable & $\mathrm{mL} / \mathrm{L}$ & 2 & 0.1 & $<0.1$ \\
\hline Solids, Total Dissolved & $\mathrm{mg} / \mathrm{L}$ & 2 & 360 & 301 \\
\hline Solids, Total Suspended & $\mathrm{mg} / \mathrm{L}$ & 2 & 30 & 17 \\
\hline Sulfide & $\mathrm{mg} / \mathrm{L}$ & 2 & $<0.022$ & $<0.022$ \\
\hline Surfactant & $\mathrm{mg} / \mathrm{L}$ & 2 & 0.034 & 0.053 \\
\hline Vanadium, Total Recoverable & $\mathrm{mg} / \mathrm{L}$ & 2 & 0.0011 & 0.0010 \\
\hline Zinc, Total Recoverable & $\mathrm{mg} / \mathrm{L}$ & 2 & 0.0102 & 0.0072 \\
\hline \multicolumn{5}{|c|}{ Rain Event Summary } \\
\hline pH of Rainfall During Sampling Event & SU & 1 & \multicolumn{2}{|c|}{5.71} \\
\hline Rainfall During Sampling Event & inches & -- & \multicolumn{2}{|c|}{0.68} \\
\hline Total Flow During Sampling Event & gallons & -- & \multicolumn{2}{|c|}{6,555} \\
\hline Maximum Flow Rate During Sampling Event & gpm & -- & \multicolumn{2}{|c|}{67.7} \\
\hline
\end{tabular}

$N$ - Number of samples

NR - Not required by permit

${ }^{a}$ The SPDES permit specifies that oil and grease concentrations shall not exceed $15 \mathrm{mg} / \mathrm{L}$.

${ }^{b}$ The September 1, 2006 modified SPDES permit no longer specifies a pH limit; the requirement was reduced to monitoring only. 
Table C-3F (concluded)

2006 Storm Water Discharge Monitoring Data for Outfall Group 6

\section{Storm Water Outfall S38}

\begin{tabular}{|c|c|c|c|c|}
\hline Analyte & Units & $\mathbf{N}$ & $\begin{array}{c}\text { First Flush Grab } \\
10 / 4 / 06\end{array}$ & $\begin{array}{c}\text { Flow-weighted Composite } \\
10 / 4 / 06\end{array}$ \\
\hline Aluminum, Total & $\mathrm{mg} / \mathrm{L}$ & 2 & 1.60 & 4.56 \\
\hline Ammonia (as $\mathrm{NH}_{3}$ ) & $\mathrm{mg} / \mathrm{L}$ & 2 & $<0.011$ & $<0.011$ \\
\hline $\mathrm{BOD}_{5}$ & $\mathrm{mg} / \mathrm{L}$ & 2 & $<2.0$ & $<2.0$ \\
\hline Copper, Total Recoverable & $\mathrm{mg} / \mathrm{L}$ & 2 & 0.0019 & 0.0040 \\
\hline Iron, Total & $\mathrm{mg} / \mathrm{L}$ & 2 & 1.53 & 4.81 \\
\hline Lead, Total Recoverable & $\mathrm{mg} / \mathrm{L}$ & 2 & 0.00080 & 0.0022 \\
\hline Nitrogen, Nitrate (as N) & $\mathrm{mg} / \mathrm{L}$ & 2 & $<0.011$ & $<0.011$ \\
\hline Nitrogen, Nitrite (as N) & $\mathrm{mg} / \mathrm{L}$ & 2 & $<0.020$ & $<0.020$ \\
\hline Nitrogen, Total (as N) & $\mathrm{mg} / \mathrm{L}$ & 2 & $<0.12$ & $<0.12$ \\
\hline Nitrogen, Total Kjeldahl & $\mathrm{mg} / \mathrm{L}$ & 2 & $<0.087$ & $<0.087$ \\
\hline Oil \& Grease $^{a}$ & $\mathrm{mg} / \mathrm{L}$ & 1 & $<2.2$ & NR \\
\hline $\mathrm{pH}^{b}$ & SU & 1 & 7.33 & NR \\
\hline Phosphorous, Total & $\mathrm{mg} / \mathrm{L}$ & 2 & $<0.008$ & 0.040 \\
\hline Solids, Settleable & $\mathrm{mL} / \mathrm{L}$ & 2 & 0.2 & 0.2 \\
\hline Solids, Total Dissolved & $\mathrm{mg} / \mathrm{L}$ & 2 & 285 & 317 \\
\hline Solids, Total Suspended & $\mathrm{mg} / \mathrm{L}$ & 2 & 32 & 69 \\
\hline Sulfide & $\mathrm{mg} / \mathrm{L}$ & 2 & $<0.022$ & $<0.022$ \\
\hline Surfactant & $\mathrm{mg} / \mathrm{L}$ & 2 & 0.031 & $<0.013$ \\
\hline Vanadium, Total Recoverable & $\mathrm{mg} / \mathrm{L}$ & 2 & 0.0019 & 0.0071 \\
\hline Zinc, Total Recoverable & $\mathrm{mg} / \mathrm{L}$ & 2 & 0.0147 & 0.0218 \\
\hline \multicolumn{5}{|c|}{ Rain Event Summary } \\
\hline pH of Rainfall During Sampling Event & SU & 1 & \multicolumn{2}{|c|}{5.71} \\
\hline Rainfall During Sampling Event & inches & -- & \multicolumn{2}{|c|}{0.68} \\
\hline Total Flow During Sampling Event & gallons & -- & \multicolumn{2}{|c|}{125,798} \\
\hline Maximum Flow Rate During Sampling Event & gpm & -- & \multicolumn{2}{|c|}{2,027} \\
\hline
\end{tabular}

$N$ - Number of samples

NR - Not required by permit

${ }^{a}$ The SPDES permit specifies that oil and grease concentrations shall not exceed $15 \mathrm{mg} / \mathrm{L}$.

${ }^{b}$ The September 1, 2006 modified SPDES permit no longer specifies a pH limit; the requirement was reduced to monitoring only. 
Table C-3G

2006 Storm Water Discharge Monitoring Data for Outfall Group 7

Storm Water Outfall S20

\begin{tabular}{|c|c|c|c|c|}
\hline Analyte & Units & $\mathbf{N}$ & $\begin{array}{c}\text { First Flush Grab } \\
5 / 15 / 06\end{array}$ & \begin{tabular}{|c|} 
Flow-weighted Composite \\
$5 / 15 / 06$
\end{tabular} \\
\hline Aluminum, Total & $\mathrm{mg} / \mathrm{L}$ & 2 & 0.383 & 0.219 \\
\hline Ammonia (as $\mathrm{NH}_{3}$ ) & $\mathrm{mg} / \mathrm{L}$ & 2 & 0.026 & $<0.011$ \\
\hline $\mathrm{BOD}_{5}$ & $\mathrm{mg} / \mathrm{L}$ & 2 & 4.0 & $<2.0$ \\
\hline Copper, Total Recoverable & $\mathrm{mg} / \mathrm{L}$ & 2 & $<0.00022$ & 0.00091 \\
\hline Iron, Total & $\mathrm{mg} / \mathrm{L}$ & 2 & 0.411 & 0.200 \\
\hline Lead, Total Recoverable & $\mathrm{mg} / \mathrm{L}$ & 2 & $<0.0001$ & 0.00018 \\
\hline Nitrogen, Nitrate (as N) & $\mathrm{mg} / \mathrm{L}$ & 2 & 0.40 & 0.11 \\
\hline Nitrogen, Nitrite (as N) & $\mathrm{mg} / \mathrm{L}$ & 2 & 0.020 & $<0.020$ \\
\hline Nitrogen, Total (as N) & $\mathrm{mg} / \mathrm{L}$ & 2 & 0.56 & $<0.22$ \\
\hline Nitrogen, Total Kjeldahl & $\mathrm{mg} / \mathrm{L}$ & 2 & 0.14 & $<0.087$ \\
\hline Oil \& Grease ${ }^{a}$ & $\mathrm{mg} / \mathrm{L}$ & 1 & $<2.2$ & NR \\
\hline $\mathrm{pH}^{b}$ & $\mathrm{SU}$ & 1 & 7.86 & NR \\
\hline Phosphorous, Total & $\mathrm{mg} / \mathrm{L}$ & 2 & $<0.008$ & $<0.008$ \\
\hline Solids, Total Dissolved & $\mathrm{mg} / \mathrm{L}$ & 2 & 97 & 62 \\
\hline Solids, Total Suspended & $\mathrm{mg} / \mathrm{L}$ & 2 & $<4.0$ & $<4.0$ \\
\hline Sulfide & $\mathrm{mg} / \mathrm{L}$ & 2 & 0.06 & 0.08 \\
\hline Surfactant & $\mathrm{mg} / \mathrm{L}$ & 2 & $<0.013$ & $<0.013$ \\
\hline Zinc, Total Recoverable & $\mathrm{mg} / \mathrm{L}$ & 2 & 0.0069 & 0.0045 \\
\hline \multicolumn{5}{|c|}{ Rain Event Summary } \\
\hline pH of Rainfall During Sampling Event & SU & 1 & \multicolumn{2}{|c|}{7.42} \\
\hline Total Rainfall During Sampling Event & inches & -- & \multicolumn{2}{|c|}{0.21} \\
\hline Total Flow During SamplingEvent & gallons & -- & \multicolumn{2}{|c|}{55,070} \\
\hline Maximum Flow Rate During Sampling Event & gpm & -- & \multicolumn{2}{|c|}{358} \\
\hline
\end{tabular}

\section{$N$ - Number of samples}

NR - Not required by permit

${ }^{a}$ The first flush grab was sampled and analyzed in duplicate and data were averaged.

${ }^{b}$ The SPDES permit specifies that oil and grease concentrations shall not exceed $15 \mathrm{mg} / \mathrm{L}$.

${ }^{c}$ The SPDES permit specifies that $\mathrm{pH}$ shall not be less than the measured $\mathrm{pH}$ of rainfall collected from the site rain gauge at WNSWROI during storm water discharge sampling or $6.0 \mathrm{SU}$, whichever is less, and the pH shall not exceed 9.0. 
Table C-3G (concluded)

2006 Storm Water Discharge Monitoring Data for Outfall Group 7

Storm Water Outfall S20

\begin{tabular}{|c|c|c|c|c|}
\hline Analyte & Units & $\mathbf{N}$ & $\begin{array}{c}\text { First Flush Grab } \\
\text { 8/3/06 }\end{array}$ & $\begin{array}{c}\text { Flow-weighted Composite } \\
8 / 3 / 06\end{array}$ \\
\hline Aluminum, Total & $\mathrm{mg} / \mathrm{L}$ & 2 & 0.464 & 1.24 \\
\hline Ammonia (as $\mathrm{NH}_{3}$ ) & $\mathrm{mg} / \mathrm{L}$ & 2 & $<0.011$ & $<0.011$ \\
\hline $\mathrm{BOD}_{5}$ & $\mathrm{mg} / \mathrm{L}$ & 2 & 2.9 & 2.2 \\
\hline Copper, Total Recoverable & $\mathrm{mg} / \mathrm{L}$ & 2 & 0.0016 & 0.0017 \\
\hline Iron, Total & $\mathrm{mg} / \mathrm{L}$ & 2 & 0.614 & 1.47 \\
\hline Lead, Total Recoverable & $\mathrm{mg} / \mathrm{L}$ & 2 & 0.00048 & 0.00093 \\
\hline Nitrogen, Nitrate (as N) & $\mathrm{mg} / \mathrm{L}$ & 2 & 0.10 & 0.15 \\
\hline Nitrogen, Nitrite (as N) & $\mathrm{mg} / \mathrm{L}$ & 2 & $<0.020$ & $<0.020$ \\
\hline Nitrogen, Total (as N) & $\mathrm{mg} / \mathrm{L}$ & 2 & $<0.21$ & $<0.26$ \\
\hline Nitrogen, Total Kjeldahl & $\mathrm{mg} / \mathrm{L}$ & 2 & $<0.087$ & $<0.087$ \\
\hline Oil \& Grease ${ }^{a}$ & $\mathrm{mg} / \mathrm{L}$ & 1 & $<2.2$ & NR \\
\hline $\mathrm{pH}^{b}$ & SU & 1 & 7.76 & NR \\
\hline Phosphorous, Total & $\mathrm{mg} / \mathrm{L}$ & 2 & 0.054 & 0.036 \\
\hline Solids, Total Dissolved & $\mathrm{mg} / \mathrm{L}$ & 2 & 213 & 62 \\
\hline Solids, Total Suspended & $\mathrm{mg} / \mathrm{L}$ & 2 & 48 & 17 \\
\hline Sulfide & $\mathrm{mg} / \mathrm{L}$ & 2 & $<0.022$ & $<0.022$ \\
\hline Surfactant & $\mathrm{mg} / \mathrm{L}$ & 2 & $<0.013$ & $<0.013$ \\
\hline Zinc, Total Recoverable & $\mathrm{mg} / \mathrm{L}$ & 2 & 0.0089 & 0.014 \\
\hline \multicolumn{5}{|c|}{ Rain Event Summary } \\
\hline pH of Rainfall During Sampling Event & SU & 1 & \multicolumn{2}{|c|}{6.36} \\
\hline Total Rainfall During Sampling Event & inches & -- & \multicolumn{2}{|c|}{0.38} \\
\hline Total Flow During SamplingEvent & gallons & -- & \multicolumn{2}{|c|}{38,205} \\
\hline Maximum Flow Rate During Sampling Event & gpm & -- & \multicolumn{2}{|c|}{611} \\
\hline
\end{tabular}

$N$ - Number of samples

NR - Not required by permit

${ }^{a}$ The SPDES permit specifies that oil and grease concentrations shall not exceed $15 \mathrm{mg} / \mathrm{L}$.

${ }^{b}$ The SPDES permit specifies that $\mathrm{pH}$ shall not be less than the measured $\mathrm{pH}$ of rainfall collected from the site rain gauge at WNSWRO1 during storm water discharge sampling or $6.0 \mathrm{SU}$, whichever is less, and the pH shall not exceed 9.0. 
Table $\mathrm{C}-3 \mathrm{H}$

\section{Storm Water Discharge Monitoring Data for Outfall Group 8}

Storm Water Outfall S27

\begin{tabular}{|c|c|c|c|c|}
\hline Analyte & Units & $\mathbf{N}$ & $\begin{array}{c}\text { First Flush Grab } \\
5 / 15 / 06\end{array}$ & $\begin{array}{c}\text { Flow-weighted Composite } \\
5 / 15 / 06\end{array}$ \\
\hline Aluminum, Total & $\mathrm{mg} / \mathrm{L}$ & 2 & 0.418 & 7.23 \\
\hline Ammonia (as $\mathrm{NH}_{3}$ ) & $\mathrm{mg} / \mathrm{L}$ & 2 & $<0.011$ & $<0.011$ \\
\hline $\mathrm{BOD}_{5}$ & $\mathrm{mg} / \mathrm{L}$ & 2 & $<2.0$ & $<2.0$ \\
\hline Copper, Total Recoverable & $\mathrm{mg} / \mathrm{L}$ & 2 & 0.004 & 0.005 \\
\hline Iron, Total & $\mathrm{mg} / \mathrm{L}$ & 2 & 0.298 & 5.67 \\
\hline Lead, Total Recoverable & $\mathrm{mg} / \mathrm{L}$ & 2 & 0.00067 & 0.0048 \\
\hline Nitrogen, Nitrate (as N) & $\mathrm{mg} / \mathrm{L}$ & 2 & 0.017 & 0.019 \\
\hline Nitrogen, Nitrite (as N) & $\mathrm{mg} / \mathrm{L}$ & 2 & $<0.020$ & 0.057 \\
\hline Nitrogen, Total (as N) & $\mathrm{mg} / \mathrm{L}$ & 2 & $<0.16$ & 0.37 \\
\hline Nitrogen, Total Kjeldahl & $\mathrm{mg} / \mathrm{L}$ & 2 & 0.12 & 0.29 \\
\hline Oil \& Grease ${ }^{a}$ & $\mathrm{mg} / \mathrm{L}$ & 1 & $<2.2$ & NR \\
\hline $\mathrm{pH}^{b}$ & SU & 1 & 6.99 & NR \\
\hline Phosphorous, Total & $\mathrm{mg} / \mathrm{L}$ & 2 & 0.044 & 0.018 \\
\hline Solids, Total Dissolved & $\mathrm{mg} / \mathrm{L}$ & 2 & 272 & 326 \\
\hline Solids, Total Suspended & $\mathrm{mg} / \mathrm{L}$ & 2 & 4.0 & 37.0 \\
\hline Surfactant & $\mathrm{mg} / \mathrm{L}$ & 2 & $<0.013$ & $<0.013$ \\
\hline Zinc, Total Recoverable & $\mathrm{mg} / \mathrm{L}$ & 2 & 0.0083 & 0.0238 \\
\hline \multicolumn{5}{|c|}{ Rain Event Summary } \\
\hline pH of Rainfall During Sampling Event & SU & 1 & \multicolumn{2}{|c|}{7.42} \\
\hline Rainfall During Sampling Event & inches & -- & \multicolumn{2}{|c|}{0.21} \\
\hline Total Flow During Sampling Event & gallons & -- & \multicolumn{2}{|c|}{1,402} \\
\hline Maximum Flow Rate During Sampling Event & gpm & -- & \multicolumn{2}{|c|}{17.6} \\
\hline
\end{tabular}

$N$ - Number of samples

NR - Not required by permit

${ }^{a}$ The SPDES permit specifies that oil and grease concentrations shall not exceed $15 \mathrm{mg} / \mathrm{L}$.

${ }^{b}$ The SPDES permit specifies that $\mathrm{pH}$ shall not be less than the measured $\mathrm{pH}$ of rainfall collected from the site rain gauge at WNSWRO1 during storm water discharge sampling or $6.0 \mathrm{SU}$, whichever is less, and the pH shall not exceed 9.0 . 


\section{Table C-3H (concluded) \\ 2006 Storm Water Discharge Monitoring Data for Outfall Group 8}

\section{Storm Water Outfall S35}

\begin{tabular}{|c|c|c|c|c|}
\hline Analyte & Units & $\mathbf{N}$ & $\begin{array}{c}\text { First Flush Grab } \\
10 / 4 / 06\end{array}$ & $\begin{array}{c}\text { Flow-weighted Composite } \\
\text { 10/4/06 }\end{array}$ \\
\hline Aluminum, Total & $\mathrm{mg} / \mathrm{L}$ & 2 & 0.383 & 0.231 \\
\hline Ammonia (as $\mathrm{NH}_{3}$ ) & $\mathrm{mg} / \mathrm{L}$ & 2 & $<0.011$ & $<0.011$ \\
\hline $\mathrm{BOD}_{5}$ & $\mathrm{mg} / \mathrm{L}$ & 2 & 2.6 & 2.2 \\
\hline Copper, Total Recoverable & $\mathrm{mg} / \mathrm{L}$ & 2 & 0.0012 & 0.0014 \\
\hline Iron, Total & $\mathrm{mg} / \mathrm{L}$ & 2 & 0.355 & 0.185 \\
\hline Lead, Total Recoverable & $\mathrm{mg} / \mathrm{L}$ & 2 & 0.0014 & 0.00065 \\
\hline Nitrogen, Nitrate (as N) & $\mathrm{mg} / \mathrm{L}$ & 2 & 0.11 & 0.060 \\
\hline Nitrogen, Nitrite (as N) & $\mathrm{mg} / \mathrm{L}$ & 2 & $<0.020$ & $<0.020$ \\
\hline Nitrogen, Total (as N) & $\mathrm{mg} / \mathrm{L}$ & 2 & $<0.17$ & $<0.22$ \\
\hline Nitrogen, Total Kjeldahl & $\mathrm{mg} / \mathrm{L}$ & 2 & $<0.087$ & $<0.087$ \\
\hline Oil \& Grease ${ }^{a}$ & $\mathrm{mg} / \mathrm{L}$ & 1 & $<2.2$ & NR \\
\hline $\mathrm{pH}^{b}$ & SU & 1 & 7.22 & NR \\
\hline Phosphorous, Total & $\mathrm{mg} / \mathrm{L}$ & 2 & $<0.008$ & 0.030 \\
\hline Solids, Total Dissolved & $\mathrm{mg} / \mathrm{L}$ & 2 & 254 & 189 \\
\hline Solids, Total Suspended & $\mathrm{mg} / \mathrm{L}$ & 2 & 8.0 & 6.0 \\
\hline Surfactant & $\mathrm{mg} / \mathrm{L}$ & 2 & 0.078 & 0.069 \\
\hline Zinc, Total Recoverable & $\mathrm{mg} / \mathrm{L}$ & 2 & 0.0145 & 0.0222 \\
\hline \multicolumn{5}{|c|}{ Rain Event Summary } \\
\hline pH of Rainfall During Sampling Event & SU & 1 & \multicolumn{2}{|c|}{5.71} \\
\hline Rainfall During Sampling Event & inches & -- & \multicolumn{2}{|c|}{0.68} \\
\hline Total Flow During Sampling Event & gallons & -- & \multicolumn{2}{|c|}{46,033} \\
\hline Maximum Flow Rate During Sampling Event & gpm & -- & \multicolumn{2}{|c|}{451} \\
\hline
\end{tabular}

$N$ - Number of samples

$N R$ - Not required by permit

${ }^{a}$ The SPDES permit specifies that oil and grease concentrations shall not exceed $15 \mathrm{mg} / \mathrm{L}$.

${ }^{b}$ The September 1, 2006 modified SPDES permit no longer specifies a pH limit; the requirement was reduced to monitoring only. 
This page intentionally left blank

$$
C-44
$$




\section{Appendix C-4 \\ Site Surface Drainage, Subsurface Drainage, and Contained Water Data}


This page intentionally left blank

$$
\text { C }-46
$$


Table C-4A

2006 Radioactivity and $\mathrm{pH}$ in Surface Water at Facility Yard Drainage (WNSP005)

\begin{tabular}{|l|c|c|c|c|c|c|}
\hline \multirow{2}{*}{\multicolumn{1}{c|}{ Analyte }} & \multirow{2}{*}{ Units } & \multirow{2}{*}{$\mathbf{N}$} & \multicolumn{3}{c|}{ WNSP005 Concentrations } & \multirow{2}{*}{$\begin{array}{c}\text { Guideline }^{\boldsymbol{a}} \text { or } \\
\text { Standard }^{\boldsymbol{b}}\end{array}$} \\
\cline { 4 - 7 } & & & Minimum & Average & Maximum & \\
\hline Gross Alpha & $\mu \mathrm{Ci} / \mathrm{mL}$ & 12 & $<7.20 \mathrm{E}-10$ & $1.29 \pm 1.96 \mathrm{E}-09$ & $1.85 \mathrm{E}-08$ & $3 \mathrm{E}-08^{c}$ \\
\hline Gross Beta & $\mu \mathrm{Ci} / \mathrm{mL}$ & 12 & $5.02 \mathrm{E}-08$ & $1.68 \pm 0.07 \mathrm{E}-07$ & $3.97 \mathrm{E}-07$ & $1 \mathrm{E}-06^{d}$ \\
\hline Tritium & $\mu \mathrm{Ci} / \mathrm{mL}$ & 12 & $<6.76 \mathrm{E}-08$ & $0.15 \pm 1.03 \mathrm{E}-07$ & $1.36 \mathrm{E}-07$ & $2 \mathrm{E}-03$ \\
\hline Sr-90 & $\mu \mathrm{Ci} / \mathrm{mL}$ & 2 & $6.40 \mathrm{E}-08$ & $7.98 \pm 0.44 \mathrm{E}-08$ & $9.56 \mathrm{E}-08$ & $1 \mathrm{E}-06$ \\
\hline Cs-137 & $\mu \mathrm{Ci} / \mathrm{mL}$ & 2 & $<1.41 \mathrm{E}-09$ & $0.32 \pm 1.43 \mathrm{E}-09$ & $<1.45 \mathrm{E}-09$ & $3 \mathrm{E}-06$ \\
\hline $\mathbf{p H}$ & $\mathrm{SU}$ & 12 & 7.25 & 7.60 & 7.78 & $6.0-9.5$ \\
\hline
\end{tabular}

$N$ - Number of samples

${ }^{a}$ DOE ingestion-based DCGs for $100 \mathrm{mrem} / \mathrm{yr}$ dose limit are provided as a guideline for radiological results.

${ }^{b}$ New York State Water Quality Standards for Class “D” as a comparative reference for nonradiological results

c Alpha as Am-241

${ }^{d}$ Beta as $\mathrm{Sr}-90$

Table C-4B

2006 Radioactivity in Surface Water at French Drain (WNSP008)

NO DISCHARGE FROM THE
FRENCH DRAIN SINCE MAY 2001

WVDP Annual Site Environmental Report

$C-47$

Calendar Year 2006 


\section{Table $C-4 C$}

\section{Water Quality of Surface Water at the North Swamp (WNSW74A)}

\section{RADIOACTIVE CONSTITUENTS}

\begin{tabular}{|c|c|c|c|c|c|c|}
\hline Isotope $^{a}$ & $\mathbf{N}$ & $\begin{array}{l}\text { Discharge } \\
\text { Activity }^{b} \\
\text { (Ci) }\end{array}$ & $\begin{array}{r}\text { Radioactivity }^{c} \\
\text { (Becquerels) }\end{array}$ & $\begin{array}{c}\text { Average } \\
\text { Concentration } \\
(\mu \mathrm{Ci} / \mathrm{mL})\end{array}$ & $\begin{array}{c}\text { DCG } \\
(\mu \mathrm{Ci} / \mathrm{mL})\end{array}$ & $\%$ of DCG \\
\hline Gross Alpha & 26 & $-1.10 \pm 4.00 \mathrm{E}-05$ & $0.41 \pm 1.48 \mathrm{E}+06$ & $-2.35 \pm 8.53 \mathrm{E}-10$ & $\mathrm{NA}^{d}$ & NA \\
\hline Gross Beta & 26 & $9.11 \pm 0.66 \mathrm{E}-04$ & $3.37 \pm 0.24 \mathrm{E}+07$ & $1.95 \pm 0.14 \mathrm{E}-08$ & $\mathrm{NA}^{d}$ & NA \\
\hline Tritium & 26 & $1.41 \pm 1.37 \mathrm{E}-03$ & $5.22 \pm 5.06 \mathrm{E}+07$ & $3.02 \pm 2.92 \mathrm{E}-08$ & $2 \mathrm{E}-03$ & $<0.01$ \\
\hline C-14 & 2 & $2.83 \pm 9.56 \mathrm{E}-04$ & $1.05 \pm 3.54 \mathrm{E}+07$ & $0.61 \pm 2.04 \mathrm{E}-08$ & 7E-05 & 0.03 \\
\hline Sr-90 & 12 & $2.89 \pm 0.17 \mathrm{E}-04$ & $1.07 \pm 0.06 \mathrm{E}+07$ & $6.17 \pm 0.36 \mathrm{E}-09$ & $1 \mathrm{E}-06$ & 0.62 \\
\hline I-129 & 2 & $-0.60 \pm 1.34 \mathrm{E}-05$ & $-2.22 \pm 4.95 \mathrm{E}+05$ & $-1.28 \pm 2.86 \mathrm{E}-10$ & $5 \mathrm{E}-07$ & 0.06 \\
\hline Cs-137 & 12 & $7.01 \pm 7.97 \mathrm{E}-05$ & $2.59 \pm 2.95 \mathrm{E}+06$ & $1.50 \pm 1.70 \mathrm{E}-09$ & $3 \mathrm{E}-06$ & 0.06 \\
\hline $\mathrm{U}-232^{e}$ & 2 & $-1.62 \pm 1.86 \mathrm{E}-06$ & $-6.00 \pm 6.89 \mathrm{E}+04$ & $-3.46 \pm 3.98 \mathrm{E}-11$ & $1 \mathrm{E}-07$ & 0.04 \\
\hline $\mathrm{U}-233 / 234^{e}$ & 2 & $1.15 \pm 0.43 \mathrm{E}-05$ & $4.24 \pm 1.58 \mathrm{E}+05$ & $2.45 \pm 0.91 \mathrm{E}-11$ & $5 \mathrm{E}-07$ & $<0.01$ \\
\hline $\mathrm{U}-235 / 236^{e}$ & 2 & $0.04 \pm 1.58 \mathrm{E}-06$ & $0.16 \pm 5.85 \mathrm{E}+04$ & $0.09 \pm 3.38 \mathrm{E}-11$ & $5 \mathrm{E}-07^{f}$ & 0.01 \\
\hline $\mathbf{U}-238^{e}$ & 2 & $4.35 \pm 2.70 \mathrm{E}-06$ & $1.61 \pm 1.00 \mathrm{E}+05$ & $9.28 \pm 5.76 \mathrm{E}-11$ & $6 \mathrm{E}-07$ & 0.02 \\
\hline Pu-238 & 2 & $6.34 \pm 9.52 \mathrm{E}-07$ & $2.35 \pm 3.52 \mathrm{E}+04$ & $1.35 \pm 2.03 \mathrm{E}-11$ & 4E-08 & 0.05 \\
\hline Pu-239/240 & 2 & $0.53 \pm 1.29 \mathrm{E}-06$ & $1.97 \pm 4.79 \mathrm{E}+04$ & $1.14 \pm 2.76 \mathrm{E}-11$ & 3E-08 & 0.09 \\
\hline Am-241 & 2 & $0.09 \pm 1.03 \mathrm{E}-06$ & $0.32 \pm 3.82 \mathrm{E}+04$ & $0.18 \pm 2.20 \mathrm{E}-11$ & $3 \mathrm{E}-08$ & 0.07 \\
\hline \multicolumn{6}{|l|}{ Total \% of DCG } & 1.05 \\
\hline
\end{tabular}

$N$ - Number of samples

NA - Not applicable

${ }^{a}$ Half-lives are listed in Table UI-1.

${ }^{b}$ Total volume released: $4.68 E+10 \mathrm{~mL}(1.23 E+07 \mathrm{gal})$

${ }^{c} 1$ curie $(\mathrm{Ci})=3.7 \mathrm{E}+10$ becquerels $(\mathrm{Bq}) ; 1 \mathrm{~Bq}=2.7 \mathrm{E}-11 \mathrm{Ci}$

${ }^{d} D O E$-derived concentration guides (DCGs) do not exist for indicator parameters gross alpha and gross beta.

${ }^{e}$ Total Uranium $(\mathrm{g})=1.80 \pm 0.06 \mathrm{E}+01$; Average Total Uranium $(\mu \mathrm{g} / \mathrm{mL})=3.85 \pm 0.12 \mathrm{E}-04$

${ }^{f}$ DCG for U-236 is used for this comparison. 


\section{Table C-4C (continued) 2006 Water Quality of Surface Water at the North Swamp (WNSW74A)}

CHEMICAL CONSTITUENTS

\begin{tabular}{|c|c|c|c|c|c|c|c|}
\hline \multirow{3}{*}{ Analyte } & \multirow{3}{*}{ Units } & \multirow{3}{*}{$\mathbf{N}$} & \multirow{2}{*}{\multicolumn{2}{|c|}{$\begin{array}{c}\text { WNSW74A } \\
\text { Concentrations }\end{array}$}} & \multirow{3}{*}{$\mathbf{N}$} & \multicolumn{2}{|c|}{ Reference Values } \\
\hline & & & & & & \multirow{2}{*}{$\begin{array}{c}\text { Background Range } \\
\text { WFBCBKG }^{a}\end{array}$} & \multirow{2}{*}{ Standard $^{b}$} \\
\hline & & & Average & Maximum & & & \\
\hline Alpha-BHC & $\mu / L$ & 2 & $<0.009$ & $<0.009$ & 2 & $0.005-<0.009$ & 0.002 \\
\hline Aluminum, Total & $\mathrm{mg} / \mathrm{L}$ & 2 & $<0.10$ & $<0.10$ & & NA & -- \\
\hline Ammonia-N & $\mathrm{mg} / \mathrm{L}$ & 2 & $<0.02$ & $<0.02$ & 2 & $<0.02-<0.02$ & $0.67-29$ \\
\hline Antimony, Total & $\mathrm{mg} / \mathrm{L}$ & 2 & $<0.003$ & $<0.003$ & 2 & $<0.003-<0.003$ & -- \\
\hline Arsenic, Dissolved & $\mathrm{mg} / \mathrm{L}$ & 2 & $<0.005$ & $<0.005$ & 2 & $<0.005-<0.005$ & 0.340 \\
\hline Boron, Total & $\mathrm{mg} / \mathrm{L}$ & 2 & 0.04 & 0.05 & 2 & $0.02-0.03$ & -- \\
\hline Bromide & $\mathrm{mg} / \mathrm{L}$ & 2 & $<0.50$ & $<0.50$ & 2 & $<0.50-<0.50$ & -- \\
\hline Cadmium, Total & $\mathrm{mg} / \mathrm{L}$ & 2 & $<0.001$ & $<0.001$ & & NA & -- \\
\hline Calcium, Total & $\mathrm{mg} / \mathrm{L}$ & 2 & 98 & 101 & 12 & $21.6-44.3$ & -- \\
\hline Chromium, Total & $\mathrm{mg} / \mathrm{L}$ & 2 & $<0.010$ & $<0.010$ & & NA & -- \\
\hline Cobalt, Total & $\mathrm{mg} / \mathrm{L}$ & 2 & $<0.005$ & $<0.005$ & 2 & $<0.005-<0.005$ & $0.110^{c}$ \\
\hline Copper, Dissolved & $\mathrm{mg} / \mathrm{L}$ & 2 & $<0.005$ & $<0.005$ & 2 & $<0.005-<0.005$ & $0.039^{d}$ \\
\hline Copper, Total & $\mathrm{mg} / \mathrm{L}$ & 2 & $<0.005$ & $<0.005$ & & NA & -- \\
\hline Fluoride & $\mathrm{mg} / \mathrm{L}$ & 2 & $<0.10$ & 0.11 & 2 & $<0.10-<0.10$ & $29.3^{d}$ \\
\hline Hardness & $\mathrm{mg} / \mathrm{L}$ & 2 & 298 & 307 & 12 & $69-136$ & -- \\
\hline Iron, Total & $\mathrm{mg} / \mathrm{L}$ & 2 & 0.17 & 0.27 & 2 & $0.25-0.55$ & 0.30 \\
\hline Lead, Total & $\mathrm{mg} / \mathrm{L}$ & 2 & $<0.0005$ & $<0.0005$ & & NA & -- \\
\hline Magnesium, Total & $\mathrm{mg} / \mathrm{L}$ & 2 & 12.9 & 13.2 & 12 & $3.58-6.19$ & -- \\
\hline Manganese, Total & $\mathrm{mg} / \mathrm{L}$ & 2 & 0.36 & 0.67 & 2 & $0.02-0.03$ & -- \\
\hline Mercury, Total, Method 1631 & $\mu \mathrm{g} / \mathrm{L}$ & 1 & 0.00101 & 0.00101 & & NA & -- \\
\hline Nickel, Total & $\mathrm{mg} / \mathrm{L}$ & 2 & $<0.04$ & $<0.04$ & & NA & -- \\
\hline Nitrate-N & $\mathrm{mg} / \mathrm{L}$ & 2 & 0.06 & 0.07 & 2 & $0.06-0.13$ & -- \\
\hline Nitrite-N & $\mathrm{mg} / \mathrm{L}$ & 2 & $<0.05$ & $<0.05$ & 2 & $<0.05-<0.05$ & -- \\
\hline NPOC & $\mathrm{mg} / \mathrm{L}$ & 2 & 5.7 & 7.5 & 2 & $1.6-2.2$ & -- \\
\hline Oil \& Grease & $\mathrm{mg} / \mathrm{L}$ & 2 & $<5$ & $<5$ & 2 & $<5-<5$ & -- \\
\hline pH & SU & 27 & 7.33 & 7.89 & 2 & $7.48-7.57$ & $6.0-9.5$ \\
\hline Selenium, Total & $\mathrm{mg} / \mathrm{L}$ & 2 & $<0.001$ & $<0.001$ & & NA & -- \\
\hline Solids, Total Dissolved & $\mathrm{mg} / \mathrm{L}$ & 2 & 806 & 843 & 2 & 202-204 & -- \\
\hline Solids, Total Suspended & $\mathrm{mg} / \mathrm{L}$ & 2 & $<4$ & 5 & 2 & $10-20$ & -- \\
\hline
\end{tabular}

$N$ - Number of samples

NA - No data available

-- No guideline or standard available for these analytes

${ }^{a}$ Background location

${ }^{b}$ New York State Water Quality Standards, Class "D" as a comparative reference for nonradiological results at WNSW74A

${ }^{c}$ Standards for cobalt, thallium, and vanadium are applicable to the acid-soluble fraction.

${ }^{d}$ Calculated from maximum measurement of hardness of surface water drainage at WNSW74A 


\section{Table C-4C (concluded)}

2006 Water Quality of Surface Water at the North Swamp (WNSW74A)

\section{CHEMICAL CONSTITUENTS (concluded)}

\begin{tabular}{|c|c|c|c|c|c|c|c|}
\hline \multirow{3}{*}{ Analyte } & \multirow{3}{*}{ Units } & \multirow{3}{*}{$\mathbf{N}$} & \multirow{2}{*}{\multicolumn{2}{|c|}{$\begin{array}{c}\text { WNSW74A } \\
\text { Concentrations }\end{array}$}} & \multirow{3}{*}{$\mathbf{N}$} & \multicolumn{2}{|c|}{ Reference Values } \\
\hline & & & & & & \multirow{2}{*}{$\begin{array}{l}\text { Background Range } \\
\text { WFBCBKG }^{a}\end{array}$} & \multirow{2}{*}{ Standard } \\
\hline & & & Average & Maximum & & & \\
\hline Sulfate & $\mathrm{mg} / \mathrm{L}$ & 2 & 37.2 & 43.3 & 2 & $19.7-21.7$ & -- \\
\hline Sulfide & $\mathrm{mg} / \mathrm{L}$ & 2 & $<0.05$ & 0.05 & 2 & $<0.04-0.06$ & -- \\
\hline Surfactants & $\mathrm{mg} / \mathrm{L}$ & 2 & $<0.10$ & $<0.10$ & 2 & $<0.02-<0.10$ & -- \\
\hline Thallium, Total & $\mathrm{mg} / \mathrm{L}$ & 2 & $<0.008$ & $<0.008$ & 2 & $<0.008-<0.008$ & $0.020^{c}$ \\
\hline Titanium, Total & $\mathrm{mg} / \mathrm{L}$ & 2 & $<0.05$ & $<0.05$ & 2 & $<0.05-<0.05$ & -- \\
\hline TOX & $\mathrm{mg} / \mathrm{L}$ & 2 & 0.03 & 0.03 & 2 & $<0.01-0.01$ & -- \\
\hline Vanadium, Total & $\mathrm{mg} / \mathrm{L}$ & 2 & $<0.01$ & $<0.01$ & 2 & $<0.01-<0.01$ & $0.190^{c}$ \\
\hline Zinc, Total & $\mathrm{mg} / \mathrm{L}$ & 2 & $<0.02$ & $<0.02$ & 0 & NA & -- \\
\hline
\end{tabular}

$N$ - Number of samples

NA - No data available

-- No guideline or standard available for these analytes

${ }^{a}$ Background location

${ }^{b}$ New York State Water Quality Standards, Class "D" as a comparative reference for nonradiological results at WNSW74A

${ }^{c}$ Standards for cobalt, thallium, and vanadium are applicable to the acid-soluble fraction. 
Table C-4D

2006 Water Quality of Surface Water at the Northeast Swamp (WNSWAMP)

RADIOACTIVE CONSTITUENTS

\begin{tabular}{|c|c|c|c|c|c|c|}
\hline Isotope $^{a}$ & $\mathbf{N}$ & $\begin{array}{l}\text { Discharge } \\
\text { Activity }^{b} \\
\text { (Ci) }\end{array}$ & $\begin{array}{r}\text { Radioactivity }^{c} \\
\text { (Becquerels) }\end{array}$ & $\begin{array}{c}\text { Average } \\
\text { Concentration } \\
(\mu \mathrm{Ci} / \mathrm{mL})\end{array}$ & $\begin{array}{c}\text { DCG } \\
(\mu \mathrm{Ci} / \mathrm{mL})\end{array}$ & $\%$ of DCG \\
\hline Gross Alpha & 26 & $-1.40 \pm 9.58 \mathrm{E}-05$ & $-0.52 \pm 3.55 \mathrm{E}+06$ & $-0.77 \pm 5.29 \mathrm{E}-10$ & $\mathrm{NA}^{d}$ & NA \\
\hline Gross Beta & 26 & $4.21 \pm 0.01 \mathrm{E}-01$ & $1.56 \pm 0.01 \mathrm{E}+10$ & $2.32 \pm 0.01 \mathrm{E}-06$ & $\mathrm{NA}^{d}$ & NA \\
\hline Tritium & 26 & $2.57 \pm 0.71 \mathrm{E}-02$ & $9.52 \pm 2.61 \mathrm{E}+08$ & $1.40 \pm 0.39 \mathrm{E}-07$ & $2 \mathrm{E}-03$ & 0.01 \\
\hline C-14 & 2 & $2.30 \pm 4.92 \mathrm{E}-03$ & $0.85 \pm 1.82 \mathrm{E}+08$ & $1.27 \pm 2.72 \mathrm{E}-08$ & 7E-05 & 0.01 \\
\hline Sr-90 & 12 & $2.20 \pm 0.01 \mathrm{E}-01$ & $8.14 \pm 0.04 \mathrm{E}+09$ & $1.21 \pm 0.01 \mathrm{E}-06$ & $1 \mathrm{E}-06$ & 121 \\
\hline I-129 & 2 & $1.43 \pm 8.71 \mathrm{E}-05$ & $0.53 \pm 3.22 \mathrm{E}+06$ & $0.79 \pm 4.81 \mathrm{E}-10$ & $5 \mathrm{E}-07$ & 0.14 \\
\hline Cs-137 & 12 & $1.50 \pm 2.18 \mathrm{E}-04$ & $5.53 \pm 8.07 \mathrm{E}+06$ & $0.83 \pm 1.20 \mathrm{E}-09$ & $3 \mathrm{E}-06$ & 0.01 \\
\hline $\mathrm{U}-232^{e}$ & 2 & $-2.64 \pm 4.77 \mathrm{E}-06$ & $-0.98 \pm 1.77 \mathrm{E}+05$ & $-1.45 \pm 2.63 \mathrm{E}-11$ & $1 \mathrm{E}-07$ & $<0.01$ \\
\hline $\mathrm{U}-233 / 234^{e}$ & 2 & $2.55 \pm 1.07 \mathrm{E}-05$ & $9.44 \pm 3.95 \mathrm{E}+05$ & $1.41 \pm 0.59 \mathrm{E}-10$ & $5 \mathrm{E}-07$ & 0.04 \\
\hline $\mathrm{U}-235 / 236^{e}$ & 2 & $3.63 \pm 4.81 \mathrm{E}-06$ & $1.34 \pm 1.78 \mathrm{E}+05$ & $2.00 \pm 2.65 \mathrm{E}-11$ & $5 \mathrm{E}-07^{f}$ & 0.01 \\
\hline $\mathrm{U}-238^{e}$ & 2 & $1.42 \pm 0.86 \mathrm{E}-05$ & $5.25 \pm 3.17 \mathrm{E}+05$ & $7.84 \pm 4.73 \mathrm{E}-11$ & $6 \mathrm{E}-07$ & 0.02 \\
\hline Pu-238 & 2 & $3.03 \pm 3.33 \mathrm{E}-06$ & $1.12 \pm 1.23 \mathrm{E}+05$ & $1.67 \pm 1.84 \mathrm{E}-11$ & 4E-08 & 0.28 \\
\hline $\mathrm{Pu}-239 / 240$ & 2 & $5.18 \pm 4.63 \mathrm{E}-06$ & $1.92 \pm 1.71 \mathrm{E}+05$ & $2.86 \pm 2.56 \mathrm{E}-11$ & 3E-08 & $<0.01$ \\
\hline Am-241 & 2 & $-0.53 \pm 3.46 \mathrm{E}-06$ & $-0.20 \pm 1.28 \mathrm{E}+05$ & $-0.29 \pm 1.91 \mathrm{E}-11$ & $3 \mathrm{E}-08$ & $<0.01$ \\
\hline \multicolumn{6}{|c|}{ Total \% of DCG } & 121 \\
\hline
\end{tabular}

$N$ - Number of samples

NA - Not applicable

${ }^{a}$ Half-lives are listed in Table UI-1.

${ }^{b}$ Total volume released: $1.81 E+11 \mathrm{~mL}(4.79 E+07$ gal $)$

${ }^{c} 1$ curie $(\mathrm{Ci})=3.7 \mathrm{E}+10$ becquerels $(\mathrm{Bq}) ; 1 \mathrm{~Bq}=2.7 \mathrm{E}-11 \mathrm{Ci}$

${ }^{d} D O E$-derived concentration guides (DCGs) do not exist for indicator parameters gross alpha and gross beta.

${ }^{e}$ Total Uranium $(\mathrm{g})=9.86 \pm 0.34 \mathrm{E}+01$; Average Total Uranium $(\mu \mathrm{g} / \mathrm{mL})=5.44 \pm 0.19 E-04$

${ }^{f} D C G$ for $U-236$ is used for this comparison. 
Table C-4D (continued)

2006 Water Quality of Surface Water at the Northeast Swamp (WNSWAMP)

CHEMICAL CONSTITUENTS

\begin{tabular}{|c|c|c|c|c|c|c|c|}
\hline \multirow{3}{*}{ Analyte } & \multirow{3}{*}{ Units } & \multirow{3}{*}{$\mathbf{N}$} & \multirow{2}{*}{\multicolumn{2}{|c|}{$\begin{array}{c}\text { WNSWAMP } \\
\text { Concentrations }\end{array}$}} & \multirow{3}{*}{$\mathbf{N}$} & \multicolumn{2}{|c|}{ Reference Values } \\
\hline & & & & & & \multirow{2}{*}{$\begin{array}{c}\text { WFBCBKG }^{a} \\
\text { Background Range }\end{array}$} & \multirow{2}{*}{ Standard $^{b}$} \\
\hline & & & Average & Maximum & & & \\
\hline Alpha-BHC & $\mu / L$ & 2 & $<0.020$ & $<0.020$ & 2 & $0.005-<0.009$ & 0.002 \\
\hline Aluminum, Total & $\mathrm{mg} / \mathrm{L}$ & 2 & $<0.15$ & $<0.20$ & 0 & NA & -- \\
\hline Ammonia-N & $\mathrm{mg} / \mathrm{L}$ & 2 & $<0.13$ & 0.16 & 2 & $<0.02-<0.02$ & $0.67-29$ \\
\hline Antimony, Total & $\mathrm{mg} / \mathrm{L}$ & 2 & $<0.004$ & $<0.004$ & 2 & $<0.003-<0.003$ & -- \\
\hline Arsenic, Dissolved & $\mathrm{mg} / \mathrm{L}$ & 2 & $<0.006$ & $<0.006$ & 2 & $<0.005-<0.005$ & 0.340 \\
\hline Boron, Total & $\mathrm{mg} / \mathrm{L}$ & 2 & 0.06 & 0.08 & 2 & $0.02-0.03$ & -- \\
\hline Bromide & $\mathrm{mg} / \mathrm{L}$ & 2 & $<0.68$ & 0.87 & 2 & $<0.50-<0.50$ & -- \\
\hline Cadmium, Total & $\mathrm{mg} / \mathrm{L}$ & 2 & $<0.0008$ & $<0.001$ & 0 & NA & - \\
\hline Calcium, Total & $\mathrm{mg} / \mathrm{L}$ & 2 & 107.6 & 125.0 & 12 & $21.6-44.3$ & -- \\
\hline Chromium, Total & $\mathrm{mg} / \mathrm{L}$ & 2 & $<0.0032$ & $<0.005$ & 0 & NA & - \\
\hline Cobalt, Total & $\mathrm{mg} / \mathrm{L}$ & 2 & $<0.003$ & $<0.005$ & 2 & $<0.005-<0.005$ & $0.110^{c}$ \\
\hline Copper, Dissolved & $\mathrm{mg} / \mathrm{L}$ & 2 & $<0.003$ & $<0.005$ & 2 & $<0.005-<0.005$ & $0.047^{d}$ \\
\hline Copper, Total & $\mathrm{mg} / \mathrm{L}$ & 2 & $<0.003$ & $<0.005$ & 0 & NA & -- \\
\hline Fluoride & $\mathrm{mg} / \mathrm{L}$ & 2 & $<0.10$ & $<0.10$ & 2 & $<0.10-<0.10$ & $35.6^{d}$ \\
\hline Hardness & $\mathrm{mg} / \mathrm{L}$ & 2 & 326 & 380 & 12 & 69-136 & -- \\
\hline Iron, Total & $\mathrm{mg} / \mathrm{L}$ & 2 & 0.18 & 0.20 & 2 & $0.25-0.55$ & 0.30 \\
\hline Lead, Total & $\mathrm{mg} / \mathrm{L}$ & 2 & $<0.0026$ & $<0.0031$ & 0 & NA & -- \\
\hline Magnesium, Total & $\mathrm{mg} / \mathrm{L}$ & 2 & 13.95 & 16.40 & 12 & $3.58-6.19$ & -- \\
\hline Manganese, Total & $\mathrm{mg} / \mathrm{L}$ & 2 & 0.25 & 0.32 & 2 & $0.02-0.03$ & -- \\
\hline Mercury, Total, Method 1631 & $\mu \mathrm{g} / \mathrm{L}$ & 2 & 0.000624 & 0.000653 & 0 & NA & -- \\
\hline Nickel, Total & $\mathrm{mg} / \mathrm{L}$ & 2 & $<0.0037$ & $<0.0050$ & 0 & NA & -- \\
\hline Nitrate-N & $\mathrm{mg} / \mathrm{L}$ & 2 & $<0.32$ & $<0.50$ & 2 & $0.06-0.13$ & -- \\
\hline Nitrite-N & $\mathrm{mg} / \mathrm{L}$ & 2 & $<1.30$ & $<2.50$ & 2 & $<0.05-<0.05$ & -- \\
\hline NPOC & $\mathrm{mg} / \mathrm{L}$ & 2 & 5.1 & 5.7 & 2 & $1.6-2.2$ & -- \\
\hline Oil \& Grease & $\mathrm{mg} / \mathrm{L}$ & 2 & 1 & 1 & 2 & $<5-<5$ & -- \\
\hline pH & SU & 28 & 7.40 & 8.05 & 2 & $7.48-7.57$ & $6.0-9.5$ \\
\hline Selenium, Total & $\mathrm{mg} / \mathrm{L}$ & 2 & $<0.005$ & $<0.005$ & 0 & NA & -- \\
\hline Solids, Total Dissolved & $\mathrm{mg} / \mathrm{L}$ & 2 & 473 & 887 & 2 & $202-204$ & -- \\
\hline Solids, Total Suspended & $\mathrm{mg} / \mathrm{L}$ & 2 & $<3$ & $<5$ & 2 & $10-20$ & -- \\
\hline
\end{tabular}

$N$ - Number of samples

NA - No data available

-- No guideline or standard available for these analytes

${ }^{a}$ Background location

${ }^{b}$ New York State Water Quality Standards, Class “D” as a comparative reference for nonradiological results at WNSWAMP

${ }^{c}$ Standards for cobalt, thallium, and vanadium are applicable to the acid-soluble fraction.

${ }^{d}$ Calculated from maximum measurement of hardness of surface water drainage at WNSWAMP 


\section{Table C-4D (concluded) \\ 2006 Water Quality of Surface Water at the Northeast Swamp (WNSWAMP)}

\section{CHEMICAL CONSTITUENTS (concluded)}

\begin{tabular}{|c|c|c|c|c|c|c|c|}
\hline \multirow{3}{*}{ Analyte } & \multirow{3}{*}{ Units } & \multirow{3}{*}{$\mathbf{N}$} & \multirow{2}{*}{\multicolumn{2}{|c|}{$\begin{array}{l}\text { WNSWAMP } \\
\text { Concentrations }\end{array}$}} & \multirow{3}{*}{$\mathbf{N}$} & \multicolumn{2}{|c|}{ Reference Values } \\
\hline & & & & & & \multirow{2}{*}{$\begin{array}{c}\text { WFBCBKG }^{a} \\
\text { Background Range }\end{array}$} & \multirow{2}{*}{ Standard $^{b}$} \\
\hline & & & Average & Maximum & & & \\
\hline Sulfate & $\mathrm{mg} / \mathrm{L}$ & 2 & 22.8 & 25.2 & 2 & $19.7-21.7$ & -- \\
\hline Sulfide (as $\mathbf{S}$ ) & $\mathrm{mg} / \mathrm{L}$ & 2 & $<0.55$ & $<1.00$ & 2 & $<0.04-0.06$ & -- \\
\hline Surfactant & $\mathrm{mg} / \mathrm{L}$ & 2 & $<0.10$ & $<0.10$ & 2 & $<0.02-<0.10$ & -- \\
\hline Thallium, Total & $\mathrm{mg} / \mathrm{L}$ & 2 & $<0.008$ & $<0.008$ & 2 & $<0.008-<0.008$ & $0.020^{c}$ \\
\hline Titanium, Total & $\mathrm{mg} / \mathrm{L}$ & 2 & $<0.003$ & 0.006 & 2 & $<0.05-<0.05$ & -- \\
\hline TOX & $\mathrm{mg} / \mathrm{L}$ & 2 & 0.03 & 0.04 & 2 & $<0.01-0.01$ & -- \\
\hline Vanadium, Total & $\mathrm{mg} / \mathrm{L}$ & 2 & $<0.003$ & $<0.005$ & 2 & $<0.01-<0.01$ & $0.190^{c}$ \\
\hline Zinc, Total & $\mathrm{mg} / \mathrm{L}$ & 2 & $<0.01$ & $<0.01$ & 0 & NA & -- \\
\hline
\end{tabular}

$N$ - Number of samples

NA - No data available

-- No guideline or standard available for these analytes

${ }^{a}$ Background location

${ }^{b}$ New York State Water Quality Standards, Class "D" as a comparative reference for nonradiological results at WNSWAMP

${ }^{c}$ Standards for cobalt, thallium, and vanadium are applicable to the acid-soluble fraction. 
Table C-4E

2006 Water Quality Results at Storage and Disposal Area Drainage

(WNNDADR)

\begin{tabular}{|l|c|c|c|c|c|c|}
\hline \multirow{2}{*}{\multicolumn{1}{c|}{ Analyte }} & \multirow{2}{*}{ Units } & \multirow{2}{*}{$\mathbf{N}$} & \multicolumn{3}{c|}{ WNNDADR Concentrations } & \multirow{2}{*}{ Standard $^{a}$} \\
\cline { 4 - 7 } & & & Minimum & Average & Maximum & \\
\hline Gross Alpha & $\mu \mathrm{Ci} / \mathrm{mL}$ & 16 & $<5.96 \mathrm{E}-10$ & $9.98 \pm 9.56 \mathrm{E}-10$ & $5.20 \mathrm{E}-09$ & -- \\
\hline Gross Beta & $\mu \mathrm{Ci} / \mathrm{mL}$ & 16 & $1.30 \mathrm{E}-07$ & $2.18 \pm 0.05 \mathrm{E}-07$ & $3.37 \mathrm{E}-07$ & -- \\
\hline Tritium & $\mu \mathrm{Ci} / \mathrm{mL}$ & 27 & $<1.17 \mathrm{E}-07$ & $7.80 \pm 1.36 \mathrm{E}-07$ & $1.64 \mathrm{E}-06$ & -- \\
\hline Sr-90 & $\mu \mathrm{Ci} / \mathrm{mL}$ & 2 & $8.79 \mathrm{E}-08$ & $1.05 \pm 0.04 \mathrm{E}-07$ & $1.22 \mathrm{E}-07$ & - \\
\hline I-129 & $\mu \mathrm{Ci} / \mathrm{mL}$ & 2 & $<3.74 \mathrm{E}-10$ & $0.03 \pm 3.37 \mathrm{E}-10$ & $4.24 \mathrm{E}-10$ & - \\
\hline Cs-137 & $\mu \mathrm{Ci} / \mathrm{mL}$ & 12 & $<1.83 \mathrm{E}-09$ & $0.68 \pm 3.66 \mathrm{E}-09$ & $2.48 \mathrm{E}-09$ & -- \\
\hline NPOC & $\mathrm{mg} / \mathrm{L}$ & 26 & 1.8 & 5.3 & 9.6 & - \\
\hline pH & $\mathrm{SU}$ & 26 & 6.94 & 7.59 & 8.13 & $6.0-9.5$ \\
\hline TOX & $\mathrm{mg} / \mathrm{L}$ & 26 & $<0.01$ & $<0.01$ & 0.02 & -- \\
\hline
\end{tabular}

$N$ - Number of samples

-- No applicable reference standard available

${ }^{a}$ New York State Water Quality Standards, Class “D” as a comparative reference for nonradiological results at WNNDADR

Table C-4F

2006 Water Quality Results in Subsurface Water at the NDA Interceptor Trench (WNNDATR)

\begin{tabular}{|l|c|c|c|c|c|}
\hline \multicolumn{1}{c|}{ Analyte } & \multirow{2}{*}{ Units } & \multirow{2}{*}{ N } & \multicolumn{3}{c|}{ WNNDATR Concentrations } \\
\cline { 4 - 6 } & & & Minimum & Average & Maximum \\
\hline Gross Alpha & $\mu \mathrm{Ci} / \mathrm{mL}$ & 12 & $1.25 \mathrm{E}-09$ & $2.77 \pm 1.60 \mathrm{E}-09$ & $7.67 \mathrm{E}-09$ \\
\hline Gross Beta & $\mu \mathrm{Ci} / \mathrm{mL}$ & 12 & $1.60 \mathrm{E}-07$ & $2.70 \pm 0.09 \mathrm{E}-07$ & $4.66 \mathrm{E}-07$ \\
\hline Tritium & $\mu \mathrm{Ci} / \mathrm{mL}$ & 12 & $1.04 \mathrm{E}-07$ & $2.34 \pm 0.18 \mathrm{E}-06$ & $4.41 \mathrm{E}-06$ \\
\hline I-129 & $\mu \mathrm{Ci} / \mathrm{mL}$ & 2 & $5.55 \mathrm{E}-10$ & $8.48 \pm 5.53 \mathrm{E}-10$ & $1.14 \mathrm{E}-09$ \\
\hline Cs-137 & $\mu \mathrm{Ci} / \mathrm{mL}$ & 12 & $<1.84 \mathrm{E}-09$ & $0.82 \pm 3.16 \mathrm{E}-09$ & $2.96 \mathrm{E}-09$ \\
\hline NPOC & $\mathrm{mg} / \mathrm{L}$ & 12 & 2.0 & 4.5 & 6.5 \\
\hline TOX & $\mathrm{mg} / \mathrm{L}$ & 12 & $<0.01$ & 0.01 & 0.04 \\
\hline
\end{tabular}

Note: No applicable reference standard available for this location. These waters are pumped and treated at the LLWTF prior to discharge at outfall WNSP001.

$N$ - Number of samples 


\section{Table C-4G}

\section{Radioactivity and $\mathrm{pH}$ in Surface Water at Cooling Tower Basin (WNCOOLW)}

\begin{tabular}{|l|c|c|c|}
\hline \multicolumn{1}{|c|}{ Analyte } & Units & N & WNCOOLW \\
\hline Gross Alpha & $\mu \mathrm{Ci} / \mathrm{mL}$ & 1 & $-1.62 \pm 4.49 \mathrm{E}-10$ \\
\hline Gross Beta & $\mu \mathrm{Ci} / \mathrm{mL}$ & 1 & $3.11 \pm 1.43 \mathrm{E}-09$ \\
\hline Tritium & $\mu \mathrm{Ci} / \mathrm{mL}$ & 1 & $-0.24 \pm 1.04 \mathrm{E}-07$ \\
\hline Sr-90 & $\mu \mathrm{Ci} / \mathrm{mL}$ & 1 & $0.76 \pm 4.79 \mathrm{E}-10$ \\
\hline Cs-137 & $\mu \mathrm{Ci} / \mathrm{mL}$ & 1 & $0.81 \pm 2.95 \mathrm{E}-09$ \\
\hline pH & $\mathrm{SU}$ & 1 & 7.66 \\
\hline
\end{tabular}

Note: No applicable reference standard available for this location. These waters are pumped and treated at the LLWTF prior to discharge at outfall WNSPOO1.

$N$ - Number of samples 
This page intentionally left blank

$$
C-56
$$




\section{Appendix C-5 Ambient Surface Water Data}

C - 57 
This page intentionally left blank

$$
\text { C }-58
$$


Table C-5A

2006 Radioactivity and pH in Surface Water Downstream of the WVDP in Cattaraugus Creek at Felton Bridge (WFFELBR)

\begin{tabular}{|c|c|c|c|c|c|c|c|}
\hline \multirow{3}{*}{ Analyte } & \multirow{3}{*}{ Units } & \multirow{3}{*}{$\mathbf{N}$} & \multirow{2}{*}{\multicolumn{2}{|c|}{$\begin{array}{c}\text { WFFELBR } \\
\text { Concentrations }\end{array}$}} & \multirow{3}{*}{$\mathbf{N}$} & \multicolumn{2}{|c|}{ Reference Values } \\
\hline & & & & & & \multirow{2}{*}{$\begin{array}{c}\text { WFBIGBR }^{a} \\
\text { Background Range }\end{array}$} & \multirow{2}{*}{$\begin{array}{c}\text { Guideline }^{b} \\
\text { or Standard }^{c}\end{array}$} \\
\hline & & & Average & Maximum & & & \\
\hline Gross Alpha & $\mu \mathrm{Ci} / \mathrm{mL}$ & 12 & $1.43 \pm 0.99 \mathrm{E}-09^{d}$ & $2.37 \mathrm{E}-09^{d}$ & 4 & $<3.59 \mathrm{E}-10-<9.42 \mathrm{E}-10$ & $3 \mathrm{E}-08^{e}$ \\
\hline Gross Beta & $\mu \mathrm{Ci} / \mathrm{mL}$ & 12 & $6.40 \pm 1.68 \mathrm{E}-09^{d}$ & $1.23 \mathrm{E}-08^{d}$ & 4 & 2.85E-09-3.62E-09 & $1 \mathrm{E}-06^{f}$ \\
\hline Tritium & $\mu \mathrm{Ci} / \mathrm{mL}$ & 12 & $0.54 \pm 9.76 \mathrm{E}-08^{d}$ & $1.59 \mathrm{E}-07^{d}$ & 4 & $<7.86 \mathrm{E}-08-<1.19 \mathrm{E}-07$ & $2 \mathrm{E}-03$ \\
\hline Sr-90 & $\mu \mathrm{Ci} / \mathrm{mL}$ & 12 & $5.46 \pm 7.07 \mathrm{E}-10$ & $1.83 \mathrm{E}-09$ & 4 & $<4.03 \mathrm{E}-10-4.79 \mathrm{E}-10$ & $1 \mathrm{E}-06$ \\
\hline Tc-99 & $\mu \mathrm{Ci} / \mathrm{mL}$ & 2 & $1.33 \pm 1.77 \mathrm{E}-09$ & $1.91 \mathrm{E}-09$ & 0 & NA & $1 \mathrm{E}-04$ \\
\hline Cs-137 & $\mu \mathrm{Ci} / \mathrm{mL}$ & 12 & $0.80 \pm 3.95 \mathrm{E}-09$ & $<9.12 \mathrm{E}-09$ & 4 & $<2.60 \mathrm{E}-09-<5.69 \mathrm{E}-09$ & $3 \mathrm{E}-06$ \\
\hline pH & SU & 33 & 7.86 & 8.36 & 4 & $8.10-8.30$ & $6.5-8.5$ \\
\hline
\end{tabular}

$N$ - Number of samples

NA - Data not available

${ }^{a}$ Background location

${ }^{b}$ DOE ingestion-based DCGs for 100 mrem/yr dose limit are provided as a guideline for radiological results in the absence of water quality standards.

"New York State Water Quality Standards, Class "B” as a comparative reference for nonradiological results

${ }^{d}$ Values represent composite concentrations weighted to monthly stream flow.

e Alpha as Am-241

${ }^{f}$ Beta as $\mathrm{Sr}-90$ 
Table C-5B

2006 Water Quality of Surface Water Downstream of the WVDP in Buttermilk Creek at Thomas Corners Bridge (WFBCTCB)

RADIOACTIVITY CONCENTRATIONS

\begin{tabular}{|c|c|c|c|c|c|c|c|}
\hline \multirow{3}{*}{ Analyte } & \multirow{3}{*}{ Units } & \multirow{3}{*}{$\mathbf{N}$} & \multirow{2}{*}{\multicolumn{2}{|c|}{$\begin{array}{c}\text { WFBCTCB } \\
\text { Concentrations }\end{array}$}} & \multirow{3}{*}{$\mathbf{N}$} & \multicolumn{2}{|c|}{ Reference Values } \\
\hline & & & & & & \multirow{2}{*}{$\begin{array}{c}\text { WFBCBKG }^{a} \\
\text { Background Range }\end{array}$} & \multirow{2}{*}{ Guideline $^{b}$} \\
\hline & & & Average & Maximum & & & \\
\hline Gross Alpha & $\mu \mathrm{Ci} / \mathrm{mL}$ & 12 & $1.38 \pm 0.77 \mathrm{E}-09$ & $6.70 \mathrm{E}-09$ & 12 & $<4.47 \mathrm{E}-10-2.58 \mathrm{E}-09$ & $3 \mathrm{E}-08^{c}$ \\
\hline Gross Beta & $\mu \mathrm{Ci} / \mathrm{mL}$ & 12 & $1.02 \pm 0.14 \mathrm{E}-08$ & $2.29 \mathrm{E}-08$ & 12 & $<1.61 \mathrm{E}-09-7.34 \mathrm{E}-09$ & $1 \mathrm{E}-06^{d}$ \\
\hline Tritium & $\mu \mathrm{Ci} / \mathrm{mL}$ & 12 & $3.59 \pm 9.55 \mathrm{E}-08$ & $7.48 \mathrm{E}-08$ & 12 & $<7.13 \mathrm{E}-08-1.02 \mathrm{E}-07$ & $2 \mathrm{E}-03$ \\
\hline Sr-90 & $\mu \mathrm{Ci} / \mathrm{mL}$ & 2 & $2.68 \pm 0.84 \mathrm{E}-09$ & 3.70E-09 & 4 & 2.74E-10-1.16E-09 & $1 \mathrm{E}-06$ \\
\hline Tc-99 & $\mu \mathrm{Ci} / \mathrm{mL}$ & 2 & $1.46 \pm 1.72 \mathrm{E}-09$ & $2.80 \mathrm{E}-09$ & 4 & 2.02E-09-2.02E-09 & $1 \mathrm{E}-04$ \\
\hline Cs-137 & $\mu \mathrm{Ci} / \mathrm{mL}$ & 2 & $1.37 \pm 4.20 \mathrm{E}-09$ & $<5.60 \mathrm{E}-09$ & 4 & $<1.90 \mathrm{E}-09-<4.41 \mathrm{E}-09$ & $3 \mathrm{E}-06$ \\
\hline
\end{tabular}

$N$ - Number of samples

a Background location

${ }^{b}$ DOE ingestion-based DCGs for $100 \mathrm{mrem} / \mathrm{yr}$ dose limit are provided as a guideline for radiological results in the absence of water quality standards.

${ }^{c}$ Alpha as Am-241

${ }^{d}$ Beta as Sr-90 
Table C-5B (continued)

2006 Water Quality of Surface Water Downstream of the WVDP in Buttermilk Creek at Thomas Corners Bridge (WFBCTCB)

CHEMICAL CONSTITUENTS

\begin{tabular}{|c|c|c|c|c|c|c|c|}
\hline \multirow{3}{*}{ Analyte } & \multirow{3}{*}{ Units } & \multirow{3}{*}{$\mathbf{N}$} & \multirow{2}{*}{\multicolumn{2}{|c|}{$\begin{array}{c}\text { WFBCTCB } \\
\text { Concentrations }\end{array}$}} & \multirow{3}{*}{$\mathbf{N}$} & \multicolumn{2}{|c|}{ Reference Values } \\
\hline & & & & & & \multirow{2}{*}{$\begin{array}{c}\text { WFBCBKG }^{a} \\
\text { Background Range }\end{array}$} & \multirow{2}{*}{ Standard $^{b}$} \\
\hline & & & Average & Maximum & & & \\
\hline Alpha-BHC & $\mu \mathrm{g} / \mathrm{L}$ & 2 & $<0.0078$ & $<0.0090$ & 2 & $<0.0050-0.0093$ & 0.002 \\
\hline Aluminum, Dissolved & $\mathrm{mg} / \mathrm{L}$ & 2 & $<0.100$ & $<0.100$ & 2 & $<0.100-<0.100$ & 0.10 \\
\hline Ammonia-N & $\mathrm{mg} / \mathrm{L}$ & 2 & $<0.06$ & 0.09 & 2 & $<0.02-<0.02$ & $0.09-2.1$ \\
\hline Antimony, Total & $\mathrm{mg} / \mathrm{L}$ & 2 & $<0.003$ & $<0.003$ & 2 & $<0.003-<0.003$ & -- \\
\hline Arsenic, Dissolved & $\mathrm{mg} / \mathrm{L}$ & 2 & $<0.005$ & $<0.005$ & 2 & $<0.005-<0.005$ & 0.150 \\
\hline Barium, Total & $\mathrm{mg} / \mathrm{L}$ & 2 & 0.07 & 0.07 & 2 & $0.08-0.10$ & -- \\
\hline Boron, Total & $\mathrm{mg} / \mathrm{L}$ & 2 & 0.03 & 0.03 & 2 & $0.02-0.03$ & 10.0 \\
\hline Bromide & $\mathrm{mg} / \mathrm{L}$ & 2 & $<0.50$ & $<0.50$ & 2 & $<0.50-<0.50$ & -- \\
\hline Cadmium, Dissolved & $\mathrm{mg} / \mathrm{L}$ & 2 & $<0.001$ & $<0.001$ & 2 & $<0.001-<0.001$ & $0.003^{c}$ \\
\hline Calcium, Total & $\mathrm{mg} / \mathrm{L}$ & 12 & 38.8 & 49.4 & 12 & $21.6-44.3$ & -- \\
\hline Chloride & $\mathrm{mg} / \mathrm{L}$ & 2 & 28 & 29 & 2 & 19-20 & -- \\
\hline Chromium, Dissolved & $\mathrm{mg} / \mathrm{L}$ & 2 & $<0.01$ & $<0.01$ & 2 & $<0.01-<0.01$ & $0.118^{c}$ \\
\hline Cobalt, Total & $\mathrm{mg} / \mathrm{L}$ & 2 & $<0.005$ & $<0.005$ & 2 & $<0.005-<0.005$ & $0.005^{d}$ \\
\hline Copper, Dissolved & $\mathrm{mg} / \mathrm{L}$ & 2 & $<0.005$ & $<0.005$ & 2 & $<0.005-<0.005$ & $0.015^{c}$ \\
\hline Dissolved, Oxygen & $\mathrm{mg} / \mathrm{L}$ & 2 & 10.2 & 10.8 & 2 & $9.5-11.0$ & $4.0(\mathrm{~min})$ \\
\hline Fluoride & $\mathrm{mg} / \mathrm{L}$ & 2 & $<0.10$ & $<0.10$ & 2 & $<0.10-<0.10$ & $3.56^{c}$ \\
\hline Hardness & $\mathrm{mg} / \mathrm{L}$ & 12 & 125 & 177 & 12 & 69-136 & -- \\
\hline Iron, Total & $\mathrm{mg} / \mathrm{L}$ & 2 & 0.41 & 0.49 & 2 & $0.25-0.55$ & 0.30 \\
\hline Lead, Dissolved & $\mathrm{mg} / \mathrm{L}$ & 2 & $<0.0005$ & $<0.0005$ & 2 & $<0.0005-<0.0005$ & $0.007^{c}$ \\
\hline Magnesium, Total & $\mathrm{mg} / \mathrm{L}$ & 12 & 6.79 & 14.4 & 12 & $3.58-6.19$ & -- \\
\hline Manganese, Total & $\mathrm{mg} / \mathrm{L}$ & 2 & 0.01 & 0.01 & 2 & $0.02-0.03$ & -- \\
\hline Mercury, Dissolved, Method 1631 & $\mu \mathrm{g} / \mathrm{L}$ & 2 & 0.000991 & 0.00106 & 2 & $0.000958-0.000972$ & -- \\
\hline Nickel, Dissolved & $\mathrm{mg} / \mathrm{L}$ & 2 & $<0.04$ & $<0.04$ & 2 & $<0.04-<0.04$ & $0.084^{c}$ \\
\hline Nitrate-N & $\mathrm{mg} / \mathrm{L}$ & 2 & 0.56 & 0.60 & 2 & $0.06-0.13$ & -- \\
\hline Nitrite-N & $\mathrm{mg} / \mathrm{L}$ & 2 & $<0.05$ & $<0.05$ & 2 & $<0.05-<0.05$ & 0.10 \\
\hline NPOC & $\mathrm{mg} / \mathrm{L}$ & 2 & $<1.0$ & $<1.0$ & 2 & $1.6-2.2$ & -- \\
\hline
\end{tabular}

$N$ - Number of samples

-- No reference standard available for this analyte

${ }^{a}$ Background location

${ }^{b}$ New York State Water Quality Standards, Class “C” as a comparative reference for nonradiological results

${ }^{c}$ Calculated from maximum measurement of hardness of surface water stream at WFBCTCB

${ }^{d}$ Standards for cobalt, thallium, and vanadium are applicable to the acid-soluble fraction. 


\section{Table C-5B (concluded)}

2006 Water Quality of Surface Water Downstream of the WVDP in Buttermilk Creek at Thomas Corners Bridge (WFBCTCB)

\section{CHEMICAL CONSTITUENTS (concluded)}

\begin{tabular}{|c|c|c|c|c|c|c|c|}
\hline \multirow{3}{*}{ Analyte } & \multirow{3}{*}{ Units } & \multirow{3}{*}{$\mathbf{N}$} & \multirow{2}{*}{\multicolumn{2}{|c|}{$\begin{array}{c}\text { WFBCTCB } \\
\text { Concentrations }\end{array}$}} & \multirow{3}{*}{$\mathbf{N}$} & \multicolumn{2}{|c|}{ Reference Values } \\
\hline & & & & & & \multirow{2}{*}{$\begin{array}{c}\text { WFBCBKG }^{a} \\
\text { Background Range }\end{array}$} & \multirow{2}{*}{ Standard $^{b}$} \\
\hline & & & Average & Maximum & & & \\
\hline Oil \& Grease & $\mathrm{mg} / \mathrm{L}$ & 2 & $<5$ & $<5$ & 2 & $<5-<5$ & -- \\
\hline pH & SU & 2 & 6.92 & 7.32 & 2 & $7.48-7.57$ & $6.5-8.5$ \\
\hline Selenium, Dissolved & $\mathrm{mg} / \mathrm{L}$ & 2 & $<0.001$ & $<0.001$ & 2 & $<0.001-<0.001$ & 0.0046 \\
\hline Sodium, Total & $\mathrm{mg} / \mathrm{L}$ & 2 & 17.7 & 18.5 & 2 & $11.6-13.5$ & -- \\
\hline Solids, Total Dissolved & $\mathrm{mg} / \mathrm{L}$ & 2 & 250 & 297 & 2 & 202-204 & 500 \\
\hline Solids, Total Suspended & $\mathrm{mg} / \mathrm{L}$ & 2 & $<4$ & $<4$ & 2 & $10-20$ & -- \\
\hline Sulfate & $\mathrm{mg} / \mathrm{L}$ & 2 & 25.0 & 25.7 & 2 & $19.7-21.7$ & -- \\
\hline Sulfide (as S) & $\mathrm{mg} / \mathrm{L}$ & 2 & $<0.06$ & 0.08 & 2 & $<0.04-0.06$ & 0.002 \\
\hline Surfactant & $\mathrm{mg} / \mathrm{L}$ & 2 & $<0.10$ & $<0.10$ & 2 & $<0.02-<0.10$ & 0.04 \\
\hline Thallium, Total & $\mathrm{mg} / \mathrm{L}$ & 2 & $<0.008$ & $<0.008$ & 2 & $<0.008-<0.008$ & $0.008^{d}$ \\
\hline Titanium, Total & $\mathrm{mg} / \mathrm{L}$ & 2 & $<0.0500$ & $<0.0500$ & 2 & $<0.0500-<0.0500$ & -- \\
\hline TOX & $\mathrm{mg} / \mathrm{L}$ & 2 & $<0.01$ & $<0.01$ & 2 & $<0.01-0.01$ & -- \\
\hline Vanadium, Total & $\mathrm{mg} / \mathrm{L}$ & 2 & $<0.0100$ & $<0.0100$ & 2 & $<0.0100-<0.0100$ & $0.014^{d}$ \\
\hline Zinc, Dissolved & $\mathrm{mg} / \mathrm{L}$ & 2 & $<0.02$ & $<0.02$ & 2 & $<0.02-<0.02$ & $0.134^{c}$ \\
\hline
\end{tabular}

$N$ - Number of samples

-- No reference standard available for this analyte

${ }^{a}$ Background location

${ }^{b}$ New York State Water Quality Standards, Class “C” as a comparative reference for nonradiological results

${ }^{c}$ Calculated from maximum measurement of hardness of surface water stream at WFBCTCB

${ }^{d}$ Standards for cobalt, thallium, and vanadium are applicable to the acid-soluble fraction. 


\section{Table C-5C}

\section{Water Quality of Surface Water Downstream of the WVDP at Frank's Creek (WNSP006)}

\section{RADIOACTIVITY CONCENTRATIONS}

\begin{tabular}{|c|c|c|c|c|c|c|c|}
\hline \multirow{3}{*}{ Analyte } & \multirow{3}{*}{ Units } & \multirow{3}{*}{$\mathbf{N}$} & \multirow{2}{*}{\multicolumn{2}{|c|}{$\begin{array}{c}\text { WNSP006 } \\
\text { Concentrations }\end{array}$}} & \multirow{3}{*}{$\mathbf{N}$} & \multicolumn{2}{|c|}{ Reference Values } \\
\hline & & & & & & \multirow{2}{*}{$\begin{array}{c}\text { WFBCBKG }^{a} \\
\text { Background Range }\end{array}$} & \multirow{2}{*}{ Guideline $^{b}$} \\
\hline & & & Average & Maximum & & & \\
\hline Gross Alpha & $\mu \mathrm{Ci} / \mathrm{mL}$ & 33 & 1.41土1.19E-09 & $5.49 \mathrm{E}-09$ & 12 & $<4.47 \mathrm{E}-10-2.58 \mathrm{E}-09$ & $3 \mathrm{E}-08^{c}$ \\
\hline Gross Beta & $\mu \mathrm{Ci} / \mathrm{mL}$ & 33 & $4.18 \pm 0.30 \mathrm{E}-08$ & $9.65 \mathrm{E}-08$ & 12 & $<1.61 \mathrm{E}-09-7.34 \mathrm{E}-09$ & $1 \mathrm{E}-06^{d}$ \\
\hline Tritium & $\mu \mathrm{Ci} / \mathrm{mL}$ & 33 & $0.90 \pm 1.06 \mathrm{E}-07$ & $3.58 \mathrm{E}-07$ & 12 & $<7.13 \mathrm{E}-08-1.02 \mathrm{E}-07$ & $2 \mathrm{E}-03$ \\
\hline C-14 & $\mu \mathrm{Ci} / \mathrm{mL}$ & 4 & $-0.11 \pm 3.05 E-08$ & $<3.73 \mathrm{E}-08$ & 4 & $<2.37 \mathrm{E}-08-<3.72 \mathrm{E}-08$ & 7E-05 \\
\hline Sr-90 & $\mu \mathrm{Ci} / \mathrm{mL}$ & 12 & $1.31 \pm 0.17 \mathrm{E}-08$ & $1.95 \mathrm{E}-08$ & 4 & $2.74 \mathrm{E}-10-1.16 \mathrm{E}-09$ & $1 \mathrm{E}-06$ \\
\hline Tc-99 & $\mu \mathrm{Ci} / \mathrm{mL}$ & 4 & $1.35 \pm 1.83 \mathrm{E}-09$ & $1.94 \mathrm{E}-09$ & 4 & 2.02E-09-2.02E-09 & $1 \mathrm{E}-04$ \\
\hline I-129 & $\mu \mathrm{Ci} / \mathrm{mL}$ & 4 & $0.61 \pm 4.66 \mathrm{E}-10$ & $4.55 \mathrm{E}-10$ & 4 & $<2.60 \mathrm{E}-10-<6.41 \mathrm{E}-10$ & $5 \mathrm{E}-07$ \\
\hline Cs-137 & $\mu \mathrm{Ci} / \mathrm{mL}$ & 12 & $2.77 \pm 4.69 \mathrm{E}-09$ & 5.01E-09 & 4 & $<1.90 \mathrm{E}-09-<4.41 \mathrm{E}-09$ & $3 \mathrm{E}-06$ \\
\hline U-232 & $\mu \mathrm{Ci} / \mathrm{mL}$ & 4 & $1.55 \pm 1.04 \mathrm{E}-10$ & $4.79 \mathrm{E}-10$ & 4 & $<7.63 \mathrm{E}-12-<6.37 \mathrm{E}-11$ & 1E-07 \\
\hline U-233/234 & $\mu \mathrm{Ci} / \mathrm{mL}$ & 4 & $2.58 \pm 1.20 \mathrm{E}-10$ & $3.15 \mathrm{E}-10$ & 4 & 7.47E-11-2.19E-10 & $5 \mathrm{E}-07$ \\
\hline U-235/236 & $\mu \mathrm{Ci} / \mathrm{mL}$ & 4 & $1.44 \pm 3.78 \mathrm{E}-11$ & $<5.70 \mathrm{E}-11$ & 4 & $<3.28 \mathrm{E}-11-<7.01 \mathrm{E}-11$ & $5 \mathrm{E}-07^{e}$ \\
\hline U-238 & $\mu \mathrm{Ci} / \mathrm{mL}$ & 4 & $1.95 \pm 1.04 \mathrm{E}-10$ & $2.38 \mathrm{E}-10$ & 4 & $<3.74 \mathrm{E}-11-1.25 \mathrm{E}-10$ & $6 \mathrm{E}-07$ \\
\hline Total U & $\mu \mathrm{g} / \mathrm{mL}$ & 4 & $7.54 \pm 0.23 \mathrm{E}-04$ & $1.05 \mathrm{E}-03$ & 4 & $1.57 \mathrm{E}-04-4.45 \mathrm{E}-04$ & -- \\
\hline Pu-238 & $\mu \mathrm{Ci} / \mathrm{mL}$ & 4 & $0.21 \pm 3.09 \mathrm{E}-11$ & $<4.05 \mathrm{E}-11$ & 4 & $<1.57 \mathrm{E}-11-<3.31 \mathrm{E}-11$ & 4E-08 \\
\hline Pu-239/240 & $\mu \mathrm{Ci} / \mathrm{mL}$ & 4 & $0.77 \pm 3.31 \mathrm{E}-11$ & $<4.11 \mathrm{E}-11$ & 4 & $<2.03 \mathrm{E}-11-<3.53 \mathrm{E}-11$ & 3E-08 \\
\hline Am-241 & $\mu \mathrm{Ci} / \mathrm{mL}$ & 4 & $0.10 \pm 1.81 \mathrm{E}-11$ & $<2.45 \mathrm{E}-11$ & 4 & $<7.25 \mathrm{E}-12-<4.51 \mathrm{E}-11$ & 3E-08 \\
\hline
\end{tabular}

$N$ - Number of samples

-- No guideline or standard available for these analytes

${ }^{a}$ Background location

${ }^{b}$ DOE ingestion-based DCGs for $100 \mathrm{mrem} / y \mathrm{r}$ dose limit are provided as a guideline for radiological results.

${ }^{c}$ Alpha as Am-241

${ }^{d}$ Beta as $\mathrm{Sr}-90$

${ }^{e}$ DCG for U-236 is used for this comparison. 


\section{Table C-5C (continued) \\ 2006 Water Quality of Surface Water Downstream of the WVDP at Frank's Creek (WNSP006)}

CHEMICAL CONSTITUENTS

\begin{tabular}{|c|c|c|c|c|c|c|c|}
\hline \multirow{3}{*}{ Analyte } & \multirow{3}{*}{ Units } & \multirow{3}{*}{$\mathbf{N}$} & \multirow{2}{*}{\multicolumn{2}{|c|}{$\begin{array}{c}\text { WNSP006 } \\
\text { Concentrations }\end{array}$}} & \multirow{3}{*}{$\mathbf{N}$} & \multicolumn{2}{|c|}{ Reference Values } \\
\hline & & & & & & \multirow{2}{*}{$\begin{array}{c}\text { WFBCBKG }^{a} \\
\text { Background Range }\end{array}$} & \multirow{2}{*}{ Standard $^{b}$} \\
\hline & & & Average & Maximum & & & \\
\hline Alpha-BHC & $\mu \mathrm{g} / \mathrm{L}$ & 2 & $<0.007$ & $<0.009$ & 2 & $0.0050-<0.0093$ & 0.002 \\
\hline Aluminum, Dissolved & $\mathrm{mg} / \mathrm{L}$ & 2 & $<0.100$ & $<0.100$ & 2 & $<0.100-<0.100$ & 0.10 \\
\hline Ammonia-N & $\mathrm{mg} / \mathrm{L}$ & 2 & $<0.02$ & $<0.02$ & 2 & $<0.02-<0.02$ & $0.09-2.1$ \\
\hline Antimony, Total & $\mathrm{mg} / \mathrm{L}$ & 2 & $<0.003$ & $<0.003$ & 2 & $<0.003-<0.003$ & -- \\
\hline Arsenic, Dissolved & $\mathrm{mg} / \mathrm{L}$ & 2 & $<0.005$ & $<0.005$ & 2 & $<0.005-<0.005$ & 0.150 \\
\hline Barium, Total & $\mathrm{mg} / \mathrm{L}$ & 2 & $<0.06$ & 0.07 & 2 & $0.08-0.10$ & -- \\
\hline Boron, Total & $\mathrm{mg} / \mathrm{L}$ & 2 & 0.03 & 0.03 & 2 & $0.02-0.03$ & 10.0 \\
\hline Bromide & $\mathrm{mg} / \mathrm{L}$ & 2 & $<0.50$ & $<0.50$ & 2 & $<0.50-<0.50$ & -- \\
\hline Cadmium, Dissolved & $\mathrm{mg} / \mathrm{L}$ & 2 & $<0.001$ & $<0.001$ & 2 & $<0.001-<0.001$ & $0.003^{c}$ \\
\hline Calcium, Total & $\mathrm{mg} / \mathrm{L}$ & 12 & 44.2 & 57.1 & 12 & $21.6-44.3$ & -- \\
\hline Chloride & $\mathrm{mg} / \mathrm{L}$ & 2 & 90 & 105 & 2 & $19-20$ & -- \\
\hline Chromium, Dissolved & $\mathrm{mg} / \mathrm{L}$ & 2 & $<0.01$ & $<0.01$ & 2 & $<0.01-<0.01$ & $0.119^{c}$ \\
\hline Cobalt, Total & $\mathrm{mg} / \mathrm{L}$ & 2 & $<0.005$ & $<0.005$ & 2 & $<0.005-<0.005$ & $0.005^{d}$ \\
\hline Copper, Dissolved & $\mathrm{mg} / \mathrm{L}$ & 2 & $<0.005$ & $<0.005$ & 2 & $<0.005-<0.005$ & $0.015^{c}$ \\
\hline Dissolved Oxygen & $\mathrm{mg} / \mathrm{L}$ & 2 & 9.8 & 10.1 & 2 & $9.5-11.0$ & 4.0 (min) \\
\hline Fluoride & $\mathrm{mg} / \mathrm{L}$ & 2 & $<0.10$ & $<0.10$ & 2 & $<0.10-<0.10$ & $3.58^{c}$ \\
\hline Hardness & $\mathrm{mg} / \mathrm{L}$ & 12 & 140 & 178 & 12 & $69-136$ & -- \\
\hline Iron, Total & $\mathrm{mg} / \mathrm{L}$ & 2 & 2.36 & 3.08 & 2 & $0.25-0.55$ & 0.30 \\
\hline Lead, Dissolved & $\mathrm{mg} / \mathrm{L}$ & 2 & $<0.0005$ & $<0.0005$ & 2 & $<0.0005-<0.0005$ & $0.007^{c}$ \\
\hline Magnesium, Total & $\mathrm{mg} / \mathrm{L}$ & 12 & 7.27 & 9.14 & 12 & $3.58-6.19$ & -- \\
\hline Manganese, Total & $\mathrm{mg} / \mathrm{L}$ & 2 & 0.12 & 0.15 & 2 & $0.02-0.03$ & -- \\
\hline Mercury, Dissolved, Method 1631 & $\mu \mathrm{g} / \mathrm{L}$ & 2 & 0.00506 & 0.00514 & 2 & $0.000958-0.000972$ & -- \\
\hline Nickel, Dissolved & $\mathrm{mg} / \mathrm{L}$ & 2 & $<0.04$ & $<0.04$ & 2 & $<0.04-<0.04$ & $0.085^{c}$ \\
\hline Nitrate-N & $\mathrm{mg} / \mathrm{L}$ & 2 & 0.42 & 0.53 & 2 & $0.06-0.13$ & -- \\
\hline Nitrite-N & $\mathrm{mg} / \mathrm{L}$ & 2 & $<0.05$ & $<0.05$ & 2 & $<0.05-<0.05$ & 0.10 \\
\hline NPOC & $\mathrm{mg} / \mathrm{L}$ & 2 & $<2.0$ & 3.1 & 2 & $1.6-2.2$ & - \\
\hline Oil \& Grease & $\mathrm{mg} / \mathrm{L}$ & 2 & $<5$ & $<5$ & 2 & $<5-<5$ & -- \\
\hline pH & SU & 2 & 7.8 & 8.01 & 2 & $7.48-7.57$ & $6.5-8.5$ \\
\hline
\end{tabular}

$N$ - Number of samples

-- No guideline or standard available for these analytes

${ }^{a}$ Background location

${ }^{b}$ New York Water Quality Standards for Class "C" surface waters as a comparative reference for nonradiological results.

${ }^{c}$ Calculated from maximum measured hardness of surface water stream at WNSP006.

${ }^{d}$ Standards for cobalt, thallium, and vanadium are applicable to the acid-soluble fraction. 
Table C-5C (concluded)

2006 Water Quality of Surface Water Downstream of the WVDP at Frank's Creek (WNSP006)

CHEMICAL CONSTITUENTS (concluded)

\begin{tabular}{|c|c|c|c|c|c|c|c|}
\hline \multirow{3}{*}{ Analyte } & \multirow{3}{*}{ Units } & \multirow{3}{*}{$\mathbf{N}$} & \multirow{2}{*}{\multicolumn{2}{|c|}{$\begin{array}{c}\text { WNSP006 } \\
\text { Concentrations }\end{array}$}} & \multirow{3}{*}{$\mathbf{N}$} & \multicolumn{2}{|c|}{ Reference Values } \\
\hline & & & & & & \multirow{2}{*}{$\begin{array}{c}\text { WFBCBKG }^{a} \\
\text { Background Range }\end{array}$} & \multirow{2}{*}{ Standard $^{b}$} \\
\hline & & & Average & Maximum & & & \\
\hline Selenium, Dissolved & $\mathrm{mg} / \mathrm{L}$ & 2 & $<0.001$ & $<0.001$ & 2 & $<0.001-<0.001$ & 0.0046 \\
\hline Sodium, Total & $\mathrm{mg} / \mathrm{L}$ & 2 & 72.2 & 81.1 & 2 & $11.6-13.5$ & -- \\
\hline Solids, Total Dissolved & $\mathrm{mg} / \mathrm{L}$ & 31 & 308 & 572 & 2 & $202-204$ & 500 \\
\hline Solids, Total Suspended & $\mathrm{mg} / \mathrm{L}$ & 2 & 105 & 145 & 2 & $10-20$ & -- \\
\hline Sulfate & $\mathrm{mg} / \mathrm{L}$ & 2 & 45 & 50.6 & 2 & $19.7-21.7$ & -- \\
\hline Sulfide (as S) & $\mathrm{mg} / \mathrm{L}$ & 2 & $<0.04$ & 0.04 & 2 & $<0.04-0.06$ & 0.002 \\
\hline Surfactants & $\mathrm{mg} / \mathrm{L}$ & 2 & $<0.06$ & $<0.10$ & 2 & $<0.02-<0.10$ & 0.40 \\
\hline Thallium, Total & $\mathrm{mg} / \mathrm{L}$ & 2 & $<0.008$ & $<0.008$ & 2 & $<0.008-<0.008$ & $0.008^{d}$ \\
\hline Titanium, Total & $\mathrm{mg} / \mathrm{L}$ & 2 & $<0.0762$ & 0.0937 & 2 & $<0.0500-<0.0500$ & -- \\
\hline TOX & $\mathrm{mg} / \mathrm{L}$ & 2 & $<0.01$ & 0.02 & 2 & $<0.01-0.01$ & -- \\
\hline Vanadium, Total & $\mathrm{mg} / \mathrm{L}$ & 2 & $<0.0100$ & $<0.0100$ & 2 & $<0.0100-<0.0100$ & $0.014^{d}$ \\
\hline Zinc, Dissolved & $\mathrm{mg} / \mathrm{L}$ & 2 & $<0.02$ & $<0.02$ & 2 & $<0.02-<0.02$ & $0.135^{c}$ \\
\hline
\end{tabular}

$N$ - Number of samples

-- No guideline or standard available for these analytes

${ }^{a}$ Background location

${ }^{b}$ New York Water Quality Standards for Class “C” surface waters as a comparative reference for nonradiological results.

${ }^{c}$ Calculated from maximum measured hardness of surface water stream at WNSP006.

${ }^{d}$ Standards for cobalt, thallium, and vanadium are applicable to the acid-soluble fraction. 
Table C-5D

2006 Total Dissolved Solids From Outfall WNSP116

\begin{tabular}{|c|c|c|c|c|c|}
\hline \multirow{2}{*}{ Month } & \multirow{2}{*}{ Units } & \multirow{2}{*}{$\mathbf{N}$} & \multicolumn{2}{|c|}{ Total Dissolved Solids } & \multirow{2}{*}{$\begin{array}{c}\text { Daily Maximum } \\
\text { Limit }\end{array}$} \\
\hline & & & Average & Maximum & \\
\hline January $^{a}$ & $\mathrm{mg} / \mathrm{L}$ & 0 & -- & -- & 500 \\
\hline February & $\mathrm{mg} / \mathrm{L}$ & 2 & 374 & 473 & 500 \\
\hline March $^{a}$ & $\mathrm{mg} / \mathrm{L}$ & 0 & -- & -- & 500 \\
\hline April & $\mathrm{mg} / \mathrm{L}$ & 2 & 237 & 239 & 500 \\
\hline May & $\mathrm{mg} / \mathrm{L}$ & 2 & 304 & 331 & 500 \\
\hline June $^{a}$ & $\mathrm{mg} / \mathrm{L}$ & 0 & -- & -- & 500 \\
\hline July $^{a}$ & $\mathrm{mg} / \mathrm{L}$ & 0 & -- & -- & 500 \\
\hline August & $\mathrm{mg} / \mathrm{L}$ & 2 & 334 & 338 & 500 \\
\hline September $^{a}$ & $\mathrm{mg} / \mathrm{L}$ & 0 & -- & -- & 500 \\
\hline October & $\mathrm{mg} / \mathrm{L}$ & 2 & 186 & 193 & 500 \\
\hline November & $\mathrm{mg} / \mathrm{L}$ & 2 & 310 & 312 & 500 \\
\hline December $^{a}$ & $\mathrm{mg} / \mathrm{L}$ & 0 & -- & -- & 500 \\
\hline
\end{tabular}

$N$ - Number of samples

${ }^{a}$ No discharge this month

Table C-5E

2006 Radioactivity and pH in Surface Water at Erdman Brook (WNERB53)

\begin{tabular}{|l|c|c|c|c|c|c|}
\hline \multirow{2}{*}{\multicolumn{1}{c|}{ Analyte }} & \multirow{2}{*}{ Units } & \multirow{2}{*}{$\mathbf{N}$} & \multicolumn{3}{c|}{ WNERB53 Concentrations } & $\begin{array}{c}\text { Reference } \\
\text { Guideline }^{\boldsymbol{a}} \text { or } \\
\text { Standardd }^{b}\end{array}$ \\
\cline { 4 - 7 } & & & Minimum & Average & Maximum & $3 \mathrm{E}-08^{c}$ \\
\hline Gross Alpha & $\mu \mathrm{Ci} / \mathrm{mL}$ & 4 & $<8.24 \mathrm{E}-10$ & $7.08 \pm 9.23 \mathrm{E}-10$ & $1.27 \mathrm{E}-09$ & $1 \mathrm{E}-066^{d}$ \\
\hline Gross Beta & $\mu \mathrm{Ci} / \mathrm{mL}$ & 4 & $1.48 \mathrm{E}-08$ & $2.22 \pm 0.18 \mathrm{E}-08$ & $3.63 \mathrm{E}-08$ & $2 \mathrm{E}-03$ \\
\hline Tritium & $\mu \mathrm{Ci} / \mathrm{mL}$ & 4 & $<7.88 \mathrm{E}-08$ & $0.52 \pm 1.01 \mathrm{E}-07$ & $<1.29 \mathrm{E}-07$ & $1 \mathrm{E}-06$ \\
\hline Sr-90 & $\mu \mathrm{Ci} / \mathrm{mL}$ & 2 & $6.16 \mathrm{E}-09$ & $6.68 \pm 1.13 \mathrm{E}-09$ & $7.19 \mathrm{E}-09$ & $3 \mathrm{E}-06$ \\
\hline Cs-137 & $\mu \mathrm{Ci} / \mathrm{mL}$ & 2 & $<2.68 \mathrm{E}-09$ & $1.19 \pm 3.11 \mathrm{E}-09$ & $<3.48 \mathrm{E}-09$ & $6.09-9.5$ \\
\hline pH & $\mathrm{SU}$ & 4 & 7.61 & 7.77 & 7.90 & \\
\hline
\end{tabular}

$N$ - Number of samples

${ }^{a}$ DOE ingestion-based DCGs for 100 mrem/yr dose limit are provided as a guideline for radiological results.

${ }^{b}$ New York State Water Quality Standards, Class “D” for surface waters as a standard for nonradiological results

${ }^{c}$ Alpha as Am-241

${ }^{d}$ Beta as Sr-90 


\section{Table C-5F \\ 2006 Radioactivity and pH in Surface Water at Frank's Creek East of the SDA (WNFRC67)}

\begin{tabular}{|c|c|c|c|c|c|c|}
\hline \multirow{3}{*}{ Analyte } & \multirow{3}{*}{ Units } & \multirow{3}{*}{$\mathbf{N}$} & \multirow{2}{*}{\multicolumn{3}{|c|}{ WNFRC67 Concentrations }} & \multirow{3}{*}{$\begin{array}{c}\text { Reference } \\
\text { Guideline }^{a} \text { or } \\
\text { Standard }^{b}\end{array}$} \\
\hline & & & & & & \\
\hline & & & Minimum & Average & Maximum & \\
\hline Gross Alpha & $\mu \mathrm{Ci} / \mathrm{mL}$ & 4 & $<3.36 \mathrm{E}-10$ & $-2.21 \pm 4.25 \mathrm{E}-10$ & $<5.23 \mathrm{E}-10$ & $3 \mathrm{E}-08^{c}$ \\
\hline Gross Beta & $\mu \mathrm{Ci} / \mathrm{mL}$ & 4 & $1.64 \mathrm{E}-09$ & $2.20 \pm 0.78 \mathrm{E}-09$ & $3.20 \mathrm{E}-09$ & $1 \mathrm{E}-06^{d}$ \\
\hline Tritium & $\mu \mathrm{Ci} / \mathrm{mL}$ & 4 & $<7.88 \mathrm{E}-08$ & $4.14 \pm 9.48 \mathrm{E}-08$ & $1.42 \mathrm{E}-07$ & $2 \mathrm{E}-03$ \\
\hline Sr-90 & $\mu \mathrm{Ci} / \mathrm{mL}$ & 4 & $4.10 \mathrm{E}-10$ & $-0.30 \pm 4.95 \mathrm{E}-10$ & $4.10 \mathrm{E}-10$ & $1 \mathrm{E}-06$ \\
\hline Cs-137 & $\mu \mathrm{Ci} / \mathrm{mL}$ & 4 & $<2.35 \mathrm{E}-09$ & $-0.70 \pm 3.35 \mathrm{E}-09$ & $<4.50 \mathrm{E}-09$ & $3 \mathrm{E}-06$ \\
\hline pH & SU & 4 & 7.39 & 7.52 & 7.86 & $6.5-8.5$ \\
\hline
\end{tabular}

$N$ - Number of samples

${ }^{a}$ DOE ingestion-based DCGs for $100 \mathrm{mrem} / \mathrm{yr}$ dose limit are provided as a guideline for radiological results in the absence of water quality standards.

${ }^{b}$ New York State Water Quality Standards for Class "C" surface waters as a comparative reference for nonradiological results.

${ }^{c}$ Alpha as Am-241

${ }^{d}$ Beta as $\mathrm{Sr}-90$

Table C-5G

2006 Radioactivity and $\mathrm{pH}$ in Surface Water at Drum Cell Drainage (WNDCELD)

\begin{tabular}{|c|c|c|c|c|c|c|}
\hline \multirow{2}{*}{ Analyte } & \multirow{2}{*}{ Units } & \multirow{2}{*}{$\mathbf{N}$} & \multicolumn{3}{|c|}{ WNDCELD Concentrations } & \multirow{2}{*}{$\begin{array}{c}\text { Reference } \\
\text { Guideline }^{a} \\
\text { or Standard }^{b}\end{array}$} \\
\hline & & & Minimum & Average & Maximum & \\
\hline Gross Alpha & $\mu \mathrm{Ci} / \mathrm{mL}$ & 6 & $<2.80 \mathrm{E}-10$ & $3.32 \pm 4.98 \mathrm{E}-10$ & $2.38 \mathrm{E}-09$ & $3 \mathrm{E}-08^{c}$ \\
\hline Gross Beta & $\mu \mathrm{Ci} / \mathrm{mL}$ & 6 & $1.13 \mathrm{E}-09$ & $3.37 \pm 0.99 \mathrm{E}-09$ & 7.39E-09 & $1 \mathrm{E}-06^{d}$ \\
\hline Tritium & $\mu \mathrm{Ci} / \mathrm{mL}$ & 6 & $<8.61 \mathrm{E}-08$ & $2.80 \pm 9.83 \mathrm{E}-08$ & $1.27 \mathrm{E}-07$ & 2E-03 \\
\hline Sr-90 & $\mu \mathrm{Ci} / \mathrm{mL}$ & 2 & $<4.64 \mathrm{E}-10$ & $2.52 \pm 6.12 \mathrm{E}-10$ & $<7.31 \mathrm{E}-10$ & $1 \mathrm{E}-06$ \\
\hline I-129 & $\mu \mathrm{Ci} / \mathrm{mL}$ & 2 & $<2.91 \mathrm{E}-10$ & $2.25 \pm 3.77 \mathrm{E}-10$ & $<4.47 \mathrm{E}-10$ & $5 \mathrm{E}-07$ \\
\hline Cs-137 & $\mu \mathrm{Ci} / \mathrm{mL}$ & 2 & $<2.39 \mathrm{E}-09$ & $1.00 \pm 2.66 \mathrm{E}-09$ & $<2.91 \mathrm{E}-09$ & $3 \mathrm{E}-06$ \\
\hline pH & SU & 6 & 7.26 & 7.58 & 7.94 & $6.5-8.5$ \\
\hline
\end{tabular}

$N$ - Number of samples

${ }^{a}$ DOE ingestion-based DCGs for $100 \mathrm{mrem} / \mathrm{yr}$ dose limit are provided as a guideline for radiological results in the absence of water quality standards.

${ }^{b}$ New York State Water Quality Standards for Class “C” surface waters as a comparative reference for nonradiological results.

c Alpha as Am-241

${ }^{d}$ Beta as $\mathrm{Sr}-90$ 


\section{Table C-5H}

\section{Water Quality of Surface Water at the Standing Water Location (WNSTAW9)}

\begin{tabular}{|l|c|c|c|c|}
\hline \multicolumn{1}{|c|}{ Analyte } & Units & N & WNSTAW9 & Reference Values $^{\text {Guideline }} \boldsymbol{a}^{\boldsymbol{a}}$ or Standard $^{\boldsymbol{b}}$ \\
\hline Gross Alpha & $\mu \mathrm{Ci} / \mathrm{mL}$ & 1 & $6.08 \pm 5.42 \mathrm{E}-10$ & $3 \mathrm{E}-08^{c}$ \\
\hline Gross Beta & $\mu \mathrm{Ci} / \mathrm{mL}$ & 1 & $1.96 \pm 0.79 \mathrm{E}-09$ & $1 \mathrm{E}-06^{d}$ \\
\hline Tritium & $\mu \mathrm{Ci} / \mathrm{mL}$ & 1 & $4.04 \pm 8.90 \mathrm{E}-08$ & $2 \mathrm{E}-03$ \\
\hline Sr-90 & $\mu \mathrm{Ci} / \mathrm{mL}$ & 1 & $3.18 \pm 3.78 \mathrm{E}-10$ & $1 \mathrm{E}-06$ \\
\hline Cs-137 & $\mu \mathrm{Ci} / \mathrm{mL}$ & 1 & $0.42 \pm 2.88 \mathrm{E}-09$ & $3 \mathrm{E}-06$ \\
\hline Chloride & $\mathrm{mg} / \mathrm{L}$ & 1 & 7 & -- \\
\hline Conductivity & $\mu \mathrm{mhos} / \mathrm{cm} @ 25^{\circ} \mathrm{C}$ & 1 & 176 & -- \\
\hline Iron, Total & $\mathrm{mg} / \mathrm{L}$ & 1 & 0.33 & 0.3 \\
\hline Manganese, Total & $\mathrm{mg} / \mathrm{L}$ & 1 & 0.07 & - \\
\hline Nitrate+Nitrite & $\mathrm{mg} / \mathrm{L}$ & 1 & $<0.05$ & -- \\
\hline pH & $\mathrm{SU}$ & 1 & 8.0 & $6.5-8.5$ \\
\hline Sodium, Total & $\mathrm{mg} / \mathrm{L}$ & 1 & 5.7 & -- \\
\hline Sulfate & $\mathrm{mg} / \mathrm{L}$ & 1 & 11.8 & - \\
\hline
\end{tabular}

$N$ - Number of samples

-- No guideline or standard available for these analytes

${ }^{a}$ DOE ingestion-based DCGs for 100 mrem/yr dose limit are provided as a guideline for radiological results.

${ }^{b}$ New York State Water Quality Standards Class “D” surface waters as a comparative standard for nonradiological results

c Alpha as Am-241

${ }^{d}$ Beta as $\mathrm{Sr}-90$ 


\section{Appendix C-6 \\ Potable Water (Drinking Water) Data}


This page intentionally left blank

$$
\text { C }-70
$$


Table C-6A

\section{Water Quality Results in Potable Well Water Around the WVDP}

\begin{tabular}{|c|c|c|c|c|c|c|c|}
\hline \multirow{3}{*}{ Analyte } & \multirow{3}{*}{ Units } & \multirow{3}{*}{$\mathbf{N}$} & \multirow{2}{*}{\multicolumn{3}{|c|}{ Annual Concentrations at Potable Wells }} & \multicolumn{2}{|c|}{ Reference Values } \\
\hline & & & & & & \multirow{2}{*}{$\begin{array}{l}\text { Background } \\
\text { WFWEL06 }\end{array}$} & \multirow{2}{*}{ Standard $^{a, b}$} \\
\hline & & & WFWEL01 & WFWELO2 & WFWEL03 & & \\
\hline Gross Alpha & $\mu \mathrm{Ci} / \mathrm{mL}$ & 1 & $1.18 \pm 1.42 \mathrm{E}-09$ & $1.53 \pm 1.66 \mathrm{E}-09$ & $2.16 \pm 1.25 \mathrm{E}-09$ & $1.58 \pm 4.67 \mathrm{E}-10$ & $1.5 \mathrm{E}-08^{c}$ \\
\hline Gross Beta & $\mu \mathrm{Ci} / \mathrm{mL}$ & 1 & $3.38 \pm 1.33 \mathrm{E}-09$ & $3.22 \pm 1.65 \mathrm{E}-09$ & $1.00 \pm 1.48 \mathrm{E}-09$ & $9.19 \pm 6.49 \mathrm{E}-10$ & $1 \mathrm{E}-06^{d}$ \\
\hline Tritium & $\mu \mathrm{Ci} / \mathrm{mL}$ & 1 & $-1.71 \pm 9.92 \mathrm{E}-08$ & $-0.96 \pm 1.00 \mathrm{E}-07$ & $-1.29 \pm 1.01 \mathrm{E}-07$ & $-3.27 \pm 0.98 \mathrm{E}-07$ & -- \\
\hline Sr-90 & $\mu \mathrm{Ci} / \mathrm{mL}$ & 1 & $0.92 \pm 1.02 \mathrm{E}-09$ & $1.31 \pm 1.05 \mathrm{E}-09$ & $1.21 \pm 1.09 \mathrm{E}-09$ & $0.74 \pm 1.01 \mathrm{E}-09$ & $8 \mathrm{E}-09^{e}$ \\
\hline Cs-137 & $\mu \mathrm{Ci} / \mathrm{mL}$ & 1 & $-0.16 \pm 1.81 \mathrm{E}-09$ & $-0.04 \pm 1.89 \mathrm{E}-09$ & $-1.29 \pm 1.89 \mathrm{E}-09$ & $2.04 \pm 1.81 \mathrm{E}-09$ & -- \\
\hline Conductivity & $\mu \mathrm{mhos} / \mathrm{cm} @ 25^{\circ} \mathrm{C}$ & 1 & 392 & 396 & 415 & 285 & -- \\
\hline pH & SU & 1 & 7.78 & 7.52 & 7.68 & 8.06 & $6.5-8.5$ \\
\hline
\end{tabular}

\begin{tabular}{|c|c|c|c|c|c|c|c|}
\hline \multirow{3}{*}{ Analyte } & \multirow{3}{*}{ Units } & \multirow{3}{*}{$\mathbf{N}$} & \multirow{2}{*}{\multicolumn{3}{|c|}{ Annual Concentrations at Potable Wells }} & \multicolumn{2}{|c|}{ Reference Values } \\
\hline & & & & & & \multirow{2}{*}{$\begin{array}{l}\text { Background } \\
\text { WFWEL06 }\end{array}$} & \multirow{2}{*}{ Standard $^{a, b}$} \\
\hline & & & WFWELO4 & WFWEL05 & WFWELO7 & & \\
\hline Gross Alpha & $\mu \mathrm{Ci} / \mathrm{mL}$ & 1 & $6.01 \pm 5.20 \mathrm{E}-09$ & $1.12 \pm 9.07 \mathrm{E}-10$ & $6.02 \pm 1.74 \mathrm{E}-09$ & $1.58 \pm 4.67 \mathrm{E}-10$ & $1.5 \mathrm{E}-08^{c}$ \\
\hline Gross Beta & $\mu \mathrm{Ci} / \mathrm{mL}$ & 1 & $2.22 \pm 3.57 \mathrm{E}-09$ & $2.83 \pm 1.04 \mathrm{E}-09$ & $1.97 \pm 1.83 \mathrm{E}-09$ & $9.19 \pm 6.49 \mathrm{E}-10$ & $1 \mathrm{E}-06^{d}$ \\
\hline Tritium & $\mu \mathrm{Ci} / \mathrm{mL}$ & 1 & $-0.65 \pm 1.01 \mathrm{E}-07$ & $-5.93 \pm 9.79 \mathrm{E}-08$ & $-8.11 \pm 9.96 \mathrm{E}-08$ & $-3.27 \pm 0.98 \mathrm{E}-07$ & -- \\
\hline Sr-90 & $\mu \mathrm{Ci} / \mathrm{mL}$ & 1 & $-9.04 \pm 7.50 \mathrm{E}-10$ & $0.07 \pm 7.21 \mathrm{E}-10$ & $0.49 \pm 1.03 \mathrm{E}-09$ & $0.74 \pm 1.01 \mathrm{E}-09$ & $8 \mathrm{E}-09^{e}$ \\
\hline Cs-137 & $\mu \mathrm{Ci} / \mathrm{mL}$ & 1 & $-0.92 \pm 1.86 \mathrm{E}-09$ & $-0.15 \pm 1.88 \mathrm{E}-09$ & $1.53 \pm 1.82 \mathrm{E}-09$ & $2.04 \pm 1.81 \mathrm{E}-09$ & -- \\
\hline Conductivity & $\mu \mathrm{mhos} / \mathrm{cm} @ 25^{\circ} \mathrm{C}$ & 1 & 1,610 & 309 & 608 & 285 & -- \\
\hline pH & SU & 1 & 7.62 & 6.52 & 7.32 & 8.06 & $6.5-8.5$ \\
\hline
\end{tabular}

\begin{tabular}{|c|c|c|c|c|c|c|c|}
\hline \multirow{3}{*}{ Analyte } & \multirow{3}{*}{ Units } & \multirow{3}{*}{$\mathbf{N}$} & \multirow{2}{*}{\multicolumn{3}{|c|}{ Annual Concentrations at Potable Wells }} & \multicolumn{2}{|c|}{ Reference Values } \\
\hline & & & & & & \multirow{2}{*}{$\begin{array}{l}\text { Background } \\
\text { WFWELO6 }\end{array}$} & \multirow{2}{*}{ Standard $^{a, b}$} \\
\hline & & & WFWEL08 & WFWEL09 & WFWEL10 & & \\
\hline Gross Alpha & $\mu \mathrm{Ci} / \mathrm{mL}$ & 1 & $0.00 \pm 1.49 \mathrm{E}-09$ & $3.57 \pm 2.60 \mathrm{E}-09$ & $1.16 \pm 2.50 \mathrm{E}-09$ & $1.58 \pm 4.67 \mathrm{E}-10$ & $1.5 \mathrm{E}-08^{c}$ \\
\hline Gross Beta & $\mu \mathrm{Ci} / \mathrm{mL}$ & 1 & $1.64 \pm 1.51 \mathrm{E}-09$ & $4.96 \pm 1.72 \mathrm{E}-09$ & $2.04 \pm 1.60 \mathrm{E}-09$ & $9.19 \pm 6.49 \mathrm{E}-10$ & $1 \mathrm{E}-06^{d}$ \\
\hline Tritium & $\mu \mathrm{Ci} / \mathrm{mL}$ & 1 & $-2.12 \pm 0.97 \mathrm{E}-07$ & $-1.50 \pm 1.00 \mathrm{E}-07$ & $-1.77 \pm 1.00 \mathrm{E}-07$ & $-3.27 \pm 0.98 \mathrm{E}-07$ & -- \\
\hline Sr-90 & $\mu \mathrm{Ci} / \mathrm{mL}$ & 1 & $-1.16 \pm 0.68 \mathrm{E}-09$ & $-5.22 \pm 8.79 \mathrm{E}-10$ & $1.58 \pm 8.63 \mathrm{E}-10$ & $0.74 \pm 1.01 \mathrm{E}-09$ & $8 \mathrm{E}-09^{e}$ \\
\hline Cs-137 & $\mu \mathrm{Ci} / \mathrm{mL}$ & 1 & $-1.11+2.04 \mathrm{E}-09$ & $1.55 \pm 1.81 \mathrm{E}-09$ & $1.78 \pm 1.87 \mathrm{E}-09$ & $2.04 \pm 1.81 \mathrm{E}-09$ & -- \\
\hline Conductivity & $\mu \mathrm{mhos} / \mathrm{cm} @ 25^{\circ} \mathrm{C}$ & 1 & 443 & 468 & 664 & 285 & -- \\
\hline pH & SU & 1 & 7.75 & 8.00 & 7.55 & 8.06 & $6.5-8.5$ \\
\hline
\end{tabular}

$N$ - Number of samples

-- No guideline or standard available for these analytes

${ }^{a}$ New York State Water Quality Standard for Class “GA” for fresh groundwater

${ }^{b}$ NYSDOH raw water supply standards (10 NYCRR Part 170.4)

${ }^{c}$ Alpha standard excludes radon and uranium, however, the WVDP results include these isotopes.

${ }^{d}$ Beta standard excludes strontium and alpha emitters, however the WVDP results include these isotopes.

e NYSDOH or EPA potable water MCL

$$
C-71
$$




\section{Table C-6B}

2006 Water Quality Results in Potable Water at the WVDP

\begin{tabular}{|c|c|c|c|c|c|c|}
\hline \multirow[t]{2}{*}{ Analyte } & \multirow[t]{2}{*}{ Units } & \multirow[t]{2}{*}{$\mathbf{N}$} & WNDNKMP & WNDNKEL & WNDNKMS & \multirow[t]{2}{*}{ Standard $^{a}$} \\
\hline & & & Annual & Annual & Annual & \\
\hline Gross Alpha & $\mu \mathrm{Ci} / \mathrm{mL}$ & 1 & $-1.48 \pm 4.87 \mathrm{E}-10$ & $-3.86 \pm 4.47 \mathrm{E}-10$ & $-3.85 \pm 4.18 \mathrm{E}-10$ & $1.5 \mathrm{E}-08$ \\
\hline Gross Beta & $\mu \mathrm{Ci} / \mathrm{mL}$ & 1 & $5.52 \pm 7.07 \mathrm{E}-10$ & $1.68 \pm 0.70 \mathrm{E}-09$ & $2.17 \pm 0.79 \mathrm{E}-09$ & $5 \mathrm{E}-08$ \\
\hline Tritium & $\mu \mathrm{Ci} / \mathrm{mL}$ & 1 & $1.13 \pm 0.77 \mathrm{E}-07$ & $1.34 \pm 0.88 \mathrm{E}-07$ & $0.74 \pm 1.06 \mathrm{E}-07$ & $2 \mathrm{E}-05$ \\
\hline Conductivity & $\mu \mathrm{mhos} / \mathrm{cm} @ 25^{\circ} \mathrm{C}$ & 1 & 198 & 229 & 232 & -- \\
\hline Haloacetic Acids-Five (5) & $\mathrm{mg} / \mathrm{L}$ & 2 & -- & $<0.027$ & -- & 0.06 \\
\hline pH & $\mathrm{SU}$ & 1 & 8.10 & 8.13 & 8.24 & -- \\
\hline Total Trihalomethanes & $\mathrm{mg} / \mathrm{L}$ & 2 & -- & 0.046 & -- & 0.08 \\
\hline
\end{tabular}

$N$ - Number of samples

-- No guideline or standard available for these analytes

${ }^{a}$ New York State Department of Health MCLs for drinking water used as a comparative reference

$$
C-72
$$


Table C-6C

2006 Water Quality Results in Utility Room Potable Water (WNDNKUR)

\begin{tabular}{|c|c|c|c|c|c|c|}
\hline \multirow{2}{*}{ Analyte } & \multirow{2}{*}{ Units } & \multirow{2}{*}{$\mathbf{N}$} & \multicolumn{3}{|c|}{ WNDNKUR Concentrations } & \multirow{2}{*}{$\begin{array}{c}\text { Standard } \\
\text { or } \\
\text { Guideline }^{a}\end{array}$} \\
\hline & & & Minimum & Average & Maximum & \\
\hline Gross Alpha & $\mu \mathrm{Ci} / \mathrm{mL}$ & 12 & $<2.79 \mathrm{E}-10$ & $1.76 \pm 5.58 \mathrm{E}-10$ & 1.64E-09 & $1.5 \mathrm{E}-08$ \\
\hline Gross Beta & $\mu \mathrm{Ci} / \mathrm{mL}$ & 12 & $7.51 \mathrm{E}-10$ & $1.80 \pm 1.16 \mathrm{E}-09$ & 3.42E-09 & $5 \mathrm{E}-08$ \\
\hline Tritium & $\mu \mathrm{Ci} / \mathrm{mL}$ & 12 & $<7.57 \mathrm{E}-08$ & $0.39 \pm 1.00 \mathrm{E}-07$ & $1.59 \mathrm{E}-07$ & $2 \mathrm{E}-05$ \\
\hline Antimony, Total & $\mathrm{mg} / \mathrm{L}$ & 1 & NA & NA & $<0.0004$ & 0.006 \\
\hline Arsenic, Total & $\mathrm{mg} / \mathrm{L}$ & 1 & NA & NA & $<0.001$ & 0.05 \\
\hline Barium, Total & $\mathrm{mg} / \mathrm{L}$ & 1 & NA & NA & $<0.20$ & 2.00 \\
\hline Beryllium, Total & $\mathrm{mg} / \mathrm{L}$ & 1 & NA & NA & $<0.0003$ & 0.004 \\
\hline Cadmium, Total & $\mathrm{mg} / \mathrm{L}$ & 1 & NA & NA & $<0.001$ & 0.005 \\
\hline Chromium, Total & $\mathrm{mg} / \mathrm{L}$ & 1 & NA & NA & $<0.007$ & 0.10 \\
\hline Conductivity & $\mu \mathrm{mhos} / \mathrm{cm} @ 25^{\circ} \mathrm{C}$ & 12 & 162 & 193 & 235 & -- \\
\hline Cyanide, Total & $\mathrm{mg} / \mathrm{L}$ & 1 & NA & NA & $<0.01$ & 0.2 \\
\hline Fluoride & $\mathrm{mg} / \mathrm{L}$ & 1 & NA & NA & $<0.20$ & 2.2 \\
\hline Free Residual Chlorine & $\mathrm{mg} / \mathrm{L}$ & 1,095 & 1.04 & NA & 3.96 & $0.2-4.0$ \\
\hline Iron, Total & $\mathrm{mg} / \mathrm{L}$ & 1 & NA & NA & $<0.05$ & 0.3 \\
\hline Manganese, Total & $\mathrm{mg} / \mathrm{L}$ & 1 & NA & NA & 0.0104 & -- \\
\hline Mercury, Total & $\mathrm{mg} / \mathrm{L}$ & 1 & NA & NA & $<0.0002$ & 0.002 \\
\hline Nickel, Total & $\mathrm{mg} / \mathrm{L}$ & 1 & NA & NA & $<0.005$ & -- \\
\hline pH & SU & 12 & 7.89 & 8.15 & 8.27 & -- \\
\hline POC $^{b}$ & $\mathrm{mg} / \mathrm{L}$ & 2 & NA & NA & 0.0003 & 0.0005 \\
\hline Selenium, Total & $\mathrm{mg} / \mathrm{L}$ & 1 & NA & NA & $<0.002$ & 0.05 \\
\hline Thallium, Total & $\mathrm{mg} / \mathrm{L}$ & 1 & NA & NA & $<0.0003$ & 0.0005 \\
\hline Turbidity & NTU & 2,186 & 0.1 & NA & 1.4 & $1.0^{c}$ \\
\hline Zinc, Total & $\mathrm{mg} / \mathrm{L}$ & 1 & NA & NA & $<0.01$ & -- \\
\hline
\end{tabular}

$N$ - Number of samples

NA - Not applicable, constituents sampled annually

-- No guideline or standard available for these analytes

${ }^{a}$ New York State Department of Health MCLs for drinking water or EPA MCLGs, whichever is more stringent

${ }^{b}$ Principal Organic Contaminant (the only volitle constituent detected was toluene)

${ }^{c}$ A treatment standard of $0.3 \mathrm{NTU}$ applies to the 95 th percentile on a monthly basis. 
Table C-6D

2006 Water Quality Results in Utility Room Raw (Untreated) Water (WNURRAW)

\begin{tabular}{|l|c|c|c|c|c|}
\hline \multicolumn{1}{c|}{ Analyte } & \multirow{2}{*}{ Units } & \multirow{2}{*}{$\mathbf{N}$} & \multicolumn{3}{c|}{ WNURRAW Concentrations } \\
\cline { 4 - 6 } & & & Minimum & Average & Maximum \\
\hline Gross Alpha & $\mu \mathrm{Ci} / \mathrm{mL}$ & 2 & $<3.33 \mathrm{E}-09$ & $0.37 \pm 4.62 \mathrm{E}-09$ & $<5.62 \mathrm{E}-09$ \\
\hline Gross Beta & $\mu \mathrm{Ci} / \mathrm{mL}$ & 2 & $<6.92 \mathrm{E}-09$ & $4.55 \pm 8.74 \mathrm{E}-09$ & $<1.02 \mathrm{E}-08$ \\
\hline Tritium & $\mu \mathrm{Ci} / \mathrm{mL}$ & 2 & $<6.36 \mathrm{E}-07$ & $-1.53 \pm 7.23 \mathrm{E}-07$ & $<8.00 \mathrm{E}-07$ \\
\hline Iron, Total & $\mathrm{mg} / \mathrm{L}$ & 52 & 0.11 & 0.66 & 6.72 \\
\hline Solids, Total Dissolved & $\mathrm{mg} / \mathrm{L}$ & 18 & 90 & 114 & 166 \\
\hline
\end{tabular}

$N$ - Number of samples

Table C-6E

2006 Biological and Chlorine Results in Tap Water From Various Site Locations (Analyzed by Cattaraugus County Health Department)

\begin{tabular}{|l|c|c|c|c|}
\hline \multicolumn{1}{|c|}{ Analyte } & \multirow{2}{*}{ Units } & \multirow{2}{*}{$\mathbf{N}$} & Various Site Tap Water Locations & \multirow{2}{*}{ Standard $^{\boldsymbol{a}}$} \\
\cline { 1 - 3 } E. coli & NA & 12 & Results & one positive sample \\
\hline Free Residual Chlorine & mg/L & 12 & Negative & 4.0 (max) \\
\hline Total Coliform & NA & 12 & Range: $0.12-1.27$ & two or more positive samples \\
\hline
\end{tabular}

$N$ - Number of samples

NA - Not applicable

${ }^{a}$ New York State Department of Health MCLs for drinking water or EPA MCLGs, whichever is more stringent

\section{Table C-6F}

2006 Nitrate Results in Tap Water From WVDP Restroom Sink (Analyzed by Cattaraugus County Health Department)

\begin{tabular}{|l|c|c|c|c|c|}
\hline \multicolumn{1}{|c|}{ Analyte } & Units & $\mathbf{N}$ & Date Collected & Annual Concentration & Standard $^{a}$ \\
\hline Nitrate-N & $\mathrm{mg} / \mathrm{L}$ & 1 & $3 / 13 / 06$ & $<1.00$ & 10 \\
\hline
\end{tabular}

$N$ - Number of samples

${ }^{a}$ New York State Department of Health MCLs for drinking water or EPA MCLGs, whichever is more stringent 


\section{Appendix D Summary of Air Monitoring Data}

$D-1$ 
This page intentionally left blank

$D-2$ 
Table D-1

2006 Effluent Airborne Radioactivity at Main Stack

(ANSTACK)

\begin{tabular}{|c|c|c|c|c|c|c|}
\hline Isotope $^{a}$ & $\mathbf{N}$ & $\begin{array}{c}\text { Total } \\
\text { Activity Released }^{b} \\
\text { (Ci) }\end{array}$ & $\begin{array}{c}\text { Average } \\
\text { Concentration } \\
(\mu \mathrm{Ci} / \mathrm{mL})\end{array}$ & $\begin{array}{c}\text { Maximum } \\
\text { Concentration } \\
(\mu \mathrm{Ci} / \mathrm{mL})\end{array}$ & $\begin{array}{c}D_{C G}^{c} \\
(\mu \mathrm{Ci} / \mathrm{mL})\end{array}$ & $\begin{array}{l}\text { Average } \\
\text { \% DCG }\end{array}$ \\
\hline Gross Alpha & 26 & $4.31 \pm 0.57 \mathrm{E}-07$ & $5.81 \pm 0.77 \mathrm{E}-16$ & $1.11 \mathrm{E}-15$ & -- & -- \\
\hline Gross Beta & 26 & $9.48 \pm 0.21 \mathrm{E}-06$ & $1.28 \pm 0.03 \mathrm{E}-14$ & $5.87 \mathrm{E}-14$ & -- & -- \\
\hline H-3 & 26 & $1.21 \pm 0.03 \mathrm{E}-03$ & $1.63 \pm 0.05 \mathrm{E}-12$ & $4.71 \mathrm{E}-12$ & $1 \mathrm{E}-07$ & $<0.01$ \\
\hline Co-60 & 2 & $0.10 \pm 5.28 \mathrm{E}-08$ & $0.13 \pm 7.03 \mathrm{E}-17$ & $<1.02 \mathrm{E}-16$ & $8 \mathrm{E}-11$ & $<0.01$ \\
\hline Sr-90 & 2 & $2.91 \pm 0.15 \mathrm{E}-06$ & $3.92 \pm 0.20 \mathrm{E}-15$ & $2.89 \mathrm{E}-15$ & $9 \mathrm{E}-12$ & 0.04 \\
\hline I-129 & 2 & $2.29 \pm 0.22 \mathrm{E}-05$ & $3.09 \pm 0.30 \mathrm{E}-14$ & $3.38 \mathrm{E}-14$ & 7E-11 & 0.04 \\
\hline Cs-137 & 2 & $3.55 \pm 0.17 \mathrm{E}-06$ & $4.78 \pm 0.23 \mathrm{E}-15$ & $5.26 \mathrm{E}-15$ & $4 \mathrm{E}-10$ & $<0.01$ \\
\hline Eu-154 & 2 & $-0.12 \pm 1.25 \mathrm{E}-07$ & $-0.16 \pm 1.69 \mathrm{E}-16$ & $<2.20 \mathrm{E}-16$ & $5 \mathrm{E}-11$ & $<0.01$ \\
\hline $\mathrm{U}-232^{d}$ & 2 & $2.49 \pm 2.82 \mathrm{E}-09$ & $3.35 \pm 3.80 \mathrm{E}-18$ & $4.41 \mathrm{E}-18$ & $2 \mathrm{E}-14$ & $<0.02$ \\
\hline $\mathrm{U}-233 / 234^{d}$ & 2 & $1.73 \pm 0.58 \mathrm{E}-08$ & $2.33 \pm 0.78 \mathrm{E}-17$ & $2.10 \mathrm{E}-17$ & 9E-14 & 0.03 \\
\hline $\mathrm{U}-235 / 236^{d}$ & 2 & $4.80 \pm-3.31 \mathrm{E}-09$ & $6.47 \pm 4.46 \mathrm{E}-18$ & $6.17 \mathrm{E}-18$ & 1E-13 & $<0.01$ \\
\hline $\mathrm{U}-\mathbf{2 3 8}^{d}$ & 2 & $1.63 \pm 0.50 \mathrm{E}-08$ & $2.19 \pm 0.68 \mathrm{E}-17$ & $2.10 \mathrm{E}-17$ & $1 \mathrm{E}-13$ & 0.02 \\
\hline Pu-238 & 2 & $5.38 \pm 1.16 \mathrm{E}-08$ & $7.25 \pm 1.56 \mathrm{E}-17$ & 7.62E-17 & $3 \mathrm{E}-14$ & 0.24 \\
\hline Pu-239/240 & 2 & $9.08 \pm 1.51 \mathrm{E}-08$ & $1.22 \pm 0.20 \mathrm{E}-16$ & $1.24 \mathrm{E}-16$ & $2 \mathrm{E}-14$ & 0.61 \\
\hline Am-241 & 2 & $1.83 \pm 0.32 \mathrm{E}-07$ & $2.47 \pm 0.43 \mathrm{E}-16$ & $2.24 \mathrm{E}-16$ & $2 \mathrm{E}-14$ & 1.23 \\
\hline Total \% of DCGs & & & & & & 2.25 \\
\hline
\end{tabular}

$N$ - Number of samples

-- DCGs are not specified for gross alpha and beta activity.

${ }^{a}$ Half-lives are listed in Table UI-1.

${ }^{b}$ Total volume released at 50,000 $\mathrm{cfm}=7.42 \mathrm{E}+14 \mathrm{~mL} / \mathrm{year}$

${ }^{c}$ Derived concentration guides (DCGs) are listed for reference only. They are applicable to average concentrations at the site boundary but not to stack concentrations, as might be inferred from their inclusion in this table.

${ }^{d}$ Total Uranium: $4.05 \pm 0.07 E-02 \mathrm{~g}$; average $=5.46 E \pm 0.09 E-11 \mu \mathrm{g} / \mathrm{mL}$ 
Table D-2

2006 Effluent Airborne Radioactivity at Vitrification System HVAC (ANVITSK)

\begin{tabular}{|c|c|c|c|c|c|}
\hline Isotope & $\mathbf{N}$ & $\begin{array}{c}\text { Total } \\
\text { Activity Released } \\
(\mathbf{C i})\end{array}$ & $\begin{array}{c}\text { Average } \\
\text { Concentration } \\
(\mu \mathrm{Ci} / \mathrm{mL})\end{array}$ & $\begin{array}{c}\text { Maximum } \\
\text { Concentration } \\
(\mu \mathrm{Ci} / \mathbf{m L})\end{array}$ & $\begin{array}{c}\mathrm{DCG}^{a} \\
(\mu \mathrm{Ci} / \mathrm{mL})\end{array}$ \\
\hline Gross Alpha & 26 & $0.01 \pm 1.26 \mathrm{E}-08$ & $0.03 \pm 3.40 \mathrm{E}-17$ & $<2.67 \mathrm{E}-16$ & -- \\
\hline Gross Beta & 26 & $-3.50 \pm 4.07 \mathrm{E}-08$ & $-0.94 \pm 1.10 \mathrm{E}-16$ & $<6.61 \mathrm{E}-16$ & -- \\
\hline Co-60 & 2 & $6.16 \pm 9.43 \mathrm{E}-09$ & $1.66 \pm 2.54 \mathrm{E}-17$ & $<4.07 \mathrm{E}-17$ & $8 \mathrm{E}-11$ \\
\hline Sr-90 & 2 & $0.24 \pm 1.98 \mathrm{E}-08$ & $0.64 \pm 5.33 \mathrm{E}-17$ & $<8.61 \mathrm{E}-17$ & $9 \mathrm{E}-12$ \\
\hline I-129 & 2 & $0.19 \pm 1.09 \mathrm{E}-07$ & $0.52 \pm 2.94 \mathrm{E}-16$ & $<5.09 \mathrm{E}-16$ & 7E-11 \\
\hline Cs-137 & 2 & $3.72 \pm 7.11 \mathrm{E}-09$ & $1.00 \pm 1.92 \mathrm{E}-17$ & $<2.77 \mathrm{E}-17$ & 4E-10 \\
\hline Eu-154 & 2 & $-1.78 \pm 2.73 \mathrm{E}-08$ & $4.81 \pm 7.34 \mathrm{E}-17$ & $<1.19 \mathrm{E}-16$ & $5 \mathrm{E}-11$ \\
\hline $\mathrm{U}-\mathbf{2 3 2}^{b}$ & 2 & $-0.94 \pm 3.03 \mathrm{E}-09$ & $-2.52 \pm 8.16 \mathrm{E}-18$ & $<1.32 \mathrm{E}-17$ & $2 \mathrm{E}-14$ \\
\hline $\mathrm{U}-\mathbf{2 3 3} / 234^{b}$ & 2 & $9.97 \pm 2.99 \mathrm{E}-09$ & $2.69 \pm 0.81 \mathrm{E}-17$ & 3.33E-17 & $9 \mathrm{E}-14$ \\
\hline $\mathrm{U}-235 / 236^{b}$ & 2 & $2.06 \pm 2.19 \mathrm{E}-09$ & $5.55 \pm 5.90 \mathrm{E}-18$ & $8.35 \mathrm{E}-18$ & $1 \mathrm{E}-13$ \\
\hline $\mathbf{U}-\mathbf{2 3 8}^{b}$ & 2 & $6.12 \pm 2.48 \mathrm{E}-09$ & $1.65 \pm 0.67 \mathrm{E}-17$ & $1.81 \mathrm{E}-17$ & $1 \mathrm{E}-13$ \\
\hline Pu-238 & 2 & $0.00 \pm 9.88 \mathrm{E}-10$ & $0.00 \pm 2.66 \mathrm{E}-18$ & $<4.42 \mathrm{E}-18$ & $3 \mathrm{E}-14$ \\
\hline Pu-239/240 & 2 & $0.18 \pm 1.21 \mathrm{E}-09$ & $0.48 \pm 3.26 \mathrm{E}-18$ & $<6.10 \mathrm{E}-18$ & 2E-14 \\
\hline Am-241 & 2 & $-0.46 \pm 2.05 E-09$ & $-1.25 \pm 5.53 \mathrm{E}-18$ & $<9.86 \mathrm{E}-18$ & 2E-14 \\
\hline
\end{tabular}

$N$ - Number of samples

-- DCGs are not specified for gross alpha and beta activity.

${ }^{a}$ Derived concentration guides (DCGs) are listed for reference only. They are applicable to average concentrations at the site boundary but not to stack concentrations, as might be inferred from their inclusion in this table.

${ }^{b}$ Total Uranium: $1.65 \pm 0.03 E-02 \mathrm{~g}$; average $=4.44 \pm 0.07 E-11 \mu \mathrm{g} / \mathrm{mL}$

$D-4$ 
Table D-3

2006 Effluent Airborne Radioactivity at 01-14 Building (ANCSSTK)

\begin{tabular}{|c|c|c|c|c|c|}
\hline Isotope & $\mathbf{N}$ & $\begin{array}{c}\text { Total } \\
\text { Activity Released } \\
(\mathbf{C i})\end{array}$ & $\begin{array}{c}\text { Average } \\
\text { Concentration } \\
(\mu \mathrm{Ci} / \mathrm{mL})\end{array}$ & $\begin{array}{c}\text { Maximum } \\
\text { Concentration } \\
(\mu \mathrm{Ci} / \mathrm{mL})\end{array}$ & $\begin{array}{c}\mathrm{DCG}^{a} \\
(\mu \mathrm{Ci} / \mathrm{mL})\end{array}$ \\
\hline Gross Alpha & 26 & $-2.03 \pm 4.60 \mathrm{E}-09$ & $-1.44 \pm 3.26 \mathrm{E}-17$ & $2.55 \mathrm{E}-16$ & -- \\
\hline Gross Beta & 26 & $-2.40 \pm 1.49 \mathrm{E}-08$ & $-1.70 \pm 1.06 \mathrm{E}-16$ & $<6.09 \mathrm{E}-16$ & -- \\
\hline Co-60 & 2 & $1.16 \pm 3.94 \mathrm{E}-09$ & $0.82 \pm 2.79 \mathrm{E}-17$ & $<4.21 \mathrm{E}-17$ & $8 \mathrm{E}-11$ \\
\hline Sr-90 & 2 & $1.38 \pm 8.71 \mathrm{E}-09$ & $0.98 \pm 6.17 \mathrm{E}-17$ & $<9.72 \mathrm{E}-17$ & $9 \mathrm{E}-12$ \\
\hline I-129 & 2 & $6.65 \pm 4.10 \mathrm{E}-08$ & $4.71 \pm 2.90 \mathrm{E}-16$ & $5.09 \mathrm{E}-16$ & $7 \mathrm{E}-11$ \\
\hline Cs-137 & 2 & $0.07 \pm 2.17 \mathrm{E}-09$ & $0.05 \pm 1.54 \mathrm{E}-17$ & $<3.76 \mathrm{E}-17$ & $4 \mathrm{E}-10$ \\
\hline Eu-154 & 2 & $-1.24 \pm 1.18 \mathrm{E}-08$ & $-8.75 \pm 8.39 \mathrm{E}-17$ & $<1.35 \mathrm{E}-16$ & $5 \mathrm{E}-11$ \\
\hline $\mathrm{U}-\mathbf{2 3 2}^{b}$ & 2 & $1.64 \pm 7.57 \mathrm{E}-10$ & $1.16 \pm 5.36 \mathrm{E}-18$ & $<7.91 \mathrm{E}-18$ & $2 \mathrm{E}-14$ \\
\hline $\mathrm{U}-\mathbf{2 3 3} / 234^{b}$ & 2 & $3.32 \pm 1.17 \mathrm{E}-09$ & $2.35 \pm 0.83 \mathrm{E}-17$ & $2.69 \mathrm{E}-17$ & 9E-14 \\
\hline $\mathrm{U}-235 / 236^{b}$ & 2 & $8.28 \pm 6.71 \mathrm{E}-10$ & $5.87 \pm 4.76 \mathrm{E}-18$ & $1.05 \mathrm{E}-17$ & $1 \mathrm{E}-13$ \\
\hline $\mathbf{U}-\mathbf{2 3 8}^{b}$ & 2 & $4.37 \pm 1.34 \mathrm{E}-09$ & $3.09 \pm 0.95 \mathrm{E}-17$ & $4.38 \mathrm{E}-17$ & $1 \mathrm{E}-13$ \\
\hline Pu-238 & 2 & $-1.39 \pm 3.50 \mathrm{E}-10$ & $-0.98 \pm 2.48 \mathrm{E}-18$ & $<4.47 \mathrm{E}-18$ & $3 \mathrm{E}-14$ \\
\hline Pu-239/240 & 2 & $-0.60 \pm 4.66 \mathrm{E}-10$ & $-0.42 \pm 3.30 \mathrm{E}-18$ & $<4.71 \mathrm{E}-18$ & $2 \mathrm{E}-14$ \\
\hline Am-241 & 2 & $1.11 \pm 3.53 \mathrm{E}-10$ & $0.79 \pm 2.50 \mathrm{E}-18$ & $<4.14 \mathrm{E}-18$ & $2 \mathrm{E}-14$ \\
\hline
\end{tabular}

$N$ - Number of samples

-- DCGs are not specified for gross alpha and beta activity.

${ }^{a}$ Derived concentration guides (DCGs) are listed for reference only. They are applicable to average concentrations at the site boundary but not to stack concentrations, as might be inferred from their inclusion in this table.

${ }^{b}$ Total Uranium: $6.65 \pm 0.11 \mathrm{E}-03 \mathrm{~g}$; average $=4.71 \pm 0.07 \mathrm{E}-11 \mu \mathrm{g} / \mathrm{mL}$ 
Table D-4

2006 Airborne Radioactivity at Contact Size-Reduction Facility

(ANCSRFK)

VENTILATION OFF;

SYSTEM DID NOT OPERATE DURING CY 2006

\section{Table D-5 \\ 2006 Effluent Airborne Radioactivity at Supernatant Treatment System (ANSTSTK)}

\begin{tabular}{|c|c|c|c|c|c|}
\hline Isotope & $\mathbf{N}$ & $\begin{array}{c}\text { Total } \\
\text { Activity Released } \\
\text { (Ci) }\end{array}$ & $\begin{array}{c}\text { Average } \\
\text { Concentration } \\
(\mu \mathrm{Ci} / \mathrm{mL})\end{array}$ & $\begin{array}{c}\text { Maximum } \\
\text { Concentration } \\
(\mu \mathrm{Ci} / \mathrm{mL})\end{array}$ & $\begin{array}{c}\mathrm{DCG}^{a} \\
(\mu \mathrm{Ci} / \mathrm{mL})\end{array}$ \\
\hline Gross Alpha & 26 & $-0.95 \pm 2.45 \mathrm{E}-09$ & $-1.43 \pm 3.67 \mathrm{E}-17$ & $<2.66 \mathrm{E}-16$ & -- \\
\hline Gross Beta & 26 & $-3.05 \pm 8.00 \mathrm{E}-09$ & $-0.46 \pm 1.20 \mathrm{E}-16$ & $6.50 \mathrm{E}-16$ & -- \\
\hline H-3 & 26 & $-4.65 \pm 1.09 \mathrm{E}-05$ & $-6.96 \pm 1.63 \mathrm{E}-13$ & $6.05 \mathrm{E}-13$ & $1 \mathrm{E}-07$ \\
\hline Co-60 & 2 & $0.93 \pm 1.76 \mathrm{E}-09$ & $1.39 \pm 2.63 \mathrm{E}-17$ & $<3.29 \mathrm{E}-17$ & $8 \mathrm{E}-11$ \\
\hline Sr-90 & 2 & $-0.33 \pm 3.95 \mathrm{E}-09$ & $-0.49 \pm 5.29 \mathrm{E}-17$ & $9.37 \mathrm{E}-17$ & $9 \mathrm{E}-12$ \\
\hline I-129 & 2 & $8.14 \pm 0.69 \mathrm{E}-06$ & $1.22 \pm 0.10 \mathrm{E}-14$ & $1.23 \mathrm{E}-13$ & $7 E-11$ \\
\hline Cs-137 & 2 & $3.58 \pm 3.12 \mathrm{E}-09$ & $5.37 \pm 4.68 \mathrm{E}-17$ & $4.62 \mathrm{E}-17$ & $4 \mathrm{E}-10$ \\
\hline Eu-154 & 2 & $-3.02 \pm 4.83 \mathrm{E}-09$ & $-4.52 \pm 7.23 \mathrm{E}-17$ & $<8.82 \mathrm{E}-17$ & $5 \mathrm{E}-11$ \\
\hline $\mathrm{U}-\mathbf{2 3 2}^{b}$ & 2 & $-0.63 \pm 3.66 \mathrm{E}-10$ & $-0.94 \pm 5.48 \mathrm{E}-18$ & $<8.76 \mathrm{E}-18$ & $2 \mathrm{E}-14$ \\
\hline $\mathrm{U}-233 / 234^{b}$ & 2 & $1.87 \pm 0.54 \mathrm{E}-09$ & $2.80 \pm 0.80 \mathrm{E}-18$ & $2.44 \mathrm{E}-17$ & 9E-14 \\
\hline $\mathrm{U}-235 / 236^{b}$ & 2 & $2.42 \pm 2.15 \mathrm{E}-10$ & $3.62 \pm 3.22 \mathrm{E}-18$ & $<4.10 \mathrm{E}-18$ & $1 \mathrm{E}-13$ \\
\hline $\mathrm{U}-\mathbf{2 3 8}^{b}$ & 2 & $1.80 \pm 0.54 \mathrm{E}-10$ & $2.69 \pm 0.80 \mathrm{E}-17$ & $2.66 \mathrm{E}-17$ & $1 \mathrm{E}-13$ \\
\hline Pu-238 & 2 & $1.71 \pm 2.48 \mathrm{E}-10$ & $2.55 \pm 3.71 \mathrm{E}-18$ & $<5.00 \mathrm{E}-18$ & $3 \mathrm{E}-14$ \\
\hline Pu-239/240 & 2 & $2.12 \pm 3.41 \mathrm{E}-10$ & $3.18 \pm 5.11 \mathrm{E}-18$ & $<7.59 \mathrm{E}-18$ & $2 \mathrm{E}-14$ \\
\hline Am-241 & 2 & $-2.11 \pm 3.41 \mathrm{E}-10$ & $-3.15 \pm 5.11 \mathrm{E}-18$ & $<7.83 \mathrm{e}-18$ & $2 \mathrm{E}-14$ \\
\hline
\end{tabular}

$N$ - Number of samples

-- DCGs are not specified for gross alpha and beta activity.

${ }^{a}$ Derived concentration guides (DCGs) are listed for reference only. They are applicable to average concentrations at the site boundary but not to stack concentrations, as might be inferred from their inclusion in this table.

${ }^{b}$ Total Uranium: $3.60 \pm 0.06 E-03 \mathrm{~g}$; average $=5.39 \pm 0.08 \mathrm{E}-11 \mu \mathrm{g} / \mathrm{mL}$

$D-6$ 
Table D-6

2006 Effluent Airborne Radioactivity at Container Sorting and Packaging Facility (ANCSPFK)

\begin{tabular}{|c|c|c|c|c|c|}
\hline Isotope & $\mathbf{N}$ & $\begin{array}{c}\text { Total } \\
\text { Activity Released } \\
\text { (Ci) }\end{array}$ & $\begin{array}{c}\text { Average } \\
\text { Concentration } \\
(\mu \mathrm{Ci} / \mathrm{mL})\end{array}$ & $\begin{array}{c}\text { Maximum } \\
\text { Concentration } \\
(\mu \mathrm{Ci} / \mathrm{mL})\end{array}$ & $\begin{array}{c}\mathrm{DCG}^{a} \\
(\mu \mathrm{Ci} / \mathbf{m L})\end{array}$ \\
\hline Gross Alpha & 26 & $-1.37 \pm 5.99 \mathrm{E}-10$ & $-0.81 \pm 3.56 \mathrm{E}-17$ & $<2.91 \mathrm{E}-16$ & -- \\
\hline Gross Beta & 26 & $2.27 \pm 2.04 \mathrm{E}-09$ & $1.35 \pm 1.21 \mathrm{E}-16$ & $1.47 \mathrm{E}-15$ & -- \\
\hline Co-60 & 2 & $2.43 \pm 4.01 \mathrm{E}-10$ & $1.44 \pm 2.38 \mathrm{E}-17$ & $<3.68 \mathrm{E}-17$ & $8 \mathrm{E}-11$ \\
\hline Sr-90 & 2 & $4.75 \pm 8.72 \mathrm{E}-10$ & $2.82 \pm 5.18 \mathrm{E}-17$ & $<8.77 \mathrm{E}-17$ & $9 \mathrm{E}-12$ \\
\hline I-129 & 2 & $1.16 \pm 0.11 \mathrm{E}-07$ & $6.86 \pm 0.67 \mathrm{E}-15$ & $7.07 \mathrm{E}-15$ & $7 \mathrm{E}-11$ \\
\hline Cs-137 & 2 & $1.32 \pm 3.50 \mathrm{E}-10$ & $0.79 \pm 2.08 \mathrm{E}-17$ & $<3.33 \mathrm{E}-17$ & $4 \mathrm{E}-10$ \\
\hline Eu-154 & 2 & $-0.50 \pm 1.04 \mathrm{E}-09$ & $-2.99 \pm 6.15 \mathrm{E}-17$ & $<1.01 \mathrm{E}-16$ & $5 \mathrm{E}-11$ \\
\hline $\mathrm{U}-232^{b}$ & 2 & $-2.24 \pm 8.48 \mathrm{E}-11$ & $-1.33 \pm 5.03 \mathrm{E}-18$ & $<9.69 \mathrm{E}-18$ & $2 \mathrm{E}-14$ \\
\hline $\mathrm{U}-\mathbf{2 3 3} / \mathbf{2 3 4} 4^{b}$ & 2 & $5.69 \pm 1.72 \mathrm{E}-10$ & $3.38 \pm 1.02 \mathrm{E}-17$ & $4.59 \mathrm{E}-17$ & 9E-14 \\
\hline $\mathrm{U}-235 / 236^{b}$ & 2 & $1.25 \pm 0.78 \mathrm{E}-10$ & $7.43 \pm 4.64 \mathrm{E}-18$ & $9.52 \mathrm{E}-18$ & $1 \mathrm{E}-13$ \\
\hline $\mathrm{U}-238^{b}$ & 2 & $4.40 \pm 1.48 \mathrm{E}-10$ & $2.61 \pm 0.88 \mathrm{E}-18$ & $2.99 \mathrm{E}-17$ & $1 \mathrm{E}-13$ \\
\hline Pu-238 & 2 & $0.00 \pm 6.20 \mathrm{E}-11$ & $0.00 \pm 3.68 \mathrm{E}-18$ & $<5.96 \mathrm{E}-18$ & $3 \mathrm{E}-14$ \\
\hline Pu-239/240 & 2 & $7.84 \pm 9.20 \mathrm{E}-11$ & $4.65 \pm 5.46 \mathrm{E}-18$ & $<8.79 \mathrm{E}-18$ & $2 \mathrm{E}-14$ \\
\hline Am-241 & 2 & $1.95 \pm 4.79 \mathrm{E}-11$ & $1.15 \pm 2.84 \mathrm{E}-18$ & $<4.15 \mathrm{E}-18$ & 2E-14 \\
\hline
\end{tabular}

$N$ - Number of samples

-- DCGs are not specified for gross alpha and gross beta activity.

${ }^{a}$ Derived concentration guides (DCGs) are listed for reference only. They are applicable to average concentrations at the site boundary but not to stack concentrations, as might be inferred from their inclusion in this table.

${ }^{b}$ Total Uranium: $7.30 \pm 0.12 E-04 \mathrm{~g} ;$ average $=4.34 \pm 0.07 E-11 \mu \mathrm{g} / \mathrm{mL}$

$D-7$ 
Table D-7

2006 Effluent Airborne Radioactivity at Outdoor Ventilation Enclosures/ Portable Ventilation Units (OVEs/PVUs)

\begin{tabular}{|c|c|c|c|c|c|}
\hline Isotope & $\mathbf{N}$ & $\begin{array}{c}\text { Total } \\
\text { Activity Released } \\
\text { (Ci) }\end{array}$ & $\begin{array}{c}\text { Average } \\
\text { Concentration } \\
(\mu \mathrm{Ci} / \mathbf{m L})\end{array}$ & $\begin{array}{c}\text { Maximum } \\
\text { Concentration } \\
(\mu \mathrm{Ci} / \mathrm{mL})\end{array}$ & $\begin{array}{c}\mathrm{DCG}^{a} \\
(\mu \mathrm{Ci} / \mathbf{m L})\end{array}$ \\
\hline Gross Alpha & 56 & $-1.81 \pm 2.04 \mathrm{E}-09$ & $-3.53 \pm 3.99 \mathrm{E}-17$ & $4.46 \mathrm{E}-16$ & -- \\
\hline Gross Beta & 56 & $6.28 \pm 6.02 \mathrm{E}-09$ & $1.23 \pm 1.18 \mathrm{E}-16$ & $9.95 \mathrm{E}-16$ & -- \\
\hline Co-60 & 2 & $0.54 \pm 1.55 \mathrm{E}-09$ & $1.05 \pm 3.02 \mathrm{E}-17$ & $<4.44 \mathrm{E}-17$ & $8 \mathrm{E}-11$ \\
\hline Sr-90 & 2 & $0.83 \pm 2.04 \mathrm{E}-09$ & $1.62 \pm 3.98 \mathrm{E}-17$ & $<7.80 \mathrm{E}-17$ & $9 \mathrm{E}-12$ \\
\hline Cs-137 & 2 & $6.55 \pm 9.15 \mathrm{E}-10$ & $1.28 \pm 1.79 \mathrm{E}-17$ & $<2.34 \mathrm{E}-17$ & $4 \mathrm{E}-10$ \\
\hline Eu-154 & 2 & $-1.00 \pm 2.56 \mathrm{E}-09$ & $-1.95 \pm 5.00 \mathrm{E}-17$ & $<6.50 \mathrm{E}-17$ & $5 \mathrm{E}-11$ \\
\hline $\mathrm{U}-\mathbf{2 3 2}^{b}$ & 2 & $-0.47 \pm 1.08 \mathrm{E}-10$ & $-0.93 \pm 2.10 \mathrm{E}-18$ & $<2.85 \mathrm{E}-18$ & $2 \mathrm{E}-14$ \\
\hline $\mathrm{U}-\mathbf{2 3 3} / 234^{b}$ & 2 & $1.36 \pm 0.33 \mathrm{E}-09$ & $2.65 \pm 0.65 \mathrm{E}-17$ & $2.83 \mathrm{E}-17$ & 9E-14 \\
\hline $\mathrm{U}-235 / 236^{b}$ & 2 & $2.06 \pm 1.34 \mathrm{E}-10$ & $4.03 \pm 2.61 \mathrm{E}-18$ & $5.69 \mathrm{E}-18$ & $1 \mathrm{E}-13$ \\
\hline $\mathrm{U}-\mathbf{2 3 8}^{b}$ & 2 & $1.03 \pm 0.78 \mathrm{E}-09$ & $2.01 \pm 0.54 \mathrm{E}-17$ & $1.89 \mathrm{E}-17$ & $1 \mathrm{E}-13$ \\
\hline Pu-238 & 2 & $0.20 \pm 1.15 \mathrm{E}-10$ & $0.38 \pm 2.25 \mathrm{E}-18$ & $<3.25 \mathrm{E}-18$ & $3 \mathrm{E}-14$ \\
\hline Pu-239/240 & 2 & $1.16 \pm 1.82 \mathrm{E}-10$ & $2.26 \pm 3.55 \mathrm{E}-18$ & $<5.27 \mathrm{E}-18$ & $2 \mathrm{E}-14$ \\
\hline Am-241 & 2 & $-0.45 \pm 2.21 \mathrm{E}-10$ & $-0.88 \pm 4.32 \mathrm{E}-18$ & $<8.51 \mathrm{E}-18$ & $2 \mathrm{E}-14$ \\
\hline
\end{tabular}

$N$ - Number of samples

-- DCGs are not specified for gross alpha and gross beta activity.

${ }^{a}$ Derived concentration guides (DCGs) are listed for reference only. They are applicable to average concentrations at the site boundary but not to stack concentrations, as might be inferred from their inclusion in this table.

${ }^{b}$ Total Uranium: $3.16 \pm 0.05 E-03 \mathrm{~g}$; average $=6.18 \pm 0.10 \mathrm{E}-11 \mu \mathrm{g} / \mathrm{mL}$

$D-8$ 
Table D-8

2006 Effluent Airborne Radioactivity at Remote-Handled Waste Facility Stack (ANRHWFK)

\begin{tabular}{|c|c|c|c|c|c|}
\hline Isotope & $\mathbf{N}$ & $\begin{array}{c}\text { Total } \\
\text { Activity Released } \\
\text { (Ci) }\end{array}$ & $\begin{array}{c}\text { Average } \\
\text { Concentration } \\
(\mu \mathrm{Ci} / \mathrm{mL})\end{array}$ & $\begin{array}{c}\text { Maximum } \\
\text { Concentration } \\
(\mu \mathrm{Ci} / \mathrm{mL})\end{array}$ & $\begin{array}{c}\mathrm{DCG}^{a} \\
(\mu \mathrm{Ci} / \mathrm{mL})\end{array}$ \\
\hline Gross Alpha & 26 & $-0.57 \pm 7.07 \mathrm{E}-09$ & $-0.48 \pm 5.94 \mathrm{E}-17$ & $<3.15 \mathrm{E}-16$ & -- \\
\hline Gross Beta & 26 & $-2.86 \pm 2.27 \mathrm{E}-08$ & $-2.40 \pm 1.91 \mathrm{E}-16$ & $6.53 \mathrm{E}-16$ & -- \\
\hline Co-60 & 2 & $-0.08 \pm 5.55 \mathrm{E}-09$ & $-0.07 \pm 4.66 \mathrm{E}-17$ & $<4.17 \mathrm{E}-17$ & $8 \mathrm{E}-11$ \\
\hline Sr-90 & 2 & $0.13 \pm 1.17 \mathrm{E}-08$ & $1.11 \pm 9.82 \mathrm{E}-17$ & $<1.10 \mathrm{E}-16$ & 9E-12 \\
\hline I-129 & 2 & $6.38 \pm 3.66 \mathrm{E}-08$ & $5.36 \pm 3.07 \mathrm{E}-16$ & $6.68 \mathrm{E}-16$ & 7E-11 \\
\hline Cs-137 & 2 & $-1.49 \pm 4.39 \mathrm{E}-09$ & $-1.24 \pm 3.69 \mathrm{E}-17$ & $<3.35 \mathrm{E}-17$ & $4 \mathrm{E}-10$ \\
\hline Eu-154 & 2 & $-0.46 \pm 1.29 \mathrm{E}-08$ & $-0.39 \pm 1.08 \mathrm{E}-16$ & $<1.03 \mathrm{E}-16$ & $5 \mathrm{E}-11$ \\
\hline $\mathrm{U}-232^{b}$ & 2 & $1.60 \pm 9.79 \mathrm{E}-10$ & $1.35 \pm 8.23 \mathrm{E}-18$ & $<9.60 \mathrm{E}-18$ & $2 \mathrm{E}-14$ \\
\hline $\mathrm{U}-\mathbf{2 3 3} / 234^{b}$ & 2 & $6.32 \pm 1.85 \mathrm{E}-09$ & $5.31 \pm 1.56 \mathrm{E}-17$ & $4.00 \mathrm{E}-17$ & 9E-14 \\
\hline $\mathrm{U}-235 / 236^{b}$ & 2 & $1.84 \pm 0.92 \mathrm{E}-09$ & $1.54 \pm 0.77 \mathrm{E}-17$ & 9.99E-18 & 1E-13 \\
\hline $\mathbf{U}-238^{b}$ & 2 & $6.74 \pm 1.71 \mathrm{E}-09$ & $5.66 \pm 1.44 \mathrm{E}-17$ & $3.82 \mathrm{E}-17$ & $1 \mathrm{E}-13$ \\
\hline Pu-238 & 2 & $-1.21 \pm 5.80 \mathrm{E}-10$ & $-1.02 \pm 4.87 \mathrm{E}-18$ & $<5.55 \mathrm{E}-18$ & $3 \mathrm{E}-14$ \\
\hline Pu-239/240 & 2 & $1.31 \pm 7.20 \mathrm{E}-10$ & $1.10 \pm 6.05 \mathrm{E}-18$ & $<5.54 \mathrm{E}-18$ & $2 \mathrm{E}-14$ \\
\hline Am-241 & 2 & $1.22 \pm 5.70 \mathrm{E}-10$ & $1.03 \pm 4.79 \mathrm{E}-18$ & $<4.87 \mathrm{E}-18$ & $2 \mathrm{E}-14$ \\
\hline
\end{tabular}

$N$ - Number of samples

-- DCGs are not specified for gross alpha and gross beta activity.

${ }^{a}$ Derived concentration guides (DCGs) are listed for reference only. They are applicable to average concentrations at the site boundary but not to stack concentrations, as might be inferred from their inclusion in this table.

${ }^{b}$ Total Uranium: $1.22 \pm 0.02 E-02 \mathrm{~g}$; average $=1.03 \pm 0.02 \mathrm{E}-12 \mu \mathrm{g} / \mathrm{mL}$ 
Table D-9

2006 Ambient Airborne Radioactivity at Lag Storage

(ANLAGAM)

\begin{tabular}{|c|c|c|c|c|c|c|}
\hline \multirow[t]{2}{*}{ Isotope } & \multirow[t]{2}{*}{$\mathbf{N}$} & \multicolumn{2}{|c|}{$\begin{array}{c}\text { ANLAGAM } \\
\mu \mathrm{Ci} / \mathrm{mL}\end{array}$} & \multirow[t]{2}{*}{$\mathbf{N}$} & \multirow{2}{*}{$\begin{array}{c}\text { AFGRVAL }^{a} \\
\mu \mathrm{Ci} / \mathrm{mL}\end{array}$} & \multirow[t]{2}{*}{$\mathbf{D C G}^{b}$} \\
\hline & & Average & Maximum & & & \\
\hline Gross Alpha & 26 & $8.50 \pm 4.36 \mathrm{E}-16$ & $2.00 \mathrm{E}-15$ & 26 & 7.68E-17-1.76E-15 & -- \\
\hline Gross Beta & 26 & $1.74 \pm 0.16 \mathrm{E}-14$ & 3.34E-14 & 26 & $1.99 \mathrm{E}-15-3.16 \mathrm{E}-14$ & -- \\
\hline K-40 & 2 & $4.11 \pm 9.55 \mathrm{E}-16$ & $7.51 \mathrm{E}-16$ & 2 & $<1.30 \mathrm{E}-15-<1.69 \mathrm{E}-15$ & $9 \mathrm{E}-10$ \\
\hline Co-60 & 2 & $0.71 \pm 3.98 \mathrm{E}-17$ & $<4.82 \mathrm{E}-17$ & 2 & $<7.41 \mathrm{E}-17-8.14 \mathrm{E}-17$ & $8 \mathrm{E}-11$ \\
\hline Sr-90 & 2 & $4.09 \pm 9.80 \mathrm{E}-17$ & $<1.08 \mathrm{E}-16$ & 2 & $<7.11 \mathrm{E}-17-<1.31 \mathrm{E}-16$ & $9 \mathrm{E}-12$ \\
\hline Cs-137 & 2 & $0.68 \pm 3.52 \mathrm{E}-17$ & $<4.06 \mathrm{E}-17$ & 2 & $<5.80 \mathrm{E}-17-9.70 \mathrm{E}-17$ & $4 \mathrm{E}-10$ \\
\hline Eu-154 & 2 & $0.28 \pm 1.09 \mathrm{E}-16$ & $<1.19 \mathrm{E}-16$ & 2 & $<1.85 \mathrm{E}-16-<2.49 \mathrm{E}-16$ & $5 \mathrm{E}-11$ \\
\hline $\mathrm{U}-232^{c}$ & 2 & $0.28 \pm 8.94 \mathrm{E}-18$ & $<1.10 \mathrm{E}-17$ & 2 & $<8.59 \mathrm{E}-18-<1.04 \mathrm{E}-17$ & $2 \mathrm{E}-14$ \\
\hline $\mathrm{U}-233 / 234^{c}$ & 2 & $2.51 \pm 1.07 \mathrm{E}-17$ & $3.00 \mathrm{E}-17$ & 2 & 4.22E-17-9.45E-17 & 9E-14 \\
\hline $\mathrm{U}-235 / 236^{c}$ & 2 & $4.16 \pm 5.61 \mathrm{E}-18$ & $<5.74 \mathrm{E}-18$ & 2 & 8.46E-18-2.84E-17 & $1 \mathrm{E}-13$ \\
\hline $\mathrm{U}-238^{c}$ & 2 & $1.43 \pm 0.90 \mathrm{E}-17$ & $1.68 \mathrm{E}-17$ & 2 & 2.70E-17-4.49E-17 & $1 \mathrm{E}-13$ \\
\hline Pu-238 & 2 & $0.49 \pm 3.71 \mathrm{E}-18$ & $<4.05 \mathrm{E}-18$ & 2 & $<3.26 \mathrm{E}-18-<8.73 \mathrm{E}-18$ & $3 \mathrm{E}-14$ \\
\hline Pu-239/240 & 2 & $2.21 \pm 4.65 \mathrm{E}-18$ & $<5.10 \mathrm{E}-18$ & 2 & $<7.30 \mathrm{E}-18-<8.28 \mathrm{E}-18$ & $2 \mathrm{E}-14$ \\
\hline Am-241 & 2 & $-0.67 \pm 5.02 \mathrm{E}-18$ & $<5.14 \mathrm{E}-18$ & 2 & $<1.98 \mathrm{E}-18-<1.40 \mathrm{E}-17$ & $2 \mathrm{E}-14$ \\
\hline
\end{tabular}

$N$ - Number of samples

-- DCGs are not specified for gross alpha and gross beta activity.

${ }^{a}$ Background air sampling location

${ }^{b}$ Derived concentration guides (DCGs) are applicable to average concentrations at the site boundary.

${ }^{c}$ Total Uranium: ANLAGAM average $=4.86 \pm 0.12 \mathrm{E}-11 \mu \mathrm{g} / \mathrm{mL} ;$ AFGRVAL average $=7.45 \pm 0.17 \mathrm{E}-11 \mu \mathrm{g} / \mathrm{mL}$ 
Table D-10

2006 Ambient Airborne Radioactivity at Rock Springs Road (AFRSPRD)

\begin{tabular}{|c|c|c|c|c|c|c|}
\hline \multirow[t]{2}{*}{ Isotope } & \multirow[t]{2}{*}{$\mathbf{N}$} & \multicolumn{2}{|c|}{$\begin{array}{c}\text { AFRSPRD } \\
\mu \mathrm{Ci} / \mathrm{mL}\end{array}$} & \multirow[t]{2}{*}{$\mathbf{N}$} & \multirow{2}{*}{$\begin{array}{c}\text { AFGRVAL }^{a} \\
\mu \mathrm{Ci} / \mathrm{mL} \\
\text { Background Range }\end{array}$} & \multirow[t]{2}{*}{$\mathbf{D C G}^{b}$} \\
\hline & & Average & Maximum & & & \\
\hline Gross Alpha & 26 & $7.79 \pm 5.30 \mathrm{E}-16$ & $1.43 \mathrm{E}-15$ & 26 & $7.68 \mathrm{E}-17-1.76 \mathrm{E}-15$ & -- \\
\hline Gross Beta & 26 & $1.72 \pm 0.20 \mathrm{E}-14$ & 3.37E-14 & 26 & $1.99 \mathrm{E}-15-3.16 \mathrm{E}-14$ & -- \\
\hline K-40 & 2 & $0.88 \pm 1.02 \mathrm{E}-15$ & $1.29 \mathrm{E}-15$ & 2 & $<1.30 \mathrm{E}-15-<1.69 \mathrm{E}-15$ & 9E-10 \\
\hline Co-60 & 2 & $-0.17 \pm 5.94 \mathrm{E}-17$ & $<6.49 \mathrm{E}-17$ & 2 & $<7.41 \mathrm{E}-17-8.14 \mathrm{E}-17$ & $8 \mathrm{E}-11$ \\
\hline Sr-90 & 2 & $0.43 \pm 1.18 \mathrm{E}-16$ & $<1.49 \mathrm{E}-16$ & 2 & $<7.11 \mathrm{E}-17-<1.31 \mathrm{E}-16$ & 9E-12 \\
\hline I-129 & 2 & $1.34 \pm 2.97 \mathrm{E}-16$ & $<3.41 \mathrm{E}-16$ & 2 & $<8.29 \mathrm{E}-17-<1.19 \mathrm{E}-16$ & $7 \mathrm{E}-11$ \\
\hline Cs-137 & 2 & $0.05 \pm 5.33 \mathrm{E}-17$ & $<5.76 \mathrm{E}-17$ & 2 & $<5.80 \mathrm{E}-17-9.70 \mathrm{E}-17$ & $4 \mathrm{E}-10$ \\
\hline Eu-154 & 2 & $0.84 \pm 1.58 \mathrm{E}-16$ & $<1.80 \mathrm{E}-16$ & 2 & $<1.85 \mathrm{E}-16-<2.49 \mathrm{E}-16$ & $5 \mathrm{E}-11$ \\
\hline $\mathrm{U}-\mathbf{2 3 2}^{c}$ & 2 & $0.96 \pm 1.61 \mathrm{E}-17$ & $<2.07 \mathrm{E}-17$ & 2 & $<8.59 \mathrm{E}-18-<1.04 \mathrm{E}-17$ & $2 \mathrm{E}-14$ \\
\hline $\mathrm{U}-233 / 234^{c}$ & 2 & $4.48 \pm 2.55 \mathrm{E}-17$ & $6.61 \mathrm{E}-17$ & 2 & 4.22E-17-9.45E-17 & 9E-14 \\
\hline $\mathrm{U}-\mathbf{2 3 5} / 236^{c}$ & 2 & $1.35 \pm 1.74 \mathrm{E}-17$ & $2.90 \mathrm{E}-17$ & 2 & $8.46 \mathrm{E}-18-2.84 \mathrm{E}-17$ & $1 \mathrm{E}-13$ \\
\hline $\mathrm{U}-238^{c}$ & 2 & $3.78 \pm 2.42 \mathrm{E}-17$ & 4.96E-17 & 2 & 2.70E-17-4.49E-17 & $1 \mathrm{E}-13$ \\
\hline Pu-238 & 2 & $-0.80 \pm 5.27 \mathrm{E}-18$ & $<6.87 \mathrm{E}-18$ & 2 & $<3.26 \mathrm{E}-18-<8.73 \mathrm{E}-18$ & $3 \mathrm{E}-14$ \\
\hline Pu-239/240 & 2 & $2.33 \pm 6.34 \mathrm{E}-18$ & $<6.85 \mathrm{E}-18$ & 2 & $<7.30 \mathrm{E}-18-<8.28 \mathrm{E}-18$ & $2 \mathrm{E}-14$ \\
\hline Am-241 & 2 & $1.17 \pm 1.59 \mathrm{E}-17$ & $<1.69 \mathrm{E}-17$ & 2 & $<1.98 \mathrm{E}-18-<1.40 \mathrm{E}-17$ & $2 \mathrm{E}-14$ \\
\hline
\end{tabular}

$N$ - Number of samples

-- DCGs are not specified for gross alpha and gross beta activity.

${ }^{a}$ Background air sampling location

${ }^{b}$ Derived concentration guides (DCGs) are applicable to average concentrations at the site boundary.

${ }^{c}$ Total Uranium: AFRSPRD average $=7.49 \pm 0.17 \mathrm{E}-11 \mu \mathrm{g} / \mathrm{mL} ;$ AFGRVAL average $=7.45 \pm 0.17 \mathrm{E}-11 \mu \mathrm{g} / \mathrm{mL}$ 
Table D-11

2006 Ambient Airborne Radioactivity at Fox Valley Road (AFFXVRD)

\begin{tabular}{|c|c|c|c|c|c|c|}
\hline \multirow[t]{2}{*}{ Isotope } & \multirow[t]{2}{*}{$\mathbf{N}$} & \multicolumn{2}{|c|}{$\begin{array}{c}\text { AFFXVRD } \\
\mu \mathrm{Ci} / \mathrm{mL}\end{array}$} & \multirow[t]{2}{*}{$\mathbf{N}$} & \multirow{2}{*}{$\begin{array}{c}\text { AFGRVAL }^{a} \\
\mu \mathrm{Ci} / \mathrm{mL}\end{array}$} & \multirow[t]{2}{*}{$\mathbf{D C G}^{b}$} \\
\hline & & Average & Maximum & & & \\
\hline Gross Alpha & 26 & $9.23 \pm 5.65 \mathrm{E}-16$ & $1.90 \mathrm{E}-15$ & 26 & $7.68 \mathrm{E}-17-1.76 \mathrm{E}-15$ & -- \\
\hline Gross Beta & 26 & $1.74 \pm 0.20 \mathrm{E}-14$ & $3.04 \mathrm{E}-14$ & 26 & $1.99 \mathrm{E}-15-3.16 \mathrm{E}-14$ & -- \\
\hline K-40 & 2 & $1.82 \pm 9.39 \mathrm{E}-16$ & $<1.17 \mathrm{E}-15$ & 2 & $<1.30 \mathrm{E}-15-<1.69 \mathrm{E}-15$ & 9E-10 \\
\hline Co-60 & 2 & $0.19 \pm 5.12 \mathrm{E}-17$ & $<5.32 \mathrm{E}-17$ & 2 & $<7.41 \mathrm{E}-17-8.14 \mathrm{E}-17$ & $8 \mathrm{E}-11$ \\
\hline Sr-90 & 2 & $0.47 \pm 1.25 \mathrm{E}-16$ & $<1.51 \mathrm{E}-16$ & 2 & $<7.11 \mathrm{E}-17-<1.31 \mathrm{E}-16$ & $9 \mathrm{E}-12$ \\
\hline Cs-137 & 2 & $2.48 \pm 4.27 \mathrm{E}-17$ & $6.09 \mathrm{E}-17$ & 2 & $<5.80 \mathrm{E}-17-9.70 \mathrm{E}-17$ & $4 \mathrm{E}-10$ \\
\hline
\end{tabular}

$N$ - Number of samples

-- DCGs are not specified for gross alpha and gross beta activity.

${ }^{a}$ Background air sampling location

${ }^{b}$ Derived concentration guides (DCGs) are applicable to average concentrations at the site boundary.

\section{Table D-12}

2006 Ambient Airborne Radioactivity at Route 240

(AFRT240)

\begin{tabular}{|c|c|c|c|c|c|c|}
\hline \multirow[t]{2}{*}{ Isotope } & \multirow[t]{2}{*}{$\mathbf{N}$} & \multicolumn{2}{|c|}{$\begin{array}{c}\text { AFRT240 } \\
\mu \mathrm{Ci} / \mathrm{mL}\end{array}$} & \multirow[t]{2}{*}{$\mathbf{N}$} & \multirow{2}{*}{$\begin{array}{c}\text { AFGRVAL }^{a} \\
\mu \mathrm{Ci} / \mathrm{mL}\end{array}$} & \multirow[t]{2}{*}{$\mathrm{DCG}^{b}$} \\
\hline & & Average & Maximum & & & \\
\hline Gross Alpha & 26 & $7.97 \pm 6.28 \mathrm{E}-16$ & $1.66 \mathrm{E}-15$ & 26 & $7.68 \mathrm{E}-17-1.76 \mathrm{E}-15$ & -- \\
\hline Gross Beta & 26 & $1.77 \pm 0.22 \mathrm{E}-14$ & $3.18 \mathrm{E}-14$ & 26 & $1.99 \mathrm{E}-15-3.16 \mathrm{E}-14$ & -- \\
\hline K-40 & 2 & $0.91 \pm 1.24 \mathrm{E}-15$ & $1.58 \mathrm{E}-15$ & 2 & $<1.30 \mathrm{E}-15-<1.69 \mathrm{E}-15$ & $9 \mathrm{E}-10$ \\
\hline Co-60 & 2 & $-0.01 \pm 5.44 \mathrm{E}-17$ & $<5.85 \mathrm{E}-17$ & 2 & $<7.41 \mathrm{E}-17-8.14 \mathrm{E}-17$ & $8 \mathrm{E}-11$ \\
\hline Sr-90 & 2 & $0.85 \pm 1.32 \mathrm{E}-16$ & $<1.65 \mathrm{E}-16$ & 2 & $<7.11 \mathrm{E}-17-<1.31 \mathrm{E}-16$ & $9 \mathrm{E}-12$ \\
\hline Cs-137 & 2 & $1.70 \pm 5.00 \mathrm{E}-17$ & $4.45 \mathrm{E}-17$ & 2 & $<5.80 \mathrm{E}-17-9.70 \mathrm{E}-17$ & $4 \mathrm{E}-10$ \\
\hline
\end{tabular}

$N$ - Number of samples

-- DCGs are not specified for gross alpha and gross beta activity.

${ }^{a}$ Background air sampling location

${ }^{b}$ Derived concentration guides (DCGs) are applicable to average concentrations at the site boundary. 


\section{Table D-13 \\ 2006 Ambient Airborne Radioactivity at West Valley (AFWEVAL)}

\begin{tabular}{|c|c|c|c|c|c|c|}
\hline \multirow[t]{2}{*}{ Isotope } & \multirow[t]{2}{*}{$\mathbf{N}$} & \multicolumn{2}{|c|}{$\begin{array}{c}\text { AFWEVAL } \\
\mu \mathrm{Ci} / \mathrm{mL}\end{array}$} & \multirow[t]{2}{*}{$\mathbf{N}$} & \multirow{2}{*}{$\begin{array}{c}\text { AFGRVAL }^{a} \\
\mu \mathrm{Ci} / \mathrm{mL} \\
\text { Background Range }\end{array}$} & \multirow[t]{2}{*}{$\mathbf{D C G}^{b}$} \\
\hline & & Average & Maximum & & & \\
\hline Gross Alpha & 26 & $8.63 \pm 5.36 \mathrm{E}-16$ & $1.57 \mathrm{E}-15$ & 26 & $7.68 \mathrm{E}-17-1.76 \mathrm{E}-15$ & -- \\
\hline Gross Beta & 26 & $1.76 \pm 0.19 \mathrm{E}-14$ & 3.09E-14 & 26 & $1.99 \mathrm{E}-15-3.16 \mathrm{E}-14$ & -- \\
\hline K-40 & 2 & $0.00 \pm 1.23 \mathrm{E}-15$ & $<1.37 \mathrm{E}-15$ & 2 & $<1.30 \mathrm{E}-15-<1.69 \mathrm{E}-15$ & $9 \mathrm{E}-10$ \\
\hline Co-60 & 2 & $-2.67 \pm 5.57 \mathrm{E}-17$ & $<6.62 \mathrm{E}-17$ & 2 & $<7.41 \mathrm{E}-17-8.14 \mathrm{E}-17$ & $8 \mathrm{E}-11$ \\
\hline Sr-90 & 2 & $-0.04 \pm 1.09 \mathrm{E}-16$ & $<1.21 \mathrm{E}-16$ & 2 & $<7.11 \mathrm{E}-17-1.31 \mathrm{E}-16$ & $9 \mathrm{E}-12$ \\
\hline Cs-137 & 2 & $1.40 \pm 4.76 \mathrm{E}-17$ & $<5.62 \mathrm{E}-17$ & 2 & $<5.80 \mathrm{E}-17-9.70 \mathrm{E}-17$ & $4 \mathrm{E}-10$ \\
\hline
\end{tabular}

$N$ - Number of samples

-- DCGs are not specified for gross alpha and gross beta activity.

${ }^{a}$ Background air sampling location

${ }^{b}$ Derived concentration guides (DCGs) are applicable to average concentrations at the site boundary.

\section{Table D-14 \\ 2006 Ambient Airborne Radioactivity at Springville (AFSPRVL)}

\begin{tabular}{|c|c|c|c|c|c|c|}
\hline \multirow[t]{2}{*}{ Isotope } & \multirow[t]{2}{*}{$\mathbf{N}$} & \multicolumn{2}{|c|}{$\begin{array}{c}\text { AFSPRVL } \\
\mu \mathrm{Ci} / \mathrm{mL}\end{array}$} & \multirow[t]{2}{*}{$\mathbf{N}$} & \multirow{2}{*}{$\begin{array}{c}\text { AFGRVAL }^{a} \\
\mu \mathrm{Ci} / \mathrm{mL}\end{array}$} & \multirow[t]{2}{*}{ DCG $^{b}$} \\
\hline & & Average & Maximum & & & \\
\hline Gross Alpha & 26 & $8.37 \pm 5.40 \mathrm{E}-16$ & $1.69 \mathrm{E}-15$ & 26 & 7.68E-17-1.76E-15 & -- \\
\hline Gross Beta & 26 & $1.73 \pm 0.20 \mathrm{E}-14$ & $3.14 \mathrm{E}-14$ & 26 & $1.99 \mathrm{E}-15-3.16 \mathrm{E}-14$ & -- \\
\hline K-40 & 2 & $0.62 \pm 1.13 \mathrm{E}-15$ & $1.24 \mathrm{E}-15$ & 2 & $<1.30 \mathrm{E}-15-<1.69 \mathrm{E}-15$ & $9 \mathrm{E}-10$ \\
\hline Co-60 & 2 & $2.63 \pm 8.46 \mathrm{E}-17$ & $<1.11 \mathrm{E}-16$ & 2 & $<7.41 \mathrm{E}-17-8.14 \mathrm{E}-17$ & $8 \mathrm{E}-11$ \\
\hline Sr-90 & 2 & $0.51 \pm 1.22 \mathrm{E}-16$ & $<1.44 \mathrm{E}-16$ & 2 & $<7.11 \mathrm{E}-17-<1.31 \mathrm{E}-16$ & $9 \mathrm{E}-12$ \\
\hline Cs-137 & 2 & $-0.15 \pm 1.32 \mathrm{E}-16$ & $<1.82 \mathrm{E}-16$ & 2 & $<5.80 \mathrm{E}-17-9.70 \mathrm{E}-17$ & $4 \mathrm{E}-10$ \\
\hline
\end{tabular}

$N$ - Number of samples

-- DCGs are not specified for gross alpha and gross beta activity.

a Background air sampling location

${ }^{b}$ Derived concentration guides (DCGs) are applicable to average concentrations at the site boundary. 
Table D-15

2006 Radioactivity in Fallout: Rain Gauge

(ANRGFOP)

\begin{tabular}{|l|c|c|c|c|c|}
\hline \multicolumn{1}{|c|}{ Analyte } & Units & N & Minimum & Average & Maximum \\
\hline Gross Alpha & $\mathrm{nCi} / \mathrm{m}^{2}$ & 12 & $2.22 \mathrm{E}-02$ & $8.08 \pm 1.66 \mathrm{E}-02$ & $1.30 \mathrm{E}-01$ \\
\hline Gross Beta & $\mathrm{nCi} / \mathrm{m}^{2}$ & 12 & $2.68 \mathrm{E}-01$ & $5.79 \pm 0.43 \mathrm{E}-01$ & $8.98 \mathrm{E}-01$ \\
\hline H-3 & $\mu \mathrm{Ci} / \mathrm{mL}$ & 12 & $<6.42 \mathrm{E}-08$ & $3.21 \pm 8.16 \mathrm{E}-08$ & $1.47 \mathrm{E}-07$ \\
\hline K-40 & $\mathrm{nCi} / \mathrm{m}^{2}$ & 12 & $<3.03 \mathrm{E}+00$ & $0.37 \pm 9.04 \mathrm{E}+00$ & $<1.54 \mathrm{E}+01$ \\
\hline Cs-137 & $\mathrm{nCi} / \mathrm{m}^{2}$ & 12 & $<2.36 \mathrm{E}-01$ & $0.81 \pm 6.77 \mathrm{E}-01$ & $3.27 \mathrm{E}-01$ \\
\hline
\end{tabular}

$N$ - Number of samples

D -14 


\section{Appendix $E$ Summary of Groundwater Monitoring Data}

E- 1 


\section{Groundwater Sampling Methodology}

Groundwater samples are collected from monitoring wells using either dedicated Teflon ${ }^{\circledR}$ well bailers or bladder pumps. Bailers are used in low-yield wells; bladder pumps are used in wells with good water-yielding characteristics. This sampling equipment is dedicated to an individual well to reduce the likelihood of sample contamination from external materials or cross contamination.

To ensure that only representative groundwater is sampled, three well volumes are removed (purged) from the well before the actual samples are collected. In low-yield wells, pumping or bailing to dryness provides sufficient purging. Conductivity and $\mathrm{pH}$ are measured before and after sampling to confirm the geochemical stability of the groundwater during sampling.

The bailer, a tube with a check valve at the bottom, is lowered slowly into the well to minimize agitation of the water column. The bailer containing the groundwater is then withdrawn from the well and emptied into a sample container. Bladder pumps use compressed air to gently squeeze a Teflon ${ }^{\circledR}$ bladder that prevents contact with the groundwater as it is pumped into a sample container with a minimum of agitation and mixing. A check valve ensures that the water flows in only one direction.

Groundwater samples are cooled and preserved, with chemicals if required, to minimize chemical and/or biological changes after sample collection. A strict chain-of-custody protocol is followed for all samples collected by the WVDP.

\section{Key to bolding convention:}

Tables E-2 $\mathbf{6 0}$ through E-11 $\mathbf{6 0}$ contain a bolding convention devised to help the reader, when viewing the data, to quickly see the range of detectable measurements within a data series. A data series is a set of chemical or radionuclide measurements (e.g., gross alpha, gross beta, tritium) from a single location or from similar locations. Note that some tables contain data that should not be technically evaluated under this convention.

Results for each analyte constitute a single data series. If a radiological result is larger than the uncertainty term, the measurement is considered positive. Otherwise, a result is considered nondetectable. Chemical results preceded by "less than" $(<)$ are considered nondetectable. The bolding convention is not applied to data series consisting of less than three values.

If all results in a data series are positive, the lowest and highest values are bolded.

If a data series contains some positive results, the highest value is bolded.

If all values in a data series are nondetectable, no values are bolded.

$$
E-2
$$




\section{Groundwater Sampling and Analysis Agenda}

\section{Analyte Group}

Contamination Indicator Parameters (I)

Radiological Indicator Parameters (RI)

Volatile Organic Compounds (V)

Semivolatile Organic Compounds (SV)

6 NYCRR Appendix 33 Metals (M)

Special Monitoring Parameters

for Early Warning Wells (SM)

Radioisotopic Analyses:

alpha-, beta-, and gamma-emitters (R)

Strontium-90 (S)

\section{Description of Parameters ${ }^{a}$}

$\mathrm{pH}$, specific conductance (field measurements)

Gross alpha, gross beta, tritium

6 NYCRR Appendix 33 Volatile Organic Compounds (VOCs) (See Table E-12 $2^{\text {at }}$ )

6 NYCRR Appendix 33 Semivolatile Organic Compounds (SVOCs) and tributyl phosphate (TBP) (See Table E-12 ${ }^{\mathrm{Wx}}$.)

Antimony, arsenic, barium, beryllium, cadmium, chromium, cobalt, copper, lead, mercury, nickel, selenium, silver, thallium, tin, vanadium, zinc

Aluminum, iron, manganese

Carbon-14, strontium-90, technetium-99, iodine-129, cesium-137, radium-226, radium-228, uranium-232, uranium-233/234, uranium-235/236, uranium-238, total uranium

Strontium-90

2006 Quarterly Monitoring Schedule:

1st Qtr - December 1, 2005 to February 28, 2006

2nd Qtr - March 1, 2006 to May 31, 2006

3rd Qtr - June 1, 2006 to August 31, 2006

4th Qtr - September 1, 2006 to November 30, 2006

${ }^{a}$ Analysis performed for selected active monitoring locations only. See Table E-1 ${ }^{\mathbf{6 0}}$ for the analytes assigned to each monitoring location.

$$
\text { E - } 3
$$


Table E-1

Groundwater Monitoring Network Sorted by Geologic Unit

Sand and Gravel Wells

\begin{tabular}{|c|c|c|c|c|c|c|c|}
\hline Well ID & SSWMU & $\begin{array}{l}\text { Gradient } \\
\text { Position }\end{array}$ & $\begin{array}{c}\text { Analytical } \\
\text { Parameters in } 2006^{a}\end{array}$ & Well ID & SSWMU & $\begin{array}{l}\text { Gradient } \\
\text { Position }\end{array}$ & $\begin{array}{c}\text { Analytical } \\
\text { Parameters in } 2006^{a}\end{array}$ \\
\hline $103^{b}$ & 1,3 & D & I, RI, V & 802 & 8 & D & I, RI, V \\
\hline 104 & 1 & $\mathrm{C}$ & I, RI & $803^{b}$ & 8 & $\mathrm{D}$ & I, RI, SV, V \\
\hline 105 & 1 & $\mathrm{C}$ & I, RI & $804^{b}$ & 8 & $\mathrm{D}$ & I, RI, V \\
\hline 106 & 1 & $\mathrm{D}$ & I, RI & 1302 & $\mathrm{NA}^{c}$ & $\mathrm{D}$ & I, RI, M, R, SV, V \\
\hline $111^{b}$ & 1 & $\mathrm{D}$ & I, RI, M, S, SV, V & 1304 & $\mathrm{NA}^{c}$ & $\mathrm{U}$ & I, RI, M, R, SV, V \\
\hline $116^{b}$ & 1,8 & $\mathrm{C}, \mathrm{U}$ & I, RI, S, V & 8603 & 8 & $\mathrm{U}$ & I, RI, S \\
\hline 201 & 2 & $\mathrm{U}$ & I, RI & 8604 & 1 & $\mathrm{C}$ & I, RI \\
\hline 205 & 2,3 & $\mathrm{D}$ & $\mathrm{I}, \mathrm{RI}$ & $8605^{b}$ & 1,2 & $\mathrm{D}$ & I, RI, M, S, SV, V \\
\hline $301^{b}$ & 3 & B & $\mathrm{I}, \mathrm{RI}$ & $8607^{b}$ & 6,4 & U, D & I, RI, V \\
\hline $401^{b}$ & 4,3 & B & I, RI, R & $8609^{b}$ & $3,4,6$ & $\mathrm{D}, \mathrm{D}, \mathrm{U}$ & I, RI, S, V \\
\hline 403 & 4 & $\mathrm{U}$ & I, RI & $8612^{b}$ & 8 & $\mathrm{D}$ & I, RI, SV, V \\
\hline $406^{b}$ & 4,6 & $\mathrm{D}, \mathrm{U}$ & I, RI, R, V & NB-1S & $\mathrm{NA}^{d}$ & B & I, RI \\
\hline $408^{b}$ & 4,3 & $\mathrm{D}$ & $\mathrm{I}, \mathrm{RI}, \mathrm{R}, \mathrm{V}$ & WP-A & $\mathrm{NA}^{e}$ & NA & $\mathrm{I}, \mathrm{RI}$ \\
\hline $501^{b}$ & 5 & $\mathrm{U}$ & I, RI, S, V & WP-C & $\mathrm{NA}^{e}$ & NA & I, RI \\
\hline $502^{b}$ & 5 & $\mathrm{D}$ & I, RI, S, SM, V & WP-H & $\mathrm{NA}^{e}$ & NA & I, RI \\
\hline $602 \mathrm{~A}$ & 6 & $\mathrm{D}$ & $\mathrm{I}, \mathrm{RI}$ & SP04 & $\mathrm{NA}^{f}$ & $\mathrm{D}$ & RI \\
\hline 604 & 6 & $\mathrm{D}$ & I, RI & SP06 & $\mathrm{NA}^{f}$ & $\mathrm{D}$ & RI \\
\hline 605 & 6 & $\mathrm{D}$ & I, RI & SP11 & $\mathrm{NA}^{f}$ & $\mathrm{D}$ & I, RI \\
\hline $706^{b}$ & 7 & B & I, RI, M, R, SV, V & $\mathrm{SP} 12^{b}$ & $\mathrm{NA}^{f}$ & $\mathrm{D}$ & I, RI, V \\
\hline $801^{b}$ & 8,6 & U, D & $\mathrm{I}, \mathrm{RI}, \mathrm{S}, \mathrm{V}$ & $\mathrm{GSEEP}^{b}$ & $\mathrm{NA}^{f}$ & $\mathrm{D}$ & I, RI, V \\
\hline
\end{tabular}

Legend: $\quad$ Gradient Positions

$B$ (background)

$C$ (crossgradient)

$D$ (downgradient)

$U$ (upgradient)

NA - Not applicable

${ }^{a}$ See $p . E-3$ (cD for a description of codes and analytes.

${ }^{b}$ Monitoring for certain parameters is required by the RCRA $\$ 3008(h)$ Order on Consent.

${ }^{c}$ Monitor upgradient and downgradient of remote-handled waste facility

${ }^{d}$ Former background well

${ }^{e}$ Monitor locations north and east of main plant

${ }^{f}$ Monitor groundwater emanating from seeps along the edge of the north plateau 


\section{Table E-1 (concluded) \\ Groundwater Monitoring Network Sorted by Geologic Unit}

Lavery Till Sand Wells

\begin{tabular}{|c|c|c|c|c|c|c|c|}
\hline Well ID & SSWMU & $\begin{array}{c}\text { Gradient } \\
\text { Position }\end{array}$ & $\begin{array}{c}\text { Analytical } \\
\text { Parameters in 2006 }\end{array}$ & Well ID & SSWMU & $\begin{array}{c}\text { Gradient } \\
\text { Position }\end{array}$ & $\begin{array}{c}\text { Analytical } \\
\text { Parameters in 2006 }\end{array}$ \\
\hline $204^{b}$ & 2,3 & D & I, RI & 302 & 3 & U & I, RI \\
\hline 206 & 2 & C & I, RI & 402 & 4 & B & I, RI \\
\hline 208 & 2 & D & I, RI & & & & \\
\hline
\end{tabular}

Weathered Lavery Till Wells

\begin{tabular}{|c|c|c|c|c|c|c|c|}
\hline Well ID & SSWMU & $\begin{array}{c}\text { Gradient } \\
\text { Position }\end{array}$ & $\begin{array}{c}\text { Analytical } \\
\text { Parameters in } 2006^{a}\end{array}$ & Well ID & SSWMU & $\begin{array}{c}\text { Gradient } \\
\text { Position }\end{array}$ & $\begin{array}{c}\text { Analytical } \\
\text { Parameters in } 2006^{a}\end{array}$ \\
\hline $906^{b}$ & 9 & D & I, RI & $1005^{b}$ & 9,10 & C, U & I, RI \\
\hline $908^{b}$ & 9 & B & I, RI & $1006^{b}$ & 9,10 & C, D & I, RI \\
\hline $909^{b}$ & 9 & D & I, RI, M, R, SV, V & 1007 & 10 & D & I, RI \\
\hline NDATR $^{b}$ & 9 & D & I, RI, M, R, SV, V & $1008 C^{b}$ & 9,10 & U & I, RI \\
\hline
\end{tabular}

Unweathered Lavery Till Wells

\begin{tabular}{|c|c|c|c|c|c|c|c|}
\hline Well ID & SSWMU & $\begin{array}{c}\text { Gradient } \\
\text { Position }\end{array}$ & $\begin{array}{c}\text { Analytical } \\
\text { Parameters in 2006 }\end{array}$ & Well ID & SSWMU & $\begin{array}{c}\text { Gradient } \\
\text { Position }\end{array}$ & $\begin{array}{c}\text { Analytical } \\
\text { Parameters in 2006 }\end{array}$ \\
\hline 107 & 1 & D & I, RI, V & 704 & 7 & D & I, RI, V \\
\hline 108 & 1 & D & I, RI, V & 707 & 7 & C & I, RI \\
\hline $110^{b}$ & 1 & D & I, RI, V & $910^{b}$ & 9 & D & I, RI \\
\hline 405 & 4 & B & I, RI, M, R, SV, V & 1301 & $\mathrm{NA}^{c}$ & D & I, RI, M, R, SV, V \\
\hline 409 & 4 & D & I, RI & 1303 & NA $^{c}$ & U & I, RI, M, R, SV, V \\
\hline
\end{tabular}

Kent Recessional Sequence Wells

\begin{tabular}{|c|c|c|c|c|c|c|c|}
\hline Well ID & SSWMU & $\begin{array}{c}\text { Gradient } \\
\text { Position }\end{array}$ & $\begin{array}{c}\text { Analytical } \\
\text { Parameters in } 2006^{a}\end{array}$ & Well ID & SSWMU & $\begin{array}{c}\text { Gradient } \\
\text { Position }\end{array}$ & $\begin{array}{c}\text { Analytical } \\
\text { Parameters in 2006 }^{a}\end{array}$ \\
\hline $901^{b}$ & 4 & B & I, RI & $1008 \mathrm{~B}$ & 10 & U & I, RI \\
\hline $902^{b}$ & 9 & U & I, RI & $8610^{b}$ & 9 & D & I, RI \\
\hline $903^{b}$ & 9 & D & I, RI & $8611^{b}$ & 9 & D & I, RI \\
\hline
\end{tabular}

Legend:

$$
\begin{aligned}
& \text { Gradient Positions } \\
& \text { B (background }) \\
& D \text { (crossgradient) } \\
& U \text { (downgradient) }
\end{aligned}
$$

NA - Not applicable

${ }^{a}$ See $p . E-3$ ㄸ for a description of codes and analytes.

${ }^{b}$ Monitoring for certain parameters is required by the RCRA $\$ 3008(h)$ Order on Consent.

${ }^{c}$ Monitor upgradient and downgradient of remote-handled waste facility

$$
\text { E- } 5
$$




\section{Table E-2}

\section{Indicator Results From the Sand and Gravel Unit}

\begin{tabular}{|c|c|c|c|c|c|c|}
\hline $\begin{array}{l}\text { Location } \\
\text { Code }\end{array}$ & $\begin{array}{l}\text { Hydraulic } \\
\text { Position }\end{array}$ & $\begin{array}{l}\mathbf{p H} \\
(\mathrm{SU})\end{array}$ & $\begin{array}{c}\text { Conductivity } \\
\left(\mu \mathrm{mhos} / \mathrm{cm} @ 25^{\circ} \mathrm{C}\right)\end{array}$ & $\begin{array}{l}\text { Gross Alpha } \\
(\mu \mathrm{Ci} / \mathrm{mL})\end{array}$ & $\begin{array}{c}\text { Gross Beta } \\
(\mu \mathrm{Ci} / \mathrm{mL})\end{array}$ & $\begin{array}{l}\text { Tritium } \\
(\mu \mathrm{Ci} / \mathrm{mL})\end{array}$ \\
\hline 301 & UP(1) & 6.81 & 1,434 & $-2.81 \pm 2.47 \mathrm{E}-09$ & $6.43 \pm 4.10 \mathrm{E}-09$ & $-0.28 \pm 1.12 \mathrm{E}-07$ \\
\hline 301 & $\mathrm{UP}(2)$ & 6.69 & 1,694 & $-1.36 \pm 2.61 \mathrm{E}-09$ & $6.43 \pm 6.74 \mathrm{E}-09$ & $-1.26 \pm 1.01 \mathrm{E}-07$ \\
\hline 301 & UP(3) & 6.62 & 2,772 & $-0.74 \pm 4.10 \mathrm{E}-09$ & $6.76 \pm 5.67 \mathrm{E}-09$ & $-1.05 \pm 1.02 \mathrm{E}-07$ \\
\hline 301 & UP(4) & 6.46 & 1,728 & $-2.79 \pm 2.36 \mathrm{E}-09$ & $7.80 \pm 3.36 \mathrm{E}-09$ & $2.89 \pm 9.71 \mathrm{E}-08$ \\
\hline 401 & $\mathrm{UP}(1)$ & 6.95 & 3,551 & $0.58 \pm 9.17 \mathrm{E}-10$ & $6.65 \pm 1.70 \mathrm{E}-09$ & $-0.72 \pm 1.09 \mathrm{E}-07$ \\
\hline 401 & $\mathrm{UP}(2)$ & 6.93 & 5,402 & $-3.03 \pm 2.63 \mathrm{E}-08$ & $-1.41 \pm 3.14 \mathrm{E}-08$ & $-0.55 \pm 1.10 \mathrm{E}-07$ \\
\hline 401 & $\mathrm{UP}(3)$ & 6.87 & 4,466 & $-4.52 \pm 5.77 \mathrm{E}-09$ & $7.12 \pm 9.34 \mathrm{E}-09$ & $0.07 \pm 1.07 \mathrm{E}-07$ \\
\hline 401 & UP(4) & 6.84 & 4,522 & $3.66 \pm 5.12 \mathrm{E}-09$ & $1.52 \pm 0.69 \mathrm{E}-08$ & $4.82 \pm 9.87 \mathrm{E}-08$ \\
\hline 403 & $\mathrm{UP}(1)$ & 6.97 & 1,022 & $-0.46 \pm 1.56 \mathrm{E}-09$ & $4.35 \pm 3.22 \mathrm{E}-09$ & $-3.60 \pm 8.95 \mathrm{E}-08$ \\
\hline 403 & UP(3) & 6.85 & 710 & $-2.83 \pm 7.76 \mathrm{E}-10$ & $5.13 \pm 1.42 \mathrm{E}-09$ & $0.36 \pm 1.01 \mathrm{E}-07$ \\
\hline 706 & UP(1) & 6.63 & 848 & $-3.08 \pm 2.94 \mathrm{E}-09$ & $8.60 \pm 3.22 \mathrm{E}-09$ & $0.54 \pm 1.05 \mathrm{E}-07$ \\
\hline 706 & $\mathrm{UP}(2)$ & 6.54 & 1,223 & $2.19 \pm 2.21 \mathrm{E}-09$ & $1.06 \pm 0.41 \mathrm{E}-08$ & $-0.80 \pm 1.07 \mathrm{E}-07$ \\
\hline 706 & UP(3) & 6.74 & 1,513 & $-0.73 \pm 1.40 \mathrm{E}-09$ & $1.07 \pm 0.32 \mathrm{E}-08$ & $-0.42 \pm 1.05 \mathrm{E}-07$ \\
\hline 706 & UP(4) & 6.51 & 1,009 & $-1.99 \pm 1.95 \mathrm{E}-09$ & $8.71 \pm 4.01 \mathrm{E}-09$ & $6.18 \pm 8.81 \mathrm{E}-08$ \\
\hline 1304 & $\mathrm{UP}(1)$ & 7.16 & 2,300 & $-1.84 \pm 1.50 \mathrm{E}-09$ & $3.41 \pm 2.88 \mathrm{E}-09$ & $0.06 \pm 1.13 \mathrm{E}-07$ \\
\hline 1304 & $\mathrm{UP}(2)$ & 6.79 & $\mathbf{6 , 4 5 8}$ & $0.31 \pm 1.43 \mathrm{E}-08$ & $0.00 \pm 1.42 \mathrm{E}-08$ & $-0.36 \pm 1.02 \mathrm{E}-07$ \\
\hline 1304 & UP(3) & 6.85 & 3,953 & $1.42 \pm 5.44 \mathrm{E}-09$ & $3.73 \pm 8.20 \mathrm{E}-09$ & $5.27 \pm 9.44 \mathrm{E}-08$ \\
\hline 1304 & UP(4) & 7.06 & 2,216 & $0.00 \pm 2.80 \mathrm{E}-09$ & $5.29 \pm 3.12 \mathrm{E}-09$ & $0.68 \pm 1.04 \mathrm{E}-07$ \\
\hline NB1S & UP(1) & 6.66 & 588 & $-0.82 \pm 1.12 \mathrm{E}-09$ & $1.21 \pm 1.44 \mathrm{E}-09$ & $0.80 \pm 1.14 \mathrm{E}-07$ \\
\hline NB1S & UP(3) & 6.93 & 740 & $-3.86 \pm 9.78 \mathrm{E}-10$ & $1.15 \pm 1.55 \mathrm{E}-09$ & $0.46 \pm 1.05 \mathrm{E}-07$ \\
\hline 201 & $\operatorname{DOWN}(1)$ & 6.62 & 1,858 & $-1.54 \pm 2.62 \mathrm{E}-09$ & $2.54 \pm 0.42 \mathrm{E}-08$ & $-0.24 \pm 1.06 \mathrm{E}-07$ \\
\hline 201 & DOWN(3) & 6.50 & 2,486 & $-1.11 \pm 2.80 \mathrm{E}-09$ & $2.78 \pm 0.49 \mathrm{E}-08$ & $0.18 \pm 1.06 \mathrm{E}-07$ \\
\hline 1302 & DOWN(1) & 7.73 & 2,075 & $0.50 \pm 1.70 \mathrm{E}-09$ & $2.31 \pm 2.71 \mathrm{E}-09$ & $-0.43 \pm 1.09 \mathrm{E}-07$ \\
\hline 1302 & DOWN(2) & 6.87 & 3,076 & $-2.49 \pm 2.93 \mathrm{E}-09$ & $4.73 \pm 4.72 \mathrm{E}-09$ & $-5.08 \pm 9.99 \mathrm{E}-08$ \\
\hline 1302 & DOWN(3) & 6.98 & 2,575 & $-0.61 \pm 2.81 \mathrm{E}-09$ & $3.03 \pm 5.80 \mathrm{E}-09$ & $5.43 \pm 9.37 \mathrm{E}-08$ \\
\hline 1302 & DOWN(4) & 7.00 & 2,032 & $-3.74 \pm 2.16 \mathrm{E}-09$ & $2.73 \pm 3.11 \mathrm{E}-09$ & $0.98 \pm 1.06 \mathrm{E}-07$ \\
\hline 103 & DOWN(1) & 8.08 & $\mathbf{3 , 1 1 0}$ & $1.99 \pm 2.19 \mathrm{E}-09$ & $3.75 \pm 0.41 \mathrm{E}-08$ & $1.23 \pm 1.09 \mathrm{E}-07$ \\
\hline 103 & $\operatorname{DOWN}(2)$ & 7.68 & 13,576 & $-2.82 \pm 1.75 \mathrm{E}-08$ & $4.78 \pm 0.45 \mathrm{E}-07$ & $0.10 \pm 1.11 \mathrm{E}-07$ \\
\hline 103 & DOWN(3) & 7.55 & 13,580 & $-0.09 \pm 1.34 \mathrm{E}-08$ & $4.40 \pm 0.32 \mathrm{E}-07$ & $3.37 \pm 9.38 \mathrm{E}-08$ \\
\hline 103 & DOWN(4) & 7.65 & 9,720 & $-1.47 \pm 1.02 \mathrm{E}-08$ & $2.02 \pm 0.20 \mathrm{E}-07$ & $8.23 \pm 9.99 \mathrm{E}-08$ \\
\hline 104 & DOWN(1) & 7.22 & 1,404 & $5.04 \pm 2.52 \mathrm{E}-09$ & $5.84 \pm 0.01 \mathrm{E}-05$ & $2.91 \pm 1.14 \mathrm{E}-07$ \\
\hline 104 & DOWN(2) & 7.22 & 1,638 & $-0.74 \pm 1.95 \mathrm{E}-09$ & $7.16 \pm 0.01 \mathrm{E}-05$ & $7.53 \pm 1.46 \mathrm{E}-07$ \\
\hline 104 & DOWN(3) & 7.05 & 1,984 & $-0.25 \pm 1.24 \mathrm{E}-09$ & $7.86 \pm 0.01 \mathrm{E}-05$ & $2.86 \pm 1.16 \mathrm{E}-07$ \\
\hline 104 & DOWN(4) & 7.03 & 2,382 & $-1.18 \pm 3.62 \mathrm{E}-09$ & $9.70 \pm 0.02 E-05$ & $4.01 \pm 1.29 \mathrm{E}-07$ \\
\hline
\end{tabular}

Note: Bolding convention applied to these data. (See p. E-2 6 (0)

Sample collection quarter is noted in parentheses next to hydraulic position. Hydraulic position is relative to other wells within the same hydrogeologic unit.

$$
E-6
$$


Table E-2 (continued) 2006 Indicator Results From the Sand and Gravel Unit

\begin{tabular}{|c|c|c|c|c|c|c|}
\hline $\begin{array}{l}\text { Location } \\
\text { Code }\end{array}$ & $\begin{array}{c}\text { Hydraulic } \\
\text { Position }\end{array}$ & $\begin{array}{l}\mathbf{p H} \\
(\mathrm{SU})\end{array}$ & $\begin{array}{c}\text { Conductivity } \\
\left(\mu \mathrm{mhos} / \mathrm{cm} @ 25^{\circ} \mathrm{C}\right)\end{array}$ & $\begin{array}{l}\text { Gross Alpha } \\
\quad(\mu \mathrm{Ci} / \mathrm{mL})\end{array}$ & $\begin{array}{c}\text { Gross Beta } \\
(\mu \mathrm{Ci} / \mathrm{mL})\end{array}$ & $\begin{array}{l}\text { Tritium } \\
(\mu \mathrm{Ci} / \mathrm{mL})\end{array}$ \\
\hline 111 & DOWN(1) & 6.73 & 713 & $4.31 \pm 2.27 \mathrm{E}-09$ & $5.38 \pm 0.03 \mathrm{E}-06$ & $1.65 \pm 1.12 \mathrm{E}-07$ \\
\hline 111 & DOWN(2) & 6.57 & 584 & $1.92 \pm 1.62 \mathrm{E}-09$ & $4.13 \pm 0.06 \mathrm{E}-06$ & $2.02 \pm 1.08 \mathrm{E}-07$ \\
\hline 111 & DOWN(3) & 6.53 & 826 & $1.94 \pm 1.74 \mathrm{E}-09$ & $6.45 \pm 0.03 \mathrm{E}-06$ & $1.63 \pm 1.09 E-07$ \\
\hline 111 & DOWN(4) & 6.17 & 1,035 & $3.91 \pm 2.50 \mathrm{E}-09$ & $7.35 \pm 0.04 E-06$ & $2.43 \pm 1.31 E-07$ \\
\hline 205 & DOWN(1) & 7.18 & 2,336 & $-2.16 \pm 4.39 \mathrm{E}-09$ & $9.31 \pm 6.63 \mathrm{E}-09$ & $0.47 \pm 1.20 \mathrm{E}-07$ \\
\hline 205 & DOWN(3) & 6.74 & 7,426 & $0.51 \pm 7.22 \mathrm{E}-09$ & $4.08 \pm 1.38 \mathrm{E}-08$ & $0.97 \pm 1.07 \mathrm{E}-07$ \\
\hline 406 & DOWN(1) & 6.90 & 940 & $-0.60 \pm 1.94 \mathrm{E}-09$ & $8.03 \pm 3.96 \mathrm{E}-09$ & $1.22 \pm 1.06 \mathrm{E}-07$ \\
\hline 406 & DOWN(2) & 6.84 & 1,464 & $-1.60 \pm 2.12 \mathrm{E}-09$ & $8.59 \pm 3.12 E-09$ & $-0.08 \pm 1.08 \mathrm{E}-07$ \\
\hline 406 & DOWN(3) & 7.13 & 1,063 & $0.00 \pm 1.32 \mathrm{E}-09$ & $5.53 \pm 3.00 \mathrm{E}-09$ & $9.50 \pm 9.58 \mathrm{E}-08$ \\
\hline 406 & DOWN(4) & 6.90 & 1,246 & $-0.82 \pm 1.51 \mathrm{E}-09$ & $5.11 \pm 3.25 E-09$ & $1.13 \pm 1.06 \mathrm{E}-07$ \\
\hline 408 & DOWN(1) & 7.54 & 1,676 & $1.95 \pm 1.70 \mathrm{E}-09$ & $1.85 \pm 0.01 E-04$ & $1.99 \pm 1.07 \mathrm{E}-07$ \\
\hline 408 & DOWN(2) & 7.25 & 2,404 & $-0.35 \pm 3.14 \mathrm{E}-09$ & $2.44 \pm 0.01 \mathrm{E}-04$ & $2.11 \pm 1.12 \mathrm{E}-07$ \\
\hline 408 & DOWN(3) & 7.18 & 2,314 & $-1.36 \pm 2.53 \mathrm{E}-09$ & $2.61 \pm 0.01 \mathrm{E}-04$ & $1.44 \pm 1.09 E-07$ \\
\hline 408 & DOWN(4) & 7.20 & 2,974 & $3.71 \pm 5.65 \mathrm{E}-09$ & $3.83 \pm 0.01 E-04$ & $2.12 \pm 1.21 \mathrm{E}-07$ \\
\hline 501 & DOWN(1) & 7.61 & 1,186 & $-0.12 \pm 1.66 \mathrm{E}-09$ & 1.17 $\pm 0.01 E-04$ & $1.57 \pm 1.10 \mathrm{E}-07$ \\
\hline 501 & DOWN(2) & 7.49 & 1,500 & $0.22 \pm 1.72 \mathrm{E}-09$ & $1.35 \pm 0.01 \mathrm{E}-04$ & $1.21 \pm 1.05 \mathrm{E}-07$ \\
\hline 501 & DOWN(3) & 7.31 & 2,350 & $1.60 \pm 4.06 \mathrm{E}-09$ & $1.95 \pm 0.01 \mathrm{E}-04$ & $-0.85 \pm 1.12 \mathrm{E}-07$ \\
\hline 501 & DOWN(4) & 7.29 & 2,598 & $-2.82 \pm 4.52 \mathrm{E}-09$ & $2.16 \pm 0.01 E-04$ & $2.23 \pm 1.24 \mathrm{E}-07$ \\
\hline 502 & DOWN(1) & 7.62 & 1,206 & $-0.36 \pm 1.58 \mathrm{E}-09$ & $1.15 \pm 0.01 E-04$ & $1.17 \pm 1.05 E-07$ \\
\hline 502 & DOWN(2) & 7.46 & 1,611 & $0.26 \pm 2.04 \mathrm{E}-09$ & $1.22 \pm 0.01 \mathrm{E}-04$ & $2.12 \pm 1.13 E-07$ \\
\hline 502 & DOWN(3) & 7.20 & 2,054 & $0.14 \pm 1.78 \mathrm{E}-09$ & $1.71 \pm 0.01 \mathrm{E}-04$ & $1.20 \pm 1.10 \mathrm{E}-07$ \\
\hline 502 & DOWN(4) & 7.17 & 1,798 & $-0.76 \pm 3.90 \mathrm{E}-09$ & $1.96 \pm 0.01 E-04$ & $1.81 \pm 1.21 \mathrm{E}-07$ \\
\hline $602 \mathrm{~A}$ & DOWN(1) & 7.07 & 556 & $0.00 \pm 1.25 \mathrm{E}-09$ & $8.60 \pm 3.19 \mathrm{E}-09$ & $0.00 \pm 1.04 \mathrm{E}-07$ \\
\hline $602 \mathrm{~A}$ & DOWN(2) & 6.98 & 1,124 & $-3.04 \pm 9.94 \mathrm{E}-10$ & $1.68 \pm 0.31 E-08$ & $3.64 \pm 1.26 \mathrm{E}-07$ \\
\hline $602 \mathrm{~A}$ & DOWN(3) & 7.01 & 868 & $-0.59 \pm 1.42 \mathrm{E}-09$ & $1.21 \pm 0.26 \mathrm{E}-08$ & $0.91 \pm 1.07 \mathrm{E}-07$ \\
\hline $602 \mathrm{~A}$ & DOWN(4) & 6.91 & 734 & $0.00 \pm 1.05 \mathrm{E}-09$ & $8.96 \pm 2.90 \mathrm{E}-09$ & $2.00 \pm 1.24 \mathrm{E}-07$ \\
\hline 604 & DOWN(1) & 6.25 & 1,222 & $-0.81 \pm 2.24 \mathrm{E}-09$ & $8.52 \pm 2.98 \mathrm{E}-09$ & $1.31 \pm 1.10 \mathrm{E}-07$ \\
\hline 604 & DOWN(2) & 6.31 & 1,129 & $1.00 \pm 1.69 \mathrm{E}-09$ & $6.22 \pm 2.92 \mathrm{E}-09$ & $0.07 \pm 1.14 \mathrm{E}-07$ \\
\hline 604 & DOWN(3) & 6.15 & 1,215 & $-2.51 \pm 2.63 \mathrm{E}-09$ & $3.89 \pm 3.85 \mathrm{E}-09$ & $2.13 \pm 9.46 \mathrm{E}-08$ \\
\hline 604 & DOWN(4) & 6.89 & 1,696 & $-0.53 \pm 2.20 \mathrm{E}-09$ & $8.95 \pm 3.17 E-09$ & $1.23 \pm 9.59 \mathrm{E}-08$ \\
\hline 8605 & DOWN(1) & 6.83 & 1,457 & $7.80 \pm 2.50 \mathrm{E}-09$ & $1.26 \pm 0.01 \mathrm{E}-05$ & $2.86 \pm 1.12 \mathrm{E}-07$ \\
\hline 8605 & DOWN(2) & 6.91 & 1,846 & $5.97 \pm 2.10 \mathrm{E}-09$ & $9.86 \pm 0.04 \mathrm{E}-06$ & $2.26 \pm 1.24 \mathrm{E}-07$ \\
\hline 8605 & DOWN(3) & 6.64 & 1,603 & $2.13 \pm 3.20 \mathrm{E}-09$ & $1.05 \pm 0.01 \mathrm{E}-05$ & $2.23 \pm 1.13 E-07$ \\
\hline 8605 & DOWN(4) & 6.65 & 2,754 & $6.57 \pm 4.06 \mathrm{E}-09$ & $9.67 \pm 0.06 E-06$ & $3.75 \pm 1.42 \mathrm{E}-07$ \\
\hline 8607 & DOWN(1) & 6.55 & 738 & $-1.12 \pm 1.40 \mathrm{E}-09$ & $1.65 \pm 0.30 \mathrm{E}-08$ & $0.99 \pm 1.13 \mathrm{E}-07$ \\
\hline 8607 & DOWN(2) & 6.39 & 2,912 & $0.00 \pm 2.51 \mathrm{E}-09$ & $6.74 \pm 0.82 E-08$ & $0.93 \pm 1.13 \mathrm{E}-07$ \\
\hline 8607 & DOWN(3) & 6.32 & 2,916 & $1.35 \pm 6.36 \mathrm{E}-09$ & $4.67 \pm 0.73 \mathrm{E}-08$ & $-2.47 \pm 9.01 \mathrm{E}-08$ \\
\hline 8607 & DOWN(4) & 6.42 & 1,240 & $-0.74 \pm 1.97 \mathrm{E}-09$ & $2.34 \pm 0.35 \mathrm{E}-08$ & $0.87 \pm 1.05 \mathrm{E}-07$ \\
\hline
\end{tabular}

Note: Bolding convention applied to these data. (See p. E-2 2 or)

Sample collection quarter is noted in parentheses next to hydraulic position. Hydraulic position is relative to other wells within the same hydrogeologic unit.

$E-7$ 


\section{Table E-2 (continued)}

\section{Indicator Results From the Sand and Gravel Unit}

\begin{tabular}{|c|c|c|c|c|c|c|}
\hline $\begin{array}{l}\text { Location } \\
\text { Code }\end{array}$ & $\begin{array}{c}\text { Hydraulic } \\
\text { Position }\end{array}$ & $\begin{array}{c}\mathbf{p H} \\
(\mathrm{SU})\end{array}$ & $\begin{array}{c}\text { Conductivity } \\
\left(\mu \mathrm{mhos} / \mathrm{cm} @ 25^{\circ} \mathrm{C}\right)\end{array}$ & $\begin{array}{l}\text { Gross Alpha } \\
\qquad(\mu \mathrm{Ci} / \mathrm{mL})\end{array}$ & $\begin{array}{c}\text { Gross Beta } \\
(\mu \mathrm{Ci} / \mathrm{mL})\end{array}$ & $\begin{array}{l}\text { Tritium } \\
(\mu \mathrm{Ci} / \mathrm{mL})\end{array}$ \\
\hline 8609 & $\operatorname{DOWN}(1)$ & 7.08 & 2,036 & $-0.40 \pm 1.51 \mathrm{E}-09$ & $2.06 \pm 0.02 \mathrm{E}-06$ & $2.86 \pm 1.48 E-07$ \\
\hline 8609 & $\operatorname{DOWN}(2)$ & 7.09 & 2,300 & $-1.30 \pm 1.57 \mathrm{E}-09$ & $1.68 \pm 0.02 E-06$ & $3.28 \pm 1.27 \mathrm{E}-07$ \\
\hline 8609 & DOWN(3) & 6.91 & 2,226 & $-6.11 \pm 2.79 \mathrm{E}-09$ & $1.70 \pm 0.02 \mathrm{E}-06$ & $3.43 \pm 1.16 \mathrm{E}-07$ \\
\hline 8609 & $\operatorname{DOWN}(4)$ & 6.76 & 2,372 & $-0.66 \pm 4.27 \mathrm{E}-09$ & $2.12 \pm 0.03 E-06$ & $4.58 \pm 1.52 \mathrm{E}-07$ \\
\hline 105 & $\operatorname{DOWN}(1)$ & 7.35 & 1,464 & $-1.08 \pm 1.31 \mathrm{E}-09$ & $4.92 \pm 0.01 E-05$ & $2.45 \pm 1.46 \mathrm{E}-07$ \\
\hline 105 & $\operatorname{DOWN}(2)$ & 7.36 & 1,636 & $0.87 \pm 1.94 \mathrm{E}-09$ & $5.67 \pm 0.01 \mathrm{E}-05$ & $3.66 \pm 1.33 \mathrm{E}-07$ \\
\hline 105 & $\operatorname{DOWN}(3)$ & 7.11 & 1,772 & $0.08 \pm 1.53 \mathrm{E}-09$ & $5.17 \pm 0.01 \mathrm{E}-05$ & $1.93 \pm 1.09 E-07$ \\
\hline 105 & $\operatorname{DOWN}(4)$ & 7.11 & 2,199 & $2.08 \pm 3.47 \mathrm{E}-09$ & $7.50 \pm 0.02 E-05$ & $4.71 \pm 1.58 \mathrm{E}-07$ \\
\hline 106 & $\operatorname{DOWN}(1)$ & 6.82 & 1,328 & $-1.02 \pm 2.20 \mathrm{E}-09$ & $6.84 \pm 0.45 E-08$ & $7.69 \pm 1.60 \mathrm{E}-07$ \\
\hline 106 & $\operatorname{DOWN}(2)$ & 7.08 & 1,538 & $-1.28 \pm 0.98 \mathrm{E}-09$ & $1.49 \pm 0.03 \mathrm{E}-07$ & $5.09 \pm 1.24 \mathrm{E}-07$ \\
\hline 106 & $\operatorname{DOWN}(3)$ & 6.66 & 1,380 & $-2.81 \pm 1.80 \mathrm{E}-09$ & $1.64 \pm 0.06 \mathrm{E}-07$ & $7.80 \pm 1.30 \mathrm{E}-07$ \\
\hline 106 & $\operatorname{DOWN}(4)$ & 6.54 & 1,590 & $0.42 \pm 1.36 \mathrm{E}-09$ & $1.73 \pm 0.06 E-07$ & $8.74 \pm 1.74 \mathrm{E}-07$ \\
\hline 116 & $\operatorname{DOWN}(1)$ & 7.27 & 1,228 & $-0.90 \pm 1.83 \mathrm{E}-09$ & $2.88 \pm 0.02 E-06$ & $2.03 \pm 1.08 \mathrm{E}-07$ \\
\hline 116 & $\operatorname{DOWN}(2)$ & 7.20 & 1,618 & $-2.50 \pm 2.21 \mathrm{E}-09$ & $4.04 \pm 0.03 \mathrm{E}-06$ & $1.91 \pm 1.23 \mathrm{E}-07$ \\
\hline 116 & $\operatorname{DOWN}(3)$ & 7.13 & 1,670 & $-1.24 \pm 1.01 \mathrm{E}-09$ & $4.55 \pm 0.02 \mathrm{E}-06$ & $1.40 \pm 1.09 \mathrm{E}-07$ \\
\hline 116 & DOWN(4) & 7.07 & 1,545 & $2.82 \pm 2.85 \mathrm{E}-09$ & $4.80 \pm 0.03 E-06$ & $2.86 \pm 1.32 \mathrm{E}-07$ \\
\hline 605 & $\operatorname{DOWN}(1)$ & 6.87 & 680 & $-0.55 \pm 6.34 \mathrm{E}-10$ & $3.43 \pm 0.22 \mathrm{E}-08$ & $0.54 \pm 1.12 \mathrm{E}-07$ \\
\hline 605 & $\operatorname{DOWN}(3)$ & 7.18 & 1,058 & $-1.29 \pm 2.29 \mathrm{E}-09$ & $3.86 \pm 0.54 \mathrm{E}-08$ & $1.36 \pm 1.07 \mathrm{E}-07$ \\
\hline 801 & $\operatorname{DOWN}(1)$ & 6.80 & 1,100 & $-0.11 \pm 1.58 \mathrm{E}-09$ & $7.54 \pm 0.04 E-06$ & $2.08 \pm 1.10 \mathrm{E}-07$ \\
\hline 801 & $\operatorname{DOWN}(2)$ & 6.76 & 1,520 & $-0.54 \pm 1.74 \mathrm{E}-09$ & $1.07 \pm 0.01 \mathrm{E}-05$ & $1.07 \pm 1.12 \mathrm{E}-07$ \\
\hline 801 & $\operatorname{DOWN}(3)$ & 6.59 & 1,576 & $-0.57 \pm 1.42 \mathrm{E}-09$ & $8.96 \pm 0.04 \mathrm{E}-06$ & $1.79 \pm 1.06 \mathrm{E}-07$ \\
\hline 801 & $\operatorname{DOWN}(4)$ & 6.62 & 1,756 & $-6.50 \pm 7.75 \mathrm{E}-09$ & $1.46 \pm 0.01 E-05$ & $1.55 \pm 1.02 \mathrm{E}-07$ \\
\hline 802 & $\operatorname{DOWN}(1)$ & 6.19 & 161 & $-1.85 \pm 6.92 \mathrm{E}-10$ & $8.51 \pm 1.02 \mathrm{E}-09$ & $1.22 \pm 1.03 \mathrm{E}-07$ \\
\hline 802 & $\operatorname{DOWN}(2)$ & 6.63 & 204 & $1.57 \pm 2.86 \mathrm{E}-10$ & $2.58 \pm 0.92 E-09$ & $1.09 \pm 1.14 \mathrm{E}-07$ \\
\hline 802 & $\operatorname{DOWN}(3)$ & 6.74 & 622 & $-1.38 \pm 1.18 \mathrm{E}-09$ & $7.61 \pm 0.38 \mathrm{E}-08$ & $0.82 \pm 1.08 \mathrm{E}-07$ \\
\hline 802 & DOWN(4) & 6.65 & 1,521 & $0.00 \pm 2.12 \mathrm{E}-09$ & $2.72 \pm 0.07 E-07$ & $1.85 \pm 0.98 E-07$ \\
\hline 803 & $\operatorname{DOWN}(1)$ & 6.98 & 1,266 & $1.67 \pm 2.41 \mathrm{E}-09$ & $1.08 \pm 0.40 E-08$ & $0.41 \pm 1.06 \mathrm{E}-07$ \\
\hline 803 & $\operatorname{DOWN}(2)$ & 7.39 & 1,233 & $1.55 \pm 1.61 \mathrm{E}-09$ & $1.30 \pm 0.34 \mathrm{E}-08$ & $2.67 \pm 1.17 E-07$ \\
\hline 803 & $\operatorname{DOWN}(3)$ & 6.95 & 1,266 & $0.27 \pm 1.48 \mathrm{E}-09$ & $1.34 \pm 0.36 \mathrm{E}-08$ & $0.25 \pm 1.09 \mathrm{E}-07$ \\
\hline 803 & DOWN(4) & 6.54 & 1,313 & $-1.14 \pm 1.57 \mathrm{E}-09$ & $1.96 \pm 0.31 E-08$ & $2.03 \pm 0.98 \mathrm{E}-07$ \\
\hline 804 & $\operatorname{DOWN}(1)$ & 6.73 & 799 & $-3.53 \pm 7.48 \mathrm{E}-10$ & $1.73 \pm 0.04 \mathrm{E}-07$ & $0.41 \pm 1.06 \mathrm{E}-07$ \\
\hline 804 & $\operatorname{DOWN}(2)$ & 6.74 & 2,322 & $-1.04 \pm 1.86 \mathrm{E}-09$ & $5.02 \pm 0.11 E-07$ & $1.29 \pm 1.13 \mathrm{E}-07$ \\
\hline 804 & $\operatorname{DOWN}(3)$ & 6.77 & 1,878 & $-1.11 \pm 1.30 \mathrm{E}-09$ & $2.95 \pm 0.08 \mathrm{E}-07$ & $1.98 \pm 1.18 E-07$ \\
\hline 804 & DOWN(4) & 6.44 & 902 & $0.77 \pm 2.66 \mathrm{E}-09$ & $1.30 \pm 0.06 \mathrm{E}-07$ & $1.39 \pm 0.97 \mathrm{E}-07$ \\
\hline 8603 & $\operatorname{DOWN}(1)$ & 7.39 & 1,346 & $-1.46 \pm 1.38 \mathrm{E}-09$ & $5.29 \pm 0.01 E-05$ & $3.29 \pm 1.14 \mathrm{E}-07$ \\
\hline 8603 & $\operatorname{DOWN}(2)$ & 7.45 & 1,628 & $-1.02 \pm 3.07 \mathrm{E}-09$ & $5.81 \pm 0.01 \mathrm{E}-05$ & $3.28 \pm 1.28 \mathrm{E}-07$ \\
\hline 8603 & $\operatorname{DOWN}(3)$ & 6.99 & 1,826 & $-1.49 \pm 2.16 \mathrm{E}-09$ & $6.46 \pm 0.01 \mathrm{E}-05$ & $2.26 \pm 1.13 E-07$ \\
\hline 8603 & DOWN(4) & 7.27 & 2,275 & $-3.76 \pm 3.26 \mathrm{E}-09$ & $7.89 \pm 0.02 E-05$ & $3.27 \pm 1.42 \mathrm{E}-07$ \\
\hline
\end{tabular}

Note: Bolding convention applied to these data. (See p. E-2 6 (0)

Sample collection quarter is noted in parentheses next to hydraulic position. Hydraulic position is relative to other wells within the same hydrogeologic unit.

$$
E-8
$$


Table E-2 (concluded)

\section{Indicator Results From the Sand and Gravel Unit}

\begin{tabular}{|c|c|c|c|c|c|c|}
\hline $\begin{array}{l}\text { Location } \\
\text { Code }\end{array}$ & $\begin{array}{l}\text { Hydraulic } \\
\text { Position }\end{array}$ & $\begin{array}{c}\mathbf{p H} \\
(\mathrm{SU})\end{array}$ & $\begin{array}{c}\text { Conductivity } \\
\left(\mu \mathrm{mhos} / \mathrm{cm} @ 25^{\circ} \mathrm{C}\right)\end{array}$ & $\begin{array}{l}\text { Gross Alpha } \\
\quad(\mu \mathrm{Ci} / \mathrm{mL})\end{array}$ & $\begin{array}{l}\text { Gross Beta } \\
(\mu \mathrm{Ci} / \mathrm{mL})\end{array}$ & $\begin{array}{l}\text { Tritium } \\
(\mu \mathrm{Ci} / \mathrm{mL})\end{array}$ \\
\hline 8604 & DOWN(1) & 7.32 & 1,293 & $1.47 \pm 2.74 \mathrm{E}-09$ & $4.95 \pm 0.01 \mathrm{E}-05$ & $3.29 \pm 1.14 \mathrm{E}-07$ \\
\hline 8604 & DOWN(3) & 7.11 & 1,843 & 4.14 $\pm 2.49 \mathrm{E}-09$ & $6.87 \pm 0.01 \mathrm{E}-05$ & $3.49 \pm 1.18 \mathrm{E}-07$ \\
\hline 8612 & DOWN(1) & 7.17 & 1,430 & $-1.17 \pm 1.74 \mathrm{E}-09$ & $0.90 \pm 3.60 \mathrm{E}-09$ & $2.90 \pm 1.43 \mathrm{E}-07$ \\
\hline 8612 & DOWN(2) & 7.21 & 1,536 & $0.67 \pm 1.54 \mathrm{E}-09$ & $1.08 \pm 2.86 \mathrm{E}-09$ & $4.16 \pm 1.27 E-07$ \\
\hline 8612 & DOWN(3) & 7.10 & 1,543 & $-1.31 \pm 1.42 \mathrm{E}-09$ & $-1.41 \pm 2.95 \mathrm{E}-09$ & $2.92 \pm 1.08 \mathrm{E}-07$ \\
\hline 8612 & DOWN(4) & 7.04 & 1,560 & $-0.12 \pm 1.66 \mathrm{E}-09$ & $2.02 \pm 2.66 \mathrm{E}-09$ & $1.92 \pm 1.02 E-07$ \\
\hline GSEEP & DOWN(1) & 7.13 & 813 & $-1.59 \pm 1.13 \mathrm{E}-09$ & 4.18+1.49E-09 & $4.47 \pm 1.28 E-07$ \\
\hline GSEEP & DOWN(2) & 6.70 & 978 & $0.09 \pm 1.16 \mathrm{E}-09$ & 7.44 $\pm 3.09 E-09$ & $4.37 \pm 1.31 \mathrm{E}-07$ \\
\hline GSEEP & DOWN(3) & 6.77 & 1,065 & $-0.65 \pm 1.25 \mathrm{E}-09$ & $4.20 \pm 2.52 \mathrm{E}-09$ & 3.82 $\pm 1.11 E-07$ \\
\hline GSEEP & DOWN(4) & 6.76 & 961 & $-0.39 \pm 1.69 \mathrm{E}-09$ & $1.62 \pm 3.02 \mathrm{E}-09$ & $4.00 \pm 1.36 \mathrm{E}-07$ \\
\hline SP04 & DOWN(1) & NS & NS & $0.22 \pm 1.58 \mathrm{E}-09$ & $1.12 \pm 0.33 \mathrm{E}-08$ & $3.20 \pm 1.42 \mathrm{E}-07$ \\
\hline SP04 & DOWN(3) & NS & NS & $-1.21 \pm 1.88 \mathrm{E}-09$ & $8.92 \pm 3.46 \mathrm{E}-09$ & $3.71 \pm 1.04 \mathrm{E}-07$ \\
\hline SP06 & DOWN(3) & NS & NS & $-2.04 \pm 1.75 \mathrm{E}-09$ & $6.37 \pm 3.29 \mathrm{E}-09$ & $1.37 \pm 0.98 \mathrm{E}-07$ \\
\hline SP11 & DOWN(1) & NS & NS & $0.76 \pm 1.85 \mathrm{E}-09$ & $8.39 \pm 0.52 E-08$ & $2.15 \pm 1.13 \mathrm{E}-07$ \\
\hline SP11 & DOWN(2) & 6.96 & 1,231 & $-0.75 \pm 1.97 \mathrm{E}-09$ & $9.07 \pm 0.49 \mathrm{E}-08$ & $2.78 \pm 1.23 E-07$ \\
\hline SP11 & DOWN(3) & 6.52 & 1,421 & $-0.80 \pm 2.00 \mathrm{E}-09$ & $1.03 \pm 0.06 \mathrm{E}-07$ & $1.90 \pm 0.98 \mathrm{E}-07$ \\
\hline SP11 & DOWN(4) & 6.94 & 962 & $-1.28 \pm 2.12 \mathrm{E}-09$ & 1.04 $\pm 0.06 E-07$ & $1.61 \pm 1.20 \mathrm{E}-07$ \\
\hline SP12 & DOWN(1) & 7.60 & 555 & $-1.24 \pm 1.83 \mathrm{E}-09$ & $2.09 \pm 2.57 \mathrm{E}-09$ & $1.99 \pm 1.21 \mathrm{E}-07$ \\
\hline SP12 & DOWN(3) & 7.57 & 767 & $-1.09 \pm 1.88 \mathrm{E}-09$ & $-1.08 \pm 3.12 \mathrm{E}-09$ & $2.55 \pm 1.07 \mathrm{E}-07$ \\
\hline WP-A & DOWN(4) & 9.16 & 130 & $-2.66 \pm 5.48 \mathrm{E}-10$ & $1.65 \pm 0.10 \mathrm{E}-08$ & $1.26 \pm 0.05 \mathrm{E}-05$ \\
\hline WP-C & DOWN(4) & 7.57 & 170 & $-1.13 \pm 3.28 \mathrm{E}-10$ & $2.72 \pm 0.12 \mathrm{E}-08$ & $3.57 \pm 0.08 \mathrm{E}-05$ \\
\hline WP-H & DOWN(4) & 6.98 & 1,350 & $0.43 \pm 1.90 \mathrm{E}-09$ & $9.27 \pm 0.04 \mathrm{E}-06$ & $2.36 \pm 0.18 \mathrm{E}-06$ \\
\hline
\end{tabular}

Note: Bolding convention applied to these data. (See p. E-2 $\mathbf{6 0}$ )

NS - Not sampled

Sample collection quarter is noted in parentheses next to hydraulic position. Hydraulic position is relative to other wells within the same hydrogeologic unit.

$E-9$ 
Table E-3

\section{Indicator Results From the Lavery Till-Sand Unit}

$\begin{array}{ccccccc}\begin{array}{c}\text { Location } \\ \text { Code }\end{array} & \begin{array}{c}\text { Hydraulic } \\ \text { Position }\end{array} & \begin{array}{c}\text { pH } \\ (\mathrm{SU})\end{array} & \begin{array}{c}\text { Conductivity } \\ \left(\mu \mathrm{mhos} / \mathrm{cm} @ 25^{\circ} \mathrm{C}\right)\end{array} & \begin{array}{c}\text { Gross Alpha } \\ (\mu \mathrm{Ci} / \mathrm{mL})\end{array} & \begin{array}{c}\text { Gross Beta } \\ (\mu \mathrm{Ci} / \mathrm{mL})\end{array} & \begin{array}{c}\text { Tritium } \\ (\mu \mathrm{Ci} / \mathrm{mL})\end{array} \\ 302 & \text { UP(1) } & \mathbf{6 . 9 5} & \mathbf{4 , 0 7 8} & \mathbf{1 . 5 5} \pm \mathbf{1 . 2 0 E}-\mathbf{0 9} & \mathbf{8 . 6 4} \pm \mathbf{2 . 5 5 E}-\mathbf{0 9} & 0.33 \pm 1.14 \mathrm{E}-07 \\ 302 & \mathrm{UP}(2) & 6.84 & 4,251 & 0.00 \pm 7.36 \mathrm{E}-09 & 0.55 \pm 1.55 \mathrm{E}-08 & 0.57 \pm 1.06 \mathrm{E}-07 \\ 302 & \mathrm{UP}(3) & \mathbf{6 . 6 5} & \mathbf{4 , 6 4 8} & -1.25 \pm 0.55 \mathrm{E}-08 & 4.31 \pm 8.76 \mathrm{E}-09 & 0.78 \pm 1.08 \mathrm{E}-07 \\ & & & & & & \\ 402 & \mathrm{UP}(1) & 7.09 & 3,246 & -2.35 \pm 6.12 \mathrm{E}-09 & 1.69 \pm 8.05 \mathrm{E}-09 & -0.60 \pm 1.09 \mathrm{E}-07 \\ 402 & \mathrm{UP}(3) & 7.00 & 3,332 & -2.70 \pm 3.95 \mathrm{E}-09 & -0.16 \pm 5.84 \mathrm{E}-09 & 0.11 \pm 1.01 \mathrm{E}-07 \\ & & & & & \\ 204 & \text { DOWN(1) } & \mathbf{7 . 3 6} & \mathbf{1 , 2 4 4} & -1.94 \pm 1.60 \mathrm{E}-09 & 3.61 \pm 2.59 \mathrm{E}-09 & 0.06 \pm 1.12 \mathrm{E}-07 \\ 204 & \text { DOWN(2) } & \mathbf{7 . 5 2} & 1,283 & 0.40 \pm 1.14 \mathrm{E}-09 & 3.38 \pm 3.34 \mathrm{E}-09 & 0.55 \pm 1.11 \mathrm{E}-07 \\ 204 & \text { DOWN(3) } & 7.40 & 1,314 & 0.21 \pm 2.47 \mathrm{E}-09 & \mathbf{4 . 1 0} \pm \mathbf{3 . 5 0 E}-\mathbf{0 9} & -0.02 \pm 1.05 \mathrm{E}-07 \\ 204 & \text { DOWN(4) } & 7.39 & \mathbf{1 , 4 0 2} & -0.53 \pm 1.34 \mathrm{E}-09 & 0.89 \pm 2.98 \mathrm{E}-09 & 0.29 \pm 1.04 \mathrm{E}-07 \\ & & & & & \\ 206 & \text { DOWN(1) } & 7.48 & 1,372 & 0.00 \pm 1.75 \mathrm{E}-09 & 2.74 \pm 3.40 \mathrm{E}-09 & 0.19 \pm 1.13 \mathrm{E}-07 \\ 206 & \text { DOWN(3) } & 7.28 & 1,432 & 0.00 \pm 1.80 \mathrm{E}-09 & 0.33 \pm 2.84 \mathrm{E}-09 & 0.13 \pm 1.05 \mathrm{E}-07 \\ & & & & & \\ 208 & \text { DOWN(1) } & 7.93 & 287 & 0.75 \pm 5.07 \mathrm{E}-10 & 1.12 \pm 0.97 \mathrm{E}-09 & 0.11 \pm 1.14 \mathrm{E}-07 \\ 208 & \text { DOWN(3) } & 7.79 & 258 & 3.90 \pm 4.81 \mathrm{E}-10 & 1.81 \pm 0.69 \mathrm{E}-09 & -0.79 \pm 1.06 \mathrm{E}-07\end{array}$

Note: Bolding convention applied to these data. (See p. E-2 $\mathbf{6 0}$ )

Sample collection quarter is noted in parentheses next to hydraulic position. Hydraulic position is relative to other wells within the same hydrogeologic unit.

$E-10$ 


\section{Table E-4}

\section{Indicator Results From the Weathered Lavery Till Unit}

\begin{tabular}{|c|c|c|c|c|c|c|}
\hline $\begin{array}{l}\text { Location } \\
\text { Code }\end{array}$ & $\begin{array}{c}\text { Hydraulic } \\
\text { Position }\end{array}$ & $\begin{array}{c}\mathbf{p H} \\
(\mathrm{SU})\end{array}$ & $\begin{array}{c}\text { Conductivity } \\
\left(\mu \mathrm{mhos} / \mathrm{cm} @ 25^{\circ} \mathrm{C}\right)\end{array}$ & $\begin{array}{l}\text { Gross Alpha } \\
\qquad(\mu \mathrm{Ci} / \mathrm{mL})\end{array}$ & $\begin{array}{c}\text { Gross Beta } \\
(\mu \mathrm{Ci} / \mathrm{mL})\end{array}$ & $\begin{array}{c}\text { Tritium } \\
(\mu \mathrm{Ci} / \mathrm{mL})\end{array}$ \\
\hline 908 & $\mathrm{UP}(1)$ & 6.91 & 2,035 & $6.59 \pm 4.15 \mathrm{E}-09$ & $2.04 \pm 0.51 \mathrm{E}-08$ & $4.94 \pm 9.10 \mathrm{E}-08$ \\
\hline 908 & $\mathrm{UP}(3)$ & 6.64 & 2,618 & $1.04 \pm 0.41 \mathrm{E}-08$ & $1.50 \pm 0.68 \mathrm{E}-08$ & $-0.07 \pm 1.04 \mathrm{E}-07$ \\
\hline 1005 & $\mathrm{UP}(1)$ & 7.19 & 735 & $2.55 \pm 1.59 \mathrm{E}-09$ & $-1.52 \pm 2.79 \mathrm{E}-09$ & $9.52 \pm 9.94 \mathrm{E}-08$ \\
\hline 1005 & $\mathrm{UP}(3)$ & 7.03 & 786 & $2.04 \pm 2.98 \mathrm{E}-09$ & $3.44 \pm 3.08 \mathrm{E}-09$ & $0.38 \pm 1.07 \mathrm{E}-07$ \\
\hline $1008 \mathrm{C}$ & $\mathrm{UP}(1)$ & 7.52 & 556 & $-0.55 \pm 1.50 \mathrm{E}-09$ & $0.72 \pm 2.60 \mathrm{E}-09$ & $0.73 \pm 1.07 \mathrm{E}-07$ \\
\hline $1008 \mathrm{C}$ & $\mathrm{UP}(3)$ & 7.43 & 592 & $2.73 \pm 6.32 \mathrm{E}-10$ & $0.58 \pm 1.41 \mathrm{E}-09$ & $-0.20 \pm 1.06 \mathrm{E}-07$ \\
\hline 906 & $\operatorname{DOWN}(1)$ & 7.44 & 536 & $0.26 \pm 1.04 \mathrm{E}-09$ & $5.69 \pm 1.49 \mathrm{E}-09$ & $1.16 \pm 1.08 \mathrm{E}-07$ \\
\hline 906 & $\operatorname{DOWN}(3)$ & 7.25 & 557 & $1.34 \pm 1.45 \mathrm{E}-09$ & $4.86 \pm 1.91 \mathrm{E}-09$ & $1.32 \pm 1.05 \mathrm{E}-07$ \\
\hline 1006 & $\operatorname{DOWN}(1)$ & 6.93 & 1,584 & $4.08 \pm 2.18 \mathrm{E}-09$ & $7.25 \pm 3.56 \mathrm{E}-09$ & $0.65 \pm 1.07 \mathrm{E}-07$ \\
\hline 1006 & $\operatorname{DOWN}(3)$ & 6.85 & 1,709 & $1.82 \pm 1.94 \mathrm{E}-09$ & $9.47 \pm 3.30 \mathrm{E}-09$ & $0.60 \pm 1.08 \mathrm{E}-07$ \\
\hline 1007 & $\operatorname{DOWN}(1)$ & 6.94 & 1,247 & $8.59 \pm 2.41 \mathrm{E}-09$ & $4.34 \pm 3.00 \mathrm{E}-09$ & $0.64 \pm 1.09 \mathrm{E}-07$ \\
\hline 1007 & $\operatorname{DOWN}(3)$ & 6.77 & 1,302 & $6.49 \pm 3.03 \mathrm{E}-09$ & $6.27 \pm 3.54 \mathrm{E}-09$ & $-1.05 \pm 1.07 \mathrm{E}-07$ \\
\hline NDATR & $\operatorname{DOWN}(1)$ & 8.22 & 698 & $1.30 \pm 1.65 \mathrm{E}-09$ & $2.99 \pm 0.08 \mathrm{E}-07$ & $2.07 \pm 0.21 E-06$ \\
\hline NDATR & $\operatorname{DOWN}(2)$ & 8.13 & 974 & $0.38 \pm 2.76 \mathrm{E}-09$ & $3.66 \pm 0.09 \mathrm{E}-07$ & $4.27 \pm 0.25 E-06$ \\
\hline NDATR & DOWN(3) & 7.14 & 987 & $1.39 \pm 1.91 \mathrm{E}-09$ & $2.06 \pm 0.06 E-07$ & $3.96 \pm 0.21 \mathrm{E}-06$ \\
\hline NDATR & DOWN(4) & 7.85 & 887 & $2.43 \pm 2.67 \mathrm{E}-09$ & $2.94 \pm 0.10 \mathrm{E}-07$ & $2.31 \pm 0.21 \mathrm{E}-06$ \\
\hline 909 & $\operatorname{DOWN}(1)$ & 6.84 & 1,199 & $1.05 \pm 2.12 \mathrm{E}-09$ & $2.95 \pm 0.08 \mathrm{E}-07$ & $8.23 \pm 1.65 E-07$ \\
\hline 909 & DOWN(3) & 6.72 & 1,263 & $-3.45 \pm 2.84 \mathrm{E}-09$ & $3.13 \pm 0.08 E-07$ & $8.22 \pm 1.32 \mathrm{E}-07$ \\
\hline 909 & DOWN(4) & 6.60 & 1,281 & $2.63 \pm 2.56 \mathrm{E}-09$ & $2.85 \pm 0.08 E-07$ & $7.32 \pm 1.46 \mathrm{E}-07$ \\
\hline
\end{tabular}

Note: Bolding convention applied to these data. (See p. E-2 $\mathbf{6 0}$ )

Sample collection quarter is noted in parentheses next to hydraulic position. Hydraulic position is relative to other wells within the same hydrogeologic unit. 


\section{Table E-5 \\ 2006 Indicator Results From the Unweathered Lavery Till Unit}

\begin{tabular}{|c|c|c|c|c|c|c|}
\hline $\begin{array}{l}\text { Location } \\
\text { Code }\end{array}$ & $\begin{array}{c}\text { Hydraulic } \\
\text { Position }\end{array}$ & $\begin{array}{c}\mathbf{p H} \\
(\mathrm{SU})\end{array}$ & $\begin{array}{c}\text { Conductivity } \\
\left(\mu \mathrm{mhos} / \mathrm{cm} @ 25^{\circ} \mathrm{C}\right)\end{array}$ & $\begin{array}{l}\text { Gross Alpha } \\
\qquad(\mu \mathrm{Ci} / \mathrm{mL})\end{array}$ & $\begin{array}{c}\text { Gross Beta } \\
(\mu \mathrm{Ci} / \mathrm{mL})\end{array}$ & $\begin{array}{c}\text { Tritium } \\
(\mu \mathrm{Ci} / \mathrm{mL})\end{array}$ \\
\hline 405 & $\mathrm{UP}(1)$ & 7.27 & 1,160 & $-0.43 \pm 2.76 E-09$ & $4.73 \pm 3.69 \mathrm{E}-09$ & $0.08 \pm 1.09 \mathrm{E}-07$ \\
\hline 405 & $\mathrm{UP}(2)$ & 7.14 & 1,450 & $-1.04 \pm 1.75 \mathrm{E}-09$ & $7.70 \pm 2.88 \mathrm{E}-09$ & $0.95 \pm 1.12 \mathrm{E}-07$ \\
\hline 405 & $\mathrm{UP}(3)$ & 7.55 & 893 & $0.00 \pm 1.62 \mathrm{E}-09$ & $5.32 \pm 4.12 \mathrm{E}-09$ & $0.21 \pm 1.03 \mathrm{E}-07$ \\
\hline 405 & $\mathrm{UP}(4)$ & 7.06 & 1,543 & $-1.34 \pm 2.89 \mathrm{E}-09$ & $5.37 \pm 3.90 \mathrm{E}-09$ & $8.50 \pm 1.71 E-07$ \\
\hline 1303 & $\mathrm{UP}(1)$ & 7.88 & 306 & $-0.50 \pm 6.22 \mathrm{E}-10$ & $6.89 \pm 9.13 \mathrm{E}-10$ & $0.86 \pm 1.13 \mathrm{E}-07$ \\
\hline 1303 & $\mathrm{UP}(2)$ & 7.80 & 472 & $1.22 \pm 4.66 \mathrm{E}-10$ & $1.18 \pm 0.94 \mathrm{E}-09$ & $1.26 \pm 1.19 \mathrm{E}-07$ \\
\hline 1303 & $\mathrm{UP}(3)$ & 7.63 & 362 & $5.46 \pm 1.13 \mathrm{E}-09$ & $2.33 \pm 1.15 E-09$ & $1.67 \pm 9.23 \mathrm{E}-08$ \\
\hline 1303 & $\mathrm{UP}(4)$ & 7.71 & 308 & $5.99 \pm 6.56 \mathrm{E}-10$ & $2.17 \pm 0.94 \mathrm{E}-09$ & $0.30 \pm 1.02 \mathrm{E}-07$ \\
\hline 110 & $\operatorname{DOWN}(1)$ & 7.46 & 480 & $6.01 \pm 8.23 \mathrm{E}-10$ & $1.62 \pm 1.37 \mathrm{E}-09$ & $1.10 \pm 0.17 E-06$ \\
\hline 110 & $\operatorname{DOWN}(2)$ & 7.46 & 529 & $-8.93 \pm 8.57 \mathrm{E}-10$ & $1.69 \pm 2.74 \mathrm{E}-09$ & $1.19 \pm 0.17 E-06$ \\
\hline 110 & DOWN(3) & 7.40 & 501 & $3.42 \pm 9.57 \mathrm{E}-10$ & $1.22 \pm 1.88 \mathrm{E}-09$ & $1.17 \pm 0.12 \mathrm{E}-06$ \\
\hline 110 & DOWN(4) & 6.37 & 518 & $-5.29 \pm 9.17 \mathrm{E}-10$ & $1.03 \pm 2.32 \mathrm{E}-09$ & $1.11 \pm 0.18 \mathrm{E}-06$ \\
\hline 704 & $\operatorname{DOWN}(1)$ & 6.64 & 762 & $0.11 \pm 1.50 \mathrm{E}-09$ & $6.71 \pm 3.31 \mathrm{E}-09$ & $-0.35 \pm 1.06 \mathrm{E}-07$ \\
\hline 704 & $\operatorname{DOWN}(2)$ & 6.57 & 840 & $0.83 \pm 2.42 \mathrm{E}-09$ & $6.26 \pm 3.42 \mathrm{E}-09$ & $0.47 \pm 1.16 \mathrm{E}-07$ \\
\hline 704 & DOWN(3) & 6.48 & 840 & $-2.45 \pm 1.59 \mathrm{E}-09$ & $7.34 \pm 3.32 \mathrm{E}-09$ & $0.62 \pm 9.09 \mathrm{E}-08$ \\
\hline 704 & DOWN(4) & 6.38 & 895 & $1.03 \pm 1.54 \mathrm{E}-09$ & $9.24 \pm 3.45 \mathrm{E}-09$ & $0.47 \pm 1.01 \mathrm{E}-07$ \\
\hline 707 & $\operatorname{DOWN}(1)$ & 6.61 & 364 & $0.00 \pm 4.76 \mathrm{E}-10$ & $4.61 \pm 1.01 \mathrm{E}-09$ & $0.94 \pm 1.07 \mathrm{E}-07$ \\
\hline 707 & DOWN(2) & 6.41 & 556 & $0.42 \pm 1.80 \mathrm{E}-09$ & $0.18 \pm 3.57 \mathrm{E}-09$ & $0.68 \pm 1.16 \mathrm{E}-07$ \\
\hline 707 & $\operatorname{DOWN}(3)$ & 6.52 & 631 & $-0.33 \pm 1.31 \mathrm{E}-09$ & $1.55 \pm 2.40 \mathrm{E}-09$ & $6.22 \pm 9.64 \mathrm{E}-08$ \\
\hline 707 & $\operatorname{DOWN}(4)$ & 6.35 & 474 & $4.64 \pm 7.08 \mathrm{E}-10$ & $6.35 \pm 1.50 \mathrm{E}-09$ & $-3.71 \pm 9.43 \mathrm{E}-08$ \\
\hline 107 & $\operatorname{DOWN}(1)$ & 7.24 & 717 & $-1.73 \pm 2.15 \mathrm{E}-09$ & $8.30 \pm 3.58 E-09$ & $3.61 \pm 1.42 E-07$ \\
\hline 107 & $\operatorname{DOWN}(2)$ & 7.53 & 718 & $0.96 \pm 1.25 \mathrm{E}-09$ & $1.20 \pm 0.30 \mathrm{E}-08$ & $1.79 \pm 1.22 E-07$ \\
\hline 107 & $\operatorname{DOWN}(3)$ & 7.26 & 683 & $-0.28 \pm 1.36 \mathrm{E}-09$ & $1.22 \pm 0.29 \mathrm{E}-08$ & $1.87 \pm 1.00 \mathrm{E}-07$ \\
\hline 107 & DOWN(4) & 6.69 & 810 & $-0.11 \pm 1.56 \mathrm{E}-09$ & $1.17 \pm 0.32 \mathrm{E}-08$ & $2.34 \pm 1.28 \mathrm{E}-07$ \\
\hline 108 & $\operatorname{DOWN}(1)$ & 7.89 & 469 & $2.35 \pm 1.14 \mathrm{E}-09$ & $1.94 \pm 2.42 \mathrm{E}-09$ & $1.22 \pm 1.08 E-07$ \\
\hline 108 & $\operatorname{DOWN}(2)$ & 7.77 & 548 & $4.31 \pm 1.38 \mathrm{E}-09$ & $3.11 \pm 2.68 \mathrm{E}-09$ & $2.31 \pm 1.25 E-07$ \\
\hline 108 & $\operatorname{DOWN}(3)$ & 7.70 & 518 & $1.82 \pm 1.28 \mathrm{E}-09$ & $2.19 \pm 1.50 \mathrm{E}-09$ & $1.81 \pm 0.98 \mathrm{E}-07$ \\
\hline 108 & DOWN(4) & 7.57 & 544 & $0.64 \pm 1.13 \mathrm{E}-09$ & $1.61 \pm 2.27 \mathrm{E}-09$ & $2.27 \pm 1.27 \mathrm{E}-07$ \\
\hline 409 & $\operatorname{DOWN}(1)$ & 7.91 & 325 & $1.03 \pm 0.53 \mathrm{E}-09$ & $2.58 \pm 0.91 \mathrm{E}-09$ & $2.58 \pm 9.93 \mathrm{E}-08$ \\
\hline 409 & $\operatorname{DOWN}(2)$ & 7.91 & 350 & $0.64 \pm 1.35 \mathrm{E}-09$ & $-0.51 \pm 2.78 E-09$ & $-0.05 \pm 1.14 \mathrm{E}-07$ \\
\hline 409 & $\operatorname{DOWN}(3)$ & 7.85 & 322 & $5.57 \pm 8.68 \mathrm{E}-10$ & $3.13 \pm 1.25 \mathrm{E}-09$ & $2.47 \pm 9.15 \mathrm{E}-08$ \\
\hline 409 & DOWN(4) & 7.71 & 350 & $9.07 \pm 5.99 \mathrm{E}-10$ & $2.50 \pm 1.13 \mathrm{E}-09$ & $1.70 \pm 9.69 \mathrm{E}-08$ \\
\hline 910 & $\operatorname{DOWN}(1)$ & 9.61 & 1,623 & $-0.48 \pm 1.15 E-09$ & $1.75 \pm 0.06 E-07$ & $2.39 \pm 1.10 \mathrm{E}-07$ \\
\hline 910 & DOWN(3) & 10.43 & 509 & $-6.84 \pm 4.25 \mathrm{E}-10$ & $8.49 \pm 0.21 \mathrm{E}-08$ & $0.47 \pm 1.03 \mathrm{E}-07$ \\
\hline 910 & DOWN(4) & 7.93 & 767 & $1.04 \pm 1.74 \mathrm{E}-09$ & $6.12 \pm 0.29 \mathrm{E}-08$ & $-2.44 \pm 9.41 \mathrm{E}-08$ \\
\hline
\end{tabular}

Note: Bolding convention applied to these data. (See p. E-2 $\mathbf{6 0}$ )

Sample collection quarter is noted in parentheses next to hydraulic position. Hydraulic position is relative to other wells within the same hydrogeologic unit.

$E-12$ 


\begin{tabular}{|c|c|c|c|c|c|c|}
\hline \multicolumn{7}{|c|}{ Table E-6 } \\
\hline $\begin{array}{l}\text { Location } \\
\text { Code }\end{array}$ & $\begin{array}{l}\text { Hydraulic } \\
\text { Position }\end{array}$ & $\begin{array}{l}\mathbf{p H} \\
(\mathrm{SU})\end{array}$ & $\begin{array}{c}\text { Conductivity } \\
\left(\mu \mathrm{mhos} / \mathrm{cm} @ 25^{\circ} \mathrm{C}\right)\end{array}$ & $\begin{array}{c}\text { Gross Alpha } \\
\qquad(\mu \mathrm{Ci} / \mathrm{mL})\end{array}$ & $\begin{array}{c}\text { Gross Beta } \\
(\mu \mathrm{Ci} / \mathrm{mL})\end{array}$ & $\begin{array}{c}\text { Tritium } \\
(\mu \mathrm{Ci} / \mathrm{mL})\end{array}$ \\
\hline 901 & $\mathrm{UP}(1)$ & 7.68 & 320 & $4.70 \pm 4.22 \mathrm{E}-10$ & $2.22 \pm 0.75 \mathrm{E}-09$ & $-0.06 \pm 1.05 \mathrm{E}-07$ \\
\hline 901 & $\mathrm{UP}(3)$ & 7.68 & 352 & $5.46 \pm 4.08 \mathrm{E}-10$ & $2.59 \pm 0.76 \mathrm{E}-09$ & $-3.96 \pm 9.36 \mathrm{E}-08$ \\
\hline 902 & $\mathrm{UP}(1)$ & 7.90 & 386 & $2.73 \pm 9.39 \mathrm{E}-10$ & $2.24 \pm 1.34 \mathrm{E}-09$ & $1.18 \pm 1.10 \mathrm{E}-07$ \\
\hline 902 & UP(3) & 7.74 & 418 & $1.55 \pm 0.75 \mathrm{E}-09$ & $3.57 \pm 1.11 \mathrm{E}-09$ & $0.30 \pm 1.04 \mathrm{E}-07$ \\
\hline $1008 \mathrm{~B}$ & $\mathrm{UP}(1)$ & 7.92 & 323 & $0.47 \pm 1.70 \mathrm{E}-09$ & $3.70 \pm 2.64 \mathrm{E}-09$ & $-0.16 \pm 1.03 \mathrm{E}-07$ \\
\hline $1008 \mathrm{~B}$ & $\mathrm{UP}(3)$ & 7.79 & 376 & $1.07 \pm 0.70 \mathrm{E}-09$ & $1.47 \pm 0.87 \mathrm{E}-09$ & $0.29 \pm 1.05 \mathrm{E}-07$ \\
\hline 903 & DOWN(1) & 7.47 & 828 & $-0.08 \pm 1.05 \mathrm{E}-09$ & $1.84 \pm 2.02 \mathrm{E}-09$ & $-4.49 \pm 9.87 \mathrm{E}-08$ \\
\hline 903 & DOWN(3) & 7.33 & 910 & $-2.96 \pm 9.77 \mathrm{E}-10$ & $3.47 \pm 3.07 \mathrm{E}-09$ & $0.09 \pm 1.05 \mathrm{E}-07$ \\
\hline 8610 & DOWN $(1$ & 7.93 & 999 & $-0.54 \pm 2.89 \mathrm{E}-09$ & $4.03 \pm 2.60 \mathrm{E}-09$ & $0.41 \pm 1.05 \mathrm{E}-07$ \\
\hline 8610 & DOWN(3) & 7.64 & 1,139 & $0.24 \pm 1.02 \mathrm{E}-09$ & $2.84 \pm 3.13 \mathrm{E}-09$ & $-1.99 \pm 1.04 \mathrm{E}-07$ \\
\hline 8611 & DOWN & 7.55 & 864 & $0.38 \pm 2.43 \mathrm{E}-09$ & $-1.01 \pm 3.64 \mathrm{E}-09$ & $0.55 \pm 1.04 \mathrm{E}-07$ \\
\hline 8611 & DOWN(3) & 7.44 & 935 & $0.73 \pm 1.97 \mathrm{E}-09$ & $4.27 \pm 1.84 \mathrm{E}-09$ & $-1.51 \pm 1.05 \mathrm{E}-07$ \\
\hline
\end{tabular}

Note: Bolding convention is not applicable to these data.

Sample collection quarter is noted in parentheses next to hydraulic position. Hydraulic position is relative to other wells within the same hydrogeologic unit.

\begin{tabular}{|c|c|c|c|c|}
\hline \multirow[b]{2}{*}{$\begin{array}{l}\text { Location } \\
\text { Code }\end{array}$} & \multicolumn{4}{|c|}{ Table E-7 } \\
\hline & $\begin{array}{l}\text { Sample } \\
\text { Quarter }\end{array}$ & $\begin{array}{c}\text { Aluminum } \\
\text { Total } \\
(\mu \mathrm{g} / \mathrm{L})\end{array}$ & $\begin{array}{c}\text { Iron } \\
\text { Total } \\
(\mu \mathrm{g} / \mathrm{L})\end{array}$ & $\begin{array}{c}\text { Manganese } \\
\text { Total } \\
(\mu \mathrm{g} / \mathrm{L})\end{array}$ \\
\hline 502 & (1) & 44 & 1,710 & 4.2 \\
\hline & (3) & 119 & 5,450 & 9.0 \\
\hline
\end{tabular}

Note: Bolding convention is not applicable to these data.

WVDP Annual Site Environmental Report

$E-13$

Calendar Year 2006 


\section{Table E-8 \\ 2006 Volatile Organic Compound Results \\ at Selected Groundwater Monitoring Locations}

\begin{tabular}{|c|c|c|c|c|c|c|c|c|}
\hline $\begin{array}{l}\text { Location } \\
\text { Code }\end{array}$ & $\begin{array}{l}\text { Sampling } \\
\text { Quarter }\end{array}$ & $\begin{array}{c}\text { 1,1-DCA } \\
(\mu \mathrm{g} / \mathrm{L})\end{array}$ & $\begin{array}{c}\text { DCDFMeth } \\
(\mu \mathrm{g} / \mathrm{L})\end{array}$ & $\begin{array}{c}\text { 1,1-DCE } \\
(\mu \mathrm{g} / \mathrm{L})\end{array}$ & $\begin{array}{c}\text { 1,2-DCE } \\
\text { (total) } \\
(\mu \mathrm{g} / \mathrm{L})\end{array}$ & $\begin{array}{c}\text { 1,2-DCE } \\
\text { (trans) } \\
(\mu \mathrm{g} / \mathrm{L})\end{array}$ & $\underset{(\mu \mathrm{g} / \mathrm{L})}{\mathbf{1 , 1 , 1 - T C A}}$ & $\begin{array}{c}\text { Vinyl } \\
\text { Chloride } \\
(\mu \mathrm{g} / \mathrm{L})\end{array}$ \\
\hline SP12 & $\begin{array}{l}1 \\
3\end{array}$ & $\begin{array}{l}<5.0 \\
<5.0\end{array}$ & $\begin{array}{l}<1.0 \\
<5.0\end{array}$ & $\begin{array}{l}<5.0 \\
<5.0\end{array}$ & $\begin{array}{l}\text { NS } \\
\text { NS }\end{array}$ & $\begin{array}{l}<1.0 \\
<5.0\end{array}$ & $\begin{array}{l}<5.0 \\
<5.0\end{array}$ & $\begin{array}{l}<10.0 \\
<10.0\end{array}$ \\
\hline 803 & $\begin{array}{l}1 \\
2 \\
3 \\
4\end{array}$ & $\begin{array}{l}<5.0 \\
<5.0 \\
<5.0 \\
<5.0\end{array}$ & $\begin{array}{l}<1.0 \\
<5.0 \\
<5.0 \\
<5.0\end{array}$ & $\begin{array}{l}<5.0 \\
<5.0 \\
<5.0 \\
<5.0\end{array}$ & $\begin{array}{l}\text { NS } \\
\text { NS } \\
\text { NS } \\
\text { NS }\end{array}$ & $\begin{array}{l}<1.0 \\
<5.0 \\
<5.0 \\
<5.0\end{array}$ & $\begin{array}{l}<5.0 \\
<5.0 \\
<5.0 \\
<5.0\end{array}$ & $\begin{array}{l}<10.0 \\
<10.0 \\
<10.0 \\
<10.0\end{array}$ \\
\hline 8609 & 1 & $<5.0$ & $<5.0$ & $<5.0$ & NS & $<5.0$ & $<5.0$ & $<10.0$ \\
\hline 8612 & $\begin{array}{l}1 \\
2 \\
3 \\
4\end{array}$ & $\begin{array}{l}\mathbf{9 . 6 0} \\
7.25 \\
7.50 \\
\mathbf{6 . 9 5}\end{array}$ & $\begin{array}{l}2.8^{a} \\
\text { 3.1 }^{a} \\
2.6^{a} \\
\mathbf{2 . 4}^{a}\end{array}$ & $\begin{array}{l}<5.0 \\
<5.0 \\
<5.0 \\
<5.0\end{array}$ & $\begin{array}{l}\mathbf{2 6 . 5} \\
\mathbf{2 1 . 5} \\
23.0 \\
23.5\end{array}$ & $\begin{array}{l}<5.0 \\
<5.0 \\
<5.0 \\
<5.0\end{array}$ & $\begin{array}{l}0.97^{a} \\
0.86^{a} \\
\mathbf{0 . 8 4}^{a} \\
\mathbf{0 . 9 9}^{a}\end{array}$ & $\begin{array}{l}\mathbf{0 . 4}^{a} \\
<10.0 \\
<10.0 \\
<10.0\end{array}$ \\
\hline
\end{tabular}

See Table E-12 $\mathbf{\text { G0 }}$ for compound definition.

Note: Bolding convention applied to these data. (See p. E-2 $\mathbf{\text { cop } )}$

NS - Not sampled.

${ }^{a}$ Compound was reported at an estimated concentration less than the practical quantitation limit.

\section{Table E-9 \\ 2006 Tributyl Phosphate Results at Selected Groundwater Monitoring Locations}

$\begin{array}{ccc}\begin{array}{c}\text { Location } \\ \text { Code }\end{array} & \begin{array}{c}\text { Sampling } \\ \text { Quarter }\end{array} & \begin{array}{c}\text { Tributyl Phosphate (TBP) } \\ (\mu \mathrm{g} / \mathrm{L})\end{array} \\ 111 & 1 & 8.0^{a} \\ & 3 & 12.0^{a} \\ 8605 & 1 & 245 \\ & 3 & 190\end{array}$

Practical quantitation limit is $10 \mu \mathrm{g} / \mathrm{L}$.

Note: Bolding convention not applicable to these data.

${ }^{a}$ Compound was reported at an estimated concentration less than the practical quantitation limit.

$E-14$

WVDP Annual Site Environmental Report

Calendar Year 2006 
Table E-10

2006 Results for Metals in Groundwater

Title 6 NYCRR Appendix 33 List

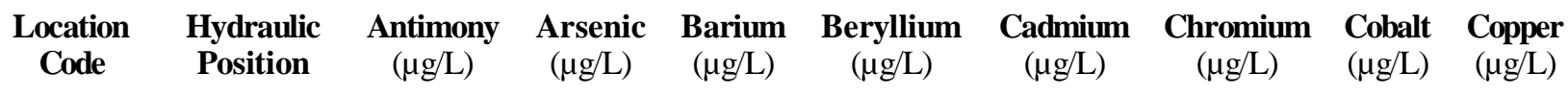

Sand and Gravel

\begin{tabular}{|c|c|c|c|c|c|c|c|c|c|}
\hline 706 & UP(1) & $<10$ & $<10$ & 114 & $<1$ & $<5$ & 228 & $<50$ & $<25$ \\
\hline 706 & $\mathrm{UP}(2)$ & $<10$ & $<10$ & 166 & $<1$ & $<5$ & 3,942 & $<50$ & 79 \\
\hline 706 & UP(3) & $<10$ & $<10$ & 161 & $<1$ & $<5$ & 1,190 & $<50$ & $<25$ \\
\hline 706 & UP(4) & $<10$ & $<10$ & 162 & $<1$ & $<5$ & 34 & $<50$ & $<25$ \\
\hline 1304 & UP(1) & $<10$ & $<10$ & 128 & $<1$ & $<5$ & 6 & $<50$ & $<25$ \\
\hline 1304 & UP(2) & $<10$ & $<10$ & 263 & $<1$ & $<5$ & $<5$ & $<50$ & $<25$ \\
\hline 1304 & UP(3) & $<10$ & $<10$ & 161 & $<1$ & $<5$ & $<5$ & $<50$ & $<25$ \\
\hline 1304 & UP(4) & $<10$ & $<10$ & 88 & $<1$ & $<5$ & $<5$ & $<50$ & $<25$ \\
\hline 1302 & DOWN(1) & $<10$ & $<10$ & 294 & $<1$ & $<5$ & $<5$ & $<50$ & $<25$ \\
\hline 1302 & DOWN(2) & $<10$ & $<10$ & 186 & $<1$ & $<5$ & $<5$ & $<50$ & $<25$ \\
\hline 1302 & DOWN(3) & $<10$ & $<10$ & 182 & $<1$ & $<5$ & $<5$ & $<50$ & $<25$ \\
\hline 1302 & DOWN(4) & $<10$ & $<10$ & 156 & $<1$ & $<5$ & $<5$ & $<50$ & $<25$ \\
\hline 111 & DOWN(1) & $<4$ & $<3$ & 111 & $<0.1$ & $<1$ & $<2$ & 5 & 2 \\
\hline 502 & $\operatorname{DOWN}(1)$ & NS & $<3$ & 281 & NS & $<1$ & 369 & $<1$ & 3 \\
\hline 502 & DOWN(3) & NS & $<6$ & 511 & NS & $<1$ & 1,020 & 1 & 7 \\
\hline 8605 & DOWN(1) & $<4$ & 7 & 174 & 0.1 & $<1$ & $<2$ & 1 & $<1$ \\
\hline
\end{tabular}

Weathered Till

\begin{tabular}{|c|c|c|c|c|c|c|c|c|c|}
\hline NDATR & DOWN(1) & $<10$ & $<10$ & 44 & $<1$ & $<5$ & $<5$ & $<50$ & $<25$ \\
\hline NDATR & DOWN(2) & $<10$ & $<10$ & 51 & $<1$ & $<5$ & $<5$ & $<50$ & $<25$ \\
\hline NDATR & DOWN(3) & $<10$ & $<10$ & 55 & $<1$ & $<5$ & $<5$ & $<50$ & $<25$ \\
\hline NDATR & DOWN(4) & $<10$ & $<10$ & 63 & $<1$ & $<5$ & $<5$ & $<50$ & $<25$ \\
\hline 909 & DOWN(1) & $<10$ & 14 & 208 & $<1$ & $<5$ & $<5$ & $<50$ & $<2$ \\
\hline
\end{tabular}

Unweathered Till

$\begin{array}{rrrrrrrrrr}405 & \text { UP(1) } & <10 & <10 & \mathbf{7 9} & <1 & <5 & 287 & <50 & <25 \\ 405 & \text { UP(2) } & <10 & <10 & 84 & <1 & <5 & \mathbf{9 0} & <50 & <25 \\ 405 & \text { UP(3) } & <10 & <10 & \mathbf{1 2 4} & <1 & <5 & \mathbf{1 , 8 8 0} & <50 & <25 \\ 405 & \mathrm{UP}(4) & <10 & <10 & 109 & <1 & <5 & 581 & <50 & <25 \\ & & & & & & & <5 & <25 \\ 1303 & \mathrm{UP}(1) & <10 & \mathbf{1 4} & 246 & <1 & <5 & 21 & <50 & <25 \\ 1303 & \mathrm{UP}(2) & <10 & 15 & \mathbf{2 8 0} & <1 & <5 & 21 & <50 & <25 \\ 1303 & \mathrm{UP}(3) & <10 & \mathbf{1 7} & 268 & <1 & <5 & \mathbf{2 4} & <50 & <25 \\ 1303 & \mathrm{UP}(4) & <10 & \mathbf{1 4} & \mathbf{2 1 1} & <1 & <5 & \mathbf{1 9} & <50 & <25\end{array}$

Note: Bolding convention applied to these data. (See p. E-2

NS - Not sampled.

Sample collection quarter is noted in parentheses next to hydraulic position. Hydraulic position is relative to other wells within the same hydrogeologic unit.

$$
E-15
$$




\section{Table E-10 (concluded) \\ 2006 Results for Metals in Groundwater}

Title 6 NYCRR Appendix 33 List

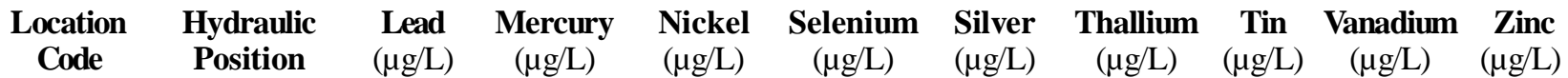

Sand and Gravel

\begin{tabular}{|c|c|c|c|c|c|c|c|c|c|}
\hline 706 & $\mathrm{UP}(1)$ & $<3$ & $<0.2$ & 695 & $<5$ & $<10$ & $<10$ & $<3,000$ & $<50$ \\
\hline 706 & $\mathrm{UP}(2)$ & $<3$ & $<0.2$ & 1,080 & $<5$ & $<10$ & $<10$ & $<3,000$ & $<50$ \\
\hline 706 & $\mathrm{UP}(3)$ & $<3$ & $<0.2$ & 2,520 & $<5$ & $<10$ & $<10$ & $<3,000$ & $<50$ \\
\hline 706 & UP(4) & $<3$ & $<0.2$ & 213 & $<5$ & $<10$ & $<10$ & $<3,000$ & $<50$ \\
\hline 1304 & $\mathrm{UP}(1)$ & $<3$ & $<0.2$ & $<40$ & $<5$ & $<10$ & $<10$ & $<3,000$ & $<50$ \\
\hline 1304 & UP(2) & $<3$ & $<0.2$ & $<40$ & $<5$ & $<10$ & $<10$ & $<3,000$ & $<50$ \\
\hline 1304 & UP(3) & $<3$ & $<0.2$ & $<40$ & $<5$ & $<10$ & $<10$ & $<3,000$ & $<50$ \\
\hline 1304 & $\mathrm{UP}(4)$ & $<3$ & $<0.2$ & $<40$ & $<5$ & $<10$ & $<10$ & $<3,000$ & $<50$ \\
\hline 1302 & DOWN(1) & $<3$ & $<0.2$ & $<40$ & $<5$ & $<10$ & $<10$ & $<3,000$ & $<50$ \\
\hline 1302 & $\operatorname{DOWN}(2)$ & $<3$ & $<0.2$ & $<40$ & $<5$ & $<10$ & $<10$ & $<3,000$ & $<50$ \\
\hline 1302 & DOWN(3) & $<3$ & $<0.2$ & $<40$ & $<5$ & $<10$ & $<10$ & $<3,000$ & $<50$ \\
\hline 1302 & DOWN(4) & $<3$ & $<0.2$ & $<40$ & $<5$ & $<10$ & $<10$ & $<3,000$ & $<50$ \\
\hline 111 & DOWN(1) & $<3$ & $<0.1$ & 5 & $<4$ & $<1$ & $<6$ & $<5$ & $<1$ \\
\hline 502 & DOWN(1) & $<3$ & $<0.1$ & 19 & $<4$ & $<1$ & $\mathrm{NS}$ & NS & 1 \\
\hline 502 & DOWN(3) & $<3$ & $<0.1$ & 60 & $<5$ & $<1$ & NS & NS & 2 \\
\hline 8605 & DOWN(1) & $<3$ & $<0.1$ & $<1$ & $<4$ & $<1$ & $<6$ & $<5$ & $<1$ \\
\hline
\end{tabular}

Weathered Till

\begin{tabular}{|c|c|c|c|c|c|c|c|c|c|c|}
\hline NDATR & $\operatorname{DOWN}(1)$ & $<3$ & $<0.2$ & $<40$ & $<5$ & $<10$ & $<10$ & $<3,000$ & $<50$ & $<20$ \\
\hline NDATR & $\operatorname{DOWN}(2)$ & $<3$ & $<0.2$ & $<40$ & $<5$ & $<10$ & $<10$ & $<3,000$ & $<50$ & $<20$ \\
\hline NDATR & DOWN(3) & $<3$ & $<0.2$ & $<40$ & $<5$ & $<10$ & $<10$ & $<3,000$ & $<50$ & $<20$ \\
\hline NDATR & DOWN(4) & $<3$ & $<0.2$ & $<40$ & $<5$ & $<10$ & $<10$ & $<3,000$ & $<50$ & 37 \\
\hline 909 & DOWN(1) & 4 & $<0.2$ & $<40$ & $<5$ & $<10$ & $<10$ & $<3,000$ & $<50$ & $<20$ \\
\hline
\end{tabular}

Unweathered Till

\begin{tabular}{|c|c|c|c|c|c|c|c|c|c|c|}
\hline 405 & UP(1) & $<3$ & $<0.2$ & 893 & $<5$ & $<10$ & $<10$ & $<3,000$ & $<50$ & $<20$ \\
\hline 405 & $\mathrm{UP}(2)$ & $<3$ & $<0.2$ & 1,070 & $<5$ & $<10$ & $<10$ & $<3,000$ & $<50$ & $<20$ \\
\hline 405 & UP(3) & 3 & $<0.2$ & 1,260 & $<5$ & $<10$ & $<10$ & $<3,000$ & $<50$ & $<20$ \\
\hline 405 & UP(4) & $<3$ & $<0.2$ & 1,140 & $<5$ & $<10$ & $<10$ & $<3,000$ & $<50$ & $<20$ \\
\hline 1303 & UP(1) & 9 & $<0.2$ & $<40$ & $<5$ & $<10$ & $<10$ & $<3,000$ & $<50$ & 56 \\
\hline 1303 & UP(2) & 11 & $<0.2$ & $<40$ & $<5$ & $<10$ & $<10$ & $<3,000$ & $<50$ & 62 \\
\hline 1303 & UP(3) & 12 & $<0.2$ & $<40$ & $<5$ & $<10$ & $<10$ & $<3,000$ & $<50$ & 68 \\
\hline 1303 & UP(4) & 9 & $<0.2$ & $<40$ & $<5$ & $<10$ & $<10$ & $<3,000$ & $<50$ & 55 \\
\hline
\end{tabular}

Note: Bolding convention applied to these data. (See p. E-2

NS - Not sampled.

Sample collection quarter is noted in parentheses next to hydraulic position. Hydraulic position is relative to other wells within the same hydrogeologic unit. 


\section{Table E-11 \\ 2006 Radioactivity in Groundwater From Selected Monitoring Locations}

\section{Location \\ Code}

\author{
C-14 \\ $(\mu \mathrm{Ci} / \mathrm{mL})$
}

Hydraulic

\begin{tabular}{|c|c|c|}
\hline 401 & $\mathrm{UP}(1)$ & $-1.12 \pm 2.60 \mathrm{E}-08$ \\
\hline 706 & UP(1) & $0.12 \pm 2.52 \mathrm{E}-08$ \\
\hline 706 & UP(2) & $-0.28 \pm 2.14 \mathrm{E}-08$ \\
\hline 706 & UP(3) & $0.35 \pm 2.70 \mathrm{E}-08$ \\
\hline 706 & UP(4) & $-0.93 \pm 2.43 \mathrm{E}-08$ \\
\hline 1304 & UP(1) & $2.71 \pm 3.42 \mathrm{E}-08$ \\
\hline 1304 & UP(2) & $0.99 \pm 2.14 \mathrm{E}-08$ \\
\hline 1304 & UP(3) & $-1.97 \pm 2.70 \mathrm{E}-08$ \\
\hline 1304 & UP(4) & $-1.46 \pm 2.42 \mathrm{E}-08$ \\
\hline 1302 & DOWN(1) & $1.14 \pm 3.35 \mathrm{E}-08$ \\
\hline 1302 & DOWN(2) & $0.19 \pm 2.18 \mathrm{E}-08$ \\
\hline 1302 & DOWN(3) & $0.00 \pm 2.70 \mathrm{E}-08$ \\
\hline 1302 & DOWN(4) & $-0.31 \pm 2.45 \mathrm{E}-08$ \\
\hline 111 & DOWN(1) & NS \\
\hline 406 & $\operatorname{DOWN}(1)$ & $-2.33 \pm 2.58 \mathrm{E}-08$ \\
\hline 408 & $\operatorname{DOWN}(1)$ & $1.17 \pm 2.38 \mathrm{E}-08$ \\
\hline 501 & $\operatorname{DOWN}(1)$ & NS \\
\hline 502 & $\operatorname{DOWN}(1)$ & NS \\
\hline 8605 & DOWN(1) & NS \\
\hline 8609 & DOWN(1) & NS \\
\hline 8609 & DOWN(3) & NS \\
\hline 116 & DOWN(1) & NS \\
\hline 116 & $\operatorname{DOWN}(3)$ & NS \\
\hline 801 & DOWN(1) & NS \\
\hline 801 & DOWN(2) & NS \\
\hline 801 & DOWN(3) & NS \\
\hline 801 & DOWN(4) & NS \\
\hline
\end{tabular}

\section{Sand and Gravel}

Note: Bolding convention applied to these data. (See p. E-2 뚜)

NS - Not sampled.

Sample collection quarter is noted in parentheses next to hydraulic position. Hydraulic position is relative to other wells within the same hydrogeologic unit.

$$
E-17
$$

WVDP Annual Site Environmental Report

\author{
Sr-90 \\ $(\mu \mathrm{Ci} / \mathrm{mL})$
}

Tc-99

$(\mu \mathrm{Ci} / \mathrm{mL})$

\begin{tabular}{|c|c|}
\hline $2.24 \pm 0.89 \mathrm{E}-09$ & $0.20 \pm 1.90 \mathrm{E}-09$ \\
\hline $1.63 \pm 0.66 \mathrm{E}-09$ & $0.40 \pm 2.01 \mathrm{E}-09$ \\
\hline $1.98 \pm 0.84 \mathrm{E}-09$ & $1.09 \pm 1.70 \mathrm{E}-09$ \\
\hline $2.01 \pm 0.89 \mathrm{E}-09$ & $1.25 \pm 2.08 \mathrm{E}-09$ \\
\hline $2.25 \pm 0.90 \mathrm{E}-09$ & $0.96 \pm 1.99 \mathrm{E}-09$ \\
\hline $0.96 \pm 3.42 \mathrm{E}-10$ & $-1.14 \pm 1.78 \mathrm{E}-09$ \\
\hline $3.84 \pm 1.02 \mathrm{E}-09$ & $1.46 \pm 1.68 \mathrm{E}-09$ \\
\hline $7.44 \pm 5.38 \mathrm{E}-10$ & $2.62 \pm 2.11 \mathrm{E}-09$ \\
\hline $2.47 \pm 4.34 \mathrm{E}-10$ & $1.27 \pm 2.01 \mathrm{E}-09$ \\
\hline $2.12 \pm 2.41 \mathrm{E}-10$ & $-0.76 \pm 1.78 \mathrm{E}-09$ \\
\hline $1.24 \pm 5.84 \mathrm{E}-10$ & $1.58 \pm 1.73 \mathrm{E}-09$ \\
\hline$-2.48 \pm 6.32 \mathrm{E}-10$ & $0.91 \pm 2.11 \mathrm{E}-09$ \\
\hline $1.11 \pm 4.07 \mathrm{E}-10$ & $8.61 \pm 2.76 \mathrm{E}-09$ \\
\hline $2.49 \pm 0.02 \mathrm{E}-06$ & NS \\
\hline $8.02 \pm 5.12 \mathrm{E}-10$ & $2.19 \pm 2.08 \mathrm{E}-09$ \\
\hline $8.55 \pm 0.01 \mathrm{E}-05$ & $1.48 \pm 0.22 \mathrm{E}-08$ \\
\hline $5.48 \pm 0.01 \mathrm{E}-05$ & NS \\
\hline $5.34 \pm 0.01 \mathrm{E}-05$ & NS \\
\hline $5.68 \pm 0.04 \mathrm{E}-06$ & NS \\
\hline $8.59 \pm 0.13 \mathrm{E}-07$ & NS \\
\hline $1.02 \pm 0.04 \mathrm{E}-06$ & NS \\
\hline $1.33 \pm 0.02 \mathrm{E}-06$ & NS \\
\hline $2.27 \pm 0.06 \mathrm{E}-06$ & NS \\
\hline $3.24 \pm 0.03 \mathrm{E}-06$ & NS \\
\hline $4.87 \pm 0.03 \mathrm{E}-06$ & NS \\
\hline $5.12 \pm 0.09 \mathrm{E}-06$ & NS \\
\hline $6.84 \pm 0.04 E-06$ & NS \\
\hline
\end{tabular}




\section{Table E-11 (continued) 2006 Radioactivity in Groundwater From Selected Monitoring Locations}

$\begin{array}{cc}\text { Location } & \begin{array}{c}\text { Hydraulic } \\ \text { Code }\end{array} \\ \text { Position }\end{array}$

Sand and Gravel (concluded)

$8603 \quad$ DOWN(1)

$8603 \quad$ DOWN(3)

\section{Weathered Till}

$\begin{array}{cc}\text { NDATR } & \text { DOWN(1) } \\ \text { NDATR } & \text { DOWN(3) } \\ 909 & \text { DOWN(1) }\end{array}$

Unweathered Till

$\begin{array}{ll}405 & \text { UP(1) } \\ 405 & \text { UP(2) } \\ 405 & \text { UP(3) } \\ 405 & \text { UP(4) } \\ & \\ 1303 & \text { UP(1) } \\ 1303 & \text { UP(2) } \\ 1303 & \text { UP(3) } \\ 1303 & \text { UP(4) }\end{array}$

\author{
C-14 \\ $(\mu \mathrm{Ci} / \mathrm{mL})$
}

NS

NS

$-1.72 \pm 2.59 \mathrm{E}-08$

$-1.33 \pm 3.34 \mathrm{E}-08$

$-0.85 \pm 2.63 \mathrm{E}-08$

$-3.70 \pm 2.53 \mathrm{E}-08$

$-0.50 \pm 2.13 \mathrm{E}-08$

$-1.50 \pm 2.67 \mathrm{E}-08$

$-0.16 \pm 2.45 \mathrm{E}-08$

$0.83 \pm 2.47 \mathrm{E}-08$

$1.20 \pm 2.20 \mathrm{E}-08$

$-1.11 \pm 2.68 \mathrm{E}-08$

$-0.06 \pm 2.45 \mathrm{E}-08$
Sr-90

$(\mu \mathrm{Ci} / \mathrm{mL})$

Tc-99

$(\mu \mathrm{Ci} / \mathrm{mL})$

$2.36 \pm 0.01 \mathrm{E}-05$

$3.52 \pm 0.02 \mathrm{E}-05$

NS

NS

$\begin{array}{lr}1.35 \pm 0.04 \mathrm{E}-07 & 0.26 \pm 1.80 \mathrm{E}-09 \\ 7.56 \pm 0.32 \mathrm{E}-08 & 2.90 \pm 2.14 \mathrm{E}-09 \\ 1.37 \pm 0.04 \mathrm{E}-07 & -0.94 \pm 1.84 \mathrm{E}-09\end{array}$

3.85 $\pm 1.04 \mathrm{E}-09$

$-0.97 \pm 1.97 \mathrm{E}-09$

$1.44 \pm 1.69 \mathrm{E}-09$

$1.10 \pm 2.13 \mathrm{E}-09$

$8.87 \pm 6.16 \mathrm{E}-10$

$1.94 \pm 2.02 \mathrm{E}-09$

$-0.76 \pm 3.21 \mathrm{E}-10$

$-1.34 \pm 1.97 \mathrm{E}-09$

$1.85 \pm 3.50 \mathrm{E}-10$

2.26 $\pm 1.72 \mathrm{E}-09$

$0.47 \pm 2.09 \mathrm{E}-09$

$1.26 \pm 5.79 \mathrm{E}-10$

Note: Bolding convention applied to these data. (See p. E-2 따)

NS - Not sampled.

Sample collection quarter is noted in parentheses next to hydraulic position. Hydraulic position is relative to other wells within the same hydrogeologic unit.

$E-18$ 


\section{Table E-11 (continued) 2006 Radioactivity in Groundwater From Selected Monitoring Locations}

\section{Location Hydraulic \\ Code Position

\author{
I-129 \\ $(\mu \mathrm{Ci} / \mathrm{mL})$
}

Cs-137
$(\mu \mathrm{Ci} / \mathrm{mL})$

\section{Ra-226}

$(\mu \mathrm{Ci} / \mathrm{mL})$
Ra-228

$(\mu \mathrm{Ci} / \mathrm{mL})$
U-232

$(\mu \mathrm{Ci} / \mathrm{mL})$

Sand and Gravel

\begin{tabular}{|c|c|c|c|c|c|c|}
\hline 401 & $\mathrm{UP}(1)$ & $1.44 \pm 0.76 \mathrm{E}-09$ & $-0.34 \pm 1.90 \mathrm{E}-09$ & $5.56 \pm 3.27 \mathrm{E}-10$ & $1.02 \pm 0.35 \mathrm{E}-09$ & $-0.89 \pm 3.05 \mathrm{E}-11$ \\
\hline 706 & UP(1) & $-0.84 \pm 4.87 \mathrm{E}-10$ & $0.86 \pm 2.62 \mathrm{E}-09$ & $2.18 \pm 2.07 \mathrm{E}-10$ & $3.18 \pm 2.90 \mathrm{E}-10$ & $0.23 \pm 5.44 \mathrm{E}-11$ \\
\hline 706 & UP(2) & $-1.16 \pm 4.67 \mathrm{E}-10$ & $0.00 \pm 6.26 \mathrm{E}-09$ & $7.97 \pm 3.61 \mathrm{E}-10$ & $1.29 \pm 0.50 \mathrm{E}-09$ & $2.12 \pm 2.18 \mathrm{E}-11$ \\
\hline 706 & UP(3) & $2.60 \pm 6.19 \mathrm{E}-10$ & $0.68 \pm 1.76 \mathrm{E}-09$ & $4.36 \pm 2.07 \mathrm{E}-10$ & $8.24 \pm 6.43 \mathrm{E}-10$ & $1.66 \pm 4.71 \mathrm{E}-11$ \\
\hline 706 & UP(4) & $3.16 \pm 6.85 \mathrm{E}-10$ & $-1.09 \pm 2.52 \mathrm{E}-09$ & $3.33 \pm 1.79 \mathrm{E}-10$ & $7.11 \pm 3.86 \mathrm{E}-10$ & $1.14 \pm 2.80 \mathrm{E}-11$ \\
\hline 1304 & UP(1) & $1.68 \pm 3.27 \mathrm{E}-09$ & $0.00 \pm 2.88 \mathrm{E}-09$ & $4.16 \pm 2.37 \mathrm{E}-10$ & $4.19 \pm 2.18 \mathrm{E}-10$ & $-0.85 \pm 3.46 \mathrm{E}$ \\
\hline 1304 & $\mathrm{UP}(2)$ & $0.08 \pm 5.32 \mathrm{E}-10$ & $0.89 \pm 2.63 \mathrm{E}-09$ & $9.19 \pm 4.63 \mathrm{E}-10$ & $6.19 \pm 3.23 \mathrm{E}-10$ & $-1.34 \pm 3.92 \mathrm{E}-11$ \\
\hline 1304 & UP(3) & $1.37 \pm 2.92 \mathrm{E}-10$ & $0.64 \pm 1.83 \mathrm{E}-09$ & $2.73 \pm 1.89 \mathrm{E}-10$ & $4.71 \pm 4.44 \mathrm{E}-10$ & $1.00 \pm 1.81 \mathrm{E}-11$ \\
\hline 1304 & $\mathrm{UP}(4)$ & $0.00 \pm 7.92 \mathrm{E}-10$ & $-1.13 \pm 2.65 \mathrm{E}-09$ & $1.87 \pm 1.61 \mathrm{E}-10$ & $7.52 \pm 4.08 \mathrm{E}-10$ & $0.58 \pm 1.79 \mathrm{E}-11$ \\
\hline 1302 & $\operatorname{DOWN}(1)$ & $3.51 \pm 4.77 \mathrm{E}-10$ & $0.00 \pm 2.82 \mathrm{E}-09$ & $4.83 \pm 2.55 \mathrm{E}-10$ & $1.71 \pm 2.34 \mathrm{E}-10$ & $-2.96 \pm 4.79 \mathrm{E}-11$ \\
\hline 1302 & OWN(2) & $0.40 \pm 1.13 \mathrm{E}-09$ & $0.00 \pm 5.40 \mathrm{E}-09$ & $2.82 \pm 3.09 \mathrm{E}-10$ & $1.58 \pm 2.23 \mathrm{E}-10$ & $-0.91 \pm 4.09 \mathrm{E}-11$ \\
\hline 1302 & DOWN(3) & $2.00 \pm 6.75 \mathrm{E}-10$ & $1.92 \pm 2.01 \mathrm{E}-09$ & $3.69 \pm 2.39 \mathrm{E}-10$ & $4.72 \pm 5.64 \mathrm{E}-10$ & $-0.53 \pm 1.71 \mathrm{E}-11$ \\
\hline 1302 & DOWN(4) & $-1.58 \pm 9.35 \mathrm{E}-10$ & $-1.77 \pm 2.48 \mathrm{E}-09$ & $2.49 \pm 1.73 \mathrm{E}-10$ & $9.35 \pm 4.70 \mathrm{E}-10$ & $-1.19 \pm 2.30 \mathrm{E}-11$ \\
\hline 406 & $\operatorname{DOWN}(1)$ & $3.55 \pm 4.35 \mathrm{E}-10$ & $-0.10 \pm 3.15 E-09$ & $3.84 \pm 2.80 \mathrm{E}-10$ & $4.37 \pm 3.37 \mathrm{E}-10$ & $-4.12 \pm 4.12 \mathrm{E}$ \\
\hline 408 & $\operatorname{DOWN}(1)$ & $0.72 \pm 6.81 \mathrm{E}-10$ & $0.44 \pm 5.18 \mathrm{E}-09$ & $3.95 \pm 2.88 \mathrm{E}-10$ & $1.61 \pm 0.36 \mathrm{E}-09$ & $.50 \pm 4.62 \mathrm{E}$ \\
\hline
\end{tabular}

\section{Weathered Till}

$\begin{array}{ccccccr}\text { NDATR } & \text { DOWN(1) } & 9.04 \pm 9.14 \mathrm{E}-10 & 1.15 \pm 1.80 \mathrm{E}-09 & 2.69 \pm 2.69 \mathrm{E}-10 & -0.42 \pm 2.09 \mathrm{E}-10 & 2.02 \pm 4.01 \mathrm{E}-11 \\ \text { NDATR } & \text { DOWN(3) } & 1.32 \pm 0.98 \mathrm{E}-09 & 0.92 \pm 3.78 \mathrm{E}-09 & 1.92 \pm 2.00 \mathrm{E}-10 & 1.17 \pm 0.58 \mathrm{E}-09 & -1.20 \pm 2.97 \mathrm{E}-11 \\ & & & & & & \\ 909 & \text { DOWN(1) } & 6.91 \pm 1.18 \mathrm{E}-09 & -1.38 \pm 1.92 \mathrm{E}-09 & 3.89 \pm 2.69 \mathrm{E}-10 & -1.74 \pm 1.90 \mathrm{E}-10 & 5.60 \pm 4.28 \mathrm{E}-11\end{array}$

\section{Unweathered Till}

$\begin{array}{lrrrrrr}405 & \text { UP(1) } & 0.62 \pm 1.27 \mathrm{E}-09 & -0.74 \pm 2.05 \mathrm{E}-09 & 1.11 \pm 2.44 \mathrm{E}-10 & 4.41 \pm 2.98 \mathrm{E}-10 & 1.46 \pm 3.88 \mathrm{E}-11 \\ 405 & \text { UP(2) } & 1.82 \pm 5.37 \mathrm{E}-10 & 1.24 \pm 7.50 \mathrm{E}-09 & 1.82 \pm 2.22 \mathrm{E}-10 & \mathbf{6 . 8 3} \pm \mathbf{3 . 2 1 E}-10 & -4.42 \pm 9.51 \mathrm{E}-12 \\ 405 & \text { UP(3) } & 1.95 \pm 3.50 \mathrm{E}-10 & 1.81 \pm 3.22 \mathrm{E}-09 & \mathbf{3 . 7 0} \pm \mathbf{2 . 8 4 E}-10 & -1.36 \pm 4.34 \mathrm{E}-10 & 2.05 \pm 2.88 \mathrm{E}-11 \\ 405 & \text { UP(4) } & -2.18 \pm 3.82 \mathrm{E}-10 & -0.04 \pm 2.90 \mathrm{E}-09 & 3.47 \pm 1.79 \mathrm{E}-10 & 6.59 \pm 3.77 \mathrm{E}-10 & 1.35 \pm 4.21 \mathrm{E}-11 \\ & & & & & & \\ 1303 & \text { UP(1) } & 0.31 \pm 1.08 \mathrm{E}-09 & \mathbf{3 . 7 6} \pm \mathbf{2 . 8 3 E}-\mathbf{0 9} & 0.65 \pm 3.02 \mathrm{E}-10 & \mathbf{1 . 4 8} \pm \mathbf{0 . 9 0 E}-\mathbf{0 9} & \mathbf{1 . 8 3} \pm \mathbf{1 . 1 2 E}-\mathbf{- 1 0} \\ 1303 & \text { UP(2) } & 1.58 \pm 3.69 \mathrm{E}-10 & -0.93 \pm 2.83 \mathrm{E}-09 & 2.77 \pm 3.04 \mathrm{E}-10 & 4.57 \pm 3.68 \mathrm{E}-10 & 5.32 \pm 4.13 \mathrm{E}-11 \\ 1303 & \text { UP(3) } & 0.67 \pm 4.65 \mathrm{E}-10 & -0.23 \pm 1.79 \mathrm{E}-09 & 2.08 \pm 2.08 \mathrm{E}-10 & 5.74 \pm 4.70 \mathrm{E}-10 & 0.00 \pm 1.92 \mathrm{E}-10 \\ 1303 & \text { UP(4) } & 1.99 \pm 5.43 \mathrm{E}-10 & 2.06 \pm 2.95 \mathrm{E}-09 & 0.43 \pm 1.23 \mathrm{E}-10 & \mathbf{4 . 5 6} \pm \mathbf{3 . 5 3 E}-10 & -4.87 \pm 4.06 \mathrm{E}-11\end{array}$

Note: Bolding convention applied to these data. (See p. E-2 따) NS - Not sampled.

Sample collection quarter is noted in parentheses next to hydraulic position. Hydraulic position is relative to other wells within the same hydrogeologic unit. 


\section{Table E-11 (concluded) 2006 Radioactivity in Groundwater From Selected Monitoring Locations}

$\begin{array}{cccccc}\begin{array}{c}\text { Location } \\ \text { Code }\end{array} & \begin{array}{c}\text { Hydraulic } \\ \text { Position }\end{array} & \begin{array}{c}\mathbf{U}-233 / 234 \\ (\mu \mathrm{Ci} / \mathrm{mL})\end{array} & \begin{array}{c}\text { U-235/236 } \\ (\mu \mathrm{Ci} / \mathrm{mL})\end{array} & \begin{array}{c}\mathbf{U}-238 \\ (\mu \mathrm{Ci} / \mathrm{mL})\end{array} & \begin{array}{c}\text { Total U } \\ (\mu \mathrm{g} / \mathrm{mL})\end{array}\end{array}$

Sand and Gravel

\begin{tabular}{|c|c|c|c|c|c|}
\hline 401 & $\mathrm{UP}(1)$ & $1.48 \pm 0.88 \mathrm{E}-10$ & $9.38 \pm 7.22 \mathrm{E}-11$ & $8.74 \pm 7.25 \mathrm{E}-11$ & $4.55 \pm 0.20 \mathrm{E}-04$ \\
\hline 706 & $\mathrm{UP}(1)$ & $0.10 \pm 3.85 \mathrm{E}-11$ & $1.66 \pm 4.54 \mathrm{E}-11$ & $-1.50 \pm 1.32 \mathrm{E}-11$ & $1.25 \pm 0.09 \mathrm{E}-04$ \\
\hline 706 & $\mathrm{UP}(2)$ & $1.42 \pm 0.88 \mathrm{E}-10$ & $1.70 \pm 4.67 \mathrm{E}-11$ & $1.03 \pm 3.82 \mathrm{E}-11$ & $0.00 \pm 3.24 \mathrm{E}-04$ \\
\hline 706 & $\mathrm{UP}(3)$ & $8.19 \pm 6.79 \mathrm{E}-11$ & $2.75 \pm 4.22 \mathrm{E}-11$ & $4.53 \pm 4.75 \mathrm{E}-11$ & $2.48 \pm 0.17 \mathrm{E}-04$ \\
\hline 706 & $\mathrm{UP}(4)$ & $1.63 \pm 0.83 E-10$ & $8.18 \pm 5.67 E-11$ & $6.65 \pm 5.33 \mathrm{E}-11$ & $2.71 \pm 0.12 E-04$ \\
\hline 1304 & $\mathrm{UP}(1)$ & $2.05 \pm 0.96 \mathrm{E}-10$ & $8.33 \pm 6.17 E-11$ & $1.35 \pm 0.76 \mathrm{E}-10$ & $6.26 \pm 0.16 \mathrm{E}-04$ \\
\hline 1304 & $\mathrm{UP}(2)$ & $2.42 \pm 1.06 \mathrm{E}-10$ & $3.15 \pm 4.57 \mathrm{E}-11$ & $2.39 \pm 1.04 \mathrm{E}-10$ & $8.51 \pm 0.42 E-04$ \\
\hline 1304 & $\mathrm{UP}(3)$ & $2.50 \pm 1.00 \mathrm{E}-10$ & $1.05 \pm 2.05 \mathrm{E}-11$ & $2.50 \pm 1.00 \mathrm{E}-10$ & $6.35 \pm 0.17 \mathrm{E}-04$ \\
\hline 1304 & $\mathrm{UP}(4)$ & $2.15 \pm 0.91 \mathrm{E}-10$ & $2.33 \pm 3.20 \mathrm{E}-11$ & $1.50 \pm 0.75 \mathrm{E}-10$ & $5.09 \pm 0.16 E-04$ \\
\hline 1302 & $\operatorname{DOWN}(1)$ & $1.00 \pm 0.90 \mathrm{E}-10$ & $-1.12 \pm 4.09 \mathrm{E}-11$ & $2.64 \pm 5.25 \mathrm{E}-11$ & $5.43 \pm 0.17 E-04$ \\
\hline 1302 & DOWN(2) & $1.58 \pm 0.77 \mathrm{E}-10$ & $2.93 \pm 3.57 \mathrm{E}-11$ & $1.40 \pm 0.70 \mathrm{E}-10$ & $0.00 \pm 3.24 \mathrm{E}-04$ \\
\hline 1302 & DOWN(3) & $1.67 \pm 1.04 \mathrm{E}-10$ & $-1.09 \pm 3.22 \mathrm{E}-11$ & $1.59 \pm 0.99 \mathrm{E}-10$ & $4.49 \pm 0.16 \mathrm{E}-04$ \\
\hline 1302 & DOWN(4) & $1.12 \pm 0.68 \mathrm{E}-10$ & $2.52 \pm 3.12 \mathrm{E}-11$ & $1.71 \pm 0.80 \mathrm{E}-10$ & $5.35 \pm 0.15 \mathrm{E}-04$ \\
\hline 406 & DOWN(1) & $1.77 \pm 0.96 \mathrm{E}-10$ & $1.68 \pm 3.79 \mathrm{E}-11$ & $1.05 \pm 3.88 \mathrm{E}-11$ & $2.29 \pm 0.10 \mathrm{E}-04$ \\
\hline 408 & $\operatorname{DOWN}(1)$ & $2.73 \pm 1.26 \mathrm{E}-10$ & $1.49 \pm 4.21 \mathrm{E}-11$ & $2.37 \pm 1.16 \mathrm{E}-10$ & $6.78 \pm 0.17 \mathrm{E}-04$ \\
\hline \multicolumn{6}{|c|}{ Weathered Till } \\
\hline NDATR & DOWN(1) & $1.14 \pm 0.22 \mathrm{E}-09$ & $1.32 \pm 0.78 \mathrm{E}-10$ & $1.29 \pm 0.24 \mathrm{E}-09$ & $3.11 \pm 0.07 \mathrm{E}-03$ \\
\hline NDATR & DOWN(3) & $2.06 \pm 0.23 \mathrm{E}-09$ & $1.53 \pm 0.65 \mathrm{E}-10$ & $1.62 \pm 0.20 \mathrm{E}-09$ & $4.66 \pm 0.11 \mathrm{E}-03$ \\
\hline 909 & $\operatorname{DOWN}(1)$ & $5.18 \pm 1.47 \mathrm{E}-10$ & $1.84 \pm 2.95 \mathrm{E}-11$ & $5.04 \pm 1.44 \mathrm{E}-10$ & $1.22 \pm 0.04 \mathrm{E}-03$ \\
\hline
\end{tabular}

Unweathered Till

\begin{tabular}{|c|c|c|c|c|c|}
\hline 405 & $\mathrm{UP}(1)$ & $3.98 \pm 1.32 \mathrm{E}-10$ & $7.83 \pm 6.03 \mathrm{E}-11$ & $3.46 \pm 1.21 \mathrm{E}-10$ & $1.03 \pm 0.03 E-03$ \\
\hline 405 & $\mathrm{UP}(2)$ & $3.24 \pm 1.04 \mathrm{E}-10$ & $1.07 \pm 2.42 \mathrm{E}-11$ & $1.71 \pm 0.75 \mathrm{E}-10$ & $9.19 \pm 0.52 \mathrm{E}-04$ \\
\hline 405 & $\mathrm{UP}(3)$ & $1.95 \pm 1.06 \mathrm{E}-10$ & $0.38 \pm 2.85 \mathrm{E}-11$ & $1.61 \pm 1.00 \mathrm{E}-10$ & $5.49 \pm 0.19 E-04$ \\
\hline 405 & $\mathrm{UP}(4)$ & $4.25 \pm 1.37 \mathrm{E}-10$ & $9.57 \pm 7.12 \mathrm{E}-11$ & $2.04 \pm 0.92 \mathrm{E}-10$ & $9.47 \pm 0.26 \mathrm{E}-04$ \\
\hline 303 & $\mathrm{UP}(1)$ & $2.73 \pm 1.26 \mathrm{E}-10$ & $7.45 \pm 7.24 \mathrm{E}-11$ & $1.33 \pm 0.92 \mathrm{E}-10$ & $6.06 \pm 0.15 E-04$ \\
\hline 1303 & $\mathrm{UP}(2)$ & $1.98 \pm 0.92 E-10$ & $-0.45 \pm 2.30 \mathrm{E}-11$ & $1.07 \pm 0.70 \mathrm{E}-10$ & $7.63 \pm 0.53 \mathrm{E}-04$ \\
\hline 1303 & $\mathrm{UP}(3)$ & $2.83 \pm 1.10 \mathrm{E}-10$ & $8.26 \pm 6.33 \mathrm{E}-11$ & $2.41 \pm 1.05 \mathrm{E}-10$ & $6.50 \pm 0.19 \mathrm{E}-04$ \\
\hline 1303 & $\mathrm{UP}(4)$ & $2.87 \pm 1.04 \mathrm{E}-10$ & $8.15 \pm 5.66 \mathrm{E}-11$ & $1.03 \pm 0.62 \mathrm{E}-10$ & $8.85 \pm 0.22 E-04$ \\
\hline
\end{tabular}

Note: Bolding convention applied to these data. (See p. E-2 뚜)

Sample collection quarter is noted in parentheses next to hydraulic position. Hydraulic position is relative to other wells within the same hydrogeologic unit.

$E-20$ 


\section{Table E-12 \\ Practical Quantitation Limits (PQLs)}

COMPOUND

PQL

$(\mu g / L)$

6 NYCRR $^{a}$ Appendix 33 Volatiles

$\begin{array}{lc}\text { Acetone } & 10 \\ \text { Acetonitrile } & 100 \\ \text { Acrolein } & 11 \\ \text { Acrylonitrile } & 10 \\ \text { Allyl chloride } & 5 \\ \text { Benzene } & 5 \\ \text { Bromodichloromethane } & 5 \\ \text { Bromoform } & 5 \\ \text { Bromomethane } & 10 \\ \text { Carbon disulfide } & 10 \\ \text { Carbon tetrachloride } & 5 \\ \text { Chlorobenzene } & 5 \\ \text { Chloroethane } & 10 \\ \text { Chloroform } & 5 \\ \text { Chloromethane } & 10 \\ \text { Chloroprene } & 5 \\ \text { 1,2-Dibromo-3-chloropropane } & 5 \\ \text { Dibromochloromethane } & 5 \\ \text { 1,2-Dibromoethane } & 5 \\ \text { Dichlorodifluoromethane (DCDFMeth) } & 5 \\ \text { 1,1-Dichloroethane(1,1-DCA) } & 5 \\ \text { 1,2-Dichloroethane(1,2-DCA) } & 5 \\ \text { 1,1-Dichloroethylene(1,1-DCE) } & 5 \\ \text { 1,2-Dichloropropane } & 5 \\ \text { Ethyl benzene } & 5 \\ \text { Ethyl methacrylate } & 5 \\ \text { 2-Hexanone } & 10 \\ \text { (1) } & \end{array}$

6 NYCRR $^{a}$ Appendix 33 Metals

$\begin{array}{lc}\text { Aluminum }^{b} & 200 \\ \text { Antimony } & 10 \\ \text { Arsenic } & 10 \\ \text { Barium } & 200 \\ \text { Beryllium } & 1 \\ \text { Cadmium } & 5 \\ \text { Chromium } & 10 \\ \text { Cobalt } & 50\end{array}$

COMPOUND PQL

$(\mu g / L)$

6 NYCRR $^{a}$ Appendix 33 Volatiles

Isobutyl alcohol $\quad 100$

Methacrylonitrile 5

Methyl ethyl ketone $\quad 10$

Methyl iodide 5

Methyl methacrylate 5

4-Methyl-2-pentanone 10

Methylene bromide 10

Methylene chloride 5

Pentachloroethane 5

Propionitrile 50

Styrene 5

1,1,1,2-Tetrachloroethane 5

1,1,2,2-Tetrachloroethane 5

Tetrachloroethylene 5

Toluene 5

1,1,1-Trichloroethane (1,1,1-TCA) 5

1,1,2-Trichloroethane 5

1,2,3-Trichloropropane 5

Vinyl acetate 10

Vinyl chloride $\quad 10$

Xylene (total) 5

cis-1,3-Dichloropropene 5

trans-1,2-Dichloroethylene (1,2-DCE[trans]) 5

trans-1,3-Dichloropropene 5

trans-1,4-Dichloro-2-butene 5

Trichloroethylene (TCE) 5

Trichlorofluoromethane 5

6 NYCRR a Appendix 33 Metals

Lead 3

Manganese $^{b} \quad 15$

Mercury $\quad 0.2$

Nickel 40

Selenium 5

Silver 10

Thallium $\quad 10$

Tin $\quad 3,000$

Note: Specific quantitation limits are highly matrix dependent and may not always be achievable.

${ }^{a}$ Title 6 of the Official Compilation of Codes, Rules, and Regulations of the State of New York.

${ }^{b}$ Not a 6 NYCRR Appendix 33 parameter; sampled for the north plateau early warning program.

$$
E-21
$$




\section{Table E-12 (continued) Practical Quantitation Limits (PQLs) \\ PQL \\ $(\mu g / L)$ \\ COMPOUND PQL \\ $(\mu g / L)$}

COMPOUND

6 NYCRR $^{a}$ Appendix 33 Semivolatiles

Acenaphthene 10

Acenaphthylene 10

Acetophenone 10

2-Acetylaminofluorene $\quad 10$

4-Aminobiphenyl 10

Aniline 10

Anthracene 10

Aramite 20

Benzo[a]anthracene 10

Benzo[a]pyrene 10

Benzo[b]fluoranthene $\quad 10$

Benzo[ghi]perylene $\quad 10$

Benzo[k]fluoranthene 10

Benzyl alcohol 10

Bis(2-chlorethyl)ether $\quad 10$

Bis(2-chloroethoxy)methane $\quad 10$

Bis(2-chloroisopropyl)ether $\quad 10$

Bis(2-ethylhexyl)phthalate $\quad 10$

4-Bromophenyl phenyl ether $\quad 10$

Butyl benzyl phthalate $\quad 10$

Chlorobenzilate 10

2-Chloronaphthalene $\quad 10$

2-Chlorophenol 10

4-Chlorophenyl phenyl ether $\quad 10$

Chrysene 10

Di-n-butyl phthalate $\quad 10$

Di-n-octyl phthalate $\quad 10$

Diallate 10

Dibenz[a,h]anthracene 10

Dibenzofuran 10

3,3-Dichlorobenzidine 10

2,4-Dichlorophenol 10

2,6-Dichlorophenol 10

Diethyl phthalate $\quad 10$

Dimethoate 10

7, 12-Dimethylbenz[a]anthracene $\quad 10$

3,3-Dimethylbenzidine 20

2,4-Dimethylphenol 10

Dimethyl phthalate $\quad 10$

4,6-Dinitro-o-cresol 25

2,4-Dinitrophenol 25
6 NYCRR $^{a}$ Appendix 33 Semivolatiles

2,4-Dinitrotoluene 10

2,6-Dinitrotoluene 10

Diphenylamine 10

Ethyl methanesulfonate $\quad 10$

Famphur 15

Fluoranthene 10

Fluorene 10

Hexachlorobenzene 10

Hexachlorobutadiene 10

Hexachlorocyclopentadiene 24

Hexachloroethane 10

Hexachlorophene 250

Hexachloropropene 10

Indeno(1,2,3,-cd)pyrene $\quad 10$

Isodrin 10

Isophorone 10

Isosafrole 10

Kepone $\quad 50$

Methapyrilene 40

Methyl methanesulfonate $\quad 10$

3-Methylcholanthrene $\quad 10$

2-Methylnaphthalene $\quad 10$

1,4-Naphthoquinone $\quad 10$

1-Naphthylamine 10

2-Naphthylamine 10

Nitrobenzene 10

5-Nitro-o-toluidine 10

4-Nitroquinoline 1-oxide 40

N-Nitrosodi-n-butylamine $\quad 10$

N-Nitrosodiethylamine 10

N-Nitrosodimethylamine $\quad 10$

N-Nitrosodipropylamine $\quad 10$

N-Nitrosodiphenylamine $\quad 10$

N-Nitrosomethylethylamine $\quad 10$

N-Nitrosomorpholine 10

N-Nitrosopiperidine $\quad 50$

N-Nitrosopyrrolidine 10

Naphthalene 10

0,0,0-Triethyl phosphorothioate $\quad 10$

0,0-Diethyl 0-2-pyrazinyl- phosphorothioate 10

Note: Specific quantitation limits are highly matrix dependent and may not always be achievable.

${ }^{a}$ Title 6 of the Official Compilation of Codes, Rules, and Regulations of the State of New York.

$E-22$ 


\section{Table E-12 (concluded) \\ Practical Quantitation Limits (PQLs)}

COMPOUND

PQL

$(\mu g / L)$

6 NYCRR ${ }^{a}$ Appendix 33 Semivolatiles

p-(Dimethylamino)azobenzene $\quad 10$

p-Chloroaniline 10

p-Chloro-m-cresol 10

p-Cresol 10

p-Dichlorobenzene 10

p-Nitroaniline 25

p-Nitrophenol 25

p-Phenylenediamine 35

Parathion 10

Pentachlorobenzene 10

Pentachloronitrobenzene $\quad 50$

Pentachlorophenol 25

Phenacetin 10

Phenanthrene 10

Phenol 10

Pronamide 10

Pyrene 10

Safrole 10

1,2,4,5-Tetrachlorobenzene $\quad 10$

Other Organic Compounds

1,2-Dichloroethelyne (Total)

Tributyl phosphate
COMPOUND

PQL

$(\mu g / L)$

6 NYCRR ${ }^{a}$ Appendix 33 Semivolatiles

2,3,4,6-Tetrachlorophenol $\quad 10$

Tetraethyl dithiopyrophosphate $\quad 10$

1,2,4-Trichlorobenzene $\quad 10$

2,4,5-Trichlorophenol 25

2,4,6-Trichlorophenol $\quad 10$

alpha,alpha-Dimethylphenethylamine $\quad 50$

m-Cresol 10

m-Dichlorobenzene 10

m-Dinitrobenzene 10

m-Nitroaniline 25

o-Cresol 10

o-Dichlorobenzene 10

o-Nitroaniline 25

o-Nitrophenol 10

o-Toluidine 10

sym-Trinitrobenzene $\quad 10$

2-Picoline 10

Pyridine 10

1,4-Dioxane 10

Note: Specific quantitation limits are highly matrix dependent and may not always be achievable.

${ }^{a}$ Title 6 of the Official Compilation of Codes, Rules, and Regulations of the State of New York.

E - 23 
This page intentionally left blank

E- 24 


\section{Appendix $F$ Summary of Biological Data}

$$
F-1
$$


The following tables contain a bolding convention devised to help the reader, when viewing the data, to quickly see the range of detectable measurements within a data series. A data series is a set of chemical or radionuclide measurements (e.g., gross alpha, gross beta, tritium) from a single location or from similar locations. Note that some tables contain data that should not be technically evaluated under this convention.

\section{Key to bolding convention:}

Results for each constituent constitute a single data series. If a radiological result is larger than the uncertainty term, the measurement is considered positive. Otherwise, a result is considered nondetectable.

If all results in a data series are positive, the lowest and highest values are bolded.

If a data series contains some positive results, the highest value is bolded.

If all values in a data series are nondetectable, no values are bolded.

$$
F-2
$$




\section{Table F-1 \\ 2006 Radioactivity Concentrations in Milk}

\begin{tabular}{|c|c|c|c|c|}
\hline $\begin{array}{l}\text { Location } \\
\qquad(\mu \mathrm{Ci} / \mathrm{mL})\end{array}$ & $\begin{array}{c}\mathbf{K}-\mathbf{4 0} \\
(\mu \mathrm{Ci} / \mathrm{mL})\end{array}$ & $\begin{array}{c}\text { Sr-90 } \\
(\mu \mathrm{Ci} / \mathrm{mL})\end{array}$ & $\begin{array}{c}\mathbf{I - 1 2 9} \\
(\mu \mathrm{Ci} / \mathrm{mL})\end{array}$ & Cs-137 \\
\hline \multicolumn{5}{|l|}{$\begin{array}{l}\text { BFMBLSY } \\
\text { (WNW Farm) }\end{array}$} \\
\hline Annual & $1.58 \pm 0.18 \mathrm{E}-06$ & $0.36 \pm 1.04 \mathrm{E}-09$ & $0.95 \pm 1.96 \mathrm{E}-10$ & $2.88 \pm 3.32 \mathrm{E}-09$ \\
\hline \multicolumn{5}{|l|}{$\begin{array}{l}\text { BFMCTLS } \\
\text { (Control) }\end{array}$} \\
\hline Annual & $1.40 \pm 0.16 \mathrm{E}-06$ & $-3.39 \pm 7.35 \mathrm{E}-10$ & $-0.17 \pm 3.42 \mathrm{E}-10$ & $-2.08 \pm 3.20 \mathrm{E}-09$ \\
\hline \multicolumn{5}{|l|}{$\begin{array}{l}\text { BFMSCHT } \\
\text { (S Farm) }\end{array}$} \\
\hline Annual & $1.12 \pm 0.15 \mathrm{E}-06$ & $1.04 \pm 1.01 \mathrm{E}-09$ & $-0.27 \pm 2.16 \mathrm{E}-10$ & $-0.42 \pm 3.09 \mathrm{E}-09$ \\
\hline \multicolumn{5}{|l|}{$\begin{array}{l}\text { BFMWIDR } \\
\text { (SE Farm) }\end{array}$} \\
\hline 1st Quarter & $1.11 \pm 0.18 \mathrm{E}-06$ & $1.13 \pm 0.93 \mathrm{E}-09$ & $-2.49 \pm 4.32 \mathrm{E}-10$ & $9.99 \pm 5.97 \mathrm{E}-09$ \\
\hline 2nd Quarter & $1.20 \pm 0.10 \mathrm{E}-06$ & $1.03 \pm 6.42 \mathrm{E}-10$ & $3.03 \pm 3.26 \mathrm{E}-10$ & $1.05 \pm 2.27 \mathrm{E}-09$ \\
\hline 3rd Quarter & $1.47 \pm 0.14 \mathrm{E}-06$ & $1.72 \pm 0.78 E-09$ & $-1.25 \pm 4.21 \mathrm{E}-10$ & $2.62 \pm 3.18 \mathrm{E}-09$ \\
\hline 4th Quarter & $1.30 \pm 0.14 \mathrm{E}-06$ & $-4.84 \pm 9.04 \mathrm{E}-10$ & $0.19 \pm 1.56 \mathrm{E}-10$ & $3.64 \pm 3.96 \mathrm{E}-09$ \\
\hline
\end{tabular}

Note: Bolding convention applied to these data. See page F-2 6 .

$$
F-3
$$


Table F-2

2006 Radioactivity Concentrations in Venison

Location

$\%$ Moisture

$\mathbf{H}-\mathbf{3}$
$(\mu \mathrm{Ci} / \mathrm{mL})$

$\mathbf{K}-\mathbf{4 0}$
$(\mu \mathrm{Ci} / \mathrm{g}-\mathrm{dry})$

Sr-90

Cs-137

$(\mu \mathrm{Ci} / \mathrm{mL}) \quad(\mu \mathrm{Ci} / \mathrm{g}-$ dry $) \quad(\mu \mathrm{Ci} / \mathrm{g}-$ dry $) \quad(\mu \mathrm{Ci} / \mathrm{g}-$ dry $)$

Deer Background

(BFDCTRL 11/06)

74.3

$0.71 \pm 1.07 \mathrm{E}-07$

1.04 $\pm 0.08 E-05$

5.89+3.09E-09

7.37+3.65E-08

Deer Background

(BFDCTRL 11/06)

75.0

$5.55 \pm 9.62 \mathrm{E}-08$

$1.16 \pm 0.07 \mathrm{E}-05$

$4.38 \pm 3.13 \mathrm{E}-09$

$0.00 \pm 3.76 \mathrm{E}-08$

Deer Background

(BFDCTRL 11/06)

72.1

$9.03 \pm 9.64 \mathrm{E}-08$

1.28 $\pm 0.11 E-05$

$0.25 \pm 2.20 \mathrm{E}-09$

$3.35 \pm 2.11 \mathrm{E}-08$

Deer Near-Site

(BFDNEAR 10/06)

70.4

2.37+0.71E-07

$1.08 \pm 0.06 \mathrm{E}-05$

$1.69 \pm 2.76 \mathrm{E}-09$

2.42 $\pm 0.13 E-06$

Deer Near-Site

(BFDNEAR 11/06)

72.8

$6.95 \pm 9.41 \mathrm{E}-08$

1.11 $+0.06 \mathrm{E}-05$

$-1.19 \pm 2.16 \mathrm{E}-09$

3.71 $\pm 1.85 E-08$

Deer Near-Site

(BFDNEAR 12/06)

72.4

$1.47 \pm 0.98 \mathrm{E}-07$

1.01 $\pm 0.05 E-05$

$0.24 \pm 2.20 \mathrm{E}-09$

5.74 $\pm 0.32 \mathrm{E}-07$

Note: Bolding convention applied to these data. See page F-2

$$
F-4
$$




\section{Table F-3 \\ 2006 Radioactivity Concentrations in Food Crops}

\begin{tabular}{|c|c|c|c|c|c|c|}
\hline on & \% Moisture & $\begin{array}{c}\mathbf{H}-\mathbf{3} \\
(\mu \mathrm{Ci} / \mathrm{mL})\end{array}$ & $\begin{array}{c}\mathbf{K}-\mathbf{4 0} \\
(\mu \mathrm{Ci} / \mathrm{g}-\text { dry })\end{array}$ & $\begin{array}{c}\text { Co-60 } \\
(\mu \mathrm{Ci} / \mathrm{g}-\mathrm{dry})\end{array}$ & $\begin{array}{c}\text { Sr-90 } \\
(\mu \mathrm{Ci} / \mathrm{g}-\mathrm{dry})\end{array}$ & $\begin{array}{c}\text { Cs-137 } \\
(\mu \mathrm{Ci} / \mathrm{g}-\mathrm{dry})\end{array}$ \\
\hline
\end{tabular}

APPLES

Background

(BFVCTRA)

$86.6 \quad 0.93 \pm 1.13 \mathrm{E}-07 \quad 7.15 \pm 0.69 \mathrm{E}-06$

$1.33 \pm 2.78 \mathrm{E}-08$

$0.51 \pm 2.26 \mathrm{E}-09 \quad-1.04 \pm 2.72 \mathrm{E}-08$

Near-Site

(BFVNEAAF)

$83.9 \quad 1.35 \pm 1.15 \mathrm{E}-07 \quad 9.94 \pm 0.53 \mathrm{E}-06$

$0.01 \pm 1.28 \mathrm{E}-08$

$5.14 \pm 2.40 \mathrm{E}-09$

$0.83 \pm 1.14 \mathrm{E}-08$

BEANS

Background

(BFVCTRB)

$84.0-0.64 \pm 1.10 \mathrm{E}-07$

$2.94 \pm 0.13 \mathrm{E}-05$

$0.30 \pm 2.78 \mathrm{E}-08$

$9.20 \pm 3.12 \mathrm{E}-09$

$0.70 \pm 2.35 \mathrm{E}-08$

Near-Site

(BFVNEAB)

92.9

$0.42 \pm 1.14 \mathrm{E}-07 \quad 3.22 \pm 0.14 \mathrm{E}-05$

$-1.56 \pm 3.25 \mathrm{E}-08$

$2.25 \pm 0.39 \mathrm{E}-08$

$2.07 \pm 2.63 \mathrm{E}-08$

\section{CORN}

\section{Background}

(BFVCTRC)

$0.28 \pm 1.12 \mathrm{E}-07 \quad 1.22 \pm 0.08 \mathrm{E}-05$

$-0.64 \pm 1.95 \mathrm{E}-08$

$-0.64 \pm 1.93 \mathrm{E}-09$

$1.80 \pm 1.84 \mathrm{E}-08$

Near-Site

(BFVNEAC)

$81.3 \quad 0.54 \pm 1.12 \mathrm{E}-07 \quad 1.53 \pm 0.09 \mathrm{E}-05$

$-0.07 \pm 2.99 \mathrm{E}-08$

$1.53 \pm 1.84 \mathrm{E}-09$

$4.18 \pm 3.89 \mathrm{E}-08$

Note: Bolding convention not applicable to these data.

$F-5$ 
Table F-4

\section{Radioactivity Concentrations in Edible Portions of Fish From Cattaraugus Creek}

\section{Cattaraugus Creek above the Springville Dam (BFFCATC)}

\begin{tabular}{|c|c|c|c|}
\hline \multirow[b]{2}{*}{ Species } & \multicolumn{3}{|c|}{ Annual 2006} \\
\hline & $\%$ Moisture & $\begin{array}{c}\text { Sr-90 } \\
(\mu \mathrm{Ci} / g-d r y)\end{array}$ & $\begin{array}{c}\text { Cs-137 } \\
(\mu \mathrm{Ci} / \mathrm{g}-\mathrm{dry})\end{array}$ \\
\hline Hog-nosed Sucker & 76.3 & NR & $-0.96 \pm 2.10 \mathrm{E}-08$ \\
\hline Hog-nosed Sucker & 79.3 & NR & $0.39 \pm 1.72 \mathrm{E}-08$ \\
\hline Hog-nosed Sucker & 79.4 & NR & $-0.33 \pm 2.13 \mathrm{E}-08$ \\
\hline Hog-nosed Sucker & 79.8 & NR & $-0.70 \pm 1.62 \mathrm{E}-08$ \\
\hline Hog-nosed Sucker & 79.1 & NR & $-0.85 \pm 2.18 \mathrm{E}-08$ \\
\hline Hog-nosed Sucker & 80.3 & NR & $0.86 \pm 1.56 \mathrm{E}-08$ \\
\hline Hog-nosed Sucker & 79.5 & NR & $-0.20 \pm 1.87 \mathrm{E}-08$ \\
\hline Hog-nosed Sucker & 81.4 & NR & $2.51 \pm 2.51 \mathrm{E}-08$ \\
\hline Hog-nosed Sucker & 79.6 & NR & $0.51 \pm 1.84 \mathrm{E}-08$ \\
\hline Hog-nosed Sucker & 79.5 & NR & $0.00 \pm 2.74 \mathrm{E}-08$ \\
\hline Average \% Moisture & 79.4 & & \\
\hline Median & & NA & $<1.98 \mathrm{E}-08$ \\
\hline Maximum & & NA & $<2.74 \mathrm{E}-08$ \\
\hline Minimum & & NA & $<1.56 \mathrm{E}-08$ \\
\hline
\end{tabular}

$$
F-6
$$




\title{
Table F-4 (continued) \\ 2006 Radioactivity Concentrations in Edible Portions of Fish From Cattaraugus Creek
}

\author{
Cattaraugus Creek below the Springville Dam (BFFCATD)
}

\begin{tabular}{|c|c|c|c|}
\hline \multirow[b]{2}{*}{ Species } & \multicolumn{3}{|c|}{$\underline{\text { Annual } 2006}$} \\
\hline & $\%$ Moisture & $\begin{array}{c}\text { Sr-90 } \\
(\mu \mathrm{Ci} / g-d r y)\end{array}$ & $\begin{array}{c}\text { Cs-137 } \\
(\mu \mathrm{Ci} / g \text { - dry })\end{array}$ \\
\hline Steelhead Trout & 74.4 & $-0.29 \pm 1.00 \mathrm{E}-09$ & $3.02 \pm 2.24 \mathrm{E}-08$ \\
\hline Steelhead Trout & 74.8 & $7.77 \pm 2.21 \mathrm{E}-09$ & $2.13 \pm 4.24 \mathrm{E}-08$ \\
\hline Steelhead Trout & 76.8 & NR & $0.74 \pm 1.66 \mathrm{E}-08$ \\
\hline Steelhead Trout & 75.3 & $-0.22 \pm 1.82 \mathrm{E}-09$ & $0.75 \pm 1.62 \mathrm{E}-08$ \\
\hline Steelhead Trout & 75.0 & $0.59 \pm 2.45 \mathrm{E}-09$ & $-0.58 \pm 1.94 \mathrm{E}-08$ \\
\hline Steelhead Trout & 76.2 & $2.10 \pm 2.37 \mathrm{E}-09$ & $-0.42 \pm 1.33 \mathrm{E}-08$ \\
\hline Steelhead Trout & 70.3 & $1.42 \pm 1.19 \mathrm{E}-09$ & $0.97 \pm 1.23 \mathrm{E}-08$ \\
\hline Steelhead Trout & 77.9 & $1.22 \pm 2.49 \mathrm{E}-09$ & $0.60 \pm 1.34 \mathrm{E}-08$ \\
\hline Steelhead Trout & 78.4 & NR & $0.00 \pm 2.35 \mathrm{E}-08$ \\
\hline Steelhead Trout & 70.2 & $-1.45 \pm 1.03 \mathrm{E}-09$ & $1.00 \pm 1.64 \mathrm{E}-08$ \\
\hline Average $\%$ Moisture & 74.9 & & \\
\hline Median & & $<2.10 \mathrm{E}-09$ & $<1.65 \mathrm{E}-08$ \\
\hline Maximum & & 7.77E-09 & $3.02 \mathrm{E}-08$ \\
\hline Minimum & & $<1.00 \mathrm{E}-09$ & $<1.23 \mathrm{E}-08$ \\
\hline
\end{tabular}

$$
F-7
$$




\section{Table F-4 (concluded) \\ 2006 Radioactivity Concentrations in Edible Portions of Fish From \\ Cattaraugus Creek}

\section{Cattaraugus Creek Background (BFFCTRL)}

\begin{tabular}{|c|c|c|c|}
\hline \multirow[b]{2}{*}{ Species } & \multicolumn{3}{|c|}{ Annual 2006} \\
\hline & $\%$ Moisture & $\begin{array}{c}\text { Sr-90 } \\
(\mu \mathrm{Ci} / \mathrm{g}-\mathrm{dry})\end{array}$ & $\begin{array}{c}\text { Cs-137 } \\
(\mu \mathrm{Ci} / \mathrm{g}-\mathrm{dry})\end{array}$ \\
\hline Brown Trout & 78.0 & NR & $1.28 \pm 1.84 \mathrm{E}-08$ \\
\hline White Sucker & 79.2 & NR & $0.14 \pm 1.67 \mathrm{E}-08$ \\
\hline Hog-nosed Sucker & 78.7 & NR & $0.31 \pm 1.28 \mathrm{E}-08$ \\
\hline Hog-nosed Sucker & 79.2 & NR & $1.35 \pm 2.20 \mathrm{E}-08$ \\
\hline Hog-nosed Sucker & 77.9 & $1.54 \pm 2.84 \mathrm{E}-09$ & $-4.91 \pm 9.84 \mathrm{E}-09$ \\
\hline Brown Trout & 80.6 & NR & $2.50 \pm 1.86 \mathrm{E}-08$ \\
\hline Brown Trout & 80.1 & NR & $1.18 \pm 4.86 \mathrm{E}-08$ \\
\hline White Sucker & 81.4 & NR & $0.25 \pm 1.49 \mathrm{E}-08$ \\
\hline White Sucker & 80.8 & NR & $1.28 \pm 1.71 \mathrm{E}-08$ \\
\hline Hog-nosed Sucker & 79.5 & NR & $2.28 \pm 2.77 \mathrm{E}-08$ \\
\hline Average $\%$ Moisture & 79.5 & & \\
\hline Median & & NA & $<1.78 \mathrm{E}-08$ \\
\hline Maximum & & NA & $2.50 \mathrm{E}-08$ \\
\hline Minimum & & NA & $<9.84 \mathrm{E}-09$ \\
\hline
\end{tabular}

$$
F-8
$$




\section{Appendix G-1 \\ Summary of Soil and Aquatic Sediment \\ Guidelines and Standards}

$G-1$ 
This page intentionally left blank

$G-2$ 


\section{Table G-1A}

Soils Cleanup Objectives and Cleanup Levels ${ }^{a}$

\begin{tabular}{|c|c|c|c|}
\hline Analyte & Units & $\begin{array}{l}\text { TAGM \#4046 Eastern U.S. } \\
\text { Background Concentrations for Soil }^{a}\end{array}$ & $\begin{array}{c}6 \text { NYCRR Subpart 375-6.8(a) } \\
\text { Remedial Soil Cleanup Objectives }\end{array}$ \\
\hline Aluminum & $\mathrm{mg} / \mathrm{kg}(\mathrm{ppm})$ & 33,000 & -- \\
\hline Antimony & $\mathrm{mg} / \mathrm{kg}(\mathrm{ppm})$ & -- & -- \\
\hline Arsenic & $\mathrm{mg} / \mathrm{kg}(\mathrm{ppm})$ & $3-12^{c}$ & 13 \\
\hline Barium & $\mathrm{mg} / \mathrm{kg}(\mathrm{ppm})$ & $15-600$ & 350 \\
\hline Beryllium & $\mathrm{mg} / \mathrm{kg}(\mathrm{ppm})$ & $0-1.75$ & 7.2 \\
\hline Cadmium & $\mathrm{mg} / \mathrm{kg}(\mathrm{ppm})$ & $0.1-1$ & 2.5 \\
\hline Calcium & $\mathrm{mg} / \mathrm{kg}(\mathrm{ppm})$ & $130-35,000$ & -- \\
\hline Chromium & $\mathrm{mg} / \mathrm{kg}(\mathrm{ppm})$ & $1.5-40^{c}$ & 30 \\
\hline Cobalt & $\mathrm{mg} / \mathrm{kg}(\mathrm{ppm})$ & $2.5-60^{c}$ & - \\
\hline Copper & $\mathrm{mg} / \mathrm{kg}(\mathrm{ppm})$ & $1-50$ & 50 \\
\hline Iron & $\mathrm{mg} / \mathrm{kg}(\mathrm{ppm})$ & $2,000-550,000$ & -- \\
\hline Lead & $\mathrm{mg} / \mathrm{kg}(\mathrm{ppm})$ & $4-61^{d}$ & 63 \\
\hline Magnesium & $\mathrm{mg} / \mathrm{kg}(\mathrm{ppm})$ & $100-5,000$ & -- \\
\hline Manganese & $\mathrm{mg} / \mathrm{kg}(\mathrm{ppm})$ & $50-5,000$ & 1,600 \\
\hline Mercury & $\mathrm{mg} / \mathrm{kg}(\mathrm{ppm})$ & $0.001-0.2$ & 0.18 \\
\hline Nickel & $\mathrm{mg} / \mathrm{kg}(\mathrm{ppm})$ & $0.5-25$ & 30 \\
\hline Potassium & mg/kg (ppm) & $8,500-43,000^{c}$ & -- \\
\hline Selenium & $\mathrm{mg} / \mathrm{kg}(\mathrm{ppm})$ & $0.1-3.9$ & 3.9 \\
\hline Silver & $\mathrm{mg} / \mathrm{kg}(\mathrm{ppm})$ & -- & 2 \\
\hline Sodium & $\mathrm{mg} / \mathrm{kg}(\mathrm{ppm})$ & $6,000-8,000$ & - \\
\hline Thallium & mg/kg (ppm) & -- & -- \\
\hline Vanadium & $\mathrm{mg} / \mathrm{kg}(\mathrm{ppm})$ & $1-300$ & -- \\
\hline Zinc & $\mathrm{mg} / \mathrm{kg}(\mathrm{ppm})$ & $9-50$ & 109 \\
\hline
\end{tabular}

-- No reference level available for these analytes

a Source: New York State Department of Environmental Conservation "Technical and Administrative Guidance Memorandum (TAGM) \#4046"

${ }^{b}$ Source: 6 NYCRR Subpart 375-6.8(a) Remedial Soil Cleanup Objectives: Unrestricted Use Soil Cleanup Objectives

${ }^{c}$ New York State background

${ }^{d}$ Background levels for lead vary widely. Average levels in undeveloped, rural areas may range from 4-61 ppm. Average background levels in metropolitan or suburban areas or near highways are much higher and typically range from 200-500 ppm. 
Table G-1B

Screening Concentrations for Contaminated Sediment ${ }^{a}$

\begin{tabular}{|c|c|c|c|}
\hline Analyte & Units & Lowest Effect Level $^{b}$ & Severe Effect Level $^{c}$ \\
\hline Aluminum & $\mathrm{mg} / \mathrm{kg}(\mathrm{ppm})$ & -- & -- \\
\hline Antimony & $\mathrm{mg} / \mathrm{kg}(\mathrm{ppm})$ & $2.0(\mathrm{~L})$ & $25.0(\mathrm{~L})$ \\
\hline Arsenic & $\mathrm{mg} / \mathrm{kg}(\mathrm{ppm})$ & $6.0(\mathrm{P})$ & $33.0(\mathrm{P})$ \\
\hline Barium & $\mathrm{mg} / \mathrm{kg}(\mathrm{ppm})$ & -- & -- \\
\hline Beryllium & $\mathrm{mg} / \mathrm{kg}(\mathrm{ppm})$ & -- & -- \\
\hline Cadmium & $\mathrm{mg} / \mathrm{kg}(\mathrm{ppm})$ & $0.6(\mathrm{P})$ & $9.0(\mathrm{~L})$ \\
\hline Calcium & $\mathrm{mg} / \mathrm{kg}(\mathrm{ppm})$ & -- & -- \\
\hline Chromium & $\mathrm{mg} / \mathrm{kg}(\mathrm{ppm})$ & $26.0(\mathrm{P})$ & $110.0(\mathrm{P})$ \\
\hline Cobalt & $\mathrm{mg} / \mathrm{kg}(\mathrm{ppm})$ & -- & -- \\
\hline Copper & $\mathrm{mg} / \mathrm{kg}(\mathrm{ppm})$ & $16.0(\mathrm{P})$ & $110.0(\mathrm{P})$ \\
\hline Iron & $\%$ & $2.0(\mathrm{P})$ & $4.0(\mathrm{P})$ \\
\hline Lead & $\mathrm{mg} / \mathrm{kg}(\mathrm{ppm})$ & $31.0(\mathrm{P})$ & $110.0(\mathrm{~L})$ \\
\hline Magnesium & $\mathrm{mg} / \mathrm{kg}(\mathrm{ppm})$ & -- & -- \\
\hline Manganese & $\mathrm{mg} / \mathrm{kg}(\mathrm{ppm})$ & $460.0(\mathrm{P})$ & $1,100.0(\mathrm{~L})$ \\
\hline Mercury & $\mathrm{mg} / \mathrm{kg}(\mathrm{ppm})$ & $0.15(\mathrm{~L})$ & $1.3(\mathrm{~L})$ \\
\hline Nickel & $\mathrm{mg} / \mathrm{kg}(\mathrm{ppm})$ & $16.0(\mathrm{P})$ & $50.0(\mathrm{~L})$ \\
\hline Potassium & $\mathrm{mg} / \mathrm{kg}(\mathrm{ppm})$ & -- & -- \\
\hline Selenium & $\mathrm{mg} / \mathrm{kg}(\mathrm{ppm})$ & -- & -- \\
\hline Silver & $\mathrm{mg} / \mathrm{kg}(\mathrm{ppm})$ & $1.0(\mathrm{~L})$ & $2.2(\mathrm{~L})$ \\
\hline Sodium & $\mathrm{mg} / \mathrm{kg}(\mathrm{ppm})$ & -- & -- \\
\hline Thallium & $\mathrm{mg} / \mathrm{kg}(\mathrm{ppm})$ & -- & -- \\
\hline Vanadium & $\mathrm{mg} / \mathrm{kg}(\mathrm{ppm})$ & -- & -- \\
\hline Zinc & $\mathrm{mg} / \mathrm{kg}(\mathrm{ppm})$ & $120.0(\mathrm{P} / \mathrm{L})$ & $270.0(\mathrm{~L})$ \\
\hline
\end{tabular}

$L-A n$ " $L$ " following a criterion indicates that it was taken from Long and Morgan (1990).

$P$ - A "P" following a criterion indicates that it was taken from Persaud et al. (1992).

-- No reference value available for these analytes

${ }^{a}$ Source: New York State Department of Environmental Conservation "Technical Guidance for Screening Contaminated Sediments," January 1999

${ }^{b}$ The Lowest Effect Level for each metal is the lowest of the either the Persaud et al. (1992) Lowest Effect Level or the Long and Morgan (1990) Effect Range-Low

${ }^{c}$ The Severe Effect Level for each metal is the lowest of either the Persaud et al. (1992) Severe Effect Level or the

Long and Morgan (1990) Effect Range-Moderate 
Table G-1C

Screening Thresholds for In-Water and Riparian Management of Sediment and Dredge Material ${ }^{a}$

\begin{tabular}{|l|c|c|}
\hline \multicolumn{1}{|c|}{ Analyte } & Units & No Appreciable Contamination Level \\
\hline Arsenic & $\mathrm{mg} / \mathrm{kg}(\mathrm{ppm})$ & $<14$ \\
\hline Cadmium & $\mathrm{mg} / \mathrm{kg}(\mathrm{ppm})$ & $<1.2$ \\
\hline Copper & $\mathrm{mg} / \mathrm{kg}(\mathrm{ppm})$ & $<33$ \\
\hline Lead & $\mathrm{mg} / \mathrm{kg}(\mathrm{ppm})$ & $<33$ \\
\hline Mercury & $\mathrm{mg} / \mathrm{kg}(\mathrm{ppm})$ & $<0.17$ \\
\hline
\end{tabular}

${ }^{a}$ Source: Draft New York State Department of Environmental Conservation Technical and Operational Guidance Series (TOGS) \#5.1.9, "In-Water and Riparian Management of Sediment and Dredge Material"

Table G-1D

Radionuclide Comparison Values for Soils

\begin{tabular}{|c|c|c|c|c|}
\hline \multirow{2}{*}{ Radionuclide } & \multirow{2}{*}{ Units } & \multicolumn{2}{|c|}{ Consultation Triggers for Soil Contamination ${ }^{a}$} & \multirow{2}{*}{$\begin{array}{c}\text { NUREG-1757 Screening Values } \\
\text { of Common Radionuclides for } \\
\text { Soil Surface Contamination } \\
\text { Levels }^{b}\end{array}$} \\
\hline & & $\begin{array}{l}\text { Residential Soil } \\
\text { Concentration }\end{array}$ & $\begin{array}{c}\text { Industrial/Commercial } \\
\text { Concentration }\end{array}$ & \\
\hline Co-60 & $\mu \mathrm{Ci} / \mathrm{g}$ & $4 \mathrm{E}-06$ & $6 \mathrm{E}-06$ & $3.8 \mathrm{E}-06$ \\
\hline Sr-90 & $\mu \mathrm{Ci} / \mathrm{g}$ & -- & -- & $1.7 \mathrm{E}-06$ \\
\hline Sr-90+D ${ }^{c}$ & $\mu \mathrm{Ci} / \mathrm{g}$ & 2.3E-05 & 1.07E-03 & -- \\
\hline Cs-137 & $\mu \mathrm{Ci} / \mathrm{g}$ & -- & -- & $1.1 \mathrm{E}-05$ \\
\hline Cs-137+D $\mathbf{D}^{c}$ & $\mu \mathrm{Ci} / \mathrm{g}$ & $6 \mathrm{E}-06$ & $1.1 \mathrm{E}-05$ & -- \\
\hline U-234 & $\mu \mathrm{Ci} / \mathrm{g}$ & 4.01E-04 & 3.31E-03 & $1.3 \mathrm{E}-05$ \\
\hline U-235 & $\mu \mathrm{Ci} / \mathrm{g}$ & -- & -- & $8 \mathrm{E}-06$ \\
\hline $\mathbf{U}-\mathbf{2 3 5}+\mathbf{D}^{c}$ & $\mu \mathrm{Ci} / \mathrm{g}$ & $2.0 \mathrm{E}-05$ & $3.9 \mathrm{E}-05$ & 2.9E-07 \\
\hline U-238 & $\mu \mathrm{Ci} / \mathrm{g}$ & -- & -- & $1.4 \mathrm{E}-05$ \\
\hline $\mathbf{U}-238+\mathbf{D}^{c}$ & $\mu \mathrm{Ci} / \mathrm{g}$ & 7.4E-05 & 1.79E-04 & $5 \mathrm{E}-07$ \\
\hline Total U & $\mu \mathrm{g} / \mathrm{g}$ & $4.7 \mathrm{E}+01$ & $1.23 \mathrm{E}+03$ & -- \\
\hline Pu-238 & $\mu \mathrm{Ci} / \mathrm{g}$ & 2.97E-04 & 1.64E-03 & $2.5 \mathrm{E}-06$ \\
\hline Pu-239 & $\mu \mathrm{Ci} / \mathrm{g}$ & $2.59 \mathrm{E}-04$ & $1.43 \mathrm{E}-03$ & 2.3E-06 \\
\hline Am-241 & $\mu \mathrm{Ci} / \mathrm{g}$ & 1.87E-04 & $5.68 \mathrm{E}-04$ & $2.1 \mathrm{E}-06$ \\
\hline
\end{tabular}

-- No reference trigger available

${ }^{a}$ Memorandum of Understanding between the Environmental Protection Agency and the Nuclear Regulatory Commission "Consultation and Finality on Decommissioning and Decontamination of Contaminated Sites," September 2002.

${ }^{b}$ U.S. Nuclear Regulatory Commission. Consolidated Decommissioning Guidance: Characterization, Survey, and Determination of Radiological Criteria. NUREG-1757, Vol. 2, Rev. 1. September 2006.

${ }^{c}$ Concentrations apply to the parent radionuclide but assume that the daughter products are present in equilibrium.

$G-5$ 
This page intentionally left blank

$G-6$ 


\section{Appendix G-2}

Soil and Sediment Data

$G-7$ 
This page intentionally left blank

$G-8$ 
Table G-2A

2006 Contaminants in On-Site Soils Downstream of the WVDP at
Frank's Creek (SNSP006)

RADIOACTIVE CONSTITUENTS

\begin{tabular}{|c|c|c|c|c|c|c|}
\hline \multirow{2}{*}{ Isotope } & \multirow{2}{*}{ Units } & \multirow{2}{*}{$\mathbf{N}$} & \multirow{2}{*}{ SNSP006 } & \multicolumn{2}{|c|}{$\begin{array}{l}\text { Consultation Triggers }{ }^{a} \\
\text { For Soil Contamination }\end{array}$} & \multirow{2}{*}{$\begin{array}{c}\text { NUREG-1757 } \\
\text { Soil Screening } \\
\text { Contamination } \\
\text { Levels }^{b}\end{array}$} \\
\hline & & & & Residential & $\begin{array}{c}\text { Industrial } \\
\text { Commercial }\end{array}$ & \\
\hline Gross Alpha & $\mu \mathrm{Ci} / \mathrm{g}$ & 1 & $9.42 \pm 2.24 \mathrm{E}-06$ & -- & -- & -- \\
\hline Gross Beta & $\mu \mathrm{Ci} / \mathrm{g}$ & 1 & $4.97 \pm 0.36 \mathrm{E}-05$ & -- & -- & -- \\
\hline K-40 & $\mu \mathrm{Ci} / \mathrm{g}$ & 1 & $1.86 \pm 0.15 \mathrm{E}-05$ & -- & -- & -- \\
\hline Co-60 & $\mu \mathrm{Ci} / \mathrm{g}$ & 1 & $0.38 \pm 2.57 \mathrm{E}-08$ & 4E-06 & $6 \mathrm{E}-06$ & $3.8 \mathrm{E}-06$ \\
\hline Sr-90 & $\mu \mathrm{Ci} / \mathrm{g}$ & 1 & $1.01 \pm 0.09 \mathrm{E}-06$ & $2.3 \mathrm{E}-05^{c}$ & $1.07 \mathrm{E}-03^{c}$ & $1.7 \mathrm{E}-06$ \\
\hline Cs-137 & $\mu \mathrm{Ci} / \mathrm{g}$ & 1 & $2.33 \pm 0.14 \mathrm{E}-05$ & $6 \mathrm{E}-06^{c}$ & $1.1 \mathrm{E}-05^{c}$ & $1.1 \mathrm{E}-05$ \\
\hline U-232 & $\mu \mathrm{Ci} / \mathrm{g}$ & 1 & $5.72 \pm 5.24 \mathrm{E}-08$ & -- & -- & -- \\
\hline U-233/234 & $\mu \mathrm{Ci} / \mathrm{g}$ & 1 & $7.66 \pm 1.52 \mathrm{E}-07$ & 4.01E-04 & $3.31 \mathrm{E}-03$ & $1.3 \mathrm{E}-05$ \\
\hline U-235/236 & $\mu \mathrm{Ci} / \mathrm{g}$ & 1 & $3.80 \pm 3.69 \mathrm{E}-08$ & $2.0 \mathrm{E}-05^{c}$ & $3.9 \mathrm{E}-05^{c}$ & $8.0 \mathrm{E}-06^{d}$ \\
\hline U-238 & $\mu \mathrm{Ci} / \mathrm{g}$ & 1 & $8.03 \pm 1.55 \mathrm{E}-07$ & $7.4 \mathrm{E}-05^{c}$ & $1.79 \mathrm{E}-04^{c}$ & $1.4 \mathrm{E}-05^{d}$ \\
\hline Total U & $\mu \mathrm{g} / \mathrm{g}$ & 1 & $1.89 \pm 0.17 \mathrm{E}+00$ & $4.7 \mathrm{E}+01$ & $1.23 \mathrm{E}+03$ & -- \\
\hline Pu-238 & $\mu \mathrm{Ci} / \mathrm{g}$ & 1 & $2.68 \pm 2.57 \mathrm{E}-08$ & $2.97 \mathrm{E}-04$ & $1.64 \mathrm{E}-03$ & $2.5 \mathrm{E}-06$ \\
\hline $\mathrm{Pu}-239 / 240$ & $\mu \mathrm{Ci} / \mathrm{g}$ & 1 & $3.82 \pm 3.14 \mathrm{E}-08$ & $2.59 \mathrm{E}-04$ & $1.43 \mathrm{E}-03$ & 2.3E-06 \\
\hline Am-241 & $\mu \mathrm{Ci} / \mathrm{g}$ & 1 & $4.82 \pm 3.24 \mathrm{E}-08$ & $1.87 \mathrm{E}-04$ & $5.68 \mathrm{E}-04$ & 2.1E-06 \\
\hline
\end{tabular}

$N$ - Number of samples

-- No reference trigger available

${ }^{a}$ Memorandum of Understanding between the EPA and the NRC "Consultation and Finality on Decommissioning and Decontamination of Contaminated Sites."

${ }^{b}$ U.S. Nuclear Regulatory Commission. "Consolidated Decommissioning Guidance: Characterization, Survey, and Determination of Radiological Criteria.” NUREG-1757, Vol. 2, Rev. 1. September 2006.

${ }^{c}$ Concentrations apply to the parent radionuclide but assume that the daughter products are present in equilibrium.

${ }^{d}$ WVDP-related uranium isotopes are not assumed to be in equilibrium with daughter products because of their relatively recent origin as processed nuclear materials. Therefore, the single-nuclide screening levels for $U-235$ and $U-238$ were selected for comparison with radionuclide concentrations in on-site soils. 


\section{Table G-2A (concluded)}

\section{Contaminants in On-Site Soils Downstream of the WVDP at Frank's Creek (SNSP006)}

\section{METALS}

\begin{tabular}{|c|c|c|c|c|c|c|}
\hline \multirow[b]{2}{*}{ Analyte } & \multirow[b]{2}{*}{ Units } & \multirow[b]{2}{*}{$\mathbf{N}$} & \multirow[b]{2}{*}{ SNSP006 } & \multicolumn{3}{|c|}{ Guidance Values } \\
\hline & & & & $\begin{array}{c}\text { Lowest Effect } \\
\text { Level }^{a}\end{array}$ & $\begin{array}{c}\text { Severe Effect } \\
\text { Level }^{a}\end{array}$ & $\begin{array}{c}\text { No Appreciable } \\
\text { Contamination } \\
\text { Level }^{b} \\
\end{array}$ \\
\hline Aluminum & $\mathrm{mg} / \mathrm{kg}(\mathrm{ppm})$ & 1 & 7,370 & -- & -- & -- \\
\hline Antimony & $\mathrm{mg} / \mathrm{kg}(\mathrm{ppm})$ & 1 & $<0.66$ & 2.0 & 25.0 & -- \\
\hline Arsenic & $\mathrm{mg} / \mathrm{kg}(\mathrm{ppm})$ & 1 & 7.6 & 6.0 & 33.0 & 14 \\
\hline Barium & $\mathrm{mg} / \mathrm{kg}(\mathrm{ppm})$ & 1 & 90.6 & -- & -- & -- \\
\hline Beryllium & $\mathrm{mg} / \mathrm{kg}(\mathrm{ppm})$ & 1 & 0.41 & -- & -- & -- \\
\hline Cadmium & $\mathrm{mg} / \mathrm{kg}(\mathrm{ppm})$ & 1 & 0.26 & 0.6 & 9.0 & $<1.2$ \\
\hline Calcium & $\mathrm{mg} / \mathrm{kg}(\mathrm{ppm})$ & 1 & 21,950 & -- & -- & -- \\
\hline Chromium & $\mathrm{mg} / \mathrm{kg}(\mathrm{ppm})$ & 1 & 11 & 26.0 & 110.0 & -- \\
\hline Cobalt & $\mathrm{mg} / \mathrm{kg}(\mathrm{ppm})$ & 1 & 9.4 & -- & -- & -- \\
\hline Copper & $\mathrm{mg} / \mathrm{kg}(\mathrm{ppm})$ & 1 & 20.4 & 16.0 & 110.0 & $<33$ \\
\hline Iron & $\%$ & 1 & 1.9 & 2.0 & 4.0 & -- \\
\hline Lead & $\mathrm{mg} / \mathrm{kg}(\mathrm{ppm})$ & 1 & 12.6 & 31.0 & 110.0 & $<33$ \\
\hline Magnesium & $\mathrm{mg} / \mathrm{kg}(\mathrm{ppm})$ & 1 & 6,685 & -- & -- & -- \\
\hline Manganese & $\mathrm{mg} / \mathrm{kg}(\mathrm{ppm})$ & 1 & 1,114 & 460.0 & $1,100.0$ & -- \\
\hline Mercury & $\mathrm{mg} / \mathrm{kg}(\mathrm{ppm})$ & 1 & 0.08 & 0.15 & 1.3 & 0.17 \\
\hline Nickel & $\mathrm{mg} / \mathrm{kg}(\mathrm{ppm})$ & 1 & 21 & 16.0 & 50.0 & -- \\
\hline Potassium & $\mathrm{mg} / \mathrm{kg}(\mathrm{ppm})$ & 1 & 962 & -- & -- & -- \\
\hline Selenium & $\mathrm{mg} / \mathrm{kg}(\mathrm{ppm})$ & 1 & $<0.71$ & -- & -- & -- \\
\hline Silver & $\mathrm{mg} / \mathrm{kg}(\mathrm{ppm})$ & 1 & $<0.11$ & 1.0 & 2.2 & -- \\
\hline Sodium & $\mathrm{mg} / \mathrm{kg}(\mathrm{ppm})$ & 1 & 201 & -- & -- & -- \\
\hline Thallium & $\mathrm{mg} / \mathrm{kg}(\mathrm{ppm})$ & 1 & $<1.08$ & -- & -- & -- \\
\hline Vanadium & $\mathrm{mg} / \mathrm{kg}(\mathrm{ppm})$ & 1 & 13.2 & -- & -- & -- \\
\hline Zinc & $\mathrm{mg} / \mathrm{kg}(\mathrm{ppm})$ & 1 & 71.9 & 120.0 & 270.0 & -- \\
\hline
\end{tabular}

$N$ - Number of samples

-- No reference standard available

${ }^{a}$ Screening guidelines for chemical constituents obtained from NYSDEC "Technical Guidance for Screening Contaminated Sediments"

${ }^{b}$ NYSDEC: Draft Technical \& Operational Guidance Series 5.1.9, "In-Water and Riparian Management of Sediment and Dredge Material," January 2003. 


\section{Table G-2B}

\section{Contaminants in On-Site Soils From North Swamp (SNSW74A)}

\section{RADIOACTIVE CONSTITUENTS}

\begin{tabular}{|c|c|c|c|c|c|c|}
\hline \multirow{2}{*}{ Isotope } & \multirow{2}{*}{ Units } & \multirow{2}{*}{$\mathbf{N}$} & \multirow{2}{*}{ SNSW74A } & \multicolumn{2}{|c|}{$\begin{array}{l}\text { Consultation Triggers }{ }^{a} \\
\text { For Soil Contamination }\end{array}$} & \multirow{2}{*}{$\begin{array}{l}\text { NUREG-1757 Soil } \\
\text { Screeening } \\
\text { Contamination } \\
\text { Levels }^{b}\end{array}$} \\
\hline & & & & Residential & $\begin{array}{l}\text { Industrial/ } \\
\text { Commercial }\end{array}$ & \\
\hline Gross Alpha & $\mu \mathrm{Ci} / \mathrm{g}$ & 1 & $1.04 \pm 0.21 \mathrm{E}-05$ & -- & -- & -- \\
\hline Gross Beta & $\mu \mathrm{Ci} / \mathrm{g}$ & 1 & $2.01 \pm 0.26 \mathrm{E}-05$ & -- & -- & -- \\
\hline K-40 & $\mu \mathrm{Ci} / \mathrm{g}$ & 1 & $1.86 \pm 0.07 \mathrm{E}-05$ & -- & -- & -- \\
\hline Co-60 & $\mu \mathrm{Ci} / \mathrm{g}$ & 1 & $-1.19 \pm 1.54 \mathrm{E}-08$ & $4 \mathrm{E}-06$ & $6 \mathrm{E}-06$ & $3.8 \mathrm{E}-06$ \\
\hline Sr-90 & $\mu \mathrm{Ci} / \mathrm{g}$ & 1 & $9.99 \pm 3.73 \mathrm{E}-08$ & $2.3 \mathrm{E}-05^{c}$ & $1.07 \mathrm{E}-03^{c}$ & $1.7 \mathrm{E}-06$ \\
\hline Cs-137 & $\mu \mathrm{Ci} / \mathrm{g}$ & 1 & $1.71 \pm 0.05 \mathrm{E}-06$ & $6 \mathrm{E}-06^{c}$ & $1.1 \mathrm{E}-05^{c}$ & $1.1 \mathrm{E}-05$ \\
\hline U-232 & $\mu \mathrm{Ci} / \mathrm{g}$ & 1 & $3.26 \pm 2.91 \mathrm{E}-08$ & -- & -- & -- \\
\hline U-233/234 & $\mu \mathrm{Ci} / \mathrm{g}$ & 1 & $7.36 \pm 1.30 \mathrm{E}-07$ & 4.01E-04 & $3.31 \mathrm{E}-03$ & $1.3 \mathrm{E}-05$ \\
\hline $\mathrm{U}-235 / 236$ & $\mu \mathrm{Ci} / \mathrm{g}$ & 1 & $3.15 \pm 2.91 \mathrm{E}-08$ & $2.0 \mathrm{E}-05^{c}$ & $3.9 \mathrm{E}-05^{c}$ & $8 \mathrm{E}-06^{d}$ \\
\hline U-238 & $\mu \mathrm{Ci} / \mathrm{g}$ & 1 & $6.82 \pm 1.25 \mathrm{E}-07$ & $7.4 \mathrm{E}-05^{c}$ & $1.79 \mathrm{E}-04^{c}$ & $1.4 \mathrm{E}-05^{d}$ \\
\hline Total U & $\mu \mathrm{g} / \mathrm{g}$ & 1 & $3.01 \pm 0.08 \mathrm{E}+00$ & $4.7 \mathrm{E}+01$ & $1.23 \mathrm{E}+03$ & -- \\
\hline Pu-238 & $\mu \mathrm{Ci} / \mathrm{g}$ & 1 & $0.31 \pm 1.23 \mathrm{E}-08$ & 2.97E-04 & $1.64 \mathrm{E}-03$ & $2.5 \mathrm{E}-06$ \\
\hline Pu-239/240 & $\mu \mathrm{Ci} / \mathrm{g}$ & 1 & $2.83 \pm 2.62 \mathrm{E}-08$ & $2.59 \mathrm{E}-04$ & $1.43 \mathrm{E}-03$ & $2.3 \mathrm{E}-06$ \\
\hline Am-241 & $\mu \mathrm{Ci} / \mathrm{g}$ & 1 & $2.64 \pm 1.83 \mathrm{E}-08$ & $1.87 \mathrm{E}-04$ & $5.68 \mathrm{E}-04$ & $2.1 \mathrm{E}-06$ \\
\hline
\end{tabular}

$N$ - Number of samples

-- No reference trigger available

${ }^{a}$ Memorandum of Understanding between the EPA and the NRC "Consultation and Finality on Decommissioning and Decontamination of Contaminated Sites."

${ }^{b}$ U.S. Nuclear Regulatory Commission. "Consolidated Decommissioning Guidance: Characterization, Survey, and Determination of Radiological Criteria.” NUREG-1757, Vol. 2, Rev. 1. September 2006.

${ }^{c}$ Concentrations apply to the parent radionuclide but assume that the daughter products are in equilibrium.

${ }^{d}$ WVDP-related uranium isotopes are not assumed to be in equilibrium with daughter products because of their relatively recent origin as processed nuclear materials. Therefore, the single-nuclide screening levels for U-235 and U-238 were selected for comparison with radionuclide concentrations in on-site soils. 


\section{Table G-2B (concluded) \\ 2006 Contaminants in On-Site Soils From North Swamp (SNSW74A)}

METALS

\begin{tabular}{|c|c|c|c|c|c|}
\hline Analyte & Units & $\mathbf{N}$ & SNSW74A & $\begin{array}{c}\text { TAGM \#4046 } \\
\text { Recommended Soil } \\
\text { Cleanup Objective }^{a}\end{array}$ & $\begin{array}{c}6 \text { NYCRR Subpart } \\
\text { 375-6.8 (a) Remedial } \\
\text { Program Soil } \\
\text { Cleanup Objective }^{b}\end{array}$ \\
\hline Aluminum & $\mathrm{mg} / \mathrm{kg}(\mathrm{ppm})$ & 1 & 8,590 & 33,000 & -- \\
\hline Antimony & $\mathrm{mg} / \mathrm{kg}(\mathrm{ppm})$ & 1 & $<0.68$ & -- & -- \\
\hline Arsenic & $\mathrm{mg} / \mathrm{kg}(\mathrm{ppm})$ & 1 & 10.7 & $3-12^{c}$ & 13 \\
\hline Barium & $\mathrm{mg} / \mathrm{kg}(\mathrm{ppm})$ & 1 & 92.2 & $15-600$ & 350 \\
\hline Beryllium & $\mathrm{mg} / \mathrm{kg}(\mathrm{ppm})$ & 1 & 0.47 & $0-1.75$ & 7.2 \\
\hline Cadmium & $\mathrm{mg} / \mathrm{kg}(\mathrm{ppm})$ & 1 & 0.62 & $0.1-1$ & 2.5 \\
\hline Calcium & $\mathrm{mg} / \mathrm{kg}(\mathrm{ppm})$ & 1 & 34,900 & $130-35,000$ & -- \\
\hline Chromium & $\mathrm{mg} / \mathrm{kg}(\mathrm{ppm})$ & 1 & 15.4 & $1.5-40^{c}$ & 30 \\
\hline Cobalt & $\mathrm{mg} / \mathrm{kg}(\mathrm{ppm})$ & 1 & 8.8 & $2.5-60^{c}$ & -- \\
\hline Copper & $\mathrm{mg} / \mathrm{kg}(\mathrm{ppm})$ & 1 & 30.1 & $1-50$ & 50 \\
\hline Iron & $\mathrm{mg} / \mathrm{kg}(\mathrm{ppm})$ & 1 & 23,400 & $2,000-550,000$ & -- \\
\hline Lead & $\mathrm{mg} / \mathrm{kg}(\mathrm{ppm})$ & 1 & 20.5 & $4-61^{d}$ & 63 \\
\hline Magnesium & $\mathrm{mg} / \mathrm{kg}(\mathrm{ppm})$ & 1 & 10,200 & $100-5,000$ & -- \\
\hline Manganese & $\mathrm{mg} / \mathrm{kg}(\mathrm{ppm})$ & 1 & 1,640 & $50-5,000$ & 1,600 \\
\hline Mercury & $\mathrm{mg} / \mathrm{kg}(\mathrm{ppm})$ & 1 & 0.04 & $0.001-0.2$ & 0.18 \\
\hline Nickel & $\mathrm{mg} / \mathrm{kg}(\mathrm{ppm})$ & 1 & 22.7 & $0.5-25$ & 30 \\
\hline Potassium & $\mathrm{mg} / \mathrm{kg}(\mathrm{ppm})$ & 1 & 954 & $8,500-43,000^{c}$ & -- \\
\hline Selenium & $\mathrm{mg} / \mathrm{kg}(\mathrm{ppm})$ & 1 & $<0.73$ & $0.1-3.9$ & 3.9 \\
\hline Silver & $\mathrm{mg} / \mathrm{kg}(\mathrm{ppm})$ & 1 & $<0.11$ & -- & 2 \\
\hline Sodium & $\mathrm{mg} / \mathrm{kg}(\mathrm{ppm})$ & 1 & 295 & $6,000-8,000$ & -- \\
\hline Thallium & $\mathrm{mg} / \mathrm{kg}(\mathrm{ppm})$ & 1 & $<1.10$ & -- & -- \\
\hline Vanadium & $\mathrm{mg} / \mathrm{kg}(\mathrm{ppm})$ & 1 & 15.7 & $1-300$ & -- \\
\hline Zinc & $\mathrm{mg} / \mathrm{kg}(\mathrm{ppm})$ & 1 & 254 & $9-50$ & 109 \\
\hline
\end{tabular}

$N$ - Number of samples

-- No reference standard available

${ }^{a}$ NYSDEC: Technical and Administrative Guidance Memorandum (TAGM) \#4046.

${ }^{b} 6$ NYCRR Subpart 375-6.8(a) Remedial Program Soil Cleanup Objectives

${ }^{c}$ New York State background

${ }^{d}$ Background levels for lead vary widely. Average levels in undeveloped rural areas may range from 4-61 ppm (reported here). Average background levels in metropolitain or suburban areas, or near highways are much higher and typically range from 200-500 ppm. 
Table G-2C

2006 Contaminants in On-Site Soils From Northeast Swamp (SNSWAMP)

RADIOACTIVE CONSTITUENTS

\begin{tabular}{|c|c|c|c|c|c|c|}
\hline \multirow{2}{*}{ Isotope } & \multirow{2}{*}{ Units } & \multirow{2}{*}{$\mathbf{N}$} & \multirow{2}{*}{ SNSWAMP } & \multicolumn{2}{|c|}{$\begin{array}{l}\text { Consultation Triggers }{ }^{a} \\
\text { For Soil Contamination }\end{array}$} & \multirow{2}{*}{$\begin{array}{c}\text { NUREG-1757 Soil } \\
\text { Screening } \\
\text { Contamination } \\
\text { Levels }^{b} \\
\end{array}$} \\
\hline & & & & Residential & $\begin{array}{l}\text { Industrial/ } \\
\text { Commercial }\end{array}$ & \\
\hline Gross Alpha & $\mu \mathrm{Ci} / \mathrm{g}$ & 1 & $1.14 \pm 0.44 \mathrm{E}-05$ & -- & -- & -- \\
\hline Gross Beta & $\mu \mathrm{Ci} / \mathrm{g}$ & 1 & $4.20 \pm 0.66 \mathrm{E}-05$ & -- & -- & -- \\
\hline K-40 & $\mu \mathrm{Ci} / \mathrm{g}$ & 1 & $2.34 \pm 0.16 \mathrm{E}-05$ & -- & -- & -- \\
\hline Co-60 & $\mu \mathrm{Ci} / \mathrm{g}$ & 1 & $3.11 \pm 1.79 \mathrm{E}-08$ & 4E-06 & $6 \mathrm{E}-06$ & $3.8 \mathrm{E}-06$ \\
\hline Sr-90 & $\mu \mathrm{Ci} / \mathrm{g}$ & 1 & $1.08 \pm 0.08 \mathrm{E}-06$ & $2.3 \mathrm{E}-05^{c}$ & $1.07 \mathrm{E}-03^{c}$ & $1.7 \mathrm{E}-06$ \\
\hline Cs-137 & $\mu \mathrm{Ci} / \mathrm{g}$ & 1 & $2.62 \pm 0.22 \mathrm{E}-05$ & $6 \mathrm{E}-06^{c}$ & $1.1 \mathrm{E}-05^{c}$ & $1.1 \mathrm{E}-05$ \\
\hline U-232 & $\mu \mathrm{Ci} / \mathrm{g}$ & 1 & $1.07 \pm 2.68 \mathrm{E}-08$ & -- & -- & -- \\
\hline U-233/234 & $\mu \mathrm{Ci} / \mathrm{g}$ & 1 & $5.92 \pm 1.51 \mathrm{E}-07$ & 4.01E-04 & $3.31 \mathrm{E}-03$ & $1.3 \mathrm{E}-05$ \\
\hline U-235/236 & $\mu \mathrm{Ci} / \mathrm{g}$ & 1 & $6.75 \pm 5.20 \mathrm{E}-08$ & $2.0 \mathrm{E}-05^{c}$ & $3.9 \mathrm{E}-05^{c}$ & $8 \mathrm{E}-06^{d}$ \\
\hline U-238 & $\mu \mathrm{Ci} / \mathrm{g}$ & 1 & $6.28 \pm 1.58 \mathrm{E}-07$ & $7.4 \mathrm{E}-05^{c}$ & $1.79 \mathrm{E}-04^{c}$ & $1.4 \mathrm{E}-05^{d}$ \\
\hline Total U & $\mu \mathrm{g} / \mathrm{g}$ & 1 & $2.31 \pm 0.24 \mathrm{E}+00$ & $4.7 \mathrm{E}+01$ & $1.23 \mathrm{E}+03$ & -- \\
\hline Pu-238 & $\mu \mathrm{Ci} / \mathrm{g}$ & 1 & $1.50 \pm 0.57 \mathrm{E}-07$ & 2.97E-04 & $1.64 \mathrm{E}-03$ & $2.5 \mathrm{E}-06$ \\
\hline Pu-239/240 & $\mu \mathrm{Ci} / \mathrm{g}$ & 1 & $2.33 \pm 0.71 \mathrm{E}-07$ & $2.59 \mathrm{E}-04$ & $1.43 \mathrm{E}-03$ & $2.3 \mathrm{E}-06$ \\
\hline Am-241 & $\mu \mathrm{Ci} / \mathrm{g}$ & 1 & $6.14 \pm 0.80 \mathrm{E}-07$ & $1.87 \mathrm{E}-04$ & $5.68 \mathrm{E}-04$ & $2.1 \mathrm{E}-06$ \\
\hline
\end{tabular}

$N$ - Number of samples

-- No reference trigger available

${ }^{a}$ Memorandum of Understanding between the EPA and the NRC "Consultation and Finality on Decommissioning and Decontamination of Contaminated Sites."

${ }^{b}$ U.S. Nuclear Regulatory Commission. "Consolidated Decommissioning Guidance: Characterization, Survey, and Determination of Radiological Criteria." NUREG-1757, Vol. 2, Rev. 1. September 2006.

${ }^{c}$ Concentrations apply to the parent radionuclide but assume that the daughter products are in equilibrium.

${ }^{d}$ WVDP-related uranium isotopes are not assumed to be in equilibrium with daughter products because of their relatively recent origin as processed nuclear materials. Therefore, the single-nuclide screening levels for U-235 and U-238 were selected for comparison with radionuclide concentrations in on-site soils. 


\section{Table G-2C (concluded) \\ 2006 Contaminants in On-Site Soils From Northeast Swamp (SNSWAMP)}

METALS

\begin{tabular}{|c|c|c|c|c|c|}
\hline Analyte & Units & $\mathbf{N}$ & SNSWAMP & $\begin{array}{c}\text { TAGM \#4046 } \\
\text { Recommended Soil } \\
\text { Cleanup Objective }^{a}\end{array}$ & $\begin{array}{c}\text { 6 NYCRR Subpart } \\
\text { 375-6.8 (a) Remedial } \\
\text { Program Soil Cleanup } \\
\text { Objectives }^{b}\end{array}$ \\
\hline Aluminum & $\mathrm{mg} / \mathrm{kg}(\mathrm{ppm})$ & 1 & 11,700 & 33,000 & -- \\
\hline Antimony & $\mathrm{mg} / \mathrm{kg}(\mathrm{ppm})$ & 1 & $<0.50$ & -- & -- \\
\hline Arsenic & $\mathrm{mg} / \mathrm{kg}(\mathrm{ppm})$ & 1 & 11.1 & $3-12^{c}$ & 13 \\
\hline Barium & $\mathrm{mg} / \mathrm{kg}(\mathrm{ppm})$ & 1 & 84.8 & $15-600$ & 350 \\
\hline Beryllium & $\mathrm{mg} / \mathrm{kg}(\mathrm{ppm})$ & 1 & 0.60 & $0-1.75$ & 7.2 \\
\hline Cadmium & $\mathrm{mg} / \mathrm{kg}(\mathrm{ppm})$ & 1 & 0.35 & $0.1-1$ & 2.5 \\
\hline Calcium & $\mathrm{mg} / \mathrm{kg}(\mathrm{ppm})$ & 1 & 5,210 & $130-35,000$ & -- \\
\hline Chromium & $\mathrm{mg} / \mathrm{kg}(\mathrm{ppm})$ & 1 & 15.7 & $1.5-40^{c}$ & 30 \\
\hline Cobalt & $\mathrm{mg} / \mathrm{kg}(\mathrm{ppm})$ & 1 & 10.1 & $2.5-60^{c}$ & -- \\
\hline Copper & $\mathrm{mg} / \mathrm{kg}(\mathrm{ppm})$ & 1 & 26.3 & $1-50$ & 50 \\
\hline Iron & $\mathrm{mg} / \mathrm{kg}(\mathrm{ppm})$ & 1 & 26,500 & $2,000-550,000$ & -- \\
\hline Lead & $\mathrm{mg} / \mathrm{kg}(\mathrm{ppm})$ & 1 & 24.7 & $4-61^{d}$ & 63 \\
\hline Magnesium & $\mathrm{mg} / \mathrm{kg}(\mathrm{ppm})$ & 1 & 5,100 & $100-5,000$ & -- \\
\hline Manganese & $\mathrm{mg} / \mathrm{kg}(\mathrm{ppm})$ & 1 & 599 & $50-5,000$ & 1,600 \\
\hline Mercury & $\mathrm{mg} / \mathrm{kg}(\mathrm{ppm})$ & 1 & 0.06 & $0.001-0.2$ & 0.18 \\
\hline Nickel & $\mathrm{mg} / \mathrm{kg}(\mathrm{ppm})$ & 1 & 24.4 & $0.5-25$ & 30 \\
\hline Potassium & $\mathrm{mg} / \mathrm{kg}(\mathrm{ppm})$ & 1 & 1,140 & $8,500-43,000^{c}$ & -- \\
\hline Selenium & $\mathrm{mg} / \mathrm{kg}(\mathrm{ppm})$ & 1 & $<0.53$ & $0.1-3.9$ & 3.9 \\
\hline Silver & $\mathrm{mg} / \mathrm{kg}(\mathrm{ppm})$ & 1 & $<0.08$ & -- & 2 \\
\hline Sodium & $\mathrm{mg} / \mathrm{kg}(\mathrm{ppm})$ & 1 & 49.5 & $6,000-8,000$ & -- \\
\hline Thallium & $\mathrm{mg} / \mathrm{kg}(\mathrm{ppm})$ & 1 & $<0.79$ & -- & -- \\
\hline Vanadium & $\mathrm{mg} / \mathrm{kg}(\mathrm{ppm})$ & 1 & 18.2 & $1-300$ & -- \\
\hline Zinc & $\mathrm{mg} / \mathrm{kg}(\mathrm{ppm})$ & 1 & 98.7 & $9-50$ & 109 \\
\hline
\end{tabular}

$N$ - Number of samples

-- No reference standard available

${ }^{a}$ NYSDEC: Technical and Administrative Guidance Memorandum (TAGM) \#4046.

${ }^{b} 6$ NYCRR Subpart 375-6.8(a) Remedial Program Soil Cleanup Objectives

${ }^{c}$ New York State background

${ }^{d}$ Background levels for lead vary widely. Average levels in undeveloped rural areas may range from 4-61 ppm (reported here). Average background levels in metropolitain or suburban areas, or near highways are much higher and typically range from 200-500 ppm.

\section{Table G-2D}

\section{Radioactivity in Surface Soils Collected at Air Stations Around the WVDP}

In 2005, collection frequency was reduced to once every three years at these locations. The samples will next be collected in CY 2007. 


\section{Table G-2E}

\section{Radioactivity in Stream Sediments Around the WVDP}

\begin{tabular}{|c|c|c|c|c|c|c|}
\hline Analyte & Units & $\mathbf{N}$ & SFCCSED & SFSDSED & $\mathbf{N}$ & \begin{tabular}{|c|} 
Background Location \\
SFBISED $^{a}$
\end{tabular} \\
\hline Gross Alpha & $\mu \mathrm{Ci} / \mathrm{g}$ & 1 & $8.99 \pm 2.23 \mathrm{E}-06$ & $6.86 \pm 2.27 \mathrm{E}-06$ & 10 & $1.16 \pm 0.35 \mathrm{E}-05$ \\
\hline Gross Beta & $\mu \mathrm{Ci} / \mathrm{g}$ & 1 & $1.96 \pm 0.24 \mathrm{E}-05$ & $1.93 \pm 0.24 \mathrm{E}-05$ & 10 & $1.69 \pm 0.29 \mathrm{E}-05$ \\
\hline K-40 & $\mu \mathrm{Ci} / \mathrm{g}$ & 1 & $1.43 \pm 0.06 \mathrm{E}-05$ & $1.55 \pm 0.11 \mathrm{E}-05$ & 10 & $1.37 \pm 0.15 \mathrm{E}-05$ \\
\hline Co-60 & $\mu \mathrm{Ci} / \mathrm{g}$ & 1 & $0.83 \pm 1.38 \mathrm{E}-08$ & $2.24 \pm 1.96 \mathrm{E}-08$ & 10 & $0.02 \pm 1.62 \mathrm{E}-08$ \\
\hline Sr-90 & $\mu \mathrm{Ci} / \mathrm{g}$ & 1 & $3.56 \pm 1.95 \mathrm{E}-08$ & $0.91 \pm 1.51 \mathrm{E}-08$ & 10 & $0.04 \pm 4.97 \mathrm{E}-08$ \\
\hline Cs-137 & $\mu \mathrm{Ci} / \mathrm{g}$ & 1 & $1.80 \pm 0.31 \mathrm{E}-07$ & $1.40 \pm 0.27 \mathrm{E}-07$ & 10 & $3.73 \pm 2.27 \mathrm{E}-08$ \\
\hline U-232 & $\mu \mathrm{Ci} / \mathrm{g}$ & 1 & $-0.80 \pm 2.22 \mathrm{E}-08$ & $0.58 \pm 3.21 \mathrm{E}-08$ & 10 & $0.00 \pm 5.52 \mathrm{E}-08$ \\
\hline U-233/234 & $\mu \mathrm{Ci} / \mathrm{g}$ & 1 & $7.24 \pm 1.38 \mathrm{E}-07$ & $6.66 \pm 1.34 \mathrm{E}-07$ & 10 & $5.42 \pm 1.19 \mathrm{E}-07$ \\
\hline U-235/236 & $\mu \mathrm{Ci} / \mathrm{g}$ & 1 & $4.52 \pm 3.95 \mathrm{E}-08$ & $3.76 \pm 3.59 \mathrm{E}-08$ & 10 & $5.73 \pm 3.88 \mathrm{E}-08$ \\
\hline U-238 & $\mu \mathrm{Ci} / \mathrm{g}$ & 1 & $7.89 \pm 1.43 \mathrm{E}-07$ & $7.20 \pm 1.37 \mathrm{E}-07$ & 10 & $5.30 \pm 1.14 \mathrm{E}-07$ \\
\hline Total U & $\mu \mathrm{g} / \mathrm{g}$ & 1 & $2.12 \pm 0.07 \mathrm{E}+00$ & $2.27 \pm 0.08 \mathrm{E}+00$ & 10 & $1.91 \pm 0.04 \mathrm{E}+00$ \\
\hline Pu-238 & $\mu \mathrm{Ci} / \mathrm{g}$ & 1 & $-1.13 \pm 9.78 \mathrm{E}-09$ & $0.00 \pm 1.17 \mathrm{E}-08$ & 10 & $1.11 \pm 1.86 \mathrm{E}-08$ \\
\hline $\mathrm{Pu}-239 / 240$ & $\mu \mathrm{Ci} / \mathrm{g}$ & 1 & $0.85 \pm 1.86 \mathrm{E}-08$ & $0.00 \pm 1.17 \mathrm{E}-08$ & 10 & $1.44 \pm 1.44 \mathrm{E}-08$ \\
\hline Am-241 & $\mu \mathrm{Ci} / \mathrm{g}$ & 1 & $0.49 \pm 1.24 \mathrm{E}-08$ & $-0.56 \pm 1.61 \mathrm{E}-08$ & 10 & $1.70 \pm 2.24 \mathrm{E}-08$ \\
\hline
\end{tabular}

\begin{tabular}{|l|c|c|c|c|c|c|}
\hline \multicolumn{1}{|c|}{ Analyte } & Units & N & SFTCSED & -- & N & $\begin{array}{c}\text { Background Location } \\
\text { SFBCSED }^{b}\end{array}$ \\
\hline Gross Alpha & $\mu \mathrm{Ci} / \mathrm{g}$ & 1 & $8.16 \pm 3.72 \mathrm{E}-06$ & -- & 10 & $7.71 \pm 2.96 \mathrm{E}-06$ \\
\hline Gross Beta & $\mu \mathrm{Ci} / \mathrm{g}$ & 1 & $1.31 \pm 0.48 \mathrm{E}-05$ & -- & 10 & $1.69 \pm 0.31 \mathrm{E}-05$ \\
\hline K-40 & $\mu \mathrm{Ci} / \mathrm{g}$ & 1 & $1.28 \pm 0.09 \mathrm{E}-05$ & -- & 10 & $1.39 \pm 0.14 \mathrm{E}-05$ \\
\hline Co-60 & $\mu \mathrm{Ci} / \mathrm{g}$ & 1 & $-0.13 \pm 1.36 \mathrm{E}-08$ & -- & 10 & $0.00 \pm 2.03 \mathrm{E}-08$ \\
\hline Sr-90 & $\mu \mathrm{Ci} / \mathrm{g}$ & 1 & $7.67 \pm 2.34 \mathrm{E}-08$ & -- & 10 & $3.49 \pm 5.31 \mathrm{E}-08$ \\
\hline Cs-137 & $\mu \mathrm{Ci} / \mathrm{g}$ & 1 & $7.44 \pm 0.59 \mathrm{E}-07$ & -- & 10 & $3.59 \pm 2.75 \mathrm{E}-08$ \\
\hline U-232 & $\mu \mathrm{Ci} / \mathrm{g}$ & 1 & $-1.98 \pm 2.26 \mathrm{E}-08$ & -- & 10 & $2.03 \pm 5.69 \mathrm{E}-08$ \\
\hline U-233/234 & $\mu \mathrm{Ci} / \mathrm{g}$ & 1 & $6.43 \pm 1.33 \mathrm{E}-07$ & -- & 10 & $6.26 \pm 1.21 \mathrm{E}-07$ \\
\hline U-235/236 & $\mu \mathrm{Ci} / \mathrm{g}$ & 1 & $3.56 \pm 3.46 \mathrm{E}-08$ & -- & 10 & $4.84 \pm 3.60 \mathrm{E}-08$ \\
\hline U-238 & $\mu \mathrm{Ci} / \mathrm{g}$ & 1 & $7.45 \pm 1.43 \mathrm{E}-07$ & -- & 10 & $6.45 \pm 1.24 \mathrm{E}-07$ \\
\hline Total U & $\mu \mathrm{g} / \mathrm{g}$ & 1 & $2.56 \pm 0.07 \mathrm{E}+00$ & -- & 10 & $2.14 \pm 0.05 \mathrm{E}+00$ \\
\hline Pu-238 & $\mu \mathrm{Ci} / \mathrm{g}$ & 1 & $-0.29 \pm 1.25 \mathrm{E}-08$ & -- & 10 & $2.12 \pm 1.78 \mathrm{E}-08$ \\
\hline Pu-239/240 & $\mu \mathrm{Ci} / \mathrm{g}$ & 1 & $0.17 \pm 1.28 \mathrm{E}-08$ & -- & 10 & $0.66 \pm 1.36 \mathrm{E}-08$ \\
\hline Am-241 & $\mu \mathrm{Ci} / \mathrm{g}$ & 1 & $1.31 \pm 1.82 \mathrm{E}-08$ & -- & 10 & $0.52 \pm 1.38 \mathrm{E}-08$ \\
\hline
\end{tabular}

$N$ - Number of samples

-- Not applicable; no additional sampling location

${ }^{a}$ Sediment sampling at Bigelow Bridge (SFBISED), the upstream Cattaraugus Creek background, was discontinued in 2005. The ten-year historical average is used as the comparative reference for the Cattaraugus Creek locations.

${ }^{b}$ Sampling data at the location upstream in Buttermilk Creek (SFBCSED) is presented as a ten-year rolling average and is used as a comparative reference for Thomas Corners in Buttermilk Creek (SFTCSED), immediately downstream of facility effluents. 
This page intentionally left blank

$G-16$ 


\section{Appendix $\mathrm{H}$ \\ Summary of Direct Radiation Monitoring Data}

$H-1$ 
This page intentionally left blank

$H-2$ 
Table $\mathrm{H}-1$

Summary of 2006 Quarterly Averages of Off-Site TLD Measurements (mR \pm 2 SD/quarter)

$\begin{array}{lrrrrr}\begin{array}{l}\text { Location } \\ \text { Number }\end{array} & \text { 1st Quarter } & \text { 2nd Quarter } & \text { 3rd Quarter } & \text { 4th Quarter } & \begin{array}{c}\text { Location } \\ \text { Average }\end{array} \\ \text { DFTLD01 } & & & & & \\ \text { DFTLD02 } & 16 \pm 4 & 17 \pm 4 & 20 \pm 4 & 17 \pm 4 & 17 \pm 4 \\ \text { DFTLD03 } & 16 \pm 4 & 17 \pm 4 & 21 \pm 5 & 18 \pm 4 & 18 \pm 4 \\ \text { DFTLD04 } & 14 \pm 4 & 14 \pm 3 & 18 \pm 4 & 15 \pm 4 & 15 \pm 4 \\ \text { DFTLD05 } & 15 \pm 4 & 16 \pm 3 & 19 \pm 4 & 18 \pm 4 & 17 \pm 4 \\ \text { DFTLD06 } & 16 \pm 4 & 17 \pm 3 & 20 \pm 4 & 17 \pm 4 & 17 \pm 4 \\ \text { DFTLD07 } & 15 \pm 4 & 16 \pm 3 & 21 \pm 5 & 17 \pm 4 & 17 \pm 4 \\ \text { DFTLD08 } & 12 \pm 3 & 14 \pm 3 & 18 \pm 4 & 15 \pm 3 & 15 \pm 3 \\ \text { DFTLD09 } & 16 \pm 4 & 17 \pm 4 & 21 \pm 5 & 18 \pm 4 & 18 \pm 4 \\ \text { DFTLD10 } & 15 \pm 4 & 16 \pm 3 & 18 \pm 4 & 17 \pm 4 & 17 \pm 4 \\ \text { DFTLD11 } & 13 \pm 4 & 16 \pm 3 & 18 \pm 4 & 16 \pm 4 & 16 \pm 4 \\ \text { DFTLD12 } & 15 \pm 4 & 13 \pm 3 & 17 \pm 4 & 14 \pm 3 & 15 \pm 3 \\ \text { DFTLD13 } & 17 \pm 4 & 16 \pm 3 & 16 \pm 4 & 17 \pm 4 & 16 \pm 4 \\ \text { DFTLD14 } & 16 \pm 4 & 18 \pm 4 & 21 \pm 5 & 19 \pm 4 & 19 \pm 4 \\ \text { DFTLD15 } & 15 \pm 4 & 17 \pm 3 & 21 \pm 5 & 17 \pm 4 & 18 \pm 4 \\ \text { DFTLD16 } & 15 \pm 4 & 16 \pm 3 & 19 \pm 4 & 18 \pm 4 & 17 \pm 4 \\ \text { DFTLD20 } & 14 \pm 4 & 16 \pm 3 & 20 \pm 4 & 16 \pm 4 & 16 \pm 4 \\ \text { DFTLD21 } & 17 \pm 4 & 14 \pm 3 & 17 \pm 4 & 15 \pm 3 & 15 \pm 3 \\ \text { DFTLD22 } & 16 \pm 4 & 17 \pm 4 & 21 \pm 5 & 18 \pm 4 & 18 \pm 4 \\ \text { DFTLD23 } & 16 \pm 4 & 18 \pm 4 & 21 \pm 4 & 19 \pm 4 & 18 \pm 4 \\ & & 17 \pm 4 & 19 \pm 4 & 18 \pm 4 & 17 \pm 4\end{array}$

${ }^{a}$ Off-site locations are shown on Figures A-13, A-14, and A-15.

Conversion factor: Milliroentgen $(m R)$ units are used to report exposure rates in air. To convert mR to $m r e m$ (dose to humans), a conversion factor of 1.03 must be applied. For example, a reported exposure rate of $18.1 \mathrm{mR} / q u a r t e r$ would be equivalent to 18.6 mrem/quarter (based upon dose-equivalent phantom calibration using cesium-137).

$H-3$ 
Table $\mathrm{H}-2$

Summary of 2006 Quarterly Averages of On-Site TLD Measurements (mR \pm 2 SD/quarter)

$\begin{array}{lccccc}\begin{array}{l}\text { Location } \\ \text { Number }\end{array} & \text { 1st Quarter } & \text { 2nd Quarter } & \text { 3rd Quarter } & \text { 4th Quarter } & \begin{array}{c}\text { Location } \\ \text { Average }\end{array} \\ \text { DNTLD19 } & 18 \pm 4 & 20 \pm 4 & & & \\ \text { DNTLD24 } & 431 \pm 84 & 434 \pm 85 & 22 \pm 5 & 21 \pm 5 & 20 \pm 4 \\ \text { DNTLD25 } & 19 \pm 5 & 20 \pm 4 & 412 \pm 81 & 432 \pm 85 & 427 \pm 84 \\ \text { DNTLD26 } & 20 \pm 5 & 22 \pm 5 & 23 \pm 5 & 21 \pm 5 & 21 \pm 5 \\ \text { DNTLD27 } & 17 \pm 4 & 18 \pm 4 & 24 \pm 5 & 23 \pm 5 & 22 \pm 5 \\ \text { DNTLD28 } & 20 \pm 5 & 20 \pm 4 & 20 \pm 4 & 19 \pm 4 & 18 \pm 4 \\ \text { DNTLD29 } & 19 \pm 5 & 20 \pm 4 & 26 \pm 5 & 22 \pm 5 & 22 \pm 5 \\ \text { DNTLD30 } & 19 \pm 5 & 21 \pm 4 & 24 \pm 5 & 20 \pm 4 & 21 \pm 5 \\ \text { DNTLD33 } & 25 \pm 6 & 28 \pm 6 & 24 \pm 5 & 21 \pm 5 & 21 \pm 5 \\ \text { DNTLD35 } & 76 \pm 15 & 75 \pm 15 & 33 \pm 7 & 36 \pm 7 & 30 \pm 6 \\ \text { DNTLD36 } & 91 \pm 18 & 64 \pm 13 & 80 \pm 16 & 84 \pm 17 & 79 \pm 16 \\ \text { DNTLD38 } & 34 \pm 7 & 31 \pm 6 & 78 \pm 15 & 97 \pm 19 & 83 \pm 16 \\ \text { DNTLD39 } & 43 \pm 9 & 47 \pm 9 & 34 \pm 7 & 32 \pm 7 & 33 \pm 7 \\ \text { DNTLD40 } & 112 \pm 22 & 100 \pm 20 & 49 \pm 10 & 48 \pm 10 & 47 \pm 9 \\ \text { DNTLD43 } & 31 \pm 7 & 27 \pm 5 & 105 \pm 21 & 82 \pm 16 & 100 \pm 20 \\ & & 35 \pm 7 & 42 \pm 8 & 33 \pm 7\end{array}$

${ }^{a}$ On-site locations are shown on Figure A-12.

Conversion factor: Milliroentgen $(m R)$ units are used to report exposure rates in air. To convert $m R$ to mrem (dose to humans), a conversion factor of 1.03 must be applied. For example, a reported exposure rate of $18.1 \mathrm{mR} /$ quarter would be equivalent to $18.6 \mathrm{mrem} / q u a r t e r$ (based upon dose-equivalent phantom calibration using cesium-137).

$H-4$ 
Table $\mathrm{H}-3$

Third-Quarter 2006 TLD Results and Instantaneous Exposure Rate Readings With a High-Pressure Ion Chamber (HPIC) at Each Monitoring Location

\begin{tabular}{|c|c|c|c|c|c|}
\hline $\begin{array}{l}\text { Off-Site } \\
\text { Location } \\
\text { Number }\end{array}$ & $\begin{array}{c}\text { 3rd-Quarter } \\
\text { TLD Result } \\
(\mu \mathrm{R} / \mathrm{hr})\end{array}$ & $\begin{array}{c}\text { 3rd-Quarter } \\
\text { HPIC Result } \\
(\mu \mathrm{R} / \mathrm{hr})\end{array}$ & $\begin{array}{l}\text { On-Site } \\
\text { Location } \\
\text { Number }\end{array}$ & $\begin{array}{c}\text { 3rd-Quarter } \\
\text { TLD Result } \\
(\mu \mathrm{R} / \mathrm{hr})\end{array}$ & $\begin{array}{c}\text { 3rd-Quarte } \\
\text { HPIC Resul } \\
(\mu \mathrm{R} / \mathrm{hr})\end{array}$ \\
\hline DFTLD01 & 9.0 & 6.2 & DNTLD19 & 9.8 & 10.0 \\
\hline DFTLD02 & 9.4 & 8.8 & DNTLD24 & 186.7 & 233.0 \\
\hline DFTLD03 & 8.1 & 8.1 & DNTLD25 & 10.6 & 12.5 \\
\hline DFTLD04 & 8.7 & 8.9 & DNTLD26 & 10.9 & 11.4 \\
\hline DFTLD05 & 8.8 & 10.4 & DNTLD27 & 9.2 & 9.1 \\
\hline DFTLD06 & 9.4 & 9.4 & DNTLD28 & 11.6 & 10.3 \\
\hline DFTLD07 & 8.0 & 8.6 & DNTLD29 & 10.9 & 10.6 \\
\hline DFTLD08 & 9.7 & 8.8 & DNTLD30 & 11.0 & 13.0 \\
\hline DFTLD09 & 8.3 & 8.9 & DNTLD33 & 14.7 & 15.8 \\
\hline DFTLD10 & 8.3 & 9.0 & DNTLD35 & 36.0 & 44.7 \\
\hline DFTLD11 & 7.7 & 7.3 & DNTLD36 & 35.3 & 47.3 \\
\hline DFTLD12 & 7.2 & 9.2 & DNTLD38 & 15.5 & 21.0 \\
\hline DFTLD13 & 9.7 & 9.3 & DNTLD39 & 22.1 & 24.0 \\
\hline DFTLD14 & 9.5 & 9.2 & DNTLD40 & 47.6 & 52.4 \\
\hline DFTLD15 & 8.8 & 9.1 & DNTLD43 & 15.9 & 18.9 \\
\hline DFTLD16 & 8.8 & 9.1 & & & \\
\hline DFTLD20 & 7.7 & 9.6 & & & \\
\hline DFTLD21 & 9.4 & 9.3 & & & \\
\hline DFTLD22 & 9.3 & 9.2 & & & \\
\hline DFTLD23 & 8.6 & 9.0 & & & \\
\hline
\end{tabular}

$H-5$ 


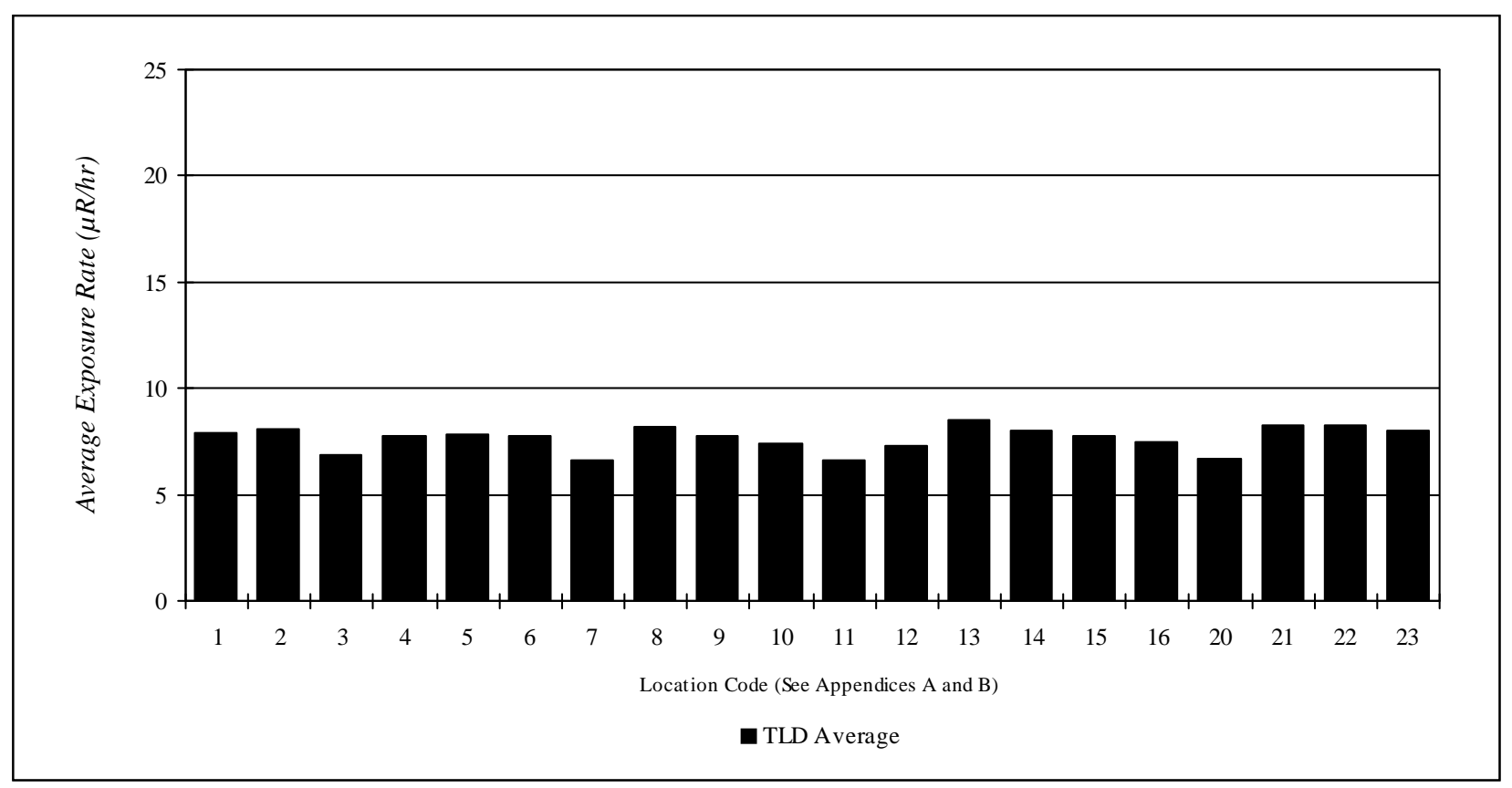

Figure H-1. 2006 Average Annual Gamma Exposure Rates Around the WVDP

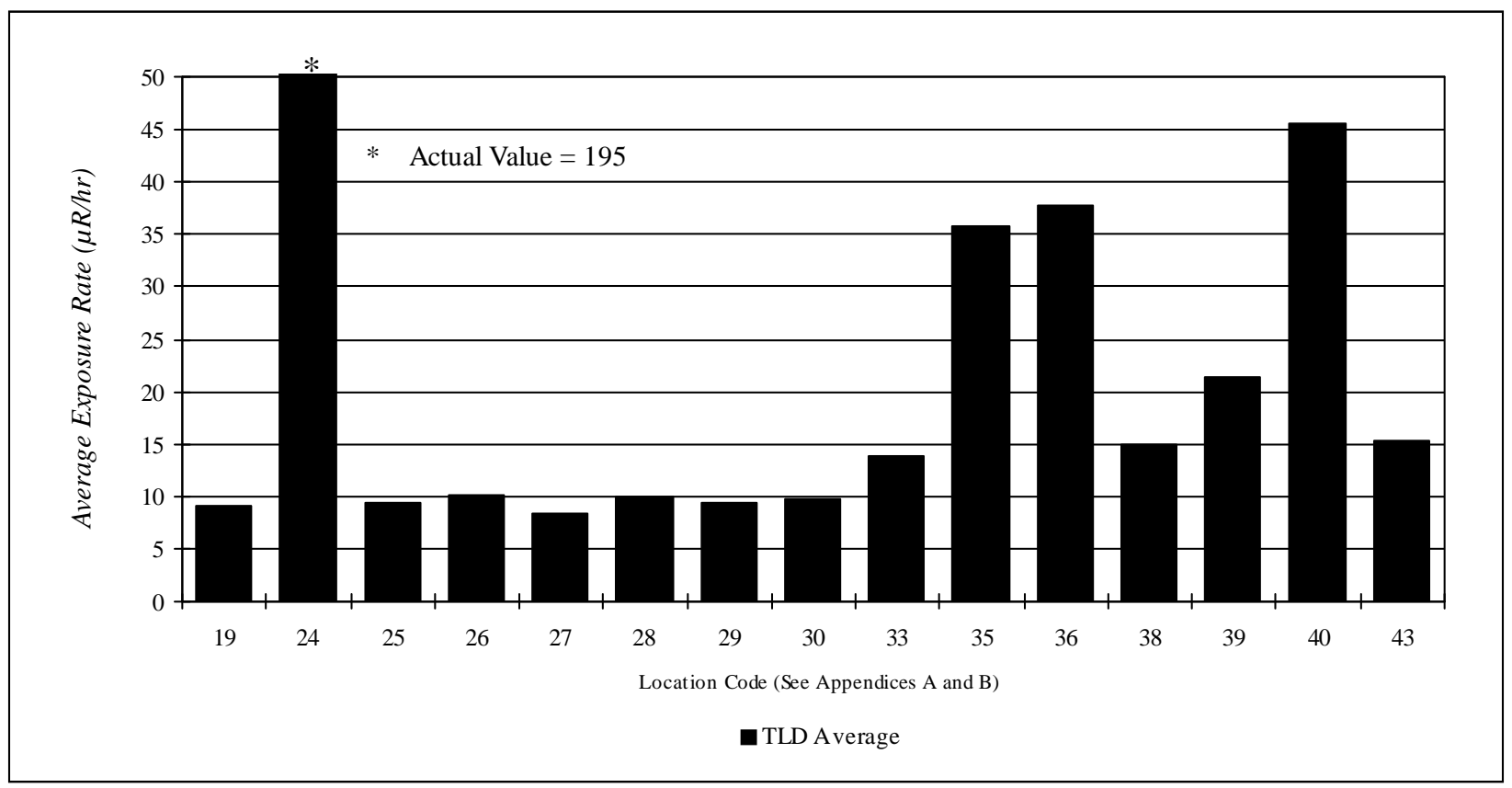

Figure H-2. 2006 Average Annual Gamma Exposure Rates on the WVDP

$$
H-6
$$




\section{Appendix I Summary of Meteorological Data}

$I-1$ 
This page intentionally left blank

$$
I-2
$$




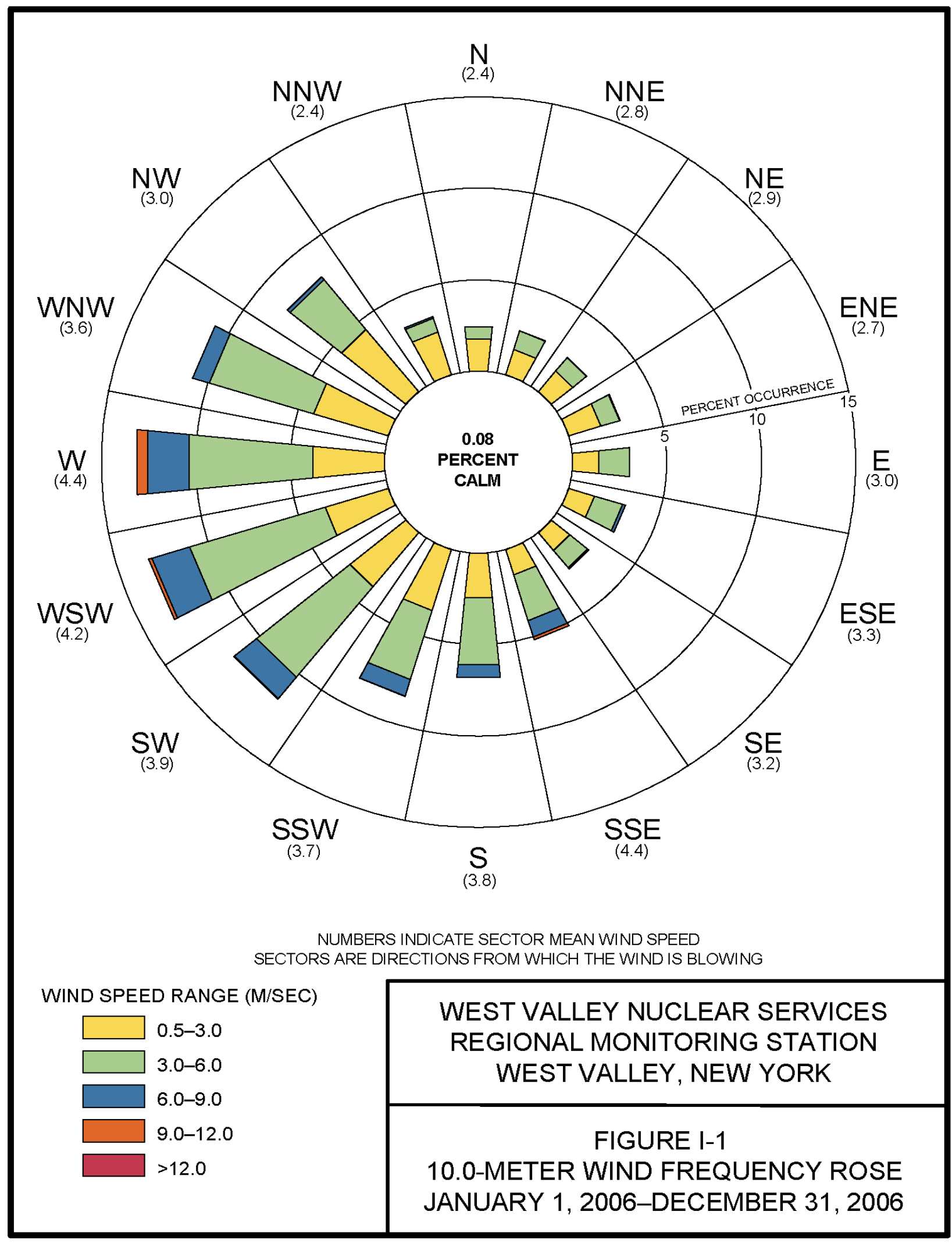

$I-3$ 


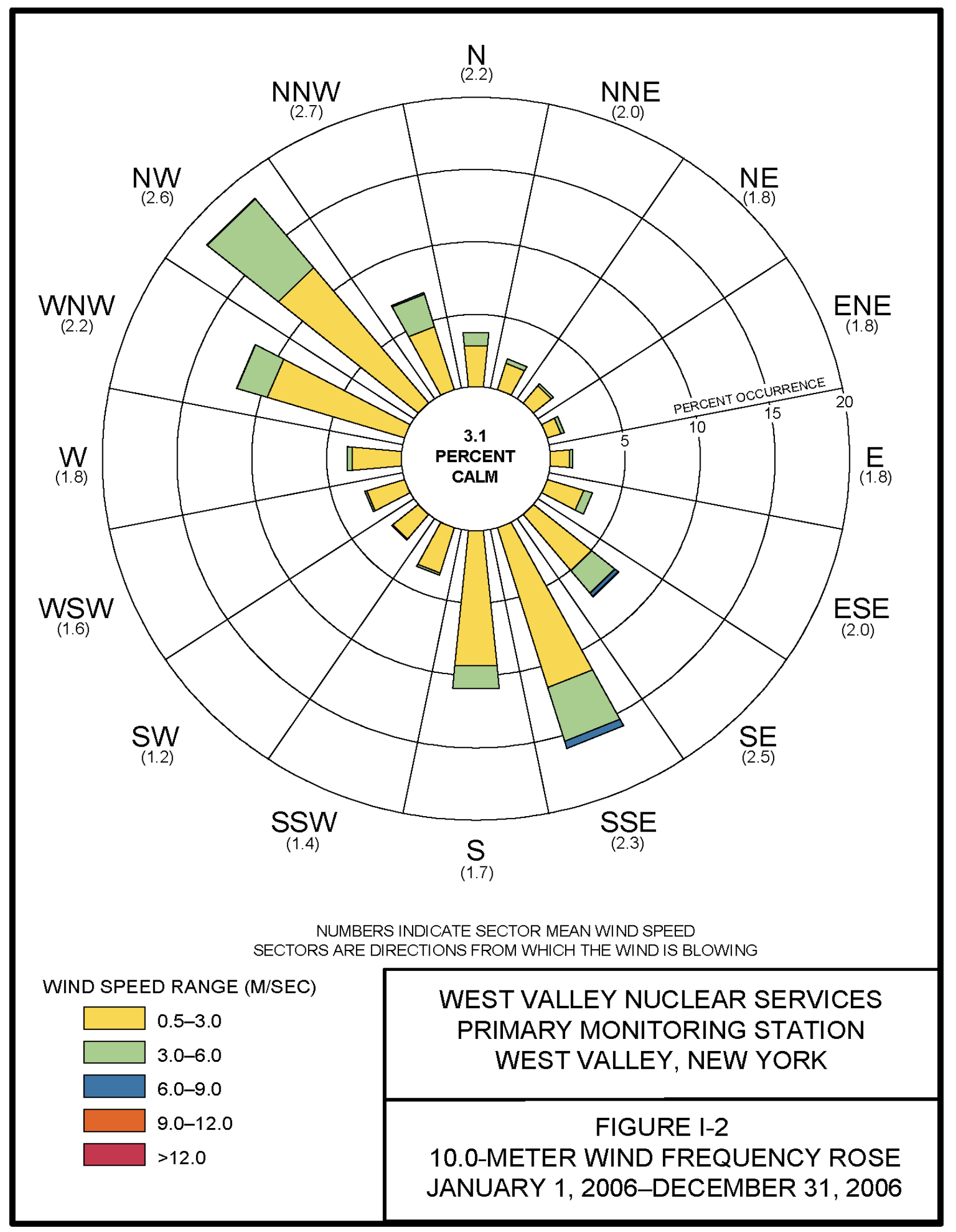




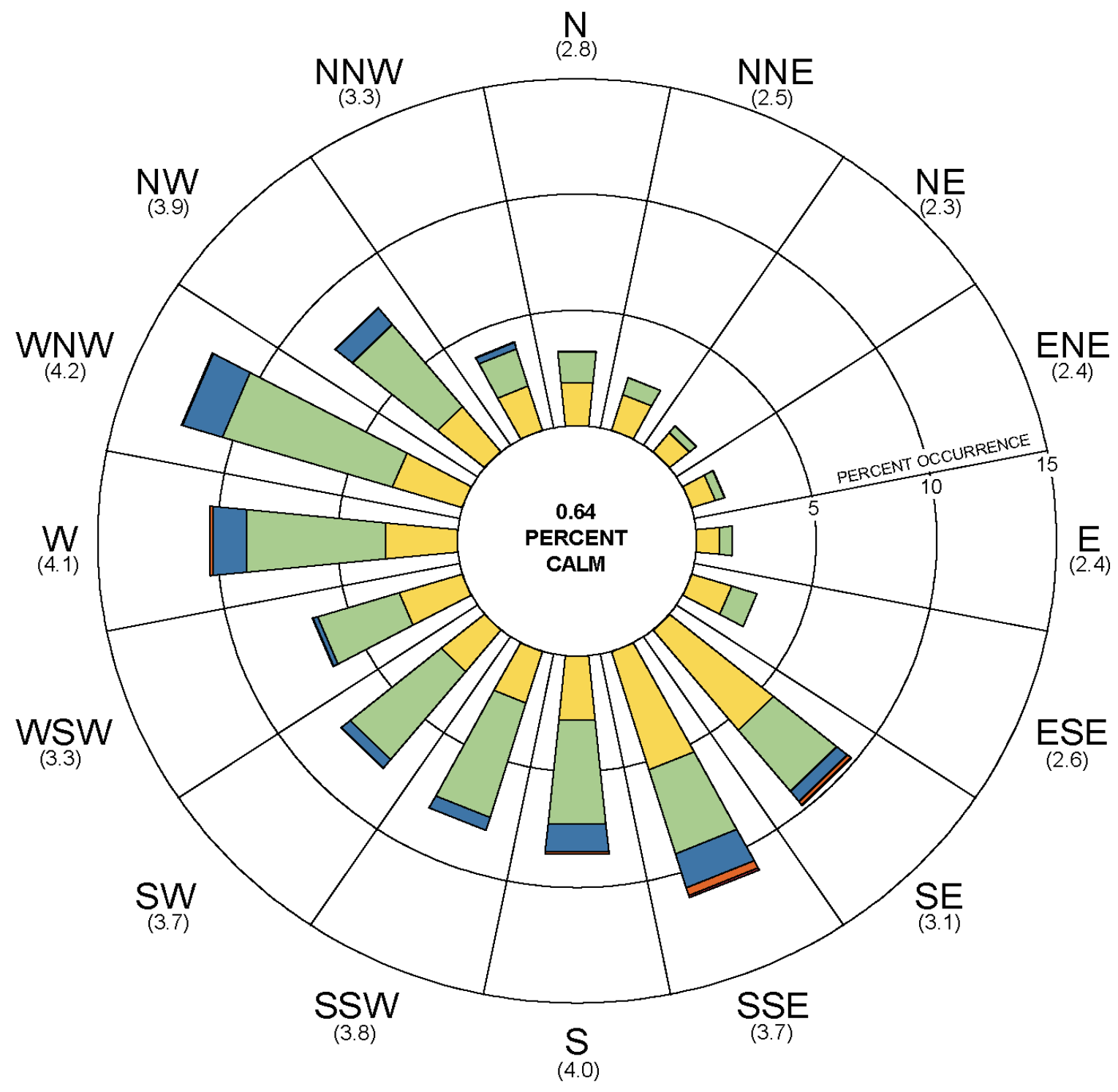

NUMBERS INDICATE SECTOR MEAN WIND SPEED

SECTORS ARE DIRECTIONS FROM WHICH THE WIND IS BLOWING

WIND SPEED RANGE (M/SEC)

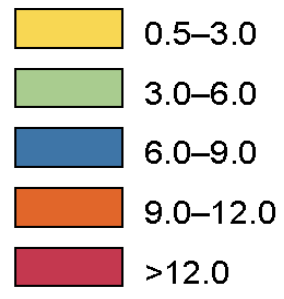

WEST VALLEY NUCLEAR SERVICES PRIMARY MONITORING STATION WEST VALLEY, NEW YORK

FIGURE I-3

60.0-METER WIND FREQUENCY ROSE JANUARY 1, 2006-DECEMBER 31, 2006

$I-5$ 


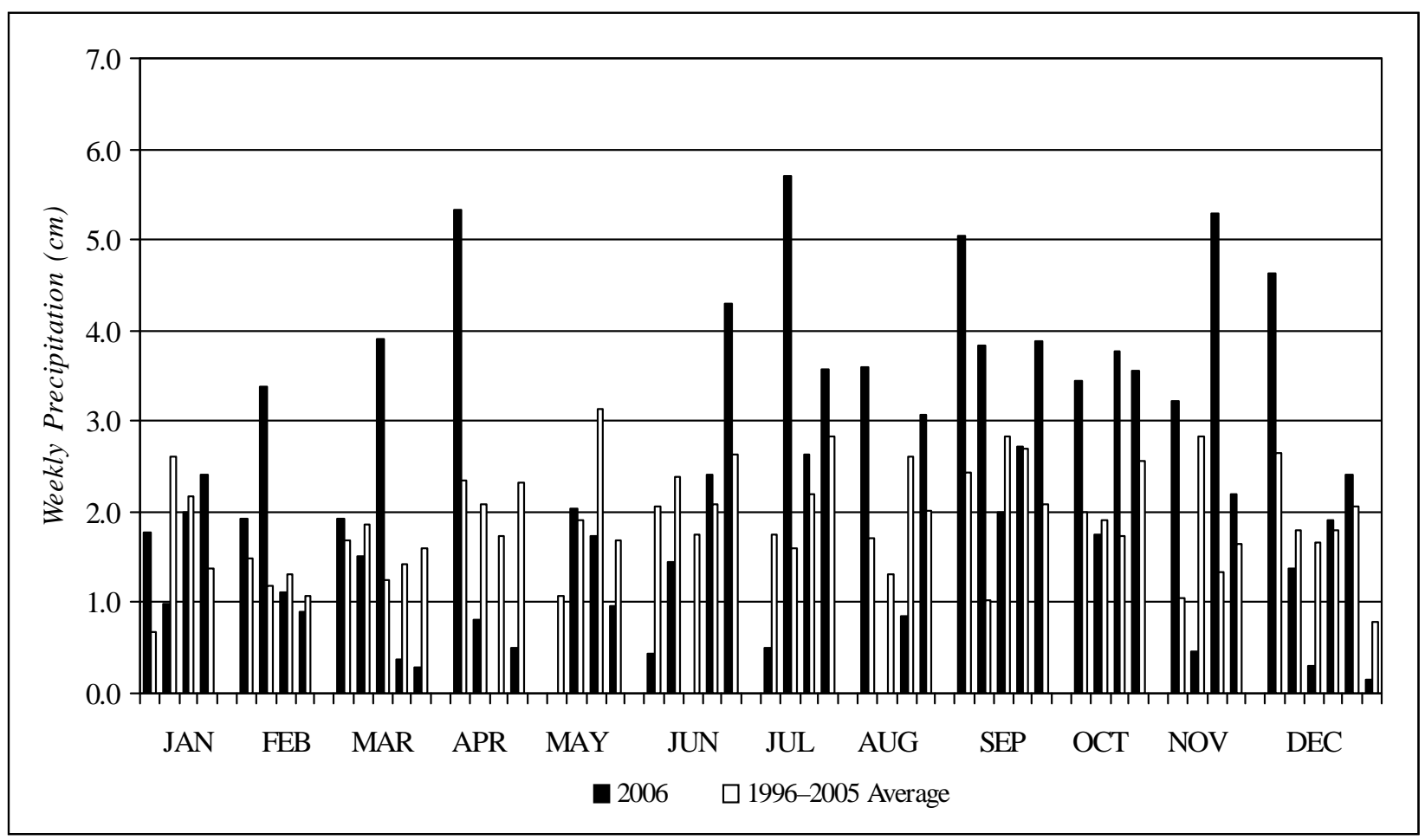

Figure I-4. Calendar Year 2006 Weekly Precipitation

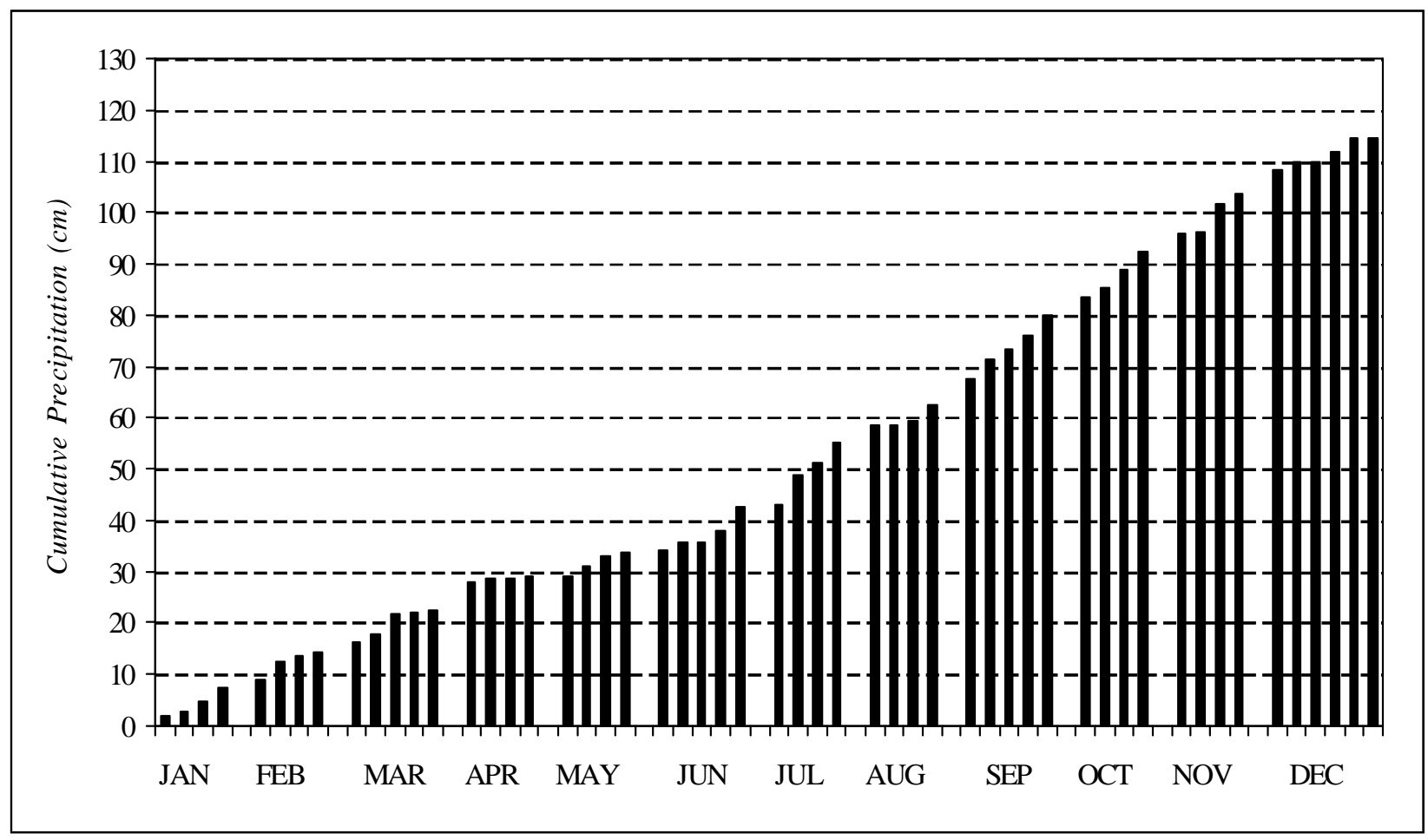

Figure I-5. Calendar Year 2006 Cumulative Precipitation

$$
I-6
$$




\section{Table I-1}

\section{Site Precipitation Collection Data}

\begin{tabular}{|c|c|c|c|c|c|c|c|c|c|}
\hline \multirow{2}{*}{$\begin{array}{l}\text { Week } \\
\text { Ending: }\end{array}$} & \multicolumn{2}{|c|}{ Weekly } & \multicolumn{2}{|c|}{ Cumulative } & \multirow{2}{*}{$\begin{array}{l}\text { Week } \\
\text { Ending: }\end{array}$} & \multicolumn{2}{|c|}{ Weekly } & \multicolumn{2}{|c|}{ Cumulative } \\
\hline & $(\mathrm{cm})$ & (inches) & $(\mathrm{cm})$ & (inches) & & $(\mathrm{cm})$ & (inches) & $(\mathrm{cm})$ & (inches) \\
\hline Jan 06 & 1.78 & 0.70 & 1.78 & 0.70 & Jul 07 & 0.51 & 0.20 & 43.00 & 16.93 \\
\hline Jan 13 & 0.99 & 0.39 & 2.77 & 1.09 & Jul 14 & 5.72 & 2.25 & 48.72 & 19.18 \\
\hline Jan 20 & 2.01 & 0.79 & 4.78 & 1.88 & Jul 21 & 2.64 & 1.04 & 51.36 & 20.22 \\
\hline Jan 27 & 2.41 & 0.95 & 7.19 & 2.83 & Jul 28 & 3.58 & 1.41 & 54.94 & 21.63 \\
\hline Feb 03 & 1.93 & 0.76 & 9.12 & 3.59 & Aug 04 & 3.61 & 1.42 & 58.55 & 23.05 \\
\hline Feb 10 & 3.38 & 1.33 & 12.50 & 4.92 & Aug 11 & 0.00 & 0.00 & 58.55 & 23.05 \\
\hline Feb 17 & 1.12 & 0.44 & 13.61 & 5.36 & Aug 18 & 0.86 & 0.34 & 59.41 & 23.39 \\
\hline Feb 24 & 0.89 & 0.35 & 14.50 & 5.71 & Aug 25 & 3.07 & 1.21 & 62.48 & 24.60 \\
\hline Mar 03 & 1.93 & 0.76 & 16.43 & 6.47 & Sep 01 & 5.05 & 1.99 & 67.54 & 26.59 \\
\hline Mar 10 & 1.52 & 0.60 & 17.96 & 7.07 & Sep 08 & 3.84 & 1.51 & 71.37 & 28.10 \\
\hline Mar 17 & 3.91 & 1.54 & 21.87 & 8.61 & Sep 15 & 2.01 & 0.79 & 73.38 & 28.89 \\
\hline Mar 24 & 0.38 & 0.15 & 22.25 & 8.76 & Sep 22 & 2.72 & 1.07 & 76.10 & 29.96 \\
\hline Mar 31 & 0.28 & 0.11 & 22.53 & 8.87 & Sep 29 & 3.89 & 1.53 & 79.98 & 31.49 \\
\hline Apr 07 & 5.33 & 2.10 & 27.86 & 10.97 & Oct 06 & 3.45 & 1.36 & 83.44 & 32.85 \\
\hline Apr 14 & 0.81 & 0.32 & 28.68 & 11.29 & Oct 13 & 1.75 & 0.69 & 85.19 & 33.54 \\
\hline Apr 21 & 0.00 & 0.00 & 28.68 & 11.29 & Oct 20 & 3.78 & 1.49 & 88.98 & 35.03 \\
\hline Apr 28 & 0.51 & 0.20 & 29.18 & 11.49 & Oct 27 & 3.56 & 1.40 & 92.53 & 36.43 \\
\hline May 05 & 0.00 & 0.00 & 29.18 & 11.49 & Nov 03 & 3.23 & 1.27 & 95.76 & 37.70 \\
\hline May 12 & 2.03 & 0.80 & 31.22 & 12.29 & Nov 10 & 0.46 & 0.18 & 96.22 & 37.88 \\
\hline May 19 & 1.73 & 0.68 & 32.94 & 12.97 & Nov 17 & 5.28 & 2.08 & 101.50 & 39.96 \\
\hline May 26 & 0.97 & 0.38 & 33.91 & 13.35 & Nov 24 & 2.18 & 0.86 & 103.68 & 40.82 \\
\hline Jun 02 & 0.43 & 0.17 & 34.34 & 13.52 & Dec 01 & 4.62 & 1.82 & 108.31 & 42.64 \\
\hline Jun 09 & 1.45 & 0.57 & 35.79 & 14.09 & Dec 08 & 1.37 & 0.54 & 109.68 & 43.18 \\
\hline Jun 16 & 0.00 & 0.00 & 35.79 & 14.09 & Dec 15 & 0.30 & 0.12 & 109.98 & 43.30 \\
\hline Jun 23 & 2.41 & 0.95 & 38.20 & 15.04 & $\operatorname{Dec} 22$ & 1.91 & 0.75 & 111.89 & 44.05 \\
\hline Jun 30 & 4.29 & 1.69 & 42.49 & 16.73 & Dec 29 & 2.41 & 0.95 & 114.30 & 45.00 \\
\hline & & & & & $\operatorname{Dec} 31$ & 0.15 & 0.06 & 114.45 & 45.06 \\
\hline
\end{tabular}

$$
I-7
$$


This page intentionally left blank

$$
I-8
$$




\section{Appendix $J$ \\ Summary of Quality Assurance Crosscheck Analyses}

$$
J-1
$$


This page intentionally left blank

$$
J-2
$$


Table J-1

Crosscheck Sample Comparisons From the DOE Mixed Analyte Performance Evaluation Program (MAPEP) ; Study 15; May 2006

\begin{tabular}{|c|c|c|c|c|c|c|c|}
\hline Analyte & Matrix & Units & Actual & Reported & $\begin{array}{l}\text { Acceptance } \\
\text { Range }\end{array}$ & Accept? $^{b}$ & $\begin{array}{c}\text { Analyzed } \\
\text { by: }\end{array}$ \\
\hline \multicolumn{8}{|c|}{ MAPEP - 06 - GrF15 Gross Alpha/Beta Air Filter } \\
\hline Gross Alpha & Air Filter & Bq/sample & 0.361 & 0.187 & $>0.0-0.722$ & Yes & ELAB \\
\hline Gross Beta & Air Filter & Bq/sample & 0.481 & 0.426 & $0.241-0.722$ & Yes & ELAB \\
\hline \multicolumn{8}{|c|}{ MAPEP - 06 - RdF15 Radiological Air Filter } \\
\hline Am-241 & Air Filter & Bq/sample & 0.093 & 0.086 & $0.065-0.121$ & Yes & GEL \\
\hline Cs-137 & Air Filter & Bq/sample & 2.531 & 2.438 & $1.772-3.290$ & Yes & GEL \\
\hline Co-60 & Air Filter & Bq/sample & 2.186 & 2.220 & $1.530-2.842$ & Yes & GEL \\
\hline $\mathrm{Pu}-238$ & Air Filter & Bq/sample & 0.067 & 0.067 & $0.047-0.087$ & Yes & GEL \\
\hline $\mathrm{Pu}-239 / 240$ & Air Filter & Bq/sample & 0.00041 & 0.002 & & Yes & GEL \\
\hline Sr-90 & Air Filter & $\mathrm{Bq} /$ sample & 0.792 & 0.563 & $0.554-1.030$ & Pass & GEL \\
\hline U-233/234 & Air Filter & Bq/sample & 0.020 & 0.028 & $0.014-0.026$ & No & GEL \\
\hline U-238 & Air Filter & Bq/sample & 0.021 & 0.025 & $0.015-0.027$ & Yes & GEL \\
\hline \multicolumn{8}{|c|}{ MAPEP - 06 - GrW15 Gross Alpha/Beta Water Standard } \\
\hline Gross Alpha & Water & $\mathrm{Bq} / \mathrm{L}$ & 0.581 & 0.339 & $>0.0-1.162$ & Yes & ELAB \\
\hline Gross Beta & Water & $\mathrm{Bq} / \mathrm{L}$ & 1.13 & 1.33 & $0.56-1.70$ & Yes & ELAB \\
\hline Gross Alpha & Water & $\mathrm{Bq} / \mathrm{L}$ & 0.581 & 0.465 & $>0.0-1.162$ & Yes & GEL \\
\hline Gross Beta & Water & $\mathrm{Bq} / \mathrm{L}$ & 1.13 & 1.313 & $0.56-1.70$ & Yes & GEL \\
\hline \multicolumn{8}{|c|}{ MAPEP - 06 - MaW15 Water Standard - Radionuclides } \\
\hline Cs-137 & Water & $\mathrm{Bq} / \mathrm{L}$ & c & 0.10 & c & Yes & ELAB \\
\hline Co-60 & Water & $\mathrm{Bq} / \mathrm{L}$ & 153.50 & 150 & $107.45-199.55$ & Yes & ELAB \\
\hline $\mathrm{H}-3$ & Water & $\mathrm{Bq} / \mathrm{L}$ & 952.01 & 934 & $666.41-1,237.61$ & Yes & ELAB \\
\hline Sr-90 & Water & $\mathrm{Bq} / \mathrm{L}$ & 13.16 & 12.5 & $9.21-17.11$ & Yes & ELAB \\
\hline Am-241 & Water & $\mathrm{Bq} / \mathrm{L}$ & 1.30 & 1.195 & $0.91-1.69$ & Yes & GEL \\
\hline Cs-137 & Water & $\mathrm{Bq} / \mathrm{L}$ & $c$ & 0.2 & ${ }^{c}$ & Yes & GEL \\
\hline Co-60 & Water & $\mathrm{Bq} / \mathrm{L}$ & 153.50 & 152.3 & $107.45-199.55$ & Yes & GEL \\
\hline $\mathrm{H}-3$ & Water & $\mathrm{Bq} / \mathrm{L}$ & 952.01 & 965.01 & $666.41-1,237.61$ & Yes & GEL \\
\hline $\mathrm{Pu}-238$ & Water & $\mathrm{Bq} / \mathrm{L}$ & 0.931 & 0.91 & $0.64-1.18$ & Yes & GEL \\
\hline $\mathrm{Pu}-239 / 240$ & Water & $\mathrm{Bq} / \mathrm{L}$ & 0.0071 & 0.013 & c & Yes & GEL \\
\hline Sr-90 & Water & $\mathrm{Bq} / \mathrm{L}$ & 13.16 & 10.4 & $9.21-17.11$ & Pass & GEL \\
\hline Tc-99 & Water & $\mathrm{Bq} / \mathrm{L}$ & 23.38 & 22.6 & $16.37-30.39$ & Yes & GEL \\
\hline U-233/234 & Water & $\mathrm{Bq} / \mathrm{L}$ & 2.09 & 2.110 & $1.46-2.72$ & Yes & GEL \\
\hline U-238 & Water & $\mathrm{Bq} / \mathrm{L}$ & 2.17 & 2.160 & $1.52-2.82$ & Yes & GEL \\
\hline
\end{tabular}

ELAB - Environmental Laboratory

GEL - General Engineering Laboratory

Note: This report includes only those matrix/analyte combinations performed in support of the analysis of samples collected at the WVDP and for which results are presented in this Annual Site Environmental Report.

${ }^{a}$ MAPEP monitors performance and requests corrective action as required.

b "Yes" - Result acceptable; "Pass" - Result acceptable with warning; "No" - Result not acceptable.

${ }^{c}$ Although no actual value or acceptance range was provided, the results were assessed by MAPEP as acceptable. 
Table J-1 (continued)

Crosscheck Sample Comparisons From the DOE Mixed Analyte Performance Evaluation Program (MAPEP) ; Study 15; May 2006

\begin{tabular}{|c|c|c|c|c|c|c|c|}
\hline Analyte & Matrix & Units & Actual & Reported & $\begin{array}{c}\text { Acceptance } \\
\text { Range }\end{array}$ & Accept $^{b}$ & $\begin{array}{c}\text { Analyzed } \\
\text { by: }\end{array}$ \\
\hline \multicolumn{8}{|c|}{ MAPEP - 06 - RdV15 Vegetation Standard } \\
\hline Cs-137 & Veg & $\mathrm{Bq} / \mathrm{sample}$ & 3.074 & 2.713 & $2.152-3.996$ & Yes & GEL \\
\hline Co-60 & Veg & $\mathrm{Bq} / \mathrm{sample}$ & 4.520 & 4.033 & $3.164-5.876$ & Yes & GEL \\
\hline Sr-90 & Veg & $\mathrm{Bq} / \mathrm{sample}$ & 1.561 & 1.163 & $1.093-2.029$ & Pass & GEL \\
\hline \multicolumn{8}{|c|}{ MAPEP - 06 - MaW15 Water Standard - Metals } \\
\hline Antimony & Water & $\mathrm{mg} / \mathrm{L}$ & 3.046 & 2.94 & $2.132-3.960$ & Yes & LVLI \\
\hline Arsenic & Water & $\mathrm{mg} / \mathrm{L}$ & 3.44 & 3.29 & $2.41-4.47$ & Yes & LVLI \\
\hline Barium & Water & $\mathrm{mg} / \mathrm{L}$ & 4.13 & 4.81 & $2.89-5.37$ & Yes & LVLI \\
\hline Beryllium & Water & $\mathrm{mg} / \mathrm{L}$ & ${ }^{c}$ & $<0.0002$ & ${ }^{c}$ & Yes & LVLI \\
\hline Cadmium & Water & $\mathrm{mg} / \mathrm{L}$ & 0.196 & 0.019 & $0.137-0.255$ & No & LVLI \\
\hline Chromium & Water & $\mathrm{mg} / \mathrm{L}$ & ${ }^{c}$ & 0.0013 & $c$ & Yes & LVLI \\
\hline Cobalt & Water & $\mathrm{mg} / \mathrm{L}$ & $c$ & 0.0014 & $c$ & Yes & LVLI \\
\hline Copper & Water & $\mathrm{mg} / \mathrm{L}$ & 0.688 & 690 & $0.482-0.894$ & No & LVLI \\
\hline Lead & Water & $\mathrm{mg} / \mathrm{L}$ & 2.262 & 2.21 & $1.583-2.941$ & Yes & LVLI \\
\hline Nickel & Water & $\mathrm{mg} / \mathrm{L}$ & 3.92 & 3.82 & $2.74-5.10$ & Yes & LVLI \\
\hline Selenium & Water & $\mathrm{mg} / \mathrm{L}$ & 0.2850 & 0.277 & $0.1995-0.3705$ & Yes & LVLI \\
\hline Silver & Water & $\mathrm{mg} / \mathrm{L}$ & $c$ & 0.0007 & ${ }^{c}$ & Yes & LVLI \\
\hline Thallium & Water & $\mathrm{mg} / \mathrm{L}$ & 2.940 & 2.85 & $2.058-3.822$ & Yes & LVLI \\
\hline Vanadium & Water & $\mathrm{mg} / \mathrm{L}$ & 2.557 & 2.55 & $1.790-3.324$ & Yes & LVLI \\
\hline Zinc & Water & $\mathrm{mg} / \mathrm{L}$ & 0.885 & 0.872 & $0.620-1.150$ & Yes & LVLI \\
\hline \multicolumn{8}{|c|}{ MAPEP - 06 - OrW15 Water Standard - Organic Compounds } \\
\hline 1,3-Dichlorobenzene & Water & $\mu \mathrm{g} / \mathrm{L}$ & 44.1 & 31 & $6.1-53.5$ & Yes & LVLI \\
\hline 1,4-Dichlorobenzene & Water & $\mu \mathrm{g} / \mathrm{L}$ & 39.9 & 27 & $4.0-51.6$ & Yes & LVLI \\
\hline 2,4-Dimethylphenol & Water & $\mu \mathrm{g} / \mathrm{L}$ & 109.2 & 81 & $23.3-143.3$ & Yes & LVLI \\
\hline 1,2,4-Trichlorobenzene & Water & $\mu \mathrm{g} / \mathrm{L}$ & 89.6 & 68 & $19.4-107.6$ & Yes & LVLI \\
\hline Napthalene & Water & $\mu \mathrm{g} / \mathrm{L}$ & 64.5 & 48 & $18.4-79.0$ & Yes & LVLI \\
\hline Hexachlorobutadiene & Water & $\mu \mathrm{g} / \mathrm{L}$ & 148.1 & 110 & $18.4-173.2$ & Yes & LVLI \\
\hline 2-Methylphenol & Water & $\mu \mathrm{g} / \mathrm{L}$ & & $<10$ & $c$ & Yes & LVLI \\
\hline 2,6-Dinitrotoluene & Water & $\mu \mathrm{g} / \mathrm{L}$ & $c$ & $<10$ & ${ }^{c}$ & Yes & LVLI \\
\hline 2,4-Dinitrotoluene & Water & $\mu \mathrm{g} / \mathrm{L}$ & 175.2 & 130 & $66.6-213.0$ & Yes & LVLI \\
\hline 4-Nitrophenol & Water & $\mu \mathrm{g} / \mathrm{L}$ & 123.8 & 140 & $12.4-167.2$ & Yes & LVLI \\
\hline Diethylphthalate & Water & $\mu \mathrm{g} / \mathrm{L}$ & 58.2 & 51 & $9.5-84.5$ & Yes & LVLI \\
\hline Hexachlorobenzene & Water & $\mu \mathrm{g} / \mathrm{L}$ & 24.9 & 18 & $9.8-33.8$ & Yes & LVLI \\
\hline Anthracene & Water & $\mu \mathrm{g} / \mathrm{L}$ & 163.7 & 120 & $68.5-202.3$ & Yes & LVLI \\
\hline Pyrene & Water & $\mu \mathrm{g} / \mathrm{L}$ & 49.5 & 41 & $16.3-70.3$ & Yes & LVLI \\
\hline Benzo(a)anthracene & Water & $\mu \mathrm{g} / \mathrm{L}$ & 98.0 & 73 & $44.5-124.3$ & Yes & LVLI \\
\hline
\end{tabular}

GEL - General Engineering Laboratories

LVLI - Lionville Laboratories, Inc.

Note: This report includes only those matrix/analyte combinations performed in support of the analysis of samples collected at the WVDP and for which results are presented in this Annual Site Environmental Report.

${ }^{a}$ MAPEP monitors performance and requests corrective action as required.

b "Yes" - Result acceptable; "Pass" - Result acceptable with warning; "No" - Result not acceptable.

${ }^{c}$ Although no actual values or acceptable range was provided, the results were assessed by MAPEP as acceptable. 
Table J-1 (concluded)

Crosscheck Sample Comparisons From the DOE Mixed Analyte Performance Evaluation Program (MAPEP) ; Study 15; May 2006

\begin{tabular}{|l|c|c|c|c|c|c|c|}
\hline \multicolumn{1}{|c|}{ Analyte } & Matrix & Units & Actual & Reported & $\begin{array}{c}\text { Acceptance } \\
\text { Range }\end{array}$ & Accept $^{\boldsymbol{b}}$ & $\begin{array}{c}\text { Analyzed } \\
\text { by: }\end{array}$ \\
\hline \multicolumn{2}{|c|}{ MAPEP - 06 - MaS15 Soil Standard - Metals } \\
\hline Antimony & Soil & $\mathrm{mg} / \mathrm{kg}$ & 72.1 & 67.2 & $50.5-93.7$ & Yes & LVLI \\
\hline Arsenic & Soil & $\mathrm{mg} / \mathrm{kg}$ & 59.4 & 55.0 & $41.6-77.2$ & Yes & LVLI \\
\hline Barium & Soil & $\mathrm{mg} / \mathrm{kg}$ & 318 & 326 & $223-413$ & Yes & LVLI \\
\hline Beryllium & Soil & $\mathrm{mg} / \mathrm{kg}$ & 14.82 & 13.9 & $10.37-19.27$ & Yes & LVLI \\
\hline Chromium & Soil & $\mathrm{mg} / \mathrm{kg}$ & 68 & 73.8 & $48-88$ & Yes & LVLI \\
\hline Cobalt & Soil & $\mathrm{mg} / \mathrm{kg}$ & 8.0 & 8.2 & $5.6-10.4$ & Yes & LVLI \\
\hline Copper & Soil & $\mathrm{mg} / \mathrm{kg}$ & 22 & 21.1 & $15-29$ & Yes & LVLI \\
\hline Lead & Soil & $\mathrm{mg} / \mathrm{kg}$ & 31.9 & 30.9 & $22.3-41.5$ & Yes & LVLI \\
\hline Mercury & Soil & $\mathrm{mg} / \mathrm{kg}$ & 0.368 & 0.36 & $0.258-0.478$ & Yes & LVLI \\
\hline Nickel & Soil & $\mathrm{mg} / \mathrm{kg}$ & 153 & 146 & $107-199$ & Yes & LVLI \\
\hline Selenium & Soil & $\mathrm{mg} / \mathrm{kg}$ & 8.43 & 8.0 & $5.90-10.96$ & Yes & LVLI \\
\hline Silver & Soil & $\mathrm{mg} / \mathrm{kg}$ & 68.9 & 64.6 & $48.2-89.6$ & Yes & LVLI \\
\hline Thallium & Soil & $\mathrm{mg} / \mathrm{kg}$ & 3.55 & 3.1 & $2.48-4.62$ & Yes & LVLI \\
\hline Vanadium & Soil & $\mathrm{mg} / \mathrm{kg}$ & 35 & 35.6 & $24-46$ & Yes & LVLI \\
\hline Zinc & Soil & $\mathrm{mg} / \mathrm{kg}$ & 121 & 130 & $84.7-157$ & Yes & LVLI \\
\hline
\end{tabular}

LVLI - Lionville Laboratories, Inc.

Note: This report includes only those matrix/analyte combinations performed in support of the analysis of samples collected at the WVDP and for which results are presented in this Annual Site Environmental Report.

${ }^{a}$ MAPEP monitors performance and requests corrective action as required.

b "Yes" - Result acceptable; "Pass" - Result acceptable with warning; "No" - Result not acceptable.

$$
J-5
$$


Table J-2

\section{Crosscheck Sample Comparisons From the DOE Mixed Analyte Performance Evaluation Program (MAPEP) ; Study 16; October 2006}

\begin{tabular}{|c|c|c|c|c|c|c|c|}
\hline Analyte & Matrix & Units & Actual & Reported & $\begin{array}{l}\text { Acceptance } \\
\text { Range }\end{array}$ & Accept? $^{b}$ & $\begin{array}{l}\text { Analyzed } \\
\text { by: }\end{array}$ \\
\hline \multicolumn{8}{|c|}{ MAPEP - 06 - GrF16 Gross Alpha/Beta Air Filter } \\
\hline Gross Alpha & Air Filter & $\mathrm{Bq} /$ sample & 0.290 & 0.109 & $>0.0-0.580$ & Yes & ELAB \\
\hline Gross Beta & Air Filter & $\mathrm{Bq} /$ sample & 0.359 & 0.384 & $0.180-0.538$ & Yes & ELAB \\
\hline \multicolumn{8}{|c|}{ MAPEP - 06 - RdF16 Radiological Air Filter } \\
\hline Am-241 & Air Filter & $\mathrm{Bq} /$ sample & 0.142 & 0.120 & $0.10-0.18$ & Yes & GEL \\
\hline Cs-137 & Air Filter & $\mathrm{Bq} /$ sample & 1.805 & 1.539 & $1.26-2.35$ & Yes & GEL \\
\hline Co-60 & Air Filter & $\mathrm{Bq} /$ sample & 1.577 & 1.412 & $1.10-2.05$ & Yes & GEL \\
\hline $\mathrm{Pu}-238$ & Air Filter & Bq/sample & 0.118 & 0.107 & $0.08-0.15$ & Yes & GEL \\
\hline $\mathrm{Pu}-239 / 240$ & Air Filter & Bq/sample & $c$ & 0.0016 & & Yes & GEL \\
\hline Sr-90 & Air Filter & Bq/sample & 0.62 & 0.441 & $0.43-0.81$ & Pass & GEL \\
\hline $\mathrm{U}-233 / 234$ & Air Filter & Bq/sample & 0.134 & 0.121 & $0.09-0.17$ & Yes & GEL \\
\hline U-238 & Air Filter & $\mathrm{Bq} / \mathrm{sample}$ & 0.139 & 0.133 & $0.10-0.18$ & Yes & GEL \\
\hline \multicolumn{8}{|c|}{ MAPEP - 06 - GrW16 Gross Alpha/Beta Water Standard } \\
\hline Gross Alpha & Water & $\mathrm{Bq} / \mathrm{L}$ & 1.033 & 1.016 & $>0.0-2.066$ & Yes & ELAB \\
\hline Gross Beta & Water & $\mathrm{Bq} / \mathrm{L}$ & 1.03 & 1.10 & $0.52-1.54$ & Yes & ELAB \\
\hline Gross Alpha & Water & $\mathrm{Bq} / \mathrm{L}$ & 1.033 & 0.820 & $>0.0-2.066$ & Yes & GEL \\
\hline Gross Beta & Water & $\mathrm{Bq} / \mathrm{L}$ & 1.03 & 0.977 & $0.52-1.54$ & Yes & GEL \\
\hline \multicolumn{8}{|c|}{ MAPEP - 06 - MaW16 Water Standard } \\
\hline Cs-137 & Water & $\mathrm{Bq} / \mathrm{L}$ & 196.14 & 195 & $137.30-254.98$ & Yes & ELAB \\
\hline Co-60 & Water & $\mathrm{Bq} / \mathrm{L}$ & 47.5 & 46.7 & $33.2-61.8$ & Yes & ELAB \\
\hline $\mathrm{H}-3$ & Water & $\mathrm{Bq} / \mathrm{L}$ & 428.85 & 396 & $300.20-557.50$ & Yes & ELAB \\
\hline Sr-90 & Water & $\mathrm{Bq} / \mathrm{L}$ & 15.69 & 14.1 & $10.98-20.40$ & Yes & ELAB \\
\hline Am-241 & Water & $\mathrm{Bq} / \mathrm{L}$ & 2.31 & 2.110 & $1.62-3.00$ & Yes & GEL \\
\hline Cs-137 & Water & $\mathrm{Bq} / \mathrm{L}$ & 196.14 & 197.6 & $137.30-254.98$ & Yes & GEL \\
\hline $\mathrm{Co}-60$ & Water & $\mathrm{Bq} / \mathrm{L}$ & 47.5 & 47.6 & $33.2-61.8$ & Yes & GEL \\
\hline $\mathrm{H}-3$ & Water & $\mathrm{Bq} / \mathrm{L}$ & 428.85 & 456.3 & $300.20-557.50$ & Yes & GEL \\
\hline $\mathrm{Pu}-238$ & Water & $\mathrm{Bq} / \mathrm{L}$ & 1.39 & 1.330 & $0.97-1.81$ & Yes & GEL \\
\hline $\mathrm{Pu}-239 / 240$ & Water & $\mathrm{Bq} / \mathrm{L}$ & 1.94 & 1.787 & $1.36-2.52$ & Yes & GEL \\
\hline Sr-90 & Water & $\mathrm{Bq} / \mathrm{L}$ & 15.69 & 13.45 & $10.98-20.40$ & Yes & GEL \\
\hline Tc-99 & Water & $\mathrm{Bq} / \mathrm{L}$ & 27.15 & 25.4 & $19.00-35.29$ & Yes & GEL \\
\hline U-233/234 & Water & $\mathrm{Bq} / \mathrm{L}$ & 2.15 & 2.137 & $1.50-2.80$ & Yes & GEL \\
\hline U-238 & Water & $\mathrm{Bq} / \mathrm{L}$ & 2.22 & 2.310 & $1.55-2.89$ & Yes & GEL \\
\hline \multicolumn{8}{|c|}{ MAPEP - 06 - RdV16 Vegetation Standard } \\
\hline Cs-137 & Veg & $\mathrm{Bq} /$ sample & 5.495 & 5.668 & $3.85-7.14$ & Yes & GEL \\
\hline Co-60 & Veg & $\mathrm{Bq} /$ sample & 5.806 & 6.154 & $4.06-7.55$ & Yes & GEL \\
\hline Sr-90 & Veg & $\mathrm{Bq} /$ sample & 1.137 & 1.095 & $0.77-1.42$ & Yes & GEL \\
\hline
\end{tabular}

ELAB - Environmental Laboratory

GEL - General Engineering Laboratories

Note: This report includes only those matrix/analyte combinations performed in support of the analysis of samples collected at the WVDP and for which results are presented in this Annual Site Environmental Report.

${ }^{a}$ MAPEP monitors performance and requests corrective action as required.

b "Yes" - Result acceptable; "Pass" - Result acceptable with warning; "No" - Result not acceptable.

${ }^{c}$ Although no actual value or acceptance range was provided, the results were assessed by MAPEP as acceptable. 
Table J-2 (continued)

Crosscheck Sample Comparisons From the DOE Mixed Analyte Performance
Evaluation Program (MAPEP) ; Study 16; October 2006

\begin{tabular}{|c|c|c|c|c|c|c|c|}
\hline Analyte & Matrix & Units & Actual & Reported & $\begin{array}{l}\text { Acceptance } \\
\text { Range }\end{array}$ & Accept $?^{b}$ & $\begin{array}{c}\text { Analyzed } \\
\text { by: }\end{array}$ \\
\hline \multicolumn{8}{|c|}{ MAPEP - 06 - MaW16 Water Standard - Metals } \\
\hline Antimony & Water & $\mathrm{mg} / \mathrm{L}$ & 0.547 & 0.55 & $0.382-0.711$ & Yes & LVLI \\
\hline Arsenic & Water & $\mathrm{mg} / \mathrm{L}$ & 1.86 & 1.8 & $1.30-2.42$ & Yes & LVLI \\
\hline Barium & Water & $\mathrm{mg} / \mathrm{L}$ & $<0.2$ & 0.065 & ${ }^{c}$ & Yes & LVLI \\
\hline Beryllium & Water & $\mathrm{mg} / \mathrm{L}$ & 0.2962 & 0.29 & $0.2073-0.3851$ & Yes & LVLI \\
\hline Cadmium & Water & $\mathrm{mg} / \mathrm{L}$ & 0.659 & 0.66 & $0.461-0.857$ & Yes & LVLI \\
\hline Chromium & Water & $\mathrm{mg} / \mathrm{L}$ & 3.237 & 3.3 & $2.266-4.208$ & Yes & LVLI \\
\hline Cobalt & Water & $\mathrm{mg} / \mathrm{L}$ & 9.19 & 9.2 & $6.43-11.95$ & Yes & LVLI \\
\hline Copper & Water & $\mathrm{mg} / \mathrm{L}$ & 1.607 & 1.6 & $1.125-2.089$ & Yes & LVLI \\
\hline Lead & Water & $\mathrm{mg} / \mathrm{L}$ & 3.027 & 3.0 & $2.119-3.935$ & Yes & LVLI \\
\hline Mercury & Water & $\mathrm{mg} / \mathrm{L}$ & 0.00452 & 0.0043 & $0.00316-0.00588$ & Yes & LVLI \\
\hline Nickel & Water & $\mathrm{mg} / \mathrm{L}$ & 7.39 & 7.3 & $5.17-9.61$ & Yes & LVLI \\
\hline Selenium & Water & $\mathrm{mg} / \mathrm{L}$ & 0.819 & 0.80 & $0.573-1.065$ & Yes & LVLI \\
\hline Silver & Water & $\mathrm{mg} / \mathrm{L}$ & $<0.01$ & $<0.0011$ & $c$ & Yes & LVLI \\
\hline Thallium & Water & $\mathrm{mg} / \mathrm{L}$ & 4.655 & 4.6 & $3.258-6.052$ & Yes & LVLI \\
\hline Vanadium & Water & $\mathrm{mg} / \mathrm{L}$ & 6.13 & 6.2 & $4.29-7.97$ & Yes & LVLI \\
\hline Zinc & Water & $\mathrm{mg} / \mathrm{L}$ & 12.12 & 12.4 & $8.48-15.76$ & Yes & LVLI \\
\hline \multicolumn{8}{|c|}{ MAPEP - 06 - OrW16 Water Standard - Organic Compounds } \\
\hline 2-Chlorophenol & Water & $\mu \mathrm{g} / \mathrm{L}$ & c & $<10$ & c & Yes & LVLI \\
\hline 1,3-Dichlorobenzene & Water & $\mu \mathrm{g} / \mathrm{L}$ & 54.7 & 37 & $7.3-65.6$ & Yes & LVLI \\
\hline Hexachloroethane & Water & $\mu \mathrm{g} / \mathrm{L}$ & 90.4 & 56 & $9.0-106.5$ & Yes & LVLI \\
\hline Nitrobenzene & Water & $\mu \mathrm{g} / \mathrm{L}$ & 104.5 & 72 & $32.7-127.2$ & Yes & LVLI \\
\hline 1,2,4-Trichlorobenzene & Water & $\mu \mathrm{g} / \mathrm{L}$ & 116.9 & 84 & $26.0-138.8$ & Yes & LVLI \\
\hline Napthalene & Water & $\mu \mathrm{g} / \mathrm{L}$ & 44.8 & 30 & $13.9-56.3$ & Yes & LVLI \\
\hline Hexachlorobutadiene & Water & $\mu \mathrm{g} / \mathrm{L}$ & 104.5 & 73 & $12.0-124.7$ & Yes & LVLI \\
\hline 2-Methylphenol & Water & $\mu \mathrm{g} / \mathrm{L}$ & ${ }^{c}$ & $<10$ & $c$ & Yes & LVLI \\
\hline 2,6-Dinitrotoluene & Water & $\mu \mathrm{g} / \mathrm{L}$ & 90.1 & 66 & $37.0-113.0$ & Yes & LVLI \\
\hline 2,4-Dinitrotoluene & Water & $\mu \mathrm{g} / \mathrm{L}$ & 148.1 & 110 & $56.0-180.8$ & Yes & LVLI \\
\hline Diethylphthalate & Water & $\mu \mathrm{g} / \mathrm{L}$ & 89.5 & 72 & $15.9-125.0$ & Yes & LVLI \\
\hline Hexachlorobenzene & Water & $\mu \mathrm{g} / \mathrm{L}$ & 49.7 & 27 & $21.0-63.1$ & Yes & LVLI \\
\hline Anthracene & Water & $\mu \mathrm{g} / \mathrm{L}$ & 79.5 & 46 & $33.6-99.6$ & Yes & LVLI \\
\hline Fluoranthene & Water & $\mu \mathrm{g} / \mathrm{L}$ & 107.4 & 79 & $47.4-128.9$ & Yes & LVLI \\
\hline Pyrene & Water & $\mu \mathrm{g} / \mathrm{L}$ & 84.5 & 58 & $27.9-115.9$ & Yes & LVLI \\
\hline Benzo(a)anthracene & Water & $\mu \mathrm{g} / \mathrm{L}$ & 109.3 & 64 & $49.8-138.3$ & Yes & LVLI \\
\hline
\end{tabular}

LVLI - Lionville Laboratories, Inc.

Note: This report includes only those matrix/analyte combinations performed in support of the analysis of samples collected at the WVDP and for which results are presented in this Annual Site Environmental Report.

${ }^{a}$ MAPEP monitors performance and requests corrective action as required.

b "Yes" - Result acceptable; "Pass" - Result acceptable with warning; "No" - Result not acceptable.

${ }^{c}$ Although no actual value or acceptance range was provided, the results were assessed by MAPEP as acceptable. 
Table J-2 (concluded)

\section{Crosscheck Sample Comparisons From the DOE Mixed Analyte Performance Evaluation Program (MAPEP) ${ }^{a}$; Study 16; October 2006}

\begin{tabular}{|c|c|c|c|c|c|c|c|}
\hline Analyte & Matrix & Units & Actual & Reported & $\begin{array}{c}\text { Acceptance } \\
\text { Range }\end{array}$ & Accept? ${ }^{b}$ & $\begin{array}{c}\text { Analyzed } \\
\text { by: }\end{array}$ \\
\hline \multicolumn{8}{|c|}{ MAPEP - 06 - MaS16 Soil Standard } \\
\hline Antimony & Soil & $\mathrm{mg} / \mathrm{kg}$ & 90.4 & 31.6 & $63.3-117.5$ & No & LVLI \\
\hline Arsenic & Soil & $\mathrm{mg} / \mathrm{kg}$ & 79.6 & 72.7 & $55.7-103.5$ & Yes & LVLI \\
\hline Barium & Soil & $\mathrm{mg} / \mathrm{kg}$ & 634 & 596 & $444-824$ & Yes & LVLI \\
\hline Beryllium & Soil & $\mathrm{mg} / \mathrm{kg}$ & 23.55 & 22.1 & $16.48-30.61$ & Yes & LVLI \\
\hline Cadmium & Soil & $\mathrm{mg} / \mathrm{kg}$ & 16.53 & 14.9 & $11.57-21.49$ & Yes & LVLI \\
\hline Chromium & Soil & $\mathrm{mg} / \mathrm{kg}$ & 42 & 43.9 & $29-55$ & Yes & LVLI \\
\hline Cobalt & Soil & $\mathrm{mg} / \mathrm{kg}$ & 102.7 & 94.4 & $71.9-133.5$ & Yes & LVLI \\
\hline Copper & Soil & $\mathrm{mg} / \mathrm{kg}$ & 94 & 90.0 & $66-122$ & Yes & LVLI \\
\hline Lead & Soil & $\mathrm{mg} / \mathrm{kg}$ & 69.8 & 65.2 & $48.9-90.7$ & Yes & LVLI \\
\hline Mercury & Soil & $\mathrm{mg} / \mathrm{kg}$ & 0.945 & 0.92 & $0.661-1.228$ & Yes & LVLI \\
\hline Nickel & Soil & $\mathrm{mg} / \mathrm{kg}$ & 65 & 60.6 & $46-84$ & Yes & LVLI \\
\hline Selenium & Soil & $\mathrm{mg} / \mathrm{kg}$ & 18.98 & 17.0 & $13.28-24.67$ & Yes & LVLI \\
\hline Silver & Soil & $\mathrm{mg} / \mathrm{kg}$ & 37.7 & 35.4 & $26.4-49.0$ & Yes & LVLI \\
\hline Thallium & Soil & $\mathrm{mg} / \mathrm{kg}$ & 54.2 & 50.2 & $37.9-70.5$ & Yes & LVLI \\
\hline Vanadium & Soil & $\mathrm{mg} / \mathrm{kg}$ & 198 & 179 & $139-257$ & Yes & LVLI \\
\hline Zinc & Soil & $\mathrm{mg} / \mathrm{kg}$ & 316 & 287 & $221-411$ & Yes & LVLI \\
\hline Am-241 & Soil & $\mathrm{Bq} / \mathrm{kg}$ & 105.47 & 83.63 & 73.83-137.11 & Pass & GEL \\
\hline Cs-137 & Soil & $\mathrm{Bq} / \mathrm{kg}$ & 525.73 & 498.3 & $368.01-683.45$ & Yes & GEL \\
\hline Co-60 & Soil & $\mathrm{Bq} / \mathrm{kg}$ & 1.98 & 0.7 & ${ }^{c}$ & Yes & GEL \\
\hline $\mathrm{Pu}-238$ & Soil & $\mathrm{Bq} / \mathrm{kg}$ & 82 & 72.13 & $57-107$ & Yes & GEL \\
\hline $\mathrm{Pu}-239 / 240$ & Soil & $\mathrm{Bq} / \mathrm{kg}$ & 0.93 & 0.76 & ${ }^{c}$ & Yes & GEL \\
\hline $\mathrm{K}-40$ & Soil & $\mathrm{Bq} / \mathrm{kg}$ & 604 & 643.3 & $423-785$ & Yes & GEL \\
\hline Sr-90 & Soil & $\mathrm{Bq} / \mathrm{kg}$ & 223.3 & 211.2 & $156.3-290.3$ & Yes & GEL \\
\hline U-233/234 & Soil & $\mathrm{Bq} / \mathrm{kg}$ & 152.44 & 142.33 & $106.71-198.17$ & Yes & GEL \\
\hline $\mathrm{U}-238$ & Soil & $\mathrm{Bq} / \mathrm{kg}$ & 158.73 & 153.00 & $111.11-206.35$ & Yes & GEL \\
\hline
\end{tabular}

LVLI - Lionville Laboratories, Inc.

GEL - General Engineering Laboratories

ND - Not detected

Note: This report includes only those matrix/analyte combinations performed in support of the analysis of samples collected at the WVDP and for which results are presented in this Annual Site Environmental Report.

${ }^{a}$ MAPEP monitors performance and requests corrective action as required.

b "Yes" - Result acceptable; "Pass" - Result acceptable with warning; "No" - Result not acceptable.

${ }^{c}$ Although no actual value or acceptance range was provided, the results were assessed by MAPEP as acceptable. 
Table J-3

Comparisons of Results From Crosscheck Samples Analyzed for Water Quality Parameters as Part of the EPA's 2006 Discharge Monitoring Report - Quality Assurance (DMR-QA) Study 26 for the National Pollutant Discharge Elimination System (NPDES)

\begin{tabular}{|c|c|c|c|c|c|c|}
\hline Analyte & Units & Actual & Reported & $\begin{array}{l}\text { Acceptance } \\
\text { Range }^{a}\end{array}$ & Accept $?^{b}$ & Analyzed by: \\
\hline Aluminum & $\mu \mathrm{g} / \mathrm{L}$ & 1,220 & 1,246 & $990-1,440$ & Yes & STL \\
\hline Ammonia (as Nitrogen) & $\mathrm{mg} / \mathrm{L}$ & 10.9 & 8.62 & $8.08-13.6$ & Pass & STL \\
\hline Antimony & $\mu \mathrm{g} / \mathrm{L}$ & 275 & 276 & $186-334$ & Yes & STL \\
\hline Arsenic & $\mu \mathrm{g} / \mathrm{L}$ & 384 & 363 & $320-451$ & Yes & STL \\
\hline Barium & $\mu \mathrm{g} / \mathrm{L}$ & 1,300 & 1,330 & $1,130-1,470$ & Yes & STL \\
\hline Biochemical oxygen demand & $\mathrm{mg} / \mathrm{L}$ & 67.1 & 69.0 & $33.8-100$ & Yes & STL \\
\hline Cadmium & $\mu \mathrm{g} / \mathrm{L}$ & 471 & 438 & $402-535$ & Yes & STL \\
\hline Chlorine (total residual) & $\mathrm{mg} / \mathrm{L}$ & 1.05 & 1.08 & $0.756-1.31$ & Yes & WWTF \\
\hline Chromium & $\mu \mathrm{g} / \mathrm{L}$ & 305 & 307 & $264-346$ & Yes & STL \\
\hline Chromium (hexavalent) & $\mu \mathrm{g} / \mathrm{L}$ & 558 & 410 & $454-656$ & No & STL \\
\hline Cobalt & $\mu \mathrm{g} / \mathrm{L}$ & 773 & 766 & $680-866$ & Yes & STL \\
\hline Copper & $\mu \mathrm{g} / \mathrm{L}$ & 463 & 474 & $417-509$ & Yes & STL \\
\hline Cyanide, total & $\mathrm{mg} / \mathrm{L}$ & 0.433 & 0.491 & $0.245-0.625$ & Yes & STL \\
\hline Iron & $\mu \mathrm{g} / \mathrm{L}$ & 440 & 518 & $386-501$ & No & STL \\
\hline Lead & $\mu \mathrm{g} / \mathrm{L}$ & 282 & 273 & $242-321$ & Yes & STL \\
\hline Manganese & $\mu \mathrm{g} / \mathrm{L}$ & 474 & 486 & $425-527$ & Yes & STL \\
\hline Mercury & $\mu \mathrm{g} / \mathrm{L}$ & 20.4 & 20.7 & $12.5-27.5$ & Yes & STL \\
\hline Nickel & $\mu \mathrm{g} / \mathrm{L}$ & 203 & 201 & $177-230$ & Yes & STL \\
\hline Nitrate (as Nitrogen) & $\mathrm{mg} / \mathrm{L}$ & 4.27 & 3.96 & $3.32-5.17$ & Yes & STL \\
\hline Nitrite (as Nitrogen) & $\mathrm{mg} / \mathrm{L}$ & 1.67 & 1.54 & $1.39-1.95$ & Yes & STL \\
\hline Nitrogen (total Kjeldahl) & $\mathrm{mg} / \mathrm{L}$ & 14.8 & 9.89 & $9.80-19.1$ & Pass & STL \\
\hline Oil \& Grease (Gravimetric) & $\mathrm{mg} / \mathrm{L}$ & 57.5 & 43.6 & $38.0-69.3$ & Yes & STL \\
\hline $\mathrm{pH}$ & SU & 7.45 & 7.46 & $7.25-7.65$ & Yes & ELAB \\
\hline Phosphorus (total, as P) & $\mathrm{mg} / \mathrm{L}$ & 1.50 & 1.63 & $1.18-1.87$ & Yes & STL \\
\hline Selenium & $\mu \mathrm{g} / \mathrm{L}$ & 1,150 & 1,109 & $915-1,330$ & Yes & STL \\
\hline Silver & $\mu \mathrm{g} / \mathrm{L}$ & 274 & 270 & $235-314$ & Yes & STL \\
\hline Sulfate & $\mathrm{mg} / \mathrm{L}$ & 28.0 & 28.1 & $22.3-33.0$ & Yes & STL \\
\hline Settleable solids & $\mathrm{mL} / \mathrm{L}$ & 24.2 & 30 & $18.8-31.2$ & Yes & WWTF \\
\hline Suspended solids (total) & $\mathrm{mg} / \mathrm{L}$ & 50.9 & 40.0 & $39.6-58.2$ & Pass & STL \\
\hline Total dissolved solids & $\mathrm{mg} / \mathrm{L}$ & 284 & 292 & $212-356$ & Yes & ELAB \\
\hline Vanadium & $\mu \mathrm{g} / \mathrm{L}$ & 490 & 481 & $429-548$ & Yes & STL \\
\hline Zinc & $\mu \mathrm{g} / \mathrm{L}$ & 1,230 & 1,207 & $1,060-1,410$ & Yes & STL \\
\hline
\end{tabular}

STL - Severn Trent Laboratories

WWTF - WVDP Wastewater Treatment Facility Laboratory

ELAB - WVDP Environmental Laboratory

Note: Samples provided by Environmental Research Associates (ERA)

${ }^{a}$ Acceptance limits are determined by ERA or the New York State Department of Health (NYSDOH), as applicable.

b "Yes" - Result acceptable; "Pass" - Result acceptable but outside warning limits; "No" - Result not acceptable. 
This page intentionally left blank

$$
J-10
$$




\section{Appendix $\mathrm{K}$ West Valley Demonstration Project Act}

$K-1$ 
This page intentionally left blank

$$
K-2
$$




\section{West Valley Demonstration Project Act (Public Law 96-368 [S. 2443]; October 1, 1980)}

(As presented in Exhibit G of the Cooperative Agreement between United States Department of Energy and New York State Energy Research and Development Authority on the Western New York Nuclear Service Center at West Valley, New York; Effective October 1, 1980 as amended September 18, 1981.)

$\underline{\text { EXHIBIT G }}$

WEST VALLEY PROJECT DEMONSTRATION ACT

PUBLIC LAW 96-368 [S. 2449]; October 1, 1980

WEST VALLEY DEMONSTRATION PROJECT ACT

For Legislative History of this and other Laws, see Table 1, Public

Laws and Legislative History, at end of final volume

An Act to authorize the Department of Energy to carry out a high-level liquid

York Service Center in West Valley. New York.

Be it enacted by the Senate and House of Representatives of the United States of America in Congress assembled,

SECTION 1. This Act may be cited as the "West Valley Demonstration Project Act".

SEc. 2. (a) The Secretary shall carry out, in accordance with this Act, a high level radioactive waste management demonstration project at the Western New York Service Center in West Valley, New York, for the purpose of demonstrating solidification techniques which can be used for preparing high level radioactive waste for disposal. Under the project the Secretary shall carry out the follow- Activities ing activities:

(1) The Secretary shall solidify, in a form suitable for transportation and disposal, the high level radioactive waste at the Center by vitrification or by such other technology which the Secretary determines to be the most effective for solidification.

(2) The Secretary shall develop containers suitable for the permanent disposal of the high level radioactive waste solidified at the Center.

(3) The Secretary shall, as soon as feasible, transport, in accordance with applicable provisions of law, the waste solidified at the Center to an appropriate Federal repository for permanent disposal.

(4) The Secretary shall, in accordance with applicable licensing requirements, dispose of low level radioactive waste and transuranic waste produced by the solidification of the high level radioactive waste under the project.

(5) The Secretary shall decontaminate and decommission(A) the tanks and other facilities of the Center in which the high level radioactive waste solidified under the project was stored.

(B) the facilities used in the solidification of the waste, and

(C) any material and hardware used in connection with the project,

in accordance with such requirements as the Commission may prescribe.

(b) Before undertaking the project and during the fiscal year ending September 30,1981 , the Secretary shall carry out the following:

(1) The Secretary shall hold in the vicinity of the Center public hearings to inform the residents of the area in which the Center
is located of the activities proposed to be undertaken under the is located of the activities proposed to be undertaken
project and to receive their comments on the project.

(2) The Secretary shall consider the various technologies available for the solidification and handling of high level radioactive waste taking into account the unique characteristics of such waste at the Center.

94 STAT. 1347

$K-3$ 


\begin{abstract}
(3) The Secretary shall-
(A) undertake detailed engineering and cost estimates for the project.

(B) prepare a plan for the safe removal of the high level radioactive waste at the Center for the purposes of solidification and include in the plan provisions respecting the safe breaching of the tanks in which the waste is stored, operating equipment to accomplish the removal, and sluicing techniques,

(C) conduct appropriate safety analyses of the project, and

(D) prepare required environmental impact analyses of the project.

(4) The Secretary shall enter into a cooperative agreement

42 USC 501 note.

State costs, percentage.

Licensing amendment application.

42 USC 2011 note. 42 USC 5801 note.

Publications in Federal Register. with the State in accordance with the Federal Grant and Cooperative Agreement Act of 1977 under which the State will carry out the following:

(A) The State will make available to the Secretary the facilities of the Center and the high level radioactive waste at the Center which are necessary for the completion of the project. The facilities and the waste shall be made available without the transfer of title and for such period as may be required for completion of the project.

(B) The Secretary shall provide technical assistance in securing required license amendments.

(C) The State shall pay 10 per centum of the costs of the project, as determined by the Secretary. In determining the costs of the project, the Secretary shall consider the value of the use of the Center for the project. The State may not use Federal funds to pay its share of the cost of the project, but may use the perpetual care fund to pay such share.

(D) Submission jointly by the Department of Energy and the State of New York of an application for a licensing amendment as soon as possible with the Nuclear Regulatory Commission providing for the demonstration.

(c) Within one year from the date of the enactment of this Act, the Secretary shall enter into an agreement with the Commission to establish arrangements for review and consultation by the Commission with respect to the project: Provided, That review and consultation by the Commission pursuant to this subsection shall be conducted informally by the Commission and shall not include nor require formal procedures or actions by the Commission pursuant to the Atomic Energy Act of 1954, as amended, the Energy Reorganization Act of 1974, as amended, or any other law. The agreement shall provide for the following:

(1) The Secretary shall submit to the Commission, for its review and comment, a plan for the solidification of the high level radioactive waste at the Center, the removal of the waste for purposes of its solidification, the preparation of the waste for disposal, and the decontamination of the facilities to be used in solidifying the waste. In preparing its comments on the plan, the Commission shall specify with precision its objections to any provision of the plan. Upon submission of a plan to the Commission, the Secretary shall publish a notice in the Federal Register of the submission of the plan and of its availability for public inspection, and, upon receipt of the comments of the Commission respecting a plan, the Secretary shall publish a notice in the Federal Register of the receipt of the comments and of the availability of the comments for public inspection. If the Secre-
\end{abstract}

94 STAT. 1348

$K-4$ 
tary does not revise the plan to meet objections specified in the comments of the Commission, the Secretary shall publish in the Federal Register a detailed statement for not so revising the plan.

(2) The Secretary shall consult with the Commission with respect to the form in which the high level radioactive waste at the Center shall be solidified and the containers to be used in the permanent disposal of such waste.

(3) The Secretary shall submit to the Commission safety analysis reports and such other information as the Commission may require to identify any danger to the public health and safety which may be presented by the project.

(4) The Secretary shall afford the Commission access to the Center to enable the Commission to monitor the activities under the project for the purpose of assuring the public health and safety.

(d) In carrying out the project, the Secretary shall consult with the Administrator of the Environmental Protection Agency, the Secretary of Transportation, the Director of the Geological Survey, and the commercial operator of the Center.

SEC. 3. (a) There are authorized to be appropriated to the Secretary for the project not more than $\$ 5,000,000$ for the fiscal year ending September 30, 1981.

(b) The total amount obligated for the project by the Secretary shall be 90 per centum of the costs of the project.

(c) The authority of the Secretary to enter into contracts under this Act shall be effective for any fiscal year only to such extent or in such amounts as are provided in advance by appropriation Acts.

SEC. 4. Not later than February 1, 1981, and on February 1 of each calendar year thereafter during the term of the project, the Secretary shall transmit to the Speaker of the House of Representatives and the President pro tempore of the Senate an up-to-date report containing a detailed description of the activities of the Secretary in carrying out the project, including agreements entered into and the costs incurred during the period reported on and the activities to be undertaken in the next fiscal year and the estimated costs thereof.

SEC. 5. (a) Other than the costs and responsibilities established by this Act for the project, nothing in this Act shall be construed as affecting any rights, obligations, or liabilities of the commercial operator of the Center, the State, or any person, as is appropriate, arising under the Atomic Energy Act of 1954 or under any other law, contract, or agreement for the operation, maintenance, or decontamination of any facility or property at the Center or for any wastes at the Center. Nothing in this Act shall be construed as affecting any applicable licensing requirement of the Atomic Energy Act of 1954 or the Energy Reorganization Act of 1974. This Act shall not apply or be extended to any facility or property at the Center which is not used in conducting the project. This Act may not be construed to expand or diminish the rights of the Federal Government.

(b) This Act does not authorize the Federal Government to acquire title to any high level radioactive waste at the Center or to the Center or any portion thereof.

SEC. 6. For the purposes of this Act:

(1) The term "Secretary" means the Secretary of Energy.

(2) The term "Commission" means the Nuclear Regulatory

Reports and other information to Commission.

Consultation

with

EPA and others.

Appropriation authorization 42 USC 2021a note.

Commission.

(3) The term "State" means the State of New York.

94 STAT. 1349

$K-5$ 
(4) The term "high level radioactive waste" means the high level radioactive waste which was produced by the reprocessing at the Center of spent nuclear fuel. Such term includes both liquid wastes which are produced directly in reprocessing, dry solid material derived from such liquid waste, and such other material as the Commission designates as high level radioactive waste for purposes of protecting the public health and safety.

(5) The term "transuranic waste" means material contaminated with elements which have an atomic number greater than 92, including neptunium, plutonium, americium, and curium, and which are in concentrations greater than 10 nanocuries per gram, or in such other concentrations as the Commission may prescribe to protect the public health and safety.

(6) The term "low level radioactive waste" means radioactive waste not classified as high level radioactive waste, transuranic waste, or byproduct material as defined in section $11 \mathrm{e}$. (2) of the Atomic Energy Act of 1954.

(7) The term "project" means the project prescribed by section 42 USC 2014.

(8) The term "Center" means the Western New York Service Center in West Valley, New York.

Approved October 1, 1980. 